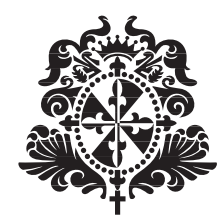



Criminalidad, Ley Penal y Estructura Social en la Provincia de Antioquia 1750-1820 
Patiño Millán, Beatriz

Criminalidad, ley penal y estructura social en la Provincia de Antioquia 1750-1820 / Beatriz Patiño Millán. Prólogo, Pablo Rodríguez Jiménez. —Bogotá: Editorial Universidad del Rosario; Escuela de Ciencias Humanas. Premio IDEA a la Investigación Histórica de Antioquia 486 páginas.-- (Colección Memoria Viva del Bicentenario, Antioquia)

ISBN: 978-958-738-352-2

Derecho penal / Criminología / Delitos / Procedimiento penal / Colombia - Historia - 1750-1820 / I. Rodríguez Jiménez, Pablo, II. Título.

345.8612609033 SCDD 20

Catalogación en la fuente - Universidad del Rosario. Biblioteca

amv

Agosto 16 de 2013

Hecho el depósito legal que marca el Decreto 460 de 1995 


\section{Criminalidad, Ley Penal y Estructura Social en la Provincia de Antioquia 1750-1820}

Beatriz Patiño Millán 
Colección Memoria Viva del Bicentenario, Antioquia

(C) 2013 Editorial Universidad del Rosario

(C) 2013 Universidad del Rosario, Escuela de Ciencias Humanas

(C) 2013 Pablo Rodríguez Jiménez, por el prólogo

(C) Beatriz Patiño Millán

Editorial Universidad del Rosario

Carrera $7 \mathrm{~N}^{\circ}$ 12B-41, oficina 501

Teléfono 2970200

http://editorial.urosario.edu.co
Segunda edición: Bogotá D.C., agosto 2013

Primera edición: Medellín IDEA, 1994

ISBN: 978-958-738-352-2

Coordinación editorial: Editorial Universidad del Rosario Diseño de cubierta: David Reyes

Imagen de cubierta: Detalle: "Reyerta popular (Bogotá)", Torres Méndez, Ramón, Aguatinta, 26 x 33 cm. Publicado en: Álbum de cuadros de costumbres, Ramón Torres Méndez, París, A. De la Rue, 1860 , p. 31.

Diagramación: Margoth C. de Olivos

Impresión: XPRESS Estudio Gráfico y Digital

Impreso y hecho en Colombia

Printed and made in Colombia

Todos los derechos reservados. Esta obra no puede ser reproducida sin el permiso previo por escrito de la Editorial Universidad del Rosario. 


\section{Contenido}

Prólogo a esta edición

$\mathrm{xi}$

Pablo Rodríguez Jiménez

Introducción

xvii

I. El deber ser o las intenciones

A. Las leyes criminales .............................................................. 3

B. El juicio criminal ................................................................... 17

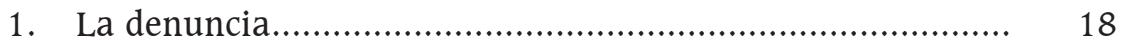

2. Comprobación del hecho.................................................. 22

3. La prisión y el embargo de bienes ........................................ 34

4. La confesión................................................................... 49

5. La acusación y la defensa ................................................. 60

6. Las pruebas..................................................................... 75

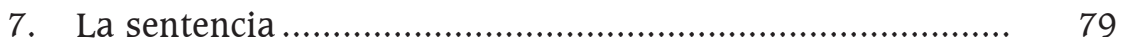

8. La apelación .................................................................... 85

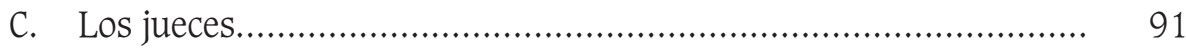

1. Los alcaldes pedáneos, comisarios de barrio y alcaldes de la Santa Hermandad...................................................... 93

2. Los Alcaldes ordinarios .................................................... 98

3. Los asesores jurídicos .................................................... 108

4. Los gobernadores .......................................................... 116

5. La Audiencia ................................................................... 126

II. El ser o las conductas

A. Injurias de palabra ................................................................ 135

1. Los ofendidos ................................................................... 137

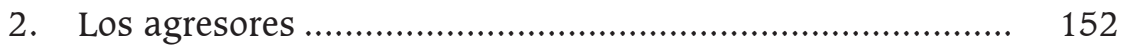

3. Las relaciones entre el agresor y la víctima......................... 160 
4. El escenario de las injurias.............................................. 166

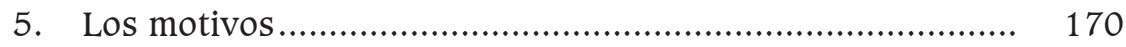

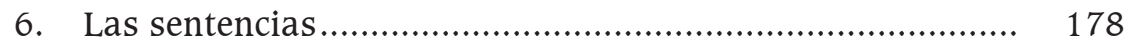

B. "Injurias de hecho" o lesiones personales .................................... 187

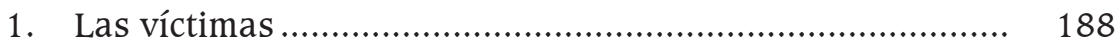

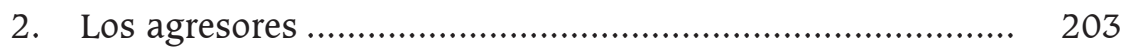

3. Relaciones entre el agresor y la víctima ............................ 215

4. El escenario de las "injurias de hecho".............................. 225

5. Las armas utilizadas ...................................................... 234

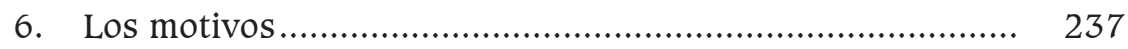

7. La sentencias ............................................................. 250

C. El homicidio …........................................................................ 263

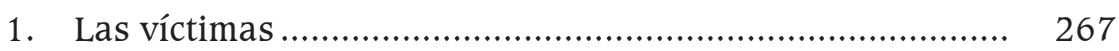

2. Los agresores ............................................................. 280

3. Relaciones entre el agresor y la víctima ........................... 296

4. El escenario de los homicidios ........................................ 306

5. Las armas utilizadas ..................................................... 314

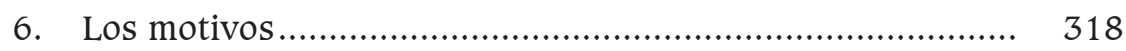

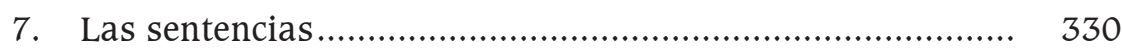

\section{Conclusiones}

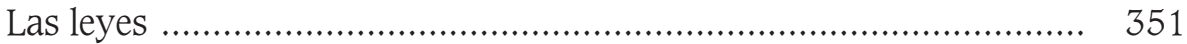

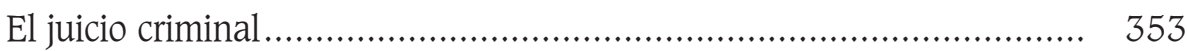

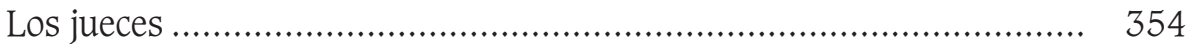

Las conductas delictivas............................................................... $\quad 356$

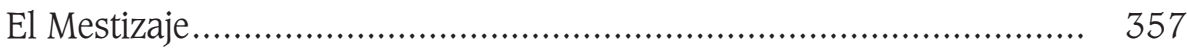

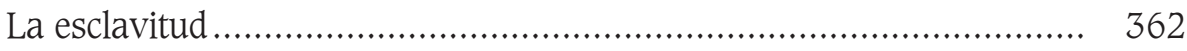

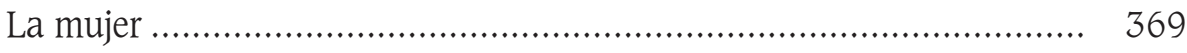

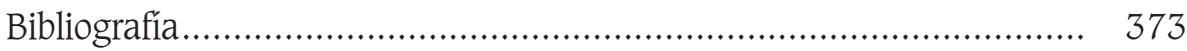

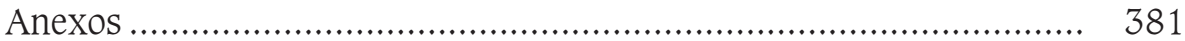


La Universidad del Rosario quiere agradecer a la familia Patiño; Anibal, Fernando, Carmenza y Carlos, por permitir la segunda edición de este libro. 



\section{Prólogo a esta edición}

El libro que el lector tiene en sus manos fue publicado por primera vez hace diecinueve años por el Instituto para el Desarrollo de Antioquia (IDEA). La investigación que Beatriz Patiño Millán presentó al concurso que dicha institución organizaba bianualmente mereció el premio en el área de la historia. El libro, de una edición muy rudimentaria y de muy corto tiraje, nunca llegó a las librerías. Sin embargo, Criminalidad, ley penal y estructura social en la Provincia de Antioquia, 1750-1820," poco a poco, se fue dando a conocer. Principalmente entre investigadores que en su búsqueda hacían el fatigoso viaje hasta las lejanas oficinas del IDEA, en Medellín, y entre los amigos de la autora, a los que generosamente les compartió su obra, fruto de varios años de dedicación. No pasó mucho tiempo para que este libro recibiera comentarios elogiosos de prestigiosos historiadores. Especialmente resaltaban la novedad de los temas que trataba, las voluminosas fuentes en las que se basaba y las conclusiones a las que llegaba. Estas distintas razones convirtieron al libro de Beatriz Patiño en una obra clásica de la literatura histórica antioqueña y en una de las investigaciones más innovadoras de la historiografía colombiana.

La idea de esta significativa investigación la elaboró la autora en Cali, su ciudad natal, entre 1987 y 1988. A Cali volvió, después de muchos años, para cursar la Maestría de Historia Andina, de la Universidad del Valle. En dicho posgrado, los profesores Germán Colmenares y Anthony McFarlane ofrecieron cursos de historia social, en los que se leían y discutían los autores y las obras más significativas sobre los conflictos sociales. De más está decir que en aquellos años autores como Eric Hobsbawm, Edward Thompson, Natalie Zemon Davies y Carlo Ginzburg iniciaron su popularización en las aulas universitarias; pero también cabe tener presente que fueron esos los mismos momentos en los que los profesores Colmenares y McFarlane adelantaban investigaciones sobre

* N. del E.: Para esta edición se ha respetado y conservado el lenguaje y ortografía de la edición original de 1994, Instituto para el Desarrollo de Antioquia (IDEA). 
temas relacionados con la justicia, los castigos y los levantamientos populares al finalizar el siglo xviI. Vistas en retrospectiva, en las dos últimas décadas del siglo pasado ocurrió una especie de extensión y profundización de la historia social. Las dudas sobre la existencia de sociedades armónicas y sin quebrantos en el pasado se consolidaron, y las evidencias de que los grupos considerados oprimidos y marginados tenían vidas activas y construían estrategias orientaron muchas investigaciones. Fue en ese contexto en el que Beatriz Patiño adelantó su investigación; pero, antes de pasar a comentar la obra, hay que decir que esta no era su primera investigación. Para entonces ya había adelantado estudios sobre la tenencia de la tierra y los sistemas de trabajo en la época colonial; indagaciones en las que llegó a adquirir un amplio conocimiento de los archivos y las fuentes documentales referidas al periodo colonial.

Extrañamente en Colombia, un país con tanta violencia en su historia, solo se habían realizado estudios sobre los delitos y los criminales de las décadas de los cincuenta y sesenta del siglo xx. Para periodos anteriores no se habían llevado a cabo investigaciones que estudiaran conflictos distintos a los que generaron los Comuneros y las rebeliones de esclavos. De allí que al tratar el libro de Beatriz Patiño todo un conjunto de delitos en un lapso extendido que va de 1750 a 1820, abrió un nuevo campo de investigación. Un hecho que sorprende de este estudio es que la autora buscó estudiar "todos" los procesos por injurias y calumnias, heridas y homicidios. En sí, el libro no es un estudio de casos judiciales; no, es un estudio de conjunto sobre la criminalidad y la justicia de la Antioquia de la época. Para ser más precisos, la masa documental analizada es la que reposaba en el Archivo Histórico de Antioquia, referida a Antioquia, la vieja capital de la provincia, y la jurisdicción que le concernía. Así, poca de esta documentación versa sobre hechos ocurridos en Medellín. Por otro lado, el periodo histórico analizado se explica por el incremento de procesos judiciales ocurrido en la época. En este fenómeno incidieron factores como el crecimiento de la población, especialmente mestiza, que exacerbó cierta conflictividad; así como las reformas y mayor eficacia de la justicia.

Un aspecto de sumo interés que nos explica la autora es que en la época no había un cuerpo de leyes unitario que guiara a los abogados y los jueces en sus determinaciones. Se basaban casi siempre en obras distintas, 
y algunas eran recopilaciones de los siglos xvi y xvir. Así, muchos de los preceptos y principios que argüían resultaban anacrónicos. Este fue un tiempo de transición, en términos de la teoría del derecho, en el que los abogados, más que aplicar fuertes castigos al cuerpo del delincuente, empezaron a considerar su redención. Así mismo, contrario a lo que suele creerse, el Estado tenía muy poca presencia: los funcionarios, para ejercer vigilancia y acometer la justicia, no solo eran pocos, sino muy poco preparados ¿Cómo controlar la amplia población mestiza y mulata que habitaba la provincia, se preguntaron los gobernadores Francisco Silvestre y Antonio Mon y Velarde? Esta tarea, que parecía irrealizable, la confiaron a un mayor número de funcionarios, especialmente alcaldes de barrio y abogados titulados que asesoraban a los jueces. De alguna manera se consiguió formalizar los procesos, cumplir los pasos del juicio, elaborar bien los sumarios, recopilar declaraciones y testimonios y tener más diligencia en la obtención de pruebas. Tras analizar cerca de trescientos expedientes referidos a injurias, heridas y homicidios, Beatriz Patiño no dudó en considerar que los procedimientos judiciales fueron utilizados para controlar a la población. En ellos se enseñaba la importancia de la ley y las normas, y especialmente un cierto sentido de la justicia, pero la autora no olvida que, a pesar de todos los cambios, los gobernantes no lograron cambiar la pésima imagen que los alcaldes tenían entre la población, pues, apartados de los códigos, la justicia la ejercían a su manera: de forma despótica y violenta.

Un hecho que enriqueció notablemente la historia social latinoamericana fue el descubrimiento de los archivos judiciales. Cada proceso criminal describe un evento traumático en la sociedad, y la rica información que proporciona les permite a los historiadores analizar aspectos sumamente reveladores sobre los valores sociales, las relaciones entre las personas y sus costumbres. Ya William Taylor había enseñado el potencial que estos archivos tenían al analizar los expedientes sobre embriaguez, homicidio y rebelión en el México colonial. Es indudable que el estudio del profesor Taylor fue una referencia importante en el proceso investigativo de Beatriz Patiño. Tal vez la influencia mayor la encontramos en el método que adoptó. Beatriz Patiño, quien supo valorar la riqueza de cada historia, prefirió describir y analizar las tendencias que marcaba la sucesión de acontecimientos presentes en los expedientes. Al final del libro manifiesta su 
confianza en que otros investigadores podrían, después de su estudio, proceder a analizar los aspectos particulares contenidos en cada documento. Hecho que efectivamente ocurrió años después.

La elección de los asuntos que la autora analizó no ocurrió al azar. Las injurias verbales, las riñas y los homicidios, en distinto grado, nos informan de la clase e intensidad de los conflictos que enfrentaban los antioqueños de la época. La sociedad colonial estaba basada en principios de jerarquía y estratificación, principalmente basados en la desigual valoración de la raza y la etnia. En Antioquia, como en muchas otras provincias de Hispanoamérica, se dieron innumerables pleitos por ofensas al honor; pero aquí llama la atención que la mitad de los agravios tenían que ver con pagos y deudas. Acusar a alguien de ser mala paga era gravísimo; mientras que el veinte por ciento de las injurias tenían que ver con ofensas al honor sexual. No debemos olvidar que esta era una sociedad en la que la palabra tenía mucha importancia en el reconocimiento de las dignidades sociales. Así que una ligereza de palabra podía tener implicaciones graves para una persona, razón por la cual las autoridades buscaban controlar y castigar a los lenguaraces.

Las riñas, en muchos casos, eran una consecuencia de una ofensa verbal. En los meses de diciembre y enero, época de fiestas en la región, era cuando más se sucedían las peleas. Normalmente era un enfrentamiento entre vecinos. En medio de la fiesta, y con unos tragos encima, los reclamos por dinero, por celos, o las disputas entre parientes, terminaban con facilidad en graves riñas.

Si hubo muchas ofensas y muchas riñas, en cambio hubo pocos homicidios. Entre 1750 y 1812 hubo 66. Casi uno por año. Un patrón que encuentra la autora es que la mayoría de los homicidios ocurría entre parientes, familiares y vecinos. En todo caso, entre cercanos. Por ejemplo, un alto índice sucedió entre esposos. Una cultura muy afirmada permitía a los maridos castigar a las esposas de forma constante y violenta. Lo que sí sorprende es la elevada participación de las mujeres en los homicidios. La tercera parte de los inculpados por homicidio eran mujeres. Muchas veces, cansadas de recibir castigos de sus maridos, decidieron vengarse. El arma utilizada en varios casos fue la piedra de moler, tan ligada al trabajo femenino en la cocina; pero también tan mortal, cuando de descargarla sobre la cabeza del marido dormido se trataba. 
Es comprensible que en estos delitos estuvieran comprometidos todos los grupos sociales y étnicos. No obstante, muy poco aparecen los indígenas; una proporción equivalente a su componente en la población global de la provincia. Igualmente, ocurrió con los blancos. Con excepción de las injurias, en que aparecen conformando casi la mitad de las víctimas, las complejas relaciones entre los blancos y los libres de todos los colores con frecuencia los exponía a recibir agravios. Aunque también parecería que vivían una especie de paranoia ante cualquier comentario sobre su calidad. De todas formas, la población que más se vio comprometida en los juzgados fueron los mestizos y los mulatos. Era la población mayoritaria en la provincia. Una población de sumo dinamismo, sobre la que se desarrollaron prejuicios no ocultos. En la órbita de la justicia eran considerados bulliciosos, pendencieros y libertinos. Amén de vagos y malentretenidos. Razón que explica en buena medida las excesivas penas que muchas veces se les aplicaban.

Con su investigación sobre estos distintos delitos, Beatriz Patiño abrió un enorme horizonte para la historia social colombiana. El modelo analítico sencillo y eficaz que utilizó, su fortaleza documental y la claridad de sus razonamientos hicieron de su investigación una obra perdurable. Una obra que encontró importantes seguidores en jóvenes investigadores. Algunos de ellos, que retengo al azar en mi memoria, son Juan Carlos Jurado, Orián Jiménez, Robert Ojeda, Iván Espinosa, Catalina Villegas y Mabel López. De esta forma, la reedición de esta obra tiene pleno sentido. Sé que la comunidad de historiadores colombianos lo agradece a la Universidad del Rosario, pues, de alguna manera, es una especie de homenaje a una historiadora ejemplar: investigadora rigurosa, profesora dedicada a sus alumnos y colega amiga de todos los historiadores. Sé que Beatriz, además, desde algún lugar, mirará con simpatía que su libro haga parte de la colección Bicentenario de la Independencia de Antioquia, una tierra y una historia que ella aprendió a querer.

Pablo Rodríguez Jiménez Profesor titular Universidad Nacional de Colombia 



\section{Introducción ${ }^{*}$}

El desarrollo de la historia social durante los últimos veinte años, ha traído consigo la búsqueda de fuentes documentales que permitan estudiar la conducta de los grupos sociales en sus múltiples dimensiones. Una de las fuentes más ricas para el estudio de la estructura y el conflicto social son los juicios criminales. El estudio de los patrones y tendencias presentes en crímenes como la injuria, el homicidio, el hurto o el concubinato, permite examinar los puntos de oposición o de armonía existentes dentro de una comunidad. A través de los procesos seguidos contra las personas acusadas de haber cometido un delito, se pueden conocer las ideas y motivaciones de quienes estaban encargados de aplicar la ley, así como el punto de vista de los reos. En otras palabras, esta fuente acerca lo que hicieron y pensaron los hombres del pasado.

En las ciencias sociales fueron los sociólogos de la desviación y del control social los que primero se interesaron por el estudio de los patrones de criminalidad. El tipo de análisis que desarrollaron entró en crisis hace dos décadas, por las limitaciones que imponía acercarse únicamente a lo actual. Después de un siglo de existencia la sociología penal vio que era necesario

\footnotetext{
" "Criminalidad, Ley Penal y Estructura Social en la Provincia de Antioquia 1750-1820" de la historiadora Beatriz Amalia Patiño Millán, fue la obra ganadora del Premio IDEA a la Investigación Histórica de Antioquia en 1993.

Según el jurado, este trabajo "cumple con las condiciones que caracterizan a una monografía histórica: Uso intensivo y originalidad de fuentes primarias -juicios criminales, protocolos notariales, criminalidad, mortuorias ...-; búsqueda de elementos de interpretación de una realidad y de las interrelaciones de ésta con otras, confrontación con "el estado del arte" de la investigación en otras latitudes, confrontación de los resultados obtenidos de otros investigadores, indicación de futuras líneas de estudio y de problemas a resolver ... Abre además camino en un terreno fundamental y apasionante de la historia social con capacidad de aportar al conocimiento sobre la historia colonial no sólo en Antioquia sino de la América Española".

El Instituto para el Desarrollo de Antioquia -IDEA-, consciente de la importancia que tiene la historia para conservar la memoria de sus pueblos, se complace en apoyar a través de este concurso, publicaciones que como ésta, contribuyen a la identificación y conocimiento de los procesos socioculturales que históricamente se han cumplido en Antioquia.

Con esta edición presentamos el nuevo diseño, que da sello de identidad a las obras que en adelante sean ganadoras del concurso.
} 
colocar su objeto de estudio en una perspectiva histórica. El diálogo entre historiadores y sociólogos acerca de lo penal, a pesar de las dificultades, ha sido productivo como lo muestra la gran cantidad de estudios sobre el tema editados en publicaciones seriadas. ${ }^{1}$

A nivel internacional es en Inglaterra y Francia donde la investigación histórica sobre la criminalidad y la ley penal ha avanzado más. Los historiadores ingleses se han interesado por el análisis de las leyes, los delitos, los criminales y los mitos populares desarrollados en torno a delincuentes célebres. Una buena parte de estos estudios se centra en el siglo xviII debido a que las estadísticas, aunque incompletas y difíciles de interpretar, muestran que en esta centuria el crimen se multiplicó. Esto parece deberse a que la oligarquía gobernante, a través del poder legislativo, redefinió como crímenes, costumbres consuetudinarias como cazar o pescar en vedado. ${ }^{2}$ Otro campo en el que los ingleses han realizado numerosos estudios es el de la significación de la violencia interpersonal. Estos trabajos se basan fundamentalmente en las series estadísticas de homicidios existentes desde el siglo xiII hasta hoy. ${ }^{3}$

Entre los estudios sobre la criminalidad en Francia, abundan las investigaciones que de una manera cuantitativa tratan de medir la relación de algunas variables socioeconómicas con el número de crímenes cometidos contra la persona o contra la propiedad. En ellas se busca someter a prueba tesis generales como la de que la violencia contra las personas es la forma característica de la actividad criminal en las sociedades primitivas, mientras que el crimen contra la propiedad es más común en la sociedad burguesa capitalista. ${ }^{4} \mathrm{La}$

${ }^{1}$ Levy, René y Philippe Robert. "Le Sociologue et L'Histoire Pénale”. Annales. Economies. Sociétés. Civilisations. 39. Année. No. 2. Mars-Avril 1984. Págs. 400-422.

${ }^{2}$ Hay, Douglas y otros. Albion's Fatal Tree. Crime and Society In Eighteenth-Century England. New York. Pantheon Books. 1975. Pág. 13.

${ }^{3}$ Stone, Lawrence. "Interpersonal Violence in English Society. 1300-1980". Past and Present. No. 101. Nov. 1983. Págs. 22-33.

${ }^{4}$ Cohen, David y Eric A. Johnson. "French Criminality: Urban-Rural Differences in the Nineteenth Century”. Journal of Interdisciplinary History. XII. 3. Winter 1982. Págs. 477-501.

Reinhardt, Steven G. "Crime and Royal Justice in Ancien Régime: Modes of Analysis". Journal of Interdisciplinary History. VIII 3. Winter 1983. Págs. 437-460. 
historiografía francesa también se ha interesado por el análisis de los castigos, especialmente lo relativo a la aplicación de la pena de muerte. ${ }^{5}$

En Latinoamérica los estudios históricos sobre la criminalidad y su control son todavía un campo pequeño de la historia social. Sin embargo, algunas de las monografías y artículos de revistas existentes sobre el crimen y el orden público, son excelentes estudios que han permitido abordar la historia económica y social de la región a través de nuevos caminos. De ellos, la mayor parte se refieren a México, Argentina, Perú y Brasil y cada uno ha realizado aportes particulares en el campo temático y el periodo que ha sido objeto de su estudio.

Con respecto a México, el estudio sobre conductas delictivas más conocido es Embriaguez, Homicidio y Rebelión en las Poblaciones Coloniales Mexicanas de William B. Taylor. El autor analizó estos comportamientos en las comunidades indígenas del Centro de México, la Mixteca Alta y el Valle de Oaxaca durante el siglo xviII, por considerar que permiten ver los polos de oposición y de armonía existentes en las relaciones de la comunidad. Escogió estos tres tipos de conducta dramática por estar directamente relacionados con la vida social de las comunidades campesinas y se concentró en el siglo xviII porque a esta época pertenecen las colecciones más ricas de procesos criminales.

En el caso del homicidio, su objetivo era hacer una estimación de la importancia de la violencia interpersonal en la vida campesina. Para ello estudió las pautas temporales y espaciales presentes en este delito, los tipos de armas utilizados, las relaciones existentes entre el agresor y la víctima, la motivación del crimen y las sentencias y tipos de penas impuestos por la justicia. Hizo hincapié en lo general o revelador de los homicidios, sin escribir acerca de los numerosos casos particulares. Le interesaba averiguar la forma en que los incidentes violentos revelan pautas de conducta social y qué relación tienen con el ambiente cultural y las condiciones externas. ${ }^{6}$

${ }^{5}$ Bée, Michel. "Le Spectacle de L'exécution dans la France D’ancien Régime”. Annales, Economies, Sociétés. Civililisations. 38e. Année. No. 4. Juillet-Aout. 1983. Págs. 843-859.

${ }^{6}$ Taylor, William B. Embriaguez, Homicidio y Rebelión en las Poblaciones Coloniales Mexicanas. México. Fondo de Cultura Económica. 1987. Págs. 16-22.

Este autor aborda una temática parecida en otros trabajos posteriores como son: "Amigos de Sombrero: The Patterns of Homicide in Rural Central Jalisco, 1784-1820". Universidad de Virginia. 1986. Copia mecanográfica. Págs. 1-56. 
Entre los investigadores que han usado los juicios criminales como fuente para el estudio de la historia social mexicana, sobresalen los miembros del Seminario de Historia de las Mentalidades y Religión en México Colonial, adscrito al Departamento de Investigaciones Históricas del Instituto Nacional de Antropología e Historia. Su propósito ha sido estudiar las mentalidades, principalmente que forman este cuerpo han recogido testimonios de los tribunales de la inquisición, la sala real del crimen y otros juzgados. Consideran que aunque estos testimonios están filtrados, pasados por el tamiz de discursos codificados, es posible para el historiador restituir por lo menos parcialmente el "otro lado de las cosas". En su concepto la gente de la época colonial no fue simple consumidora de discursos que no siempre captaban y a veces no les llegaba. En otras palabras no fueron las víctimas pasivas de una ideología dominante. ${ }^{7}$

Los historiadores anglosajones han sido los encargados de empezar a explorar el tema del crimen y el orden público en la región del Río de la Plata. A diferencia del caso mexicano en donde buena parte de la bibliografía existente se refiere a la época colonial, los investigadores dedicados a examinar los problemas de la criminalidad en Argentina y Uruguay se han centrado en el siglo xix y primera década del xx. Esto se debe a que los índices de bandidaje y otras formas de crimen y desorden parecen haberse elevado en las tumultuosas décadas que siguieron a la Independencia. Esto fue visto como un obstáculo para el comercio y la inversión de capitales. Por ello, el orden público se convirtió en uno de los objetivos de los gobiernos centralistas que se dieron a partir de 1890 . Estas naciones adoptaron las prácticas que en este campo se habían establecido en los países industrializados, como eran preparar la policía, llevar estadísticas criminales, construir prisiones, etc. La nueva ciencia de la criminología también encontró una audiencia entusiasta.

"Bandolerismo e Insurgencia en el Centro de Jalisco. 1790-1816". Revista Encuentro. Guadalajara. No. 3. Abril-Junio 1984. Págs. 5-54.

${ }^{7}$ Ortega, Sergio. Editor. De la Santidad a la Perversión. O de porqué no se cumplía la ley de Dios en la sociedad novohispana. México. Grijalbo. 1985. Págs. 17-18.

Seminario de Historia de las Mentalidades. El Placer de Pecar y el Afán de Normar. México. Joaquín Mortiz. Instituto Nacional de Antropología e Historia. 1987. Págs. 9-11. 
Para analizar este fenómeno no hay que olvidar que la consolidación política coincidió en estos países con la expansión de una economía exportadora. En las últimas décadas del siglo xix las mejoras en el transporte, la introducción de la refrigeración y una ola de inmigrantes europeos permitieron a los productores de carne y granos de la región competir con los exportadores norteamericanos por el mercado europeo. De acuerdo con los investigadores de la criminalidad en cada una de las etapas de esta transformación, el poder coercitivo de la policía y las cortes fue usado para proteger la propiedad, mantener el orden público y proveer una fuerza de trabajo disciplinada. Estas entidades trabajaron para mantener las convenciones de la jerarquía social existente. ${ }^{8}$

Un buen porcentaje de los trabajos sobre el Perú que han utilizado juicios criminales se refieren a la época colonial. La bibliografía peruana que hemos tenido a nuestro alcance, se refiere fundamentalmente al control de los esclavos y gentes de color. La mayor parte de los esclavos negros introducidos al Perú fueron dedicados a las labores agrícolas en la zona de la costa, especialmente en el área de Lima. El control de esta población fue motivo de preocupación tanto de los propietarios como de las autoridades. El historiador Frederick P. Bowser sostiene que la delincuencia e inquietud entre la población de color, fue exagerada por los españoles, debido al temor que tenían a una rebelión de esclavos y a la posibilidad de que éstos apoyaran a invasores extranjeros. Con base en los procesos criminales existentes para el periodo 1560-1650, este autor estudió los tipos de crímenes más comunes entre los esclavos y los métodos utilizados para su control y castigo. Un capítulo de su trabajo se refiere al delito de fuga y se dedica a analizar la conformación de bandas de asaltantes

8 Johnson, Lyman L. Editor. The Problem of Order in Changing Societies. Essays on Crime and Policing in Argentina and Uruguay, 1750-1940. Albuquerque. University of New Mexico Press. 1990. Págs. ix-xx. El único artículo de esta selección que corresponde a la época colonial es "Women and Crime: Buenos Aires, 1757-97", escrito por Susan Migden Socolow. Este ensayo originalmente apareció en el Journal of Latin American Studies. I. 12. May 1980. Págs. 39-54.

Szuchman, Mark D. "Disorder and Social Control in Buenos Aires, 1810-1860". Journal of Interdisciplinary History. XV. I. Summer 1984, 83-100. 
por parte de los fugitivos, las cuales se convirtieron en una amenaza para las empresas agrícolas y para el comercio. ${ }^{9}$

El tema de las bandas de asaltantes en la costa peruana, con un enfoque distinto y para el siglo xviII, también fue investigado por el historiador peruano Alberto Flores Galindo. Este autor elabora una tipología de los bandidos con base en variables como edad, casta, estado civil y armas usadas; así mismo, analiza la imagen que el pueblo tenía de ellos y estudia las penas que la justicia imponía en esta clase de crimen. ${ }^{10}$ En su opinión, el bandolerismo termina por ser funcional a la sociedad colonial, ya que no ataca los centros de poder ni los mecanismos de extracción de excedentes. Considera que hay una desproporción entre los actos de los bandidos (robos en la mayor parte de los casos) y las penas de muerte, destierro y prisión prolongada a que eran condenados. La violencia de las ejecuciones y de los azotes tenían una función ejemplificadora, siendo su escenario preferido la plaza principal de Lima. Flores Galindo sostiene que durante el siglo xvir la violencia contaminaba el conjunto de la sociedad limeña. Ella se expresaba a través de una tensión étnica que acentuaba la fragmentación de intereses entre los diferentes grupos raciales.

También en Brasil se han realizado numerosas investigaciones, que con base en los juicios criminales, intentan explorar aspectos sobre la historia social de ese país. Desafortunadamente esta producción historiográfica es poco conocida en nuestro medio, tal vez por la barrera idiomática y nuestra tendencia a usar como parámetro la historiografía europea en lugar de la hispanoamericana. ${ }^{11}$

Como puede apreciarse, la mayor parte de la bibliografía latinoamericana sobre la criminalidad y su control, se centra en las décadas finales del

${ }^{9}$ Bowser, Frederick P. El Esclavo Africano en el Perú Colonial (1524-1650). México. Siglo xxi Editores S.A. 1977. Capítulo 7. Págs. 198-241. Capítulo 8. Págs. 242-279.

${ }^{10}$ Flores Galindo, Alberto. Los Rostros de la Plebe. Revista Andina. Cusco. Tomo I. No. 2. Diciembre 1983. Págs. 315-352. Este artículo es parte del texto Aristocratie et Plebe: Lima. 17601830. Classes Sociales et Société Coloniale au Pérou. Paris. Tesis de doctorado de 3r ciclo. 1983.

${ }^{11}$ Un ejemplo de los numerosos artículos de revistas sobre la criminalidad y los juicios en Brasil son : Lewin, Linda. "The Oligarchical Limitation of Social Banditry in Brazil: The Case of the "Good” Thief Antonio Silvino". Past and Present. No. 82. February. 1979. Págs. 116-146.

Aufdertheide, Patricia. "Upright Citizens in Criminal Records: Investigations in Cachoeira and Geremoabo, Brazil, 1780-1836”. The Americas. Vol. XXXVIII. October 1981. No. 2. Págs. 173-184. 
régimen colonial (1780-1820). Esto se debe a que en los archivos nacionales y regionales existe una gran cantidad de documentación perteneciente a este periodo. A pesar de que se han adelantado trabajos sobre diversas regiones, no existe todavía la posibilidad de hacer generalizaciones y desarrollar teorías. Una de las limitaciones que impiden lograr esto, es que la mayor parte de las investigaciones se han elaborado con base en los archivos centrales existentes en las capitales de los países, sin que se haya explorado todavía la riqueza de los archivos regionales y locales. Por esta razón buena parte de la bibliografía existe se refiere a las ciudades capitales como México, Lima y Buenos Aires, que eran los ejes políticos y económicos y en donde operaban los órganos centrales de gobierno.

Para poder avanzar en la comprensión de estos fenómenos y lograr estudios de tipo comparativo es necesario explorar la documentación relativa a las provincias, donde los tipos de crímenes y la forma de aplicar la justicia eran diferentes. El establecimiento de tendencias de largo plazo, sólo será posible cuando se trabajen los juicios existentes para la época de gobierno de los Habsburgo y se exploren las series documentales pertenecientes a la época republicana. Por lo tanto, si se quiere llegar a establecer pautas generales, se impone la tarea de estudiar estos temas para periodos largos y diversas áreas geográficas.

Es difícil hacer una síntesis de las investigaciones que sobre aspectos de la criminalidad en América Latina se han desarrollado. Uno de los obstáculos es que la mayoría de los trabajos han sido publicados como artículos de revistas. Dada la gran cantidad de publicaciones seriadas que existen, para una persona es complicado mantenerse al día por otra parte, las revistas editadas en Latinoamérica circulan muy poco fuera del país de origen. Otra gran cantidad de trabajos son tesis de grado que no han sido editadas, lo que hace difícil tener acceso a ellas.

Con respecto a Colombia, a fines del siglo xix, varios médicos y abogados realizaron investigaciones sobre la criminalidad. Los primeros estaban interesados en establecer la incidencia de la violencia como causa de muerte y los segundos en los aspectos jurídicos del tema. Gran parte de estos 
trabajos son tesis de grado, en las que no se aborda la perspectiva histórica del problema. ${ }^{12}$

Sólo a mediados del presente siglo, tal vez como consecuencia del agudo proceso de violencia política y social que vivió el país, la criminalidad empieza a ser abordada por los científicos sociales. En la década de los sesenta las facultades de sociología adelantaron trabajos importantes sobre violencia y otros temas relacionados como la prostitución, la pobreza, etc. Sin embargo, la crisis en que entraron los estudios sociológicos en la década siguiente hizo que esta clase de investigaciones se dejaran de lado. Como lo ha afirmado Gonzalo Cataño, los sociólogos colombianos abandonaron lo social por algo que creían más firme como lo económico y dejaron de lado las investigaciones de problemas concretos para dedicarse a las construcciones conceptuales. ${ }^{13}$

Dentro de la disciplina histórica, en la década de los ochenta se realizaron numerosas investigaciones sobre la época de la violencia (1946-1966), y se empezaron a adelantar explicaciones sobre la violencia actual. No obstante, la mayor parte de estos trabajos abordan el problema de la violencia en las relaciones interpersonales en un periodo coyuntural, sin que se haya visto y evolución en la larga duración. Por otra parte, se han intentado algunas síntesis globales, pero falta todavía adelantar estudios sobre regiones particulares que permitan una mayor solidez. ${ }^{14}$

Por lo anterior, entre nosotros, el estudio desde una perspectiva histórica de la criminalidad, su relación con la estructura social y la forma como han operado las autoridades encargadas de su control, apenas empieza. Como en Inglaterra, México y Perú los historiadores que han incursionado en este campo han centrado su atención en el siglo xviII.

Aunque no se refieren en forma concreta a la criminalidad, podemos considera como trabajos pioneros en la utilización de los juicios criminales para el estudio del conflicto social, los artículos "Esclavos y Señores en la Sociedad

\footnotetext{
${ }^{12}$ Un ejemplo de este tipo es: Martínez, Miguel. La Criminalidad en Antioquia. Tesis para doctorado. Medellín. 1895.

${ }^{13}$ Cataño, Gonzalo. La Sociología en Colombia. Bogotá. Plaza y Janés. 1986. Págs. 66-67.

${ }^{14}$ Sánchez G., Gonzalo. "Lo Estudios sobre la Violencia: Balance y Perspectivas". En: Pasado y Presente de la Violencia en Colombia. Bogotá. Fondo Editorial Cerec. 1986. Págs. 11-30.
} 
Colombiana del Siglo xviII" y "Mestizaje y Diferenciación Social en el Nuevo Reino de Granada en la Segunda Mitad del Siglo xvin" del historiador Jaime Jaramillo Uribe. En el primero de ellos, al referirse al tratamiento dado a los esclavos usa la información proveniente de causas criminales seguidas a los amos por maltrato. Por otra parte, tomando como base los numerosos juicios seguidos a los esclavos por ofensas hechas a sus amos, homicidios, huidas, sublevaciones y otros delitos, muestra que las relaciones esclavistas en la Nueva Granada estuvieron cargadas de tensiones, conflictos y odios.

En el segundo artículo, utilizando pleitos por injurias, muestra la discriminación de que fue objeto el mestizo por parte de los blancos y las autoridades. Señala como los apelativos de mestizo, mulato y zambo se convirtieron en conceptos peyorativos que constituían verdaderas ofensas al honor de quienes se consideraban blancos y el decírselos a alguien daba pie para que se iniciara un juicio por difamación. Registra además, los innumerables pleitos que se promovieron por la usurpación o negativa a dar el título de "don". ${ }^{15}$

Un trabajo que toma como base los datos que portan los juicios criminales, para estudiar el delito y sus relaciones e implicaciones sociales, es "Delito y Sociedad en el Nuevo Reino de Granada. Período Virreinal (1740-1810)" de la socióloga Zoila Gabriel de Domínguez. La autora concibió el estudio como una investigación en el campo de la sociología criminológica. Su intención era analizar la relación delito-sanción en la sociedad neogranadina virreinal, buscando aportar elementos para una comprensión global de esa sociedad. El trabajo se hizo con base en un muestreo de los expedientes criminales existentes en el Archivo Histórico Nacional. Recogió datos sobre los aspectos geográficos y cronológicos del delito, el delincuente y agredido, los motivos que indujeron al delito y la sentencia.

En nuestro concepto algunas de las conclusiones a las que llegó esta autora pueden ser cuestionadas. Al interpretar los datos, cometió muchos errores debido a su desconocimiento de la estructura social colonial y la forma como operaba

\footnotetext{
${ }^{15}$ Jaramillo Uribe, Jaime. "Mestizaje y Diferenciación Social en el Nuevo Reino de Granada en la Segunda Mitad del Siglo XVII", "Esclavos y Señores en la Sociedad Colombiana del Siglo XVIII". En: Ensayos Sobre Historia Social Colombiana. Bogotá. Biblioteca Universitaria de Cultura Colombiana. 1968. Págs. 5-77, 163-203.
} 
el sistema judicial. Así, por ejemplo, no tuvo en cuenta que con excepción de los casos relativos a Santa fe, en este archivo se encuentran los expedientes enviados a la Audiencia para apelar o consultar una sentencia proferida en un juzgado de primera instancia. Esto tiene influencia en el tipo de delito encontrado, pues este trámite suele hacerse en las sentencias por delitos graves como el homicidio, mientras que pocas veces se pide la revisión de las penas impuestas por delitos como el concubinato. Pero el error más grande lo cometió al analizar la información relativa al origen étnico de las víctimas y los agresores. El no contabilizar los casos en que este dato se omitió, la lleva a afirmar que los mestizos eran el grupo más adaptado a las pautas legales de comportamiento. Esta afirmación contradice lo encontrado en los demás estudios sobre el tema. ${ }^{16}$

En los últimos años ha aumentado el interés por el estudio de los delitos y la forma como se ha buscado controlar las conductas "desarregladas". Dentro de la producción reciente está un artículo de Germán Colmenares titulado "La Aplicación de la Ley Penal a fines de la Colonia y comienzos de la República” en el cual analiza la forma como se aplicó la legislación penal, utilizando juicios criminales seguidos en la gobernación de Popayán. El autor parte de considerar que en la Nueva Granada durante el periodo colonial, la ejecución de la ley fue una de las pocas manifestaciones tangibles del Estado. En su opinión, las causas criminales ilustran demostraciones concretas de poder y las condiciones específicas que las hacían posibles. Esta presencia del Estado era más evidente en el ámbito de las ciudades coloniales, pues en el sector rural la aplicación de la justicia era muy problemática. ${ }^{17}$

Señala además, que en la Nueva Granada los mestizos fueron el blanco de los guardianes del orden. La peligrosidad no se atribuía a las clases laboriosas (indígenas y esclavos), sino al grupo mestizo por escapar a un

${ }^{16}$ Gabriel de Domínguez, Zoila. "Delito y Sociedad en el Nuevo Reino de Granada. Período Virreinal (1740-1810)”. Universitas Humanística. Nos. 8 y 9. Años 1974 y 1975. Págs. 281-398.

${ }^{17}$ Colmenares, Germán. "La Aplicación de la Ley Penal a fines de la Colonia y comienzos de la República”. Versión mecanográfica sin publicar. s.f. Págs. 2-29. Este artículo ha sido recientemente publicado con el título de "El Manejo Ideológico de la Ley en un Período de Transición" en la revista Historia Crítica. No. 4. Julio-Diciembre de 1990. Págs. 8-31. Una versión distinta fue publicada con el título de "La Ley y el Orden Social: Fundamento Profano y Fundamento Divino" en la revista Boletín Cultural y Bibliográfico. Volumen XXVII. No. 22. 1990. Págs. 3-19. 
molde aceptado y previsible de conducta. En este trabajo se analizan algunas conductas delictivas como el concubinato, el abigeato, el fraude a las rentas y los castigos impuestos a los delincuentes.

Otros trabajos recientes sobre el tema son los artículos "Vida Inquieta y Gente Baldía” y "Zahúrdas de Plutón: Chicherías en Santa fe” de Julián Vargas Lesmes. Estos textos forman parte de la investigación sobre historia de Bogotá, llevada a cabo por la Fundación Misión Colombia al cumplirse 450 años de la fundación de la ciudad. En el primero de ellos se refiere a las rondas efectuadas por las autoridades coloniales en Santa fe con el fin de mantener la moral y seguridad del vecindario. Muestra que el objetivo principal era perseguir los robos y los delitos que afectaban la moral y las buenas costumbres de la sociedad. También analiza las causas seguidas por juegos de azar, tratando de hacer una tipología de los jugadores y mostrando la forma en que eran penalizados por desobedecer las leyes sobre juegos. ${ }^{18}$

En el segundo escrito anota que para las autoridades coloniales las chicherías eran lugares que alteraban la tranquilidad pública, pues en sus proximidades se originaban riñas y peleas, además de servir para cobijar mucho delitos contra la moral.

Con excepción del trabajo de Germán Colmenares, los otros escritos reseñados se han elaborado con base en documentación del Archivo Histórico Nacional. Sin embargo, el fondo de juicios criminales de este archivo, que consta de 218 volúmenes, está prácticamente inexplorado. Falta realizar investigaciones más sistemáticas, que permitan llegar a conclusiones sólidas.

Los archivos regionales, que cuentan con una gran documentación de esta clase, apenas se comienzan a trabajar. En el caso concreto de Antioquia encontramos que en los últimos años se han hecho algunas tesis de grado y escrito artículos usando como fuente los juicios criminales de la época colonial que se conservan en el Archivo Histórico de Antioquia. La mayor parte de ellos son

${ }^{18}$ Vargas Lesmes, Julián. La Sociedad de Santa fe. Bogotá. Centro de Investigación y Educación Popular. CINEP. 1990. Págs. 345-366, 367-382. 
sobre delitos contra la familia y la moral como el adulterio, el concubinato, el incesto, el estupro y el homicidio. ${ }^{19}$

Este ligero balance historiográfico muestra que en América Latina y en Colombia los estudios históricos sobre la legislación penal, la criminalidad y la forma como se administraba justicia todavía tienen un desarrollo precario. En el estado actual de la investigación hay necesidad de combinar el análisis de tipo cuantitativo que permite medir la importancia de determinados delitos, elaborar tipologías de los delincuentes, ver la manera cómo ciertas variables socioeconómicas influyen en estos fenómenos, con el análisis de tipo cualitativo que remite a la significación de la ley, las infracciones y los castigos.

El presente trabajo intenta contribuir al estudio de la criminalidad y su relación con la estructura social. En una primera parte se propone estudiar la aplicación de la ley penal en la provincia de Antioquia durante la etapa final del régimen colonial y la Independencia. Para ello se trató de precisar el marco legal vigente y determinar la forma cómo se llevan a cabo los juicios criminales. En esta parte se analizó el papel que cumplían los peritos, testigos, defensores, fiscales y demás personas que intervenían en el desarrollo de los procesos. También se buscó establecer la estructura de la administración de justicia, determinando las funciones de los diferentes tipos de jueces y la instancia en que conocían los juicios.

La segunda parte es un estudio sobre los crímenes contra la persona que se cometieron en la jurisdicción de la ciudad de Antioquia entre 1750 y 1819. Se analizaron 136 juicios de injurias, 203 de heridas y lesiones personales y 43 de homicidios, existentes en el Fondo de Juicios Criminales del Archivo Histórico de Antioquia. La intención era establecer las pautas de la violencia interpersonal en esa sociedad. Por ello para cada delito se determinaron las características de los agresores, de las víctimas, el tipo de relación que existía

\footnotetext{
${ }^{19}$ Luna Rivillas, Gloria. Documentos para el Estudio de la Criminalidad Sexual en la Provincia y Gobernación de Antioquia. (Siglos XVII-XVIII). Crímenes, Escándalos y Pecados Públicos o del poco temor y respeto a las dos Majestades. Tesis de grado. Facultad de Ciencias Humanas. Universidad Nacional-Sede Medellín. 1988.

Rodríguez, Pablo. "Promesas, Seducción y Matrimonio en Antioquia Colonial", "El Amancebamiento en Medellín Colonial". 1990-1991. Estos trabajos se publicaron en un libro que tiene por título Seducción, Amancebamiento y Abandono en la Colonia.
} 
entre ellos y las motivaciones que tuvieron para infringir la ley. También se estudiaron las pautas espaciales y temporales de los crímenes, así como las armas utilizadas. Por último, se analizaron los tipos de penas con las que se castigaron los delitos y las consideraciones que se tuvieron en cuenta al establecerlas.

Se escogió trabajar sobre los crímenes contra la integridad personal por ser los delitos que mejor reflejan el grado de violencia y conflicto existentes en una sociedad. El homicidio y las lesiones personales graves han sido considerados delitos en casi todas las culturas; por esta razón son las conductas delictivas que más se han estudiado. Ello hace posible comparar las pautas encontradas con las existentes para otros lugares de Hispanoamérica y Europa.

Otro motivo para haber escogido trabajar esta clase de juicios, fue el periodo de violencia por el que atraviesa la región antioqueña. Considero que la mayor parte de los diagnósticos existentes se remiten a las causas recientes del proceso, lo que no permite investigarlo a fondo. Hay necesidad de establecer en la larga duración los puntos de conflicto y de armonía que han existido en esta sociedad. Estudiar la violencia interpersonal durante la época colonial y la independencia no ayuda a resolver la coyuntura, pero permite ir estableciendo algunas de las raíces históricas del fenómeno.

Aunque la intención inicial era trabajar sobre varias subregiones de la provincia de Antioquia, para establecer la significación que en cada una tuvieron los diferentes tipos de delitos contra la persona, esto no fue posible, porque el 90\% de los juicios criminales existentes en el Archivo Histórico de Antioquia corresponde a lugares pertenecientes a la jurisdicción de la ciudad de Antioquia. (Parte occidental de la Gobernación. Ver Mapas). Además, en los archivos de las localidades se conservan muy pocos juicios del periodo estudiado. Así, en el caso del Archivo Judicial de Medellín no existe ningún juicio criminal del siglo xviII y sólo hay 17 causas del periodo 1801-1820, en su mayor parte por concubinatos y robos.

Sin embargo, se justificaba trabajar la jurisdicción de la ciudad de Antioquia por varios motivos. Esta ciudad era la capital provincial, lo que llevaba a que en ella se tramitara una mayor cantidad de causas. Allí residían los Gobernadores y los tenientes de Gobernador asesor, personajes que durante 
la época estudiada tuvieron un papel muy importante en la administración de justicia. La documentación encontrada permitía comparar los casos tramitados ante el tribunal provincial, con los seguidos por los Alcaldes ordinarios.

Desde el punto de vista demográfico era interesante trabajar esta zona, debido a que fue la más poblada de la provincia y en la que se había presentado un proceso de mestizaje más profundo. ${ }^{20}$ Esto llevó a que en su población estuvieran presentes todos los grupos socio-raciales que la jerarquía social colonial contemplaba. Así, a esta jurisdicción pertenecían los pueblos de indios más importantes de la región, lo que hizo posible estudiar los conflictos en que se vieron inmiscuidos los miembros de este grupo.

Desde la fundación misma de la ciudad de Antioquia (1541) se empezaron a introducir en la zona negros esclavos. En el siglo xvi se utilizaron fundamentalmente para explotar los aluviones del río Cauca y las minas de veta de Buriticá. En el siglo xviI en esta área vivía la tercera parte de la población esclava de la gobernación, la cual se dedicaba a la explotación de grandes y medianas propiedades agrarias y a la minería en la región del Valle de los Osos (ver cuadro $\left.\mathrm{N}^{\circ} 65\right) \cdot{ }^{21}$ Este hecho permitió investigar la clase de violencia a que daban lugar las relaciones esclavistas.

Durante la crisis minera del siglo xvi en esta subregión se originó una abundante población negra y mulata libre. En la misma época, a partir de los resguardos indígenas se creó un sector mestizo importante. Como resultado de este proceso, en el siglo xvil el 65\% de los habitantes de la zona eran libre de "varios colores" (ver cuadro $\mathrm{N}^{\circ} 65$ ).

Económicamente este grupo estaba constituido por pequeños propietarios agrícolas, mineros independientes y un número apreciable de gente sin tierra que trabajaba como jornalera o estaba agregada en tierras ajenas. La minería con las labores comerciales permitieron crear un núcleo de mestizos enriquecidos.

${ }^{20}$ Según los datos del censo de 1788 en la jurisdicción de la ciudad de Antioquia había 19.318 habitantes, en la de Medellín 16.750, en las de Rionegro y Marinilla 14.206, en la de Remedios 3625, en la de Zaragoza 3504 y en la de Cáceres 1915.

Colmenares, Germán. Relaciones e Informes de los Gobernantes de la Nueva Granada. Bogotá. Biblioteca Banco Popular. 1989. Tomo I. Cuadro B. Padrón de la provincia de Antioquia de 1788.

${ }^{21}$ Patiño Millán, Beatriz. "La Provincia en el siglo XVIII". En: Historia de Antioquia. Medellín. Suramericana de Seguros. 1988. Págs. 69-90. 
Por esta razón los conflictos interétnicos fueron muy fuertes en esta zona y con base en ellos se pudo evaluar el papel jugado por los mestizos y mulatos.

Si bien la mayor parte de los procesos trabajados corresponden a esta subregión, en el trabajo se incluyeron datos de juicios de lugares no pertenecientes a ella. Esto se debe a que en el archivo de juicios criminales se conservan procesos enviados al juzgado del Gobernador desde diferentes partes de la provincia. También se analizaron unos pocos casos de los tramitados en la Audiencia que se encuentran en el Archivo Histórico Nacional de Bogotá.

Se trabajó el periodo 1750-1819 por varias razones. En primer lugar, en el archivo existen muy pocos expedientes de fechas anteriores a 1750 . De acuerdo con la información que se tiene, esta documentación se perdió hace mucho tiempo. En los informes presentados por los visitadores de la segunda mitad del siglo xvili, reiteradamente se habla de la inexistencia de los archivos judiciales y de su desorden. ${ }^{22}$

En segundo lugar, investigar los procesos tramitados entre $1750 \mathrm{y}$ 1819 permitía ver las reformas introducidas por los Borbones en la administración de justicia. Desde 1760 el gobierno de la provincia estuvo en manos de personajes "ilustrados" que buscaron ejercer un mayor control sobre la población. Como resultado de este proceso se empezaron a perseguir delitos que antes eran poco vigilados. Es el caso de los crímenes contra la moralidad como el concubinato, el adulterio y el amancebamiento, o de crímenes contra la persona, como la injuria.

El papel que estos funcionarios otorgaron a la administración de justicia, llevó a que aumentara el número de personas que recurrían a ella para resolver conflictos. Esto se refleja en el aumento del número de juicios por delitos privados, tramitados a petición de un denunciante o acusador.

En tercer lugar el periodo estudiado coincide con un momento de aumento de la población. El número de habitantes de la provincia de Antioquia pasó de 44.167 en 1777 a 110.662 en $1803 .{ }^{23}$ Sólo en la jurisdicción de la ciudad de Antioquia la población aumentó de 19.318 habitantes en 1788 a 40.758 en

\footnotetext{
${ }^{22}$ Archivo Histórico de Antioquia. En adelante A.H.A. Visitas. Tomos 75 y 76.

${ }^{23}$ Melo, Jorge Orlando. "La Minería Antioqueña en el Siglo XVIII: Interpretaciones y Perspectivas”. Versión mecanográfica. 1984.
} 
1808 , lo que significa que en 20 años se duplicó (ver cuadros $N^{\circ} 65$ y 67). En el trabajo se buscó establecer la incidencia que este crecimiento demográfico tuvo en la criminalidad y su control.

Por último, es necesario precisar que en el Archivo Histórico de Antioquia existen pocos juicios posteriores a 1819. Este hecho evidencia que al comenzar la República hubo cambios en la organización de la administración de justicia.

Al tomar el periodo 1750-1819 era posible trabajar con un marco legal uniforme. Las leyes penales castellanas estuvieron vigentes en la Nueva Granada hasta 1837 cuando se expidió el primer código penal neogranadino. ${ }^{24}$

Consideramos que esta clase de estudios deben hacerse para periodos largos, pues sólo de esta manera se pueden ver los procesos de larga duración. En el presente trabajo, el haber estudiado expedientes correspondientes a 70 años permitió establecer tendencias y ver cambios. Para hacer visibles las transformaciones, los cuadros en que se procesó la información cuantitativa, se hicieron por décadas. El lector puede así analizarlos y sacar sus propias conclusiones.

Una buena parte del trabajo consiste en el análisis de los cuadros que se elaboraron a partir de los datos suministrados por los juicios. Aunque es un análisis esencialmente de tipo cuantitativo, consideramos conveniente hacerlo porque permite conocer algunas características de la sociedad estudiada. Para poder elaborar interpretaciones más cualitativas y globales, es necesario primero contar con datos que nos aclaren la magnitud de los fenómenos y su incidencia.

Es necesario aclarar que el análisis de los datos contenidos en los juicios sólo permite determinar tendencias. Varios factores impiden que se pueda establecer la incidencia de las conductas delictivas en términos absolutos. Uno es que no todos los delitos cometidos son denunciados ante la justicia. Es difícil establecer la cantidad de contravenciones a las normas que no dieron lugar a que se siguiera un juicio, bien fuera porque no fueron denunciadas, o debido a que los jueces no consideraron conveniente abrir un sumario. El homicidio suele ser el único delito en que el número de casos reportados se aproxima al

${ }^{24}$ Vélez, Fernando. Datos para la Historia del Derecho Nacional. Medellín. Imprenta del Departamento. 1891. Pág. 196. 
total de crímenes cometidos, pero se debe tener en cuenta que muchas muertes que pasan por naturales o accidentales pueden ser provocadas. Por otra parte, no sabemos cuántos de los procesos tramitados han llegado hasta nosotros. El número de expedientes extraviados debió ser muy alto si se tiene en cuenta que los archivos judiciales han sido unos de los más descuidados en el país.

Para elaborar el presente trabajo se consultaron todos los juicios por injurias, lesiones personales y homicidios existentes en el Fondo de Juicios Criminales. La intención era poder conocer los diferentes tipos de conflictos que dieron lugar a la tramitación de un expediente. Esto llevó a que se tuviera que tratar un sinnúmero de temas como las relaciones amo-esclavo, las relaciones conyugales, los problemas entre los comerciantes y sus clientes, etc., sin que se hubiera profundizado en ninguno. Dado el escaso desarrollo de estas investigaciones en nuestro medio, se consideró conveniente elaborar un cuadro general del tipo de problemas que se daban en la sociedad antioqueña del siglo xvir. Sobre eta base se pueden realizar estudios que aborden más exhaustivamente cada uno de estos problemas.

Esta investigación pretende establecer pautas y tendencias generales y por eso no se detiene a analizar ningún juicio en particular. Ellos son utilizados profusamente a manera de ejemplo, pero no se trata de una historia de casos. Consideramos que algunos de los procesos trabajados ameritan que algún investigador realice esa clase de trabajo.

De otra parte, los juicios criminales nos acercan a las personas que tuvieron problemas con la justicia y en casi todas las sociedades ellas suelen ser un porcentaje relativamente pequeño. A través de los datos suministrados por ellos se pueden establecer los conflictos y algunas características de la sociedad, pero se debe tener en cuenta que la visión que se construye es parcial. Los interrogatorios a testigos, víctimas o acusados permiten conocer ideas y creencias vigentes en una comunidad, pero no reflejan necesariamente las verdaderas motivaciones y circunstancias de los hechos. Por lo tanto, es necesario contrastar los datos encontrados en los juicios criminales con los aportados por otras fuentes.

Algunas limitaciones en el análisis provienen de nuestra ignorancia sobre ciertos temas. Tal vez el problema más grave fue la falta de cono- 
cimientos sobre el derecho español y la jurisprudencia en general. Aunque lo tratamos de suplir con la lectura de las obras de algunos juristas españoles, en este campo se le pueden hacer muchas correcciones al trabajo. Confío que investigaciones posteriores permitirán avanzar en el estudio de la naturaleza y función de la ley penal.

No puedo concluir la presentación del trabajo sin agradecer a las personas que me ayudaron en su elaboración. Al profesor Roberto Luis Jaramillo le agradezco haber puesto a mi disposición buen parte de la bibliografía jurídica correspondiente a la época. Por su parte, el profesor Nodier Agudelo Betancur me introdujo en el estudio de las obras de Cesare Beccaria y Manuel de Lardizábal y Uribe, las cuales me permitieron conocer las críticas hechas al sistema penal vigente.

Las conversaciones con el profesor Víctor Alvarez me permitieron aclarar muchos de los problemas teóricos y metodológicos que se me presentaron. Además, sin su ayuda no hubiera aprendido a manejar el mundo de los computadores. También debo darle las gracias a la estudiante Adriana Alzate quien me ayudó en la tarea de digitar parte del texto.

Debo agradecer igualmente al personal del Archivo Histórico de Antioquia, que me atendió a lo largo de un año. A pesar de la estrechez del local actual y de los problemas que en la atención al público se presentan, debo reconocer que sus empleados buscaron siempre facilitarme la consulta. Así mismo, doy las gracias al profesor Jorge Orlando Melo por haberme servido de director de tesis. Sus múltiples ocupaciones no le impidieron leer el manuscrito y hacer las anotaciones pertinentes.

Por último, quiero hacer un reconocimiento a la labor desarrollada por el profesor Germán Colmenares en pro de la materia para la cual presento esta tesis. Su muerte prematura privó al país de uno de sus mejores historiadores y pensadores y a la Universidad del Valle de uno de sus más prestigiosos docentes. Para mí es un honor haber sido una de sus discípulas. Sus enseñanzas y escritos me han servido mucho en mi actividad como docente e inspiraron la realización de este trabajo. 


\section{El deber ser o las intenciones}





\section{A. Las leyes criminales}

Las leyes criminales usadas en las colonias americanas por la Corona española fueron las mismas vigentes en la metrópoli. En opinión de los autores del siglo xviI éstas consistían en un cuerpo de leyes confusas, contradictorias, oscuras y variables. De allí que fueran reiteradas las peticiones para que se elaborara una legislación clara, corta y uniforme. ${ }^{1}$

La legislación criminal se encontraba dispersa en varios códigos que tenían vigencia y cobertura diferente. Para tener una idea clara del origen y autoridad de estas leyes es pertinente hacer un breve recuento histórico.

La mayor parte de los autores afirman que el derecho español tiene su origen en la legislación establecida por los invasores godos para su gobierno. ${ }^{2}$ Al principio de su reinado los godos permitieron a los iberos, acostumbrados al uso de las leyes romanas, continuar su observancia. El Rey Eurico (reinó del 466 al 484) fue el primero entre los reyes godos que ordenó recopilar y poner por escrito los usos y costumbres que habían traído de Germania, así como las leyes que sus antecesores y él habían promulgado. ${ }^{3}$

Un siglo después, Leovigildo (568-586) corrigió y dio nueva forma al código, añadiéndole muchas leyes que se habían omitido y quitándole algunas que le parecieron superfluas.

Chindasvinto, (Khindasvinto 642-649) por su parte, fundió las legislaciones romana y goda, formando un nuevo código nacional que sirviese de

\footnotetext{
${ }^{1}$ Lardizábal y Uribe, Manuel de. Discurso sobre las Penas. México. Editorial Porrúa S. A. 1982. Págs. XXVIII y XXXI.

${ }^{2}$ Sala, Juan. Sala Adicionado o Ilustración del Derecho Español. Valencia. Librería de Malleen y Sobrinos. 1844. Tomo I. Pág. 3.

${ }^{3}$ La información sobre los códigos formados por los reyes godos, en especial del Fuero Juzgo, se tomó de:

Escriche, Joaquín. Diccionario Razonado de la Legislación y Jurisprudencia. Paris. México. Librería de la Vda. De Ch. Bouret. 1911. Págs. 715-717.

Sala, Juan. Ob. cit. Tomo I. Págs. 4-6.

Los datos sobre las fechas de los reinados de los Reyes Godos fueron tomados de:

Menéndez Pidal, Ramón. (Director). Historia de España. Madrid. Espasa-Calpe. S.A. 1940. Tomo III. España Visigoda. (414-711 d. J.C.).
} 
norma y regla para todos y abolió el uso y autoridad de las leyes romanas hasta entonces observadas; su hijo y sucesor Recesvindo (649-672) prohibió el uso de las leyes romanas, imponiendo la pena de 50 libras a quien las citara en juicio y al juez que diese sentencia según ellas. La última colección de leyes visigodas parece ser la ordenada por Flavio Egida (687-702), que de acuerdo con la opinión del jurisconsulto don Manuel de Lardizábal y Uribe en el estudio hecho para la edición de 1815, es la que hoy conocemos.

El código visigodo, por lo tanto, comprende las leyes establecidas desde mediados del siglo v cuando reinaba Eurico, hasta los primeros años del siglo viII, cuando reinó Witiza (que fue asociado al trono por su padre Egica desde el año 698 hasta el año 710). Las leyes que lo conforman son de cuatro clases:

1. Las que hicieron los príncipes por su propia autoridad, con la intervención de los principales señores de la corte.

2. Las que se hacían en los concilios nacionales, "toledanos", a los que asistían "los prelados de la Iglesia, los magnates legos y los altos funcionarios de la corte y del reino".

3. Las que se hallan sin fecha ni nombre del autor, creyéndose que se tomaron de las colecciones antiguas.

4. Las que tienen una nota que dice "antigua", las cuales algunos suponen se tomaron de la legislación de los romanos.

Este código se publicó en latín a fines del siglo vil o principios del siglo VII, con el nombre del Liber Judicum (codex legum, liber legum, liber gothorum). En el siglo xili, durante el reinado de San Fernando III, fue traducido a la lengua castellana y llamado Fuero de los Jueces, cuyo nombre se corrompió en el de Fuero Juzgo.

El Fuero Juzgo consta de un exordio que contiene 18 leyes sobre la elección de los príncipes, sus derechos y obligaciones y de 12 libros divididos en 54 títulos con 559 leyes. Para abordar la legislación criminal son pertinentes los libros: tercero, de los matrimonios, raptos, adulterios, ayuntamientos incestuosos, sacrílegos y sodomíticos; y de los divorcios. Sexto, de las acusaciones, de los malhechores y sus cómplices, de los envenenamientos, de los abortos, de las heridas y de los homicidios. Séptimo, de los robos y falsedades. Octavo, de las fuerzas y daños. Duodécimo, de la conducta de los jueces en 
la administración de justicia, de los herejes judíos y demás sectarios y de los denuestos y palabras injuriosas.

El libro de los jueces siguió vigente después de la invasión de los árabes (711-718), tanto entre los españoles que vivían en los territorios sujetos a los "mahometanos", como entre los que se conservaron libres en las montañas, especialmente en las de Asturias y los Pirineos. Los árabes respetaron la religión, leyes y costumbres de los vencidos y sólo promulgaron algunas leyes penales, como por ejemplo sobre la blasfemia contra su profeta Mahoma. Los "cristianos" refugiados en las montañas de Asturias reputaron por leyes patrias las de los godos y las extendieron a los pueblos que iban recobrando de los moros. No obstante, durante la reconquista se formaron y se dieron a varios pueblos fueros municipales o códigos privilegiados. El Fuero Juzgo quedaba como código al que había que acudir para los casos no contemplados en los fueros locales. A pesar de las recopilaciones hechas con posterioridad, el "libro de los jueces", como código nacional, no fue totalmente derogado hasta el siglo xix. ${ }^{4}$

Buscando uniformar la legislación y remediar el desorden y confusión que reinaba en los tribunales, desde mediados del siglo xil hasta mediados del siglo xiv, se publicaron varias colecciones de leyes. ${ }^{5}$ En 1255 el Rey don Alfonso x "El Sabio" (1252-1284), publicó un código que se llamó "Fuero de las Leyes" o "Fuero Real". A pesar de que este cuerpo legal comprendía las leyes más importantes de los fueros municipales y de estar acomodado a las costumbres de Castilla y al Fuero Juzgo, el Rey Alfonso x no pudo lograr que se observase en todos los pueblos bajo su dominio. Muchos pueblos por fuera de Castilla hicieron reclamaciones contra el Fuero Real; debido a ello se mandó que Castilla, León, Extremadura, Toledo y Andalucía administrasen justicia y arreglasen los juicios de acuerdo con sus respectivas cartas forales.

${ }^{4}$ Escriche, Joaquín. Ob. cit. Pág. 717.

${ }^{5}$ La información sobre estas colecciones de leyes fue sacada de:

Sala, Juan. Ob. cit. Tomo I. Págs. 7-9.

Escriche, Joaquín. Ob. cit. Págs. 717, 720-721, 1174, 1329-1330.

Los datos sobre las fechas de los reinados de los Reyes Castellanos fueron tomados de:

Aguado Bleye, Pedro. Manual de Historia de España. Madrid Espasa-Calpe. S.A. 1971. Tomo I. Prehistoria, edades Antigua y Media. 
A fines del siglo xill y principios del xiv se publicaron las llamadas "Leyes del Estilo", colección compuesta por 252 leyes.

Por su parte, el Rey Fernando III (1217-1252) proyectó una obra que permitiera dar uniformidad a la legislación, pero no llegó a empezarla, dejándola encargada a su hijo Alfonso "El Sabio". La obra comenzó a elaborarse en 1256 y se concluyó en 1263, pero no se publicó hasta el año de 1343, durante el reinado de don Alfonso xi (1312-1350). El código Alfonsino recibió el nombre de "Las Siete Partidas", por constar de siete partes. De ellas, la más importante con relación a la legislación criminal es la séptima, que se refiere a las acusaciones, delitos y penas.

Este código se formó "en cuanto a la religión y a la Iglesia", de las sentencias de los Santos Padres; y en lo demás, de usos y costumbres que parecieron útiles y principalmente de las leyes romanas. Las partidas eran una romanización del derecho español, de allí que los jurisconsultos de los siglos XIV y xv hayan llamado contrafuero o desafuero las leyes de las partidas que no concordaban con las Fuero Juzgo. ${ }^{6}$

Hasta el siglo xix las Partidas fueron el código español más completo, pero su uso en los tribunales en el siglo xviII era restringido, por hallarse reformado en gran parte por legislación posterior.

Después hubo otros esfuerzos por sistematizar la legislación. ${ }^{7}$ En 1348 se publicó el Ordenamiento de Alcalá, código que contiene treinta y dos títulos, divididos en leyes, las cuales fueron en gran parte incluidas en la Recopilación de 1537. En tiempo de los Reyes Católicos (1474-1516) fue publicado el Ordenamiento Real. Esta es una compilación alfabética de varias leyes que existían dispersas o contenidas en colecciones anteriores realizada por Alonso Montalvo, quien le hizo unas glosas y repertorio. A la misma época pertenecen

${ }^{6}$ Sala, Juan. Ob. cit. Tomo I. Pág. 8.

${ }^{7}$ Sobre estos intentos de sistematizar la legislación se puede consultar

Escriche, Joaquín. Ob. cit. Págs. 1302-1303, 1174-1175.

Sala, Juan. Ob. cit. Tomo I, Págs. 9-11.

Los datos sobre las fechas de los reinados de los reyes españoles fueron sacados de:

Aguado Bleye, Pedro. Ob. cit. Tomo II. Reyes Católicos. Casa de Austria. (1474-1700). Tomo III. Casa de Borbón (1700-1808). España Contemporánea (1808-1955). 
Las Leyes de Toro, cuya composición se ordenó bajo los auspicios de los Reyes Católicos en las cortes de Toledo del año 1502, pero sólo se publicaron en 1505 en las Cortes celebradas en la ciudad de Toro. Las 83 leyes que la componen no forman un código completo y metódico. Se formaron con el objeto de dirimir las contiendas que se suscitaban sobre la inteligencia de los diferentes códigos y de suplir vacíos en la legislación.

Por último, bajo el reinado de Felipe II (1556-1598) se publicó un nuevo código, que recibió el nombre de Recopilación. ${ }^{8}$ Esta contiene las leyes promulgadas desde la formación de las Siete Partidas y El Fuero Real, como también algunas contenidas en colecciones anteriores. La Recopilación consta de 9 libros divididos en títulos y éstos en leyes. De ellos, el Libro $8^{\circ}$ es el que se refiere a las leyes criminales. En cada una de las ediciones que se hicieron de este código se añadieron las leyes que se habían promulgado en el intermedio. En el año de 1806 se publicó la última con el título de "Novísima Recopilación".

La "Novísima Recopilación" está dividida en 12 libros, de los cuales, con relación a la legislación criminal, es importante el duodécimo, pues se ocupa de los delitos, sus penas y de los juicios criminales.

De acuerdo con la "Novísima Recopilación" (1806), el orden de observancia de las leyes contenidas en los códigos anteriores era el siguiente: en primer lugar se debían seguir las leyes de la recopilación y las establecidas después de ella, con advertencia de que las más antiguas cedían a las más recientes que les fueran contrarias. En segundo lugar, se debía tener en cuenta el Fuero Real y los Fueros Municipales, y por último, las de las Siete Partidas. ${ }^{9}$

Con relación a las leyes criminales, en primer lugar se observaban las leyes de la Recopilación (Libro $8^{\circ}$.) y después de 1805, las de la Novísima Recopilación (Libro $12^{\circ}$ ). En los casos allí no estipulados se debía remitir a las Siete Partidas (Partida $7^{\text {a }}$, que en este campo fue, hasta el siglo xix, el cuerpo de leyes más completo.

Este recuento histórico nos da una idea de la desactualización y confusión que existía en materia de leyes penales. No debe extrañarnos que, en el

\footnotetext{
${ }^{8}$ Escriche, Joaquín. Ob. cit. Pág. 1418.

Sala, Juan. Ob. cit. Tomo I. Págs. 10-11.

${ }^{9}$ Ibídem. Pág. 12.
} 
último cuarto del siglo xviII, muchos jurisconsultos españoles opinaran que la mayor parte de leyes criminales vigentes no eran adecuadas para la época, por haberse promulgado en "tiempos tenebrosos" en los que se creía:

Que para contener los delitos y refrenar las pasiones de los hombres, no podía haber otro medio que la fuerza, el rigor, la dureza, la severidad, el fuego y la espalada. En unos tiempos en que la venganza pronunciaba y la cólera ejecutaba los juicios. ${ }^{10}$

También en los círculos gubernamentales se consideraba necesario adelantar una reforma de las leyes criminales. Por esta razón Carlos III (1759-1788), en el año de 1770, designó para trabajar en la elaboración de un nuevo código penal al mexicano don Manuel Lardizábal y Uribe y tres consejeros de Castilla.

Este trabajo no tuvo un resultado inmediato, pues sólo en 1822 se publicó el primer código penal español, inspirado en el Código Napoleónico. ${ }^{11}$

Para las colonias americanas no se hizo una legislación penal específica. No obstante, el Libro séptimo de la Recopilación de Leyes de Indias de 1680 recoge una serie de Reales Cédulas expedidas por los monarcas españoles para resolver asuntos relacionados con el derecho criminal.

Este libro está dividido en ocho títulos, los cuales se subdividen en leyes. El título $1^{\circ}$. Habla de "los pesquisidores y jueces de comisión" (29 leyes), el título $2^{\circ}$. "de los juegos y jugadores" ( 7 leyes), el título $3^{\circ}$. "de los casados y desposados en España e Indias que están ausentes de sus mujeres y esposas" (9 leyes), el título $4^{\circ}$. "de los vagabundos y gitanos" (5 leyes), el título $5^{\circ}$. "de los mulatos, negros, berberiscos e hijos de indios" (29 leyes), el título $6^{\circ}$. "de las cárceles y carceleros" (23 leyes), el título 7º "de las visitas de cárcel" (21 leyes) y el título $8^{\circ}$. "de los delitos y penas y su aplicación" (28 leyes).

\footnotetext{
${ }^{10}$ Ladizábal y Uribe, Manuel de. Ob. cit. Pág. VI. Prólogo.

${ }^{11}$ Tomado de: Delvat, Juan Antonio. "Beccaria en España”. En: Beccaria, Cesare. De los Delitos y de las Penas. Madrid. Alianza Editorial. S.A. 1982. Pág. 171.
} 
La mayor parte de las disposiciones del último título ordenaban que en las Indias se aplicasen a los delitos las penas impuestas por las leyes generales de España.

En el caso de la Nueva Granada el derecho castellano fue utilizado con carácter de supletorio hasta bien entrada la República. Hay que anotar que la Novísima Recopilación (1806) no alcanzó a tener vigencia durante la época colonial, pero fue ampliamente usada en el siglo xix. ${ }^{12}$

En la segunda mitad del siglo xvil los funcionarios que administraban justicia en la Nueva Granada también consideraron necesario eliminar la multitud de leyes que la hacían difícil y confusa. Así, el Gobernador de Antioquia Francisco Silvestre en su "Relación de la Provincia de Antioquia" opinaba:

Las leyes mientras más claras y concisas son mejores porque no dan lugar a interpretaciones y tergiversaciones. Unas son fundamentales y que no admiten variación; $\mathrm{y}$ otras que la deben tener según la variación de costumbres y tiempos a que debe siempre acomodarse. ${ }^{13}$

La necesidad de una reforma en este campo también fue sostenida por los hombres de la Independencia. En la Constitución del Estado de Antioquia, sancionada en 1812, se estipulaba que tan pronto como lo permitieran las circunstancias se debía formar un código criminal, en el que las penas:

Guarden exacta proporción con los delitos; los delincuentes sean justa y brevemente castigados y ninguno sufra privaciones violentas, ni vejaciones antes de ser sentenciado. ${ }^{14}$

12 Vélez, Fernando. Datos para la Historia del Derecho Nacional. Medellín. Imprenta del Departamento. 1891. Pág. 194.

${ }^{13}$ Este personaje fue Gobernador interino de 1775 a 1776 y en propiedad de 1782 a 1785.

Silvestre, Francisco. Relación de la Provincia de Antioquia. Medellín. Ediciones especiales. Vol. 4. Secretaría de Educación y Cultura de Antioquia. 1988. Pág. 505.

${ }_{14}$ Pombo, Manuel Antonio y Guerra, José Joaquín. Constituciones de Colombia. Bogotá. Biblioteca Banco Popular. Tomo I. 1986. Artículo 10. Pág. 483. 
Tampoco en este caso la tan anhelada reforma pudo llevarse a cabo inmediatamente. Un primer paso se dio por la Constitución de 1821, una vez lograda la Independencia. En ella se estableció como esencial en el Derecho Penal "la igualdad de todos ante la ley", modificando ciertos principios del Derecho Penal Español que establecía diferencias entre los delincuentes a causa de su condición social. Se garantizaba además la libertad y seguridad personales, de domicilio y correspondencia, la propiedad, el derecho de asociación y el de petición.

Sólo hasta el año de 1837 (Ley del 27 de Junio), se expidió el Primer Código Penal Neogranadino, que estaba dividido en 4 libros a su vez subdivididos en títulos, éstos en capítulos y algunos de ellos en secciones. El Libro $1^{\circ}$. Trataba "De los delitos y de las penas en general"; el Libro $2^{\circ}$. "De los delincuentes y del modo de graduar los delitos y aplicar las penas", el Libro $3^{\circ}$. "De los delitos y culpas contra la sociedad y de sus penas" y el Libro $4^{\circ}$. "De los delitos y culpas contra los particulares y de sus penas”. Al igual que el Código Penal Español de 1822, el Código de 1837 se basaba fundamentalmente en el derecho penal francés. ${ }^{15}$

Uno de los mayores problemas que afrontó la administración de justicia en el siglo xviI, debido a la existencia de leyes "oscuras" o que estaban sin uso, fue el dejar buena parte de las decisiones judiciales al arbitrio de los jueces. Para los críticos de la legislación criminal existente, esto daba lugar a la impunidad de los delitos o a que un mismo delito se castigase con diferentes penas, según la diversidad de jueces y en el mismo tribunal, de acuerdo al momento. ${ }^{16}$

Sobre el papel que el juez debía cumplir como intérprete de las leyes, los autores tenían opiniones contrarias. El crítico más conocido de los códigos penales existentes en la Europa del siglo xvill, es el Marqués Cesare Beccaria. En su obra "De los delitos y de las penas", publicada en 1764, afirmaba que los jueces no debían tener autoridad para interpretar las leyes penales, por no ser legisladores. Para él, el juez debía actuar de acuerdo con un sistema de

${ }^{15}$ Vélez, Fernando. Ob. cit. Pág. 195-199.

${ }^{16}$ Lardizábal y Uribe, Manuel. Ob. cit. Pág 71. 
silogismo perfecto: La premisa mayor debía ser la ley general; la menor la acción conforme o no a la ley, y la consecuencia, la libertad o la pena. ${ }^{17}$

Los autores españoles, por su parte, eran partidarios de dejar a discreción del juez la aplicación de la ley, porque éstas no podían hacerse de modo que comprendieran todos los casos que pudieran suceder. ${ }^{18}$

Al no haberse adelantado la anhelada reforma legal, los jueces de las posesiones americanas, al igual que en la metrópoli, quedaron sometidos a una doble alternativa: proceder de acuerdo con las leyes, decretando penas tenidas por crueles, o ser indulgentes y no observar las leyes que se debían cumplir. Al no haberse adecuado a los cambios del tiempo, las leyes criminales quedaban reducidas al papel de referentes. ${ }^{19}$

Fue lugar común en las sentencias de las causas seguidas en la jurisdicción de la ciudad de Antioquia decir que por piedad "no se aplicaban las penas de ley" y que en caso de reincidencia se procedería con todo el "rigor de derecho". Las penas dispuestas por la legislación eran usadas como una amenaza pero no se consideraba prudente, ni oportuno, aplicarlas. Un ejemplo típico de este comportamiento constituye el dictamen dado por el doctor Ignacio Uribe en el sumario instruido a Juan Bautista Díaz por unas heridas que con navaja infirió a José Aniceto Barrantes en 1803:

Es de condenarse en la pena de dos años de presidio confinándosele a uno de los de la plaza de la ciudad de Cartagena, pues la Ley $2^{\text {a }}$. Tít. 31. Part. $7^{\mathrm{a}}$ y la ley $2^{\mathrm{a}}$. Tít. 23. Libro 8 R. C. (Recopilación Castellana) miran semejante especie de atentados con tal horror que han predefinido que sus perpetraciones sean castigadas con la pena del último suplicio, pero la práctica de los superiores tribunales conformándose con la piedad que siempre resplandece en nuestros sabios legisladores, y por todas partes respira nuestra legislación, ha temperado esta pena conmutándola en la de presidio y galeras teniendo por apoyo mi concepto a la ley $1^{\mathrm{a}}$. Tít 24 . Libro $8^{\circ}$. De las castellanas y aún el señor D. Francisco Elisondo doctrinando

\footnotetext{
${ }^{17}$ Beccaria, Cesare. De los Delitos y de las Penas. Bogotá. Editorial Temis. S.A. 1987. Pág. 7.

${ }^{18}$ Lardizábal y Uribe, Manuel. Ob. cit. Pág. 75.

${ }^{19}$ Ibídem. Pág. 73.
} 
sobre el asunto Tomo $1^{\circ}$. Pág. 312 dice que esta pena fue impuesta más para el terror que para la ejecución. ${ }^{20}$

La no aplicabilidad de la ley dejaba el campo abierto a la costumbre. Esta era definida como la práctica frecuente que había adquirido fuerza de ley o el derecho no escrito que se había introducido por el uso. Para que una costumbre pudiera ser utilizada como ley era necesario que no fuera perjudicial al bien común ni contraria al derecho natural; que estuviera establecida públicamente sin que hubiera sido contradicha por el soberano; que se hubiera observado en el lugar donde se iba a aplicar 10 o 20 años y que se hubieran desechado en juicio las demandas presentadas contra su observancia. ${ }^{21}$

En el caso de la provincia de Antioquia hubo algunas sentencias que se constituyeron en referencias para los jueces que seguían juicios de igual naturaleza. Es el caso del dictamen dado por el doctor Ignacio Uribe en el juicio seguido en 1777 por injurias entre Isabel de Vargas y Rivera, vecina de Antioquia y Lorenzo de Agudelo:

Y aún cuando hubiese probado concluyentemente que dicha Isabel era mulata, con todo no se libertaría de esta pena, porque las injurias o defectos que no convienen a la República que se sepan (como la presente) aunque sean ciertas, se debe castigar al injuriante por convenir esto a la mayor paz y quietud del público, compruébase este acerto por doctrina del sabio regnícola Antonio Gómez y corrobora y confirma esta doctrina la ley $1^{\text {a }}$. Tít. 9. Libro 8. Ordenamiento. ${ }^{22}$

En el año de 1798 en una causa criminal seguida por Vicente Espinosa contra Juan de Dios de Vargas por haberlo tratado de zambo, el demandante pedía que el espíritu de la sentencia a que dio origen el dictamen de Uribe se tuviera presente en el caso. ${ }^{23}$

\footnotetext{
${ }^{20}$ A. H. A. Criminal. B. 30. Leg. 1800-1810. Doc. N 13. Fols. 67v.-68v.

${ }^{21}$ Escriche, Joaquín. Ob. cit. Pág. 521. Sala. Juan. Ob. cit. Págs. 18-19.

${ }^{22}$ A. H. A. Criminal. B. 54. Leg. 1770-1780. Doc. N ${ }^{\circ}$ 7. Fols. 65r.-66r.

${ }^{23}$ A. H. A. Criminal. B. 37. Leg. 1790-1800. Doc. $\mathrm{N}^{\circ}$ 13. Fols. 61r.-63r.
} 
Los problemas anotados hacen necesario precisar la base legal y jurídica utilizada por los asesores y jueces que actuaron en la jurisdicción de la ciudad de Antioquia en el periodo $1750-1814 .{ }^{24}$

Al inventariar los libros citados en sus dictámenes y sentencias, así como los títulos que conformaban sus bibliotecas, encontramos que las Siete Partidas y la Recopilación Castellana fueron los códigos más usados en la época colonial. La Nueva Recopilación de Castilla, publicada en 1806, fue utilizada durante el periodo de la Independencia como lo atestigua el hecho de que figurara entre los libros del doctor Ignacio Uribe, muerto en $1815 .{ }^{25}$

La obra jurídica más citada fue la Curia Filípica, escrita por Juan de Hevia Bolaños, natural de Oviedo, Principado de Asturias, publicada por primera vez en Lima en 1603 y reeditada con frecuencia a lo largo de los siglos xvir y xviII. Los autores mencionados por Hevia Bolaños, en su mayoría juristas españoles del siglo xvi, fueron los tratadistas más consultados en el Nuevo Reino de Granada. ${ }^{26}$

Con el fin de ubicar históricamente a estos eruditos, se reseñan, a continuación, algunos datos sobre la vida y obra de los más sobresalientes:

Alfonso de Acevedo (1518-1598), autor del "Comentarium juris civilis in Hispaniae regias constitutiones” que se empezó a imprimir en Salamanca en 1583 y las "Additiones ad Curiam Pisanam", impresa en Salamanca en 1593. ${ }^{27}$

Jerónimo Castillo de Bobadilla (mediados S. xv al xvi), natural de Medina del Campo, quien escribió la "Política para Corregidores y señores de vasallos en tiempos de paz y guerra y para prelados", publicada en $1597 .{ }^{28}$

${ }^{24}$ Lo complejo del derecho y la doctrina jurídica española se puede medir si tenemos en cuenta que en el libro Ilustración del Derecho Español de Juan Sala, publicado en 1803, se citaron 1958 leyes españolas, 1094 leyes romanas y se consultaron las obras de 53 autores españoles. Sala, Juan. Ob. cit. Tomo I. Pág. sin número.

${ }^{25}$ A. H. A. Mortuorias. Tomo 327. Doc. No 6216. Fols. 1r-5v.

${ }^{26}$ Diccionario Enciclopédico Hispanoamericano de Literatura, Ciencias, Artes, etc. Barcelona. Montaner y Simón. Nueva York. W.M. Jackson Inc. Tomo XI. Pág. 273.

Aguilera, Miguel. La Legislación y el Derecho en Colombia. Historia Extensa de Colombia. Vol. XXIV. Bogotá. 1965. Pág. 379.

${ }^{27}$ Enciclopedia Universal Ilustrada Europeo-Americana. Espasa-Calpe. S.A. Madrid. 1958. Tomo II. Pág. 204.

${ }^{28}$ Diéz Echarri, Emiliano y Roca Franquesa, José María. Historia de la Literatura Española e Iberoamericana. Madrid. Aguilar. 1960. 
Diego Covarrubias y Leiva (1512-1577), teólogo y jurista, estudió en la Universidad de Salamanca y en el Colegio Mayor de Oviedo, autor de "Variarum resolutionum ex jure pontificio regio et caesareo libri Iv" (1552-1570), "In Clementis constitutionem, sive Clementinam, sifuriosus, de homicidio; in regulam pecatu, in caput alma mater, de sententia excommunicationes; in regulam peccatum; in regulam possessor malae fidel, de regules jure lib. vi, relatione, practicarum quaestionum librum singulares" (1556-1594). ${ }^{29}$

Antonio Gómez (Siglo xvi), estudio en la Universidad de Salamanca de la que luego fue profesor. Entre sus obras figuran "Variarum resolutionum juris civilis comunis et regii Libri III" (Salamanca, 1552) y "Ad legis taurus commentarius absolutissimum". ${ }^{30}$

Juan Gutiérrez (Siglo xvi), también estudió en Salamanca, autor de una "Práctica civil, criminal y canónica”. ${ }^{31}$

Gregorio López de Tovar (Siglo xvi), graduado igualmente en Salamanca, se distinguió en la administración de justicia, para la cual fue elegido por Carlos I, obteniendo más tarde una plaza en el Consejo de Indias. Su fama se debió a la glosa con que ilustró el Código de las Partidas, trabajo publicado con el título de "Las Siete Partidas del Sabio Rey don Alonso el Nono, nuevamente glosadas por el Licenciado Gregorio López" (Salamanca, 1555).32

Este grupo de juristas forma parte de los sabios del Siglo de Oro español, al lado de literatos, médicos, astrónomos, botánicos, filólogos e historiadores. Llama la atención el que su vigencia se prolongara por más de dos siglos, a pesar de que las ideas sobre muchas prácticas jurídicas estaban cambiando.

En los escritos presentados en los juicios no encontramos referencias a autores "ilustrados". Sin embargo algunos de ellos eran conocidos en la provincia de Antioquia, como lo atestigua el hecho de tener el doctor Ignacio Uribe en su biblioteca varios tomos de los escritos de Benito Jerónimo Feijoo (16761764), autor de "El Teatro Crítico" (1726-1749) y "Las Cartas Eruditas"

\footnotetext{
${ }^{29}$ Enciclopedia Universal Ilustrada Europeo-Americana. Tomo XV. Págs. 1413-1414.

30 Ibídem. Tomo XXVI. Pág. 544.

${ }^{31}$ Ibídem. Tomo XXVII. Pág. 365.

${ }^{32}$ Diccionario Enciclopédico Hispanoamericano de Literatura, Ciencias, Artes, etc. Tomo XII. Pág. 1117.
} 
(1741-1760), a quien se le dio el sobrenombre de "El Voltaire Español" y parte de las obras de Pedro Rodríguez, Conde de Campomanes (1723-1803), el fundador de las Sociedades Económicas de Amigos del País, uno de los políticos españoles más importantes de su época. ${ }^{33}$

El Doctor José Pardo, por su parte, tenía entre sus libros el "Proyecto económico en que se proponen varias providencias dirigidas a promover los intereses de España con los medios y fondos necesarios para su plantificación" (1782), escrito por Bernardo Ward, economista irlandés, quien se estableció en España donde fue Presidente del Tribunal de Comercio y Director de la Casa de la Moneda. ${ }^{34}$

Entre los autores clásicos, Cicerón (106-44 A. d. J.C.) fue el más leído por los abogados antioqueños. Los escritos de este autor romano están recopilados en 18 volúmenes, de los cuales 3 son tratados de "retórica", 6 de discursos escritos para ser pronunciados en el Senado o en los tribunales de Justicia, 4 de cartas, 4 de obras filosóficas y uno de fragmentos. ${ }^{35}$

De los autores medievales, al que más autoridad se le otorgó fue al fraile dominico, de origen lombardo, Santo Tomás de Aquino (1225-1274), quien fue profesor de filosofía y teología en la Universidad de París. De su extensa obra, las más difundidas eran la "Suma contra los gentiles" escrita de 1259 a 1264 y la "Suma Teológica" cuya composición se inició en 1266 y no había concluido al morir el autor. Este libro es una síntesis orgánica del pensamiento cristiano elaborado a lo largo de 13 siglos. ${ }^{36}$

${ }^{33}$ Enciclopedia Universal Ilustrada Europeo-Americana. Tomo X. Pág. 1318. Tomo XXIII. Págs. 1159-1162.

${ }^{34}$ Diccionario Enciclopédico Hispanoamericano de Literatura, Ciencias, Artes, etc. Tomo XXIII. Pág. 16.

A. H. A. Mortuorias. Tomo 270. Doc. $N^{\circ}$ 5657. Fols. 30r.-31v.

${ }^{35}$ Barrow, R. H. Los romanos. México. Fondo de Cultura Económica. 1970. Págs. 71-72.

${ }^{36}$ Ortega Noriega, Sergio. "El discurso teológico de Santo Tomás de Aquino sobre el Matrimonio, La Familia y los Comportamientos Sexuales”. En: El Placer de Pecar y el Afán de Normar. México. Joaquín Mortiz. Instituto Nacional de Antropología e Historia. 1987. Págs. 19-23. 
Esta simple enumeración explica por qué un abogado de la época señalaba la necesidad de consultar la multitud de códigos, leyes y autores existentes como una de las causas de la lentitud de los juicios. ${ }^{37}$

Del cuadro que hemos pintado podemos inferir que en la provincia de Antioquia, para la época estudiada, la "ley" no tenía un significado unívoco. Los gobernantes enfrentados a los problemas que se derivaban de su ejercicio como jueces, consideraban necesaria la publicación de un código que no diera lugar a "interpretaciones ni comentos". Los gobernados, por su parte, sentían el rigor de la aplicación de la ley o se beneficiaban de la imposibilidad de ponerla en práctica. La legislación era constantemente invocada por las autoridades, pero los datos de los juicios arrojan dudas sobre la forma como era respetada y acatada por parte del pueblo. ${ }^{38}$

Este es el contexto en que algunos gobernantes ilustrados, de la segunda mitad del siglo xviII, se propusieron hacer reformas a la administración de justicia.

${ }^{37}$ Restrepo, José Manuel. Historia de la Revolución de la República de Colombia. Medellín. Editorial Bedout. 1969. Tomo I. Pág. 31.

${ }^{38}$ Silvestre, Francisco. Ob. cit. Pág. 206. (N. del E.) En la edición de 1994 el llamado de esta nota no está señalado dentro del texto, pero sí al final del capítulo. En la presente edición se determinó su ubicación actual. 


\section{B. El juicio criminal}

El derecho español definía el juicio criminal como aquel que tenía por objeto la averiguación de un delito, el descubrimiento del que lo cometió y la imposición de la pena merecida. ${ }^{1}$

Para la correcta tramitación de una causa, los diferentes códigos vigentes prescribían una serie de procedimientos. Los defectos que en uno de los pasos tuviera el juicio podrían dar origen a que se invalidara su resultado, de allí que muchos procesos se acrecentaran con discusiones sobre si los jueces habían cumplido correctamente lo dispuesto. Esto no siempre era fácil de determinar debido a la cantidad de leyes existentes y a la diversidad de interpretaciones que se les podían dar.

Teóricamente un juicio criminal se dividía en dos partes: Una primera encaminada a la justificación del delito y a sus autores, contenía diligencias como el examen del agraviado o representante, reconocimiento de facultativo en casos de heridas $u$ homicidios, recolección de los instrumentos o efectos con que se cometió el delito, examen de testigos, arresto del autor y los cómplices, embargo de los bienes, declaración indagatoria y confesión del reo.

En la segunda parte se discutía la culpabilidad o inocencia de los procesados y culminaba con la sentencia proferida por el juez. Incluía la acusación por parte del ministerio fiscal o querellante, la defensa y las pruebas presentadas por cada parte. ${ }^{2}$

En la práctica, muchas de las causas tramitadas por homicidios, lesiones personales o injurias en la jurisdicción de la ciudad de Antioquia, entre 1750 y 1819, no cumplieron con la totalidad de los pasos enumerados, debido a que el juez seguía un procedimiento abreviado para sustanciación. De otra parte, un gran número de juicios (95 de 356) quedó inconcluso, porque el acusador no volvió a presentarse, el reo huyó o no se concluyeron las diligencias.

${ }^{1}$ Escriche, Joaquín. Diccionario Razonado de Legislación y Jurisprudencia. Paris. México. Librería de la Vda. De Ch. Bouret. 1911. Pág. 1002.

${ }^{2}$ Escriche, Joaquín. Ob. cit. Págs. 1011-1012. 
A continuación se analizará cada una de las partes en que se dividía el juicio criminal: Denuncia, comprobación del hecho, prisión y embargo de bienes, confesión, acusación, defensa, presentación de pruebas, sentencia y apelación. Para su examen se partirá de lo dispuesto por la legislación y de la información contenida en los casos estudiados para jurisdicción de la ciudad de Antioquia en el periodo 1750-1820.

\section{La denuncia}

Toda causa criminal comenzaba cuando el acusador o denunciador manifestaba un delito delante de un juez. El acusador era quien denunciaba el delito al juez para tomar venganza, acusando al delincuente y pidiendo que le condenaran en las penas estipuladas por la ley. ${ }^{3}$ El denunciador por su parte, sólo manifestaba al juez el crimen cometido y su autor si lo sabía, para que este procediera a practicar lo que le correspondía. ${ }^{4}$ Toda persona, sin excepción ni prohibición alguna, podía ser denunciador. ${ }^{5}$

La posibilidad de ser acusador dependía de que el delito fuera público o privado. El derecho español consideraba como público todo delito hecho en ofensa de Dios, en contra el Príncipe o del Estado, y el que cometido contra los particulares, amenazaba la seguridad de todos como el asesinato, la violencia y el incendio. En esta clase de delitos la acción de acusar competía a todo el pueblo. ${ }^{6}$ Delito privado era el que ofendía y dañaba directamente a un particular, sin que peligrara el resto de la sociedad, como la injuria verbal. En este caso la acción de queja sólo competía a los ofendidos.

Teniendo en cuenta estas diferencias, veamos la forma como se dio principio a las causas estudiadas. De las 136 causas por injuria, 118 (86,7\%) comenzaron al presentarse el agraviado directamente o a través de un representante. Por tratarse de un delito privado es explicable que sólo 12 juicios

${ }^{3}$ Hevia Bolaños, Juan. Curia Filipica. Madrid. Impresor Pedro Marín. 1776. Tomo I. Pág. 198.

${ }^{4}$ Escriche, Joaquín. Ob. cit. Págs. 1010.

${ }^{5}$ Hevia Bolaños, Juan de. Ob. cit. Tomo I. Pág. 198.

${ }^{6}$ Alvarez Posadilla, Juan Lic. Práctica Criminal por Principios, o Modo y Forma de Instruir los Procesos Criminales de las Causas de Oficio de Justicia. Valladolid. Imprenta de la Vda. E Hijos de Santander. 1802. Tomo III. Págs. 4-5.

Escriche, Joaquín. Ob. cit. Pág. 534. 
$(8,8 \%)$ fueran empezados de oficio por el juez, debido a quejas o noticias (ver cuadro $\mathrm{N}^{\circ} 54$ ).

Aunque por las Leyes de Partida se prohibía que las mujeres actuaran como acusadoras, 17 de las 33 mujeres víctimas de injurias presentaron su queja directamente ante la justicia. Sólo dos de ellas dejaron constancia de tener licencia del marido. De las restantes, 12 comparecieron por medio de un apoderado, casi siempre un hombre miembro de su familia. ${ }^{7}$

La iniciación de un juicio por una injuria verbal dependía del interés del agraviado en seguir un proceso que podía ser largo y costoso. A mediados del Siglo xviII el bajo número de juicios iniciados por esta causa ( 5 entre 1750 y 1759) nos muestra que la gente prefería resolver las diferencias por fuera del arbitrio de la justicia. Al finalizar el siglo la situación era completamente distinta (39 juicios en la década 1790-1799), lo que podría deberse a una aceptación cada vez mayor de la Real Justicia como mediadora en los conflictos de los particulares. ${ }^{8}$ Este cambio podría ser el producto del interés de los Gobernadores visitadores Francisco Silvestre (1782-1785) y Juan Antonio Mon y Velarde (1785-1788) por fortalecer y hacer más expedito el funcionamiento de la justicia. Con respecto a los pleitos, Silvestre opinaba que:

consumen a los vasallos, los distraen de sus principales atenciones se pierden $\mathrm{o}$ arruinan sus familias y apartan una porción de brazos útiles a la agricultura, y a otras artes útiles. ${ }^{9}$

Para remediarlo proponía la elaboración de un nuevo código, que se mandase a observar sin dar lugar a interpretaciones, lo que evitaría la información de procesos prolongados.

Pero independientemente de la mayor eficacia de los tribunales, hay que preguntarse qué impulsaba a una persona a seguir una causa por injurias

\footnotetext{
${ }^{7}$ Hevia Bolaños, Juan de. Ob. cit. Tomo I. Pág. 199.

${ }^{8}$ Reinhardt, Steven. "Crime and Royal Justice in Ancien Regime France: Modes of Analisis" Journal of Interdisciplinary History. XIII. Winter. 1983. Págs. 455-459.

${ }^{9}$ Silvestre, Francisco. Relación de la Provincia de Antioquia. Medellín. Ediciones Especiales. Vol. 4. Secretaría de Educación y Cultura de Antioquia. 1988. Págs. 505-506.
} 
y quiénes eran los que acudían a los juzgados por este motivo. El historiador Jaime Jaramillo Uribe ha propuesto como explicación, que el grupo español y blanco al ver amenazadas sus ventajas y privilegios por el creciente aumento de la población mestiza, reaccionó defendiéndolos con mayor celo e intransigencia. Opina que en el caso de Antioquia y Santander, los que defendían su honor mancillado lo hacían con la convicción de estar defendiendo el orden social y la justicia. ${ }^{10}$ Corroborando esta afirmación encontramos que de 1750 a 1780 , 42 blancos presentaron acusaciones por haber sido insultados, mientras que 24 libres hicieron lo propio. Lo llamativo es que en las dos décadas siguientes (1790-1809) la proporción se invierte, siendo 52 los libres y 26 los blancos que inician juicios de esta clase. Qué había ocurrido? Es difícil dar una respuesta concluyente, pero no debemos olvidar que a partir de 1780, las cifras de fundición de la caja de la ciudad de Antioquia muestran un aumento considerable en la producción del oro extraído por los mazamorreros o trabajadores mineros libres (El promedio anual de fundición entre 1780 y 1800 es de 236,387 pesos). La mayor parte de estos trabajadores mestizos y negros libres estaban localizados en la Región de los Osos, que correspondía a la jurisdicción de la ciudad de Antioquia. Estos años también reflejan un incremento en la actividad comercial de la zona, lo que muestra una elevación en el nivel de vida de la población libre. ${ }^{11}$ Otro indicativo del aumento de la capacidad de compra de los mestizos y mulatos de la región, fue que 84 de ellos compraran esclavos entre 1785 y $1799 .{ }^{12}$

Como resultado de este desarrollo, a fines del siglo, parece haber un proceso de ascenso social de algunos libres, especialmente de gente vinculada a las actividades comerciales. El origen de algunos conflictos parece estar en los resquemores que producían los éxitos económicos de personas pertenecientes a las castas, entre los miembros de su grupo.

${ }^{10}$ Jaramillo Uribe, Jaime. "Mestizaje y Diferenciación Social en el Nuevo Reino de Granada en la segunda mitad del Siglo XVIII". Ensayos sobre Historia Social Colombiana. U. Nacional. 1968. Págs. 181-182.

${ }^{11}$ Twinam, Ann. Mineros, Comerciantes y Ladradores. Las Raíces del Espíritu empresarial en Antioquia 1763-1810. Medellín. FAES. 1985. Págs. 60-61 y 98 a 101.

${ }^{12}$ Archivo Notarial de Antioquia. Protocolos Notariales. 1785-1799. 
Un ejemplo que ilustra este fenómeno es el del comerciante Salvador Sarrazola, quien de 1794 a 1798 se vio involucrado en cuatro juicios por injurias verbales con mestizos y negros libres. Uno de los agresores, Miguel Marín acusó a Sarrazola de "malos tratos" y de tener dos caras con la gente "pobre y campesina".

Halagüeño y atractivo para vender, pero ríspido y temerario para cobrar. ${ }^{13}$

Si se analizan los datos correspondientes a las causas seguidas por heridas y lesiones personales, se encuentra que de 203 juicios 127 (62,56\%) comenzaron al presentarse la víctima o un representante suyo ante un juez. Los casos que involucraban violencia, 56 (27,58\%), fueron seguidos de oficio por los jueces competentes (ver cuadro $\mathrm{N}^{\circ} 57$ ). Estas cifras revelan que la mayor parte de las causas eran por golpes, bofetones, arañazos y heridas de poco riesgo. Desde el punto de vista procedimental, estos juicios no se diferencian de los de injurias y los motivos por los cuales las personas presentaban una acusación de esta clase, suelen ser los mismos.

Por tratarse de personas a las que la ley no les daba la facultad de ser acusadores, es interesante detallar lo relativo a los juicios en que los agredidos eran mujeres o esclavos. En cuanto al primer grupo tenemos que de 84 mujeres objeto de algún tipo de violencia física, únicamente 18 (21,42\%) se presentaron, a nombre propio, a hacer la acusación. Por su parte 24 (28,57\%) pusieron su demanda a través de un representante y 25 (29,76\%) se vieron involucradas en causas que empezó algún juez por noticias o denuncios. Para analizar estos datos, no se debe perder de vista que $34(40,4 \%)$ eran mujeres que habían sido maltratadas por sus maridos. En esa época debía ser difícil que una esposa pusiera una denuncia de esta clase, pues sólo siete presentaron la demanda directamente en el juzgado.

${ }^{13}$ Archivo Histórico de Antioquia. Criminal. B. 37. Leg. 1790-1800. Doc. № 1. Fols. 55r-58v. Un indicativo del éxito económico de Sarrazola es que entre 1782 y 1795 compró 7 esclavos, siendo el libre que más esclavos adquirió. A. N. A. Protocolos Notariales. Años 1782, 1785, $1789,1790,1794$ y 1795. 
Con respecto al segundo grupo, el de los esclavos, 33 figuran como víctimas; de ellos, cuatro se presentaron directamente, 14 lo hicieron a través de un representante y 12 estuvieron comprometidos en juicios seguidos de oficio o por denuncias de un tercero. A partir de la década del 80 se hicieron frecuentes las causas por maltratos seguidas por los esclavos contra sus amos. En la mayor parte de ellas actuó como representante el defensor de menores o el protector de esclavos. Se trataba de quejas por castigos indebidos, falta de alimentos y ropa, que tenían por objeto lograr un cambio de dueño o un avalúo bajo que les permitiera comprar su libertad. Este hecho se explica por la promulgación de algunas regulaciones relativas al tratamiento de los esclavos; especialmente de la Real Cédula del 31 de Mayo de 1789 "Sobre trato y Educación de los Esclavos en todos los territorios de las Indias e Islas Filipinas". ${ }^{14}$

La situación que se presenta en los juicios por homicidio es totalmente distinta. El Derecho Romano siempre lo reputó por delito público y el Derecho Español, como derivado de éste, lo catalogó de la misma manera. ${ }^{15}$ Consecuentemente, encontramos que 30 (69,77\%) de los 43 casos estudiados, fueron iniciados de oficio por los Alcaldes o el Gobernador; cinco juicios se iniciaron después de la acusación hecha por la familia de la víctima y cuatro por presentarse los dueños de esclavos muertos (ver cuadro $\mathrm{N}^{\circ} 60$ ). En este caso no se trataba de un delito cuya denuncia fuera opción del agraviado, sino que una vez se tenía conocimiento de un asesinato la justicia abría la causa. La situación se prestaba para hacer denuncias de "muertes sospechosas", lo que casi siempre terminaba con la absolución de los supuestos inculpados, por falta de pruebas.

\section{Comprobación del hecho}

Los pasos siguientes de un juicio debían llevar a la comprobación del hecho y la indicación del delincuente, de allí que lo primero que un juez debía hacer era averiguar si se había cometido el delito. En los juicios por heridas u homicidio,

\footnotetext{
${ }^{14}$ Jaramillo. U., Jaime. Ob. cit. Pág. 33.

${ }^{15}$ Alvarez Posadilla, Juan. Ob. cit. Tomo III. Pág. 101.
} 
el juez procedía de oficio o por petición de parte, debía ir o enviar un oficial suyo al lugar de los hechos, para dar fe de la existencia de un herido o muerto. ${ }^{16}$

Aunque se supone que este era un trámite obligatorio, no todos los juicios por lesiones personales cumplieron con este requisito, ya fuera porque el delito se había cometido mucho antes de la denuncia o porque la herida o golpes eran de poca importancia. Así, de las 283 personas víctimas de agresiones físicas, solamente 74 fueron reconocidas por el juez, el escribano o un perito.

De los hombres que actuaron como peritos, únicamente tres, que figuraron coyunturalmente, fueron denominados "médicos", mientras que 12 eran designados como "prácticos cirujanos". Entre este último grupo sobresalen algunos que ejercieron esta profesión por largo tiempo e intervinieron en varias causas. Los más importantes en orden de aparición fueron: Juan Quintero quien dio dictámenes entre 1757 y 1766. Rafael Quintero, quien en 1780 a los 25 años emitió su primer concepto y en 1815 a los 60 años hizo su último peritazgo. Agustín Muriel Pérez, contemporáneo de Quintero, inició su actividad en 1782 y la culminó en 1803; en la década del 90 se le daba el título de Maestro Mayor. Martín Agudelo, actuó en la segunda década del siglo xix, figurando en 1817 como cirujano de la tropa.

Por su parte, seis mujeres que eran parteras o "inteligentes en la materia" emitieron conceptos. De ellas la única que hizo reconocimientos en caso en que los heridos eran hombres, y participó en la curación de éstos, fue doña Isabel de Poveda, quien ejerció la profesión entre 1759 y 1767 en Sopetrán. Las mujeres tenían que vencer la idea común de que su intervención dilataba el tiempo necesario para sanar una herida. En una de las causas en que intervino doña Isabel se decía:

Confiando la curación de ella a una mujer cuando aún la ropa de este sexo es nociva, según los cirujanos, a toda úlcera. ${ }^{17}$

${ }^{16}$ Hevia Bolaños, Juan de. Ob. cit. Tomo I. Pág. 206.

${ }^{17}$ A. H. A. Criminal. B. 74. Leg. 1760-1780. Doc. $\mathrm{N}^{\circ}$ 1. Fol. 58r-61r. 
Esta debió ser una de las razones para que a partir de 1765 las prácticas sólo atendieran a personas del sexo femenino.

En ocasiones (25 de los 74 casos), debido a que el hecho había ocurrido en un lugar alejado o por no existir un cirujano a mano, el trámite del reconocimiento lo hacía el juez, el escribano o personas nombradas para este fin, quienes actuaban acompañados de testigos.

Aún los exámenes hechos por los "prácticos cirujanos" reflejan un escaso conocimiento de la anatomía, pues los músculos no son designados por precisión. Las opiniones sobre la gravedad de la herida se limitaban a comentarios generales y las curaciones realizadas se reducían a prescribir una dieta y algunas bebidas y a alertar sobre contraindicaciones. Un ejemplo típico de reconocimiento de heridas fue el que hicieron, en 1804, los cirujanos Muriel Pérez y Rafael Quintero, de 22 y 25 años de experiencia.

Aunque no son profesores de cirugía y que sólo les asiste algunas experiencias, y en esta virtud procedieron a practicar la diligencia por estar y tener de presente la persona de Aniceto Barrantes... en cumplimiento de lo mandado han reconocido a Aniceto Barrantes, en cuya persona y en el brazo del lado derecho se ha reconocido, que tiene dos heridas, una sobre el hombro y otra en la muñeca: Que éstas según les parece son hechas con instrumento cortante, que no están de gravedad, y que tampoco traerán malos resultos, siempre que el paciente se cuide de sol y sereno, que son dos cosas que causan malos efectos. ${ }^{18}$

Teniendo en cuenta el precario desarrollo de la atención médica y que sólo uno de los pacientes falleció por complicaciones ulteriores, se puede deducir que la mayoría de las heridas reportadas no debían ser muy graves.

Tampoco en los juicios por homicidio se hizo el reconocimiento del cadáver en todos los casos. De los 44 supuestas víctimas sólo 19 fueron examinadas, habiendo realizado la mayor parte de estos trámites los jueces con testigos (14 casos). En tres casos el reconocimiento inicial fue por heridas, a

${ }^{18}$ A. H. A. Criminal. B. 30. Leg. $1800-1810$. Doc. $\mathrm{N}^{\circ} 13$. Fol. 3r-4r. 
consecuencia de las cuales se produjo la muerte. En dos ocasiones de estas la primera observación la hizo un "cirujano" y con posterioridad se consignó el fallecimiento por parte del juez o un delegado.

La descripción del cadáver y las circunstancias en que había sido hallado era esquemática, reduciéndose a consignar la presencia de heridas o golpes que hubieran podido causar la muerte y evidenciar rastros de acciones violentas. Un ejemplo que ilustra la forma como se realizaba esta diligencia es el siguiente:

Don Francisco Javier Jaramillo Alcalde juez pedáneo... habiendo llegado a al casa de don Francisco Antonio Cossio, por quien se me había dado la noticia, le pregunté que adonde estaba la muerta, a lo que me respondió: vamos a verla y con efecto bajamos a la quebrada con Juan José Pimienta y Gregorio Moreno; y encontré una mujer muerta, que según le reconocimos las heridas fue a piedra, como que tenía tres, una en una cien y las otras dos en la cabeza... pasamos al paraje en donde sucedió la muerte y encontramos la playa ensangrentada y tres piedras también con alguna sangre que nos hicimos cargo que con ellas sucedió la muerte y también vimos el arrastradero por donde la habían echado a la quebrada. ${ }^{19}$

Después de haber hecho constar la existencia del delito, el juez debía proceder a averiguar por el delincuente, a través de una sumaria información de testigos. Primero debía tomar la declaración del herido u ofendido, para instruirse del caso y después examinar a los que pudieran saber de él, preguntándoles cómo, de qué manera y por qué causa ocurrió el hecho, quién fue el agresor, qué palabras intercambió con el agredido, en qué lugar fue cometido el delito, qué día y a qué hora y las personas que se hallaban presentes. Estas declaraciones debían ser consignadas en el proceso.

Escribiéndolas por las mismas palabras elegantes o torpes que los testigos dijeron. ${ }^{20}$

\footnotetext{
${ }^{19}$ A. H. A. Criminal. B. 52. Leg. 1780-1790. Doc. No 8. Fol. 1 r-v.

${ }^{20}$ Hevia Bolaños, Juan de. Ob. cit. Tomo I. Pág. 207.
} 
Veamos ahora lo que a este respecto ocurría en las causas analizadas. En los juicios por heridas no todas las víctimas hicieron declaración, bien por estar incluido su caso en un proceso en el cual la agresión principal había sido hecha contra otra persona, o porque al presentarse a instaurar la demanda expuso los hechos y el juez no consideró necesario interrogarlo por separado.

De las 283 personas a quienes se les infringió golpes, heridas, arañazos, únicamente a 77 se les tomó declaración y 11 fueron sometidas a una confesión por presumirse que tenían culpabilidad en los hechos. Si comparamos estos datos con los obtenidos en los reconocimientos de heridas, se puede deducir que en una tercera parte de los juicios, las lesiones fueron lo suficientemente graves para exigir que la causa se instruyera de acuerdo con las normas establecidas por la ley.

En las causas por injuria fue menor el número de agraviados que dio declaración. Así, en la década del 90, cuando se siguió la mayor cantidad de juicios de esta clase, de 49 víctimas, sólo tres fueron interrogadas por el juez y a una se le tomó confesión. Esto parece tener relación con el hecho de que el 90\% de estos procesos fueron seguidos a petición del injuriado.

El examen de los testigos debía ser hecho personalmente por el juez, sin delegarlo al escribano o a otra persona. Esta disposición se fundamentaba en la idea de que de esta manera el juez se informaba mejor del hecho y podía saber el crédito que debía dar a cada testimonio. ${ }^{21}$ Según la definición de las Siete Partidas y la Novísima Recopilación, testigo era toda persona fidedigna, de uno y otro sexo, que pudiera manifestar la verdad o falsedad de los hechos controvertidos. Para ser testigo se necesitaba edad, conocimiento, probidad e imparcialidad. ${ }^{22}$ Teniendo como referencia esta definición analicemos en el caso de la ciudad de Antioquia quiénes actuaron como testigos y cuáles eran sus características.

En las causas por homicidio seguidas en la ciudad de Antioquia de 1750 a 1812, encontramos que el número de hombres que actuaron como testigos fue superior al de mujeres (319 sobre 78). Esta relación también se encuentra

${ }^{21}$ Ibídem. Pág. 207.

${ }^{22}$ Ley 9. Tít. 16. Partida 3. Título 11. Libro 11 de la Novísima Recopilación. Escriche, Joaquín. Ob. cit. Pág. 1499. 
en las causas por injuria o heridas tramitadas entre 1810 y 1819 , en las que declararon 227 hombres contra 28 mujeres (ver cuadros $\mathrm{N}^{\circ} 44$ y 49 ). ${ }^{23}$

Aunque desde el punto de vista legal no encontramos una disposición que restara credibilidad a las declaraciones de las mujeres, existía la creencia popular de que éstas eran dadas a exagerar las cosas o a mentir. Así, por ejemplo, en el juicio seguido en 1773 contra Salvador Ochoa por maltratos a su esposa María Sebastiana Ruiz, los cuatro testigos interrogados sobre los hechos fueron mujeres, circunstancia que trató de ser aprovechada por el defensor del reo, capitán don Pablo Carvajal, para cuestionar la gravedad del caso. Su razonamiento era el siguiente:

Mas no obstante, hallo no ser el delito cometido tan grave como lo figura la información del juez comisionado don Felipe de Aguirre. Las razones; Que los testigos de la sumaria son todas mujeres. Estas por su naturaleza son enemigas de los hombres y como tales, no me maravilla hayan declarado a favor de la mujer del dicho Ochoa. Lo que me maravilla es haberse hallado presentes tan tarde de la noche siendo horas de dar descanso al cuerpo con el sueño acostumbrado, éstas dejan el reposo y andan fuera de su casa en casas ajenas y aún en los campos y no haberse encontrado ni hallado un varón sino todas mujeres. Pregunta mi ignorancia. Es prueba suficiente la declaración de cuatro mujeres rústicas que aún no sabrán la gravedad del juramento para que haciéndose cargo de su peso se presuma han dicho la verdad, cuando es axioma muy cierto que la mujer miente cuando puede y llora cuando quiere ${ }^{24}$

En el mismo contexto se puede inscribir el discurso del defensor en el juicio por homicidio seguido en 1757 contra Ignacio Arias, Bonifacio Arias y Juana María Crespo, por la muerte de Pedro Ramírez, marido de Juana. En este caso,

${ }^{23}$ Se tomaron los datos de los juicios por homicidio por ser los casos en que los testimonios fueron evaluados con mayor cuidado por la fiscalía, la defensa y el juez que dictaba sentencia. Como la serie de causas por homicidio llega hasta 1812, se procesaron los datos de los testigos que intervinieron en los juicios de injurias y lesiones personales entre 1810 y 1819, por considerar necesario ilustrar lo ocurrido durante el periodo de la Independencia.

${ }^{24}$ A. H. A. Criminal. B. 37. Leg. 1700-1780. Doc. $\mathrm{N}^{\circ}$ 18. Fol. 37r-38r. 
la defensa pidió la absolución de los reos sobre la base de que la acusación había tenido su origen en afirmaciones hechas por la negra María Severina Gómez, a quien tildaba de "chismosa y enredadora" y "devota del dios baco". Argumentaba que como "tonta y loca”, juzgó que las señales del cuerpo del difunto hacían suponer que había sido asesinado y como "un tonto hace ciento" todos repitieron su "temerario juicio". ${ }^{25}$

Un dato que se consignaba en las declaraciones era la procedencia étnica de los testigos, sobre todo al tratarse de indios o de esclavos. Estos últimos debían contar con licencia de los amos. La composición racial del grupo de 397 testigos que declaró en los juicios por homicidio era la siguiente: 83 blancos (20,9\%), 269 libres (67,7\%), 32 esclavos (8,0\%), y 13 indígenas (3,2\%) (ver cuadro $\mathrm{N}^{\circ} 45$ ). En este caso la participación de los blancos como testificantes es bastante elevada, pues de acuerdo con los datos de los censos de población de la jurisdicción de la ciudad de Antioquia del periodo (1777-1820), eran menos del 10\% de los habitantes (ver cuadros $\mathrm{N}^{\circ} 63,65$ y 66). Adicionalmente se debe tener presente que en pocos procesos por homicidio los blancos se vieron inmiscuidos como víctimas o agresores (ver cuadros $\mathrm{N}^{\circ} 29$ y 30 ). El que los blancos fueran llamados a declarar pudo deberse a que se confiaba más en su palabra que en la de los miembros de las "castas".

En el periodo colonial la etnia y su relación con una condición económica, era utilizada como argumento para demeritar la veracidad de una declaración. De acuerdo con las leyes de Partida no podía ser testigo el hombre muy pobre, a menos que fuera de buena reputación y arreglada conducta. ${ }^{26}$

Un ejemplo de la forma como se cuestionaba a los testigos por pertenecer a una "condición baja", es uno de los alegatos presentados por Salvador Sarrazola, en un juicio por injuria que siguió de 1794 a 1796 contra Miguel Marín. Al hablar de la información presentada por el contrario, decía:

Esta no solamente está formada por preguntillas pueriles, vanas y ridículas, que tienen más parte de malicia que de realidad, sino también con testigos

\footnotetext{
${ }^{25}$ A. H. A. Criminal. B. 27. Leg. 1750-1760. Doc. No 7. Fol. 74r-76v.

${ }^{26}$ Leyes 8 y 22. Titulo 16. Partida 3. En: Escriche, Joaquín. Ob. cit. Pág. 1499.
} 
ineptos e incapaces de hacer prueba y fe como reprobados y repelidos por derecho, Miguel Valenzuela por pobre miserable, que por cualquier interés se hará venal, el negro zapatero Raimundo Ferraro por clase y condición vil, el negro liberto zapatero Francisco Rave, por la misma razón, Francisco Zamora por ser otro pobre. ${ }^{27}$

Como consecuencia de estas afirmaciones Raimundo Ferraro instauró un pleito contra Sarrazola, en el que pedía al Gobernador declarar si las expresiones vertidas por Sarrazola le serían obstáculo para ser testigo. En sentencia dada en abril de 1796, el Gobernador Inciarte decidió que en cuento a la "calidad de la persona", no podía atestiguar en algunos casos y circunstancias y en cuanto a la ocupación, no tenía impedimento porque:

Los oficios que en sí se dicen mecánicos no es porque envilezcan la persona sino por distinguirlos de otros que tienen mayor realce. ${ }^{28}$

En los juicios por injuria o lesiones personales seguidos en la década de 1810 a 1819, de 255 declarantes, 38 eran blancos (14,90\%), 208 libres (81,56\%), 5 indios (1,96\%) y 4 esclavos (1,56\%) (ver cuadro $\mathrm{N}^{\circ} 50$ ). Relacionando estos datos con los precedentes encontramos un aumento de la participación del grupo de gente libre. Sin embargo, este hecho puede deberse sólo a cambios en el lenguaje utilizado. En la época de la Independencia, por influencia de la ideología republicana, se dejó de diferenciar a los blancos del resto de gente libre. Esto se corrobora con el Censo de 1820 en donde se clasifica a la población en libres, indígenas y esclavos (ver cuadro $\mathrm{N}^{\circ} 68$ ).

Es interesante anotar que en las causas seguidas en la época del gobierno patriota (1810-1819), sólo 22 testigos usan el título de ciudadano. Hay que tener presente que por la Constitución del Estado Soberano de Antioquia de 1812, era ciudadano con pleno derecho de elegir y ser elegido.

${ }^{27}$ A. H. A. Criminal. B. 37. Leg. 1780-1790. Doc. $\mathrm{N}^{\circ}$ 1. Fol. 36r-38r.

${ }^{28}$ A. H. A. Criminal. B. 43. Leg. 1800-1810. Doc. $\mathrm{N}^{\circ} 25$. Fol. 16r-17r. 
Todo varón libre, padre o cabeza de familia, que viva de sus rentas u ocupación, sin pedir limosna, ni depender de otro, que no tenga causa criminal pendiente, ni haya sufrido pena corporal aflictiva o infamatoria, que no sea sordo, mudo, loco, mentecato, deudor moroso del tesoro público, fallido, culpable o alzado con la hacienda ajena. Igualmente deberá ser habitante de la parroquia, teniendo casa poblada, habiendo vivido en ella el año anterior y en la provincia los dos años precedentes con ánimo de establecerse. ${ }^{29}$

En la Constitución de 1815 se puso como condición ser mayor de 21 años y se eliminó la de "ser padre o cabeza de familia". ${ }^{30}$

La dificultad de llenar estas condiciones explicaría el número tan limitado de hombres que declararon gozar de este título. Si analizamos la información relativa a los 22 testigos que utilizaron el apelativo, se encuentra que eran personas libres con edades entre 25 y 74 años, de las cuales dos no sabían firmar.

Otro factor que se debe tener en cuenta para interpretar estos datos, es que el uso de la dominación de ciudadano por parte de los testigos, se restringe a los años 1814 a 1816 y 1819, a los que corresponden únicamente 12 causas. $^{31}$

Las Leyes de Partida ordenaban que ningún sujeto podía ser apremiado para que testificase en causa criminal contra sus ascendientes, descendientes o parientes colaterales hasta el cuarto grado, ni el suegro contra el yerno, ni el padrastro contra el entenado o al contrario. ${ }^{32}$ El interrogatorio que se hacía a

\footnotetext{
${ }^{29}$ Esta definición se encuentra en la Constitución de 1812, en la Sección Segunda "Del Senado" Artículo 7.

Pombo, Manuel Antonio y Guerra, José Joaquín. Constituciones de Colombia. Bogotá. Biblioteca Banco Popular. 1986. Tomo I. Pág. 494.

${ }^{30}$ La definición de la Constitución de 1815 está en el Título II: "De las elecciones2. Sección Primera. Artículos 4 y 5.

Pombo y Guerra. Ob. cit. Tomo II. Págs. 340-341.

${ }^{31}$ Hay que aclarar que la cantidad de juicios existentes disminuye radicalmente a partir de 1812, lo que puede deberse a los traumatismos causados por la organización de la justicia como un poder público separado, de acuerdo a lo dispuesto en la Constitución sancionada el 3 de mayo de ese año. La escasez de causas también podría indicar la eliminación o sustracción de la documentación perteneciente al Supremo Tribunal de Justicia de la provincia, pero es difícil precisar si esto ocurrió y cuándo.
}

${ }^{32}$ Ley 11. Título 16. Partida 3. En: Escriche, Joaquín. Ob. cit. Pág. 1500. 
testigos siempre incluía una pregunta sobre "las generales de la ley", que eran las tachas señaladas por la ley a los testigos. Estas eran: ser menor de edad, la amistad o parentesco con las partes, la enemistad u odio hacia alguna de ellas.

Los datos que sobre parentesco dieron las personas interrogadas en los juicios por homicidio, muestran que $72(18,13 \%)$ de 397, tenían con los implicados lazos de parentesco consanguíneo o espiritual. De ellos, siete eran padres, siete cónyuges, 13 hermanos, 11 tíos o primos, 13 parientes políticos, 19 parientes colaterales y dos compadres (ver cuadros $\mathrm{N}^{\circ} 48$ y 53). El porcentaje de parientes fue menor entre los testificantes en las causas de injuria o heridas que venimos analizando (26 de 255).

Las declaraciones a favor, hechas por parientes, no hacían plena probanza en una causa, pues se consideraba que no eran imparciales. ${ }^{33}$ Así, en una causa por injuria instaurada en 1760 por José de Agudelo contra Salvador de Agudelo, su hermano, por haber dicho que la mujer e hija del primero habían hurtado una cantidad de oro, la prueba presentada por Salvador para su afirmación es cuestionada porque los testigos eran:

Parientes inmediatos por lo que omite tacharlos por estarlo por derecho, es digno de reparo que habiendo tantos sujetos en el sitio, sin parentesco quiera probar niñedades que no vienen al caso. ${ }^{34}$

También se consideraba discutible lo dicho por un "enemigo capital" sirviendo un argumento de este orden para poner en entredicho lo que se quería demostrar. Era corriente que esta razón se invocara para cuestionar la validez no sólo de algunas testificaciones, sino también de la demanda. Esto es lo que hace Francisco Miguel Quintero, residente en el sitio de La Chiquita, acusado en 1773 por Manuel Berrío de mala vecindad y quitarle el crédito a una hija. El supuesto agresor sostenía que los testigos presentados eran aliados y protegidos de Bartolomé Cartagena, cuñado de Berrío, enemigo de su familia. Como prueba de esto afirmaba que Cartagena, en unión de dos hijos, le había

${ }_{33}^{33}$ Leyes 10 y 14. Título 16. Partida 3. En: Escriche, Joaquín. Ob. cit. Pág. 1499.

${ }^{34}$ A. H. A. Criminal. B. 28. Leg. 1760-1770. Doc. No 1. Fol. 21r-22v. 
salido con un garrote a molerlo a palos o a quitarle la vida. Según él, este era el origen de la acusación hecha en su contra. ${ }^{35}$

Otro factor que se tenía en cuenta para evaluar a un testigo era su edad. En las causas criminales no podía ser testigo quien no hubiera cumplido 20 años y en caso de ser llamado a declarar su testimonio se tenía como presunción. ${ }^{36}$ Esta disposición se tenía en cuenta, pues de los testigos de los juicios por homicidio analizados, sólo nueve de 397 eran menores de 20 años. Uno de estos declarantes fue una niña de ocho a nueve años, a quien se le interrogó por haber llevado recados entre los implicados en un caso de infanticidio. ${ }^{37}$ Este testimonio se puso como una nota y se omitió el requisito de tomar juramento.

Por grupos de edades los atestiguantes se distribuían así: 277 eran adultos con edades entre 20 y 49 años, 72 tenían más de cincuenta años y 39 no especificaron su edad (ver cuadro $\mathrm{N}^{\circ} 46$ ). Como se observa, a medida que aumenta la edad, disminuye el número de testigos, lo que presumiblemente refleja la distribución por edades de la población general. Las mismas tendencias se presentan entre los declarantes en los juicios por injuria y heridas seguidos entre 1810 y 1819 , pues cuatro tenían entre 10 y 19 años, 199 entre 20 y 49 años, 33 más de 50 años y en 17 casos se omitió el dato (ver cuadro $\mathrm{N}^{\circ} 51$ ).

Un aspecto adicional que se puede estudiar a partir de la información dada por los testigos es si sabían firmar, pues una vez terminada su declaración debían hacerlo con el juez y el escribano. Este dato es muy ilustrativo, pues muestra que de los 397 testigos que depusieron en los juicios por homicidio, 228 (60\%) eran totalmente analfabetas (ver cuadro $N^{\circ} 47$ ). Este número no es muy elevado, si tenemos en cuenta que la ciudad de Antioquia terminando el periodo colonial (1808), sólo contaba con "una escuela de malos principios, por su miserable dotación". ${ }^{38}$

Como era de esperarse, la mayor parte de los blancos sabía firmar (70 de 83), pero lo llamativo es que lo hubieran hecho un esclavo y un indio. En la segunda década del siglo xix el porcentaje de analfabetismo disminuye, pues

\footnotetext{
${ }_{35}$ A. H. A. Criminal. B. 80. Leg. 1750-1780. Doc. $\mathrm{N}^{\circ}$ 17. Fol. 11r-v.

${ }^{36}$ Ley 9. Título 16. Partida 3. En: Escriche, Joaquín. Ob. cit. Pág. 1499.

${ }^{37}$ A. H. A. Criminal. B. 39. Leg. 1780-1790. Doc. No 14. Fol. 20r.

${ }^{38}$ A. H. A. Censos. B. 52. Tomo 343. Doc. 6538.
} 
de 255 testigos que declararon en las causas por injuria y heridas, sólo 134 sabían firmar (ver cuadro $\mathrm{N}^{\circ} 52$ ). ${ }^{39}$

De acuerdo con la legislación vigente, para que la declaración de un testigo hiciera fe y prueba, debía concordar con las de otros en: el acto, delito, tiempo, lugar y persona que lo cometió. En caso de ser discordante en cualquier dato, un testimonio se volvía singular y no hacía plena probanza. Para poder condenar a alguien, había necesidad de contar por lo menos con dos testigos mayores y de toda excepción, que declararan a ciencia cierta. Para poder ser catalogado como tal, debía decir la razón por la cual conocía el hecho y exponer detalladamente las circunstancias en que éste había ocurrido. ${ }^{40}$

En caso de no contarse con los testimonios pedidos por la ley, no se podía condenar al reo a la pena estipulada para ese delito, sino a una menor. Esta circunstancia no era rara, sobre todo en los casos de homicidio, debido a que muchas veces no había nadie que hubiera sido testigo presencial.

Algunos críticos de las leyes penales vigentes en el siglo xvill, controvertían los argumentos existentes contra el uso del testimonio de determinadas

\footnotetext{
${ }^{39}$ Los datos sobre testigos obtenidos para la jurisdicción de la ciudad de Antioquia los podemos comparar con los que la investigadora Patricia Aufderheide encontró en el caso de las ciudades Brasileras de Cachoeira y Geremoabo en el periodo 1780-1836. Esta autora analiza la composición por sexo, etnia, edad, ocupación y estado civil de un grupo de 1003 testigos, partiendo de la base de que la muestra resultante refleja la conformación de esa sociedad y la importancia local de cada grupo. Encuentra que los esclavos y las mujeres tenían una participación mínima ( 7 casos solamente), debido a disposiciones legales en el primer caso y a la costumbre en el segundo. Para la ciudad de Cachoeira los testigos eran usualmente residentes en el área rural, pequeños productores independientes y es visible el incremento a lo largo del periodo estudiado de la participación de hombres de color libres. En Geremoabo es más significativa la participación como testigos de los blancos, siempre pequeños negociantes. Comparando estas conclusiones con los resultados obtenidos para la ciudad de Antioquia encontramos que en el caso de los esclavos la situación era claramente diferente, por no estar prohibido taxativamente en la legislación española que se los llamara a testificar. Con respecto a las mujeres, también se presenta una tendencia divergente, pues aunque existían prejuicios sobre la validez de su palabra, esto no llevó a que se decidiera prescindir de sus declaraciones. Es interesante anotar que tanto en la región Cachoeira como en la de Antioquia a principios del siglo xix, era notable el aumento de la participación como testigos de los mestizos o mulatos libres. En los dos casos parece haber sido el resultado de un proceso de expansión del número de pequeños propietarios rurales y de pequeños comerciantes.

Aufderheide, Patricia. "Upright Citizens in Criminal Records: Investigations in Cachoeira and Geremoabo. Brazil. 1780-1836". The Americas. Vol. XXXVIII. October 1981. Number 2. Págs. 173-184.

${ }^{40}$ Hevia Bolaños, Juan de. Ob. cit. Tomo I. Págs. 226-227.
} 
personas en razón de su sexo o condición. Beccaria, por ejemplo, sostenía que la medida de la veracidad de un declarante debía ser el interés que tuviera en decir la verdad, el cual disminuía en proporción al odio, la amistad o las relaciones íntimas que mediaran entre él y el acusado. Consideraba casi nula la credibilidad de un testigo cuando se trataba de un delito de palabras, porque "lo dicho", se podía alterar y modificar. La situación era diferente en cuanto a las acciones violentas, pues éstas dejaban huella en multitud de circunstancias y efectos. ${ }^{41}$ Concluido el interrogatorio de los testigos, el juez debía evaluar las declaraciones para ver si había presunciones o pruebas de haberse cometido un delito y estaban identificados los inculpados. Si encontraba méritos, debía proceder a tomar preso al reo y secuestrar sus bienes, lo que daba comienzo a otra etapa del proceso. ${ }^{42}$

\section{La prisión y el embargo de bienes}

La diligencia de poner en prisión al reo no se realizaba siempre, bien fuera por haber huido los implicados, por estar acogidos al asilo eclesiástico, o por tratarse de un delito que no implicaba la imposición de pena corporal.

De acuerdo con la legislación vigente en la época, la cárcel tenía carácter preventivo; se utilizaba para "la custodia y seguridad de los reos". ${ }^{43}$ La cárcel debía tener diferentes piezas, pues los presos se debían separar de acuerdo con su "calidad y sexo". ${ }^{44}$

Estas disposiciones legales no siempre pudieron cumplirse debido a que la mayoría de las localidades carecía de una cárcel segura, higiénica y con espacio suficiente. Así, la ciudad de Antioquia, siendo capital provincial, no contó con una buena edificación para la cárcel hasta la construcción de la Casa del Cabildo, adelantada durante el gobierno del visitador Mon y Velarde (1785-1788). Antes de hacer esta construcción, el Gobernador Silvestre había descrito la cárcel como:

\footnotetext{
${ }^{41}$ Beccaria, Cesare. De los Delitos y las Penas. Bogotá. Editorial Temis. S. A. 1987. Págs. 14-17.

${ }^{42}$ Hevia Bolaños, Juan de. Ob. cit. Tomo I. Pág. 207.

${ }^{43}$ Lardizábal y Uribe, Manuel de. Discurso sobre las Penas. México. Editorial Porrúa S.A. 1982. Pág. 211.

${ }^{44}$ Hevia Bolañ os, Juan de. Ob. cit. Tomo I. Pág. 209.
} 
Tres pequeños cuartos indecentes, que ni corresponden al decoro de la República, ni están seguros los reos sino cuando no quieren hacer fuga que es muy ordinaria y regular en los criminales. ${ }^{45}$

Para remediar esta situación, en la planta baja de la nueva casa del Cabildo se construyó la cárcel para hombres con un calabozo para la gente ordinaria, otro para los blancos y una "sala de malos". La vivienda del alcalde de cárcel se hizo independiente y al frente se colocaron dos escribanías públicas del número, con un cuarto intermedio que servía para tomar la confesión a los reos, "libres de prisiones como lo previene la ley", pero sin correr el riesgo de que se fugaran o hicieran algún insulto al juez. Al otro lado se edificó la cárcel de mujeres con cuartos para calabozos, de trabajo y de dormir y una pieza separada para las reas de alguna calidad. ${ }^{46}$

El número de agresores que era apresado variaba de un tipo de delito a otro. En teoría, todos los sospechosos de haber participado en un caso de homicidio debían ser encarcelados, pero por estar determinado por ley para este delito la pena de muerte, era corriente que los implicados huyeran impidiendo su captura o que se fugaran de la cárcel. De las 70 personas procesadas por este delito en la jurisdicción de la ciudad de Antioquia, 19 huyeron y sólo fue posible la captura de siete de ellos. En cuatro de estos casos el reo nunca fue apresado, siguiéndose la causa como reo ausente y cuatro se fugaron después de haber sido dictada la sentencia.

Las fugas se veían favorecidas por múltiples circunstancias como nos lo ilustra el caso del negro Juan José Medina quien fue procesado en 1781 por haber matado alevosamente a José Escudero, en el sitio de Santa Bárbara, jurisdicción de Arma. Medina estuvo prófugo cerca de un año, habiéndose refugiado en la boca de la quebrada de San Juan sobre el río Cauca. Como el asesinato ocurrió en la zona rural alejada de la sede de la justicia, tuvo tiempo para ocultarse y

\footnotetext{
${ }^{45}$ Silvestre, Francisco. Descripción del Reino de Santa fe de Bogotá. Biblioteca Popular de Cultura colombiana. Bogotá. 1950. Págs. 179-180.

${ }^{46}$ Robledo, Emilio. Bosquejo Biográfico del Señor Oidor Juan Antonio Mon y Velarde. Visitador de Antioquia. 1785-1788. Bogotá. Publicaciones del Banco de la República. 1954. Tomo II. Pág. 298. Nº 9 y 10.
} 
evitar su captura. Esta sólo se logró en 1782, cuando el Gobernador Cayetano Buelta Lorenzana despachó una comisión con este objetivo, por considerar que el refugio de Medina estaba sirviendo de abrigo a otros delincuentes, lo que ocasionaba perjuicios a los habitantes de aquella comarca. En abril de 1783 Medina huyó de la cárcel de la ciudad de Antioquia y logró mantenerse prófugo hasta octubre de 1785 . Según su declaración, se mantuvo buscando oro y haciendo rocerías en la zona de río arriba de Cauca. La fuga la hizo moliendo con una piedra los grillos que tenía puestos; una vez logró safárselos, salió por la puerta que estaba abierta hasta las 8 de la noche. El motivo por el que se fugó fue:

temeroso del castigo, viendo que era larga su prisión y las muchas necesidades que padecía en ella. ${ }^{47}$

Este relato muestra que las medidas de seguridad de la cárcel eran mínimas y que un reo sólo debía esperar la oportunidad más propicia para fugarse.

Los deudos de algunas víctimas presionaban por una resolución rápida de los juicios, pues consideraban que la poca seguridad de la cárcel hacía fácil la huida de los reos. En la causa seguida en 1754 contra cuatro esclavos por la muerte de su amo don Juan de Areiza, el hijo de éste culpaba al Alcalde de la Santa Hermandad por la huida de la cárcel de tres de los sindicados, pues había procedido con lentitud en la causa y descuidado a los reos, a pesar de conocer el riesgo de fuga. Se quejaba al gobernador de que al capturar dos reos, el Alcalde le había compelido por un auto a pagar cincuenta pesos para cubrir el costo de la vigilancia que se les debía dar. El Gobernador, Manuel López de Castilla, determinó que se depositaran los cincuenta pesos para pagar con ellos el costo de las prisiones, la alimentación de los reos y los gastos que fueran necesarios para la vigilancia. Consideró al Alcalde responsable de la falta de vigilancia antes de la fuga, pues ésta fue resultado de haberla omitido. El mismo López de Castilla, señalaba que el Alcalde no había enviado comisiones para la captura de los reos, ni librado las requisitorias a los lugares por donde podían

${ }^{47}$ A. H. A. Criminal. B. 86. Leg. 1780-1800. Doc. No 1. Fol. 3r, 37v, 39v. 
salir de la provincia. Por eso le mandaba que se dedicara a concluir la causa con rapidez y celo. ${ }^{48}$

Los incidentes de esta clase ocasionaban grandes retrasos en el seguimiento de las causas, con el consiguiente aumento de costos. En estos casos, como era factible que se condenara a muerte a los implicados y no era seguro que alguien respondiera por los costos, los reos eran abandonados a su suerte.

La situación en que se encontraban en la cárcel los presos por homicidio era bastante precaria. Algunos permanecían varios años aguardando la definición de su causa, dependiendo de la caridad pública para alimentarse y vestirse. Así, por ejemplo, la negra esclava Cayetana, acusada en 1787 de infanticidio, fue abandonada por su amor en la cárcel, donde permaneció más de dos años. Durante este tiempo su mantenimiento corrió por cuenta del Alcalde Francisco Santana, quien la tuvo a su servicio. Santana presentó una cuenta de gastos que incluía el pago de médico, medicina y un parto que la esclava tuvo mientras estaba en prisión. ${ }^{49}$

Debido a la situación de abandono total, era corriente que los presos enfermaran gravemente, siendo necesario trasladarlos para su curación. El defensor general de menores, Lorenzo de Lora y García, pedía en 1795, que se autorizara el traslado al hospital real del preso Agustín Sánchez, procesado por haber abierto el vientre a su esposa para extraerle una criatura. Sánchez estaba tullido y con calenturas, debido a:

Hallarse acostado en el suelo y cuasi desnudo y sin aliento alguno. ${ }^{50}$

No es de extrañar que los presos aprovecharan la menor oportunidad para escapar de estas condiciones, como sucedió en el caso de Sánchez quien huyó del hospital en donde estaba recuperándose.

\footnotetext{
${ }^{48}$ A. H. A. Criminal. B. 27. Leg. 1750-1760. Doc. $\mathrm{N}^{\circ}$ 5. Fol. 78v-79v.

${ }^{49}$ A. H. A. Criminal. B. 81. Leg. 1780-1789. Doc. $\mathrm{N}^{\circ}$ 18. Fol. $49 \mathrm{r}-\mathrm{v}, 63 \mathrm{r}, 64 \mathrm{v}$.

${ }^{50}$ A. H. A. Criminal. B. 76. Leg. 1790-1796. Doc. No 8. Fol. 58r, 65 r-v.
} 
Las leyes de Partida y la Recopilación establecían que el preso que huía de la prisión, debía considerarse confeso en el delito por el que estaba siendo procesado y ser castigado por la fuga con pena arbitraria. ${ }^{51}$

Otro recurso usado por los convictos de homicidio para evitar la cárcel y el procesamiento, era acogerse al asilo eclesiástico. Según los tratadistas del derecho español, gozaba de inmunidad eclesiástica el que se amparaba en iglesias, ermitas, oratorios públicos y cementerios, siempre y cuando se acogiera estando libre y no preso, ni llevándosele como tal a la prisión u otra parte. ${ }^{52}$

Todos los delincuentes que se refugiaban en la iglesia, gozaban de inmunidad, sin poder ser sacados de ella, salvo algunas excepciones entre las que se contaban: el que había matado o herido en una iglesia o cementerio, el que delinquía cerca de la iglesia con esperanza de retraerse en ella, el que estando en la iglesia salía a ejecutar el delito y luego volvía a ella, el que había perpetrado delito de lesa majestad humana y traición contra el Rey o el Reino, el que había cometido el pecado nefando y sodomía, el que mataba a otro segura y alevosamente, el que cometía delito de parricidio matando ascendiente o descendiente y los que asesinaban por dinero o precio. ${ }^{53}$

En la jurisdicción de la ciudad de Antioquia de las 70 personas enjuiciadas por homicidio, ocho se acogieron al asilo eclesiástico temporal o definitivamente. Este recurso fue utilizado intensamente antes de 1780, decayendo su uso con posterioridad debido a que las autoridades se negaban a otorgarlo por considerar que era una forma de burlar la justicia, estimular la fuga de los sindicados y lograr que quedaran impunes los delitos.

Determinar si un reo debía gozar o no de la inmunidad eclesiástica era un proceso prolongado, que ordinariamente ocasionaba conflictos entre las autoridades civiles y eclesiásticas. Veamos dos ejemplos que ilustran la posición de los Alcaldes ordinarios y los curas vicarios, permitiendo ver su evolución en el tiempo. En el primer caso, ocurrido entre 1753 y 1754, se discutió si tenía derecho a acogerse a la inmunidad el negro esclavo Bartolo, quien en una riña había amatado a su amo Valentín Ruiz. El cura vicario de

\footnotetext{
${ }^{51}$ Hevia Bolaños, Juan de. Ob. cit. Tomo I. Pág. 209.

52 Ibídem. Págs. 211-212.

${ }^{53}$ Ibídem. Págs. 213-217.
} 
Antioquia, doctor Juan Antonio de Toro Cataño, al pedir el Alcalde ordinario que se le diera licencia para extraer el implicado de la ermita de Jesús Nazareno, argumentaba no tener jurisdicción para tomar esta decisión. Se basaba en una bula del Papa Gregorio xiv, expedida en el año de 1591, en la cual se mandaba que para sacar de la iglesia a los reos que no gozaban de inmunidad eclesiástica se requería licencia del Obispo del territorio o de su oficial. De acuerdo con la legislación existente, él tampoco podía determinar si el reo debía gozar o no del asilo.

El Alcalde ordinario don Juan Agustín de Villa y Castañeda, por su parte, opinaba que el reo no debía gozar del asilo, porque en los autos estaba justificado el delito de alevosía y de quedar sin castigo, se daría pie a que se cometieran muchos excesos:

Quedarán tímidos y obligados a todos los vecinos de esta provincia a no servirse de sus esclavos por aquel recelo, que prudentemente tendrán de ellos y en éstos como de tan mala índole crecerá a este paso su malignidad y atrevimiento para cometer semejantes y aún mayores delitos. ${ }^{54}$

Objetaba la decisión del cura, dado que posibilitaba la fuga del reo, por faltar en la ermita de Jesús Nazareno una puerta. No era factible poner guardias durante todo el tiempo que se tardar la respuesta del Obispo, pues los vecinos eludían el cumplimiento de esta tarea argumentando que estaban ocupados en sus labranzas y no recibían ninguna compensación por el servicio. Por esta razón solicitaba permiso para poner al reo en la cárcel pública, mientras se decidía si debía gozar de la inmunidad eclesiástica, comprometiéndose a entregarlo o restituirlo a lugar sagrado en caso de que se fallara a favor.

En este caso, el Obispo de Popayán doctor don Diego del Corro, declaró que el reo debía gozar del asilo. Se basó en el dictamen dado por el promotor fiscal eclesiástico del Obispado de Popayán, doctor don Felipe Sánchez de la Concha, quien consideró, de acuerdo al sumario, que la muerte había sido resultado de un acto impulsivo y colérico. En su concepto, sólo constaba el delito por la confesión del acusado, sin que hubiera testigo ocular del hecho

${ }^{54}$ A. H. A. Criminal. B. 27. Leg. 1750-1760. Doc. No 4. Fol. 8r-v. 
cuya declaración permitiera saber si había sido muerte alevosa o no. Opinaba además, que los motivos que ocasionaron la pelea, el estar el esclavo enfermo y haberle dado el amo dos golpes, eran causa suficiente para el furor del reo, por lo que no se podía atribuir alevosía del hecho.

La actitud de la autoridad eclesiástica fue distinta unos años más tarde, en 1771, cuando se trató de decidir si debía otorgarse la inmunidad al esclavo Marcos, quien mató a puñaladas a la esclava María de Jesús.

El Alcalde ordinario don Nicolás Zapata García solicitó a los curas de la ciudad de Antioquia que le permitieran sacar al reo de la Iglesia Parroquial, donde se había refugiado, porque al oficiarse misa la aglomeración de gente posibilitaba la fuga. Sustentaba su petición en una Real Cédula expedida en San Lorenzo el 18 de Octubre de 1750, en la cual se mandaba que para asegurar la persona del reo, buscando evitar los daños que podía ocasionar el delincuente con su fuga e impedir que quedara impune el delito, los ministros reales podían extraer al acusado del lugar sagrado, previa licencia de la autoridad eclesiástica, otorgando caución juratoria de que no se le ofendería ni haría daño hasta que se decidiera si debía gozar de la inmunidad. En caso de que los eclesiásticos se negaran se podía extraer al reo y ponerlo en la cárcel bajo las condiciones anotadas. ${ }^{55}$

Ante esta directriz real, que buscaba impedir que la iglesia se convirtiera en "cueva de ladrones" y evitar la proliferación de pleitos entre las autoridades civiles y eclesiásticas, los curas de Antioquia, el doctor Juan Ignacio Rodríguez y el bachiller Pedro Zapata declararon conformarse con la "regia disposición" y permitieron que se extrajera el reo, una vez se otorgara la caución para asegurar la inmunidad. ${ }^{56}$

${ }^{55}$ Como los eclesiásticos continuaban oponiéndose a que los reos fueran extraídos de los lugares sagrados antes de que se decidiera si tenían derecho a la inmunidad, el Rey expidió una Real Cédula el 5 de abril de 1764 en que ratificaba el contenido de la de 1750. En ella se mandaba que cuando un reo había cometido un delito "enorme y gravísimo", las justicias seculares podían extraerlo del lugar sagrado en que estuviera refugiado, para asegurar su persona y evitar que se ocultara o fugara. El juez debía otorgar caución juratoria de que no se ocasionaría daño al delincuente hasta que se decidiera si debía gozar de la inmunidad.

A. H. A. Criminal. B. 38. Leg. 1770-1780. Doc. N 3. Fol. 9r.-13r. Capitulares. Tomo 641. Doc. $\mathrm{N}^{\circ}$ 10211. Fols. 68r.-71r.

${ }^{56}$ A. H. A. Criminal. B. 38. Leg. 1770-1780. Doc. N 3. Fols. 7v.-8v., 53r.-55r., 97r.-v. 
Inmediatamente su suscitó otro problema jurídico, pues había dudas sobre la forma como se debía remitir la causa al Obispo para que determinara lo relativo al asilo. Para decidir sobre este aspecto se enviaron los autos al doctor Lorenzo Benitez, abogado de la Real Audiencia, vecino de Medellín, quien dictaminó que de acuerdo con los tratadistas del derecho español se debía poner la causa en estado de ratificación de los testigos del sumario.

El reo perdió el derecho a la inmunidad por haberse fugado de la cárcel. Cuando fue nuevamente apresado alegó haber huido para pasar a Medellín a refugiarse en lugar sagrado, pero el juez no acogió este argumento debido a que fue capturado en despoblado y en un camino opuesto al de esa villa. En consecuencia, se declaró cancelada la caución juratoria otorgada y se siguió el juicio de forma ordinaria, habiendo sido sentenciado a la horca por haber ejecutado la muerte "sobre seguro" y estando indefensa la víctima.

A partir de este momento fueron muy pocos los reos que se acogieron a este recurso, pues no les garantizaba no ser procesados. En las décadas del 50 y 60 se encuentran testimonios que hablan de varios reos refugiados en una misma iglesia. Después de 1780 se vuelve esporádico y transitorio el acogerse al asilo. ${ }^{57}$

En el caso de los acosados del delito de lesiones personales la situación era un poco distinta. Ante todo hay que anotar que un porcentaje elevado de los agresores no fue puesto preso por acusárseles de golpes, empellones o bofetadas leves. De los apresados un número elevado fue dejado en libertad por haber llegado a un convenio con la víctima, haber desistido ésta de la demanda o aprobar el juez el pago de una fianza de cárcel seguro o de "pagar lo juzgado". ${ }^{58}$ La fianza de cárcel segura se adjudicaba en aquellos casos en que el inculpado no era merecedor de una pena corporal, obligándose por ella a presentarse a la cárcel siempre que le fuera mandado. ${ }^{59}$ La fianza de "pagar lo juzgado" estaba limitada a penas pecuniarias y por ella un fiador se obligaba a pagar, si el reo no cubría lo juzgado y sentenciado. ${ }^{60}$

\footnotetext{
${ }^{57}$ A. H. A. Criminal. B. 41. Leg. 1740-1770. Doc. $\mathrm{N}^{\circ}$ 11. Fols. 3v-7r.

${ }^{58}$ Hevia Bolaños, Juan de. Ob. cit. Tomo I. Pág. 209-210.

${ }^{59}$ Escriche, Joaquín. Ob. cit. Pág. 688.

${ }^{60}$ Ibídem. Pág. 687.
} 
Lo anterior explica que fuera reducido el número de reos por heridas, que huyeron para no ser apresados, o que se fugaron de la cárcel (29 de 273 implicados). Algunos de los prófugos se presentaban a la autoridad tan pronto como tenían conocimiento de que la víctima estaba fuera de peligro. Así, por ejemplo, Juan Félix de León, pasador del río Cauca, enjuiciado en 1755 por haber golpeado con un palo a Jorge de Castro, huyó de la cárcel al haber tenido noticas de que éste podía morir. El reo se presentó cuando Castro estaba restablecido, después de haber hecho con él un convenio por el cual se comprometía a pagar las costas procesales y los gastos de la curación, a cambio de que desistiera de la querella. ${ }^{61}$

Otro reo, don Manuel Romero, quien fue procesado en 1780 por haber herido gravemente a José Sánchez, dio como razón de su fuga de la cárcel el temor que sintió al ser apresado y ponérsele un par de grillos. Sólo salió del monte donde se refugió, cuando supo que el herido estaba totalmente recuperado. ${ }^{62}$

Estos prófugos buscaban acogerse a la Ley de la Recopilación, en la cual se establecía que el reo huido que se presentaba voluntariamente a la cárcel, quedaba libre de la pena del delito cometido y de la pena de la fuga. ${ }^{63}$

Algunos de los reos por lesiones personales huyeron para comparecer ante una autoridad de más alto rango, por considerar que los jueces que inicialmente conocieron su causa no tenían en cuenta sus descargos, por estar vinculados a la víctima a través de lazos de parentesco, comadrazgo o amistad, Los implicados huían de los Alcaldes Pedáneos o tenientes de Gobernador para presentarse al Alcalde Ordinario o al Gobernador. Un caso de éstos fue el de Manuel López, vecino del sitio de San Antonio del Infante, a quien el Teniente de Gobernador de Santa Rosa de Osos ordenó, en 1807, apresar y embargarle los bienes, por haber dado un porrazo a don José María Sierra. López huyó para presentarse al juzgado del Gobernado, donde pidió que se inhibiera al Teniente de Gobernador de conocer su causa, por ser pariente cercano y compadre espiritual del padre de su oponente. ${ }^{64}$

\footnotetext{
${ }^{61}$ A. H. A. Criminal. B. 73. Leg. 1700-1740. Doc. $\mathrm{N}^{\circ} 18$. Fols. 5r, 7r-v.

${ }^{62}$ A. H. A. Criminal. B. 60. Leg. 1780-1790. Doc. $\mathrm{N}^{\circ}$ 5. Fols. $11 \mathrm{v}-16 \mathrm{v}$.

${ }^{63}$ Hevia Bolaños, Juan de. Ob. cit. Tomo ı. Pág. 209.

${ }^{64}$ A. H. A. Criminal. B. 104. Leg. 1810-1850. Doc. $\mathrm{N}^{\circ} 1$.
} 
En otras ocasiones los reos se fugaron para presentarse ante la $\mathrm{Au}-$ diencia, por considerar apasionados y parcializados a los jueces locales. Este argumento fue esgrimido en 1781 por el comerciante don Miguel de Acevedo, vecino de la villa de guaduas, quien se evadió de la cárcel de Rionegro donde estaba recluido por heridas dadas a don Vicente Tobón. El reo se quejaba de que el Alcalde don Juan Francisco Echeverri, primo hermano de Tobón, lo había reducido a una dura prisión y confiscado todos sus bienes. Escapó por el temor de perder la vida y por no tener quien se hiciera cargo de su defensa, pues ningún vecino aceptaba defenderlo.

No porque no conociesen mi inocencia sino porque consideraban la suma pasión del juez, con quien procuraban todos por su despótico dominio, evitar cualquier encono. ${ }^{65}$

El recurso de huir "hacia la justicia" fue también utilizado por reos implicados en juicios por injuria. Según una ley de la Recopilación no quebrantaba la cárcel el que huía para presentarse a un juez superior. ${ }^{66}$ El uso de esta disposición se hace notorio a partir de la década de 1780 , lo que puede deberse a un mayor conocimiento de la legislación por parte de los acusados y sus asesores.

El derecho de asilo eclesiástico, en cambio, dejó de usarse por la misma fecha. En el periodo 1752-1780 doce personas implicadas en causas de lesiones personales o agravios, se refugiaron en lugar sagrado para impedir su procesamiento. Los abusos que a la sombra del asilo se cometían, llevaron a las autoridades provinciales a pedir a las dignidades eclesiásticas, que permitieran el encarcelamiento de los inculpados. Sobre esta situación el gobernador Francisco Silvestre en 1776 decía:

No es creíble, que aquella propia madre cuyo seno es la paz y mansedumbre, quiera hacerse guarda y protectora de la iniquidad y el desorden, y lo que es

\footnotetext{
${ }^{65}$ Archivo Histórico Nacional. Juicios Criminales. Tomo 15. Fols. 677r a 678r.

${ }^{66}$ Hevia Bolaños, Juan de. Ob. cit. Tomo I. Pág. 209.
} 
más, atender al privado temporal favor de uno sólo, con daño y detrimento espiritual y temporal de tantos millares de otros. ${ }^{67}$

Veamos dos ejemplos que ilustran la situación. En 1760 José de Agudelo y Salvador de Ochoa, fueron acusados de valerse de la coartada que les brindaba estar refugiados en la iglesia de Chiquinquirá, para herir con una pistola al Alcalde Ordinario don Francisco Salvador de Lara y Moncada, quien estaba procesando al primero por amancebamiento. La gravedad del delito cometido contra el honor de "ambas majestades", fue puesta de presente al cura y vicario de la ciudad de Antioquia por el Gobernador José Barón de Chaves quien solicitó que se permitiera encarcelar a los implicados. La petición fue aceptada por el cura debido a los denuncios de que Agudelo y Ochoa jugaban naipe y hacían alboroto en la sacristía. Puso como condición que no se les aplicara una pena corporal hasta que el Obispo de Popayán decidiera si debían gozar de la inmunidad. El proceso quedó inconcluso por haber huido los reos de la cárcel, al igual que un tercer implicado hijo de Agudelo y hermano medio de Ochoa. ${ }^{68}$

Otro reo que fue acusado de abusar del derecho de asilo eclesiástico fue don José Urbina, forastero que se dedicaba a la profesión de médico cirujano. Urbina se refugió en la Viceparroquia de Jesús Nazareno a principios de 1775, temeroso de los resultados de una casusa que se le seguía por heridas y calumnia. A mediados de 1776, el Gobernador Silvestre, hizo una sumaria información para demostrar que Urbina había llevado a cabo "acciones injuriosas" al lugar sagrado. Se le acusó de tener armas prohibidas en la sacristía, salir constantemente del lugar, entrar mujeres con el "pretexto de novenas o enfermedades" practicar operaciones de cirugía en el lugar e insultar y deshonrar a parte del vecindario. El cura doctor José Salvador Cano, con orden extrajudicial del Vicario Superintendente de la provincia, concedió la licencia necesaria para sacar al acusado del lugar sagrado y desterrarlo de allí. ${ }^{69}$

\footnotetext{
${ }^{67}$ A. H. A. Criminal. B. 79. Leg. 1740-1780. Doc. $\mathrm{N}^{\circ} 18$. Fols. $41 \mathrm{v}-43 \mathrm{r}$

${ }^{68}$ A. H. A. Criminal. B. 92. Leg. 1740-1740. Doc. $N^{\circ}$ 9. Fols. 52v-56v, 175r-176v, 270r-271v.

${ }^{69}$ A. H. A. Criminal. B. 79. Leg. 1740-1780. Doc. $\mathrm{N}^{\circ}$ 18. Fols. 1r, 41v-43r, 44r-v.
} 
Muchos juristas del siglo xviI criticaban la institución del asilo eclesiástico por considerar que invitaba a delinquir. Opinaban que daba lugar a que se constituyeran pequeñas soberanías, donde se formaban leyes contrarias a las comunes y un espíritu opuesto al del cuerpo entero de la sociedad. La acogida que estas ideas tuvieron entre los gobernantes antioqueños de la segunda mitad del siglo xviII explica que se mostraran opuestos a la vigencia de esta costumbre. Ella reñía abiertamente con el propósito de hacer eficaz y ágil la administración de justicia. ${ }^{70}$

Las circunstancias que solían rodear la captura de los reos, el que fueran puestos en grillos que les formaban llagas, las condiciones infrahumanas en que permanecían en la cárcel la mayoría de los capturados, hacían que el sistema fuera objeto de duras críticas. Los oponentes señalaban como defecto de la legislación existente, el que se pudiera aprisionar a alguien por cargos inventados por un enemigo o se dejara de poner en prisión a los amigos, aunque hubiera fuertes indicios de culpabilidad..$^{71}$

Estas reflexiones eran compartidas por los miembros de los gobiernos que se constituyeron en Antioquia durante la Independencia. Consecuentemente, en la Constitución de 1812 se incluyó dentro de los derechos del hombre en sociedad un artículo en el que se estipulaba que nadie podía ser acusado, preso, arrestado, arraigado, ni confinado sino en los casos y bajo las formas prescritas por la ley. A renglón seguido, otro artículo establecía que en caso de juzgarse necesaria la prisión de un acusado, la ley debía prohibir todo rigor que no fuera de absoluta necesidad para asegurar su persona. ${ }^{72}$

En las prevenciones generales acerca del poder judicial, esta Constitución fijaba tres modos de cortar la libertad a los ciudadanos. Por prisión, encerrando a las personas en las casas públicas destinadas para el efecto (cárceles); por arresto, previniendo a la persona se mantuviera en la casa de su domicilio a disposición del juzgado o tribunal que dictaba la providencia y por arraigo, mandando que la persona permaneciera en el poblado en donde residía. Se estipulaba que la prisión en las causas criminales tendría lugar en los delitos

\footnotetext{
${ }^{70}$ Beccaria, Cesare. Ob. cit. Pág. 49.

${ }^{71}$ Ibídem. Pág. 11.

${ }^{72}$ Pombo, Manuel Antonio y José Joaquín Guerra. Ob. cit. Tomo I. Pág. 476.
} 
de gravedad, si hubiere prueba verdaderamente semiplena, el arresto en aquellas en que hubiera indicios o presunciones vehementes y el arraigo si existiesen indicios o presunciones de menor entidad..$^{73}$

Los defensores de los reos que fueron procesados durante este periodo utilizaron esta legislación para obtener la excarcelación del detenido. Felipe Montes, defensor de Pedro Antonio Montes, a quien se le seguía juicio en 1815 por maltrato a su esposa, al solicitar que se lo dejara libre para tratarse el "gálico" que padecía, exponía:

Un corazón noble americano no puede ver a sus semejantes reducidos a tal miseria. Una cosa es el delito que se le imputa y de que ya va a sacudirse y otra el derecho que le asiste a que Usted lo proteja apoyado en la benignidad de las leyes, que castigan sí al culpado, pero que también tiene sus excepciones. Yo me glorio de no estar entre los Caribes; y con esta satisfacción me atrevo a suplicar a usted se digne dar licencia a mi defendido libertándolo internamente de la prisión, para que pase a medicinarse. ${ }^{74}$

Como se puede apreciar, los defensores se apropiaban del discurso de los gobernantes, diseñando sus escritos conforme a la filosofía imperante en el momento.

En los delitos que conllevaban responsabilidad pecuniaria, si el juez encontraba en la sumaria motivos para poner en prisión al acusado, debía decretar el secuestro de sus bienes. El embargo podía hacerse en dinero y bienes muebles o semovientes, los que una vez inventariados eran depositados durante el tiempo que durara la causa, en persona "llana y abonada". También estaba autorizado el secuestro de bienes raíces, pero en este caso era difícil restringir su uso al reo o su familia. El acusado o su representante podía solicitar que se levantara el embargo, depositando una cantidad equivalente al valor de los bienes incautados $u$ otorgando fianza en la que se comprometía a responder por ella..$^{75}$

\footnotetext{
${ }^{73}$ Ibídem. Págs. 517-518.

${ }^{74}$ A. H. A. Criminal. B. 78. Leg. 1800-1820. Doc. N 19. Fol. 43 r-v.

${ }^{75}$ Escriche, Joaquín. Ob. cit. Pág. 1015.
} 
Teóricamente el embargo de bienes debía hacerse siempre que se encarcelara al reo. Con esta medida se buscaba asegurar el pago de los daños y perjuicios que el delito hubiese ocasionado en personas o bienes, el de una multa o cantidad determinada que se fijara a favor del ofendido y el de las costas procesales. ${ }^{76}$

En la práctica, por lo que respecta a la provincia de Antioquia, durante el periodo 1750-1820, esta diligencia se realizó con menos de la quinta parte de los reos. De 70 agresores procesados por homicidio, sólo a 13 se les secuestraron bienes, mientras que de 273 enjuiciados por el delito de lesiones personales, únicamente con 42 se hizo este trámite.

Como la mayoría de los reos eran personas de pocos recursos económicos, el verse involucrados en un juicio podía significar la pérdida total de sus bienes. En los casos en que se hizo embargo, éstos se deterioraron y la mayor parte fueron utilizados para cubrir las costas procesales. Un ejemplo es el de Antonio Restrepo, mulato libre, oficial de herrero, quien fue procesado en 1773 por intentar asesinar con una pistola a Ignacio Mira. A Restrepo, quien vivía en el sitio de la Trinidad de Osos, se le secuestraron unas petacas que contenían ropa de vestir y alhajas de oro y plata, las cuales se depositaron en Francisco Javier de Urrego. La casa que tenía en Trinidad, así como la fragua y las herramientas de su oficio fueron depositadas en Juan José de Casos. Se le embargaron además un macho negro y un caballo moro. Las costas de la parte del proceso que se llevó a cabo en el Valle de los Osos fueron tasadas en 44 pesos y un tomín y las del juzgado del Gobernador a donde se remitió la causa, en 98 pesos y tres tomines. Para pagar los gastos del juzgado, fue vendida parte de las alhajas de plata labrada y oro al Alcalde de la Santa Hermandad don Bernardo González, por 98 pesos y seis tomines. Las joyas restantes se entregaron a don Bernardo Martínez, mientras Restrepo pagaba al comerciante don Juan Pablo Pérez de Rublas 125 pesos que le debía. La fragua y demás bienes muebles se ordenó entregarlos al hijo de Restrepo, una vez pagara 15 pesos y tres tomines que debía de las diligencias actuadas en el Valle de los Osos. Como se ve fueron

${ }^{76}$ Ibídem. Pág. 1015. Alvarez Posadilla, Juan. Ob. cit. Tomo III. Págs. 475-476. 
muy pocos los bienes de Restrepo que quedaban cuando falleció, poco después del juicio. ${ }^{77}$

Los grandes perjuicios económicos que un embargo de bienes ocasionaba, hacían que los reos lo catalogaran como un castigo que les quería infringir un juez enemigo. Esta queja fue expresada por don Juan Ignacio Tamayo, mercader, vecino de Santa Rosa, a quien en 1810 se le siguió un juicio por maltratar a su esposa doña María Josefa Tamayo. En una representación hecha al Gobernador, Tamayo acusaba al Alcalde de ese partido, don Joaquín Muñoz, de ser su "enemigo capital", razón por la cual le puso una multa de 50 pesos, que luego dobló a 100 pesos y aprovechó su ausencia para embargar los bienes de su tienda y casa. Decía haber convenido con su suegro don Manuel Sacramento Tamayo cortar la causa, pues el prolongarla

Sería perjudicial a la misma parte ofendida, que es mi mujer, porque las costas que se causarían empobreciéndome a mí, la arruinarían a ella. Esto es puntualmente y no otra cosa, lo que apetece mi enemigo capital don Joaquín Muñoz. ${ }^{78}$

Tratando de evitar que los embargos se convirtieran en instrumento para perjudicar a los reos, los redactores de la Constitución de 1815, incluyeron un artículo estableciendo que se harían únicamente en los delitos en que había confiscación o pena pecuniaria y en las demás causas criminales sólo hasta la cantidad que se juzgare suficiente para satisfacer las costas del proceso. ${ }^{79}$

Aunque durante la época estudiada la prisión y el embargo de bienes tenían un carácter preventivo, los reos que se veían sometidos a ellos los consideraron un castigo, debido a los prejuicios que les representaban. Corroborando esta idea, era corriente que cuando se sentenciaba la causa, la pena se les conmutara por la prisión sufrida (ver cuadros $\mathrm{N}^{\circ} 13,27$ y 43).

${ }^{77}$ A. H. A. Criminal. B. 38. Leg. 1770-1780. Doc. $\mathrm{N}^{\circ}$ 5. Fols. 9r-11r, 24v-25v, 28r-v, 31v32e, 42r-43r, 49v. 51r, 52r-v, 53r-v, 71r, 75r.

${ }^{78}$ A. H. A. Criminal. B. 44. Leg. 1800-1810. Doc. $\mathrm{N}^{\circ}$ 19. Fols. 8v-10v, 11r-12r, 23r-24v.

${ }^{79}$ Pombo, Manuel Antonio y José Joaquín Guerra. Ob. cit. Tomo II. Pág. 366. 


\section{La confesión}

Una vez que el inculpado estaba preso, el juez, ante escribano, debía tomar su confesión bajo juramento. Cuando el delincuente era menor de edad se le nombraba un curador quien debía estar presente en la toma del juramento, pero no en la confesión por ser ésta una diligencia de carácter secreto. ${ }^{80}$

La confesión era el acto más delicado y peligroso del juicio, pues la aceptación por parte del delincuente de haber cometido el delito, se consideraba como la prueba más segura. ${ }^{81}$

Los juristas españoles Antonio Gómez, Rodrigo Suárez y Cristóbal Paz, siguiendo a Santo Tomás, opinaban que el reo preguntado por el juez, bajo juramento, estaba obligado a jurar, declarar y responder la verdad aunque por su confesión se le hubiera de imponer la pena de muerte. ${ }^{82}$

A fines del siglo xviII, los críticos del derecho medieval como Beccaria, conceptuaban que en este punto había una contradicción entre las leyes y los sentimientos naturales del hombre. Según su reflexión, el juramento exigía a un hombre ser veraz, cuando tenía el máximo interés en ser falso. De ello se seguía que el juramento se convirtiera en una formalidad, lo que destruía la fuerza de la religión.

Única garantía de honestidad en la mayor parte de los hombres. ${ }^{83}$

En la confesión se mezclaba lo jurídico con lo religioso. Era clara su relación con el sacramento de la penitencia, "confesión de los pecados". En la mentalidad popular delito y pecado eran casi equivalentes, aunque de acuerdo con las leyes, existían "pecados internos" no sujetos a penas civiles.

Para que un pecado fuera delito debía ser una acción externa que perturbara la tranquilidad pública o la seguridad de los particulares. ${ }^{84}$

\footnotetext{
${ }^{80}$ Hevia Bolaños, Juan de. Ob. cit. Tomo I. Pág. 220.

${ }^{81}$ Escriche, Joaquín. Ob. cit. Pág. 1024.

${ }^{82}$ Hevia Bolaños, Juan de. Ob. cit. Tomo I. Pág. 220.

${ }^{83}$ Beccaria, Cesare. Ob. cit. Pág. 20.

${ }^{84}$ Alvarez Posadilla, Juan. Ob. cit. Tomo III. Págs. 25-26. Lardizábal y Uribe, Manuel. Ob. cit.
} Pág. 95. 
Como muchos autores lo anotaban, la exigencia del juramento exponía a los reos a cometer el delito de perjurio. Tampoco les era posible quedarse callados, puesto que según diversos tratadistas si un reo jurídicamente preguntado no respondía, se presumía "en el fuero exterior" que había ejecutado el delito.

En los juicios estudiados encontramos que a pesar de las presiones ejercidas por el "juez confesor", un número elevado de reos negaban los cargos que contra ellos se hacían con base en pruebas materiales o declaración de testigos. Un recurso utilizado por la autoridad para clarificar los hechos era someter al culpado a varias confesiones. A través de sucesivos interrogatorios se indagaba por hechos ya preguntados o circunstancias e incidentes que antes se desconocían o se habían omitido. ${ }^{85}$

Un ejemplo de la complejidad que este proceso adquiría es el juicio seguido contra Cayetana Espinosa, esclava de Matías Espinosa, vecino de Antioquia. La causa se inició al presentarse el amo ante el Alcalde ordinario, acusando a Cayetana de haber dejado botado en la puerta de la casa de doña Martina y doña Lucía López el hijo que esperaba. Al ser interrogada en septiembre de 1787 , la esclava declaró haber tenido el parto a las cinco de la mañana cuando iba por agua al río Tonusco; al dar a luz una niña la dejó en la casa antes anotada. Dijo haber sido aconsejada por las señoras López, quienes al saber de su embarazo le solicitaron darles quien les sirviera. A sus amos los había engañado diciendo unas veces "que no había parido" y otras, que había "mal parido". Reconviniéndola el juez por el delito cometido, dijo que fue "tentada del enemigo malo" en el parto.

Como doña Martina López en su declaración negó lo afirmado por la negra, el juez procedió a hacer un careo, durante el cual las partes se reafirmaron en lo dicho. En diciembre de 1787, tres meses después, la acusada fue sometida a un nuevo interrogatorio presentado por don Andrés Antonio López, hermano de las implicadas. A estas alturas la esclava había comenzado a ser procesada por el delito de infanticidio. En una nueva confesión, tomada un año después, en febrero de 1789, Cayetana afirmó ser falsa la declaración anterior. Sostuvo no haber estado en embarazo sino "enferma del vientre". Inventó el "enjambre

${ }^{85}$ Hevia Bolaños, Juan de. Ob. cit. Tomo I. Pág. 221. Escriche, Joaquín. Ob. cit. Pág. 1024. 
de falsedades" cuando sus amos la presionaron para que dijera dónde estaba la criatura. En el alegato de conclusión el defensor trató de justificar a la rea catalogándola de "demente y loca” y afirmaba que por lo tanto sus mentiras no debían ser tenidas en cuenta. En enero de 1790 después de dos años y medio de estar presa, el asesor jurídico nombrado para dictaminar sobre el caso conceptuó que el único delito comprobado de Cayetana era el de perjurio. Teniendo en cuenta la dilatada prisión que había sufrido, la condenó con 50 “azotes de vergüenza” y un año de servicio en obras públicas, pena de la que se podía liberar si su amo pagaba 25 castellanos. ${ }^{86}$

El temor de los críticos sobre la exigencia del juramento quedó corroborado con el resultado del proceso. Las sucesivas confesiones no ayudaron a esclarecer los hechos, pero al haber sido hechas bajo juramento dieron origen al cargo de perjurio.

El ejemplo anterior demuestra, como lo ha afirmado el historiador Germán Colmenares, lo difícil que fue para las autoridades coloniales crear en las clases bajas el sentido de culpa propio de la tradición judeo-cristiana. ${ }^{87} \mathrm{La}$ influencia de las ideas religiosas en este grupo era limitada, porque al vivir disperso en explotaciones agrícolas o mineras era imposible una acción continua por parte de la Iglesia.

En estas condiciones, para los jueces fue difícil dar una confesión hecha por esclavos o indios el carácter probatorio que tenía, pues existían dudas sobre su conocimiento acerca de las implicaciones de un juramento y el significado de la confesión.

Así, en 1799 para conceptuar sobre la validez de la confesión hecha por María Francisca Santana, hija del esclavo Juan Félix Santana, acusada de los delitos de incesto e infanticidio, se la sometió a un interrogatorio sobre doctrina cristiana. Las preguntas que se le hicieron fueron "cuántas cosas eran necesarias para hacer una buena confesión” y el número de veces que se había confesado.

${ }^{86}$ A. H. A. Criminal. B. 81. Leg. 1780-1790. Doc. $\mathrm{N}^{\circ}$ 18. Fols. 10v-11v, 13v-14v, 31r-v, 50v-51r, 53r-54r, 68v-69r.

${ }^{87}$ Colmenares, Germán. "La Aplicación de la Ley Penal a fines de la Colonia y comienzos de la República”. Cali. Versión Mecanografiada sin publicar. Pág. 17. 
No obstante esta diligencia, el juez no la condenó a la horca, como lo pidió el fiscal, en consideración a

Su menor edad, su vida campesina y la ninguna instrucción que le dieron sus padres, deduciéndose de esto que este delito fue cometido por ignorancia de su gravedad. ${ }^{88}$

En otro caso, el de la indígena chocoa Fernanda Chaquerivia (Sagedibia), acusada en 1801 de haber ahogado a la menor Josefa Domicó, el juez se declaró imposibilitado para tomar su confesión por no hablar castellano la rea. Mandó entregarla al Regidor don José Cruz Robledo, para que la instruyera en la doctrina cristiana y el idioma. ${ }^{89}$

Una situación parecida se presentó en 1807 al ser procesado el indígena de 13 años Torcuato Tuberquia, quien era sindicado de haber matado a otro muchacho indio por robarle unos panes. Inicialmente la diligencia de la confesión se dejó en suspenso por algún tiempo buscando que el reo se instruyera en la doctrina cristiana y tuviera más reflexión. Sólo se le tomó confesión en 1810, después de tres años de estar preso. Habiéndosele preguntado si sabía el delito que cometía y que por eso iba ser castigado por la justicia respondió que:

No se hizo cargo de cosa ninguna más que el de comer.90

Los ejemplos anteriores muestran hasta qué punto los jueces tenían en cuenta las formalidades prescritas por la ley, porque de no hacerlo podían invalidar la confesión, elemento esencial en la comprobación del delito. En la jurisdicción de la ciudad de Antioquia esta rigurosidad en el procedimiento se cumplió básicamente en los casos de homicidio, en razón a que si las pruebas permitían catalogarlo como premeditado y alevoso, se debía condenar al reo a la pena de muerte.

\footnotetext{
${ }^{88}$ A. H. A. Criminal. B. 37. Leg. 1790-1800. Doc. $\mathrm{N}^{\circ}$ 18. Fols. 2v-3v, 16v-17r, 26r-v.

${ }^{89}$ A. H. A. Criminal. B. 97. Leg. 1790-1810. Doc. $\mathrm{N}^{\circ} 12$. Fols. $13 \mathrm{r}-\mathrm{v}$.

${ }^{90}$ A. H. A. Criminal. B. 99. Leg. 1800-1810. Doc. $\mathrm{N}^{\circ} 30$. Fols. 10v, 16v-18r.
} 
La aplicación estricta de la ley en este punto parece haberse incrementado a fines del régimen colonial (1790-1810), como resultado de una mejor formación jurídica por parte de los jueces y de la supervisión ejercida por los asesores jurídicos y la Audiencia.

Nos ilustra esta actitud de los funcionarios encargados de la administración de justicia, lo sucedido en la causa seguida entre 1807 y 1808 al negro Venancio Londoño por haber ahogado una hija. Al enviar a la Audiencia para su aprobación la sentencia dictada por el Gobernador Francisco de Ayala, con la asesoría jurídica del Teniente de Gobernador Antonio Viana, fue devuelta porque el fiscal del crimen de la Audiencia encontró que a Venancio, siendo menor de edad, se le tomó confesión sin asistencia de curador. El fiscal ordenó que la causa se "repusiera a aquel estado", amonestando a los jueces y letrados de la provincia para que en lo sucesivo fueran más exactos en el cumplimiento de sus oficios. ${ }^{91}$

Cuando era difícil obtener la confesión del reo y las pruebas con que se contaba eran escasas, según las Siete Partidas, se le podía someter a tormento para que declarara. Este procedimiento sólo se aplicaba en aquellos delitos en los que se podía imponer pena corporal, como el homicidio, porque de lo contrario, el tormento sería mayor que la pena a que era acreedor el acusado. ${ }^{92}$

De acuerdo con las Leyes de las Partidas estaban exceptuados de la aplicación del tormento el menor de catorce años, el viejo decrépito, la mujer preñada o recién parida, el clérigo de orden sacro, el militar o caballero, el noble o hidalgo, el doctor o maestro de ciencia, el consejero o Regidor de alguna villa o ciudad. ${ }^{93}$

La regla vigente era que el tormento se podía utilizar cuando el delincuente era "vil o de mala fama". La confesión obtenida por este medio, sólo valía si después de 24 horas se ratificaba voluntaria y espontáneamente. ${ }^{94}$

\footnotetext{
${ }^{91}$ A. H. A. Criminal. B. 88. Leg. 1810-1830. Doc. $\mathrm{N}^{\circ}$ 3. Fol. 34v.

${ }^{92}$ Hevia Bolaños, Juan de. Ob. cit. Tomo I. Pág. 229.

${ }^{93}$ Ibídem. Págs. 229-230.

${ }^{94}$ Ibídem. Pág. 231.
} 
Si en el tormento el reo confesaba el delito y en la ratificación lo negaba, podía ser atormentado otras dos veces en días diferentes. ${ }^{95}$

El uso del tormento fue uno de los aspectos más duramente criticados de la legislación medieval vigente en el siglo xviI. Beccaria en su libro De los delitos y de las Penas, publicado en 1764, sostenía que la tortura era un rezago de las pruebas del fuego y del agua hirviendo - juicios de Diosexistentes en la legislación antigua. Por medio de un vehemente discurso pedía su abolición por ser:

El medio seguro para absolver a los criminales robustos y condenar a los inocentes débiles. ${ }^{96}$

El jurista mexicano Manuel de Lardizábal y Uribe en el libro Discurso sobre las Penas, editado en 1783, decía que aunque el tormento era reputado por una prueba y como un medio para descubrir la verdad, él estaba persuadido de que era una "verdadera y gravísima pena". Siguiendo a Beccaria afirmaba que era una prueba falible, inútil y desigual. En ella:

\begin{abstract}
El inocente siempre pierde, y el delincuente puede ganar porque, o confiesa el inocente, y es condenado, o niega, y después de haber sufrido el tormento, que no merecía, sufre también una pena extraordinaria, que tampoco merece; pero el delincuente tiene un caso favorable que es cuando tiene constancia para negar, y se libra de la pena que merecía. ${ }^{97}$
\end{abstract}

Para solicitar al Rey Carlos in la abolición del tormento, Lardizábal argumentaba que no estaba realmente autorizado por las leyes españolas. Anotaba que la tortura se introdujo en la legislación española a través de las Leyes de las Partidas, elaboradas con base al derecho romano y a las opiniones de los doctores del siglo xilI. Esta colección de leyes no tuvo autoridad pública ni fuerza, hasta el año de 1348 cuando el Rey Alonso xi, por una ley

\footnotetext{
${ }^{95}$ Idem.

${ }^{96}$ Beccaria, Cesare. Ob. cit. Pág. 22-23.

${ }^{97}$ Lardizábal y Uribe, Manuel de. Ob. cit. Págs. 243, 244, 252.
} 
del Ordenamiento de Alcalá, mandó observar lo determinado en ellas en los casos que no se pudieran decidir por el Ordenamiento o los Fueros. ${ }^{98}$

El debate sobre el carácter bárbaro del tormento parece haber llevado en el siglo xviı a restringir su uso en los tribunales españoles. En lo que atañe a la jurisdicción de la ciudad de Antioquia encontramos que en ninguno de los juicios consultados fue empleado. ${ }^{99}$ Sólo en dos causas, seguidas en el año de 1760, se discutió la posibilidad de aplicarlo para obtener la confesión del crimen.

El primer caso fue en el juicio seguido contra Francisco Telmo de Piedrahíta y María Rita García, por la muerte de Juan Primero García, marido de la sindicada. El fiscal de la causa, el maestro mayor Miguel Jerónimo de Vargas Machuca, pidió que los reos fueran puestos "a cuestión de tormentos" para que no quedase dudosa la prueba. Don Pedro Félix Pastor, juez subdelegado de bienes de difuntos, en su papel de defensor, se opuso a la aplicación de la tortura argumentando:

Cuando el reo justifica su inocencia, debe ser libre sin pasar a tortura, o cuando se le justifica el delito, debe ser castigado sin tortura.

Concluía su reflexión afirmando que el tormento era una pena grave que, por atroz, estaba prohibida en muchas partes y sus resultados eran dudosos, debido a que los reos por liberarse del castigo, confesaban lo que no habían hecho.

El Alcalde ordinario don Fermín García negó la petición argumentando que con arreglo a la ley 3 del título $3^{\circ}$ de la partida $7^{\text {a }}$, se podía atormentar al delincuente vil o de mala fama lo que no ocurría con Francisco Telmo:

Hombre de bien arreglados procederes, de natural pacífico, nada quimerista, ni ruidoso y que procuró excusar y excusó distintas provocaciones que le hizo el referido difunto. ${ }^{100}$

\footnotetext{
${ }^{98}$ Ibídem. Págs. 273-280.

99 Delval, Juan. "Beccaria en España”. En: Beccaria, Cesare. De los Delitos y de las Penas. Madrid. Alianza Editorial. 1982. Pág. 169.

${ }^{100}$ Es sorprendente la similitud entre los argumentos expuestos por el defensor y los sustentados por Beccaria y Lardizábal, sobre todo si se tiene en cuenta que el escrito es anterior a la publicación de sus obras.
} 
El segundo caso fue en la causa ya citada contra José Agudelo, su hijo Juan de Agudelo Guerra y Salvador de Ochoa, por haber herido con una pistola al Alcalde ordinario don Francisco Salvador de Lara y Moncada. De los tres supuestos reos sólo pudo ser apresado Juan de Agudelo, de 16 años, quien fue sometido a confesión por tres veces consecutivas sin que se pudiera obtener prueba concluyente de estar involucrado en los hechos. Por esta razón el procurador general don Diego Hernández de Sierra pidió que se le sometiera a tortura para que confesara la verdad. El procurador general de menores don Manuel de Aguirre contradijo la solicitud por considerar que Agudelo

Como ignorante, dirá en el tormento, varios y muchos desatinos y quizá, y sin quizá podrá culpar algún inocente, persuadido a que de esta forma, se libra y libra a su padre y hermano. ${ }^{101}$

No obstante, el Gobernador José Barón de Chaves por medio de una sentencia interlocutoria, condenó a Juan de Agudelo, en noviembre de 1760, a la pena de tormento. Esta determinación fue apelada, remitiéndose la causa a estudio de la Real Audiencia. El procurador de pobres Pedro de Hinestrosa en representación hecha a este tribunal sostenía que la sentencia de tormento era injusta, porque sólo estaba autorizado atormentar a un menor en el delito de lesa majestad u otros atroces, no siendo la herida infringida al Alcalde un delito de esa calidad. Además, el acusado no podía ser obligado a declarar contra su padre por ser opuesto al derecho natural. Por su parte, el fiscal de la Audiencia, afirmó que Agudelo podía ser sometido a tormento por ser mayor de 17 años y que el delito cometido contra un juez se comparaba al de lesa majestad humana. En la definición del caso, en agosto de 1761, el doctor Francisco de Santamaría determinó por razones de derecho, absolver al reo de la cuestión de tormento.

El poco empleo del tormento en la provincia de Antioquia en el siglo xviI es corroborado por el testimonio de José Antonio Benítez, autor del Carnero de

A. H. A. Criminal. B. 74. Leg. 1740-1760. Doc. $\mathrm{N}^{\circ}$ 3. Fols. $111 \mathrm{r}-113 \mathrm{r}, 117 \mathrm{r}-1 \mathrm{dos} 5 \mathrm{v}, 126 \mathrm{r}-$ $129 \mathrm{v}$.

${ }^{101}$ A. H. A. Criminal. B. 92. Leg. 1740-1770. Doc. No 9. Fols. 52v-56v, 57v-50r, 108r-v, 187v-188r, 193r-196r, 197v-198v. 
Medellín, quien asegura que por orden del visitador Mon y Velarde se hizo en Medellín el primer instrumento de tormento. Según su descripción éste era un cajón largo y delgado, en donde cabía un hombre ajustado, con agujeros para los ojos, oídos y boca, por donde podía respirar y hablar. El interior del cajón estaba lleno de puyas de hierro que el verdugo movía desde afuera para que sus puntas hirieran al atormentado.

El 22 de diciembre de 1785 se ejecutó una sentencia de tormento, espectáculo que

Movía a compasión a todo este vecindario que miraba con horror semejante impiedad nunca vista en Medellín. ${ }^{102}$

La misma opinión se expresa en un documento anónimo enviado a la Audiencia en 1786 sobre la visita hecha a la provincia de Antioquia por Mon y Velarde. El autor enumera como uno de los cargos contra el Oidor el haber sometido a tormento al administrador de la renta de tabaco don Antonio del Valle, para que confesara dónde tenía el dinero del alcance que le resultó en las cuentas del estanco. De acuerdo con su relato, luego de ser desnudado por el verdugo, Del Valle estuvo metido en el ataúd una hora, de donde salió casi muerto. Afirma que el resultado obtenido con este procedimiento fue escandalizar a la provincia e infamar a sus principales familias, emparentadas con la mujer de Del Valle. ${ }^{103}$

Debido a la reacción provocada, la Audiencia declaró que la tortura a que fue sometido, no debía perjudicar a Del Valle y debía restaurársele su buena reputación y fama. ${ }^{104}$

Testimonios como los anteriores, permiten conducir que aunque desde el punto de vista legal estaba autorizado el empleo de la tortura, socialmente ésta

${ }^{102}$ Benitez, José Antonio. Carnero de Medellín. Ed. Autores Antioqueños. 1988. Pág. 179.

${ }^{103}$ A. H. N. Visitas de Antioquia. Tomo II. Fols. 376-380. Por las circunstancias anotadas los dos testigos parecen referirse al mismo hecho.

${ }^{104}$ Benitez, José Antonio. Ob. cit. Págs. 179-180. 
no tenía mucha aceptación en la Antioquia del siglo xvir y su práctica se había limitado. ${ }^{105}$

No es de extrañar, por lo tanto, que en la independencia los redactores de las Constituciones del Estado de Antioquia (1812 y 1815), incluyeran dentro de las prevenciones generales acerca del poder judicial un artículo en donde se determinaba que ningún juez o tribunal usara la "bárbara cuestión del tormento", la cual quedaba marcada con "execración pública”. ${ }^{106}$

Si el reo en su confesión hacía afirmaciones que contradecían lo dicho por la parte ofendida a los testigos, de modo que sus declaraciones resultaran incompatibles, el juez para esclarecer la verdad debía someterlos a un careo. Este método se basaba en la creencia de que poniendo la verdad frente a la mentira para que controvirtieran, debía salir triunfante la primera porque era enérgica, valiente y firme, mientras que la mentira era débil, cobarde y vacilante. ${ }^{107}$

En la práctica el careo pocas veces permitía obtener más pruebas de las que se tenían, pues los interrogados solían mantenerse en lo anteriormente afirmado. Un ejemplo típico es el careo a que fueron sometidos Melchor Ciceros y María Teresa de Guzmán, su esposa, en la causa que en 1798 se le siguió a ella por acusarla su marido de querer envenenarlo. Los motivos que Ciceros declaró tener, para hacer el cargo eran: Recién casados había encontrado a su esposa en "acto carnal" con Pablo de Vargas; estando ausente en Honda, su mujer había parido un hijo que escondió; en tres años ella había gastado 500 pesos que él tenía y cuando estaba en Honda le vendió la ropa, y por último, ella no lo quería, pues se negaba a dormir con él en su cama. Al hacerle a ella los cargos confesó que era cierto el pasaje con Pablo de Vargas, pero que lo de más era falso. Aunque el juez trató de obtener más información cada uno se mantuvo en lo dicho. ${ }^{108}$ Aunque el reo admitiera el delito en la confesión,

\footnotetext{
${ }^{105}$ Es aventurado suponer, como lo hace un autor mexicano, que la razón por la cual no aparecen datos sobre esta práctica en los procesos realizados en el siglo XVIII, es por conservarse aparte.

Giraud, François. "La Reacción Social ante la violación: del Discurso a la Práctica. Nueva España. Siglo XVIII”. En: El Placer de Pecar y el Afán de Normar. México. Joaquín Mortiz. Instituto Nacional de Antropología e Historia. 1987. Pág. 324.

${ }^{106}$ Pombo, Manuel Antonio y Jose Joaquín guerra. Ob. cit. Tomo I. Pág. 517. Tomo II. Pág. 365.

${ }^{107}$ Escriche, Joaquín. Ob. cit. Pág. 1020.

${ }^{108}$ A. H. A. Criminal. B. 37. Leg. 1780-1800. Doc. No 14. Fols. 11r-v, 12 r.
} 
no podía ser condenado si no existían otras pruebas que lo corroboraran. ${ }^{109}$ Igualmente las leyes mandaban que la diligencia de tomar la confesión no se omitiera, aunque el delito estuviera plenamente probado, porque importaba conocer los motivos que el sindicado había tenido para cometerlo, y éste podía explicar los hechos de manera que los cargos quedaran desvanecidos en todo o en parte. ${ }^{110}$

Sin embargo, por múltiples razones el trámite de tomar la confesión a los reos no se cumplió en todas las causas ni con todos los implicados. Así, en los procesos por homicidio, estudiados, de 70 personas comprometidas en la ejecución de los hechos, se hizo la diligencia de tomar la confesión a 43 (61,4\%), mientras que 14 (20\%) rindieron declaración por no estar presos. Con respecto a los juicios por lesiones personales encontramos que la proporción de agresores sometidos a esta diligencia fue menor, pues de 273 personas procesadas, a 116 (42\%) se les recibió confesión y a 29 (11\%) declaración. En las causas por injuria el porcentaje fue todavía más bajo, como se infiere del hecho de que en la década 1790-1799 se tomó confesión a 12 (25\%) y declaración a 12 (25\%) de las 48 personas inculpadas en esta clase de juicio.

Estos datos adicionalmente muestran que el número de implicados puestos en prisión aumentaba de acuerdo con la gravedad del delito.

Al evaluar las confesiones, hay que tener en cuenta que son el producto de un interrogatorio hecho por el juez; ellas se ajustan a la estructura formal del esquema de preguntas y respuestas. Además, al ser consignadas por escrito pasaban por el filtro de un escribano que no siempre transcribía textualmente lo dicho por el reo. No obstante, dentro del formalismo legal de los juicios era la única oportunidad que tenían los acusados de expresar los motivos de su acción, de describir el contexto en que habían ocurrido los hechos, de expresar cuál era la imagen e idea que tenían de la autoridad y la ley.

${ }^{109}$ Hevia Bolaños, Juan de. Ob. cit. Tomo I. Pág. 222.

${ }^{110}$ Escriche, Joaquín. Ob. cit. Pág.1024 


\section{La acusación y la defensa}

Con la confesión del reo terminaba la primera parte del juicio llamada sumario, la cual tenía por objeto la justificación del delito y la identificación de sus autores. Se debía proceder entonces a abrir una segunda parte denominada plenario, dirigida a "discutir contradictoriamente" la culpabilidad o la inocencia de los procesados y a dictar sentencia condenatoria o absolutoria.

En la mayoría de los juicios por injuria o lesiones personales, esta parte se abreviaba y pasaba el juez a dictar sentencia rápidamente. También era alto el porcentaje de causas de esta índole, en las que no se pasaba al plenario, por desistir al querellante de continuar el juicio, o haberse llegado a un acuerdo entre la víctima y el agresor. Lo contrario ocurría en los juicios por homicidio o complicados, en los que la realización de cada diligencia o presentación de escritos podía demorar varias semanas, alargando exageradamente su duración. Esta etapa del proceso podía prolongarse por meses y aun años, haciendo difícil de quienes se veían involucrados en un juicio.

En que por lo común perdían toda o la mayor parte de su fortuna. ${ }^{111}$

El juicio plenario empezaba con la formalización de la acusación hecha por el querellante, el ministerio fiscal o por ambos, con base en los datos que proporcionaba el sumario. ${ }^{112}$ En la jurisdicción de la ciudad de Antioquia, durante la época estudiada, esta diligencia fue realizada por el querellante en los juicios iniciados a petición de parte (injurias y lesiones personales leves) y por un fiscal, nombrado por el juez, en la mayoría de los juicios seguidos de oficio (homicidios y heridas graves).

La acusación, ya fuera presentada por el agraviado o por el fiscal, debía contener los siguientes puntos:

1. La historia del hecho que dio motivo al sumario.

2. La participación que hubiere tenido cada uno de los inculpados y los datos en los que se fundaba la acusación.

${ }^{111}$ Restrepo, José Manuel. Historia de la Revolución de la República de Colombia. Medellín. Bedout. 1969. Tomo I. Pág. 31.

${ }^{112}$ Escriche, Joaquín. Ob. cit. Pág.1020. 
3. Las circunstancias agravantes o atenuantes que existían en contra o a favor de los acusados.

4. Las disposiciones legales y doctrina de derecho o jurisprudencia que definían el hecho que se perseguía, y las penas que se señalaban a sus autores y cómplices.

5. La pena que debía imponerse a cada uno de los procesados. ${ }^{113}$

Tomando como ejemplo las 43 causas por homicidio tramitadas en el periodo 1750-1812, encontramos que en 11 de ellas no se llega a esta etapa del proceso. De los 32 casos restantes, en dos (ocurridos en 1751 y 1754) los acusadores fueron familiares de la víctima o sus representantes; en dos (pertenecientes a los años 1762-1764) el papel de fiscal fue desempeñado por el Alcalde ordinario a nombre del proceso; en siete fueron designados para este cargo vecinos de la localidad y en 22 la función fue realizada por el síndico procurador general.

Nombrar para este oficio al procurador general se vuelve corriente en la década de 1780, tal vez como resultado de las reformas, que introdujeron en la administración de justicia a los Gobernadores visitadores Francisco Silvestre y Juan Antonio Mon y Velarde. Así, en la Relación de la Provincia de Antioquia que elaboró Silvestre, proponía que para desempeñar este cargo se nombraran personas de la "mayor probidad e inteligencia", pues esto incidiría en que la justicia se administrara con imparcialidad e igualdad. ${ }^{114}$

De las personas que en los juicios estudiados ejercieron este oficio, sólo dos tenían título de abogado. El primero de ellos fue el doctor Juan de Dios Martínez, hijo del comerciante español don Bernardo Martínez, quien actuó en 1787. El otro fue el doctor José María Ortiz, hijo del español don José Domingo Ortiz y Argota, quien ocupó el cargo en 1803 y 1807. Este abogado fue uno de los miembros de la Junta que proclamó la Independencia y como diputado de la ciudad de Antioquia figura entre los firmantes de las Constituciones del Estado de Antioquia de 1812 y $1815 .{ }^{115}$

${ }^{113}$ Ibídem. Pág. 1030.

${ }^{114}$ Silvestre, Francisco. Relación de la Provincia de Antioquia. Pags. 508-509.

${ }^{115}$ Arango Mejía, Gabriel. Genealogía de Antioquia y Caldas. Medellín. Imprenta Departamental. 1942. Tomo I. Págs. 369-374. Tomo II. Pág. 136. 
Algunas veces era complicado para el juez encontrar quien desempeñara el papel de fiscal, debido a que las personas nombradas no aceptaban el cargo por tener vínculos de amistad o enemistad con el reo. En el juicio seguido en 1797 contra don José Cruz Robledo, importante vecino de Antioquia, por la presunción de estar vinculado con la muerte de don Félix Lemos, el procurador general Nicolás de Lara, y cinco vecinos más, se excusaron de desempeñar este oficio. De ellos, el doctor José Antonio Gómez se negó por ser amigo y compadre de Robledo. Por su parte, don Juan Bautista Méndez rehusó por haber tenido un pleito con él. ${ }^{116}$

Es difícil saber quién elaboraba la acusación y demás representaciones presentadas por los querellantes o sus apoderados en los juicios por delitos privados. Según el Gobernador Francisco Silvestre la abundancia de pleitos en la provincia se debía a la existencia de una "casta de tinterillos", quienes se dedicaban a "papelistas".

Ya fuese por comer estafando a los porfiados, ya por vengar sus privadas pasiones o tener parte en el gobierno o mando, que no les tocaría de otro modo. ${ }^{117}$

Entre los vecinos de la ciudad de Antioquia, Silvestre sindicaba de ejercer este oficio al contador don Francisco Visadías, de quien afirmaba "parece que es abogado". En su concepto, en los escritos hechos por él se zahería a las partes y se trataba con desacato a los jueces. Otro personaje a quien acusaba de hacer escritos era a don Pedro Julio Pastor, fundidor de las cajas Reales, quien en su concepto "dirigía” a la mayor parte de los jueces y al Cabildo. También amonestó por papelista a don Manuel Ladrón de Guevara, quien ejerció varias veces el cargo de procurador general. Igualmente apercibió por este motivo a don Carlos Piedrahíta, en su opinión, una especie de "rufián o vago". ${ }^{118}$

Pombo y Guerra. Ob. cit. Tomo I. Pág. 531 y tomo II. Pág. 377.

${ }_{116}$ A. H. A. Criminal. B. 37. Leg. 1790-1800. Doc. N 12. Fols. 20r-24r.

${ }^{117}$ Silvestre, Francisco. Ob. cit. Pág. 189.

${ }^{118}$ Ibídem. Págs. 190-194. 
A pesar de las amonestaciones, las actividades de los tinterillos no parecen haber disminuido. Un ejemplo es el juicio seguido en 1795 contra don Luis María Fernández, papelista de la ciudad de Antioquia, de quien se decía

Su principal oficio en que comenzó en su juventud a instruirse fue el de platero y habiéndolo abandonado enteramente, se dedicó y metió a papelista, haciendo escritos a unos y a otros. Sin embargo de habérsele privado de que los hiciese por auto de visita de gobierno ha continuado haciéndolos y fomentando de este modo discordias, aún entre parientes y aún estando en la misma cárcel los ha estado haciendo. ${ }^{119}$

Los abogados no salían mejor librados de los tinterillos al ser evaluadas las expresiones que utilizaban en los alegatos elaborados para su representado. Un ejemplo de esto es el juicio por injuria seguido en 1787 por don Alonso Elías Jaramillo y don Nicolás Jaramillo contra el doctor Ignacio Uribe, vecino de Medellín.

El origen de este pleito fue una representación elaborado por Uribe como apoderado de don Gabriel Muñoz, en una causa por agravios que éste seguía con don Nicolás Jaramillo. En el escrito se había sindicado a los Jaramillos de faltar al amor y lealtad que debían al soberano, cuando el movimiento de los comuneros de Guarne en 1781. La Audiencia en la sentencia proveida en 1789 dictaminó:

No debiendo producirse en los alegatos expresiones perjudiciales al honor de las partes faltando al respeto debido de los tribunales, se declara que el doctor Ignacio Uribe se ha excedido en las que produjo en el escrito que se halla testimoniado en este expediente contra la familia de los Jaramillos a quienes no obstarán y se les apercibe use en los sucesivo de la moderación y comedimiento que está prevenido por las leyes. ${ }^{120}$

119 A. H. A. Criminal. B. 33. Leg. 1790-1817. Doc. $\mathrm{N}^{\circ} 11$. Fols. 39r-41r.

120 A. H. N. Juicios Criminales. Tomo 117. Fols. 432 a 597. Fol. 484v. 
Estos hechos permiten ver por qué el Gobernador Silvestre tildaba a los abogados de fomentadores de pleitos. En su plan para la reforma de la administración de justicia proponía como solución del problema limitar su número y asignarles un salario fijo. ${ }^{121}$

En la primera década del siglo xix buena parte de los escritos presentados a los tribunales empezaron a ser elaborados por procuradores del número, personas nombradas para este fin. De acuerdo con las leyes de las Partidas procurador era

Aquel que recabda, o face algunos pleitos o cosas ajenas por mandado del dueño de ellas. ${ }^{122}$

Parece que este era un cargo que se compraba, pudiendo el dueño venderlo o renunciar a él cuando quisiera. ${ }^{123}$ Durante los años de 1803 a 1811 ejercieron este oficio Lorenzo Justiniano Yepes, Vicente del Campillo y Juan Salvador Palacio, quienes a pesar de no ser abogados hacían gala de conocimientos jurídicos en los documentos que redactaban. De ellos, Yepes se especializó en representar a la parte acusadora, mientras que Campillo escribía la defensa de los reos.

Para el periodo de la independencia no sabemos si este cargo siguió vigente. La Constitución del Estado de Antioquia de 1812, al referirse al poder judicial determinaba que el Supremo Tribunal de Justicia proveería las plazas de escribanos y procuradores del número, precediendo una rigurosa selección para asignarlas por mérito y virtud. Estos oficios dejarían de ser vendibles o renunciables, pero los que los ocupaban podían seguir en ellos. ${ }^{124}$ Sin embargo, en la revisión hecha a esta Constitución en 1815 se eliminó este parágrafo. ${ }^{125}$ En los pocos juicios que existen pertenecientes al periodo 1812-1816, no encontramos alusión a personas que ejercieran este oficio. Lo mismo ocurre

\footnotetext{
${ }^{121}$ Silvestre, Francisco. Ob. cit. Pág. 111.

${ }^{122}$ Sala, Juan de. Ob. cit. Tomo II. Pág. 192.

${ }^{123}$ Pombo, Manuel Antonio y José Joaquín Guerra. Ob. cit. Tomo I. Pág. 514.

${ }^{124}$ Ibídem. Pág. 514.

${ }^{125}$ Ibídem. Tomo II. Págs. 333-337.
} 
para los años 1816-1819 cuando los españoles nuevamente ejercieron el poder en la provincia.

Una vez formalizada la acusación, se debía dar traslado al reo de la culpa que contra él resultaba, con los nombres de los testigos que en su contra declararon, para que pudiera defenderse. ${ }^{126}$

Los escritos de la defensa debían estar orientados a:

1. Descubrir y demostrar la insuficiencia, nulidad o falsedad de las pruebas materiales o morales del hecho.

2. Contradecir los datos en que se fundaba su participación, desvaneciendo y destruyendo un indicio con otro, una declaración adversa con otra favorable, etc.

3. Anular o desvirtuar la confesión que de su criminalidad hubiese hecho, manifestando haber sido hecha por ignorancia, error, violencia o miedo.

4. Excusar o justificar la criminalidad del reo, demostrando que cometió el hecho en un estado en que no podía ser responsable de sus acciones o haber sido algo fortuito y contra su voluntad.

5. Involucrar doctrinas y costumbres suaves adoptadas en la práctica por los tribunales, en oposición a la severidad y rigor de las disposiciones legales y doctrinas invocadas por el acusador o fiscal.

6. Pedir que se declarara la inocencia del reo, o al menos, que se le impusiera la menor pena posible. ${ }^{127}$

Para saber quienes actuaron como defensores, tomaremos los 43 juicios por homicidio seguidos en la ciudad de Antioquia de 1750 a 1812. En 12 casos, que en su mayor parte están inconclusos, no actuó defensor. La justificación fue asumida por el reo o un familiar en cuatro casos. Como defensores de oficio actuaron el protector de naturales, en tres casos que involucraban indígenas; el defensor de menores, figura que aparece a partir de 1761, en 14 y particulares nombrados por el juez en $15 .{ }^{128}$

\footnotetext{
${ }^{126}$ Hevia Bolaños, Juan de. Ob. cit. Tomo I. Pág. 224.

${ }^{127}$ Escriche, Joaquín. Ob. cit. Págs. 1030-1031.

${ }^{128}$ La diferencia entre el número de defensores y el número de casos obedece a que en causas que involucraban a más de un reo, se nombraron varios defensores.
} 
Entre los defensores figuran dos abogados, los doctores José Antonio Gómez Londoño, quien se desempeñó como defensor en 1787, 1799 y 1804 y Andrés Avelino Uruburu, quien actuó con este carácter en 1803 y 1807. El primero, hijo del español don Antonio Adriano Gómez, nació en Medellín en 1754. En 1773 vistió la beca del colegio de San Bartolomé, donde estudió hasta obtener el título de doctor en ambos derechos. Desde 1786 se radicó en la ciudad de Antioquia donde ocupó los cargos de Alcalde ordinario, contador y tesorero de la Caja Real y fue administrador de la Renta de Aguardientes por más de 20 años. En enero de 1811 fue nombrado secretario de la Junta Suprema Gubernativa que se había formado en la provincia, como resultado de los sucesos ocurridos en Bogotá el 20 de Julio de 1810. Desempeñando este cargo firmó la Constitución provisional del 27 de junio de 1811, en la cual todavía se reconocía la soberanía de Fernando viI. Fue elegido Presidente del Estado de Antioquia el 11 de octubre de ese año, siendo su principal actividad en la presidencia, la preparación de hombres para la carrera militar. Intervino en la expedición de la Constitución de 1812, y murió el 10 de Octubre de ese año. ${ }^{129}$

El segundo personaje, el doctor Andrés Avelino Uruburu también tuvo una participación importante en la Independencia. Nació en la ciudad de Antioquia en 1781, del matrimonio del español don Valerio Ramón Uruburu y doña Lucía Pardo y Otálora. Vistió la beca del colegio del Rosario en 1796, donde obtuvo el grado de doctor en derecho. En la época de la Independencia fue fiscal (1811) y presidente (1815) del Tribunal de Justicia de Antioquia. Fue secretario del Colegio Electoral Constituyente de la provincia, habiendo suscrito con este carácter y como diputado de la ciudad de Antioquia la Constitución de 1812. Durante la reconquista fue perseguido por el comandante Warleta a pesar de haber firmado en abril de 1816 el acta de obediencia a Fernando vil. Después de la Independencia, en abril de 1821, fue nombrado Teniente Asesor de la provincia de Antioquia, cargo que ocupó hasta enero de 1822. El 25 de febrero de 1822 fue nombrado Secretario de Gobierno de la Provincia de Antioquia. ${ }^{130}$

${ }^{129}$ Restrepo Sáenz, José María. Gobernadores de Antioquia. 1571-1819. Bogotá. Imprenta Nacional. 1931. Tomo I. Págs. 245-249.

${ }^{130}$ Ibídem. Tomo II. Pág. 119. 
Los datos anteriores, al igual que los referidos a los fiscales, muestran que en la provincia de Antioquia, a partir de la década de 1780, los abogados empiezan a tener injerencia en la tramitación de los juicios criminales. Pero sólo en los primeros años del siglo xix su papel se vuelve importante, lo que parece constituirse en un antecedente de su participación en el proceso de la Independencia. Sus conocimientos jurídicos, puestos a prueba en la práctica, se plasmaron en la propuesta de organización del poder judicial, que contienen las Constituciones de 1812 y 1815.

En los juicios por delitos privados lo común era que el reo asumiera su defensa, pero al igual que en el caso de los acusadores, sus representaciones parecen haber sido escritas por tinterillos, abogados o procuradores del número.

Teniendo claro quiénes fueron los redactores de los documentos presentados por la fiscalía o la defensa, es bueno pasar a analizar su contenido. Para hacerlo, hay que tener en cuenta que los argumentos utilizados en contra o a favor de un reo, permiten conocer lo que se consideraba aceptable en una sociedad dada y en un periodo determinado.

Más allá de la norma legal, los escritos presentados por las partes emplean razonamientos que se suponía iban a ser bien recibidos en el tribunal. ${ }^{131}$

Los textos elaborados por los fiscales eran más concisos y directos que los de la defensa. Sobre la base de elementos extraídos de las declaraciones y la confesión, el fiscal siempre pedía que el reo fuera condenado a la máxima pena prescrita por la ley, por convenir así a "Dios, al Rey y a la Vindicta Pública”.

En otras palabras, el castigo prescrito debía buscar reparar el daño causado a la religión, al Estado y al cuerpo social. Un escrito típico es el presentado por el fiscal en el juicio seguido en 1771 contra el esclavo Marcos Méndez, alias Vísperas, por la muerte de María de Jesús, esclava de la misma casa. El discurso comienza acusando al reo de haber cometido un delito atroz y alevoso contra una mujer totalmente indefensa. La afirmación la fundamenta en las declaraciones de dos testigos presenciales, en la confesión hecha por la víctima antes de morir y en la confesión del reo. Una vez hecho el cargo se dedica a probar que la muerte no se ejecutó por defensa propia, por no haber tenido la occisa

${ }^{131}$ Giraud, François. Ob. cit. Pág. 238. 
oportunidad de atacarlo por estar desarmada y sentada, que la consumó "de hecho pensado", pues mandó a llamarla, y califica el hecho de "muerte sobre seguro", por valerse para realizarlo de la confianza que daba vivir en la misma casa. A renglón seguido trata de demostrar que el crimen no se cometió por causa "justa y grave", sino por celos motivados en no querer la víctima continuar con la "ilícita amistad" que tenían. Se trataba de un "delito agravado" porque con anterioridad, Marcos había herido a la víctima por el mismo motivo y la amenazó de muerte. El homicidio además fue perpetrado contra las "leyes de la caridad" porque el agresor no hizo caso a la petición de la esclava de que "por la Virgen Santísima” no la matara. Concluía su argumentación afirmando que el reo no estaba comprendido en alguna de las razones que el derecho daba para ejecutar una muerte, por lo cual no debía valerle la inmunidad eclesiástica a que se había acogido. Al final pedía a nombre del Rey, la vindicta pública y "la sangre de la pobre difunta" que Marcos Méndez fuera condenado al último suplicio, cortándole la mano derecha que sería exhibida en paraje público para "recuerdo y ejemplo de escarmiento de malhechores".

Es indudable que el uso de tesis como la del abuso de la confianza que nacía de vivir en la misma casa o la de la falta de caridad cristiana, referidas a hechos que escandalizaban a la sociedad, se dirigía un reforzar la idea de la culpabilidad y a obtener como pena un castigo riguroso para que

Con su mal ejemplo no infeccione a los demás miembros del cuerpo de la república que maten al prójimo sin causa. ${ }^{132}$

El discurso de los fiscales en los juicios por homicidio y lesiones personales graves, se orientaba a demostrar que el delito se había ejecutado con alevosía y premeditación.

La utilización del temor y el miedo como argumento se dio básicamente en las causas que involucraban como reos a esclavos o mujeres, que eran presentados como enemigos encubiertos que se tenían dentro de la casa.

${ }^{132}$ A. H. A. Criminal. B. 38. Leg. 1770-1780. Doc. $\mathrm{N}^{\circ}$ 3. Fols. $64 \mathrm{r}-70 \mathrm{r}$. 
En cierto momento en que los delitos cometidos por ellos fueron comunes, se pidió que no fueran mirados con conmiseración porque

Con la falta de ejemplar no cesarán semejantes maldades como se están experimentado y han experimentado en esta provincia y ciudad. ${ }^{133}$

El texto de estos escritos refleja tanto el sentimiento de la sociedad como la opinión de los encargados del gobierno. De allí que el juez los tuviera muy en cuenta en el momento de dictar sentencia.

En este contexto es explicable que fueran pocas las causas en que los fiscales optaran por solicitar la excarcelación del reo, por no encontrar en los autos, méritos para que se siguiera el proceso.

Los escritos de los defensores eran más extensos y variados. Unos se dirigían a establecer los hechos, tratando de demostrar que no existía evidencia de la participación del reo en el crimen, y otros, a aminorar la responsabilidad del inculpado. Así, en el juicio seguido contra Juana María Crespo y los hermanos Ignacio y Bonifacio Arias, por haber envenenado al marido de la primera, el defensor pidió que se les declarara libres de la acusación por no existir prueba contra ellos, dado que ninguno de los testigos interrogados había presenciado los hechos. Trató de demostrar, con base en testimonios, que la víctima estaba enferma antes de la muerte, siendo el mal tan grave que echaba sangre por la boca y tenía desencajados los dientes. Por lo tanto, decía que las señales que presentaba el cadáver debían ser fruto de este padecimiento. En el caso particular de Bonifacio, señalaba que no existía evidencia de que hubiera tenido problemas con el occiso, constando además que desde días antes de la muerte estaba en Medellín, a dos días de camino del sitio donde ocurrió el hecho. ${ }^{134}$

Este tipo de argumentación era bastante usada en los casos de homicidio porque al ser cometidos en lugares alejados como las quebradas y los montes, muchas veces no existían testigos presenciales del crimen. Si el reo no había confesado el delito, el defensor se centraba en demostrar que se carecía de

${ }^{133}$ A. H. A. Criminal. B. 27. Leg. 1750-1760. Doc. $\mathrm{N}^{\circ}$ 5. Fols. 45v-49v. B. 101. Leg. $1800-$ 1810. Doc. No 2. Fol. 6v.

${ }^{134}$ A. H. A. Criminal. B. 27. Leg. 1750-1760. Doc. N 7. Fols. 74r-76v. 
pruebas para culparlo. El éxito de esta estrategia se puede medir si consideramos que en cuatro casos el defensor logró que se absolviera a los reos; en otros cuatro, ante la falta de evidencias claras, obtuvo que la pena se conmutara por la prisión sufrida y, en uno, la Audiencia concedió un indulto. ${ }^{135}$

Cuando los testimonios y la confesión no permitían dudar de la existencia del delito, la defensa se encaminaba a tratar de disminuir la responsabilidad del reo. Un primer camino era alegar que se había actuado en legítima defensa.

En el caso concreto del homicidio, la legislación estipulaba que no era delito la muerte hecha en defensa propia, siempre que el culpado no hubiera estado en condición de huir o defenderse de otro modo. La posibilidad de utilizar este recurso dependía del tipo de relación que había existido entre las partes comprometidas, los antecedentes del reo y las evidencias existentes. Así, el defensor de Ignacio Oquendo, quien fue acusado en 1751 de haber matado en una riña a Francisco Torres, se valió de los testimonios del sumario para probar que la víctima hirió al acusado con una lanza que tenía escondida y éste por defenderse, se la quitó y la mató con ella. Para demostrar que el reo había actuado sin traición, malicia o alevosía, señalaba que al haber tenido un incidente con Torres, trató de salir del baile en donde estaban, pero éste se lo impidió y lo provocó para que peleara. Luego pasaba a señalar que el occiso estaba disgustado porque la ventera de aguardiente no le quiso empeñar la lanza por un trago, habiendo llegado a baile dispuesto a "saciar su enojo" con cualquiera. ${ }^{136}$

De las circunstancias en que había ocurrido la muerte, también se valió el defensor de menores para pedir que se le declarara libre la pena de alevosía a Antonio, esclavo de don Francisco Piedrahíta, quien admitió haber matado a Antonio, esclavo de don Diego de la Sierra. La primera prueba que se esgrimió a su favor era haber sido el acusado quien informó del crimen, signo de que actuaba sin malicia, por no existir testigos.

De acuerdo con la declaración del reo, la víctima se negó a pagarle un trabajo y lo agredió con un machete, obligándolo a defenderse con el

${ }^{135}$ Ley 2 da. Título 8․ Partida 7. En: Alvarez Posadilla, Juan. Ob. cit. Tomo III. Págs. 102-103. [N. del E .] En la edición de 1994 el llamado de esta nota no está señalado dentro del texto, pero sí al final del capítulo. En la presente edición se determinó su ubicación actual.

${ }^{136}$ A. H. A. Criminal. B. 27. Leg. 1750-1760. Doc. $\mathrm{N}^{\circ}$ 1. Fols. 18r, 28r-29r. 
hacha con que estaba rajando leña. La defesa señalaba a favor del agresor que el hacha no era considerada instrumento alevoso; la víctima en cambio había utilizado un machete que era arma ofensiva y que el golpe no había sido propinado por la espalda sino de frente..$^{137}$

El recurso legal de la legítima defensa fue utilizado eficazmente en cuatro juicios por homicidio, habiendo logrado el defensor en dos casos que los reos fueran absueltos; en uno que se le indultara y en uno que se diera como pena la prisión sufrida. La receptividad de estos escritos se debe sin duda a que en la sociedad antioqueña del siglo xvir se consideraba la defensa de la vida y de la honra como un derecho inalienable. Aunque en las clases bajas, de las que provenía la mayor parte de los reos sindicados de este delito, estos ideales no tuvieran una especial connotación, los redactores de las defensas sabían que los encargados de administrar justicia sí los tenían en cuenta.

Más que una relación de lo acaecido, estos escritos reflejan lo que los jueces estaban dispuestos a oir. ${ }^{138}$ Otras defensas se dirigían a probar que el reo no era culpable por haber actuado "fuera de juicio" y "sin conocimiento". La locura, la enfermedad o la ebriedad eran causales invocadas para disminuir su responsabilidad.

Para disculpar a Venancio Londoño, quien en 1807 ahogó una hija de 10 meses, el procurador del número Lorenzo Yepes señaló que este padecía un trastorno del juicio que lo llevaba a "ignorar sus hechos", producto de la caída de un caballo cuando niño. La "baja cuna” y la "tosca educación” eran factores que hacían más comprensible su actuación. Además, para tratar de disminuir la pena, procuró probar que era un sujeto de buena conducta y laborioso. ${ }^{139}$

En el caso de Ignacio de Arévalo quien con unas tijeras mató a don Agustín Tapia en 1781, el defensor general de menores decía que había actuado "ciego de ira y arrebato de cólera". Además el reo estaba

${ }^{137}$ A. H. A. Criminal. B. 41. Leg. 1740-1770. Doc. N 11. Fols. 19r-22v.

${ }^{138}$ Sobre este punto se puede consultar a: Taylor, William B. Embriaguez, Homicidio y Rebelión en las Poblaciones Coloniales Mexicanas. México. Fondo de Cultura Económica, 1987. Págs. 140-142.

${ }^{139}$ A. H. A. Criminal. B. 88. Leg. 1810-1830. Doc. No 3. Fols. 13r-15r, 29v-32v. 
Constituido entre el común, por un mentecato, con lucidos de loco y clásico majadero. ${ }^{140}$

Las mujeres, por su parte, solían ser presentadas como víctimas de una pasión histérica que las llevaba a la privación del sentido y a la locura. El defensor de la negra María Chavarría, enjuiciada por matar, en 1799, a un esclavo de don Pedro Chavarría, para salvarla de la horca decía:

La dicha rea desde antes del acontecimiento y suceso de la muerte del esclavillo se hallaba poseída de una violenta pasión histérica, cuya enfermedad como envía los vapores a la garganta, corazón y cerebro, descomponen la máquina humana de tal suerte, que entorpecidos y preocupados los conductos por donde la naturaleza ejerce sus funciones viene la paciente a hallarse aglomerada de distintos accidentes contrarios, ya de temor, de ira, de desmayos, de delirios y finalmente de locura y desesperación; afligiéndola de modo, que si se les proporcionara ocasión serían homicidas de sí mismas. Y si una indisposición tal precipita a una mujer a sacrificar su vida con sus propias manos, que dificulta cabe en que también la constriña y violente (con algo de tentación diabólica) a que le quite la vida a otro?. ${ }^{141}$

La ebriedad era otro argumento utilizado para demostrar que la agresión no era premeditada y así lograr la disminución de la pena. En la ideología española el alcohol era considerado como destructor del juicio natural y el buen sentido de las personas, siendo el origen de muchos delitos. ${ }^{142}$

${ }^{140}$ A. H. A. Criminal. B. 31. Leg. 1780-1790. Doc. $\mathrm{N}^{\circ}$ 1. Fol. 54v-58v.

${ }^{141}$ A. H. A. Criminal. B. 37. Leg. 1780-1800. Doc. N 19. Fols. 72v-75r.

${ }^{142}$ William B. Taylor en su estudio sobre el homicidio en la parte central de México durante el siglo XVIII, encontró que en el 26,7\% de los casos el uso de alcohol fue esgrimido como causante de los hechos. Según el trabajo de François Giraud sobre la violación en México en el mismo siglo, la ebriedad fue uno de los argumentos más utilizados por parte de los defensores para disminuir la gravedad de los hechos.

Taylor William B. Ob. cit. Págs. 143-148.

Giraud, François. Ob. cit. Pág. 330. 
Sin embargo, en la jurisdicción de la ciudad de Antioquia los defensores sólo alegaron ebriedad en aquellos casos en que no contaban con otro recurso. El defensor del esclavo Francisco, acusado en 1757 de matar a su amor don Juan de Areiza, trató de probar que los esclavos implicados habían bebido el día del asesinato. La misma estrategia se empleó en el juicio seguido en 1806 contra Manuel Díaz del Castillo por la muerte de su esposa Cornelia Velásquez. ${ }^{143}$ No obstante, la única causa en que la defensa sólo esgrimió la embriaguez como disculpa fue en el juicio ya mencionado contra Marcos "Vísperas", a quien se sindicó de ser un notorio bebedor "cofrade del dios baco". ${ }^{144}$

Aunque los tratadistas del derecho español consideraban la ignorancia, la embriaguez, la locura como elementos que disminuían la gravedad del delito, en la provincia de Antioquia los jueces casi no tenían en cuenta estas consideraciones a la hora de dictar sentencia. ${ }^{145}$ En ninguno de los cuatro casos en que el defensor trató de demostrar que el crimen se había cometido bajo los efectos de la embriaguez, se libró el reo de la pena de muerte. Lo mismo ocurrió cuando se alegó locura. La única causal que se consideró para disminuir la pena fue la de sufrir una enfermedad que "alteraba el juicio".

Una estrategia empleada por los defensores para salvar a sus defendidos en caso de homicidio o heridas graves, era sustentar que la víctima había sometido al agresor a maltratos e insultos reiterados, siendo el crimen producto de la rabia, ira y desesperación. El éxito de esta defensa parece haber dependido del sexo del reo. Las mujeres eran vistas con mayor benignidad en estos casos, debido a que se consideraba que su delicada constitución las hacía débiles corporalmente. ${ }^{146}$ El doctor José Antonio Gómez, defendió a Marcela Metauten, quien asesinó a su marido en 1799, sobre la base de que el delito era el producto del maltrato y sevicia del marido. Los 20 años de matrimonio habían sido

“...un martirio de opresión, trabajo y tristeza”. ${ }^{147}$

${ }^{143}$ A. H. A. Criminal. B. 27. Leg. 1750-1760. Doc. $N^{\circ}$ 5. Fol. 132r-v. B. 101. Leg. 18001810. Doc. $\mathrm{N}^{\circ} 1$. Fols. 83 r-86r.

${ }^{144}$ A. H. A. Criminal. B. 38. Leg. 1770-178. Doc. $\mathrm{N}^{\circ}$ 3. Fols. 76r-78v.

${ }^{145}$ Lardizábal y Uribe, Manuel. Ob. cit. Págs. 113-117.

${ }^{146}$ Ibídem. Pág. 118.

${ }^{147}$ A. H. A. Criminal. B. 101. Leg. 1800-1810. Doc. $\mathrm{N}^{\circ}$ 2. Fols. 7r-v. 
En esta ocasión la defensa logró que la sindicada se salvara de la pena de muerte.

Cinco años después el mismo abogado no tuvo igual éxito al defender a Manuel Díaz del Castillo, quien asesinó a su esposa. En esta ocasión puso en consideración

El martirio que padeció el repetido reo en el tiempo de su matrimonio con una mujer, tan desvergonzada, tan atrevida y tan insufrible. ${ }^{148}$

La actuación de la acusación y la defensa eran distintas en los juicios por delitos privados. En las causas por injuria, el agraviado, por sí mismo o a través de un apoderado, solicitaba que el reo justificara la calumnia infringida. De no poder hacerlo pedía que el juez lo condenara imponiéndole las penas prescritas por la ley. El agresor, por su parte, basaba su defensa en tratar de demostrar que era cierto lo dicho por él.

El análisis de los juicios muestra que los reos tenían muy pocas posibilidades de ser declarados libres del cargo. Al dictar sentencia los jueces consideraban la calidad de la ofensa "irrogada", deteniéndose muy poco en las pruebas que sobre la verdad de lo dicho presentara el acusado. La mayor parte de los casos fueron sentenciados de acuerdo con el dictamen jurídico ya citado del doctor Ignacio Uribe:

Porque las injurias o defectos que no convienen a la República que se sepan. Aunque sean cierta, se debe castigar al injuriante, por convenir esto a la mayor paz y quietud del púbico. ${ }^{149}$

Esta clase de decisión parece haber sido empleada por los jueces para prevenir la proliferación de pleitos.

No obstante, en algunos pocos casos el acusado logró demostrar que lo afirmado por él era cierto, haciendo que el querellante pasara de víctima a reo.

148 A. H. A. Criminal. B. 101. Leg. 1800-1810. Doc. $\mathrm{N}^{\circ} 1$. Fols. 50v-54r.

${ }^{149}$ A. H. A. Criminal. B. 54. Leg. 1770-1780. Doc. $\mathrm{N}^{\circ}$ 7. Fols. 65r-66r. 
Así sucedió en el juicio entablado en 1791 por Santiago Hidalgo, vecino del partido de Quebrada Seca, contra María Lucía Duarte, acusándola de haberlo tratado delante del vecindario de "forzador de mujeres casadas". Al interrogarse a los testigos nombrados por la rea en su confesión, se estableció que era cierto lo afirmado por ella. En la acusación contra Hidalgo el procurador general Juan José de Lora y Nuño, en calidad de fiscal, afirmaba que estaba corroborado que el reo había tratado de violentar a varias mujeres. El acusado afirmó que él las había intentado enamorar, no forzar. Para defenderse argumentaba:

Los rústicos como yo, no teniendo más estudio ni discreción que los propios efectos que brinda la torpe y mal inclinada naturaleza éstos se enamoran con retozos, con mordiscos y demás juegos de manos que el caso trae aparejados. ${ }^{150}$

El alcalde ordinario encontró culpable a Hidalgo condenándolo a trabajar tres meses en obras públicas y a pagar las costas procesales. A Lucía Duarte, aunque la absolvió de la queja puesta contra ella, la previno para que en lo sucesivo se abstuviera de decir injurias de este tipo.

\section{Las pruebas}

Para que la acusación y la defensa pudieran probar sus asertos el juez debía abrir la causa a prueba, por un término común y proporcionado, dentro del cual con citación de la parte contraria se procedía a practicar las diligencias solicitadas y a ratificar los testigos. ${ }^{151}$ En desarrollo de este proceso cada parte presentaba los interrogatorios por los que debían ser examinados los testigos y pedía a las autoridades civiles y eclesiásticas las certificaciones pertinentes. Estos trámites solían demorarse bastante, ocasionando retrasos en la determinación de la causa.

La complejidad de este proceso puede ilustrarse con lo ocurrido en el juicio por injuria entablado en 1804 por don José Manuel Zapata contra don

\footnotetext{
${ }_{150}$ A. H. A. Criminal. B. 96. Leg. 1790-1800. Doc. $\mathrm{N}^{\circ}$ 10. Fols. 1r, 16r-v.

${ }^{151}$ Escriche, Joaquín. Ob. cit. Pág. 1012 y 1031.
} 
Nicolás López, a quien acusó de haber vertido expresiones deshonrosas a su cuna. Para obtener las pruebas al representante del querellante presentó tres interrogatorios a los que fueron sometidos 15 testigos y pidió constancias de partidas de bautismo y matrimonio. Al escribano José Pantaleón González, le solicitó una certificación de legitimidad, limpieza de sangre y nobleza, de Zapata y su esposa, para lo cual puso de manifiesto 15 cuadernos que tenían 33 folios. También pidió constancia sobre el lugar que la familia de cada uno de los querellantes había ocupado en los 12 censos efectuados en la ciudad de Antioquia de 1771 a 1804 y sobre las veces que los parientes del oponente habían ejercido los oficios concejiles. Por último solicitó que el escribano le diera una certificación de la sentencia pronunciada en el pleito por injuria entre don Carlos Piedrahíta y don Lorenzo Zapata, padre del agredido. Estas diligencias efectuadas entre noviembre de 1804 y febrero de 1805, estaban contenidas en un cuaderno de 69 folios.

El agresor comenzó la causa pidiendo que se le recibiera información sobre su pobreza, pues alegaba no tener medios para llevar a cabo el pleito puesto contra él. Al abrirse la causa a prueba su apoderado presentó tres interrogatorios por los que fueron examinados 16 testigos. Además solicitó certificación de partidas de bautismo y matrimonio y constancia de la Real Provisión ganada por don Felipe de Vargas en el pleito que siguió con don Juan Bautista Menéndez. El cuaderno de las pruebas presentadas por él tenía 41 folios. ${ }^{152}$ La multitud de pruebas presentadas por Zapata sobre su calidad, llevaron al doctor Ignacio Uribe a dictaminar que se debía obligar a López a darle satisfacción de la ofensa en presencia de cuatro sujetos distinguidos. Acogiéndose a esta asesoría, el juez lo condenó a la pena de 1200 maravedíes, de los cuales se daría la mitad al querellante, y al pago de las costas procesales.

La realización de estas diligencias solía ser costosa para las partes, por esta razón ls querellantes trataban de lograr un convenio antes de llegar a esta etapa del proceso. Don José Cruz Robledo, quien fue acusado en 1797 de haber ahogado a don Félix Lemos, presentó una cuenta de costos en la que afirmaba haber gastado 323 castellanos y 4 tomines, en conseguir las pruebas

${ }^{152}$ A. H. A. Criminal. B. 99. Leg. 1800-1810. Doc. No 20. Fols. 20r-132v, 161r-162v. 
necesarias para liberarse del cargo. A esta cantidad se sumaban las costas del proceso, el precio del papel sellado, los gastos de asesoría. En un escrito sobre la sentencia decía:

El pan de la boca he quitado para acudir a la defensa de la honra que es patrimonio del alma, mi salud quebrantada, se ha expuesto a mayores riesgos, por camino de agua y tierra, pasando a Cáceres a solicitar las pruebas más patéticas, mi familia quedó abandonada sujeta a miserias. Mis créditos sin cubrir porque todo así lo ha querido la maledicencia, la enemiga y la venganza. ${ }^{153}$

Cuando una de las partes demoraba innecesariamente la respuesta al traslado de los alegatos y pruebas presentadas por el contrario, se le acusaba de rebeldía. La dilación era una táctica usada por los reos de delitos privados para cansar al oponente y lograr que desistiera de seguir la causa.

Así, Lorenzo Agudelo en el juicio por injuria que se le siguió por querella de Isabel de Vargas, pidió que se le admitiesen pruebas por fuera del término y demoró dar respuesta. Por esto el 17 de marzo de 1777, la injuriada le acusó la primera rebeldía, ocho días después de la segunda y a la semana siguiente la tercera. Al no presentarse, el juez le mandó entregar los autos con respuesta o sin ella. ${ }^{154}$

El procedimiento de acusar rebeldía también era utilizado en los juicios en que el reo había hecho fuga. El juez que tenía a su cargo la causa debía emplazar al acusado cada nueve días, haciéndole las notificaciones en su casa, si la tuviere y fijando un edicto de emplazamiento en un lugar público de la ciudad o villa. Si no aparecía al tercer plazo, se formalizaba la acusación mandándole a responder en tres días. Al no presentarse se declaraba concluido el pleito, abriéndose la causa a prueba para que el reo no careciera de defensa se nombrara un defensor o excusador de oficio. ${ }^{155}$

${ }^{153}$ A. H. A. Criminal. B. 37. Leg. 1790-1800. Doc. No 12 . Fols. 173r-174r, 191r-192v.

${ }^{154}$ A. H. A. Criminal. B. 54. Leg. 1770-1780. Doc. $\mathrm{N}^{\circ}$ 7. Fols. 58r-61r.

${ }^{155}$ Sala, Juan. Ob. cit. Tomo II. Págs. 546-547.

Hevia Bolaños, Juan de. Ob. cit. Tomo I. Pág. 237-238. 
Durante la Independencia la oportunidad que debía darse a las partes para hablar en defensa propia en el juicio fue considerada como uno de los derechos del hombre en sociedad.

El artículo 12 del título I sección segunda de la Constitución de 1812 disponía:

\footnotetext{
"Ninguno debe ser juzgado ni castigado sino después de habérsele oído y convencido legalmente, $\mathrm{y}$ en virtud de una ley promulgada antes de cometerse el delito". ${ }^{156}$
}

Es interesante ver la forma como los comprometidos en los juicios se apropiaron de estas ideas. En una causa seguida en 1813 contra Manuel Mariaca por haber golpeado a su esposa, éste protestaba porque el Alcalde ordinario había proveído un acto en que le mandaba que se abstuviera de comunicarse con Lucas Galván y Lucía Flórez, sin haber mediado la declaración de testigos. Conceptuaba que había sido juzgado y sentenciado sin ser "oído y vencido", quebrantando su derecho el Alcalde se había guiado únicamente por los "dichos" de su esposa "nacidos de sus locuras". Acogiéndose a la disposición constitucional que le favorecía, pedía al Alcalde revocar el auto, pues de lo contrario acudiría con su queja al Supremo Tribunal de Justicia. El Alcalde ordinario para "cubrir el juzgado" determinó que fueron interrogados los testigos presentados por Mariaca. ${ }^{157}$

Terminado el tiempo probatorio, la acusación y la defensa debían presentar el alegato de conclusión y buena prueba, en el que se hacía un resumen de los testimonios a favor y se tachaban los que beneficiaban a la parte contraria. La causa estaba entonces lista para que el juez dictara sentencia.

${ }^{156}$ Pombo Manuel Antonio y José Joaquín Guerra. Ob. cit. Tomo I. Pág. 476.

${ }^{157}$ A. H. A. Criminal. B. 102. Leg. 1800-1820. Doc. $\mathrm{N}^{\circ}$ 20. Fols. 3r-4r, 6r. 


\section{La sentencia}

Las leyes españolas definían la sentencia como la legítima decisión del juez sobre una causa controvertida ante él. Para que ésta tuviera valor era necesario que no fuera contra la naturaleza, las leyes o las buenas costumbres. ${ }^{158}$

Antes de dictar sentencia el juez debía examinar el proceso, observando los cargos que resultaban contra el reo, sus exculpaciones y las razones alegadas en su defensa. Si los autos demostraban la existencia del delito y la participación del acusado estaba comprobada, debía ser condenado a la pena señalada por la ley o adoptada por la jurisprudencia.

Cuando estaba justificada la inocencia del reo o la facultad legítima que había tenido para la ejecución del hecho incriminado, se lo debía absolver. En los delitos no probados claramente o dudosos, las leyes de partida mandaban que el juez se inclinara más a absolver al reo que a condenarlo, por considerar que era más justo quitar la pena al que la merecía que darla al inocente, por ser el daño reparable. ${ }^{159}$

Para estar seguros de que la causa no tenía vicios de procedimiento y dictar sentencia de acuerdo con la ley, los Alcaldes ordinarios y los gobernadores que actuaron como jueces en la jurisdicción de la ciudad de Antioquia acostumbraron a enviar los autos a estudio de un asesor jurídico. En una primera etapa, que abarcó de 1773 a 1795, el oficio de asesor fue desempeñado por cualquiera de los abogados residentes en la provincia.

Una segunda etapa se inició en 1795 con la creación del cargo de Teniente de Gobernador asesor, quedando este funcionario encargado del estudio de las causas seguidas en los juzgados ordinario y de gobernación. Esta prevención era casi obligatoria en los juicios con sentencias que involucraban pena capital o penas corporales como el presidio de Cartagena, destierro o cárcel. Adicionalmente, desde la década del 90, ates de aplicar penas graves se consultaba a la Audiencia para que ésta decidiera sobre la ejecución.

\footnotetext{
${ }^{158}$ Sala, Juan. Ob. cit. Tomo II. Pág. 244.

${ }^{159}$ Escriche, Joaquín. Ob. cit. Pág. 1032-1033.
}

Hevia Bolaños, Juan de. Ob. cit. Tomo I. Pág. 232. 
De acuerdo con los datos que nos proporcionan los juicios analizados, el porcentaje de causas en que se llegó a la etapa de sentencia fue mayor a medida que aumentaba la gravedad del delito. Paralelamente la proporción de juicios en que se declaraba a los reos libres de cargos también crecía. En 86 $(63,23 \%)$ de las 136 causas por injuria seguidas en la ciudad de Antioquia se dictó sentencia. Sólo en 11 (8.08\%) de estos juicios el juez determinó que el querellante no había probado la imputación. De las causas por lesiones personales se sentenciaron 137 (68,5\%) de 200, siendo absueltos los reos de 26 casos. Con respecto a los juicios por homicidio, encontramos que en 31 (73,8\%) de 42 procesos se emitió fallo, habiéndose considerado en ocho causas que no existían pruebas para condenar a los culpados. Estas cifras permiten concluir que en la provincia de Antioquia la eficacia de la justicia dependía del tipo de delito, persiguiéndose más durante aquellos que atentaban directamente contra el orden social establecido.

El objeto de la sentencia era establecer las penas correspondientes al delito cometido por el reo. De acuerdo con la definición admitida por los juristas españoles de la pena era

El mal que uno padece contra su voluntad y por superior precepto, por el mal que voluntariamente hizo con malicia o por culpa. ${ }^{160}$

Las penas por naturaleza debían ser impuestas por autoridad pública y ser contra la voluntad del que las padecía, por lo tanto no se contaban entre ellas la venganza privada tomada en cobro de un daño, las mortificaciones y penitencias voluntarias, las calamidades que ocurrían natural o indirectamente a los hombres. Se requería igualmente que el daño fuera hecho voluntariamente, con malicia o culpa, porque de lo contrario se consideraba que no había moralidad en las acciones humanas y por consiguiente tampoco imputabilidad. ${ }^{161}$

La jurisprudencia de la época consideraba la facultad de establecer y regular las penas como un derecho inmanente de la Majestad, necesario para

${ }^{160}$ Lardizábal, Manuel de. Ob. cit. Págs. 19-20.

Alvarez Posadilla, Juan. Ob. cit. Tomo III. Págs. 23-24.

${ }^{161}$ Lardizábal, Manuel de. Ob. cit. Págs. 20-21. 
el gobierno y conservación de la república. Este derecho dimanaba de Dios, juez supremo de todas las cosas. ${ }^{162}$

Como lo ha anotado el historiador inglés Douglas Hay al referirse a Inglaterra en el siglo xviII, en esta sociedad los jueces al dictar sentencia eran comparables a Dios. Después de todo su autoridad procedía de la que el Rey había recibido de la autoridad divina. ${ }^{163}$

El fin general de las penas era la seguridad de los ciudadanos y la salud de la república. Además de ésta había otros fines particulares, sin los cuales no se podía verificar el general, como eran el ejemplo, para que sirviera de escarmiento a los que no habían delinquido y se abstuvieran de hacerlo, la reparación o satisfacción del daño causado al orden social o a los particulares y sí se podía, la corrección del delincuente, buscando que no volviera a perjudicar a la sociedad. ${ }^{164}$

Como uno de los fines esenciales era el ejemplo, la ejecución de las penas debía ser pública, así los que veían u oían sentirían miedo y escarmentarían.

En algunos casos dada la gravedad del delito, la sentencia se ejecutaba donde se había cometido el crimen. Las Leyes de Partida mandaban que se diera a conocer con voz de pregonero, realizándose siempre de día, excepto cuando existía el temor de que se quitara al delincuente o se estorbara su ejecución. ${ }^{165}$

Las penas y castigos se ejecutaban contra los bienes que el delincuente tenía, los cuales eran la vida, el cuerpo, la honra y los bienes de fortuna. Consecuentemente las penas se dividían en capitales, corporales, de infamia y pecuniarias. ${ }^{166}$

Cuando el delito tenía una pena determinada por ley, bastaba que en la sentencia se declarar que el reo lo había cometido. En los delitos que tenían

162 Ibídem. Pág. 24.

${ }^{163}$ Hay, Douglas. "Property, Authority and The criminal Law”. En: Albion's Fatal Tree. Crime and Society in Eighteenth-Century England. New York. Pantheon Books. 1975. Pág. 30.

${ }^{164}$ Lardizábal, Manuel. Ob. cit. Págs. 83-85.

Alvarez Posadilla, Juan. Ob. cit. Tomo III. Pág. 24.

${ }^{165}$ Lardizábal, Manuel. Ob. cit. Págs. 51-52.

Hevia Bolaños, Juan de. Ob. cit. Tomo I. Pág. 233.

${ }^{166}$ Lardizábal, Manuel. Ob. cit. Págs. 152, 153.

Alvarez Posadilla, Juan. Ob. cit. Tomo III. Pág. 24-25. 
pena arbitraria, ésta se debía estipular "cierta y determinantemente" para mayor claridad y para evitar dudas. ${ }^{167}$ De los delitos estudiados, el homicidio era el que tenía establecida pena ordinaria. De acuerdo con la Ley 4, Título 23, Libro 8 de la Recopilación, el que mataba debía morir por ello, sin distinción de que el muerto fuera libre o esclavo y el "matador" caballero, noble o plebeyo. ${ }^{168}$

Con respecto al delito de heridas la Novísima Recopilación estipulaba que quien hería a otro con asechanza, fuera tratado como homicida aunque el herido no hubiera muerto. Si la herida había sido hecha con arcabuz o pistolete era tenido por alevoso y perdía todos sus bienes, destinándose la mitad para el fisco y la mitad para el herido. En caso de no ser las heridas mortales o calificadas, se imponía la pena según las circunstancias y la mayor o menor gravedad del delito. ${ }^{169}$

El delito de injuria por su parte, no tenía una pena señalada debiéndola determinar el juez de acuerdo con la calidad del agravio y lo que pidiera el injuriado. ${ }^{170}$

Como lo veremos más adelante al referirnos a cada delito, durante el siglo xviII en la provincia de Antioquia la pena capital sólo se aplicó en caso de homicidio agravado y en determinadas circunstancias. La tendencia a atenuar el rigor de la ley es más visible en los procesos por injuria o heridas leves en los que se impusieron penas pecuniarias.

Entre estos dos extremos se utilizó una variada gama de castigos, sin que pueda establecerse una correspondencia clara entre las circunstancias del delito y el tipo de pena (ver cuadros $\mathrm{N}^{\circ} 13,27$ y 43).

Esta arbitrariedad de las penas fue uno de los puntos más discutidos por los pensadores ilustrados. En su concepto las penas de debían graduar conforme a la gravedad de los delitos, las circunstancias de éstos y a su mayor o menor atrocidad, para que los hombres aprendieran a diferenciarlos. Si distintas clases de delitos se castigaban con la misma pena, la desproporción que de allí nacía daba lugar a la impunidad y al aumento de su frecuencia. Otro problema

\footnotetext{
${ }^{167}$ Hevia Bolaños, Juan de. Ob. cit. Tomo I. Pág. 233.

168 Alvarez Posadilla, Juan. Ob. cit. Tomo III. Pág. 116,

${ }^{169}$ Escriche, Joaquín. Ob. cit. Pág. 766

${ }^{170}$ Sala, Juan. Ob. cit. Tomo II. Págs. 51.
} 
señalado por ellos era que la excesiva duración de los juicios terminaba por diluir la unidad del delito y la pena que debía quedar gravada en los ánimos. ${ }^{171}$

Como seguidores de las ideas de los ilustrados, los redactores de la Constitución del Estado de Antioquia de 1812 incluyeron un artículo en que se mandaba

La ley no ha de establecer penas crueles, sino proporcionadas a la naturaleza de los delitos, ellas deben ser estricta y evidentemente necesarias y útiles a la sociedad. ${ }^{172}$

Además, en las prevenciones generales acerca del Poder Judicial estipularon que la justicia debía ser administrada tan pronta y gratuitamente como fuera posible. Para conseguirlo se estrecharían los términos y plazos judiciales, se reformaría el abuso de las costas excesivas y se eliminarían las prisiones y pesquisas arbitrarias.

La clemencia era otra de las prerrogativas del trono. Al nivel más bajo era practicada por los jueces cuando trataban con benevolencia a los reos, imponiéndoles penas más suaves que las estipuladas por la ley. La clemencia para perdonar sólo residía en el Rey como legislador, limitándose los jueces ordinarios, Gobernadores y la Audiencia, a estudiar si el reo estaba comprendido en el indulto otorgado por la Corona. ${ }^{173}$

Durante el periodo 1750-1810, en cuatro oportunidades se expidieron Reales Cédulas por las cuales se indultaba a los reos que estuvieran en la cárcel en ese momento. De esta gracia solían exceptuarse los que hubieran cometido los delitos de lesa Majestad Divina y Humana, alevosía, homicidio de sacerdotes, fabricación de moneda falsa, incendio, extracción de cosas prohibidas del Reino,

${ }^{171}$ Beccaria, Cesare. Ob. cit. Pág. 45-47.

Lardizábal, Manuel. Ob. cit. Págs. 42-46, 54-55.

172 Pombo, Manuel Antonio y José Joaquín Guerra. Ob. cit. Tomo I. Págs. 476, 518-519.

${ }^{173}$ Lardizábal. Ob. cit. Pág. 59. 
blasfemia, falsedad, resistencia a la justicia y malversación de la Real Hacienda; así como el que antes hubiese sido perdonado de otro delito. ${ }^{174}$

En enero de 1760, se otorgó por primera vez perdón Real, con motivo del ascenso al trono de Carlos III (1759-1788). Se benefició con esta disposición al esclavo Antonio, quien era juzgado por la muerte involuntaria de otro esclavo llamado igualmente Antonio. ${ }^{175}$

En enero de 1781 don José Ignacio tuesta, reo en una causa por golpes, pidió ser absuelto al cargo en virtud de un perdón Real publicado con posterioridad a los hechos. El Alcalde ordinario teniendo en cuenta el indulto y la condescendencia del agraviado lo absolvió de la pena. ${ }^{176}$

El siguiente indulto fue concedido en enero de 1784 para celebrar el nacimiento de los infantes Carlos y Felipe, nietos del Rey. Bajo este perdón fue dejada libre Juan María de Mora quien estaba siendo juzgada por la muerte de Anselma Torres. ${ }^{177}$

Un mayor número de reos se acogió al perdón Real otorgado en 1804 a raíz del matrimonio del príncipe con la princesa de Nápoles doña María Antonia. En esta oportunidad se beneficiaron con el Real indulto tres reos a quienes se les seguía juicio por heridas - Julián Valderrama, indio de Sopetrán, don Bautista Díaz y Florencio de Cárdenas - así como dos acusados de homicidio - la indígena Gertrudis Guillén procesada por infanticidio y el esclavo Marcos Mejía sindicado de la muerte de otro esclavo- ${ }^{178}$ El Gobernador de Antioquia Víctor Salcedo remitió las peticiones de indulto a la Audiencia para que este tribunal decidiera si estos reos quedaban cobijados con el beneficio.

La costumbre de que se promulgaran indultos con motivo de la jura de un Rey, nacimiento de un infante, importantes victorias militares, etc., llevó a

${ }^{174}$ Hevia Bolaños, Juan de. Ob. cit. Tomo I. Págs. 236-237.

A. H. A. Criminal. B. 52. Leg. 1780-1790. Doc. $\mathrm{N}^{\circ}$ 8. Fol. 11v-13v.

${ }^{175}$ A. H. A. Criminal. B. 41. Leg. 1740-1770. Doc. $N^{\circ} 11$. Fols. 33r.34r.

${ }^{176}$ A. H. A. Criminal. B. 52. Leg. 1780-1790. Doc. $\mathrm{N}^{\circ}$ 3. Fols. 6r.-8r.

177 A. H. A. Criminal. B. 52. Leg. 1780-1790. Doc. No 8. Fol. 21r.

${ }^{178}$ A. H. A. Criminal. B. 42. Leg. 1800-1810. Doc. No 7. Fols. 5v-6v.; B. 30. Leg. 1800-1810. Doc. No 13. Fols. 71r, 86r.-87v.; B. 101. Leg. 1800-1810. Doc. N 8. Fols. 25r-v., 28v-29r.; B. 97. Leg. 1790-1810. Doc. No 15. Fols. 3v.-4r.

A.H.N. Negros y Esclavos de Antioquia. Tomo IV. Fols. 987v-988r. 
que varios reos se acogieran al Real perdón en 1808 cuando Carlos iv abdicó a favor de Fernando vil. Las autoridades de la provincia tuvieron que aclarar que no habían recibido Real Orden ni providencia de indulto, lo que era obvio pues en ese momento España estaba siendo invadida por tropas francesas. ${ }^{179}$

Los indultos eran presentados como actos de gracia, expresión de la piedad del Rey. Para algunos jurisconsultos de la época, la clemencia administrada con prudencia podía producir buenos efectos. Los reos que se beneficiaban con ella tenían la idea de haber recibido un don o gracia especial, se rehabilitarían y serían leales al Rey. ${ }^{180}$

Algunos críticos del derecho vigente consideraban que la clemencia era necesaria para el absurdo de las leyes y lo atroz de las condenas. Una legislación en que las penas fuesen suaves y el método de juzgar expedito no necesitaría de la benevolencia. ${ }^{181}$

Los gobernantes antioqueños de la época de la Independencia, por su parte, suscribían las ideas sobre las bondades de los indultos. Consecuentemente en el numeral 35 del título iv de la Constitución de 1812 se estipuló que residía en el Presidente del Estado la facultad de conceder indultos generales cuando lo permitiera el bien del Estado. ${ }^{182}$

\section{La apelación}

Una vez que el juez pronunciaba la sentencia debía ser notificada a las partes, para que declararan si estaban conformes o no. Toda sentencia dada por juez

179 A. H. A. Criminal. B. 42. Leg. 1800-1810. Doc. $\mathrm{N}^{\circ}$ 10. Fols. 7v. $-8 \mathrm{v}$.

${ }^{180}$ Lardizábal y Uribe, Manuel. Ob. cit. Págs. 58-59.

${ }^{181}$ Beccaria, Cesare. Ob. cit. Pág. 48.

La crítica de Beccaria parece referirse al sistema judicial inglés. Durante el siglo xviI el número de delitos por los cuales se condenaba en Inglaterra a la pena de muerte aumentó de 50 a más de 200. En contraste con el uso del terror en la legislación, la mitad de los condenados a la horca eran perdonados cambiándoles la pena por destierro a las colonias o por cárcel. Las peticiones de clemencia eran tramitadas a través de intermediarios convirtiéndose el perdón en un instrumento selectivo de la justicia en el cual jugaban papel importante las influencias. El Historiador Douglas Hay señala que el perdón, tal como se practicaba en Inglaterra, tenía un rol sobresaliente en el uso de la ley como ideología. La ley era selectiva pero simultáneamente podía proclamar su incorruptibilidad e imparcialidad.

Hay, Douglas. Ob. cit. Págs. 40-49.

${ }^{182}$ Pombo, Manuel Antonio y Guerra, José Joaquín. Ob. cit. Tomo I. Pág. 510. 
ordinario o de gobernación podía ser apelada por el que se sintiere agraviado, fuera el procesado o el acusador. ${ }^{183}$

Según las Leyes de las Siete Partidas, apelación era querella y provocación del juicio agraviado del juez menor al mayor, para que le desagravie. Por naturaleza la apelación se interponía del juez ordinario al inmediatamente superior o directamente al Rey o su Audiencia, no siendo posible que se apelara a juez de igual o menor rango. En el fuero secular la apelación se debía formalizar dentro de los cinco días siguientes a la notificación de la sentencia, pues de lo contrario ésta se tenía por "pasada en cosa juzgada" y firme. Regularmente la apelación tenía dos efectos, uno suspensivo con respecto a la jurisdicción del juez que había pronunciado la sentencia y otro devolutivo, por devolver el conocimiento de la causa a otro juez superior. ${ }^{184}$

En la jurisdicción de la ciudad de Antioquia no fue corriente que se apelaran las sentencias. Las partes en conflicto se abstenían de interponer este recurso por carecer de los medios económicos necesarios para cubrir el costo del envío y tramitación de la casusa en la Audiencia de Santa fe de Bogotá. Además, a muchos litigantes la diligencia debió parecerles superflua, pues rara vez en esta instancia se cambiaba sustancialmente la sentencia. Esto explica que de 200 sentencias proferidas en causas por lesiones personales, sólo se hayan apelado seis, y de 136 sentencias dictadas en juicios por injuria, se apelaran siete. De los 13 casos en que se apeló la sentencia, dos se tramitaron antes de 1790; diez entre 1790 y 1809, y uno durante el periodo de la reconquista (1816-1819), cuando la Audiencia volvió a funcionar. Este hecho se explica porque casi la mitad de las causas estudiadas corresponden a la última década del siglo xvil y a la primera del xix.

Las medidas de control social impuestas por los gobernadores visitadores Francisco Silvestre (1782-1785) y Juan Antonio Mon y Velarde (1785-1788) parecen haber tenido como efecto un incremento en la actividad de los juzgados, la cual estuvo acompañada por un mayor rigor en el uso de los recursos legales y procedimentales.

${ }^{183}$ Escriche, Joaquín. Ob. cit. Pág. 1033.

${ }^{184}$ Hevia Bolaños, Juan de. Ob. cit. Tomo I. Pág. 207-249. 
En la Provincia de Antioquia estas reformas en la administración de justicia coincidieron con un incremento de las actividades mineras y comerciales, lo que posibilitó a algunos sujetos contar con el dinero necesario para tramitar la apelación de sentencias. ${ }^{185}$ Salvador Sarrazola, mulato dedicado a las actividades comerciales, apeló las sentencias dictadas en dos causas por agravio que siguió en la década del 90. En el primer caso, correspondiente a la causa que siguió desde 1794 contra Miguel Marín por haberlo tratado de "hombre de mala fe" y "defraudador de tratos y contratos", apeló la sentencia dada por el Alcalde ordinario debido a que el sindicado sólo fue condenado a pagar las costas del proceso. ${ }^{186}$

La segunda oportunidad fue en el juicio que siguió en 1796 contra Francisco Rave por haberlo tratado de ladrón. En el escrito en que solicitaba se le aprobara el recurso de apelación, se quejaba de que el agresor había sido condenado únicamente en las costas, sin obligarlo a dar una satisfacción plena y pública. Consideraba que de no imponerse las penas prescritas por las leyes

Quedarían las partes agraviadas con el agravio coinferido (sic) con su honor, buena opinión y reputación perdida, como a mí en el presente caso me sucede y por consiguiente sin ningún escarmiento el calumniante, el público quedaría como habrá de quedar ahora en la opinión de ser cierta la tal injuria a vista de no haberse procedido al menor castigo. ${ }^{187}$

La razón que lo impulsó a solicitar la revisión de la sentencia fue indudablemente el deseo de limpiar su crédito como comerciante. Esto explica que estuviera dispuesto a invertir dinero para lograrlo.

La poca utilidad de apelar una sentencia se puede ilustrar con lo sucedido en la causa seguida contra don Juan Bernardo Aguirre, por haber amenazado con azotes a doña Tomasa Aguirre.

En mayo de 1810 se concedió al reo apelación de la sentencia condenatoria pronunciada por el Gobernador Francisco de Ayala. Cuando se estaban

\footnotetext{
${ }^{185}$ Twinam, Ann. Ob. cit. Gráfico N 1, Pág. 61 y Gráfico N 3. Pág. 97.

${ }^{186}$ A. H. A. Criminal. B. 37. Leg. 1790-1800. Doc. $\mathrm{N}^{\circ}$ 1. Fol. 79 r.

${ }^{187}$ A. H. A. Criminal. B. 63. Leg. 1790-1800. Doc. $\mathrm{N}^{\circ}$ 7. Fols. 14r.-15v.
} 
haciendo los trámites para remitir el proceso se tuvo noticia de que la Real Audiencia había dejado de existir, como consecuencia del grito de Independencia del 20 de julio. Se determinó entonces conceder la apelación para la Junta Superior Provincial Gubernativa de Antioquia, cuyos miembros en marzo del año siguiente confirmaron la sentencia. Como se puede ver el acusado gastó tiempo y dinero sin obtener un resultado favorable. ${ }^{188}$

Con respecto a los juicios por homicidio y delitos graves estudiados, se debe anotar que sólo una de las sentencias dictadas fue apelada por el involucrado. Sin embargo, a partir de 1790 los jueces acostumbraron consultar a la Audiencia las sentencias proferidas en estos casos. Tal consulta parece haber convertido la apelación en un trámite de oficio. ${ }^{189}$

Consecuentemente encontramos que la Audiencia, en algunos de los juicios remitidos para su estudio, cambió la clase o la duración del castigo. Así, en el juicio seguido en 1799 a Juan Félix Santana y su hija por incesto e infanticidio, el Alcalde ordinario de Antioquia condenó al primero a seis años de destierro en uno de los presidios de Cartagena y a Francisca en seis años de reclusión en la cárcel y 200 azotes. La Audiencia por auto proveído en enero de 1801 cambió la sentencia condenando a Santana en 10 años de presidio en Cartagena y 10 años de destierro de la provincia. A su hija le impuso como castigo 10 años de cárcel y 10 de destierro de la provincia. Como se puede ver este tribunal consideró muy suave la pena impuesta por el juez local. ${ }^{190}$

Las sentencias emitidas por la Audiencia, máximo tribunal de justicia en las colonias americanas, no podían ser apeladas y quedaba como último recurso suplicar ante ella. ${ }^{191}$ Esta diligencia rara vez se efectuó pues significaba dilatar más la conclusión del juicio.

Durante la Independencia, la Constitución de 1812 adjudicó al "Supremo Tribunal de Justicia” la función de conocer en grado de apelación o súplica las causas civiles y criminales que se suscitaran en el distrito de la provincia.

\footnotetext{
${ }^{188}$ A. H. A. Criminal. B. 61. Leg. 1800-1810. Doc. N 6. Fols. 30v.-31r., 35r., 36v., 48v.-49v.

${ }^{189}$ Escriche, Joaquín. Ob. cit. Pág. 1033.

190 A. H. A. Criminal. B. 37. Leg. 1790-1800. Doc. N ${ }^{\circ} 18$. Fols. 26r-v y 28 r.

${ }^{191}$ Hevia Bolaños, Juan. Ob. cit. Tomo I. Pág. 247.
} 
Lamentablemente no se encuentran recursos de apelación interpuestos a este tribunal, que permitieran conocer la filosofía aplicada en estos casos. ${ }^{192}$

Con la sentencia concluía el juicio desde el punto de vista jurídico, quedando por realizar la diligencia de tasación de costas. Este trámite formaba parte de la ejecución de la pena impuesta, pues en los juicios por injuria y lesiones personales leves, usualmente el reo era condenado a pagar los gastos del proceso. En algunas ocasiones se presentaban problemas para cobrar esta cantidad por no tener el reo dinero o por negarse a pagar. A este respecto es ilustrativo lo ocurrido en el juicio seguido contra Santiago Hidalgo por el delito de intentar forzar a varias mujeres. En junio de 1792 el juez mandó destinar los bienes embargados al reo para el pago de las costas, diligencia que fue cuestionada por la madre del reo, alegando que lo embargado era de su propiedad. Al no probar esta afirmación, el Alcalde ordenó, un mes después, que se vendieran los bienes para hacer los pagos. Hecha la tasación de las costas del proceso, la cual ascendió a 30 pesos y 6 tomines, el reo la impugnó por considerarla demasiado elevada.

Se suscitó entonces una disputa sobre el cumplimiento de una Real Cédula expedida el 6 de enero de 1792 en la que se mandaba a tasar las costas en tierra de oro haciendo equivaler un real de plata a un tomín de oro. Como la equivalencia vigente era de dos reales por tomín, esto significaba que el costo de los procesos de elevada al doble. La Real Sala Capitular de Antioquia conceptuó en marzo de 1793 que la tasación era excesiva, debiéndose suspender su cobro hasta que el tasador general de la Audiencia decidiera una petición hecha por los escribanos de la ciudad de Antioquia sobre el asunto. El reo debía pagar las costas de acuerdo con el Real arancel expedido el 20 de septiembre de 1761. Casi un año se gastó en la definición del pago de las cosas, lo cual iba en detrimento de la parte contraria. ${ }^{193}$

Las autoridades de la provincia gustaban de condenar en el pago de las costas a la parte que hubiera perdido el pleito, por parecerles un método eficaz

192 Pombo, Manuel Antonio y Guerra, José Joaquín. Ob. cit. Tomo I. Págs. 512 y 514.

193 A. H. A. Criminal. B. 5296 Leg. 1790-1800. Doc. N 10. Fols. 24r., 25r., 26r., 28r., 32v.34r., 38v.-39v., 45v.-46r. 
para escarmentar y lograr que a muchos se les quitase "el prurito de pleitear". ${ }^{194}$ La medida no parece haber tenido el efecto deseado, pues los pleitos y peleas se acrecentaron a lo largo del siglo.

En resumen, podemos afirmar que en los 70 años estudiados la administración de justicia en la jurisdicción de la ciudad de Antioquia se volvió más rigurosa desde el punto de vista procedimental. Esto es visible en aspectos como la forma en que se tomaban y evaluaban los testimonios y las confesiones, partes fundamentales en el establecimiento del delito e identificación de los culpables. A partir de la década de 1770 empiezan a actuar en los juicios abogados bien sea como asesores jurídicos, fiscales, defensores o jueces. Su presencia jugó un papel importante en el aumento del formalismo legal, pues desde las diferentes instancias en que actuaban señalaban los vicios jurídicos que podían afectar el seguimiento de una causa.

Paralelamente, por parte de los gobernantes ilustrados, existió el propósito de agilizar y hacer más eficaz la administración de justicia. Ante la falta de policía, la justicia se convirtió en un instrumento para lograr el control social. A través de ella se perseguían las conductas que se consideraban desviadas y podían poner en peligro la estabilidad social. Para cumplir esta función debía transformarse la imagen que la población tenía de la justicia, lo que se logró parcialmente al hacer hincapié en el cumplimiento de los procedimientos, pues se hacía visible para la gente, que la justicia funcionaba y que nadie podía estar exento de ella.

El nuevo esquema de administración de justicia conllevó la eliminación de algunos aspectos heredados de la legislación medieval española como el uso del asilo eclesiástico y la utilización del tormento para obtener confesiones.

Aunque las leyes no se reformaron, en la práctica, algunas costumbres jurídicas cayeron en desuso y se suavizó la aplicación de otras. Estos cambios iban en la dirección señalada por algunos críticos de la legislación vigente.

Muchos de ellos van a estar consignados en las disposiciones adoptadas en las Constituciones de 1812 y 1815 , fruto de las ideas y postulados defendidos por los abogados que participaron en su redacción.

${ }^{194}$ Silvestre, Francisco, Ob. cit. Pág. 507. 


\section{Los jueces}

Las Siete Partidas definían la justicia como raigada virtud, que dura en la voluntad de los hombres justos y da a cada uno su derecho igualmente. Los juristas españoles distinguían entre justicia conmutativa y distributiva. La primera era la que daba a cada uno lo que era suyo o se le debía por razón de contrato $\mathrm{u}$ otra causa legítima. Distributiva era la que daba premios, honores, oficios, cargas o penas, según los méritos, prendas, bienes o delitos de cada uno. ${ }^{1}$

La ley estipulaba que nadie podía hacerse justicia por sí mismo ni tomársela por su propia mano, sino que debía acudir al juez para que se la hiciera, bajo la pena de perder su derecho y ser tenido por forzador. ${ }^{2}$ La administración de justicia por lo tanto estaba en manos del juez, quien investido de autoridad pública conocía los pleitos y los decidía.

Según la legislación no podían ser jueces los religiosos ni las mujeres, exceptuando a las reinas o las que heredasen señorío. Nadie podía actuar como juez en causa propia, ni en aquellas en que hubiese actuado como abogado o consejero. ${ }^{3}$

La jurisdicción del juez dimanaba del Rey, sin que pudiera tener origen en los particulares. Se dividía en ordinaria y delegada. En general, juez ordinario era el que juzgaba en su nombre por derecho propio de su oficio. En sentido estricto, la justicia ordinaria residía en los jueces de primera instancia que eran los Alcaldes ordinarios. El juez delegado era el que tenía poder para juzgar, ya fuera por mandato del Rey o de los jueces ordinarios.

Los jueces ordinarios sólo podían ser nombrados por el Rey, o aquellas instancias a las que éste hubiera concedido el privilegio de hacerlo. Los delegados, en cambio, podían ser designados por cualquier juez ordinario. ${ }^{4}$

${ }^{1}$ Sala, Juan de. Ilustración del Derecho Español. Valencia. Librería de Mallen y sobrinos. 1844. Tomo i. Págs. 13-14.

${ }^{2}$ Escriche, Joaquín. Diccionario Razonado de Legislación y Jurisprudencia. París. México. Librería de la Viuda de Ch. Bouret. 1911. Pág. 1132.

${ }^{3}$ Sala, Juan. Ob. cit. Tomo II. Pág. 162.

${ }^{4}$ Sala, Juan. Ob. cit. Tomo II. Pág. 167-168.

Escriche, Joaquín. Ob. cit. Pág. 132. 
En las ciudades y villas de las colonias americanas, el Cabildo fue la instancia facultada para nombrar las autoridades encargadas de la administración de justicia local. El Cabildo o Ayuntamiento era el congreso o justa de personas destinadas para el gobierno político de los pueblos. Estaba compuesto de la justicia, los Alcaldes ordinarios elegidos anualmente y los Regidores, miembros propietarios quienes compraban sus cargos a la Corona. ${ }^{5}$ También asistían a las reuniones del Cabildo el escribano y el síndico procurador general, quien tenía voz pero no voto, estando prohibida la presencia de otras personas, aunque fueran caballeros. La función más importante de los Cabildos coloniales fue la elección de los miembros anuales y la recepción de los permanentes, lo que les permitía tener control sobre sus miembros. En las elecciones anuales, realizadas el primero de enero de cada año, votaban los Regidores (alférez real, alguacil mayor, Alcalde mayor provincial, fiel ejecutor, Regidor decano, Regidores sencillos) y los Alcaldes ordinarios del año precedente. ${ }^{6}$

El número de dignidades elegidas varió con el tiempo, aumentando a medida que la ciudad crecía y se volvía más compleja. Los cargos básicos eran los de Alcalde ordinario de primero y segundo voto, dos Alcaldes de la Santa Hermandad, procurador general, padre general de menores y mayordomo de propios. Fuera de éstos, en 1779 se elegía Regidor de temporalidades, maestro mayor de carpintería, alarife, fiel contraste y Alcaldes pedáneos para los 12 partidos pertenecientes a la jurisdicción de la ciudad. A principios del siglo xIX la nómina había cambiado, pues fuera de los puestos básicos se nombraba juez de propios, juez de policía y hospital, dos comisarios de barrio y los Alcaldes pedáneos que eran 27. Los resultados de la elección eran confirmados por el Gobernador, quien a veces impedía el nombramiento de los elegidos y promovía la designación de otras personas. ${ }^{7}$

Con excepción del mayordomo de propios, los cargos básicos elegidos por el Cabildo tenían funciones importantes en la administración de justicia,

${ }^{5}$ Sala, Juan. Ob. cit. Tomo II. Pág. 204-205.

Escriche, Joaquín. Ob. cit. Pág. 389.

${ }^{6}$ Marzhal, Peter. Town in the Empire Gobernment Politics and Society in Seventeenth Century Popayán. Texas. University of Texas. 1978. Págs. 59-61.

${ }^{7}$ A. H. A. Capitulares. Tomo 644. Documento 10242. Fols. 13v-14v, 19r-v. tomo 648. Documento 10314. Fols. 1r-2r, 4v-5v. 
bien fuera en el papel de jueces, defensores o fiscales. Aunque con jurisdicción restringida, los Alcaldes pedáneos y comisarios de barrio también formaban parte del engranaje de la justicia.

\section{Los alcaldes pedáneos, comisarios de barrio y alcaldes de la Santa Hermandad}

En el nivel más bajo de la administración de justicia actuaban los Alcaldes pedáneos, que eran los jueces de un lugar o sitio pequeño sujeto a la jurisdicción de la villa o ciudad en cuyo distrito estaba ubicado. Se los denominaba pedáneos por parecerse a los jueces pedáneos de los romanos, que recibían esta denominación del hecho de que para las causas de poco interés, cuyo despacho les estaba encargado, no necesitaban sentarse al dar Audiencia. La jurisdicción de estos Alcaldes era limitada, pues sólo podían castigar con prisión de tres o menos días a los que faltaban el respeto a las autoridades, escandalizaban con obscenidades, causaban pendencias, proferían injurias, violaban propiedades ajenas, siempre que no se tratara de hechos graves. En las causas graves debían recibir las declaraciones de testigos, prender o asegurar a los sindicados, embargar sus bienes y remitir los reos junto con los autos al Alcalde ordinario. ${ }^{8}$

Debido a la frecuencia con que se cometían asesinatos, hurtos y otros delitos en los sitios alejados de las ciudades o villas, la Audiencia del Nuevo Reino de Granada en 1756 amplió la jurisdicción concedida a los Corregidores de los pueblos de indios, los Alcaldes de la Santa Hermandad y los Alcaldes pedáneos, autorizándolos para tomar confesión al reo, antes de remitirlo a la cárcel de la ciudad a cuya jurisdicción pertenecían. ${ }^{9}$

En la jurisdicción de la ciudad de Antioquia los Alcaldes pedáneos iniciaron, a petición de parte o de oficio, cerca de la quinta parte de los juicios tramitados. $\mathrm{Su}$ participación en las diligencias de tomar la declaración a los testigos y aprehender a los reos, varió ligeramente con el tipo de delito. En las causas por injuria dieron comienzo a $22(16,17 \%)$ de las 136 que se siguieron entre 1750 y 1819; de las causas por lesiones personales iniciaron $42(20,68 \%)$ de

\footnotetext{
${ }^{8}$ Escriche, Joaquín. Ob. cit. Pág. 134-135.

${ }^{9}$ A. H. A. Criminal. B. 58. Leg. 1780-1790. Doc. $\mathrm{N}^{\circ}$ 5. Fol. 2r-v.
} 
los 203 juicios instaurados y de las causas por homicidio empezaron $8(18,6 \%)$ de las 43 existentes.

Las autoridades coloniales, especialmente los Gobernadores, tenían una idea negativa de los Alcaldes pedáneos. Se quejaban de que este puesto fuera servido por gentes del campo, de poca inteligencia y cortos bienes, que apenas sabían firmar. Por estas razones, afirmaban, seguían las demandas dirigidos por tinterillos o cavilosos, sin tener en cuenta lo dispuesto por la ley y gastaban los bienes embargados a los reos al cobrarles costas excesivas. Cuando las diligencias eran remitidas al Gobernador o al Alcalde ordinario, les era forzoso recomponerlas, y quedaba entorpecida muchas veces la administración de justicia. El Gobernador Silvestre, por ejemplo, se quejaba de que los vecinos de "comodidad y experiencia" que residían la mayor parte del año en sus minas o labranzas, desdeñaran ocupar este empleo, considerándolo de poco honor y como una carga. Proponía que se les obligara a prestar este servicio, porque

Aunque su jurisdicción es limitada y preventiva, la que ejerce es decorosa y que le añade honra el servir, y ser útil a la sociedad y república de que son miembros. ${ }^{10}$

No sólo las autoridades tenían quejas reiteradas de los Alcaldes pedáneos. También era frecuente que los reos que quejaran de sus procedimientos y aún, que se instauraran contra ellos causas por agravios o lesiones. Luis de Agudelo, vecino del partido de Sacaojal, en una causa por injuria seguida contra él en 1796, se quejó de que el Alcalde de ese partido, sin tener pruebas, lo había apresado y puesto en un cepo, primero de cabeza, luego "despernancado" y por último de ambos pies, por espacio de 10 días. Ante esta situación el reo decidió fugarse de la cárcel y presentarse al Alcalde ordinario por considerar que éste lo oiría sin pasión, ira u odio y lo juzgaría de acuerdo a los trámites del derecho. ${ }^{11}$

${ }^{10}$ Silvestre, Francisco. Relación de la Provincia de Antioquia. Medellín. Ediciones Especiales. Secretaría de Educación y Cultura de Antioquia. 1988. Págs. 196-198.

${ }^{11}$ A. H. A. Criminal. B. 51. Leg. 1790-1800. Doc. N 11. Fols. 1r-v. 
El año siguiente Juan Bautista Rendón, en una instancia con Vicente Torres, recusó al Alcalde pedáneo de San Jerónimo por "odioso, sospechoso y apasionado". ${ }^{12}$

En las dos últimas décadas del régimen colonial las demandas contra los Alcaldes pedáneos se incrementaron. Doña María Antonia Galván, por ejemplo, instauró un pleito contra el Alcalde de Miranda, su primo Manuel Salvador Galván, por haberla insultado, conducido amarrada a la prisión y puesto en una herradura en medio de dos negros que tenía presos. Acusaba al juez de formar sumarios para venderlos a los implicados, de maltratar o estropear a los reos, de suponer delitos para apresar sujetos que ponía a trabajar gratis en su estancia. El Alcalde se defendió diciendo que el origen de la queja estaba en no haberle querido vender el sumario que había formado contra ella. Afirmaba que los vecinos declararon contra él porque había perseguido sus delitos, impidiéndoles vivir sin temor de Dios ni de la justicia. Aseguraba que los archivos de los juzgados estaban llenos de causas contra la gente del partido de Miranda por asesinatos, amancebamiento, destilación de aguardiente e irrespetos. El juez que intentaba sujetarlo estaba expuesto a "morir mártir" o vivir atormentado con los informes contra él. ${ }^{13}$

Las acusaciones contra los Alcaldes pedáneos no cesaron en el periodo de la Independencia. Estos jueces por su parte seguían quejándose de que los vecinos testimoniaban contra ellos por tratar de hacerlos cumplir con los preceptos divinos y humanos. ${ }^{14}$

También se presentaban problemas con las autoridades que actuaban como jueces en los pueblos de indios. Los indios se quejaban constantemente de los Corregidores y los vecinos mestizos y mulatos que vivían en los resguardos se negaban a someterse a las autoridades indígenas aduciendo que no tenían jurisdicción sobre ellos. ${ }^{15}$

Por más que las autoridades provinciales intentaron volver eficaz y rápida la administración de justicia en este nivel, no lo lograron. Entre las causas

\footnotetext{
${ }^{12}$ A. H. A. Criminal. B. 95. Leg. 1780-1800. Doc. $\mathrm{N}^{\circ}$ 16. Fols. 12r-v.

${ }^{13}$ A. H. A. Criminal. B. 99. Leg. 1800-1810. Doc. $\mathrm{N}^{\circ} 13$. Fols. 1r-2r, 5r-8v.

${ }^{14}$ A. H. A. Criminal. B. 33. $2^{\circ}$. Legajo 1790-1810. Doc. $\mathrm{N}^{\circ} 14$. Fols. 7r-9v.

${ }^{15}$ A. H. A. Criminal. B. 51. Leg. 1730-1800. Doc. $\mathrm{N}^{\circ} 4$. Fol. 32v.
} 
estaban la imposibilidad de conseguir personas capacitadas para ejercer estos cargos y los vínculos de amistad o enemistad existentes entre los pedáneos y sus subordinados, que les hacía difícil actuar con imparcialidad.

Aunque el número de alcaldes pedáneos creció al ir aumentando la población y formarse nuevos sitios, lo cierto es que la acción de la justicia en las zonas rurales encontraba muchos obstáculos. Para tener una idea de la magnitud de la tarea hay que considerar que la población de la extensa jurisdicción de la ciudad de Antioquia tuvo una tasa de crecimiento muy alta en el periodo estudiado. De más de 10.000 habitantes hacia 1778 pasó a 40.758 en 1808 , mientras que el número de Alcaldes pedáneos aumentó de 12 a 27. El Alcalde del sitio de La Claras, por ejemplo, en 1779 tenía bajo su mando 178 personas, en tanto que en 1808 eran 1572 (ver cuadro $\mathrm{N}^{\circ} 63$ y 67). También se debe tener en cuenta que esta población vivía dispersa en las minas y labranzas, lo que hacía más difícil su control. En vastas zonas pobladas por mestizos, mulatos y negros libres no tenía cabida un orden regulado por jerarquías sociales y patrones de dominación económica e ideológica. ${ }^{16}$

La acción de los jueces era más efectiva en el estrecho ámbito de la ciudad y los lugares más inmediatos a ella. Para ayudar a preservar el orden social en la ciudad de Antioquia, se creó al principio del siglo xix el cargo de comisario o Alcalde de barrio. Este funcionario era una especie de juez pedáneo, que se nombraba en las ciudades para cuidar de la quietud y la "policía" de cada uno de los barrios o distritos en que estaba dividida. Dentro de sus atribuciones estaban formar la matrícula de todos los habitantes de su distrito, celar tabernas, casas de juego y casas públicas, prender los delincuentes que hallare in flagranti dentro de su distrito, cuidar que los vecinos cumplieran los bandos de policía sobre alumbrado y limpieza y celar a los vagos y "mal entretenidos" de su barrio. ${ }^{17}$

El cabildo de la ciudad de Antioquia nombraba anualmente dos comisarios, uno para el barrio de Buga y otro para el barrio de Santa Lucía. A diferencia de lo que ocurría con los Alcaldes pedáneos, los vecinos importantes aceptaron

${ }^{16}$ Colmenares, Germán. "La Aplicación de la Ley Penal a fines de la Colonia y comienzos de la República”. Cali. Versión mecanografiada sin publicar. Págs. 17-18.

${ }^{17}$ Escriche, Joaquín. Ob. cit. Pág. 127. 
desempeñar el cargo de comisario de barrio. En el año de 1804, por ejemplo fueron elegidos para estos puestos don Angel José Martínez y don Jacinto Buelta Lorenzana, miembros de familias de gran prestigio, el primero de los cuales fue años después Alcalde ordinario (ver figura $\mathrm{N}^{\circ} 1$, cuadro Genealógico Familia Martínez Ferriro-Buelta Lorenzana Ferreiro).

A medida que el número de Alcaldes pedáneos aumentó y que su jurisdicción se amplió, las funciones de los Alcaldes de la Santa Hermandad se restringieron. En su origen la Hermandad en España fue una especie de confraternidad formada entre los pueblos, con el fin de refrenar los delitos que se cometían fuera de poblado y de impedir las vejaciones de los poderosos. En cada pueblo se elegían dos Alcaldes, uno por el estado noble y otro por el general, a quienes estaban subordinados oficiales menores, llamados cuadrilleros por la cuadrilla que formaban. Estos Alcaldes juzgaban los delincuentes siguiendo los mismos trámites que los jueces ordinarios, correspondiéndoles conocer entre otros delitos los hurtos, raptos y violencia de mujeres, muertes, heridas hechas a traición, siempre y cuando se hubieran cometido fuera de las poblaciones. ${ }^{18}$

En las colonias americanas los Alcaldes de la Santa Hermandad representaron la jurisdicción de la ciudad en el campo. Durante los siglos xvi y xvi compartieron el control de las zonas rurales con los Corregidores de indios y los Alcaldes mayores de minas. Durante el siglo xvili, a medida que la población mestiza y mulata libre crecía y se ubicaba en lugares cada vez más alejados del núcleo urbano, su actividad se restringió. ${ }^{19}$ En la jurisdicción de la ciudad de Antioquia su papel en la administración de justicia fue importante hasta 1770, pues a partir de esa fecha se limitó su facultad para sentenciar causas y quedó su actividad reducida a funciones policivas (ver cuadros $\mathrm{N}^{\circ} 59$ y 62).

En la Independencia, la Constitución de 1812 determinó que los Alcaldes de la Hermandad y los jueces pedáneos, conocieran en primera instancia en los asuntos contenciosos entre partes, tanto civiles como criminales. La jurisdicción que se dio a los pedáneos se restringió en la Constitución de 1815, cuando fueron autorizados, junto con los comisarios de barrio, para conocer

\footnotetext{
${ }^{18}$ Escriche, Joaquín. Ob. cit. Pág. 768.

${ }^{19}$ Marzhal, Peter. Ob. cit. Págs. 69-70.
} 
verbal y privativamente hasta su cantidad de 50 pesos. El empleo de Alcalde de la Hermandad, por su parte, fue suprimido. ${ }^{20}$

Es difícil establecer si esta legislación fue puesta en práctica. Los datos que aportaron las pocas causas existentes para el periodo 1812-1816, muestran que ante los Alcaldes pedáneos fueron puestas denuncias por injuria o lesiones, pero no se puede saber si ejercieron la facultad de sentenciar.

\section{Los Alcaldes ordinarios}

De todos los cargos elegibles el más importante era el de Alcalde ordinario de primer voto, dado que le tocaba ejercer las funciones ejecutivas judiciales y aún legislativas en la órbita municipal. Sus deberes eran muy amplios e iban desde presidir el Cabildo, dictar "autos de buen gobierno" y velar por su cumplimiento, hasta actuar como Gobernador interino cuando éste moría, era suspendido o se ausentaba. De todas sus funciones, sin embargo, la más importante era conocer en primera instancia todas las causas civiles y criminales que ocurrieran en su jurisdicción. El Alcalde de segundo voto lo reemplazaba cuando no podía cumplir con alguno de estos deberes. ${ }^{21}$

Para saber cuál fue el papel que, como jueces, cumplieron los dos Alcaldes ordinarios, hay que tener en cuenta los siguientes datos: 49 (36,02\%) de 136 causas por injuria que se siguieron en el periodo 1750-1819 fueron comenzadas ante ellos. Profirieron fallos en 44 (51,16\%) de los 86 juicios de esta clase que se sentenciaron. En cuanto a las causas por lesiones personales encontramos que $72(35,47 \%)$ de 203 se comenzaron por ellos y dictaron 80 $(58,39 \%)$, de las 137 sentencias que se pronunciaron. Su participación en los juicios por homicidio fue un poco menor pues de 43 causas iniciaron 10 $(23,26 \%)$ y profirieron $15(48,38 \%)$, de las 31 sentencias emitidas (ver cuadros $\mathrm{N}^{\circ} 55,56,58,59,61$ y 62$)$.

\footnotetext{
${ }^{20}$ Pombo, Manuel Antonio y José Joaquín Guerra.

Constituciones de Colombia. Bogotá. Biblioteca del Banco Popular. 1986. Tomo I. Pág. 516 y Tomo II. Pág. 364.

${ }^{21}$ Colmenares, Germán. Cali: Terratenientes, Mineros y comerciantes. Siglo XVIII. Cali. Universidad del Valle. 1976. Pág. 192-193.
}

Marzhal, Peter. Ob. cit. Págs. 67-69. 
Es bueno saber quiénes fueron las personas que como Alcaldes ordinarios jugaron un papel tan decisivo en la administración de justicia. En teoría todos los "vecinos blancos" eran elegibles para el cargo de Alcalde ordinario. En la práctica existían convenciones y restricciones que limitaban el número de personas que podían ser nombradas. Si se analiza el padrón general de la ciudad de Antioquia de 1805 vemos que de los hombres que figuran en la lista de blancos nobles, 54 estaban en condiciones de ser Alcaldes por ser mayores de 26 años. Sin embargo, sólo 29 ejercieron este cargo entre 1771 y 1819. De los que en esta época eran menores de edad, tres fueron nombrados Alcaldes ordinarios durante el periodo de la Independencia. Ninguno de los que aparecían en la lista de blancos del estado llano fue designado para el puesto. ${ }^{22}$

El cargo de Alcalde ordinario de primero y segundo voto fue monopolizado por algunas familias importantes de la ciudad de Antioquia. Individualmente las personas que durante los 70 años estudiados ocuparon alguno de los dos cargos un mayor número de veces fueron don Gregorio Francisco Díez de la Torre y Acevedo (1750, 1758, 1763, 1765 y 1770), don Juan José de Lora y Nuño $(1766,1775,1778,1788$ y 1795) y don Francisco Antonio de Otero Cossio $(1767,1777,1785,1793$ y 1802) que los ejercieron cinco veces. En orden descendente siguen el teniente maestre de campo don José Ignacio de Montoya /1755, 1765, 1772 y 1776), don Juan Pablo Pérez de Rublas (1781, 1786, 1791 y 1794), don Enrique de Villa y Toro (1771, 1776, 1796 y 1811) y el doctor José Pardo y Otálora (1792, 1800, 1805 y 1818), quienes los desempeñaron en cuatro oportunidades.

La concentración en el ejercicio del poder local es más visible si se analizan núcleos familiares. El caso más importante es el de la familia Martínez Ferreiro, cuyos miembros a los largo de cuatro generaciones ocuparon 20 veces el cargo de Alcalde ordinario (ver figura $\mathrm{N}^{\circ} 1$ Familia Martínez Ferreiro-Buelta Lorenzana Ferreiro). El fundador de la familia don Bernardo Martínez, natural de la villa de Muros en Galicia, llegó a la ciudad de Antioquia con el Gobernador Osorio de Velasco en 1744. Allí contrajo matrimonio con doña Francisca Ferreiro, hija de don Antonio Ferreiro Cervino (Alcalde ordinario en 1752) y doña Angela

${ }^{22}$ A. H. A. Censos y Estadísticas. Tomo 333. Doc. 6359. Fols. 1r-6r. 
Rita Pérez. Martínez se dedicó a la actividad comercial llegando a ser uno de los 20 comerciantes más importantes de la provincia durante el siglo xvili. En el año de 1757 ocupó el cargo de Alcalde, comprando poco después el puesto de alférez real lo que lo convirtió en miembro permanente del Cabildo hasta su muerte ocurrida en 1788.23

Su hijo Juan Esteban (Alcalde en 1787) y su yerno el español don Juan Pablo Pérez de Rublas mencionado arriba, también figuraron entre los comerciantes más acaudalados de la época. Los tres controlaron gran parte del mercado de la ciudad de Antioquia por 40 años, lo que indudablemente les dio un gran poder económico. El éxito en los negocios estuco acompañado en Pérez de Rublas por un gran prestigio social. Habiendo llegado a Antioquia a fines de la década de 1760, se convirtió en socio de Martínez. Esta compañía se disolvió en 1776 cuando contrajo matrimonio con la hija de éste, doña Rita Martínez Ferreiro, habiendo recibido 8.000 pesos de dote. Fue Alcalde ordinario en cuatro oportunidades y desempeñando este cargo en 1795 le tocó ejercer las funciones de Gobernador encargado, debido al abandono del puesto que por enfermedad hizo el Gobernador Francisco Baraya y la Campa. No pararon allí sus actividades políticas, pues como propietario del cargo de Regidor decano fue uno de los miembros más activos del Cabildo. En desarrollo de esta función fue encargado y costeó el trámite para la creación del obispado de Antioquia y para la escuela de primera letras de la ciudad. Fue mayordomo de la iglesia parroquial y junto con su esposa aportó el dinero necesario para concluir el tempo de Santa Bárbara, que había sido de los jesuitas. En compensación de sus servicios la Corona Española le otorgó la orden de Carlos iII, creada para ennoblecer a los funcionarios que carecían de antecedentes en la élite burocrática tradicional o en la aristocracia. Según Mark A. Murkholder y D.S. Chandler las personas honradas con esta orden eran la crema y nata de los

${ }^{23}$ Arango Mejía, Gabriel. Genealogías de Antioquia y Caldas. Medellín. Imprenta Departamental. 1942. Tomo II. Págs. 12-17.

Twinam, Ann. Mineros, Comerciantes y Labradores. 1763-1810. Las Raíces del Espíritu Empresarial en Antioquia. Medellín. fondo Rotatorio de Publicaciones. FAES. 1985. Págs. 130, 150. Cuadro $\mathrm{N}^{\circ} 18$.

A. N. A. Tomo 1786-1788. Legajo 1788. Folio 65v. 
funcionarios coloniales y representaban el nuevo tipo de empleados que la Corona buscaba para desempeñar los puestos altos. En 1805 cuando estaba confirmando esta gracia, Pérez de Rublas murió. ${ }^{24}$

Otros miembros de la tercera generación que ocuparon el cargo de Alcalde ordinario fueron el doctor Manuel Martínez, hijo de don Bernardo (Alcalde en 1790 y 1799) y sus cuñados el doctor José Pardo y Otálora (Alcalde en cuatro oportunidades), don Tomás Pérez de Rublas (alcalde en 1800) y don Gabriel García de Hoyos (alcalde en 1803 y 1819).

El doctor Pardo y Otálora era hijo del español don Andrés Pardo, quien llego a la Nueva Granda con el Virrey Solís en 1753. El padre residió primero en Panamá, donde desempeñó el puesto de tesorero real y se casó en 1763 con doña Josefa Otálora. Siendo nombrado contador de la Caja Real de Antioquia se trasladó a esta ciudad en 1772, y ocupó este cargo hasta 1799 cuando murió. Su hijo, que se había graduado de abogado en Santa fe, consolidó el prestigio de la familia al casarse con doña Josefa Martínez, hija de don Bernardo. Al contraer matrimonio, Pardo recibió una dote de 16.770 pesos de oro representados en mercaderías, oro en polvo, una casa y dos esclavas. El caudal de Pardo, que en ese momento era de 15.000 pesos, se incrementó notablemente pues al morir en 1819 se calculó en 56.854 pesos. Fue juez diputado de comercio y fundó a principios del siglo xix una gran hacienda cacaotera denominada Los Llanitos. Al lado de otros miembros de la familia Martínez participó activamente en la Independencia y firmó, en calidad de diputado de la ciudad de Antioquia, la Constitución de $1812 .{ }^{25}$

La posición económica y social de la familia Martínez al finalizar el siglo xviII, se puede ver en una declaración hecha en 1799 por el Gobernador

${ }^{24}$ Burkholder Mark A. y D. S. Chandler. De la Impotencia a la Autoridad. La corona Española y las Audiencias en América. 1687-1808. México. Fondo de Cultura Económica. 1984. Pag. 172.

Restrepo Sáenz, José María. Gobernadores de Antioquia. 1571-1819. Bogotá. Imprenta Nacional. 1931. Tomo I. Págs. 201-202.

Arango Mejía, Gabriel. Ob. cit. Tomo I. Pág. 87-88.

A. N. A. Tomo 1804. Leg. 1805. Fols. 23r-42r.

${ }^{25}$ A. H. A. Mortuorias. Tomo 270. Docs. 5657 y 5659.

Arango Mejía, Gabriel. Ob. cit. Tomo II. Págs. 159-161. Pombo, Manuel Antonio y José Joaquín Guerra. Ob. cit. Tomo I. Pág. 531. 
Víctor Salcedo. Al darlos por fiadores, para cubrir un traslado de cajas reales, catalogaba a los hermanos Martínez y sus cuñados como

Los primeros y más acaudalados vecinos de esta ciudad. ${ }^{26}$

La cuarta generación representada por los hijos de don Juan Esteban Martínez y doña Juana María Pastor, jugó un papel muy importante en la Independencia. Dos de ellos, don Eugenio y don Angel José fueron electos como Alcaldes durante el gobierno republicano (1814 y 1815). Un tercero, el doctor José Faustino, quien estudio derecho en el colegio de San Bartolomé, fue un entusiasta realista. Las circunstancias políticas de la provincia lo llevaron a emigrar cuando se estableció el Estado de Antioquia. En 1818 regresó para ejercer el cargo de teniente asesor del gobierno realista, empleo que sirvió hasta la entrada del teniente coronel José María Córdoba a Antioquia en agosto de 1819. Perseguido por el gobierno republicano, logró huir hacia la costa desde donde viajó a La Habana. Sólo regresó a Antioquia a fines de 1837, y vivió en esta ciudad hasta su muerte, ocurrida en $1857 .{ }^{27}$

La familia Martínez también estuvo vinculada con personas que ocuparon el cargo de gobernador de la provincia. El español Cayetano Buelta Lorenzana, quien gobernó entre noviembre de 1776 y octubre de 1782 , se casó con una hermana de la esposa de don Bernardo Martínez, doña María Ignacia Ferreiro. Concluido el periodo de su mandato se radicó en la ciudad de Antioquia, donde vivió hasta su muerte en 1793. Su hijo don Juan Manuel fue elegido como Alcalde ordinario en 1817.28

Otro mandatario provincial que tuvo nexos familiares con los Martínez fue el Presidente dictador del Estado de Antioquia don Juan del Corral. Este momposino llegó a Antioquia a finales del siglo xviII, como representante de su padre el comerciante español don Ramón del Corral, vecino de Mompox. En 1800 se casó con una hija de don Juan Pablo Pérez de Rublas, y después se dedicó a cultivar cacao en los alrededores de la ciudad. Fue miembro per-

\footnotetext{
${ }^{26}$ A. N. A. Tomo 1798-1799. Leg. 1799. Fol. 137r-138v.

${ }^{27}$ Restrepo Sáenz, José María. Ob. cit. Págs. 369-374.

${ }^{28}$ Ibídem. Págs. 171-175.
} 
manente del Cabildo desde 1808, cuando se posesionó del cargo de Regidor. Al producirse los acontecimientos de 1810, apoyó la Junta provincial que se formó, y se consagró a organizar las milicias de Antioquia. Con las noticias del avance del ejército de Sámano, la legislatura del Estado de Antioquia resolvió suspender el régimen constitucional y nombró a Del Corral Presidente Dictador del Estado. Este cargo lo ejerció desde julio de 1813 hasta el 7 de abril de 1814 cuando murió. ${ }^{29}$

Otro núcleo familiar cuyos miembros ocuparon varias veces el cargo de Alcalde ordinario fue el conformado por los descendientes de don Juan José de Lora Sandoval. Este individuo, que fue criado por la mestiza Faustina Tabares, en 1735 realizó una diligencia ante el Alcalde de la ciudad para demostrar que era hijo legítimo de doña Catalina Mejía Delgado y don Pedro de Lora y Sandoval, español residente en Mompox. Juan José de Lora Sandoval era comerciante, pues en calidad de tal firmó en el año de 1756 una petición para solicitar el establecimiento de una bodega en el puerto de Espíritu Santo. ${ }^{30} \mathrm{Su}$ hijo, el presbítero Antonio de Lora, fue un gran propietario de tierras y esclavos. En 1777 compró a don José Joaquín de Otero Cossio, por 1.275 pesos, las tierras de Güintar, las cuales habían sido de los jesuitas; el precio incluía además 40 reses y tres esclavos. En su testamento el cura Lora decía que se había ordenado a título de un patrimonio de 2000 pesos que impusieron sus padres sobre el quinto de sus bienes. ${ }^{31}$

Don Juan José fue Alcalde ordinario en 1758 y 1762. Sus hijos don Juan José y don Francisco José Lora y Nuño también desempeñaron este cargo varias veces. El primero como lo anotamos antes, fue Alcalde ordinario en cinco ocasiones. En 1795 ejerció por cinco meses las funciones de Gobernador encargado, mientras se posesionaba don José Felipe Inciarte nombrado, en febrero de ese año, Gobernador interino de la provincia. Lora y Nuño fue el único antioqueño que ocupó este cargo en el siglo xviII. Su participación en

\footnotetext{
${ }^{29}$ Ibídem. Págs. 259-266.

${ }^{30}$ A. H. N. Caciques e indios. Tomo III. Fol. 1r-v, 100.

${ }^{31}$ A. N. A. Tomo 1775-1777. Legajo 1777. Folio 157.

A. H. A. Mortuorias. Tomo 249. Doc. 5466.

Arango Mejía, Gabriel. Ob. cit. Tomo I. Págs. 533-535.
} 
el gobierno de la ciudad no se redujo al ejercicio de estos cargos, pues a más de ser Regidor, fue elegido como síndico procurador general en 1771, 1781, 1782, 1788 y 1791. Tanto en el carácter de juez como en el de fiscal fue la persona que tuvo para participación más amplia en la administración de justicia durante el periodo estudiado. ${ }^{32}$

La tercera generación de la familia también tuvo un papel destacado en la política local. Don Lorenzo de Lora García, hijo de don Francisco, fue Alcalde en 1804 y 1808. Heredó parte de las tierras y esclavos de su tío, el presbítero Antonio, lo que permite suponer que se dedicó a las actividades agropecuarias. Su hermano don José Toribio desempeñó el cargo en 1809.

Estos dos ejemplos muestran que la administración de justicia en la ciudad de Antioquia estuvo en manos de las mismas familias por varias generaciones. Los vínculos de parentesco y amistad que existían entre los miembros de la élite, hacía que se dudara de la posibilidad de que los vecinos pobres fueran oídos en los tribunales. El Gobernador silvestre pintaba la situación de la siguiente manera:

Porque, como las Justicias Ordinarias son Españoles patricios, o si son Europeos, tienen relaciones con ellos por sus matrimonios, de ordinario se administra con acepción, y miramiento a las personas. El que no lo hace así, y que espera los mismo a su turno del pariente, experimenta luego el resentimiento, no sólo del que se creyó agraviado, si no es de toda su familia y de sus amigos; porque hacen punto de honor, el que es capricho, y por su respeto y miramiento no se ha de hacer pagar al que se deba, o a de quedar impune la injuria, o el delito. ${ }^{33}$

Un mecanismo que utilizaron las partes implicadas en los juicios para remediar esta situación fue recusar al juez. De acuerdo con la definición de las leyes de partida, recusación era la excepción que se ponía a un juez u otro ministro para que no conociera la causa. Era un remedio legal para evitar parcialidades injustas de parte de un juez, asesor o escribano, de quien tenía

\footnotetext{
${ }^{32}$ Restrepo, Sáenz, José María. Ob. cit. Págs. 203-204.

${ }^{33}$ Silvestre, Francisco. Ob. cit. Págs. 187-188.
} 
sospecha algunos de los litigantes. La recusación se podía hacer en cualquier momento del juicio antes de la sentencia. Si el juez procedía sin tener en cuenta este impedimento legal, era nulo lo que hacía, a no ser que el recusante siguiera litigando ante él sin protestar, pues en tal caso se presuponía que había renunciado a usar este recurso. ${ }^{34}$

En la jurisdicción de la ciudad de Antioquia los motivos por los que se recusaba eran básicamente el parentesco, la amistad o la enemistad existente entre el juez y algunos de los comprometidos en la causa. Así, María Zoila Lezcano, rea por agravio en una causa seguida en 1798, recusó al Alcalde ordinario de primer voto don José Marín, por estar casada su oponente, Andrea Bran, con un esclavo del tío del Alcalde. ${ }^{35}$

En otros casos los litigantes no explicitaban la causa por la cual dudaban de la imparcialidad del juez. Da la impresión que algunas personas con experiencia en el manejo de los tribunales usaban este recurso para entorpecer la acción de la justicia. Don Felipe de Vargas, Anselmo Marín y Julián Ibarra, en un juicio por injuria que el primero siguió contra los otros dos, se dedicaron entre noviembre de 1808 y enero de 1809 a recusar a los Alcaldes y Regidores que fueron propuestos para hacer de jueces. Siete miembros del Cabildo fueron tachados por algunos de los implicados y el Alcalde ordinario nombrado en 1809, don José Manuel Zapata, se disculpó de conocer la causa por ser pariente de la mujer de Vargas. Finalmente el pleito se trasladó al juzgado del gobernador. ${ }^{36}$ Hay que anotar que don Felipe de Vargas y su esposa estuvieron comprometidos en cuatro causas por injuria y golpes entre 1799 y 1810.

Los Gobernadores visitadores de la década del 80 , señalaron constantemente la necesidad de solucionar los problemas que se derivaban de la actuación de los Alcaldes ordinarios como jueces de primera instancia. Entre los mecanismos con que se buscó controlar el poder de estos funcionarios, se destacan la creación del cargo de Teniente de Gobernador asesor y el fortalecimiento de las prerrogativas que en lo judicial tenía el Gobernador. Como resultado de este proceso, en las dos últimas décadas del régimen colonial,

\footnotetext{
${ }^{34}$ Escriche, Joaquín. Ob. cit. Pág. 1421.

35 A. H. A. Criminal. B. 65. Leg. 1790-1810. Doc. 31. Fol. 7r-8r.

${ }^{36}$ A. H. A. Criminal. B. 77. Leg. 1800-1810. Doc. 22. Fol. 11r-14r.
} 
un alto porcentaje de causas se tramitó en el juzgado de gobernación. Así, de las 58 sentencias dictadas en las causas por homicidio, lesiones personales e injuria, seguidas en la década del 90, los gobernadores profirieron 25 (43,10\%). Al empezar el siglo xix su participación fue aún mayor, pues emitieron 19 $(55,88 \%)$, de los 34 fallos existentes (ver cuadro $\left.\mathrm{N}^{\circ} 56,59,62\right)$.

El control de la administración de justicia retornó a manos de los Alcaldes ordinarios en la época de la Independencia. En virtud de la separación de los poderes públicos, decretada en las Constituciones de 1812 y 1815, el cargo de Presidente del Estado o Gobernador quedó con funciones exclusivamente ejecutivas. Como jueces de primera instancia quedaron los Alcaldes ordinarios quienes estaban facultados para conocer las causas civiles y criminales, así como los juicios de comercio. Según la constitución de 1815 las personas que ocupaban este cargo debían ser elegidas anualmente por los Cabildos y cuerpos electorales. El juez mayor que nombraba la legislatura para cada cantón o departamento era el encargado de confirmar la elección. ${ }^{37}$

Mientras se fortalecían las funciones del Alcalde ordinario en la rama judicial, desparecieron muchas de las prerrogativas ejecutivas y legislativas que antes tenían. El que su nombramiento continuara efectuándose por los Cabildos, se explica porque durante la primera etapa del movimiento de Independencia en la provincia de Antioquia (1810-1815), llamada "rebelión de los Cabildos", éstos asumieron buena parte del control político.38

Las mismas familias que habían ocupado el cargo en la época colonial, continuaron ejerciéndolo durante la Independencia, bien fuera bajo el gobierno patriota o el realista. Esta es una demostración de que las estructuras de poder local no se alteraron.

Nada ejemplifica mejor cómo la administración de justicia siguió estando sujeta a los lazos de amistad y enemistad con los jueces, como lo ocurrido en dos causas por heridas e intento de asesinato seguidas en 1811 contra el Sargento

${ }^{37}$ Pombo, Manuel Antonio y José Joaquín Guerra. Ob. cit. Tomo I. Págs. 515-517 y Tomo II. Págs. 363-365.

${ }^{38}$ Uribe de Hincapié, María Teresa y Jesús María Alvarez. Las Raíces del Poder Regional. El Caso Antioqueño. Documento Preliminar. $N^{\circ}$ 5. Medellín. Centro de Investigaciones de las Ciencias sociales. "CENICS". 1986. Introducción. Pág. II. 
Mayor don Gabriel García de Hoyos, por el cura de Antioquia doctor José Félix Mejía y los hermanos Pedro, Santos y José Castro. El motivo de las dos disputas fue el mismo; la relación adulterina que García tenía con Marta Yepes. Tanto el cura, como los Castro, pusieron su demanda ante el Presidente del Estado quien la remitió al Coronel Comandante Juan Esteban Martínez, por corresponderle conocerlas debido al fuero militar que tenía el acusado. Martínez se negó a intervenir por ser cuñado de García. Se pasaron entonces al subinspector don José Manuel Zapata, quien se excusó por tener con el implicado un parentesco de tercer grado mixto. El Presidente del Estado también se declaró inhibido para proceder en las causas, por haber estado casado con una prima hermana de García y establecer la Constitución vigente que el ejecutivo no podía intervenir en asuntos contenciosos. Las causas fueron remitidas al Alcalde ordinario de primer voto don Juan Bernardo Aguirre, quien expuso que el fuero militar de que disfrutaba García era incompatible con la jurisdicción ordinaria y política gubernativa que él ejercía. Además estaba ligado al implicado por parentesco espiritual. También se excusó el Alcalde ordinario de segundo voto don José María de la Calle. No es de extrañar que el cura de Antioquia se quejara en marzo de 1812 de estar "cansado de esperar" el desagravio de las ofensas hechas por García. Afirmaba:

Yo he visto con dolor transcurrirse más de cinco meses, sin que se haya dado un paso que toque a la averiguación del hecho más grave, separado de mi beneficio, errante en otra jurisdicción esperando la satisfacción y mi seguridad, más al fin he palpado con mis propios ojos, que mi queja tiene el mismo estado, que cinco meses antes cuando la elevé al señor Presidente del Estado, informe y sin el menor principio, mientras que el agresor cruza la ciudad de Antioquia libre y orgulloso, impune, condecorado y a la par de los más beneméritos hijos de la patria. ${ }^{39}$

${ }^{39}$ A. H. A. Eclesiásticos. Tomo 84. Doc. 2340. Fols. 11v-13v.

Criminal. B. 102. Leg. 1800-1820. Doc. 14. 
Los intentos de los gobernantes coloniales ilustrados de separar la administración de justicia de las redes de poder local, quedaron truncos con la independencia. Aunque la justicia se estructura como un poder público separado, en la práctica esto no significa que sea más imparcial, eficaz y rápida.

\section{Los asesores jurídicos}

Uno de los mecanismos que se utilizó en la jurisdicción de la ciudad de Antioquia para controlar el excesivo poder de los Alcaldes ordinarios, fue la introducción de asesores jurídicos. Estos eran abogados que asistían a los jueces legos para aconsejarlos en los asuntos pertenecientes a la administración de justicia. ${ }^{40}$ Con su presencia se trató de subsanar la falta de conocimiento jurídico de los Alcaldes, que era notoria a mediados del siglo xvil. Basta señalar que en la década del 50 el único abogado existente en la provincia de Antioquia fue el Gobernador interino licenciado Manuel López de Castilla (1752-1755).

En esta época los hijos de los antioqueños adinerados que iban a estudiar a Santa fe seguían la carrera eclesiástica. La situación se puede ilustrar con los datos del censo de Medellín de 1778, donde figuran 49 sacerdotes, de los cuales 27 eran doctores y 22 maestros, mientras que sólo fueron empadronados cinco abogados. ${ }^{41}$

En el último cuarto del siglo xvili, como resultado del crecimiento de la actividad minera y comercial, así como de la influencia de las ideas ilustradas, los grandes propietarios se inclinaron por dar a sus hijos una formación más práctica que la eclesiástica y los enviaron a estudiar derecho en los colegios de Santa fe. Como producto de este proceso, a partir de 1787, en la ciudad de Antioquia empiezan a ser elegidos como Alcaldes ordinarios abogados graduados. Otro indicativo de la transformación de la mentalidad con que la élite educaba a sus hijos, es que en la primera década del siglo xix en el censo de la ciudad figuraran sólo cinco sacerdotes, en tanto que ya residían allí ocho doctores en derecho. ${ }^{42}$

${ }^{40}$ Sala, Juan. Ob. cit. Tomo II. Pág. 163.

${ }^{41}$ A. H. A. Censos. Tomo 339. Doc. 6502.

42 A. H. A. Censos. Tomo 333. Doc. 6359. Fols. 1r-4r.

Es extraño que en la lista de abogados inscritos em la Real Audiencia, publicada en el "Kalendario Manual y Guía de Forasteros em Santa fe de Bogotá" de 1806, sólo figuren 4 abogados residentes en la provincia de Antioquia. Según este libro los abogados con título reconocido exis- 
La formación de un grupo intelectual civil diferenciado del clero es un proceso visible en la Nueva Granada a finales de la época colonial. Esto se puede constatar con la superioridad del número de grados concedidos en jurisprudencia frente a los de teología. La Universidad de Santo Tomás de Aquino, que tenía el privilegio de otorgar los grados académicos a los estudiantes de los colegios de Santa fe, Cartagena y Popayán, concedió 373 grados en teología y 1036 grados en jurisprudencia entre 1768 y 1808. De éstos últimos, 156 fueron en leyes, 706 en cánones, 134 en civil y 40 en derecho. El que los títulos en derecho canónico (cánones) aventajaran a los de derecho civil, muestra que el proceso de secularización de la intelectualidad había empezado pero no era total. El impulso al derecho civil fue producto del plan de estudios de Moreno y Escandón (1774-79), pero a partir de 1790 se prohibió su estudio y se reimplantó el de derecho Real. ${ }^{43}$

Lo anterior explica porqué en la década de 1770 empiezan a actuar como asesores jurídicos de los Alcaldes ordinarios, los abogados residentes en la provincia con título reconocido por la Real Audiencia. Los jueces tenían la prerrogativa de pedir consejo legal a cualquier abogado, pero dado el escaso número de doctores existente, las posibilidades de escogencia no eran muchas. De acuerdo con los datos que suministran los procesos, el oficio de asesor, entre 1773 y 1796, fue ejercido fundamentalmente por los siguientes abogados:

El doctor Lorenzo Benítez, cartagenero nacido hacia 1740, quien habiendo contraído matrimonio con la medellinense doña Carmen de Madrid se radicó en la villa de Medellín, donde ocupó el cargo de Alcalde ordinario en varias oportunidades. Actuó como asesor jurídico de los jueces de la ciudad de Antioquia entre 1773 y $1788 .{ }^{44}$

tentes en la Nueva Granada eran 128, de los cuales 71 estaban radicados en Santa fe de Bogotá y 19 en Cartagena.

García, Antonio José D. D. Kalendario Manual y Guía de Forasteros en Santa fe de Bogotá Capital del Nuevo Reino de Granada para el año de 1806. Edición Facsimilar. Bogotá. Banco de la República. Departamento Editorial. 1988. Págs. 57-72.

${ }^{43}$ Silva Olarte, Renán. Escolares y Catedráticos en la Sociedad Colonial. Bogotá. Universidad Pedagógica Nacional. Centro de Investigaciones. CIUP. 1985. Pág. 78-82.

${ }^{44}$ Arango Mejía, Gabriel. Ob. cit. Tomo I. Pág. 107. 
El doctor Ignacio Uribe, hijo de don Vicente Uribe de Betancur y doña Juana Mejía de Tobar, vecinos de Medellín, quien estudió derecho en Santa fe en el colegio de San Bartolomé. Al graduarse se instaló en su ciudad natal donde desempeñó múltiples cargos y contrajo matrimonio con doña Joaquina Mondragón. Fue tal vez el abogado más prestigioso de la provincia en el siglo xviII, como lo atestigua el hecho de que sus dictámenes fueran constantemente citados, invocando su autoridad de "mejor y más antiguo abogado". Su larga trayectoria como asesor empezó en 1777 y terminó en 1811. Se recurrió a él por tantos años debido a que cuando el Teniente de Gobernador asesor y los otros abogados eran recusados, se acostumbró pedir su consejo legal por ser el de mayor acogida entre el pueblo. Como diputado de la villa de Medellín figura entre los firmantes de la Constitución del Estado de Antioquia de 1812. Murió en 1815.45

El doctor José Joaquín Gómez Londoño, hijo del español don Antonio Adriano Gómez y doña Bárbara Londoño Castañeda, vecinos de Medellín, nació en esta villa en 1756. Estudió derecho en Bogotá, presumiblemente en el colegio de San Bartolomé. Después de graduarse, en 1784 contrajo matrimonio con doña Manuela Barrientos, miembro de una importante familia del Valle del Aburrá. Aunque su actividad como asesor no fue continua, profirió dictámenes entre 1785 y 1803. Falleció en Medellín en 1843.46

Estos datos muestran que los abogados que inicialmente prestaron servicios como asesores jurídicos residían en la villa de Medellín, lo que significó para los implicados en los juicios seguidos en la ciudad de Antioquia, tener que asumir los gastos de la conducción de las causas. El costo de la asesoría era cubierto por los litigantes o reos, quienes debían pagar el honorario del abogado, estipulado en ocho pesos de oro, el costo del "chasqui" y cualquier otro gasto que se presentara. ${ }^{47}$ Los vínculos de parentesco por nacimiento o matrimonio que existían entre estos abogados y las familias adineradas de la

${ }^{45}$ Ibídem. Tomo II. Págs. 413-416.

A. H. A. Criminal. B. 51. Leg. 1730-1800. Doc. 5. Fols. 29r-33v.

Pombo, Manuel Antonio y Guerra, José Joaquín. Ob. cit. Tomo I, Pág. 531.

${ }^{46}$ Arango Mejía, Gabriel. Ob. cit. Tomo I. Págs. 386-388.

${ }^{47}$ A. H. A. Criminal. B. 54. Leg. 1770-1780. Doc. $\mathrm{N}^{\circ}$ 7. Fol. 64r. 
provincia, hacía que su imparcialidad fuera cuestionada por las autoridades coloniales. Como el Alcalde solía acoger el consejo del asesor, los problemas que se derivaban de sus decisiones y los reclamos por procedimientos hechos contra la ley, solían cobijarlos a los dos.

Para solucionar los problemas que se presentaban en la asesoría legal de las autoridades con funciones ejecutivas y judiciales, la Corona creó los cargos de asesores generales para los Virreyes y tenientes asesores para los Gobernadores e intendentes. Estos empleos eran desempeñados por abogados, nombrados para un periodo de cinco años, a quienes se les asignaba sueldo fijo. Esta reforma empezó a operar en la Nueva España (México) en 1777, y se extendió en los años siguientes a los otros virreinatos. ${ }^{48}$

Siguiendo esta tendencia, en su propuesta para reorganizar la administración de justicia en la provincia de Antioquia, el gobernador Francisco Silvestre (1782-1785), consideró como prioritario el nombramiento de un teniente letrado, que aconsejase al Gobernador. En su opinión, este funcionario debía tener un sueldo "competente", ajustado al costo de la vida en la región, sin que pudiera cobrar derecho alguno por estudiar las causas. ${ }^{49}$ Esta petición fue acogida sólo en 1796. El Teniente de Gobernador asesor nombrado, quedó encargado de dar los conceptos y dictámenes jurídicos en las causas seguidas en el juzgado ordinario de la ciudad de Antioquia.

Los abogados que ocuparon este cargo tuvieron un papel protagónico en las últimas décadas del régimen colonial y participaron activamente en el proceso de la Independencia, como lo muestran los siguientes datos:

El primer teniente asesor fue el licenciado Pantaleón Arango, nacido en San Juan de Girón en 1765. Sus padres fueron el doctor Tomás Arango, antioqueño y doña Manuela González del Busto. Estudió en el colegio San Bartolomé y se recibió de abogado de la Real Audiencia en 1796. Luego se radicó en Medellín donde se casó dos veces, la primera con doña Isabel Moreno, viuda del comerciante español Juan José Callejas.

\footnotetext{
${ }^{48}$ Burkholder, Mark. A y D. S. Chandlet. Ob. cit. Págs. 154-178.

${ }^{49}$ Silvestre, Francisco. Ob. cit. Pág. 509.
} 
Arango fue nombrado por el Virrey Ezpeleta Teniente de Gobernador asesor de Antioquia y desempeñó el cargo por tres años a partir de enero de 1796. Durante este tiempo le correspondió trabajar con los Gobernadores José Felipe Inciarte y Víctor Salcedo. Durante la Independencia participó como diputado de Medellín en el congreso provincial de Antioquia, que se reunió del 30 de agosto al 7 de septiembre de 1810. En octubre de 1811, al producirse cambios en el poder ejecutivo de la región, fue nombrado Vicepresidente del Estado. Representó a Medellín en el colegio revisor que sesionó en junio y julio de 1815, y figuró entre los firmantes de la Constitución que este organismo redactó. Al llegar las tropas españolas, don Pantaleón firmó un documento en que imploraba clemencia.

No obstante su participación en el gobierno revolucionario, el Gobernador realista Sánchez Lima lo propuso para el cargo de teniente asesor interino, empleo que volvió a ocupar entre agosto de 1816 y mayo de 1818. En calidad de tal le tocó actuar como Gobernador encargado entre marzo y mayo de 1818. En junio de 1818 el Virrey Sámano lo nombró teniente asesor del gobierno de Santa Marta, cargo que no aceptó aunque significaba un ascenso. Arango, que además era médico, tenía la virtud de acomodarse rápidamente a los cambios políticos; es así como después de la Independencia ocupó varios empleos en la administración provincial. Murió en Medellín en abril de $1848 .{ }^{50}$

El segundo Teniente de Gobernador fue el doctor Antonio Viana, quien nació en Honda en 1769. Sus padres fueron don Diego Antonio Viana, cartagenero y doña Catalina Ceballos. Vistió la beca del colegio de San Bartolomé en 1781, se graduó de doctor en 1789 y se recibió de abogado de la Real Audiencia en 1793. Se casó en Mariquita con doña Anselma Armero y Conde.

Empezó su carrera como Teniente de Gobernador asesor de su ciudad natal. Por Decreto de 18 de junio de 1798 fue promovido a desempeñar el mismo oficio en la Provincia de Antioquia. Ocupó ese cargo desde el 15 de noviembre de ese año hasta principios de 1810. En ejercicio de sus funciones le tocó asumir interinamente la gobernación de Antioquia desde noviembre de 1804 a julio de 1805 cuando se posesionó el Gobernador propietario don Francisco de Ayala.

${ }^{50}$ Restrepo Sáenz, José María. Ob. cit. Tomo I. Págs. 325-330. 
El 20 de julio de 1810 estaba desempeñando el cargo de Teniente de Gobernador de la provincia de Santa Marta. Viana figuró entre quienes conformaron en agosto de ese año una Junta provincial de gobierno, semejante a las creadas en otras provincias. Se dedicó a la causa de la Independencia, y se vió obligado a renunciar a su puesto debido a que Santa Marta se declaró leal al Rey.

En julio de 1811 fue elegido por el Senado Sustituto, consejero del Estado de Cundinamarca. A fines de ese año fue nombrado por el gobierno patriota teniente coronel comandante del batallón de milicias de infantería de Honda. Al comenzar la República, Viana fue designado para el cargo de ministro de la alta corte de justicia de Bogotá, donde trabajó varios años. Murió a finales de 1839 o principios de $1840 .{ }^{51}$

En reemplazo de Viana fue nombrado don Juan Elías López de Tagle, cartagenero nacido en 1777, hijo del español don José López de Tagle y la cartagenera María Teresa de Madariaga. López vistió la beca del colegio de San Bartolomé y obtuvo el grado de bachiller en derecho canónico en la Universidad pontificia de Santo Tomás en agosto de 1801. Se recibió de abogado de la Real Audiencia en octubre de 1804.

Su carrera como letrado comenzó al ser designado por el Virrey Amar como Teniente de Gobernador asesor interino de provincia de Santa Marta, puesto que ocupó entre agosto de 1808 y principios de 1810. En marzo de 1810 se casó en Cartagena con doña María Dolores de Leguina y López Tagle, su pariente. La Junta Suprema central gubernativa de España, en nombre de Fernando vil, lo nombró Teniente de Gobernador letrado de la provincia de Antioquia en julio en 1809. A mediados de 1810 llegó López a Antioquia y reemplazó en el cargo al asesor interino doctor José Manuel Restrepo. En agosto de ese año dirigió, por delegación del Gobernador Francisco de Ayala, el congreso provincial que se proponía organizar el gobierno después de los sucesos del 20 de julio de 1810. Esta entidad depositó el poder en la Suprema Junta provincial gubernativa, compuesta por representantes de las principales poblaciones y presidida por el Gobernador. Don Juan Elías fue Vicepresidente de esa junta desde septiembre de 1810. Asumió como Presidente de la junta el gobierno

\footnotetext{
${ }^{51}$ Ibídem. Págs. 215-218.
} 
político de la provincia, al renunciar el Gobernador Ayala. Le correspondió ejercer este cargo de marzo a julio de 1811.

Partidario fervoroso de la Independencia, fue nombrado por el gobierno patriota en agosto de 1811 Teniente de Gobernador de Mompox. En 1814 fue elegido miembro del colegio electoral de Cartagena, reunido para revisar la Constitución de 1812. Este organismo lo nombró en diciembre de 1814 Teniente de Gobernador de Cartagena, le correspondió asumir en noviembre de 1815 la gobernación por enfermedad del titular don Juan de Dios Amador. Durante su corto mandato le tocó hacer frente al sitio de la plaza de Cartagena por parte de Morillo, y fue el encargado de ordenar su evacuación el 5 de diciembre de 1815. López emigró a Jamaica, donde permaneció hasta marzo de 1819 cuando se incorporó a la expedición de Mac Gregor, que intentó reconquistar la Nueva Granada. Defendió como Gobernador la plaza de Portobelo, que se había tomado y fue derrotado el 2 de mayo por el teniente coronel José Santa Cruz, siendo degollado. ${ }^{52}$

El cargo de teniente asesor de intendentes y Gobernadores se constituyó en el primer peldaño de la carrera de un magistrado. El sistema de escalafón vigente disponía que a los cinco años de servicio fuera confirmado, trasladado o despedido. Su continuidad dependía de las capacidades que demostrara, las que le podían permitir ascender hasta convertirse en miembro de una Audiencia, David S. Chandler y Mark. A. Burkholder, en su estudio sobre las Audiencias americanas, señalan que de 1791 a 1808 los tenientes asesores se constituyeron en el grupo más numeroso de gente nueva que ocupó cargos de importancia. ${ }^{53}$

Considerados como grupo los personajes que ocuparon este cargo tenían unas características definidas, de las que participaban los que actuaron en Antioquia. En un porcentaje muy alto eran criollos, pero se buscó nombrarlos fuera de la provincia donde habían nacido o estaban radicados. Al comenzar la carrera, una buena parte estaban casados, con lo que se quiso evitar los problemas que conllevaba el matrimonio con damas de la sociedad local. La razón de estas medidas estaba en que la Corona y muchos funcionarios coloniales creían

\footnotetext{
52 Ibídem. Págs. 227-233.

${ }^{53}$ Chandler, David S. y Burkholder, Mark. Ob. cit. Págs. 178-179.
} 
que nombrando como tenientes a "forasteros e independientes" se lograría una mayor libertad e imparcialidad en la administración de justicia. De esta manera se eliminaba la posibilidad de que los vecinos se quejaran de que procedían por odio o amistad. ${ }^{54}$

Es notorio el papel que en la formación de esta nueva burocracia colonial desempeñaron los Colegios y Universidades Americanas. La Universidad de San Marcos de Lima dejó de ser la principal proveedora de miembros de altas cortes de justicia, y fue reemplazada por las Universidades de México y Santa fe de Bogotá. Entre quienes desempeñaron el cargo en Antioquia es sorprendente la coincidencia de que todos hubieran estudiado en el Colegio de San Bartolomé. ${ }^{55}$

La carrera de los asesores que actuaron en Antioquia comenzó con el desempeño de puestos de nivel local. Después de concluir su labor en la provincia, eran nombrados para Santa Marta, que tenía un rango superior, de donde debían ser promovidos a un puesto más alto. La Independencia interrumpió este proceso, pero no significó el final en la carrera de estos magistrados. El caso del doctor Antonio Viana muestra como el gobierno republicano se sirvió de estos personajes para llenar con ellos los cargos de las nuevas cortes y tribunales de justicia.

La Constitución de Antioquia de marzo de 1812 eliminó el cargo de Teniente de Gobernador asesor. Sin embargo, en la Constitución de 1815 volvió a crearse y se nombró para el cargo al doctor Andrés Avelino de Uruburu. Siguiendo el pensamiento ilustrado, en estas Constituciones se postulaba la separación de los poderes públicos: ejecutivo, legislativo y judicial, por considerar que su reunión en una sola persona o cuerpo daba lugar a la tiranía. Consecuentemente, el empleo de Teniente de Gobernador letrado fue adscrito a la rama ejecutiva, eliminándosele la mayor parte de las funciones relativas a la administración de justicia. Se lo facultó únicamente para conocer y sentenciar las causas contra los "enemigos de la libertad y la tranquilidad de la provincia". ${ }^{56}$

En el organigrama del poder judicial contenido en estas Constituciones no se habla de asesores jurídicos de los jueces, pero éstos existieron. En las

\footnotetext{
${ }^{54}$ Silvestre, Francisco. Ob. cit. Págs. 188-189.

${ }^{55}$ Chandler, D. y Burkholder, M. Ob. cit. Pág. 174.

${ }^{56}$ Pombo, Manuel A. y Guerra, José J. Ob. cit. Tomo II. Págs. 358-360.
} 
causas pertenecientes al periodo 1811-1816 figuran como tales los doctores Andrés Avelino Uruburu y José María Ortiz, cuyos datos biográficos fueron incluidos al hablar de los fiscales y los defensores.

Al reimplantarse el régimen español, en marzo de 1816, la organización del aparato de gobierno de la provincia volvió a ser igual a la que imperaba en 1810. El Teniente de Gobernador asesor, por lo tanto, retomó el lugar que ocupaba en la administración de justicia. En esta oportunidad los problemas político militares que enfrentaban las autoridades realistas, impidieron nombrar para este cargo personas de otras provincias. Desarticulado el cuerpo de tenientes asesores de Gobernador que se estaba conformando, se tuvo que recurrir a abogados locales que fueran leales a la Corona. En el caso de Antioquia fueron designados para este empleo los doctores Pantaleón Arango (1816-1818) y José Faustino Martínez (1818-1819).

Estos funcionarios no eran jueces en sentido estricto, no obstante, un apreciable número de sentencias se profirió en consonancia con su parecer lo cual pone de manifiesto su importante papel en la administración de justicia. Su acción servía de limitante al arbitrio de los jueces en razón del carácter obligatorio que tenían sus conceptos. Tanto era así que la ley los consideraba responsables de las "resultas de la causa". ${ }^{57}$

La creación del cargo de Teniente de Gobernador asesor deja ver el propósito que tenía la Corona de lograr una profesionalización entre los funcionarios encargados del ramo judicial. Se buscaba crear un grupo selecto de magistrados suficientemente experimentados y conocedores de sus funciones.

\section{Los gobernadores}

El Gobernador tenía el mando político y militar de la provincia y ejercía simultáneamente la jurisdicción real ordinaria y la militar. En cuanto a la primera, dependía directamente de la Audiencia a la cual estaba adscrito el territorio bajo su autoridad. ${ }^{58}$

\footnotetext{
${ }^{57}$ Escriche, Joaquín. Ob. cit. Pág. 290.

${ }^{58}$ Ibídem. Pág. 734.
} 
En la ciudad de Antioquia como sede del gobierno de la provincia funcionó un juzgado de gobernación a lo largo del periodo colonial. A él concurrían las personas que tenían quejas de los Alcaldes pedáneos y ordinarios, buscando un juez más imparcial que oyera sus descargos. Bajo su jurisdicción estaba el conocimiento de las causas que involucraban a militares y extranjeros transeúntes. También intervenía en los juicios en que estaba inmiscuida la población indígena.

El papel de los Gobernadores como jueces ordinarios de primera instancia se incrementó en la segunda mitad del siglo xviII. Sus esfuerzos para volver más eficaz la administración de justicia fueron producto del interés de los gobernantes ilustrados por lograr un mayor control de la población de las colonias americanas. A este respecto es ilustrativa la opinión emitida en 1788 por el Gobernador visitador Juan Antonio Mon y Velarde:

\begin{abstract}
Es la buena administración de justicia, uno de los mayores bienes que pueden gozar y hacer felices los pueblos; de este principio nace la quietud pública por respeto a los superiores, el amor y felicidad (sic) para con los soberanos, y últimamente que cumpliendo cada uno los deberes propios de su obligación, guarda a sus conciudadanos el respeto y consideración que a cada uno corresponde..$^{59}$
\end{abstract}

La participación de los Gobernadores en las causas seguidas en la jurisdicción de la ciudad de Antioquia la podemos medir por las siguientes cifras: Ellos dieron comienzo a $41(30,15 \%)$ de las 136 causas seguidas por injurias y emitieron $32(37,20 \%)$ de las 86 sentencias. En los juicios por heridas su intervención fue menor, pues ante ellos empezaron 49 (24,14\%) de los 203 existentes. Dictaron la sentencia en $42(30,65 \%)$ de los 137 juicios de esta clase fallados. De los juicios por homicidio iniciaron 10 (23,26\%) de los 43 que se conservan, mientras que sólo sentenciaron 6 (19,35\%) de los 31 que llegaron a esta etapa del proceso (ver cuadros $\mathrm{N}^{\circ} 55,56,58,59,61$ y 62). Estos datos

\footnotetext{
${ }^{59}$ Robledo, Emilio. Bosquejo Biográfico del Señor Oidor Juan Antonio Mon y Velarde. Visitador de Antioquia 1785-1788. Bogotá. Publicaciones del Banco de la República. 1954. Tomo II. Pág. 316.
} 
dan cuenta sólo de una parte de su trabajo como jueces, pues a ellos eran remitidas causas de todas las ciudades y villas de la provincia. Hay que anotar, sin embargo, que su intervención en estos casos era parcial debido a que se trataba de consultas o peticiones de cambio de juez. Un porcentaje apreciable de ellas se devolvía para su conclusión al juzgado en el cual se habían iniciado.

En el caso de la ciudad de Antioquia, sede de su residencia, la situación era distinta dado que ante ellos se tramitaba un número considerable de las causas de primera instancia seguidas en la jurisdicción. Esta labor, de acuerdo con el testimonio del Gobernador Francisco Silvestre, aumentaba considerablemente su trabajo, puesto que debía oír demandas "sin excepción de horas ni días". ${ }^{60}$

Es interesante precisar las características de los Gobernadores que entre 1750 y 1810 tuvieron el mando de la provincia. De los 11 que fueron nombrados para el cargo en propiedad o interinamente, siete eran españoles, dos habían nacido en la Nueva Granada (Panamá y Cartagena) y sobre dos se ignora su lugar de origen, pero se presume que eran americanos. Los gobernantes consideraban conveniente que para este puesto se nombraran forasteros, porque de esta manera tenía mayor libertad o independencia para distribuir justicia, sobre todo en los casos en que estaban involucradas personas que se tenían por "principales". ${ }^{61}$

Los datos sobre sus cónyuges muestran que cuatro se casaron con criollas, de las cuales tres eran santafereñas y una antioqueña. Este último caso es el ya mencionado del Gobernador Buelta Lorenzana, quien era viudo y se casó con la hija de un español radicado en Antioquia, doña María Ignacia Ferreiro. Como las leyes de indias prohibían que estos funcionarios se casaran con hijas de sus gobernados mientras estuvieran en ejercicio, Buelta Lorenzana fue denunciado y tuvo que enfrentar cargos. ${ }^{62}$

Por ser el cargo de Gobernador de carácter militar, siete de los miembros habían seguido esta carrera. De 1755 a 1776 los nombrados habían llegado al grado de capitanes, luego de ser cadetes subtenientes y tenientes. De los cuatro

\footnotetext{
${ }^{60}$ Silvestre, Francisco. Ob. cit. Pág. 187.

${ }^{61}$ Ibídem. Pág. 188-189.

${ }^{62}$ Restrepo Sáenz, José María. Ob. cit. Tomo I. Pág. 175.
} 
elegidos a fines del régimen colonial (1788-1810), tres llegaron a tenientes coroneles y uno a brigadier.

Para tener una idea de las condiciones como se desarrollaban estas carreras, tomaremos como ejemplo la del Gobernador Víctor Salcedo y Somodevilla. Este personaje nació en Santo Domingo de la Calzada, en la Rioja (España) en 1751, siendo sus padres de familia noble. Empezó su carrera militar a los 18 años como cadete del regimiento de infantería de Saboya. Fue ascendido a alférez en el mismo cuerpo en 1770. A fines de ese año se trasladó a Cartagena de Indias, como miembro del primer batallón de Saboya. En 1772 ejerció el empleo de ayudante de campo en una expedición de pacificación de los indios guajiros en la región de Riohacha. El $1^{\circ}$. De mayo de 1773 fue promovido a teniente en el regimiento de infantería fijo de Cartagena. En 1774 se trasladó a la ciudad de Guayaquil, donde sirvió, en la compañía de veteranos de la citada ciudad. Ascendió a capitán el 24 de Mayo de 1775 y a teniente coronel el 26 de noviembre de 1783. En 1784 se le promovió a comandante de las milicias disciplinadas de Quito, cargo que desempeñó por más de 8 años. Fue Gobernador interino de Cuenca y Guayaquil. El 28 de julio de 1794 alcanzó el grado de coronel.

En 1795 fue nombrado Gobernador civil y militar de la provincia de Antioquia, cargo del que se posesionó el 22 de octubre de 1796 y ejerció hasta 1804, luego de ser reelegido en 1800. Salcedo fue promovido al empleo de Gobernador militar y político de Santa Marta en mayo o junio de 1804. Tomó posesión en enero de 1805, debiendo enfrentar la guerra de España con los británicos. En agosto de 1810 fue elegido Presidente de la Junta provincial que se formó, en esta provincia, después de los acontecimientos del 20 de julio en Santa fe. En 1811 Salcedo fue ascendido a brigadier, gracias que había solicitado reiteradamente, alegando además de sus méritos, el ser sobrino del marqués de la Ensenada. Fue transferido después a la plaza de Panamá donde sirvió durante un año a la comandancia general. En 1815 pidió permiso para volver a España, hacia donde partió poco después. En 1817 le fue otorgada la placa y cruz de la orden militar de San Hermenegildo. Ignoramos cuándo murió. ${ }^{63}$

\footnotetext{
${ }^{63}$ Ibídem. Tomo I. Págs. 209-214.
} 
Como podemos apreciar, Salcedo necesitó 42 años para llegar a brigadier. Habiendo sido transferido de España al virreinato de la Nueva Granada sirvió en Cartagena, Guayaquil, Quito, Antioquia, Santa Marta y Panamá. Cada una de estas estaciones significó una promoción en su carrera. Durante su larga gobernación y a pesar de la oposición de la Corona, su familia estableció lazos permanentes con Antioquia, pues su hija Juana se casó con el antioqueño don Andrés Pardo y Otálora.

Dos de los Gobernadores, don Manuel López de Castilla (1752-1755) y el Oidor visitador don Juan Antonio Mon y Velarde (1785-1788) eran abogados de los reales consejos. Aunque no fue común que un Oidor de la audiencia asumiera el gobierno de una provincia, la carrera de Mon y Velarde sirve para tipificar la trayectoria de los funcionarios ilustrados. Nacido en el lugar de Mon, en el principado de Asturias, estudió artes en la Universidad de Oviedo y se graduó de bachiller en cánones y leyes en la Universidad de Salamanca. Comenzó su carrera en las Indias como director general de obras públicas de la Nueva España. Posteriormente fue designado Oidor de la Real Audiencia de Guadalajara. En 1778 fue nombrado Oidor de la Audiencia de Santa fe para reemplazar a don Juan Romualdo Navarro. Mon arribó a Santa fe en octubre de 1781 y se desempeñó como Oidor hasta mayo de 1785. Por petición del Gobernador Francisco Silvestre, el Arzobispo Virrey creó el cargo de juez visitador de la provincia de Antioquia y, a fines de 1784, fue designado para llevar a cabo la visita el Oidor Mon, quien al llegar a la provincia en julio de 1785 asumió la jurisdicción del Gobernador en reemplazo del titular Francisco Silvestre y desempeñó estas funciones hasta agosto de 1788. Fue promovido a la presidencia y comandancia general de la provincia de Quito por Real título de 21 de noviembre de 1789 y se posesionó en abril de 1790. En mayo de 1790 se le nombró para una plaza togada, vacante en el Supremo Consejo de Indias, por fallecimiento de don Jacobo de Huerta. A los 15 días de llegar a España para asumir el puesto, murió a consecuencia del envenenamiento que le produjo consumir alimentos guardados en una vasija de cobre. ${ }^{64}$

${ }^{64}$ Ibídem. Tomo I. Pág. 177-194.

Robledo, Emilio. Ob. cit. Tomo I. Capítulo II. 
La carrera de Mon muestra que, a fines del siglo xvili, se nombraron como miembros del Consejo de Indias hombres con experiencia en América. El que estos puestos pudieran ser ocupados por magistrados que habían servido en las colonias, hizo que los españoles no siguieran considerando una humillación el desempeñar cargos fuera de la Península. ${ }^{65}$

Los dos Gobernadores restantes, don Francisco Antonio Osorio de Velasco y don Francisco Silvestre, no tenían una profesión definida, pero se trataba de burócratas de carera. Silvestre, por ejemplo, nació en 1734 en el lugar de Masueco, Castilla La Vieja, y estudió en el Seminario de San José en Masueco. En 1751, a petición de su tío don Pedro Silvestre, quien residía en Cartagena de Indias, se trasladó a la Nueva Granada. Inició su carrera como empleado de la Corona en el cargo de oficial de la Real Contaduría de Mompox. En marzo de 1764 ascendió a la secretaría del Virreinato, fue nombrado primer oficial en 1766 y secretario del Virrey en 1768. Por decreto de diciembre de 1774 fue nombrado Gobernador interino de la provincia de Antioquia, cargo que ocupo de 1775 a 1776. Después regresó a Santa fe para encargarse nuevamente de la oficialía mayor de la secretaría del virreinato, donde se desempeñó, entre 1777 y 1782 . En 1780 fue nombrado Gobernador en propiedad de la provincia de Antioquia, puesto que ejerció entre octubre de 1782 y julio de 1785. Al trasladarse nuevamente a Santa fe sirvió la vara de Alcalde ordinario den 1790. Como podemos ver, por cerca de 30 años este típico funcionario ilustrado ejerció cargos estatales en la Nueva Granada. Estableció vínculos estrechos con la élite santafereña, debido a su matrimonio con doña Juana Inés Prieto, hija de José Prieto de Salazar, tesorero de la Real Casa de la Moneda, y Mariana de Ricaurte y Terreros, miembro de la familia Ricaurte que era una de las más importantes de la ciudad. ${ }^{66} \mathrm{Su}$ nombramiento como Gobernador de Antioquia se enmarca dentro del sistema de ascensos regulares de la burocracia colonial. Los traslados en su caso debieron hacerse para alejarlo de Santa fe, donde estaba ligado a un núcleo importante de funcionarios de la Real Hacienda, la milicia y el clero.

${ }^{65}$ Burkholder, Mark A y D. S. Chandler. Ob. cit. Pág. 170.

${ }^{66}$ Restrepo Sáenz, José María. Ob. cit. Tomo I. Págs. 159-169.

Robinson, David J. "Estudio Preliminar”. En: Silvestre, Francisco. Relación de la Provincia de Antioquia. Ob. cit. Pág. 18-34. 
El término de duración en el cargo de Gobernador era de cinco años. Sin embargo, algunas veces fueron reelegidos sin exceder los 15 años. En el periodo estudiado, los Gobernadores que ejercieron el empleo por más tiempo fueron: don Francisco Antonio Osorio de Velasco, quien fue Gobernador de febrero de 1744 a diciembre de 1752 (8 años), don José Barón de Chaves, que tuvo el mando de la provincia entre Mayo de 1755 y octubre de 1769 (14 años) y don Víctor de Salcedo, que ocupó el cargo desde octubre de 1796 hasta noviembre de 1804 (8 años).

Para cumplir el encargo de organizar la administración de justicia, estos funcionarios debieron solucionar algunos problemas. Según los informes presentados por los Gobernadores Silvestre y Mon y Velarde las fallas más graves del sistema eran:

- El que la justicia estuviera dirigida por el respeto, el sentimiento privado, el parentesco y no por la imparcialidad. Esto se debía a que los Alcaldes ordinarios eran vecinos acomodados y principales que defendían los intereses de sus parientes y relacionados. ${ }^{67}$

- La pérdida continua de papeles de los archivos de los juzgados. Entre las causas de esta situación enumeraban el que los archivos anduvieran de mano en mano; la sustracción que por soborno, venta o conexiones de familia hacían los jueces y escribanos y la falta de un inventario de los papeles y documentos que correspondían a cada escribanía. ${ }^{68}$

Con respecto a lo anterior, afirmaban que los escribanos eran poco inteligentes en su oficio y nada honorables. Silvestre describía al escribano de la ciudad de Antioquia, don Simón Robledo, como indolente y poco inteligente. En cuanto a los de Medellín decía que el del Cabildo, don José Lotero, era bebedor, jugador, vicioso, camorrista y vivía siempre entrampado. El del número, don Jacobo Facio y Lince, yerno del anterior, era más inteligente y trabajador, razón por la cual era preferido por los jueces. Con respecto al de Rionegro, don

${ }^{67}$ Silvestre, Francisco. Descripción del Reino de Santa fe de Bogotá. Bogotá. Biblioteca Popular de Cultura Colombiana. 1950. Pág. 211.

${ }^{68}$ Silvestre, Francisco. Relaciones de la Provincia de Antioquia. Pág. 195.

Robledo, Emilio. Ob. cit. Tomo II. Pág. 316-320. 
Francisco Gutiérrez, afirmaba que estaba suspendido por varias falsedades, falta de legalidad y presunción de complicidad en un robo. ${ }^{69}$

- La falta de cárceles, no sólo en los sitios y poblaciones menores sino también en las capitales. En la ciudad de Antioquia, por ejemplo, no había cárcel de mujeres y la de hombres era tan reducida, incómoda y poco segura, que continuamente huían los reos, quedando burlada la justicia. Lo mismo sucedía en Medellín, mientras que la de Rionegro era mejor dispuesta. ${ }^{70}$

- La creencia de que los esclavos estaban exentos de la justicia ordinaria, razón por la cual los jueces no podían procesarlos ni tomarles declaraciones sin permiso de sus amos. ${ }^{71}$

- El que algunos eclesiásticos conocieran causas temporales y omitieran implorar auxilio cuando lo necesitaban, lo que se hacía en perjuicio de la jurisdicción Real. ${ }^{72}$

Ambos Gobernadores proponían como solución parcial de estas fallas el nombramiento de un Teniente de Gobernadores letrado, instruido y de conocimiento. La petición la basaban en el hecho de que las consultas a la Audiencia eran lentas y costosas, debido a la distancia existente entre Antioquia y Santa fe. Mon argumentaba que en Popayán había un Teniente de Gobernador, aunque estaba más cerca de la Real audiencia de Quito. ${ }^{73}$

Como es previsible, algunos de los problemas anotados fueron difíciles de superar, sobre todo los que se relacionaban con la calidad de las personas que ocupaban los cargos. No obstante, a partir de la década de 1780 la administración de justicia de la provincia se vuelve más rápida en la toma de decisiones y amplía su cobertura.

Debido a su larga permanencia en el cargo, Barón de Chaves y Salcedo fueron los Gobernadores que un mayor número de veces actuaron como jueces. El primero, un militar cartagenero, fue el encargado de implementar varias de las reformas fiscales y administrativas ordenadas por el Rey Carlos III (1759-

\footnotetext{
${ }^{69}$ Silvestre, Francisco. Ob. cit. Pág. 195-196.

${ }^{70}$ Robledo, Emilio. Ob. cit. Tomo II. Pág. 318.

${ }^{71}$ Ibídem. Pág. 317.

72 Ibídem. Págs. 317-318.

${ }^{73}$ Ibídem. Págs. 346-347. Silvestre, Francisco. Ob. cit. Pág. 509.
} 
1788), como fue la creación del monopolio del aguardiente. En ejercicio de sus funciones, debió dar cumplimiento a la Real Pragmática, de agosto de 1767, por medio de la cual se ordenaba la expulsión de los jesuitas.

Con él empieza el incremento de la actividad judicial de los Gobernadores, como lo demuestran estos datos: De 16 sentencias que en juicios por delitos contra la persona se dictaron en la década de 1750, los Alcaldes ordinarios profirieron diez, los Alcaldes de la Santa Hermandad cuatro, el Gobernador una y la Audiencia una. La situación cambió en los diez años siguientes, pues los Alcaldes ordinarios emitieron 18 de las 32 sentencias dictadas, el Gobernador 11 y los Alcaldes de la Santa Hermandad tres. Se puede apreciar un aumento en la actividad judicial, que corresponde en cierta medida a aquellos juicios tramitados ante el Gobernador. Es interesante anotar que el crecimiento en la cantidad de juicios se debe en buena parte a que un mayor número de personas iniciaron procesos por injuria. Para analizar estos datos no debemos olvidar que en esta época el Gobernador no contó con los servicios de un asesor jurídico que le ayudara a realizar esta tarea. En opinión de Barón de Chaves, era importante que los delitos no quedaran impunes, porque los ministros reales, sólo se sostenían por el "respeto y autoridad" con que los veían sus gobernados. ${ }^{74}$ Las condiciones en que actuó el Gobernador Salcedo fueron distintas. A mediados del siglo los Gobernadores antioqueños sólo intervinieron en juicios por injuria y lesiones personales, mientras que finalizando el periodo colonial su labor se extendió a los juicios por homicidio (ver cuadros $\mathrm{N}^{\circ} 56,59$ y 62). Aunque su acción como jueces de primera instancia era más amplia, estuvo sometida a mayores controles; Salcedo trabajó en compañía de los tenientes de Gobernador, asesores, Pantaleón Arango y Antonio Viana, quienes supervisaban sus decisiones desde el punto de vista jurídico. Además todas las sentencias que dictó en causas graves fueron consultadas a la Audiencia, como organismo del que dependía.

Las funciones judiciales del Gobernador cesaron con la Independencia. El encargado del gobierno en ese momento, el militar panameño Francisco de Ayala, quien había asumido el cargo en 1805, fue elegido Presidente de la Junta

${ }^{74}$ A. H. A. Criminal. B. 92. Leg. 1740-1770. Doc. $\mathrm{N}^{\circ}$ 9. Fols. 13v-15r. 
Superior que se conformó en septiembre de 1810. Desempeñó este cargo hasta febrero de 1811, cuando renunció espontáneamente para ir a ocupar el empleo de Teniente de Rey en Panamá. ${ }^{75}$

Desde ese momento hasta marzo de 1816, la Presidencia del Estado fue ocupada por siete criollos de los cuales tres eran abogados: los doctores Juan Elías López Tagle, José María Montoya y José Antonio Gómez, y uno era sacerdote: don José Miguel de la Calle.

En el periodo del gobierno se presentaron solamente cuatro denuncias ante el Presidente o el Vicepresidente del Estado; quienes se limitaron a transferir las causas a las autoridades competentes, por estarles prohibido el conocimiento de asuntos contenciosos. ${ }^{76}$

La Constitución de 1812 establecía que el poder ejecutivo residía en el Presidente del Estado, quien debía haber sido vecino de la provincia los tres años anteriores y tener una renta equivalente a 2.000 pesos. A él correspondía el ejercicio de todas las funciones relativas al gobierno político, militar y económico del Estado en todo aquello que no fuera legislativo o contencioso, sujetándose a las leyes, para cuya ejecución podía publicar bandos, proclamas y decretos. Debía velar por la observancia de la Constitución y las leyes, estando a la mira de las operaciones de todos los jueces, tribunales y empleados públicos, para que cada uno cumpliera las obligaciones de su destino. En la Constitución de 1815 se le vuelve a dar la denominación de Gobernador. Para ser elegido debía ser natural o vecino de la provincia por 10 años, haber cumplido 30 años y no ser eclesiástico. ${ }^{77}$

Los Gobernadores que tuvieron el mando de la provincia durante el gobierno realista (abril de 1816 a agosto de 1819), tampoco actuaron como jueces. La necesidad de organizar la defensa de la provincia, hizo que se dedicaran a su papel de jefes militares. Las funciones judiciales se dejaron en manos de los Alcaldes ordinarios que fueron supervisados por el Teniente de

\footnotetext{
${ }^{75}$ Restrepo Sáenz, José María. Ob. cit. Tomo I. Págs. 219-226.

${ }^{76}$ A. H. A. Criminal. B. 102. Leg. 1800-1820. Doc. N 14. Fol. 6r-7r y B-78. Leg. 18001820. Doc. $\mathrm{N}^{\circ}$ 7. Fol. 3r.

${ }^{77}$ Pombo, Manuel Antonio y José Joaquín Guerra. Ob. cit. Tomo I. Págs. 502-503, 508, 509. Tomo II. Págs. 353.
} 
Gobernador asesor. En esta época sólo un juicio comenzó por denuncia puesta ante el Gobernador, el comandante general Vicente Sánchez de Lima.

La reorganización administrativa de las colonias emprendida en el reinado de Carlos III, conllevó un cambio en el sistema de escogencia de los Gobernadores. Para ejercer el cargo en la provincia de Antioquia, las autoridades seleccionaron personas que correspondían al prototipo del funcionario ilustrado, buscando que no tuvieran muchos vínculos con la sociedad local. Su función principal fue controlar a la población criolla, para lo cual, utilizaron sus prerrogativas como jueces de primera instancia. Ane la falta de un cuerpo policial y de un ejército, la administración de justicia fue el instrumento utilizado para mantener el poder.

\section{La Audiencia}

La Audiencia era el tribunal superior de una o más provincias, compuesto por ministros togados que representaban la persona del Rey en la administración de justicia. ${ }^{78}$

Según las leyes de la Novísima Recopilación, la Audiencia conocía en segunda y tercera instancia, por apelación o súplica, los pleitos decididos en primera por los juzgados inferiores de su territorio. En la mayor parte de las causas no había recurso alguno de sus sentencias, aún cuando fueran de pena capital. Conocía en primera instancia los llamados casos de la Corte y aquellos en que se controvertían intereses de menores, viudas, personas miserables, iglesias y comunidades, sobre todo si las acciones se dirigían contra personas poderosas, por existir la probabilidad de que la justicia no se administrara imparcialmente por los jueces inferiores. La protección de los indios le estaba especialmente encomendada. ${ }^{79}$

Las Reales Audiencias, creadas en territorios americanos a partir de la fundación de la de Santo Domingo en 1511, fueron la célula central de la administración colonial. En América rebasaron el papel de tribunal de justicia que tuvieron en España, adquirieron amplias funciones de gobierno y tuvieron

${ }^{78}$ Escriche, Joaquín. Ob. cit. Pág. 299.

${ }^{79}$ Restrepo, José Manuel. Historia de la Revolución de la República de Colombia. Medellín. Editorial Bedout. 1969. Tomo I. Pág. 30. 
poderes legislativos extensos, pues podían legislar sobre todos los asuntos no contemplados en las leyes o cédulas reales. ${ }^{80}$

Teóricamente estaban conformados por un número variable de magistrados llamados Oidores (jueces civiles), Alcaldes del crimen (jueces penales) y Fiscales (representantes de la Corona). Para ocupar estos cargos se debía ser jurista con preparación universitaria. ${ }^{81}$

En la práctica su composición varió de un lugar a otro y a través del tiempo. En 1806, por ejemplo, la Audiencia de Santa fe estaba constituida por el Virrey, que actuaba como Presidente; el Regente, cargo creado en 1776, cinco Oidores, de los cuales uno era Oidor decano; el Fiscal civil y el Fiscal del crimen y protector de indios. Fuera de estos miembros básicos había un alguacil mayor, un capellán, tres relatores, un agente fiscal de lo civil y uno de lo criminal, dos escribanos de cámara, un "chanciller”, un tasador general, un portero de lo civil y uno de lo criminal y el padre general de menores. ${ }^{82}$

Aunque los Virreyes y la Audiencia solicitaron reiteradamente la creación de una sala de Alcaldes de crimen, esto no se logró en Santa fe. En la relación de mando del Arzobispo Virrey Caballero y Góngora, fechada en 1789, se pedía la creación de esa sala debido a que la gran cantidad de asuntos que se tramitaban ante la Audiencia y la escasez de ministros, ocasionaban lentitud en el despacho de los pleitos civiles y el fenecimiento de las causas criminales. El Virrey Ezpeleta, en su relación de 1796, reiteró la petición argumentando el aumento en los negocios de justicia, en razón del crecimiento de la población, y el que los ministros de la Audiencia además del despacho diario debían atender otras obligaciones como eran: el Juzgado de Provincia, la Junta Real de Diezmos, la de Temporalidades y las Juntas de Tribunales, el Juzgado de Bienes de Difuntos, la Dirección del Montepío, etc. ${ }^{83}$

${ }^{80}$ Jaramillo Uribe, Jaime. "La Administración Colonial". Manual de Historia de Colombia. Bogotá. Procultura S.A. Instituto Colombiano de Cultura. 1982. Tomo I. Págs. 358-359.

${ }^{81}$ Burkholder, Mark A y D. S. Chandler. Ob. cit. Pág. 13.

82 García, Antonio Joseph. D. D. Ob. cit. Págs. 55-57.

${ }^{83}$ De las 13 Audiencias que durante el siglo XVIII funcionaron en las colonias americanas sólo en la de México y la de Lima existieron Alcaldes del crimen. Las restantes estaban compuestas por Oidores, Fiscales, y después de 1776, por el Regente. 
A mediados del siglo xviII los reyes borbónicos emprendieron una reorganización administrativa de las colonias americanas, buscando mejorar su gobierno. Después de una época de inercia, España volvió a tomar en sus manos el control de sus posesiones. Para hacerlo, se crearon virreinatos y unidades administrativas y se introdujeron nuevos métodos de gobierno. Dentro de esta política, en 1740, al estar próxima a estallar una confrontación bélica con Gran Bretaña, se creó de manera definitiva el virreinato de la Nueva Granada. ${ }^{84}$ A él quedaron sujetas las Audiencias de Santa fe y Quito. A la de Santa fe, creada en 1550, estaban adscritas las provincias de la Nueva Granada, incluida Antioquia. El territorio de Quito comprendía la antigua presidencia de este nombre y parte de la gobernación de Popayán.

Como resultado de la intención del gobierno español de restablecer y expandir la autoridad Real, la forma de escogencia de los miembros de las Audiencias cambió. Se buscó reducir la influencia de los nativos y limitar la presión indirecta que se ejercía por medio del matrimonio. De 1778 a 1808 , la Corona consolidó su dominio sobre estos tribunales, al poner en práctica unos procedimientos estrictos para designar, ascender y vigilar a los magistrados que los componían. ${ }^{85}$

En el caso de los magistrados designados para la Audiencia de Santa fe, encontramos que de 1700 a 1758 los puestos de Oidores y Fiscales fueron ocupados por nueve criollos, 17 españoles y se desconoce el origen de cuatro ministros. Esta situación varió durante el reinado de Carlos III, de 1759 a 1788, cuando ejercieron estos cargos 12 españoles y sólo dos criollos. La tendencia cambió en el periodo siguiente, de 1789 a 1819, pues este tribunal

Colmenares, Germán. Relaciones e Informes de los gobernantes de la Nueva Granada. Bogotá. Biblioteca del Banco Popular. 1989. Tomo I. Pág. 402. Tomo II. Pág. 196.

Burkholder, Mark A. y David S. Chandler. Ob. cit. Pág. 308-443.

${ }^{84}$ Restrepo, José Manuel. Ob. cit. Tomo I. Pág. 50.

Lynch, John. Las Revoluciones Hispanoamericanas 1808-1826. Barcelona. Editorial Ariel S. A. 1983. Pág. 15.

${ }^{85}$ Burkholder, Mark y D. S. Chandler. Ob. cit. Págs. 13, 151. 
tuvo entre sus miembros nueve criollos, nueve españoles y cinco dignatarios cuyo lugar de origen se ignora. ${ }^{86}$

Algunos autores señalan que la política de exclusión irritó a los criollos que creían tener méritos para pertenecer a este organismo, lo que agravó el tradicional antagonismo entre americanos y españoles. Como ejemplo de este sentimiento criollo se cita la cláusula 22 de las capitulaciones suscritas por los representantes de los comuneros de 1781 , en donde se pedía:

Que los empleos de primera, segunda y tercera plana hayan de ser antepuestos y privilegiados los nacionales de esta América a los europeos, por cuanto diariamente manifiestan la antipatía que contra la gente de acá conservan, sin que baste conciliarles correspondida voluntad, pues están creyendo ignorantemente que ellos son los amos y los americanos todos, sin distinción, sus inferiores criados. ${ }^{87}$

El resentimiento que se produjo ha sido presentado tradicionalmente como una de las causas de la Independencia. ${ }^{88}$ Sin embargo, al finalizar el régimen colonial algunos miembros de la élite intelectual neogranadina tenían una imagen positiva de la Audiencia como tribunal de justicia:

Es preciso decir con la severa imparcialidad de la historia, que los miembros de las Audiencias españolas desempeñaban sus elevadas funciones y administraban justicia con brevedad y rectitud. Pocas veces imponían la pena de muerte y por lo común los Oidores eran magistrados íntegros. ${ }^{89}$

Fueron pocas las causas pertenecientes a la jurisdicción de la ciudad de Antioquia que se tramitaron directamente en la Audiencia. Casi siempre se trató de personas que se presentaban a este tribunal por considerar que en los

\footnotetext{
${ }^{86}$ Phelan, John Leddy. El Pueblo y el Rey. La Revolución Comunera en Colombia. 1781. Bogotá. Carlos Valencia Editores. 1980. Pág. 27.

${ }^{87}$ Cárdenas Acosta, Pablo E. El Movimiento Comunal de 1781 en el Nuevo Reino de Granada. Reivindicaciones Históricas. Bogotá. Ed. Kelley. 1960. Tomo II. Pág. 26.

${ }^{88}$ Lynch, John. Ob. cit. Págs. 27-28.

${ }^{89}$ Restrepo, José Manuel. Ob. cit. Tomo I. Pág. 31.
} 
niveles inferiores no se les estaba juzgando con imparcialidad. Entre $1750 \mathrm{y}$ 1810, los vecinos o residentes de Antioquia pusieron ante ella tres denuncias por injuria, una por homicidio y una por lesiones personales. De los casos estudiados, la Audiencia emitió fallos en primera instancia en cuatro juicios por agravios, tres por heridas y tres por homicidio. Se trataba a causas remitidas a esta corte sin sentenciar debido a diversas circunstancias (ver cuadros $\mathrm{N}^{\circ} 55$, $56,58,59,61$ y 62$)$.

Como ya lo anotamos, fue reducido el número de sentencias pronunciadas en los juzgados antioqueños que se apelaron ante la Audiencia. En opinión del Oidor Visitador Mon y Velarde, esto se debía a la lentitud y el costo de la presentación de estos recursos. De allí nacía un notable perjuicio a la buena administración de justicia, pues los "infelices" se veían precisados a conformarse con la primera sentencia..$^{90}$

Al ocurrir la Independencia, la Audiencia fue uno de los organismos que primero se desintegró. En el caso de Antioquia, inicialmente fue reemplazada por la Juna Provincial Gubernativa. De esta época se conserva una sentencia dictada por este organismo en un juicio por injuria.

Posteriormente, la Constitución de 1812 estableció que el poder judicial de la provincia residía en el Supremo Tribunal de Justicia. El recién creado poder judicial era definido como:

La facultad de aplicar las leyes a los casos particulares, ya sea decidiendo las querellas y demandas que ocurran entre partes, dando a cada ciudadano lo que le pertenece, ya imponiendo a los delincuentes e infractores las penas que han establecido las mismas leyes o administrando justicia civil y criminal en todo lo contencioso. ${ }^{91}$

Este tribunal estaba compuesto de tres ministros y un fiscal que llevaba la voz en lo civil, lo criminal, de gobierno y policía contenciosa. Cada tercer jueves de abril, la legislatura debía renovar uno de sus miembros, de tal suerte

\footnotetext{
${ }^{90}$ Robledo, Emilio. Ob. cit. Tomo II. Pág. 346.

${ }^{91}$ Pombo, Manuel Antonio y José Joaquín Guerra. Ob. cit. Tomo I. Pág. 512.
} 
que al cabo de cuatro años habría cambiado su composición como supremo poder judicial. El tribunal era el encargado de conocer las segundas y terceras instancias, en apelación y súplica, de los asuntos contenciosos, tanto civiles como criminales. Así mismo, debía vigilar que los jueces inferiores observaran las leyes y no oprimieran a los ciudadanos..$^{92}$

De las actuaciones de este tribunal sólo se conserva una consulta hecha en un juicio seguido en 1815 contra Bernardino González, por heridas dadas a Roso Serna. González suplicó que se le conmutase la pena de seis meses de trabajo en la fábrica de Antioquia, impuesta por el Alcalde de segundo voto de esa ciudad, por la prisión que había sufrido. El tribunal, siguiendo el concepto del fiscal consideró que no se debía permitir el uso de estos "efugios" para cometer asesinatos y confirmó la sentencia. Adicionalmente llamó la atención al juez por los "defectos" que tenía el proceso, como era el no haber ratificado los testigos del sumario. ${ }^{93}$

Aunque no contamos con muchas pruebas documentales por la pérdida de gran parte de los procesos correspondientes a la época de la Independencia, se puede percibir que no fue fácil para el gobierno republicano organizar la administración de justicia. Reemplazar un tribunal como la Audiencia, que tuvo en sus manos buena parte del gobierno de la colonia, tomó tiempo. Para poner a funcionar el poder judicial se utilizaron personas que habían actuado como jueces, defensores o fiscales bajo el régimen español.

Para concluir esta reseña sobre los jueces y tribunales, debemos señalar que uno de los aspectos que más interesó a los gobernantes ilustrados de la segunda mitad del siglo xviI fue la reorganización de la administración de justicia. Para lograrlo, trataron de eliminar el poder que en esta rama del gobierno tenían los criollos. En el caso de la ciudad de Antioquia, los Alcaldes ordinarios fueron controlados al ser obligados a consultar sus decisiones a los asesores jurídicos. Paralelamente se fortaleció el papel de los Gobernadores como jueces de primera instancia.

\footnotetext{
92 Ibídem. Págs. 512-514.

${ }^{93}$ A. H. A. Criminal. B. 77. Leg. 1800-1810. Doc. 24. Fols. 17v-18v.
} 
Los Gobernadores y los tenientes de Gobernador asesor, personajes fundamentales en la reforma de la justicia, eran burócratas de carrera. La mayor parte de los primeros eran militares españoles, que habían prestado servicio en diferentes regimientos de España y América. Los segundos eran abogados criollos, que solían ejercer esta función en diferentes lugares. Estos funcionarios estaban sujetos a un sistema estricto de designación, control y promoción. Ello garantizaba que fueran eficaces, pues de no serlo, perdían las posibilidades de ascenso.

El objetivo de estos cambios fue recuperar el poder que la corona había perdido y lograr sujetar a la creciente población libre. Lo irónico fue que los criollos ilustrados incorporados en esta burocracia terminaron siendo líderes del proceso de independencia. 


\section{El ser o las conductas}





\section{A. Injurias de palabra}

La legislación castellana definía la injuria como:

Deshonra que es fecha o dicha a otro a tuerto o a despreciamiento, de él. ${ }^{1}$

Como la injuria se podía cometer por medio de palabras, hechos o escritos, las leyes las dividían en: injuria verbal, real y literal o escrita. Debido a la diferencia que había entre las injurias, cualquiera que fuese su especie, se dividían en leves o simples o graves o atroces. Según las leyes de Partida, una injuria era grave en razón de las siguientes circunstancias:

1. La naturaleza o importancia del hecho. Por ejemplo, que se diese a alguien afrentosamente bofetadas, puntapiés, palos, azotes o latigazos.

2. La parte del cuerpo donde se hiciera el daño.

3. El lugar donde se cometiese el hecho, bien fuera tribunal, iglesia, plaza u otro lugar público.

4. La dignidad, carácter o calidad del injuriado, es decir, que el superior recibiera ofensa del inferior que le estaba subordinado, el padre del hijo, el amo del criado, el patrono del liberto.

5. El modo como se hacía. Por ejemplo, a través de un libelo famoso.

6. La solemnidad del momento o las circunstancias. Por ejemplo, cuando se ultrajaba a una persona en el acto de celebrar su matrimonio.

7. La trascendencia de la imputación injuriosa, es decir, si se inculpaba a alguien de un delito, culpa, vicio, mala acción que pudiera tener responsabilidad criminal o generarle odio, aversión o desprecio de las gentes del pueblo. ${ }^{2}$

La injuria podía ser directa o indirecta. En el primer caso, era recibida por el agraviado en su misma persona y, en el segundo, en personas de su familia.

${ }^{1}$ Sala, Juan de. Ilustración del Derecho Español. Valencia, Librería de Mallen y Sobrinos. 1844. Tomo II. Pág. 51.

${ }^{2}$ Escriche, Joaquín. Diccionario Razonado de Legislación y Jurisprudencia. México. París. Librería de la Viuda de ch. Bouret. 1911. Pág. 871. 
De ahí que la ley le diera a una persona acción para denunciar las injurias que se hiciesen a sus hijos, mujer y aún sus dependientes o criados. ${ }^{3}$

Teniendo en cuenta estas divisiones, nos referiremos primero a las injurias verbales.

Según la definición, cometía injuria verbal quien denostaba a otro, le escarnecía o ponía apodos, le decía palabras con las que se sentía deshonrado o hablaba mal de él en su presencia o ausencia; le echaba en cara o imputaba ante otras personas algún yerro que lo exponía a la infamia o al desprecio, ya lo hiciera por sí mismo o se valiera para ello de cualquier otro sujeto. ${ }^{4}$

Dentro de este grupo de incluyen las injurias escritas, que durante la época estudiada, fueron muy pocas en la región de Antioquia por tratarse de una sociedad en la cual un porcentaje muy amplio de la población era analfabeta. Básicamente fueron denuncias puestas por expresiones vertidas en documentos presentados en los juzgados. El análisis conjunto de estas dos clases de injuria se sustenta en el hecho de que muchos autores reducen a injurias de palabras las que se hacen por escrito. ${ }^{5}$

Las causas por ofensas al honor fueron muy comunes en el Virreinato de la Nueva Granada, en la segunda mitad del siglo xviI. Los archivos judiciales conservan numerosos testimonios de causas para probar hidalguía y limpieza de sangre. Las regiones donde parece haber sido más común este tipo de litigios fueron Santander y Antioquia, donde las pugnas de esta clase envenenaron constantemente la atmósfera social. ${ }^{6}$

En la jurisdicción de la ciudad de Antioquia, los juicios por injuria de palabra empiezan a ser abundantes en la década de 1760, pero fue en los diez últimos años del siglo, cuando un mayor número de personas instauraron demandas por ofensas a su honor. Al comenzar el siglo xix, disminuyeron estos pleitos, tal vez como producto del propósito de los gobernantes de impedir que

${ }^{3}$ Ibídem. Pág. 872.

${ }^{4}$ Idem.

${ }^{5}$ Sala, Juan. Ob. cit. Tomo II. Pág. 54.

${ }^{6}$ Jaramillo Uribe, Jaime. "Mestizaje y Diferenciación Social en el Nuevo Reino de Granada en la segunda mitad del siglo XVIII". En: Ensayos sobre Historia Social Colombiana. Bogotá. Biblioteca Universitaria de Cultura Colombiana. Universidad Nacional de Colombia. 1968. Pág. 182-183. 
prosperaran estas disputas en que se invertía tiempo y dinero (ver cuadro $\left.\mathrm{N}^{\circ} 55\right) \cdot{ }^{7}$

\section{Los ofendidos}

Los procesos criminales son una fuente que permite conocer los conflictos, valores y pautas de vida de una sociedad determinada. Dentro de la amplia gama de información que proporcionan, es importante analizar los datos que contienen sobre las víctimas y los agresores pues con base en ellos es posible hacer una tipología de los individuos que se vieron involucrados en las diferentes clases de delitos.

Empezaremos por estudiar las personas que, entre 1750 y 1819 , se presentaron en la ciudad de Antioquia a entablar demandas por injuria de palabra y las clases de ofensa que los movieron a hacerlo.

La primera característica es que la mayor parte de los ofendidos eran hombres (134 de 167 víctimas (ver cuadro $\mathrm{N}^{\circ} 1$ ). Esto se explica porque, de acuerdo con la ideología vigente, eran ellos los responsables de mantener el honor familiar. Para muchos de ellos la defensa del honor era una garantía de la preservación del orden social. Basándose en el derecho romano, consideraban que era más estimable el honor que la vida misma, pues la apreciaba en poco el que había perdido su honor. Constantemente repetían la Ley 26, título 13, Partida $2^{a}$, que decía

Por ende, los sabios antiguos, pusieron la ferida de la fama por más extraña que la de la muerte. ${ }^{8}$

Los insultos por los cuales una mayor cantidad de hombres entablaron juicios por injuria verbal fueron los que ponían en duda su origen racial. También consideraban un agravio el que personas de una condición social inferior "pretendieran igualárseles". El ser tratado con apelativos como mulato, zambo

\footnotetext{
${ }^{7}$ Consideramos que los datos extraídos de los juicios existentes nos permiten hablar de tendencias, todo indica que una gran cantidad de sumarios se perdieron del archivo, pero no creemos que por esto se invaliden las conclusiones.

${ }^{8}$ A. H. A. Criminal. B. 99. Leg. 1800-1810. Doc. N 26. Fol. 3r-v.
} 
e indio fue considerado denigrante y ofensivo. Estas designaciones aludían a una procedencia incierta e ilegítima y los ofendidos pretendían demostrar ante los tribunales que eran de nacimiento conocido.

A modo de ejemplo veamos algunos juicios instaurados por esta clase de agravios:

En 1757, don Bernardo de los Santos, blanco, natural de Anserma, vecino de la ciudad de Antioquia, puso demanda contra Juan Esteban de Aldave por haberlo tratado de mulato o zambo, al decirle "perro grifo". El ofendido se quejaba de que Aldave quería que

Seamos los españoles todos unos porque somos nacidos en estas partes de las Indias. ${ }^{9}$

A partir de 1780 se incrementaron notablemente esta clase de pleitos. Así, en 1782 don Francisco Periañez y Santana, vecino y comerciante de la ciudad de Antioquia, se querelló contra Javier Correa, pardo libre, vecino del Valle de San Andrés del Cauca, por haberle gritado públicamente que era un indio y "aún duda que de tributo". Al demandarlo Periañez decía que el insulto no sólo era un deshonor para él, sino que iba contra su dilatada y honrada parentela. Señalaba su conocida procedencia anotando que su padre don Agustín Periañez, y su tío materno, don Francisco Solano Santana, habían ejercido los "empleos honoríficos" de la ciudad. ${ }^{10}$

Un año después, don Francisco Escobar, vecino y Alcalde de la Santa Hermandad de la ciudad de Antioquia, entabló demanda contra don Juan Antonio Díaz, quien había afirmado estar pronto a "justificarle que era mulato". Según un testigo, Díaz había afirmado que el abuelo o bisabuelo de Escobar había "venido a tocar chirimía a Antioquia". En una de sus representaciones Díaz le discutía la afirmación de que sus antepasados y él, hubieran ejercido los oficios concejiles, argumentando que sólo su padre había sido Alcalde ordinario

${ }_{9}^{9}$ A. H. A. Criminal. B. 92. Leg. 1740-1770. Doc. $N^{\circ}$ 5. Fols. 16r-7v. Grifo significa crespo, enmarañado e indudablemente aludía al pelo de las personas de origen negro.

${ }^{10}$ A. H. A. Criminal. B. 62. Leg. 1780-1790. Doc. N 2. Fol. 5r-6r. 
“a más de 60 años de edad” y sólo porque su yerno, don Simón Robledo era el escribano del Cabildo. ${ }^{11}$

En 1786, José Ignacio Bermúdez, vecino de Antioquia, se querelló contra Fermín Sarrazola por haberlo tratado de "revuelto". El agresor se disculpaba argumentando que Bermúdez lo había hecho levantar de su siesta con "potestad y señorío", no teniendo sobre él dominio alguno y lo llamó "traste". Con ironía se refería a la pretensión de su oponente de ser blanco de segunda clase.

El blanco es blanco y el mestizo mestizo, con que siendo Bermúdez, nieto de una mestiza e hijo de otra, mal se compadece ser blanco como dice la segunda, y más cuando por parte paterna no ha justificado ni justificará nobleza alguna por ser constante en los autos de que tratan, así por sus testigos como por los de él, que su abuela y madre eran mestizas, cuya mixtura jamás podrá desviar de sí, con lo que es visto no es tal blanco como se presume y tiene jurado, respecto a estar mixturado y toda cosa mixturada es asentado estar revuelta. ${ }^{12}$

Este tipo de litigios continuaron siendo comunes en la década siguiente. En el año de 1795, don Justo Pastor Sánchez de Movellán, originario de la villa de Mompox, residente en el pueblo de Sopetrán, puso demanda contra Bernardino de Vargas por haberlo sindicado públicamente de "mulato". Se quejó al Gobernador de que el Alcalde pedáneo se había desentendido de su queja, diciendo que eran "chismes de cocina". Para él era una clara referencia a la afirmación del agresor de que era "hijo de una negra cocinera de los de su casa" ${ }^{13}$

Poco después, en 1796, don Manuel Bermúdez, vecino del mismo sitio, denunció al negro José María Cárdenas por no haberle dado el título de don. Tildaba al oponente de bandolero, que andaba de baile en baile armando escándalos

\footnotetext{
${ }^{11}$ A. H. A. Criminal. B. 81. Leg. 1780-1790. Doc. $\mathrm{N}^{\circ}$ 10. Fols. 33r-34r.

12 A. H. A. Criminal. B. 52. Leg. 1780-1790. Doc. $N^{\circ} 12$. Fols. 24r-25r.

${ }^{13}$ A. H. A. Criminal. B. 65. Leg. 1790-1800. Doc. $N^{\circ}$ 3. Fol. 1r-v, 27r-29r.
} 
y peleas, sin respetar a ninguna persona. Este respondió que no lo había tratado como don porque le parecía no serlo, de acuerdo con "las voces del vulgo". ${ }^{14}$

Finalizando la década, en 1798, Vicente Espinosa, vecino de Antioquia, acusó a don Juan de dios Vargas, por tratarlo de "zambo". Pedía que le justificara, por qué parte de sus ascendientes le veía este vejamen. En una representación presentada por el ofendido se decía

no se puede negar la grave, urgente necesidad que hay en esta capital de que se contenga el orbullo (sic) e irregular modo de producir especies infamatorias, de que se haya tan propagado este vicio, inundaba la ciudad de maldicientes, sin que se pueda atribuir a otra causa esta multitud de gentes empeñadas a decir mal y a sacar defecto, que a la falta de ejemplares en los castigos de los que así delinquen, por la demasiada tolerancia y disimulo con que los señores jueces, por motivos de piedad y de compasión se han portado. ${ }^{15}$

Las demandas por esta clase de injuria disminuyen al comenzar el siglo XIx, hasta casi desaparecer después de 1805. Entre las últimas causas está el juicio seguido en 1802 por don José Manuel de Villa, vecino de Antioquia, contra el zambo libre Benedicto Delgado, por haberlo tratado, en un camino público, de tu y vos, como si fuera su igual. Villa veía esto como un agravio debido a que la familia de Delgado había vivido agregado en sus tierras. ${ }^{16}$

Todos estos juicios eran una defensa de la "nobleza", noción clave en la sociedad colonial. Esta idea estaba vinculada a un nacimiento legítimo y a la pertenencia a un tronco con ascendientes y descendientes ilustres, que habían ocupado los cargos altos de la administración local. También se involucraba el concepto de "honor", relacionado con servicio militar, nobleza y con el desprecio por el trabajo manual.

\footnotetext{
${ }^{14}$ A. H. A. Criminal. B. 82. Leg. 1790-1800. Doc. $\mathrm{N}^{\circ}$ 3. Fols. 1, 8r-v.

${ }^{15}$ A. H. A. Criminal. B. 37. Leg. 1790-1800. Doc. $\mathrm{N}^{\circ} 13$. Fols. $1 \mathrm{r}-\mathrm{v}, 15 \mathrm{v}-17 \mathrm{r}$.

${ }^{16}$ A. H. A. Criminal. B. 9946 Leg. 1800-1810. Doc. No 8. Fols. 1r-2r.
} 
Estos conceptos se complementaban para producir una preocupación extrema por la "limpieza de sangre". ${ }^{17}$

Ello se explica porque en la sociedad hispanoamericana colonial el ordenamiento social se hizo con base en criterios raciales. En el siglo xvi esta clasificación fue sencilla. El grupo de los "españoles" incluía a españoles peninsulares, criollos y mestizos legítimos. Los indios, reconocidos como vasallos y súbditos de la Corona, constituían el estrato inferior de los "rústicos y miserables". Un tercer grupo dotado de estado legal especial fueron los esclavos negros, quienes por definición eran propiedad de otros y estaban bajo su arbitrio. Esta situación se complicó por el surgimiento de gente libre de origen racial mixto, que no había sido prevista en la clasificación y legislación primitiva. A causa de su ilegitimidad los mestizos (cruce indio-blanco) fueron privados del acceso a puestos honoríficos y relacionados con los indios (caciques, protectores de indio). Los mulatos, descendientes de negros, no se pudieron librar de los estigmas combinados de esclavitud e ilegitimidad y sufrieron toda clase de restricciones originadas en el desdén o el temor. Estas mezclas fueron denominadas por los blancos con desprecio "castas" y tuvieron que soportar discriminaciones que iban más allá de lo dispuesto por la ley. ${ }^{18}$

En el siglo xvir esta sociedad de castas estaba siendo socavada por el proceso de cruzamiento de razas, que había contribuido a crearla y por el crecimiento económico, que cambió la situación a una parte de la población. Para las autoridades era cada vez más difícil aplicar un criterio estricto en la clasificación de la población. En este contexto algunos individuos pertenecientes a una capa modesta y "oscura", pero que tenían propiedades, trataban de pasar a otra más "clara”. También se daba el proceso inverso, blancos pobres eran tratados como personas pertenecientes a las castas.

Esto explica la importancia otorgada a los insultos raciales y a ser tratado sin la deferencia y trato requerido. A través de estas alusiones el origen de una

${ }^{17}$ Silva Olarte, Renán. Prensa y Revolución a finales del Siglo xviII. Contribución a un Análisis de la Formación de la Ideología de Independencia Nacional. Bogotá. Colección Bibliográfica Banco de la República. 1988. Pág. 105.

Mömer, Magnus. "Estratificación Social Hispanoamericana durante el Período Colonial”. Versión preliminar mecanográfica. Estocolmo. 1980. Págs. 14-15.

${ }^{18}$ Ibídem. Págs. 8-10. 
persona era puesto en duda, lo que repercutía en el puesto que ella ocupaba en la sociedad. Los términos mulato, mestizo, zambo e indio eran usados como denigrantes y ofensivos. Los vecinos que se consideraban blancos trataban de reivindicarse de una sindicación de esta clase. A su vez, los mestizos buscaban no ser catalogados como mulatos y los mulatos, no pasar por zambos. Es decir, que cada uno buscaba el reconocimiento del puesto a que su linaje y sangre lo hacía acreedor y si era posible mejorarlo.

Como parte de esta situación hay que analizar los pleitos adelantados para reivindicar que se tenía derecho a ser tratado como "don". Durante la edad media en España este título estuvo reservado a miembros de la alta nobleza, pero a lo largo del proceso de reconquista contra los moros su uso se extendió a pequeños hidalgos y aun a gente baja. En Hispanoamérica, desde un comienzo, se le reconoció este título a los caciques indígenas, como equivalentes a hidalgos españoles y los blancos comenzaron a usarlo como producto de un proceso de autoennoblecimiento. En el siglo xvil era un título usado por los blancos, peninsulares y criollos, como símbolo de la limpieza de sangre. Este grupo utilizó los tribunales de justicia para defender su derecho a ser tratado como tal y para impedir que la gente de sangre mixta lo empleara. Ello muestra que el "don" había dejado de ser un apelativo propio de una minoría, que lo demandaba como distintivo de blancura y nobleza, y empezó a ser usado por individuos de raza mezclada. ${ }^{19}$

Lo interesante de los pleitos por insultos raciales tramitados en la ciudad de Antioquia, es que parecen ser blancos pobres y aún mestizos los interesados en defender una posición dentro de la sociedad, con base en el nacimiento. Son ellos los que se hacen voceros de una pretendida "limpieza de sangre", al sentirse desplazados por una capa cada vez más numerosa de pardos y mulatos libres. Como lo evidencian las citas transcritas, estas disputas crearon un clima de odios y competencias, en el cual cada quien trataba de colocarse en un determinado puesto de las jerarquía social, mientras que impugnaba el del vecino.

${ }^{19}$ Ibídem. Pág. 23. Jaramillo Uribe, Jaime. Ob. cit. Págs. 196-203. 
La movilidad social de las "castas" parece ser lo que alarmó a los blancos. La política de la Corona en este sentido fue contraria a sus intereses, pues permitió a los pardos entrar en la milicia, posibilitó comprar la blancura legal mediante la adquisición de "Cédulas de gracias al sacar", los autorizó a recibir educación y a casarse con blancos. Los blancos pobres y medianos propietarios, vieron desaparecer la línea que los separaba de la población libre. Su respuesta a estas concesiones fue dedicarse a defender en los juzgados el puesto que en la estructura social les correspondía por su origen racial. ${ }^{20}$

Otra clase de insultos por los cuales fue corriente que se entablaran demandas por injuria de palabra, eran los que ponían en duda la honradez de la persona. Muchos hombres consideraron una ofensa que se los tratara de ladrones, pícaros y "malos tratos". Entre estos pleitos se encuentran los siguientes:

En 1763 Miguel Méndez, vecino de Antioquia, se querelló contra Carmelo Méndez, quien había sido esclavo de su tío Santiago Méndez, por haberle gritado en la calle que era un ladrón y su mujer una puta. La mujer de Méndez también lo sindicó de ladrón, al decir que por esta causa lo había "echado del arado". El ofendido afirmaba que su buena conducta se probaba por haber aguantado las injurias

de uno que nació esclavo en mi casa y que todavía discurro está debiendo la mayor parte de su libertad. ${ }^{21}$

Las disputas de este tipo también se presentaron entre parientes. Juan de Agudelo, vecino de la parroquia de Sacaojal, demandó en 1785 a su hermana Catalina de Agudelo y a Javier de Agudelo, por sindicarlo en la plaza de ese sitio, de ladrón y forzador. El Alcalde ordinario doctor José Antonio Gómez, opinaba que se debía castigar a los reos severamente para que sirviera de escarmiento a la "perniciosa gente" de Sacaojal, que con frecuencia acudía a los juzgados con quejas semejantes. ${ }^{22}$

${ }^{20}$ Lynch, John. Las Revoluciones Hispanoamericanas. 1808-1826. Barcelona. Editorial Ariel. S. A. 1983. Págs. 30-31.

${ }^{21}$ A. H. A. Criminal. B. 79. Leg. 1740-1780. Doc. $\mathrm{N}^{\circ}$ 7. Fols. 1r-2r, 10r-v.

${ }^{22}$ A. H. A. Criminal. B. 58. Leg. 1780-1790. Fol. 1r-v, 12r-13r. 
Al final de esta década, en 1789, don Antonio Salazar entabló pleito contra Sereno Lezcano, pardo libre, quien lo tildó de ladrón. La víctima pedía que se castigara al agresor para que

se contengan los humildes como humildes y no sean libertosos.

El Alcalde ordinario Francisco José de Lora afirmó que las palabras denigrativas eran más injuriosas en razón de la calidad y buena reputación del ofendido. ${ }^{23}$

La década siguiente estuvo plagada de disputas semejantes. En 1791, Graciliano de Lorza denunció a Marcos de Villa, negro libertino, por haber dicho que era hombre de "malos y cochinos tratos" y "chino de mala raza". Villa argumentaba que el oponente le había insultado primero, diciéndole "zambo, hijo de puta", cuando él era mulato, clase que no eran tan "sonrojosa como la vituperable de zambo". ${ }^{24}$

Unos años más tarde, en 1795, don Esteban Díaz del Mazo, demandó a don Vicente Tamayo, quien, en su papel, lo ultrajó diciéndole "pícaro, tramposo y alcahuete". ${ }^{25}$

En 1797, Vicente de la Torre, vecino de San Jerónimo, se querelló contra don Juan Bautista Rendón, por sindicarlo del robo de seis arrobas de dulce. El agresor sostenía que De la Torre le había faltado al respeto en sus escritos, siendo él un hombre blanco y estando su mujer emparentada con las mejores familias del sitio. Subrayaba además que su contrario había sido sirviente de la casa de los ascendientes de su esposa, pues el padre de De la Torre había sido esclavo de ella. ${ }^{26}$

Los juicios por esta causa no disminuyeron al comenzar el siglo xIx. Es así, como José Tomás Londoño, mazamorrero, vecino del sitio de San Pedro, acusó en 1804 a don Antonio Builes, vecino del mismo lugar, de haberlo

\footnotetext{
${ }^{23}$ A. H. A. Criminal. B. 60. Leg. 1780-1790. Doc. $\mathrm{N}^{\circ} 27$. Fols. 1r, $2 \mathrm{v}$.

${ }^{24}$ A. H. A. Criminal. B. 96. Leg. 1790-1800. Doc. $\mathrm{N}^{\circ} 11$. Fols. 1r-v, 2v, 9r-v.

${ }^{25}$ A. H. A. Criminal. B. 65. Leg. 1790-1800. Doc. No 16. Fols. 2r-v.

${ }^{26}$ A. H. A. Criminal. B. 95. Leg. 1780-1800. Doc. $\mathrm{N}^{\circ} 16$. Fol. 1r-v, 7r-9r.
} 
imputado de ladrón. También se quejaba de que José María Uribe había vociferado cosas contra su honor. ${ }^{27}$

Dos años después, don José María Zamorano, natural de España, vecino de Antioquia, "pobre de solemnidad”, denunció a don José Cuéllar, por haber dicho que le había robado unas varas de listado. Sostenía que su oponente le profesaba una "injusta y rencorosa enemistad". Terminaba pidiendo que se le aplicaran penas y represiones serias, pues era el único medio de lavar la mancha con que Cuéllar lo difamó. De lo contrario, quedaría

expuesto a las funestas y terribles consecuencias que atraen los lances de honor, pues verdaderamente señor que la vida sin honor no es vida..$^{28}$

La mayor parte de estas causas fueron seguidas por mestizos y pardos libres, que trataban de limpiar su reputación. Esto era supremamente importante en una provincia donde la mayor parte de la población estaba constituida por pequeños propietarios y mazamorreros libres, que dependían para abastecerse del crédito que les otorgaban los comerciantes. ${ }^{29}$ Ser tildado de ladrón, "malos tratos", pícaro, podía significar una limitación en la capacidad de hacer tratos y contratos, derecho del que disfrutaba la población libre. Esta idea está muy bien expresada en una representación presentada en 1790 por José Agudelo, a quien Javier de Vargas acusó de robar 900 pesos de la papelera de don Manuel Antonio de Aguirre, en cuentas y débitos. El sindicado decía que el agresor había procedido

sin obstarle, al nominado Vargas, la buena reputación, crédito y hombría de bien que he profesado y profeso en mi modo de vivir, lo que es notorio, no sólo aquí sino en todo el reino donde por la gran misericordia de dios he merecido la estimación y confianza pública y privada, tanto en intereses

${ }^{27}$ A. H. A. Criminal. B. 100. Leg. 1800-1810. Doc. $\mathrm{N}^{\circ} 15$. Fols. $1 \mathrm{r}-\mathrm{v}$.

${ }^{28}$ A. H. A. Criminal. B. 99. Leg. 1800-1810. Doc. $\mathrm{N}^{\circ}$ 26. Fol. 1r, 3r-v.

${ }^{29}$ Robledo, Emilio. Bosquejo Biográfico del oidor Juan Antonio Mon y Velarde. Visitador de Antioquia 1785-1788. Bogotá. Publicaciones del Banco de la República. 1954. Tomo II. Pág. 317. 
crecidos como de otras cosas que se han puesto a mi cargo, de sujetos distinguidos y caracterizados. ${ }^{30}$

Aunque más esporádicamente, también se presentaron demandas por acusaciones en que se ponía en duda la conducta sexual del ofendido o de miembros de su familia. Uno de estos pleitos fue el instaurado, en 1762, por Rafael Holguín e Ignacio Barrera, vecinos del Valle de San Andrés, contra Francisco de Castro, por haberlos tratado de "alcahuetes de sus mujeres e hijas". Holguín buscó probar a través de testigos que no se metía en los enredos, chismes y alborotos que continuamente se "ofrecían en ese Valle", que frecuentaba los sacramentos y que su casa era de la mayor "estimación y aprecio" por parte de vecinos y forasteros. ${ }^{31}$

En 1777, don José Vicente de Agreda, español, vecino de Antioquia, puso querella contra José Miguel de Vergara, por haberle dicho, al pedir el pago de una deuda que si su mujer "no tenía el con qué y el conco". Según el ofendido, había querido decir que con "el útero fuera de consorte a buscar con qué pagarle”. Había agregado además, que de dote le dieron "peaña de la barriga de su consorte", pretendiendo afirmar que cuando su esposa se casó estaba preñada de otro. Estas injurias las había hecho llevado del humor "pecante y picante" que tenía y de la "enemiga pasión que tiene a los españoles". En su representación, Vergara decía que el pleito había surgido por el poco afecto de Agreda a pagar lo que debía. Trató de limpiarse de la sindicación que se le hizo de ser de "bajo y ruin linaje", argumentando que aunque nacido fuera del matrimonio, sus padres habían sido de la "primera y distinguid nobleza" de la provincia. Pedía al gobernador que solicitara a su contrincante una fe de bautismo auténtica para saber quién era y que indagara por qué salió del ejército. El ignoraba la filiación, méritos, calidad, distinción, patria y estado del querellante, porque:

${ }^{30}$ A. H. A. Criminal. B. 65. Leg. 1790-1800. Doc. $\mathrm{N}^{\circ}$ 1. Fols. 5r-6r.

${ }^{31}$ A. H. A. Criminal. B. 79. Leg. 1740-1780. Doc. $N^{\circ}$ 6. Fols. 3r-v, 6r-7r. 
aunque sea castellano puede ser del estado llano inferior y pechero y puede ser grande de España, título de Castilla, príncipe o potenciario. ${ }^{32}$

Los insultos con connotaciones sexuales iban casi siempre dirigidos a la esposa e hijos del ofendido. Los hombres se veían obligados a limpiar la reputación de su familia, en un mundo en el que el hablar del vecino era la norma. La opinión popular, siguiendo las creencias españolas, sostenía que el que no quitaba las manchas de la honra se veía expuesto a ser injuriado muchas veces, porque estas afirmaciones quedaban gravadas en la memoria de los hombres.

Las mujeres instauraron pocos juicios por injuria, como lo demuestra el hecho de que sólo 33 de las 167 víctimas que se presentaron a quejarse por este delito pertenecieran al sexo femenino (ver cuadro $\mathrm{N}^{\circ} 1$ ). Esto puede deberse a que en los juzgados se daba poca credibilidad a los "dichos de mujeres" y despreciaban las demandas puestas por ellas. La opinión de las personas vinculadas a la administración de justicia sobre dicha credibilidad la podemos apreciar en un escrito presentado en 1810 por el doctor Andrés Avelino de Uruburu. Al pedir que se truncara la causa que se seguía a Vicente Vahos por haber permitido que su mujer e hija desacreditaran a la hija de María Bernarda Mario, india del pueblo de Sopetrán, argumentaba

que no darían a vasto, todos los juzgados ni todo el papel sellado si a esta clase de demandas se prestase sería atención, porque las mujeres de la clase común, que son innumerables, no tienen más arma ni más desahogos, que brotar palabras semejantes, dichas sin más juicio ni madurez que el que puede tener un ebrio o un loco. ${ }^{33}$

Sólo al final del siglo xviI las mujeres empezaron a comparecer, por sí mismas o a través de apoderados, a poner querellas por haber sido agraviadas. La mayor parte de estas denuncias eran por insultos relacionados con la vida sexual. Para ilustrar esta clase de pleitos veamos los siguientes casos:

\footnotetext{
32 A. H. A. Criminal. B. 93. Leg. 1770-1790. Doc. $\mathrm{N}^{\circ}$ 5. Fols. 1r-6r, 7r-9r, 16r-19v.

${ }^{33}$ A. H. A. Criminal. B. 84. Leg. 1810-1840. Doc. $\mathrm{N}^{\circ} 4$. Fol. 12v.
} 
En 1797, Vicente Montes se presentó al juzgado de gobernación para quejarse contra Santiago Hidalgo vecino del sitio de Quebrada Seca, por haberle quitado la "honra y buena reputación" a su hija Nicolasa, al decirle a su esposo que estaba amancebada. El padre puso la denuncia porque debido a ello Nicolasa había tenido "malas razones" con su marido. Aseguraba que el agresor era propenso a injuriar a las mujeres de ese sitio.

Pues aunque sea casada, soltera, doncella o viuda, ninguna tiene honra para dicho Hidalgo. ${ }^{34}$

Rita Rodríguez, mujer legítima de Toribio García, vecina de San Jerónimo, demandó en 1801 a José Figueroa, liberto, por gritarle que "era una mujer puta y amancebada". Decía que se había presentado a la justicia, buscando la restitución de la "honra y el honor lastimado", porque su marido la iba a abandonar. El oponente en su confesión decía que Rita lo había insultado primero al decirle que era un "zambo, hijo de puta, ladrón". ${ }^{35}$

Al año siguiente, Paula Sarrazola, vecina de Antioquia, se querelló contra Bárbara Herrón, por haber dicho que ella estaba amancebada con don José Antonio Valenzuela y que la enfermedad que recientemente había tenido era resultado de "preñez y aborto". ${ }^{36}$

A fines de la Independencia se incrementaron los pleitos por acusaciones de este tipo. Es así como en 1819, Maria Urciana Flórez, mujer de Miguel Montaña, vecina de Sopetrán, puso denuncio contra el "ciudadano" don Pedro Madrid, por haber afirmado que estaba amancebada con Nepomuceno Serna. Por esta razón ella se hallaba "desunida con su marido" y estaba corriendo "riesgo de vida" debido a las amenazas de éste. ${ }^{37}$

El mismo año, las "ciudadanas" Petrona y María Parias, viudas, vecinas de Antioquia, se querellaron con Felipa Ferraro, alias "chapetona”, por haberlas tratado de putas y alcahuetas de sus hijas en presencia de varias

\footnotetext{
${ }^{34}$ A. H. A. Criminal. B. 33. Leg. 1790-1817. Doc. $\mathrm{N}^{\circ}$ 16. Fol. 1r-2v.

${ }^{35}$ A. H. A. Criminal. B. 30. Leg. 1800-1810. Doc. $\mathrm{N}^{\circ}$ 4. Fol. 1r-v, 4r-v.

${ }^{36}$ A. H. A. Criminal. B. 44. Leg. 1800-1810. Doc. No 3. Fol. 3r-v.

${ }^{37}$ A. H. A. Criminal. B. 78. Leg. 1800-1820. Doc. $N^{\circ} 27$. Fol. 1r-2r.
} 
personas. La agresora se disculpó diciendo que ella sólo había repetido los informes que le habían dado las sobrinas de las ofendidas. ${ }^{38}$

Es interesante anotar que a fines de la época colonial, las mujeres reemplazaron a los hombres en la presentación de demandas por esta clase de insultos. Como lo dejan ver los casos enumerados, es el honor del esposo el que se encuentra lastimado. No obstante, éstos no comparecieron en los juzgados, dejando que fuera la esposa la encargada de limpiar la honra familiar. Este hecho ilustra el complejo papel que la mujer antioqueña, trabajadora y bastante independiente, tenía dentro del hogar.

Otra ofensa que dio origen a que las mujeres instauraran demandas por injuria era la imputación de haber cometido un robo. Igual que en el caso de los hombres, estos pleitos fueron muy comunes al comenzar el siglo xix. En 1800, Dolores Usuga, india del pueblo de Buriticá, instauró un pleito contra Antonio Higuita, libre, vecino de este pueblo, por haber sindicado a su hija Alejandra del robo de 18 castellanos en dinero. El agresor renunció a presentar pruebas, porque según él, no tenía personas imparciales con quienes justificar el hecho. ${ }^{39}$

Diez años después, Susana Ramírez, india del pueblo de Sopetrán, se quejó de Benedicto Ramírez, su hermano, por haber dicho que era una ladrona de gallinas en su vecindad. Por esta razón ella estaba pasando muchos sinsabores con su marido Matías Romero, con quien se hallaba en "buena armonía". 40

Las mujeres también se vieron inmiscuidas en demandas por insultos raciales. En una época en que éstos proliferaron, como la década de 1790, don José Javier Bermúdez puso un denuncio contra Juan José Cañola por proferir que su esposa era una zamba. El sindicado, quien se titulaba blanco, decía que la mujer de Bermúdez había infamado a su esposa diciéndole negra. El Alcalde ordinario, don Lorenzo Capara, determinó que Cañola dejara de nominarse don, en sus escritos, hasta que probara que le correspondía este distintivo por sus natales. ${ }^{41}$

\footnotetext{
${ }^{38}$ A. H. A. Criminal. B. 31A. Leg. 1810-1840. Doc. $\mathrm{N}^{\circ}$ 17. Fol. 1r-v, 9r-v.

${ }^{39}$ A. H. A. Criminal. B. 100. Leg. 1800-1810. Doc. $\mathrm{N}^{\circ}$ 7. Fols. 1r-v, 2 r.

${ }^{40}$ A. H. A. Criminal. B. 33. $2^{\circ}$. Legajo. 1790-1817. Doc. $\mathrm{N}^{\circ}$ 3. Fol. $1 \mathrm{r}$.

${ }^{41}$ A. H. A. Criminal. B. 35. Leg. 1790-1800. Doc. $\mathrm{N}^{\circ}$ 2. Fols. 3r-2r, 5v.
} 
Los insultos por los que se presentaron demandas por injuria fueron básicamente los mismos, pero la importancia otorgada a algunas sindicaciones variaba con el sexo. Mientras que los hombres se preocuparon por vindicarse de agravios contra su origen racial y honradez, las mujeres se vieron obligadas a limpiar ofensas relacionadas con su vida sexual. Muchos de los insultos utilizados como ladrón, tramposo, puta, eran típicamente españoles. Las referencias peyorativas a la piel oscura, zambo, mulato, etc. también fueron desarrolladas por los blancos. ${ }^{42}$

El que la población libre promoviera juicios por esta causa, indica que las creencias y normas de conducta de los blancos se habían extendido a las otras capas de la población. Este hecho se puede corroborar al analizar los datos sobre el origen étnico de las 167 víctimas involucradas en juicios por injuria de palabra. De ellos, 75 (44,91\%) eran blancos; 82 (49,1\%) libres, nueve $(5,39 \%)$ indígenas y un esclavo $(0,60 \%)$ (ver cuadro $\left.\mathrm{N}^{\circ} 2\right)$.

La composición racial de los demandantes muestra, como era de esperarse, que los blancos frecuentaron los tribunales, por pleitos de esta clase. Su número es muy significativo si se tiene en cuenta que no eran más del 10\% de la población de la ciudad de Antioquia (ver cuadros $\mathrm{N}^{\circ} 63,65$ y 66).

Los libres, que a mediados del siglo, eran cerca del $70 \%$ de los habitantes de la zona, no se presentaban a hacer estas reclamaciones. Finalizando la época colonial, cuando su situación económica había mejorado como consecuencia del auge minero y comercial que se presentó a partir de 1780, empezaron a recurrir a los jueces para transar sus disputas verbales.

La pregunta que hay que hacerse es ipor qué razón algunos mestizos y mulatos libres tomaron como propias las normas de conducta de los blancos? Para contestarla habría necesidad de indagar hasta qué punto la adopción por parte de la población libre de valores como la nobleza, el honor, la honradez,

${ }^{42}$ A este respecto hay que ver: Taylor, William B. Embriaguez, Homicidio y Rebelión en las poblaciones Coloniales Mexicanas. México. Fondo de Cultura Económica. 1987. Págs. 127-129. En su estudio. Taylor muestra que entre los campesinos indígenas de la Mixteca Alta los insultos más comunes fueron acusaciones de tipo sexual, que tenían que ver con las relaciones que existían entre esposos. Eran comunes palabras como puta, cornudo, alcahuete y cabrón. En el caso del centro de México, las alusiones sexuales también predominaron, pero se utilizaron como afirmaciones de la superioridad de un varón en hombría y en proezas sexuales respecto a otro. Págs. 127-128. 
fue fruto de una aculturación deliberada o de una convergencia espontánea de intereses. ${ }^{43}$ Lo que la escasa evidencia documental muestra, es que algunos mazamorreros y medianos comerciantes enriquecidos intentaron blanquearse, para hacer posible su ascenso social.

Para ilustrar este proceso podemos tomar el caso de Julián y José Antonio Valenzuela, pardos, hijos de José Valenzuela y Rosa Sarrazola, naturales y vecinos de la ciudad de Antioquia. Los primeros lograron reunir una fortuna apreciable a través de la actividad comercial e invirtieron parte de ella en la adquisición de tierras y esclavos. El ser pardo acaudalado posibilitó el nombramiento de José Antonio como Alférez de la compañía de pardos de la ciudad de Antioquia. En desempeño de estas funciones le correspondió hacer frente al levantamiento de los cosecheros de tabaco de Sacaojal en 1781, y fue distinguido por las autoridades por haberse portado "con honor y amor a la causa del Rey". Los favores de los Valenzuela a la Corona no pararon allí, pues entre abril de 1796 y diciembre de 1798 le prestaron a las Cajas Reales 8050 pesos de oro para ayudar a cubrir los gastos de la guerra que España libraba en Europa. En recompensa de estos servicios y por ser hombre acaudalado, Julián Valenzuela obtuvo el 5 de Julio de 1796 una Real Cédula que lo dispensaba de la calidad de pardo, puesto que

su color blanco, sus modales, su educación y buenas costumbres a que debe el trato y atención de las gentes del primer orden de aquella ciudad, pudiera muy bien quitarle este borrón que le aflige en extremo. ${ }^{44}$

En 1806, tanto Julián Valenzuela como su hermano José Antonio, que se había casado con una blanca, doña María Ignacia Puerta, figuraba en el censo de la ciudad de Antioquia como blancos del estado llano y recibían el

\footnotetext{
${ }^{43}$ Ginzburg, Carlo. El Queso y los Gusanos. El Cosmos según un Molinero del siglo XVI. Barcelona. Muchnek Editores. 1986. Pág. 20.

${ }^{44}$ Cortés Santos, Rodulfo. El Régimen de "Las Gracias al Sacar" en Venezuela durante el Período Hispano. Tomo II. Fuentes para la historia colonial de Venezuela. Caracas. Biblioteca de la Academia Nacional de la Historia. 1978. Págs. 113-114.

Patiño, Beatriz A. Riqueza, Pobreza y Diferenciación Social en la Antioquia del Siglo XVIII. Texto mecanografiado. Medellín. Universidad de Antioquia. 1985. Págs. 98-101.
} 
apelativo de don. Como puede verse, el intento de los pardos y mestizos de blanquearse y asumir el modelo de vida propio de este grupo, recibió sanción por parte de la Corona.

Fueron pocos los indígenas que hicieron reclamos por injuria. La mayor parte de los juicios instaurados por ellos corresponden al periodo 17901819 , cuando entre la población no blanca se volvió corriente poner pleitos de esta clase. Un dato interesante es que cinco de los ocho indígenas que en esta época concurrieron a los juzgados eran mujeres. Este hecho no es sorprendente si tenemos en cuenta que una gran cantidad de mujeres indígenas eran jefes de hogar. Según la matrícula de Sopetrán de 1787, de las 128 cabezas de familia indígenas allí existentes, 72 eran mujeres. ${ }^{45}$

Como es obvio, los esclavos no concurrieron a los juzgados por esta clase de disputas. La única demanda en que se vieron involucrados fue una pelea entre amos que se hizo extensiva a los esclavos. En un pleito que por la propiedad de una playa del río Cauca siguieron en 1771, el padre Francisco Porras y don Juan Escalante, un esclavo del primero rompió las cercas que estaba haciendo para cerrarle el camino a su amo e insultó con palabras "ásperas y provocativas" a unos esclavos de otro sacerdote, el doctor Ignacio Gutiérrez. ${ }^{46}$

Es imposible estudiar otras características de las víctimas de agravios, como la edad, el estado civil, la ocupación, porque no se acostumbró tomarles declaración o confesión, que eran las partes del juicio en donde se preguntaban estos datos (ver cuadro $\mathrm{N}^{\circ} 4$ ).

\section{Los agresores}

El perfil de los agresores está mejor delineado en los sumarios, toda vez que contra ellos iba dirigida la acción de la justicia. En lo que atañe a los juicios por injuria verbal encontramos que la composición de los reos, según el sexo, es muy semejante a la de las víctimas, pues de 168 personas procesadas, 140 eran hombres y 28 mujeres (ver cuadro $\mathrm{N}^{\circ} 1$ ).

\footnotetext{
${ }^{45}$ A. H. A. Indios. Tomo 26. Doc. 794. Fols. 7r-14v.

${ }^{46}$ A. H. A. Esclavos. Tomo 30. Doc. 977.
} 
Algunos de los hombres sindicados de proferir injurias se vieron involucrados en varias causas de esta clase. Los testimonios de los ofendidos y del vecindario, muestran que existían sujetos peleadores, "quimeristas", amantes de armar escándalo que se constituían en el dolor de cabeza de los jueces. Este perturbador de la paz pública puede ser tipificado por don José Urbina, español, soltero, quien se dedicaba a la profesión de médico cirujano. Según palabras del Gobernador Francisco Silvestre, quien era juez en una causa que en 1776 se le seguía a Urbina, éste era la piedra de escándalo de la ciudad de Antioquia.

Infestando con la voracidad de su lengua cuantas familias y personas la habitan, con injuria de su crédito y reputación y sin que perdone su atrevida insolencia, estado, calidad, ni sexo; produciendo con este detestable procedimiento, desavenencias entre las familias y casas privadas de ese vecindario, con desunión de los ánimos de ellas y riesgo evidente de la paz y tranquilidad pública. ${ }^{47}$

En prevención de las "consecuencias fatales" que podían seguirse de los pleitos que había formado, el Gobernador determinó desterrarlo de la provincia por 10 años y para que moderara sus "palabras y genio procaz" lo condenó a seis meses de reclusión en la plaza de Cartagena.

Una descripción parecida era la que en 1796 se hacía de Miguel Gabriel de Rojas, quien, en el partido de Santa Rosa de Osos tuvo "descomedimientos con varios sujetos de distinción”. El teniente de Gobernador del Valle de los Osos, don José Antonio Velásquez, certificó que Rojas era de genio petulante, díscolo, atrevido y con su "tolerado orgullo" había

perturbado la paz y quietud, así de los tribunales de justicia, como de los sujetos de honor habitantes de este sitio, sin que le fueran bastantes para su contención y enmienda, los autos judiciales y extrajudiciales que se han dirigido en apercibirle a fin de sujetarle a un buen procedimiento

${ }^{47}$ A. H. A. Criminal. B. 79. Leg. 1740-1780. Doc. $\mathrm{N}^{\circ} 18$. Fols. $1 \mathrm{r}-\mathrm{v}, 73 \mathrm{r}-74 \mathrm{v}$. 
y subordinación, pero antes si se han experimentado lo contrario por sus reincidencias. ${ }^{48}$

Las mujeres, por su parte, eran tildadas de "tener una lengua inquieta" o de ser de "genio altanero". A pesar de su fama de chismosas, sólo una, Catalina de Agudelo, mestiza, vecina de Sacaojal, se vio inmiscuida en más de un juicio. En una causa seguida en 1796 se le acusó de vociferar públicamente contra el crédito de hombres y mujeres solteras o casadas. ${ }^{49}$

La composición étnica de los agresores nos permite delinear mejor sus características. De los 168 sindicados, 45 eran blancos (26,79\%); 109 mestizos o mulatos libres $(64,89 \%) ; 13$ indígenas $(7,745)$ y uno, esclavo $(0,60 \%)$ (ver cuadro $\mathrm{N}^{\circ} 3$ ).

Como se ve, la presencia de los blancos fue mucho menor como agresores que como víctimas. Es al grupo de los mestizos y mulatos libres al que pertenecen la mayor parte de los reos. Para explicar el hecho no se puede olvidar que contra este sector de la población existían numerosos prejuicios y que las autoridades siempre buscaron controlarlo.

Desde mediados del siglo xvi la Corona comenzó a tomar medidas discriminatorias contra el mestizo. Con el propósito de proteger a los indígenas, las autoridades les prohibieron vivir en sus pueblos, comerciar con ellos y utilizarlos como sirvientes o cargueros. En el siglo xvil se constituyen en el sector mayoritario de la población y crece la prevención que contra ellos tenía el grupo de blancos, peninsulares y criollos. Las autoridades comparten esta opinión, pues constantemente en los documentos oficiales eran calificados de vagabundos, inestables, gente de vida irregular y pleitistas. Así, el criollo Francisco Antonio Moreno y Escandón, Fiscal de la Audiencia, decía en 1758 que los mestizos estaban reputados por gente de costumbres depravadas y perversas. ${ }^{50}$

La superioridad numérica de la población mestiza y mulata libre la convirtió en una amenaza para la permanencia de un orden social establecido

\footnotetext{
${ }^{48}$ A. H. A. Criminal. B. 83. Leg. 1790-1820. Doc. $\mathrm{N}^{\circ}$ 9. Fols. 12v, 20r-v.

${ }^{49}$ A. H. A. Criminal. B. 51. Leg. 1790-1800. Doc. No 11. Fols. 4r-5r, 11v-13r.

${ }^{50}$ Jaramillo Uribe, Jaime. Ob. cit. Págs. 172-174.
} 
con base en criterios raciales. La magnitud del problema se hace evidente al analizar los datos de los censos de población de 1778 a 1780 . De acuerdo con tales cifras, en el distrito de la Audiencia de Santa fe había 190.323 indios, 365.614 libres y 46.165 esclavos, lo que sumaba un total de 742.759 habitantes. ${ }^{51}$ Como puede apreciarse, una cuarta parte de la población era blanca, mientras que la población mezclada constituía cerca de la mitad.

En la provincia de Antioquia la población libre constituía un porcentaje aún mayor, pues de 46.366 habitantes empadronados para la misma época, 7.866 eran blancos (16,9\%), 2.034 indios (4,3\%), 27.535 libres $(59,3 \%)$ y $8.931(19,2 \%)$ esclavos (ver cuadro $\left.\mathrm{N}^{\circ} 64\right)$. Los datos del siguiente censo, efectuado 10 años después, muestran que la población mestiza se incrementaba. En ese momento se contabilizaron 34.914 libres, quienes constituían el 62,2\% de la población total que era de 56.052 habitantes (ver cuadro $\mathrm{N}^{\circ}$ 65).

Las cifras de los censos de 1778 y 1788 muestran que en la región antioqueña los negros esclavos eran numéricamente superiores a los indios. Por esa razón, la mezcla de raza se hizo fundamentalmente con individuos de origen negro, lo que dio lugar a la formación de un grupo grande de gente mulata y parda. Este proceso fue particularmente visible en la jurisdicción de la ciudad de Antioquia, donde un porcentaje elevado de la población pertenecía a este sector (ver cuadros $\mathrm{N}^{\circ}$ 63, 66 y 67). La discriminación que contra ellos se desarrolló fue muy fuerte, pues eran considerados propensos al desorden e inquietos. Así, en 1792 un ofendido afirmaba que

${ }^{51}$ En la población del distrito de la Audiencia de Santa fe están incluidos los habitantes Panamá, Portobelo y Veragua, lugares que hoy no pertenecen al territorio colombiano. Dentro de él no se contabiliza la población de la provincia de Popayán que en ese momento dependía de la Audiencia de Quito. También hay que aclarar que esta cifra, extraída del Padrón General del Virreinato del Nuevo Reino de Granada que figura en la relación de mando del Arzobispo Virrey, difiere de la dada por Francisco Silvestre para la misma época. Él le adjudica al distrito de Santa fe 826.550 habitantes, de los cuales 277.068 eran blancos, 136.753 indios, 368.093 libres y 44.646 esclavos. Como puede verse la diferencia más apreciable se refiere a la población blanca, pues de acuerdo a sus datos esta era el 33,5\% de la población.

Colmenares, Germán. Relaciones e Informes de los Gobernantes de la Nueva Granada. Bogotá. Biblioteca Banco Popular. 1989. Tomo i. Cuadro A. Tomo Ir. Pág. 55. 
en esta provincia esta gente canalla y ruin está como levantisca queriéndose igualar con el primer estado de la nobleza, faltándoles, por lo general al debido respeto y veneración aunque sean sujetos de carácter. ${ }^{52}$

Los Alcaldes ordinarios de Medellín en 1809, el doctor José Joaquín Gómez y don José Ignacio Cadavid, también compartían esta idea. A fines de ese año prohibieron la organización de una mojiganga que se preparaba para el día de Inocentes, por considerar que en esta clase de eventos abundaba la gente parda que "debía reprimirse". ${ }^{3}$

Esta suspicacia contra las castas las convertía en blanco especial de los jueces. La libertad de movilización de que disfrutaban los libres y el hecho de que no tuvieran una sujeción específica, hacía que se consideraran "peligrosos". Los prejuicios que contra ellos tenían los blancos, estaban basados en generalizaciones, valores subjetivos y temores o ventajas percibidas. Como producto de tales prejuicios los miembros de las castas eran objeto de discriminaciones a través de las cuales se les negaba la igualdad que deseaban. Sufrían restricciones en cuanto al vestido, les estaba prohibido poseer armas de fuego y espada, no tenían acceso a las universidades y no podían ser miembros del Cabildo. Al perseguirlos las autoridades se erigían en guardianes de la estructura social, que se veía vulnerada por la actividad y actitudes de estos grupos. ${ }^{54}$

En la violencia verbal que se daba en los juicios por injuria, se puede identificar la presencia de una tensión étnica que atraviesa la sociedad colonial antioqueña. No sólo existe el conflicto entre blancos y castas, sino que al interior de la población libre se producen continuos enfrentamientos. Los altercados y disputas eran el pan diario en los barrios de la ciudad y los poblados rurales. Como consecuencia de ellos había una fragmentación de intereses, que hacía difícil la acción colectiva. ${ }^{55}$

${ }^{52}$ A. H. A. Criminal. B. 96. Leg. 1790-1800. Doc. $\mathrm{N}^{\circ} 11$. Fols. $7 \mathrm{v}-8 \mathrm{v}$.

${ }_{53}^{5}$ A. H. A. Eclesiásticos. Tomo 84. Doc. 2355. fol. 5r-v.

${ }^{54}$ Colmenares, Germán. "La Aplicación de la Ley Penal a fines de la Colonia y comienzos de la República”. Versión mecanográfica sin publicar. S. f. Pág. 9.

Möner, Magnus. Ob. cit. Págs. 1-2, 10.

${ }^{55}$ Flores Galindo, Alberto. "Los Rostros de la Plebe”. Revista Andina. Cuzco Andina. Cuzco. Perú. Tomo i. N² 2. 1983. Pág. 337. 
En opinión de Pedro Fermín de Vargas, pensador preindependientista del siglo xvili, la Corona podía conservar estos dominios porque la población estaba compuesta de diversas castas cuyos intereses sino opuestos, eran totalmente inconexos. De acuerdo con su descripción la case de los criollos.

mira con desdén a todas las demás de indios, mulatos y negros. La mayor injuria que se puede hacer a un criollo es decirle que desciende de alguna de estas dos últimas clases. De aquí resulta que los criollos viven enteramente separados de ellas, y que la corte funda en esta separación su mayor seguridad. El mismo desvió subsiste entre el indio y el negro, y los mulatos mismos ocultan cuanto pueden su origen africano. En medio de esta diversidad de opiniones y de intereses el gobierno marcha tranquilo aprovechándose de la máxima política que dice divide et Impera. ${ }^{56}$

Otro aspecto que es interesante analizar es el de la edad de los sindicados. Los datos con que se cuenta muestran que los jóvenes entre 20 y 29 años eran los más propensos a participar en estas peleas (ver cuadro $\mathrm{N}^{\circ} 5$ ). Los menores de 10 años no podían ser acusados de este delito, porque la ley consideraba que no tenían el conocimiento necesario para responder de sus acciones. ${ }^{57}$

Este supuesto parece cobijar a los menores de 20 años, que todavía estaban bajo la tutela de sus padres. Por otra parte, las personas de más de 60 años que era un porcentaje relativamente pequeño de la población, continuaban interviniendo en estas disputas.

Esta información se complementa con la relativa al estado civil. Un porcentaje apreciable de los agresores eran personas casadas, lo que implica que muchos de estos pleitos eran alegatos entre cabezas de familia (ver cuadro $\mathrm{N}^{\circ} 7$ ). Las ofensas al honor que fueron denunciadas eran las proferidas por personas a las que la ley les daba dominio de sus acciones, por estar emancipadas de cualquier sujeción familiar o laboral.

${ }^{56}$ Vargas, Pedro Fermín. Pensamientos Políticos. Bogotá. Nueva Biblioteca Colombiana de Cultura. Procultura. 1986. Págs. 178, 196-197.

${ }^{57}$ Escriche, Joaquín. Ob. cit. Pág. 871. 
El análisis de las ocupaciones de los sindicados posibilita tener un mayor conocimiento de ellos. De 73 reos para los que existe información, 26 estaban vinculados a actividades agropecuarias (ver cuadro $\mathrm{N}^{\circ}$ 6). Eran pequeños o medianos propietarios que se mantenían del producto de una posesión o personas que arrendaban o vivían a merced de tierras ajenas. Por ejemplo, a José Hermenegildo Montoya, mestizo, vecino del Valle de Urrao, a quien se procesó en 1790 por tildar a Juana María Garcés y Damasia Urrego de brujas yerbateras, se le embargaron los siguientes bienes: 75 reses, nueve yeguas, tres mulas, dos caballos y tres potros que mantenía en los "pasteaderos de ganado"; medio derecho de tierra que valía 25 castellanos y una casa de paja con cocina. ${ }^{58}$

Por su parte, José Antonio Ibarra, mulato que había sido esclavo de Jerónima Ibarra, vecino de Antioquia, a quien se apresó en 1802 por insultar a Juana Manuela Salazar con palabras "despreciativas, insultantes y provocativas", se le embargaron: cinco reses, dos novillones, una coneja, dos yeguas, dos potrancas y cuatro caballos. Tres rastrojos en tierras propias, una casa cubierta de hojas de iraca, situada en los ejidos con su solar cercado de "tabla de guadua". El mobiliario consistente en cajas de madera, mesita, silla, taburetes y la armazón de cama. ${ }^{59}$

Al trabajo minero se dedicaban siete de los agresores. Se trataba de mazamorreros que combinaban la minería con la agricultura, lo que era posible debido al carácter estacional de las dos actividades. Así, a Bernardino de Vargas en 1795 le embargaron: Una casa pajiza con su cocina, situada en Sopetrán, tres yeguas y una roza de dos almudes que tenía en compañía de Jacinto Rivero en el paraje de Guayabal. Además, un amagamiento (mina) en el paraje "Vertientes a la Amoladera”, distante medio día de Sopetrán, donde tenía una casita, un recatón y tres bateas. ${ }^{60}$

De los procesados, nueve estaban vinculados al comercio. La mayoría eran pequeños tratantes o rescatantes que tomaban fiada la mercancía de un gran comerciante. Para ilustrar esta situación podemos tomar el caso de don

\footnotetext{
${ }^{58}$ A. H. A. Criminal. B. 37. Leg. 1790-1800. Doc. $\mathrm{N}^{\circ}$ 2. Fol. 23v-24v.

${ }^{59}$ A. H. A. Criminal. B. 46. Leg. 1800-1810. Doc. $N^{\circ}$ 9. Fols. $8 \mathrm{v}-10 \mathrm{v}$.

${ }^{60}$ A. H. A. Criminal. B. 65. Leg. 1790-1810. Doc. $N^{\circ}$ 3. Fol. 34r-v.
} 
Juan de Almeida, forastero, procesado en 1769 por haber dicho que el Alcalde ordinario, don José Manuel de Villa y Cepeda, y el cura de San Jerónimo, maestro Francisco Díaz de Mazo, lo habían sobornado. Este sujeto se dedicaba, en el sitio de San Jerónimo, a vender efectos que había traído fiados de la villa de Honda. ${ }^{61}$

Siete artesanos (plateros, zapateros, sastre y carpintero), fueron denunciados por injuria verbal. Otros cinco reos dijeron vivir de su trabajo como jornaleros o peones. Un grupo de 17 sindicados declararon tener oficios varios. Entre ellos figuran ocho mujeres que manifestaron realizar oficios domésticos como lavar, cargar leña, hilar, hacer jabón.

Contemporáneos como el visitador Mon y Velarde, hablan de la existencia de vagos y los presentan como la fuente y origen de los delitos. ${ }^{62} \mathrm{Sin}$ embargo, los datos anteriores muestran que la mayor parte de los procesados por injuria verbal eran personas dedicadas a actividades productivas. La población mestiza y mulata de la jurisdicción de la ciudad de Antioquia estaba constituida por pequeños propietarios y trabajadores libres, que disfrutaban de mucha independencia. Este grupo era bastante heterogéneo pues lo conformaban desde comerciantes enriquecidos hasta "pobres de solemnidad". Es la irrupción de este sector de la población en el campo económico lo que parece generar la conflictividad.

Otra variable que nos permite conocer quiénes eran las personas sindicadas de injuria verbal es su grado de alfabetismo. Hemos intentado medirlo usando como indicativo el que la persona hubiera firmado una confesión, declaración o notificación. Se pudo recoger información para 109 procesados, de los cuales 63 firmaron y 46 dijeron no saber hacerlo (ver cuadro $\mathrm{N}^{\circ} 8$ ). Las personas con algunos conocimientos de lectura y escritura eran 30 blancos y 33 mestizos y mulatos libres, entre los que se contaban dos mujeres.

Este dato es llamativo pues la ciudad de Antioquia en el año de 1808 sólo contaba con una escuela de "malos principios por su miserable dotación". ${ }^{63}$ Para que una persona adquiera los conocimientos de primeras letras era necesario

\footnotetext{
${ }^{61}$ A. H. A. Criminal. B. 79. Leg. 1740-1800. Doc. $\mathrm{N}^{\circ} 16$. Fols. 35r-36v.

${ }^{62}$ Robledo, Emilio. Ob. cit. Tomo II. Pág. 317.

${ }^{63}$ A. H. A. Censos. Tomo 343. Doc. 6538. Fols 2r-5v.
} 
que pudiera contratar un maestro o tuviera vínculos con una persona que le enseñara. Lo anterior indica que una buena parte de las involucradas en estas pendencias contaban con recursos económicos que les permitían sufragar estos gastos.

La información disponible permite concluir que la mayor parte de los procesados por injuria eran hombres de 20 a 60 años de edad, casados, pequeños propietarios o trabajadores libres. La prevención existente contra las castas hizo que estuvieran en la mira de las autoridades. Sin embargo, hay que anotar que un poco más de la cuarta parte de los acusados eran blancos. Los agravios denunciados eran los que provenían de personas con autonomía en sus actos, por no tener "lazos" de sujeción familiar o laboral. Se trataba de disputas entre personas a las que los cambios económicos hacia más o menos iguales.

\section{Las relaciones entre el agresor y la víctima}

Para analizar adecuadamente los móviles y consecuencias de los pleitos es necesario conocer la clase de vínculo que une a los participantes en él. A partir de este estudio podemos ver el papel que el parentesco, el compadrazgo y la amistad tienen en una sociedad.

Las relaciones que el agresor y la víctima tenían entre sí, las hemos agrupado en cuatro categorías:

1. Familia, cuando los implicados eran cónyuges, padres-hijos, hermanos y tíos-sobrinos, primos o parientes políticos.

2. Mundo Doméstico, cuando el pleito era entre personas que vivían en una misma casa (esclavos, agregados) o tenían una rivalidad o relaciones de tipo sexual.

3. Vecindad, cuando los contrincantes eran vecinos del mismo lugar o se trataba de conflictos entre éstos y las autoridades locales.

4. Extraños, cuando la pelea era con personas que no tenían vínculos más estrechos con la comunidad por ser oriundos de otra provincia o vecinos de un sitio distinto a aquel donde se presentó el conflicto.

La primera característica para anotar es que los pleitos en que se proferían injurias verbales, siempre se daban entre personas que se conocían. Como 
se trataba de imputaciones contra el origen, la honestidad, la honorabilidad, sólo podían provenir de personas que alegaban tener pruebas de lo afirmado.

En la jurisdicción de la ciudad de Antioquia durante el siglo xvir las relaciones familiares no parecen haber sido muy cordiales, como los demuestra el hecho de que cerca de la quinta parte de las agresiones verbales fueran entre parientes (ver cuadro $\mathrm{N}^{\circ} 11$ ). Con frecuencia los hermanos, cuñados, primos $\mathrm{y}$ parientes políticos se tildaron de ladrones, de estar amancebados, forzadores, brujas yerbateras, etc. Un porcentaje elevado de estos pleitos no debió ser denunciado a la justicia, pues los jueces tenían orden de truncar las causas por injuria entre parientes. Esta situación la ilustra el juicio que en 1795 entabló Valero García, vecino de Sacaojal contra Ignacio Salas, su suegro, por haberlo sindicado de robarle un macho. García decía que esta calumnia iba en perjuicio de su reputación que "aunque pobre, he mantenido ilesa hasta la fecha”. Salas, por su parte, afirmó ante el juez, haberlo tratado de ladrón y poder justificarlo. Aunque las partes estaban dispuestas a seguir el juicio, el Alcalde ordinario don Juan José de Lora y Nuño, lo declaró trunco, por considerar que las demandas por injuria entre parientes eran "odiosas y mal sonantes". En la sentencia mandó a los contrincantes a vivir en paz, sin injuriarse y los condenó en las costas causadas. ${ }^{64}$

Un poco más de la mitad de los juicios por injuria se siguieron entre vecinos de un mismo lugar. Es preciso aclarar que la categoría de "vecino" evolucionó a lo largo de la época colonial, adquiriendo una significación diferente. En el siglo xvi, dentro de una sociedad dual constituida por españoles e indígenas, los vecinos de una ciudad eran los habitantes privilegiados, generalmente encomenderos que podían ser elegidos al Cabildo de la ciudad. ${ }^{65}$ Para el siglo xvir la vecindad se había ampliado a todos los blancos que tenían casa poblada en el perímetro urbano. En la segunda mitad del siglo xviI el término se empleaba para designar tanto a los blancos como a la población mestiza y mulata libre que tenía establecido su domicilio en un poblado con ánimo de permanecer en él. La permanencia se probaba por el transcurso de 10 años, el

${ }^{64}$ A. H. A. Criminal. B. 65. Leg. 1790-1800. Doc. No 19. Fol. 1r-2r, 7r-v.

${ }^{65}$ Colmenares, Germán. Historia Económica y Social de Colombia. 1537-1819. Cali. Universidad del Valle. 1972. Pág. 301. 
estar casado con una mujer natural y haber fijado la habitación, la compra o adquisición de bienes raíces, el desempeño de los oficios concejiles u honoríficos que sólo podían desempeñar los naturales. Los vecinos de cada pueblo estaban sujetos a los cargos y tributos vecinales del mismo y disfrutaban de los pastos y derechos que como a tales les correspondían. ${ }^{66}$

En una sociedad de pequeñas localidades, como la antioqueña de ese entonces, cualquier afirmación contra la honra de un vecino se volvía rápidamente de dominio público, suscitando comentarios. El chisme y la murmuración parecen estar en el origen de muchas de las disputas. ${ }^{67}$

En las vecindades no existía la privacidad. La conducta de las personas estaba bajo el escrutinio continuo de los moradores, pues se compartían muchos lugares como la calle, los patios y solares y el templo. No es extraño, por lo tanto, que al presentarse un problema con un vecino se le imputara lo visto $\mathrm{u}$ oído. ${ }^{68}$ Las autoridades también propiciaban la interferencia en la vida de las personas, pues al hacer rondas persiguiendo amancebamientos, robos, vagos, daban pie a los comentarios del vecindario.

Algunos de los acusados de haber proferido injuria se excusaban argumentando que ellos sólo habían repetido lo oído a otras personas. Es el caso de Miguel de Agudelo, vecino de San Jerónimo, que fue apresado en 1783 por haber dicho que don Nicolás de Arias, vecino del mismo lugar, era un zambo. El reo en su confesión dijo haberlo dicho:

Porque se lo había oído decir a varios que otros se lo habían gritad. ${ }^{69}$

Por su parte, José Figueroa, vecino de San Jerónimo, acusado en 1801 por proferir injurias contra Rita Rodríguez, vecina del mismo lugar, dijo en su confesión haber oído contra ella varias cosas "aún a su mismo marido". ${ }^{70}$

${ }^{66}$ Escriche, Joaquín. Ob. cit. Pág. 1526.

${ }^{67}$ Valencia Llano, Alonso. "El Chisme y el escándalo en la sociedad colonial". En Estudios Sociales. Medellín. FAES. N 3. Septiembre de 1988. Pág. 39.

${ }^{68}$ Viqueira Albán, Juan Pedro. ¿Relajados o Reprimidos? Diversiones Públicas y Vida Social en la Ciudad de México durante el Siglo de las Luces. México. Fondo de Cultura Económica. 1987. Pág. 133.

${ }^{69}$ A. H. A. Criminal. B. 32. Leg. 1780-1790. Doc. $\mathrm{N}^{\circ}$ 9. Fols. 2r-2v.

${ }^{70}$ A. H. A. Criminal. B. 30. Leg. 1800-1810. Doc. N 4. Fols. 4r-v. 
La vecindad propiciaba el acercamiento de las personas y la confluencia de intereses; sin embargo, los roces cotidianos por el cobro de una deuda, la pérdida de una vaca o una gallina, originaban disputas que a veces terminaban en hecho de sangre.

Un poco más de la décima parte de los pleitos son contra funcionarios civiles y eclesiásticos, o generados por ellos. Es importante señalar que la mayor parte ocurrieron en los pueblos de indios, en donde se presentaban continuos problemas con los curas o los Corregidores. El origen de estos conflictos solía estar en la presencia de la población libre dentro de los terrenos de los resguardos y la actitud complaciente que las autoridades tenían con ellos. A modo de ejemplo veamos la disputa que durante los años 1755 y 1756 tuvieron los indígenas del pueblo de Sopetrán con el cura doctrinero, el licenciado José Javier Pérez. En julio de 1755, el cura pidió un interrogatorio de testigos para hacer constar que Diego Sisquiarco, indio Gobernador, y Tomás Saranda, su yerno, habían proferido "varias demasías" en su casa. Según el licenciado Pérez, estos indios afirmaron que no iba a quedar ningún libre agregado en las tierras del resguardo. Al defender el cura a los feligreses libres, pues ellos costeaban la "lámpara de la Santa Iglesia", le respondieron:

que el Santísimo Sacramento se consumiera y que ellos no tenían necesidad del y que la iglesia que se arruine y caiga importara muy poco que con una choza pajiza que le hicieran el portentoso de prodigios y milagros de milagros de Nuestra Señora de Sopetrán quedaban gustosos. ${ }^{71}$

Además lo habían tildado de "cura de muchachos" por no tener facultad para corregir a ningún "indio de macana”. Al mes siguiente el cura se quejó del indio Esteban Guingue, por haberle armado un alboroto y amenazarlo con un machete; esto había ocurrido cuando el Corregidor fue a cobrar el tributo para cumplir una orden del Gobernador Manuel López Castilla.

Un poco después, en enero de 1756, el licenciado Pérez se querelló contra Diego Sisquiarco y el indio Alcalde Joaquín Machado por haberlo insultado.

\footnotetext{
${ }^{71}$ A. H. A. Criminal. B. 55. Leg. 1700-1740. Doc. $\mathrm{N}^{\circ}$ 25. Fols. $1 \mathrm{r}-\mathrm{v}, 8 \mathrm{r}, 17 \mathrm{r}, 23 \mathrm{r}-\mathrm{v}, 30 \mathrm{r}-\mathrm{v}$.
} 
En una representación pidió que se expulsara del pueblo a Sisquiarco, su yerno Saranda y a Esteban Guingue por inducir a los indios a no pagar primicias ni tributos y a no ir a misa. El protector de naturales, por su parte, tachó a los testigos del cura por ser "enemigos de los indios", dado que por orden del Virrey José Alfonso Pizarro se les había pedido desalojar el resguardo.

Las circunstancias que rodean estos pleitos hacen pensar que los indios reaccionaban a abusos por parte del sacerdote, quien actuaba a favor de los libres. Como lo ha señalado el historiador Germán Colmenares, a fines de la colonia la población indígena estaba sujeta al cobro por parte del cura doctrinero de derechos por sacramentos, celebración de fiestas y mantenimiento de cofradías. No era extraño que los indígenas, al sentirse presionados, suscitaran conflictos. ${ }^{72}$

El 13\% de los juicios por injuria verbal tuvo origen en disputas con forasteros. Algunos hombres llegados de otra provincia o españoles, sin vínculo con alguna de las familias del lugar, se vieron involucrados en disputas con vecinos. En estos procesos es posible percibir cierto prejuicio contra el extraño, "sin arraigo", de quien se desconoce el origen y pasado. Es lo que ocurrió en 1769 cuando el Alcalde ordinario don José Manuel de Villa y Cepeda se querelló contra don Juan de Almeida, forastero, vagante, residente en San Jerónimo, por haber dicho que estaba sobornando testigos en un pleito que tenía con don Juan Antonio del Mazo. Por la misma razón lo denunció el cura de San Jerónimo, don Francisco Manuel Díaz del Mazo. Este pedía que se le arrestara por ser

persona levente, no conocida y sin habitación fija ni bienes raíces conocidos. $^{73}$

El Gobernador José Barón de chaves determinó absolver a Almeida, teniendo en cuenta que el Alcalde y el cura se apartaron del juicio. Lo previno para que se moldeara y se abstuviera de excederse cuando hablaba con sujetos de calidad.

72 Colmenares, Germán. Ob. cit. Pág. 112-113.

${ }^{73}$ A. H. A. Criminal. B. 79. Leg. 1740-1780. Doc. No 16. Fols. 32r-33r, 57r-v, 69v-71v. 
Dos años después, el cura Díaz de Mazo, volvió a querellarse contra Almeida por andar provocándolo esparciendo voces contra "el honor de su casa y familia”. Añadía que el sindicado era extranjero de la Corona y no se sabía que se hubiera connaturalizado. Pedía que se pusieran en ejecución las disposiciones contra los extranjeros

Pues que estos como generalmente opuestos a los naturales y por natural antipatía siempre les procuran inquietudes y conmociones de que dimanan ordinariamente perturbaciones en la paz pública y muy perniciosas consecuencias a la Corona y a los vasallos con corrupciones a las conciencias por donde no deben ser permitidos en las repúblicas. ${ }^{74}$

El Gobernador Enciso, en cumplimiento de dos Reales Cédulas de 1761 y 1767 , en que se mandaba no permitir extranjeros en las colonias sin que tuvieran licencia del Rey, determinó solicitar a Almeida la suya. Lamentablemente la causa se quedó sin terminar, por haber huido el reo de la prisión.

Los forasteros que tuvieron pleitos con vecinos, usualmente eran solteros, no tenían oficio definido y de algunos se sospechaba que hubieran llegado huyendo de la justicia. En una sociedad en la que las agresiones verbales eran comunes no es extraño que éstas se intensificaran con personas de quienes se desconocía su origen.

Los datos anteriores muestran que un gran porcentaje de las agresiones verbales fueron conflictos que se presentaron entre vecinos de un mismo lugar. En el núcleo urbano de la ciudad de Antioquia estos pleitos solían ocurrir en los barrios (Santa Lucía, Buga), en donde convivían blancos pobres, mestizos y mulatos. Se trataba de peleas entre personas que por procedencia racial podían pertenecer a grupos jurídicamente diferentes, pero cuya situación económica era parecida.

En cuanto a los sitios pertenecientes a esta jurisdicción (Sopetrán, San Jerónimo, Sacaojal, Santa Rosa de Osos, San Pedro, etc.) hay que anotar que eran eminentemente rurales. El "lugar" estaba constituido por la iglesia y unas

${ }^{74}$ A. H. A. Criminal. B. 85. Leg. 1770-1790. Doc. $\mathrm{N}^{\circ}$ 4. Fol. 1r-v, 7r-v, 13r-v. 
cuantas casas a su alrededor. La escasa población que habitaba en ellos, 500 a 2000 mestizos y mulatos libres, vivía dispersa en minas y pequeñas propiedades agrícolas. Las disputas que se presentaron en este ambiente se originaban en conflictos entre vecinos con condiciones de vida más o menos iguales.

\section{El escenario de las injurias}

Para estudiar los delitos es necesario tener en cuenta los momentos y los lugares donde solían cometerse. En las sociedades rurales, como la antioqueña de ese entonces, la vida solía estar regulada por los ciclos agrícola o minero, que determinaban los momentos de trabajo y los de descanso. Al llegar a América, los españoles trasladaron el calendario festivo europeo, el cual coincidía con momentos de la vida agrícola. A él se adaptaron los ciclos de la economía y la política, que determinaban las costumbres de manera muy precisa. De acuerdo con los testimonios documentales en la jurisdicción de la ciudad de Antioquia durante el siglo xvir eran días de descanso los domingos y 18 fiestas religiosas. ${ }^{75}$ Si miramos con detenimiento este calendario encontramos que el único mes en que no había fiesta de guarda era octubre. Los periodos en que se concentraba una mayor cantidad de días de descanso eran el fin y comienzo de año (25 de diciembre, la Natividad del Señor, 26 de diciembre, San Esteban Protomártir, 1 de enero, Circuncisión del Señor y el 6 de enero, la Epifanía), el mes de marzo (19 de marzo, San José, 25 de marzo, la Anunciación de Nuestra Señora y dependiendo de la fecha en que cayera Semana Santa, el lunes de Pascua) y el mes de junio (24 de junio, Natividad de San Juan Bautista, 29 de junio, San Pedro y San Pablo Apóstoles y dependiendo de Semana Santa, el lunes de Pentecostés y el jueves del Corpus Christi). ${ }^{76}$

${ }^{75}$ A. H. A. Esclavos. Tomo 30. Doc. 983. Fols. 425r-425v.

${ }^{76}$ García, Antonio José D. D. Kalendario Manual y Guía de Forasteros en Santa fe de Bogotá Capital del Nuevo Reino de Granada para el año de 1806. Edición Facsimilar. Bogotá. Banco de la República. Departamento Editorial. 1988. Págs. 17 a 52.

Fuera de las fiestas anotadas, se celebraban las siguientes: 2 de febrero, la Purificación de Nuestra Señora (La Candelaria), 25 de julio, Santiago Apóstol, patrono de España, 15 de agosto la Asunción de Nuestra Señora, 8 de septiembre, la Natividad de Nuestra Señora, 1 de noviembre, Todos los Santos y 8 de diciembre la concepción de Nuestra Señora. De las fiestas móviles que dependían de la Semana Santa además de las señaladas, se guardaba el jueves de la Ascensión (abril-mayo). 
El primer momento, el de las festividades de fin y comienzo de año, coincidía con la designación, el $1^{\circ}$. de enero, de los Alcaldes ordinarios y otras dignidades del Cabildo, lo que tenía repercusiones directas en la administración.

Historiadores como William B. Taylor, quien ha estudiado los conflictos que se presentaron en algunas regiones mexicanas en las últimas décadas del régimen colonial, sostienen que los pleitos y agresiones violentas en las sociedades campesinas suelen ocurrir fuera de los periodos normales de trabajo. ${ }^{77}$ Sin embargo, en el caso de las injurias verbales no es posible establecer una pauta temporal definida a que las denuncias de este delito solían hacerse algún tiempo después de ocurridos los hechos. En algunos procesos se dice que la disputa había ocurrido un mes, un año y hasta tres años antes de iniciarse la causa. No entendemos por qué se admitieron estas acusaciones, cuando la ley establecía que por prescripción una injuria de palabra se extinguía al año de haberse proferido, pues después de un silencio tan largo se presumía que la persona no se había considerado deshonrada o había perdonado la ofensa. ${ }^{78}$

Si tomamos las fechas de iniciación de causa, encontramos que la época del año en la cual se hacía una mayor cantidad de denuncias por injuria eran los meses de julio, agosto y septiembre 49 de 139 (ver cuadro $\mathrm{N}^{\circ} 10$ ). Es decir, que después de las festividades de junio, mucha gente acudía a los juzgados a demandar. Por el contrario, el periodo en que menos querellas se presentaron fue el de diciembre, enero y febrero (23 de 139). Esto puede deberse a que se acostumbraba cerrar los juzgados durante el periodo de navidad. El Oidor visitador Mon y Velarde, en las ordenanzas que dictó en 1787 para el gobierno del Cabildo de la ciudad de Antioquia, mandó abolir la costumbre de cerrar los juzgados desde el día de San Andrés (30 de noviembre) hasta después de la fiesta de Reyes (6 de enero). Dispuso que se atendieran demandas y causas civiles hasta la víspera de navidad y que el curso de las causas criminales no se suspendiera. ${ }^{79}$

La pauta espacial de las injurias es más fácil de establecer, aunque en un gran porcentaje de las causas $(46,62 \%)$ no se suministre información sobre

\footnotetext{
77 Taylor, William B. Ob. cit., Pág. 122.

${ }^{78}$ Escriche, Joaquín. Ob. cit. Pág. 878.

${ }^{79}$ Robledo, Emilio. Ob. cit. Tomo II. Pág. 89.
} 
este aspecto. Al ser la injuria verbal un delito que no deja huellas tangibles, las palabras agraviantes debían ser pronunciadas delante de testigos que pudieran dar constancia del hecho. Por esta razón se denunciaron pocos pleitos ocurridos en caminos, labores agrícolas, minas y quebradas o ríos (ver cuadro $\mathrm{N}^{\circ} 9$ ).

La mayor parte de estas disputas ocurrieron en el núcleo urbano de la ciudad de Antioquia o en los pequeños poblados. En las calles, mundo bullicioso y donde todos confluían, sucedió una parte de ellas. Durante las festividades religiosas, el pueblo se las tomaba con procesiones, bailes, paseos y en este ambiente de mayor libertad y flexibilidad se generaban conflictos. Un ejemplo de esto es lo ocurrido durante la celebración del día de los Inocentes, el 28 de diciembre, en 1806. Facundo Fajardo, vecino del curato de Anzá, se quejó contra Manuel Flórez, José Sacramento Ramírez y Viviano Tamayo, vecinos de ese sitio, por haber cantado ese día en las calles de la ciudad de Antioquia versos indecorosos contra su "honor y sentada reputación". El texto de los versos que se conserva, lo sindicaba del robo de una vaca:

\author{
Al prrobesito Fajardo \\ le rodaba la comida \\ y hoy ha llegado a la estrrema \\ de comer carne podrida
}

Grrabiel Fajardo hiso sogas

del dicho cuero de la vaca

Torribia Diaz hiso mole

de la cabesa y las patas

Los gallinazos se fueron

desterrados de este mundo

para no bolber jamas

porque los corrió Facundo... ${ }^{80}$

${ }^{80}$ A. H. A. Criminal. B. 84. Leg. 1810-1840. Doc. $\mathrm{N}^{\circ}$ 2. Fols. 1r,8v. 
Para esa fecha era costumbre en la ciudad de Antioquia organizar comparsas que cantaban versos referentes a la conducta de los vecinos. Era tal la cantidad de disputas que el Gobernador, ese año había publicado un bando en el que prohibía los "versos de injuria".

El lugar donde más altercados se producían era en la casa del agresor o la víctima. Lo corriente era que una persona se presentara en la casa de otra a hacer un reclamo, a cobrar una deuda y por esta causa se llegara al intercambio de palabras. Así, don Juan Antonio Carvajal, vecino de San Jerónimo, puso una querella en 1794 contra don Manuel Mejía por una disputa que se suscitó en la casa del primero cuando revisaban el libro de cuentas para saber la cantidad que le adeudaba el segundo. Al discutir sobre la forma de pago, la mujer de Carvajal afirmó que "eso sacaba de haberla fiado", Mejía le replicó no haber tenido trato alguno con ella. En el pleito que se formó, Carvajal tildó a su oponente de "Manuel Mejía del Rincón” y éste le respondió llamándolo "Juan Antonio Carvajal del Monte de la Concepción”. La denuncia la puso Carvajal por considerar que se lo había sindicado de ser "un hombre de deplorable nacimiento". 81

Una cantidad apreciable de conflictos se generaba en la casa o lugar donde despachaban los jueces, al tramitarse una demanda. Era corriente que las personas que intervenían en los litigios por propiedades o deudas terminaran discutiendo entre sí e insultándose. El juicio por injuria era usualmente iniciado en el mismo juzgado donde habían sucedió los hechos. Lo anterior ocurrió en una causa que Vicente Serna, vecino de Antioquia, instauró en 1801 contra Manuel Rodríguez por tildarlo de ladrón. La agresión verbal ocurrió cuando Rodríguez tramitaba en el juzgado del Alcalde de Buga un pleito con Salvador Bravo, a quien le había hecho una venta por vale. El vendedor se quitó del negocio alegando que en el vale escrito por Serna, no estaba escrito lo que se había mandado poner. ${ }^{82}$ Lo que los datos anteriores muestran es que las injurias para poder ser denunciadas debían haberse proferido en público. Esta condición sólo podía cumplirse en los poblados o lugares en los que

\footnotetext{
${ }^{81}$ A. H. A. Criminal. B. 51. Leg. 1730-1800. Doc. $\mathrm{N}^{\circ}$ 5. Fols. 1r-2r, 2v-3v.

${ }^{82}$ A. H. A. Criminal. B. 98. Leg. 1800-1810. Doc. $\mathrm{N}^{\circ} 11$. Fol. 1r.
} 
hubiera una concentración de gente. Para hacer este análisis no debe olvidarse que la diferencia entre la calle y la casa no era tan tajante como es hoy; lo que pasaba en el interior de las casas de habitación era conocido por todo el vecindario, ya que estas se comunicaban entre sí a través de los solares o por la calle. El vecindario conocía quien y a qué hora se entraba o salía de una casa, oía todo lo que se decía o gritaba dentro de ellas y estaba pronto a intervenir cuando se presentaba algún problema. Por esta razón no es raro que cuando un demandante intentaba probar algo, siempre pudiera valerse de las declaraciones de los vecinos.

\section{Los motivos}

Estudiar los motivos por los cuales se infringe la ley ha sido uno de los temas que más ha interesado a la criminología. Para analizar este aspecto hay que tener en cuenta que en los juicios no siempre figuran las causas reales de las agresiones. Sin embargo, es posible tener una idea aproximada de ellas al utilizar las declaraciones de los ofendidos, agresores y testigos de los hechos. En el caso de las injurias, las representaciones presentadas por las partes enfrentadas casi siempre describen la situación que dio origen al intercambio de palabras. Al analizar esta información se debe tener en cuenta que los motivos a veces no tienen relación directa con las palabras agraviantes por las cuales se instauró la demanda.

Examinar la motivación de los delitos permite conocer cuáles son los focos de tensión y de conflicto de una sociedad. En relación con la sociedad antioqueña del periodo 1750-1819, una característica es que los problemas de tipo económico figuran entre las causas más comunes de las disputas (ver cuadro $\left.\mathrm{N}^{\circ} 12\right) .{ }^{83}$

Dentro de este grupo sobresale como origen de un mayor número de pleitos, los problemas suscitados por sindicar a una persona de un robo y los derivados del cobro de deudas o de posesión y uso de la tierra.

${ }^{83}$ El número de motivos (154) es mayor que el número de juicios tramitados por injuria (136), debido a que en algunos juicios hay incluidos varios pleitos y en otros se enumeran varias causas. 
Los juicios por injuria originados en la imputación de un robo eran casi idénticos a los seguidos por el delito de hurto, sólo que en este caso el papel de acusador lo tenía aquel que en el segundo hubiera sido el reo.

De acuerdo con la legislación vigente el hurto era la "fraudulenta contratación de una cosa", su uso o posesión con ánimo de lucrarse contra la voluntad del dueño de ella. ${ }^{84}$

Da la impresión de que la imposibilidad de probar que la sustracción de una propiedad se había hecho maliciosamente, permitía al sindicado replantear el pleito en otros términos. Por lo menos eso es lo que sucedió en el juicio que Antonio Rivera, vecino de Antioquia, tramitó en 1806 contra Gaspar Gómez por sindicarlo en el juzgado de comisario de barrio de 2ladrón abigeato o de vacas". En una representación, Rivera sostenía que había tomado un ternero de Gómez por haberlo confundido con uno suyo que tenía perdido. Sostenía que su oponente no podía probar que le hubieran advertido que ese no era su ternero antes de cogerlo y venderlo y cuando se lo dijeron ya lo había matado. Sobre el hurto que le atribuía por un ternero que compró a Manuel Marín y resultó ser de Nicolás Durán, sostenía que el juez lo declaró inocente por haberlo adquirido de buena fe. Terminaba su argumentación diciendo que para condenar a otro eran menester pruebas que excluyeran toda señal de bondad, lo que no podía lograrse con un examen superficial de los hechos. Por su parte, Gómez se reafirmó en su intención de poner demanda a Rivera por el robo del toro, pues alegaba que éste debía conocer los suyos por el color y marca".

En junio de 1807 el teniente asesor doctor Antonio Viana determinó absolver a Rivera del delito que se le imputaba por haber "probado su intención". Debía pagar el ternero por el precio que tenía cuando mató equivocadamente, creyendo que era suyo. Condenó en las costas de la actuación a Gómez por no probar el delito con que inculpó a Rivera. ${ }^{85}$

El riesgo que corría la persona que ponía una demanda por un delito y no lograba probarlo, era verse convertido en reo por injuria. Era una situación

${ }^{84}$ Alvarez Posadilla, Juan. Práctica Criminal por Principios o Modo y forma de Instruir los Procesos Criminales de las Causas de Oficio de Justicia. Valladolid. Imprenta de la Vda. E hijos de Santander. 1802. Tomo III. Pág. 385.

${ }^{85}$ A. H. A. Criminal. B. 98. Leg. 1800-1810. Doc. No 24. Fol. 1r-v, 12r-13r, 15r-19r, 68v. 
paradójica, pero se derivaba del formalismo con que se aplicaba la ley y en patrón de conducta vigente. Lo llamativo es que las personas no parecían estar satisfechas con que un juez las declarara absueltas de un cargo, necesitaban que la persona que los había acusado fuera condenada por su falsa imputación.

Otra situación propicia para que se generaran conflictos era el cobro de deudas. Como se anotó antes, en Antioquia durante el siglo xvil la mayor parte de las transacciones comerciales se hacían a crédito. El intercambio de mercancías se hacía a través de una cadena en la cual aquellas pasaban de mano en mano, siempre fiadas. Los grandes comerciantes antioqueños compraban a crédito a los vendedores mayoristas de Cartagena, Santa fe de Bogotá y Popayán. Ellos a su vez, entregaban a los tratantes y rescatantes las mercancías para que las vendieran a la población dispersa en las minas y pequeñas propiedades agrícolas. Tampoco los compradores pagaban de contado, pues iban abonando a la cuenta que tenían con uno de estos comerciantes. Por lo tanto es comprensible que cuando alguna de las personas que intervenía en estos negocios tenía que cubrir una obligación con los proveedores, tratara de obtener que sus deudores le pagaran. ${ }^{86}$

Las incriminaciones que se hacían las personas al cobrar una deuda, daban pie a la instauración de juicios por injuria. Los comerciantes y cobradores se quejaban de que la gente era poco inclinada a pagar y utilizaban muchas disculpas para no hacerlo. Así, don Gabriel Rivero, vecino de Antioquia residente en los resguardos de Sopetrán, en un juicio que siguió en 1767 contra Antonio Valderrama originado en el cobro de cuatro pesos y siete tomines, decía:

Los tratantes de este territorio han experimentado de algunos sujetos, que su amistad permanece en tanto que no se les cobra lo que deben, y llegando este término le imputan de ilegales. ${ }^{87}$

86 Twinam, Ann. Mineros, Comerciantes y Labradores: Las Raíces del Espíritu Empresarial en Antioquia. 1763-1810. Medellín. fondo Rotatorio de Publicaciones FAES. 1985. Págs. 103-104.

${ }^{87}$ A. H. A. Criminal. B. 35. Leg. 1750-1770. Doc. N 3. Fol. 6r-v. 
Los deudores, por su parte, argumentaban que muchas personas acostumbraban a cobrar las deudas de "mano poderosa". En un pleito seguido en 1800 entre Graciliano de Lorza, vecino del sitio de San Pedro y Juan Bernardo Flórez por el cobro de seis pesos y seis tomines, éste último aseguró ante el juez del partido de Miranda que había ofrecido pagar la deuda en maíz para que su oponente "no lo matara". 88

Toda la complejidad de las relaciones comerciales se encuentra descrita en el juicio seguido entre 1794 y 1796 a Miguel Marín, vecino de Antioquia, por haber sindicado de "hombre de mala fe y defraudador de tratos y contratos" al tratante Salvador Sarrazola. El agraviado decía haber presentado la querella porque de no hacerlo, otros deudores le "negarían sus créditos" y terminarían apoderándose.

de los intereses que con su sudor, trabajo e industria he adquirido. ${ }^{89}$

Para probar su condición de rescatante honorable, presentó como testigo al Regidor decano, el comerciante don Juan Pablo Pérez de Rublas. Este declaró que por espacio de 12 años había entregado a Sarrazola mercancías para vender, y en 1784 lo había llevado como acompañante a Santa Marta y Cartagena, prestándole dinero para hacer compras. En estos negocios había procedido con "pureza y legalidad", razón por la cual le recomendó a comerciantes de Cartagena y Mompox, quienes no se habían quejado de "mala versación en sus tratos".

Marín contestó argumentando que él no había afirmado que Sarrazola fuera un mercader mal acreditado o que hubiese defraudado a los señores del estado "mayor y noble". Aclaraba que cuando lo sindicó de hombre de dos caras "halagüeño y atractivo" para vender, pero "ríspido y temerario" para cobrar, se refería a sus negocios con la gente "ordinaria, campestre y rústica" que compraba fiadas las mercancías.

${ }^{88}$ A. H. A. Criminal. B. 61. Leg. 1800-1810. Doc. $\mathrm{N}^{\circ}$ 1. Fols. $1 \mathrm{r}-\mathrm{v}, 12 \mathrm{r}-13 \mathrm{v}$.

${ }^{89}$ A. H. A. Criminal. B. 37. Leg. 1790-1800. Doc. No 1. Fol. 1r-v, 25r-26v, 55r-58v.

Este documento también se encuentra en el Archivo Histórico Nacional, bajo la referencia: A. H. N. Juicios Criminales. Tomo 117. Fols. 343 a 431. 
Como puede apreciarse en los ejemplos dados, tanto las deudas que se cobraban, como los objetos que supuestamente habían sido robados, no tenían mucho valor. Desde el punto de vista económico no se explica fácilmente que la gente estuviera dispuesta a gastar dinero tramitando este tipo de demanda. Sin embargo, hay que tener presente que la actividad básica de la economía antioqueña durante el siglo xviII fue la minería, y ésta dependía del comercio para mantener el flujo de suministros. Esto explica por qué era tan importante todo lo que afectaba la circulación de mercancías como el incumplimiento de los tratos o la apropiación indebida de bienes.

Los problemas derivados de la posesión y uso de las tierras también daban lugar a la presentación de juicios por injuria. Algunos de estos pleitos se produjeron entre indígenas y libres que vivían en sus resguardos, otros tuvieron origen en daños causados por los vecinos, o eran litigios entre herederos.

Las diligencias judiciales adelantadas en pleitos de carácter civil, daban origen a disputas que terminaban convirtiéndose en juicios criminales. Un ejemplo de este proceso es la causa seguida contra Dionisio González, mulato libre, por tratar de perjuro y falsario a don Ignacio de Villa y Gutiérrez, vecino de Medellín, quien había sido encargado de hacer un reconocimiento de pastos en el pleito que González tenía en 1770 con su colindante don Manuel Pajón. Los hechos tuvieron origen en una demanda instaurada por Pajón, debido a que estaba recibiendo perjuicios de la gran cantidad de ganado propio y ajeno que González mantenía en sus tierras. Al comunicársele a Dionisio el resultado de la regulación, expresó que Villa había hecho lo que José Manuel de la Cruz, comisionado de Pajón, le dijo. En la causa se sindicó al agresor de "desórdenes y libertades" con toda clase de personas; Villa solicitó un severo castigo para que sirviera de escarmiento a otros

que hay de esa misma naturaleza, que por disimularles y tolerarles sus demasías y atrevimientos... se hallan ya cuasi sublevados... y los pocos sujetos que habemos de distinción quedaremos sujetos a sufrir sus injurias. ${ }^{90}$

${ }^{90}$ A. H. A. Criminal. B. 56. Leg. 1740-1770. Doc. $\mathrm{N}^{\circ}$ 25. Fols. $1 \mathrm{r}-2 \mathrm{r}, 15 \mathrm{r}-16 \mathrm{r}$. 
Los motivos por los cuales se instauraban los pleitos por injuria no sólo eran de tipo económico. Muchas veces estas demandas tuvieron origen en acusaciones vertidas contra la honra familiar y personal. Es interesante anotar que casi una quinta parte de los juicios por injuria se suscitaron por sindicaciones de adulterio o concubinato. Para medir la gravedad de esta imputación debemos tener en cuenta que el adulterio era considerado en esa época pecado y delito. ${ }^{91}$

acto de una persona casada que violando la fidelidad conyugal concede sus favores a otra persona

La persecución de esta conducta considerada desviada y peligrosa para la conservación del orden social, fue una preocupación continua de los gobernantes borbones. Las causas criminales existentes en el Archivo Histórico de Antioquia muestran que antes de 1760 se siguieron muy pocos procesos por este delito. Son los Gobernadores Francisco Silvestre /1782-1785) y Mon y Velarde (1785-1788) quienes comienzan a controlar estos

excesos que parece nunca habían sido objeto de la buena administración de justicia, o que se miraba con indiferencia. ${ }^{92}$

Como resultado de esta política, durante el periodo 1780-1809, una gran cantidad de personas fue enjuiciada por concubinato, amancebamiento y adulterio. En la jurisdicción de la ciudad de Antioquia se tramitaron 303 juicios de esta clase, suma que está muy por encima de los seguidos por cualquier otro delito. Téngase en cuenta que por las mismas fechas, las causas por injuria verbal fueron 97 y las de homicidio 26.

El objetivo de esta "cruzada" era la consolidación de la familia monogámica católica como la célula básica de la sociedad. El empeño con que se llevó a cabo explica por qué muchas personas estaban dispuestas a gastar

\footnotetext{
${ }^{91}$ Escriche, Joaquín. Ob. cit. Pág. 98.

${ }^{92}$ Robledo, Emilio. Ob. cit. Tomo II. Pág. 317.
} 
tiempo y dinero para demostrar la falsedad de una acusación de adulterio. Al igual que en el caso de la imputación de robo, el posible reo se veía en la obligación de instaurar una demanda para evitar ser procesado.

Los juicios por injuria que tuvieron origen en sindicaciones de concubinato o adulterio, revelan que muchas de estas acusaciones eran hechas con el fin de perjudicar a un enemigo. Esta costumbre se puede ilustrar con lo ocurrido con el juicio seguido en 1786 contra Juan María de Flórez, mulato, labrado y rescatante por tener "ilícita amistad" con María Ignacia Rivera, mujer casada. El supuesto reo solicitó al Alcalde ordinario de segundo voto, el doctor don José Antonio Gómez, que le admitiese una fianza de juzgado y sentenciado, para poder hacer las diligencias necesarias para demostrar que el sumario se le había seguido por "odio, pasión y mala voluntad" de algunos vecinos del sitio de Obregón. Las pruebas presentadas por él mostraron que los habitantes y jueces de ese lugar ignoraban el amancebamiento "público y escandaloso" de que había sido acusado. Únicamente los testigos del sumario, parientes de Timoteo Montes o de su concubina Juana María Santamaría, decían conocerlo. Quedó claro además que el denuncio contra Flórez se había hecho después de que Montes fue apresado por el delito de concubinato. Sobre esta base, el asesor jurídico, doctor Ignacio Uribe, concluyó en su dictamen que la acusación había tenido origen en la creencia de que Flórez era el "actor de la prisión de Montes". En consecuencia, el Alcalde ordinario declaró al incriminado libre del delito y condenó a los siete testigos a pagar cada uno tres pesos de multa y entre todos las costas procesales. ${ }^{93}$

Otra situación en que se generaban conflictos era cuando las autoridades intentaban hacer cumplir algunas órdenes. En estas ocasiones fueron corrientes los desacatos y resistencias a la justicia que daban lugar a la instauración de juicios por injuria. La pretensión de no estar bajo la jurisdicción de una autoridad o no poder ser cobijado por la medida, era utilizada como excusa por los sindicados de haber cometido el delito. Un caso que sirve como ejemplo es la causa por injuria instaurada en 1783 por don Francisco Escobar, alcalde de la Santa Hermandad, contra don Juan Antonio Díaz de Mazo,

${ }_{93}$ A. H. A. Criminal. B. 93. Leg. 1770-1790. Doc. $\mathrm{N}^{\circ}$ 10. Fols. 1r, 14r, 48r-v, 49r-v. 
administrador de la renta del tabaco del partido de Sopetrán. El juicio tuvo origen en la supuesta negativa de Díaz a contribuir en la apertura del camino de la Loma del Guayabal, ordenada por el Gobernador Silvestre. Escobar lo acusaba de que había inducido a algunos habitantes de ese partido para que no concurrieran a ese trabajo. El implicado respondió señalando que su oponente había buscado privarlo de la renta que administraba. Su negativa a participar en la reparación del camino la justificaba por estar exento de esta clase de pensión por las instrucciones de la renta del tabaco. Además acusaba al Alcalde de la Hermandad de no haberlo auxiliado para hacer una ronda a fin de descubrir una siembra clandestina de tabaco y de haber estado amancebado por más de ocho años con una india del pueblo de Sopetrán. Por esta razón, había expresado

que más bien merecía estar en Bocachica que no yo. ${ }^{94}$

Hay que anotar que aunque los indígenas y vecinos libres muchas veces no acataran las órdenes de las autoridades, esto no significa que discutieran la legitimidad de éstas.

El análisis de los motivos que dieron origen a los conflictos que desembocaron en la instauración de juicios por injuria verbal, muestra que se trataba de situaciones que requerían la intervención de la justicia. Tanto el cobro de deudas, que muchas veces estaba precedido de la presentación de una demanda verbal ante el juez, como los pleitos por la propiedad y uso de la tierra daban origen a juicios de carácter civil. En el caso de la imputación de robos y adulterios o de resistencia a la justicia, eran conductas que se consideraban delictivas y que debían ser investigadas. Los intercambios de palabras parecen presentarse debido a que las autoridades no actuaban con la rapidez e imparcialidad necesaria.

Una buena parte de las personas que participaban en estas querellas trataban de hacer valer sus derechos o defenderse de acusaciones que les eran perjudiciales. Aunque externamente estos juicios tienen la apariencia de "feria

\footnotetext{
${ }^{94}$ A. H. A. Criminal. B. 81. Leg. 1780-1790. Doc. $\mathrm{N}^{\circ} 10$. Fols. $1 \mathrm{r}-\mathrm{v}, 16 \mathrm{r}-17 \mathrm{r}, 20 \mathrm{r}-23 \mathrm{v}$.
} 
de vanidades", el estudio de la motivación muestra que al poner estas demandas se buscaba que la justicia mediara en los conflictos entre particulares.

\section{Las sentencias}

La Recopilación Castellana establecía que por el delito de injuria de palabras mayores, se debía condenar al agresor a que se desdijera ante el Alcalde y en la pena de 1200 maravedíes, de los cuales la mitad eran para la Cámara y la mitad para el querelloso. Si el inculpado era hijodalgo, no podía ser obligado a desdecirse y la pena pecuniaria era de 2000 maravedíes. Fuera de estas penas, el juez podía imponer las que considerara convenientes de acuerdo con la calidad de las personas y de las injurias.

En cuanto a las injurias escritas, las Leyes de Partida determinaban que sus autores incurrían en la misma pena en que se debía condenar el infamado, si se probase que era verdad lo que decía el libelo. ${ }^{95}$

Sin embargo, los jueces que actuaron en la ciudad de Antioquia no se guiaron por estas disposiciones. Al proferir las sentencias tenían en cuenta aspectos como la calidad del injuriante, la condición social del agraviado, las disposiciones de las autoridades virreinales sobre estos asuntos y lo que estaba establecido por la costumbre.

Lo común en las causas por injuria fue condenar al agresor a pagar las costas del proceso (ver cuadro $\left.\mathrm{N}^{\circ} 13\right) \cdot{ }^{96} \mathrm{El}$ monto de esta pena pecuniaria dependía del tamaño y duración del proceso, de allí que en los procesos estudiados su valor haya oscilado entre 3 y 71 pesos de oro. Sin embargo, en la mayor parte de los casos ellas no excedieron los 20 pesos. Durante el periodo de la Independencia, la tasación de hizo en pesos de plata, lo que significaba una reducción.

Otras penas pecuniarias como el pago de multas y el arreglo de daños, se usaron muy ocasionalmente. Estas dependieron del arbitrio de los jueces

${ }^{95}$ Alvarez Posadilla, Juan. Ob. cit. Tomo III. Págs. 464-466.

${ }^{96}$ El número de penas impuestas (220) fue mucho mayor que el de juicios seguidos por injuria de palabra (136), debido a que una sentencia solía incluir varias penas. Así, cuando se compurgaba el delito con la prisión sufrida, también se condenaba al reo a pagar las costas del proceso. En los casos en que se hicieron convenios o se desistió de la querella, el inculpado casi siempre se comprometió a sufragar las costas. 
encargados de dictar sentencia, como lo refleja el hecho de que cuatro de las seis multas impuestas correspondan al periodo 1786-1787, cuando estaba actuando como Gobernador de la provincia el Oidor Mon y Velarde. En este caso el monto de la pena varió de 3 a 50 pesos.

La disposición legal de condenar al agresor a dar satisfacción al ofendido delante de la justicia sólo se cumplió en 13 de los juicios estudiados. En estos escritos el inculpado se retractaba de lo dicho y pedía que la honra de la víctima quedara sin nota o mancha alguna. Un ejemplo de esta clase de documento es el presentado en 1785 por don Carlos de Piedrahíta, en el litigio que tenía con don Lorenzo Zapata, a quien había sindicado de descender de un Juan Araújo, penitenciado del Santo Tribunal.

ha procurado, por otros medios dar la satisfacción correspondiente a una injuria, que promovió únicamente el encono de los pasados disgustos, sin otro fundamento, porque ni entonces supo, ni ahora sabe del referido don Lorenzo otra cosa que lo que en esta ciudad es público y notorio, esto es que él y toda su familia ha sido y es de las principales de esa ciudad sin nota, ni mancha alguna y mucho menos de la especie de la querella. ${ }^{97}$

Al dar satisfacción parece haberse incluido en la sentencia cuando el agraviado era un blanco de "primera clase".

El aplicar penas corporales como cárcel, reclusión en el presidio de Cartagena, trabajo en obras públicas o destierra, no fue muy común en los pleitos por injuria. La cárcel, como ya lo habíamos anotado, era para custodia y seguridad de los reos, no para castigo. ${ }^{98}$

Además pocos reos por injuria fueron encarcelados durante el proceso por que no existía el peligro de fuga tan común en otros delitos. Lo anterior explica que únicamente en 16 causas se haya impuesto como pena la prisión sufrida o se determinara que el agresor fuera condenado a unos días de prisión

${ }_{97}$ A. H. A. Criminal. B. 97. Leg. 1790-1810. Doc. N². Fol. 26v-27v.

${ }^{98}$ Lardizábal, Manuel de. Discurso sobre las Penas. México. Editorial Porrúa. S. A. 1982. Pág. 211. 
(de 8 a 15 días). En uno de los últimos casos, claramente se establecía que se apelaba a la pena de prisión por no poder el reo pagar las costas del proceso. ${ }^{99}$

Las penas de presidio, arsenales y trabajos públicos tampoco fueron muy usadas en esta clase de delitos, tal vez porque los jueces consideraban que de imponerlas, la pena sería mayor que la infracción cometida. Sólo coyunturalmente se impuso la pena de presidio, tratándose de personas a las que se le acumulaban sentencias anteriores o eran originarias de otras provincias. Así, en un proceso seguido en 1781, se condenó a Antonio Díaz, "forastero y vago" a que se dedicara al "servicio de su Majestad" en la plaza de Cartagena. Esta sentencia se hacía en virtud de una orden del Virrey Flórez (diciembre de 1780) en la cual, debido a la guerra que se libraba con Inglaterra, determinaba que se enviara al regimiento fijo de Cartagena todos los reos "que no tengan delitos feos" y que por su talla, color y robustez, fueran aptos para el servicio de las armas. Además debían remitirse los vagos o mal entretenidos que no dejaran abandonados mujeres, padres, huérfanos o inválidos. ${ }^{100}$

La condena a trabajo en obras públicas también fue utilizada temporalmente. De los cuatro casos en que se impuso, tres fueron de la década del 90 y la duración de la pena fue de uno a seis meses. Según el asesor jurídico, doctor José Joaquín del Pino, se recurría a este castigo para que "sirviera de escarmiento" a los que denigraban contra la buena fama de sus compatriotas. Durante la década del 90 fue cuando se presentó un mayor número de demandas por injuria. Por tal razón, esta pena debió ser empleada para sentar un ejemplo y evitar la proliferación de causas. ${ }^{101}$

El destierro fue utilizado como pena entre 1760 y 1799 , siendo también muy notorio su empleo en la década del 90 . Este castigo se usó con forasteros, a quienes se remitía a su lugar de origen o con personas que no tenían propiedades que abandonar. Algunos eran desterrados por un periodo corto de tiempo (uno o dos años), pero en otros casos se buscaba que el reo saliera en forma definitiva de un lugar. A este último grupo pertenece la sentencia dictada contra José Ortega, natural de Cartagena, oficial de carpintero, a quien en 1797 se le

\footnotetext{
${ }^{99}$ A. H. A. Criminal. B. 46. Leg. 1800-1810. Doc. $\mathrm{N}^{\circ} 14$. Fols. 14r-v, 61r.

100 A. H. A. Criminal. B. 81. Leg. 1780-1790. Doc. No 4. Fols. 14r-15r, 18r-v.

101 A. H. A. Criminal. B. 65. Leg. 1790-1800. Doc. No 1. Fol. 70v-71v.
} 
ordenó salir para "su patria". El reo pidió una certificación en que constara el delito por el que se le desterraba, pues de lo contrario los vecinos de Cartagena podían suponer que era por

alevoso, matador, forzador, ladrón o sacrílego. ${ }^{102}$

El poco uso del destierro pudo deberse a que los juristas del siglo xviI consideraban que esta pena no debía imponerse a hombres depravados, pues por liberar del daño a un lugar, se le causaba a otro. ${ }^{103}$

Un porcentaje apreciable de los juicios por injuria terminaba con transacciones hechas extrajudicialmente. Algunos querellantes terminaban el pleito mediante la suscripción de un convenio en que se perdonaban mutuamente y dejaban constancia de quedar ambos con su "honor a salvo". En estos documentos se señalaba que el convenio era fruto de la interposición de algunos sujetos de autoridad, lo que permite suponer que las autoridades usaban este medio para cortar las causas. Al exponer las razones por las que se hacía el convenio, invariablemente se hablaba de la caridad para con el prójimo, la pérdida de tiempo y dinero que representaban los pleitos y los pocos motivos que había tenido el agresor para hacer las sindicaciones, a las que siempre se presentaba como producto de un "acto primo". ${ }^{104}$

Este recurso fue utilizado para acabar los juicios seguidos entre parientes, pues como lo expresaban en 1794 Martín Rodríguez y José Manuel Durango, tío y sobrino, la opinión popular consideraba que si la discordia era "abominable" entre extraños, lo era mucho más entre parientes. En su convenio decían que la sindicación de perjuro, que el segundo le hizo al primero era

efecto de la pasión irascible, que entorpece los ánimos y como vertidas sin deliberación alguna; y que por consiguiente continúe cada uno en la posesión de su buena opinión y fama y se califique nuestra desavenencia,

\footnotetext{
102 A. H. A. Criminal. B. 64. Leg. 1790-1800. Doc. N 13. Fol. 9r-v.

${ }^{103}$ Lardizábal, Manuel. Ob. cit. Págs. 218-219.

${ }^{104}$ A. H. A. Criminal. B. 96. Leg. 1790-1800. Doc. N 11. Fol. 11 r-v.
} 
como discordias domiciliares de tíos y sobrinos que hoy riñen y mañana comen juntos en un plato. ${ }^{105}$

Algunos de estos convenios eran aprobados por la autoridad y en otros casos la causa simplemente concluía con su presentación. Los jueces solían considerar las transacciones "obras cristianas" que se dirigían tanto al bien sobrenatural como a tranquilizar a la república de las enemistades, odios e inquietudes que generaban los pleitos. ${ }^{106}$

Otros juicios concluían porque una de las partes desistía de continuar con el pleito. Se diferenciaba de la situación anterior en que la decisión era tomada por uno sólo de los implicados, casi siempre el ofendido. Así, por ejemplo, José Santana, quien siguió en 1793 un juicio a nombre de su suegra, doña Josefa López, contra José Martín Betancur y Paulino García, por haberla tratado de alcahueta de la mujer de Santana, decidió acabar el pleito atendiendo las súplicas de los hermanos de Paulino y otras personas de respeto. ${ }^{107}$

Esta determinación la tomaba la parte agraviada cuando se le ofrecía restituirle el "crédito", buscando evitar las consecuencias de un pleito largo. ${ }^{108}$ Igual que en el caso anterior, los jueces solían aprobar la "deserción voluntaria" que se hacía del pleito.

Un buen número de juicios por injuria (38 de 136, el 28\%) quedaron inconclusos porque las partes no volvieron a comparecer ante el juez. ${ }^{109}$ Es difícil saber las causas por las que se deja de tramitar un juicio, muchas veces apenas comenzado, otras cuando ya se habían presentado las pruebas. Sin embargo no es descabellado suponer que en algunos de estos pleitos se llegó a transacciones, sólo que no se protocolizaron ante la justicia.

${ }^{105}$ A. H. A. Criminal. B. 53. Leg. 1790-1800. Doc. $\mathrm{N}^{\circ} 11$. Fol. 34r-35r.

${ }^{106}$ A. H. A. Criminal. B. 96. Leg. 1790-1800. Doc. No 11 . Fols. $17 \mathrm{v}-12$ r.

${ }^{107}$ A. H. A. Criminal. B. 35. Leg. 1790-1800. Doc. $\mathrm{N}^{\circ}$ 7. Fol. 5r-v.

${ }^{108}$ A. H. A. Criminal. B. 37. Leg. 1790-1800. Doc. $\mathrm{N}^{\circ}$ 2. Fol. $27 \mathrm{r}-\mathrm{v}$.

${ }^{109}$ En esta cantidad también están computados unos pocos procesos que están incompletos por haberse perdido los folios finales. Este número no coincide con el del cuadro $\mathrm{N}^{\circ} 56$, debido a que en éste se contabilizaron los juicios que no terminaron con sentencia proferida por juez, lo que ocurrió en algunos de los casos de convenios o desistimiento. 
Así como el estudio de los motivos por los cuales se generaron los pleitos por injuria, ilustra sobre los conflictos que se presentaban en esa sociedad, el análisis de las causas por las que se hacían los convenios y se desistía de seguir una querella, permite conocer de qué manera se restablece la armonía. Las vecindades no eran sólo el lugar donde se daban confrontaciones y enemistades, también existían en ellas las alianzas y la amistad. Tomando como base las relaciones de compadrazgo y clientelismo, los jueces se apoyan en "personas de autoridad", para lograr un arreglo extrajudicial. En otras palabras la administración de justicia recurría a los servicios de los particulares para acabar los pleitos.

El propósito de los jueces al sentenciar los juicios por injuria no fue montar un "teatro del terror" que sirviera de escarmiento al resto de la población sino lograr que las partes se comprometieran a no agredirse. ${ }^{110} \mathrm{~A}$ través de la imposición de penas pecuniarias buscaban enseñar que los pleitos de esta clase eran una pérdida de tiempo y dinero. Las penas corporales las aplicaban a los reincidentes o a los forasteros "vagos y mal entretenidos".

Como lo ha anotado el historiador William B. Taylor refiriéndose a México en el siglo xviII, los gobernantes coloniales concebían los procesos como una experiencia instructiva para la población, en la que la ley era enseñada por las autoridades. ${ }^{111}$ Esto es especialmente cierto en los pleitos por injuria a través de los cuales los jueces trataban de hacer comprender que a nadie le era facultativo "tomar satisfacción de propia mano". En estos juicios se buscaba que la gente se apropiara de la idea de que la justicia estaba para arreglar los conflictos entre particulares. Esta noción está presente en un escrito presentado por un demandante en 1763 , quien decía haber acudido a la intermediación de la justicia pues en adelante podía

${ }^{110} \mathrm{El}$ concepto de teatro del poder es usado por E. O. Thompson para referirse a las ejecuciones y otros castigos empleados en Inglaterra durante el siglo XVIII.

Thompson, E. P. "Folklore, Anthropology, and Social History". Brighton. John L. Noyce Publischer. 1979. Págs. 10-11.

${ }^{111}$ Taylor, William B. Ob. cit. Pág. 141. 
no tener el sufrimiento que hasta aquí ha tenido amparado en la misericordia de Dios. ${ }^{112}$

Desde este punto de vista el juicio por injuria ayudaba a que los conflictos terminaran sin que se produjeran hechos de sangre. El que la gente presentara una demanda también significada que tenía confianza en que la autoridad oiría su queja y buscaría solucionar el problema.

Aunque los contemporáneos opinaban que estos pleitos únicamente servían para aumentar innecesariamente el trabajo de los juzgados y actualmente se ven como pérdida inútil de tiempo y dinero, la existencia de estos juicios era funcional para las autoridades coloniales que buscaban preservar el orden social. Por medio de ellos se controló la conducta de los miembros de las "castas", considerados como propensos a la vagancia, a los pleitos y a cometer ciertos delitos como el amancebamiento y el hurto.

La existencia de una cantidad tan grande de pleitos por injuria refleja que no existía cohesión en los vecindarios rurales o urbanos. Por el contrario, es visible la presencia de tensión étnica y oposición de intereses económicos entre los diferentes grupos raciales y sociales. Para las autoridades coloniales esto era conveniente, porque dificultaba la posibilidad de realizar una acción colectiva contra el régimen. De todos los grupos raciales los indios eran los que tenían una mayor conciencia colectiva, como lo demuestran los problemas que constantemente tenían con las autoridades civiles y eclesiásticas. En la jurisdicción de la ciudad de Antioquia, durante la época estudiada, la única protesta en que participó la gente mestiza y mulata fue en la que se hizo contra la implementación del estanco de tabaco en 1781. En esta ocasión, la intervención de los mulatos y pardos enriquecidos, miembros de las milicias de pardos, fue decisiva para controlar la revuelta e impedir que los amotinados entraran a la ciudad de Antioquia. El que el movimiento no se expandiera también dependió de la negativa de los indígenas de Sopetrán a vincularse. En muchos documentos de la época ellos dejaron constancia de que no habían participado en el motín, por estar liderado por mestizos y mulatos que habían invadido las tierras de sus

${ }^{112}$ A. H. A. Criminal. B. 79. Leg. 1740-1780. Doc. $\mathrm{N}^{\circ}$ 7. Fols. 1r. -2 r. 
resguardos. ${ }^{113}$ Como puede verse en esta coyuntura la estabilidad del régimen dependió de la oposición existente entre los intereses de los diversos grupos.

Las disputas que daban origen a los juicios por injuria muestran que los vecindarios eran conflictivos, pero la violencia verbal que ellos testimonian no ponía en peligro el orden social vigente. Al contrario, las autoridades utilizaron estos pleitos para controlar la conducta de los miembros de las "castas". Por lo que respecta a la región antioqueña este objetivo parece haberse logrado parcialmente.

${ }_{113}$ A. H. A. Comuneros. Tomo 332. Doc. N 6328. Fols. 18r.-19r. Criminal. B. 76. Leg. 17971800. Doc. $\mathrm{N}^{\circ}$ 2. Fols. 



\section{B. "Injurias de hecho" o lesiones personales}

En el derecho castellano, vigente para el siglo xviII, no existían como delito específico las lesiones personales o heridas. Las heridas, golpes, rasguños, bofetadas, etc., estaban incluidos en la categoría de injurias reales o de hecho. De acuerdo con las Leyes de Partida y el Fuero Real, cometía el delito de injuria real quien hería a otra persona con mano, pie, palo, piedra, arma o cualquier instrumento; le alzaba la mano con palo y otra cosa para herirle, aunque no le hiriera; le escupía la cara, le rasgaba o despojaba del vestido; pisaba o ensuciaba sus cosas; lo seguí apara herirlo o cogerlo; le encerraba en algún lugar o se metía por la fuerza en su casa. ${ }^{1}$ Este delito incluía toda clase de lesiones personales, siempre que de ellas no resultare la muerte, porque en este caso dejaba de ser injuria para convertirse en homicidio. ${ }^{2}$

Es importante precisar que desde el punto de vista legal se entendía como herida toda lesión hecha con violencia en las partes duras o blandas del cuerpo, es decir que este concepto cobijaba tanto las heridas propiamente dichas como las contusiones, fracturas, quemaduras y golpes capaces de perturbar las acciones vitales. De acuerdo a su gravedad, las heridas se dividían en mortales y no mortales. Las primeras se subdividían en "absolutamente mortales", es decir las que causaban la muerte a pesar de los auxilios que recibiera el afectado y "ordinariamente mortales", o sea las que con tratamiento podían dejar de serlo. Las segundas se subdividían en "heridas curables con lesión de funciones" y "heridas curables sin lesión consecutiva". ${ }^{3}$

En esta parte del trabajo nos referiremos a las heridas no mortales, porque dadas las condiciones de la atención médica existente en la provincia de Antioquia durante el periodo estudiado, ninguna persona a la que se le

\footnotetext{
${ }^{1}$ Escriche, Joaquín. Diccionario Razonado de Legislación y Jurisprudencia. París. México. Librería de la Viuda de Ch. Bouret. 1911. Pág. 875.

${ }^{2}$ Alvarez Posadilla, Juan. Práctica Criminal por Principios o Modo y Forma de Instruir los Procesos Criminales de las Causas de Oficio de Justicia. Imprenta de las Viuda e Hijos de Santander. Valladolid. 1802. Tomo III. Pág. 468.

${ }^{3}$ Escriche, Joaquín. Ob. cit. Pág. 765.
} 
infringía una herida mortal sobrevivía. La mayoría de los juicios consultados se refieren a lesiones leves que no tuvieron consecuencias, como lo atestigua el hecho de que sólo 74 de las 283 víctimas hubieran sido reconocidas por un práctico cirujano. Otro indicativo de la poca gravedad de los golpes o contusiones denunciados, es que únicamente 56 (27,59\%), de las 203 causas estudiadas, fueron seguidas de oficio por el juez.

A diferencia de los pleitos por injuria de palabra, cuyo número aumenta súbitamente en la década del 90, para después bajar rápidamente, los juicios por lesiones personales van aumentando progresivamente a lo largo del periodo estudiado. De 17 causas existentes para mediados del siglo xviII, se pasó, entre 1780 y 1809 , a un promedio por década de 34, para luego ascender a 41 en el decenio de la Independencia (ver cuadro $\mathrm{N}^{\circ} 58$ ). Este aumento no parece deberse a un mayor celo de los jueces en la persecución de este delito o a un cambio en la mentalidad de la población, sino que más bien es producto del crecimiento paulatino del número de habitantes de la jurisdicción de la ciudad de Antioquia durante esta época. En otras palabras, las heridas y golpes tendieron a ser denunciadas por las víctimas y las autoridades permanentemente procesaron gente por este delito.

\section{Las víctimas}

Para saber cuál era la opinión que la sociedad antioqueña del siglo xviII tenía del delito de "injuria de hecho", empezaremos analizando, quiénes y en qué circunstancias se vieron inmiscuidos en esta clase de delito.

A este respecto, lo primero que se encuentra es que de las 283 víctimas que figuran en los juicios estudiados, 199 (70,32\%) eran hombres y 84 $(29,68 \%)$ mujeres (ver cuadro $\left.N^{\circ} 14\right)$. Llama la atención el aumento progresivo en la proporción y número de mujeres que denunciaron haber sido agredidas físicamente. Mientras que en la década de 1750, sólo una de 17 víctimas era del sexo femenino, en la época de la Independencia, 25 de 55, eran de este grupo. Lo anterior puede haber sido el resultado de un cambio de actitud hacia el maltrato de las mujeres. Todo indica que los jueces empezaron a perseguir esta clase de delito, que anteriormente se había aceptado tácitamente, especialmente en el caso de las esposas. 
Existen ciertas diferencias en la clase de agresión que denunciaban hombres y mujeres. Un número apreciable de los juicios en que la víctima o víctimas pertenecían al sexo masculino fueron por heridas hechas con instrumentos cortopunzantes, especialmente en bazos, espalda y cabeza. Así, en 1752, el Alcalde ordinario don Antonio Ferreiro Cervino siguió una causa a Benito Garro, por haber herido con una espada en el "cuadril izquierdo" a Juan Lezcano. En la disputa, Garro en compañía de un esclavo suyo, atacaron al oponente con una espada y un machete. La víctima, por su parte, decía haberse defendido con un garrote y con piedras. ${ }^{4}$

En 1789 el Alcalde ordinario don Francisco José de Lora enjuició a Francisco Javier de Flórez, quien alevosamente había salido al camino y herido a Salvador Bravo, que se encontraba desarmado. Rafael Quintero, cirujano que hizo el peritazgo, hizo constar que la víctima tenía seis heridas "de riesgo", hechas con hierro cortante. De ellas, dos eran en la cabeza, tres en el brazo izquierdo hacia la muñeca y una en el brazo derecho, también hacia la muñeca. En su concepto era probable que el herido quedara "manco" de ambos brazos. ${ }^{5}$

A principios del siglo xix, en 1804, el Alcalde ordinario don Francisco Londoño procesó a don Bautista Díaz, vecino de Sopetrán, por haber hecho dos heridas a José Aniceto Barrantes, vecino del mismo lugar. De acuerdo con los prácticos cirujanos Agustín Muriel Pérez y Rafael Quintero, Barrantes tenía en el brazo derecho dos heridas, una en el hombro y otra en la muñeca, hechas con instrumento cortante. Estas no revestían gravedad y tampoco

traerán malos resultados, siempre que el paciente se cuide de sol y sereno, que son dos cosas que causan malos efectos. ${ }^{6}$

Años más tarde, en 1806, Agapito Sierra fue enjuiciado por el Alcalde José María Ortiz por haber herido gravemente al soldado Justo Erazo. El cirujano Rafael Quintero, quien hizo el reconocimiento dijo que el soldado tenía seis

\footnotetext{
${ }^{4}$ A. H. A. Criminal. B. 27. Leg. 1750-1760. Doc. $\mathrm{N}^{\circ}$ 2. Fols. 1r2r, 6v-7v.

${ }^{5}$ A. H. A. Criminal. B. 9975 Leg. 1788-1790. Doc. $N^{\circ}$ 1. Fol. 5r-6r.

${ }^{6}$ A. H. A. Criminal. B. 30. Leg. 1800-1810. Doc. ${ }^{\circ}$ 13. Fols. 1r-v, 3r-4r.
} 
heridas, de las cuales dos eran en un brazo, una en "los pechos" y tres en el rostro. De acuerdo con sus conocimientos, el herido estaba

bastante golpeado y que si no se cura tiene riesgo de la vida. ${ }^{7}$

Estas heridas eran lesiones graves en las que los jueces casi siempre procedían de oficio, después de haber tenido noticias del incidente a través del agredido o de un pariente suyo. En esta clase de delito siempre se empezaba la causa sin esperar que la víctima presentara una demanda escrita. La mayor parte de los heridos eran personas libres y pobres que solicitaban que su oponente pagara los gastos de su curación y los jornales que habían dejado de percibir.

También fue frecuente que los hombres denunciaran golpes dados con piedras o con palos, casi siempre en el rostro o la cabeza. Un ejemplo de estos juicios es el seguido en 1755 por el Gobernador José Barón de Chaves, contra Juan Félix de León, pasador del río Cauca, por haber maltratado con "obras violentas” y dado un golpe en la cabeza con un palo a José de Castro, vecino de Antioquia. ${ }^{8}$

En 1812, el Alcalde ordinario don Juan Bernardo Aguirre, procesó a Gabriel Periañez y a don Celedonio Mejía por golpear a don Toribio Jiménez con un palo. Según el reconocimiento hecho al herido, éste tenía el hueso de la nariz "quebrado o sentido", pero la herida no ofrecía riesgo. ${ }^{9}$

Cuatro años más tarde, el Alcalde pedáneo de Sopetrán, don Cristóbal Velásquez, empezó un juicio contra Antonio Navas por haberle dado a Vicente García un golpe sobre "una vista" con una piedra que tenía oculta en un pañuelo. El agresor decía que le había dado con la mano y García no había quedado privado, pues luego que los apartaron se levantó del suelo. ${ }^{10}$

Algunos hombres instauraron pleitos por "maltrato", palabra con la que se denominaba una combinación de bofetones, golpes, azotes y arañazos. En 1792,

\footnotetext{
${ }^{7}$ A. H. A. Criminal. B. 99. Leg. 1800-1810. Doc. $\mathrm{N}^{\circ} 28$. Fol. 1r-v.

${ }^{8}$ A. H. A. Criminal. B. 73. Leg. 1700-1740. Doc. $\mathrm{N}^{\circ}$ 18. Fol. 1r-2r.

${ }^{9}$ A. H. A. Criminal. B. 102. Leg. 1800-1820. Doc. No 17. Fol. 1r-v.

${ }^{10}$ A. H. A. Criminal. B. 78. Leg. 1800-1820. Doc. No 22. Fola. 2r-3r.
} 
don Cristóbal Velásquez, vecino de Antioquia, residente de Otra Banda de Cauca, presentó querella contra Gregorio Machado, Gobernador de los indios del pueblo de Sopetrán, por haberlo empujado y pegarle una bofetada. También acusó a los indios Ignacio Machado y Pedro Renegado de darle bofetones y tirones para apresarlo, así como de maltratarlo al intentar ponerlo en el cepo. Sin embargo, don Felipe Agustín de Castañeda, el "inteligente" que hizo el reconocimiento de las heridas, decía que sólo encontró una confusión no penetrante en la cabeza que "no amenazaba" peligro. ${ }^{11}$

De la misma clase fue la demanda instaurada en 1794 por Miguel de Urrego, del vecindario de Hato Viejo, jurisdicción de Medellín, "pobre y miserable”, contra el minero don Plácido Misas, de quien era jornalero, por haber ordenado a cinco esclavos suyos que lo castigaran. Estos negros lo golpearon y tumbaron al suelo, dándole contra una tarima donde cayó casi privado. Luego lo amarraron con un cordel grueso y lo colgaron de una viga, donde lo desnudaron de "medio cuerpo abajo", para darle 200 azotes. Afirmaba que lo anterior había sucedido a "ciencia y paciencia” de don Ramón Echendía, entenado de Misas. Gabriel y José Antonio de Rojas, quienes hicieron el reconocimiento de las heridas, dijeron que por las cicatrices dejadas se podía ver que el castigo había sido excesivo. ${ }^{12}$

Como se puede apreciar, varias de las acusaciones por maltrato fueron presentadas por el ofendido algún tiempo después de sucedidos los hechos. Ello podría deberse a que los golpes no eran graves o a que el castigo era dado en forma tan privada que los jueces sólo tenían noticias cuando el agraviado decidía comparecer. El carácter de vejamen o afrenta que tenía esta clase de delito tal vez impedía que más hombres los denunciaran. Las personas que lo hacían era para quejarse de la forma de proceder de personas prevalidas de su poder como autoridad o ricos propietarios. Es el caso de los esclavos o agregados que eran fuertemente castigados por sus amos o patrones.

Los hombres también instauraron demandas por golpes, bofetadas y contusiones leves. Se trataba de pleitos muy parecidos a los de injurias verbales,

\footnotetext{
${ }^{11}$ A. H. A. Criminal. B. 65. Leg. 1790-1800. Doc. $\mathrm{N}^{\circ}$ 10. Fols. 1r-2v.

${ }^{12}$ A. H. A. Criminal. B. 29. Leg. 1790-1800. Doc. $N^{\circ}$ 3. Fol. 1r-2r, 4r.
} 
en los que los litigantes pasaban a las vías de hecho. Como en el caso de los juicios por agravio, muchos ocurrían en los juzgados o en presencia del vecindario. Uno de estos juicios es el seguido en 1781 por el Alcalde pedáneo de San Jerónimo contra don José Ignacio Tuesta, por haber abofeteado en su presencia a don Vicente Arbeláez. Los hechos ocurrieron cuando las partes se encontraban litigando el pago de una deuda en el juzgado del Alcalde. El Alcalde al empezar el proceso decía que Tuesta había faltado al respeto debido a la Real Justicia, pues se había fugado de la prisión en donde lo puso y se fue para la ciudad de Antioquia. ${ }^{13}$

En esta clase de juicios, el agraviado solía ser un blanco, y los jueces actuaban a petición de parte.

Aunque fueron pocos, algunos hombres demandaron a mujeres por hacerles hechicerías o por intentar asesinarlos usando venenos. En estas causas se habla del uso del solimán (sublimado corrosivo) y de yerbas del bien querer y para matar. De esta clase fue la queja que Francisco José Sarrazola, vecino de Antioquia, presentó contra Teresa Pérez, con quien había tenido amistad ilícita. El agraviado sostenía que esta mujer había truncado su amor.

en rabia, rencor y deseos de venganza llegando su maldad a tanto que sin temor de Dios, ni a la justicia ha creído e intentado conseguirla por medio de maleficio o hechicería. Con estas solo no ha sido su ánimo privarme de la vida, sino que también ha hecho diligencias exquisitas para hallar quien a palos me la quite, lo que no habiéndole sido fácil, piensa arruinar mi honor cortos bienes, con falsos denuncios por cartas. ${ }^{14}$

De acuerdo con lo anterior, los juicios en que las víctimas eran hombres, pueden dividirse en dos grandes grupos: los seguidos por heridas más o menos graves, ejecutadas con instrumento cortopunzante y las lesiones personales leves, hechas con las manos o pies, sin intervención de arma alguna (ver cuadro $\mathrm{N}^{\circ}$ 26).

${ }^{13}$ A. H. A. Criminal. B. 52. Leg. 1780-1790. Doc. $\mathrm{N}^{\circ}$ 3. Fol. $1 \mathrm{r}-\mathrm{v}$.

${ }^{14}$ A. H. A. Criminal. B. 45. Leg. 1800-1810. Doc. $\mathrm{N}^{\circ} 13$. Fols. 1r-3r. 
La mayor parte de estos pleitos comenzaba con un intercambio de palabras en donde además de los insultos habituales de zambo, ladrón, pícaro, hijo de puta, era usual amenazar, desafiar o afirmar que no se estaba bajo la jurisdicción de una autoridad. Las amenazas eran del tipo de "el que tiene enemigos no duerme", "no había de parar hasta no matar a un salinero", "si venían cuatro Alcaldes los había de hacer pescadilllo", "le había de meter dos balas". En ellas se expresaba el propósito de atentar contra la vida de la persona, siendo usadas en los juicios como indicativo de haber realizado la acción con alevosía y de hecho "pensado". Los desafíos por su parte, eran afirmaciones de hombría y superioridad, con los que se instaba al otro a pelear. Algunas de estas expresiones eran: "que peliaba con quien iba a peliar", "que él era hombre para cobrarle por su puño su dinero", "deseaba estrellarse y echarlo al infierno", "que él tenía plata y que no se le daba nada”. También fue común que los agresores desafiaran la autoridad de los jueces, padres o personas mayores, mediante el uso de declaraciones del corte de: "que para él no había justicia”, "que fuera a gobernar en sus calzones", "Alcalde de porquería, que se ensuciaba en él y los demás blancos de Sopetrán”. Los enunciados anteriores eran empleados para demostrar que las lesiones personales no eran fruto de la casualidad o de un accidente, sino que habían estado precedidas de intencionalidad.

La mayor parte de los juicios en que las víctimas eran mujeres fueron por maltrato. Fueron pocos los casos en que recibieron heridas con arma blanca, siendo lo común que se les pegara y azotara. En algunas ocasiones las mujeres eran agredidas a golpes por personas con las que tenían un conflicto. Esto fue lo que le sucedió, en 1758, a Teresa de la Serna, mujer casada, quien fue maltratada por Juan Quintero en una disputa que tuvieron por un poco de iraca que el agresor cortó en tierras de la querellante. El médico don Antonio Martínez, quien hizo el reconocimiento, encontró que Teresa había sido golpeada en la cara, barriga y espalda, aunque no de riesgo. ${ }^{15}$

Otro ejemplo de estas peleas, es el pleito seguido en 1762 por Juana Antonia de León, negra libre, contra Mateo Lobato, quien le amarró ambos brazos, la colgó y le dio azotes y golpes estando embarazada. Este castigo se

\footnotetext{
${ }^{15}$ A. H. A. Criminal. B. 92. Leg. 1740-1770. Doc. $\mathrm{N}^{\circ}$ 7. Fol. 1r-v.
} 
lo propinó por haberle informado a la mujer de Lobato acerca el concubinato que éste tenía con Francisca Serna, mulata libre. ${ }^{16}$

Al igual que en el caso de los hombres, los juicios por golpes leves o bofetadas se asemejan a las causas por injuria. Esta situación nos la ilustra la demanda puesta a fines del siglo, en 1799, por don Juan Bautista Méndez contra Felipe de Vargas, por haber dado unos bofetones a su esposa doña Petrona Díaz. En la disputa también intervino el padre de Felipe, Ignacio de Vargas, quien supuestamente insultó a la víctima diciéndole que "ella no podía hablar porque tenía porquerías". En una representación, Vargas decía que el querellante, que era forastero, no había hecho constar su fe de bautismo, filiación y licencia del soberano para pasar a Indias. Argumentaba que había intervenido, pues la mujer de Méndez había tratado a su esposa de "grandísima puta”. Sostenía que Petrona, en compañía de su madre, hermano y una mulata esclava, intentaron matar a piedras a su hijo Felipe, por lo cual él actuó en defensa. Concluía demandando a la mujer de Méndez para que probara el insulto "con que ofendió a su esposa". ${ }^{17}$

Dentro de las agresiones contra mujeres se encuentran unos pocos juicios por violación o intento de "forzamiento". La descripción de los hechos que se hace en ellos no permite saber con certeza si la violación se llevó a cabo o si se trataba de mujeres golpeadas por haberse negado a tener relaciones sexuales. Esta ambigüedad está presente en la demanda puesta en 1775 contra Manuel Maxilio del Valle, libre, casado con una india del pueblo de Sabanalarga, por Agustín Mejía, libre, quien lo acusaba de solicitar y perseguir a su hija Salvadora Teodora Mejía. En una representación se decía que el citado buscaba "cogerla sola y en despoblado" para violarla, y en una ocasión Salvadora se defendió dándole un mordisco en la lengua, pues Manuel Maxilio se la había metido en la boca. Al contar la muchacha a la mujer de Del Valle que éste la solicitaba, el citado la insultó y la maltrató hasta descalabrarla. En su confesión, el agresor decía que nunca había tenido efecto "la consecución de lo que con ella pretendía". ${ }^{18}$

\footnotetext{
${ }^{16}$ A. H. A. Criminal. B. 57. Leg. 1760-1770. Doc. $\mathrm{N}^{\circ}$ 7. Fol. $1 \mathrm{r}$.

${ }_{17}^{17}$ A. H. A. Criminal. B. 87. Leg. 1800-1810. Doc. $\mathrm{N}^{\circ} 1$. Fols. 1r, 4r-5r.

${ }^{18}$ A. H. A. Criminal. B. 85. Leg. 1770-1790. Doc. $N^{\circ}$ 10. Fols. 1r-2v.
} 
La misma situación se presentó en 1796, cuando el Alcalde ordinario don Francisco Londoño y Gallón abrió un proceso contra José Antonio Castañeda, pardo libre, por haber golpeado a María Antonia Ferraro con intención de forzarla. ${ }^{19}$

Tampoco es claro lo que sucedió en 1814, con Bernarda Vallejo, pobre mendiga a quien José Zapata y Rudesindo Bolívar privaron de su libertad, le levantaron la saya y "maltrataron" en presencia de dos menores. ${ }^{20}$

La violación era definida por la ley como la violencia que se hacía a una mujer para abusar de ella contra su voluntad. Como probar este delito era difícil, se aconsejaba a los legisladores que sólo admitieran las quejas de violencia evidentes y reales. ${ }^{21}$ Tal vez esto explique que en los juicios estudiados no se hizo hincapié en la violación misma, sino en el maltrato y las heridas causadas. Para evitar que la honestidad de la comprometida fuera puesta en duda, se subraya la oposición hecha por la víctima al agresor. De esta manera la imagen de la mujer era reparada y se limpiaba su honor frente a la sociedad. No obstante, las murmuraciones que despertaba un pleito de éstos, hacía que fueran pocos los juicios que se instauraban por violación. Llama la atención que todos los ejemplos anteriores se refieran a mujeres de condición humilde, lo que significa que las clases altas preferían no seguir este tipo de pleitos, por no vulnerar la reputación de la víctima y de su familia. ${ }^{22}$

Una actitud diferente es la que se desarrolló con relación al maltrato que los maridos daban a las esposas. A mediados del siglo eran pocos los pleitos de esta clase que se tramitaban. Un ejemplo de las disputas que eran denunciadas es el juicio seguido en 1773 por el Alcalde ordinario don Fermín García contra Salvador Ochoa, residente en San jerónimo, por haber maltratado a su esposa María Sebastiana Ruiz. De acuerdo con la declaración de ella, el marido primero le había aporreado la cabeza y el cuerpo hasta dejarla aturdida,

${ }^{19}$ A. H. A. Criminal. B. 51. Leg. 1790-1800. Doc. No 14. Fol. 1 r.

${ }^{20}$ A. H. A. Criminal. B. 102. Leg. 1800-1820. Doc. $\mathrm{N}^{\circ} 27$. Fol. $1 \mathrm{r}-\mathrm{v}$.

${ }^{21}$ Escriche, Joaquín. Ob. cit. Pág. 1538.

${ }^{22}$ Un análisis de la tradición católica frente a la violación y del comportamiento de los inmiscuidos en esta clase de pleitos se puede ver en: Giraud, François. "La Reacción Social ante la Violación: Del Discurso a la Práctica. Nueva España. Siglo XVIII". En: El Placer de Pecar y el Afán de Normar. México. Joaquín Mortiz. Instituto Nacional de Antropología e Historia. 1987. 
después la colgó, para castigarla con una soga. El cirujano José de Borja, al hacer el reconocimiento encontró que la víctima tenía dos heridas peligrosas en el muslo, de mal olor y aspecto, que parecían hechas con instrumento cortante. El resto del cuerpo, estaba cubierto de heridas desde la planta del pie hasta la cintura, al parecer ejecutadas con azote. Además en el costado izquierdo, sobre las costillas, tenía un tumor, lo que podía significar que había algún hueso quebrado. Las heridas más gruesas y profundas estaban corruptas y la paciente tenía calentura. ${ }^{23}$

La renuencia a denunciar esta clase de agresiones, se explica por el temor de las esposas a posibles venganzas por parte del marido y a quedar expuesta a los comentarios del vecindario, parece haber cedido a partir de la década del 80. El cambio pudo ser producto de la acción de los gobernadores visitadores, Francisco Silvestre y Mon y Velarde, quienes se dedicaron a controlar las conductas desviadas con respecto a los postulados de la religión católica y las leyes. Gran parte de los casos tramitados fueron denunciados por vecinos o parientes de la víctima, por tratarse de lesiones graves. Es lo que sucedió en 1785, cuando Bruno Benítez fue procesado de oficio por el Alcalde ordinario don Francisco Antonio Otero y Cossio, al tener noticas de que éste había herido a su mujer. En el reconocimiento hecho por Rafael Quintero se encontró que Gabriel de Torres, su esposa, tenía una herida honda y "suelta de sangre" en la cabeza, varios golpes en la caja del cuerpo y un golpe sobre la ceja del ojo derecho, los cuales parecían hechos con garrote. En concepto del perito, si no se la trataba con las "medicinas correspondientes", estaba en "peligro de muerte". Según el testimonio de la víctima, su marido la golpeó en la cabeza con un mazo de carpintería, habiendo caído privada. Los hechos ocurrieron a las 9 de la mañana y estuvo tendida en el suelo hasta las 4 de la tarde, cuando llegó el Alcalde. ${ }^{24}$

A principios del siglo xix, los juicios por maltrato a la esposa se incrementaron. Así, de 47 causas existentes, 24 corresponden al periodo 1800-1819. En esta época se siguieron algunas causas por lesiones graves, como el proceso

${ }^{23}$ A. H. A. Criminal. B. 34. Leg. 1700-1780. Doc. $\mathrm{N}^{\circ} 18$. Fols. $1 \mathrm{r}-2 \mathrm{v}, 3 \mathrm{r}-4 \mathrm{r}$.

${ }^{24}$ A. H. A. Criminal. B. 32. Leg. 1780-1790. Doc. $\mathrm{N}^{\circ} 12$. Fols. 1r-2r, 9r-10r. 
adelantado en 1815 contra Pedro Antonio Montes, quien castigó a su esposa Feliciana Palacio como a "vil esclava", teniéndola amarrada y con herradura. La citada declaró que hacía aproximadamente un mes, su marido la encerró en la tienda de su casa, le puso una herradura de hierro en una pierna, le ató de ambas manos, la colgó de una viga de la casa y luego de desnudarla le azotó el cuerpo con unas riendas de rejo. Después da darle este castigo, intentó darle puñaladas con un cuchillo. Al otro día la golpeó y aporreó, y con una vela le quemó los vellos de las "partes más ocultas". Una semana después el marido la hizo seguirlo a un rastrojo, donde le ató las muñecas, la pegó a un tronco y desnudándola la castigó con un rejo. Unos días más tarde, la azotó con ropa puesta, sin amarrarla, dándole golpes y pescozadas hasta descomponerle la quijada. Terminaba su declaración afirmando que durante todo el matrimonio, su marido la había golpeado, y desde hacía un mes que la había puesto presa, amarrado, desnudado y azotado, razón por la cual presentó querella ante el juez. El reconocimiento de la víctima fue encargado a tres mujeres, quienes dijeron que aquella estaba muy castigada con rejo en las nalgas, muslos y espaldas. En el párpado derecho tenía una contusión, en el muslo izquierdo tenía una cicatriz de mordisco y los vellos de sus "partes" estaban chamuscados. ${ }^{25}$

A fines de la época de la Independencia, los juzgados estaban atestados de causas por maltrato a mujeres. Cuando uno esperaba encontrar disputas entre partidarios del gobierno realista y el patriótico, vemos que las autoridades estaban dedicadas a dirimir pleitos familiares. A diferencia de lo ocurrido en los juicios por injuria, en los que las denuncias presentadas por mujeres tendían a ser descartadas por los jueces como chismes, "dichos" o "voces" la evidencia material del maltrato, hizo que tuvieran que tramitar estos pleitos.

Para trazar un perfil más completo de las víctimas de agresiones físicas debemos analizar los datos disponibles sobre su origen étnico. De acuerdo con la información recogida, de 283 víctimas, 40 (14,13\%) eran blancos, 193 $(68,20 \%)$ mestizos y mulatos libres, $17(6,01 \%)$ indios y $33(11,66 \%)$ negros esclavos (ver cuadro $\mathrm{N}^{\circ} 15$ ).

${ }^{25}$ A. H. A. Criminal. B. 78. Leg. 1800-1820. Doc. $\mathrm{N}^{\circ} 19$. Fols. $1 \mathrm{r}-6 \mathrm{r}$. 
Si comparamos estos datos con los obtenidos en el caso de las injurias de palabra, vemos que la presencia de los blancos como víctimas disminuye visiblemente (pasa del 44,91\% al 14,13\%). Adicionalmente hay que anotar que gran parte de los pleitos en que están involucrados se asemejan a los juicios por agravio. Un ejemplo que nos sirve para corroborar esta afirmación es la demanda puesta en 1785 por don Miguel de Palacios y Navarro, español, vecino de Antioquia, contra Juan Balbín, pardo libre, del mismo vecindario, por haberle dado una bofetada. El ofendido consideraba que éste era un hecho "injurioso y alevoso", más proviniendo de un

ser tan inferior a él, por ser como es un mulato libre. ${ }^{26}$

Otro juicio que ilustra lo dicho es el seguido en 1799 por don Juan Antonio de Salazar, oficial segundo de las Cajas Reales de Antioquia, contra Andrés García también apellidado Yepes, mulato libre e hijo de esclavo. En una disputa originada en el hecho de que García estaba imitando a don Juan Bautista del Corral, éste trató a Salazar de "cochino" (persona sucia, mezquina) y le dio un golpe con un garrote. Con posterioridad, al ir a la casa del ofendido a comunicar una citación del juzgado, García discutió con la hermana de éste y la trató de zamba. El agredido decía que ninguna paciencia podía tolerar tales vejámenes, inferidos por

un hombre tan de baja esfera y sin freno alguno. ${ }^{27}$

Como se puede apreciar los demandantes eran blancos que sentían su posición social amenazada por una capa de mulatos y mestizos cada vez más numerosa y menos sujeta a lazos de dependencia económica. En sus representaciones pedían que se castigara a estos libres de "genio altivo y atrevido", para que sirviera de escarmiento a los de su "naturaleza y condición".

${ }^{26}$ A. H. A. Criminal. B. 36. Leg. 1780-1790. Doc. No 2. Fol. $1 \mathrm{r}-\mathrm{v}$.

${ }^{27}$ A. H. A. Criminal. B. 83. Leg. 1790-1820. Doc. $\mathrm{N}^{\circ} 25$. Fols. 1r-2v. 
Algunas de las agresiones contra blancos se originaron en acciones que éstos desarrollaron como jueces. Tal vez el atentado más grave contra una autoridad ocurrió en 1760 cuando el Alcalde ordinario don Francisco Salvador de Lara y Moncada fue herido en el brazo derecho con una pistola. Al interrogarlo el Gobernador Barón de Chaves sobre los autores del atentado, el Alcalde declaró sospechar de José de Agudelo a quien, por estar concubinado, le había prohibido pasar a la ciudad de Antioquia. También sospechaba de algunos de los parientes de José de Lenes, quien estaba preso por haber herido con una piedra a Ignacio Bastida. Como este reo había hecho resistencia cuando se lo puso preso, y después habló "contra su Majestad”, el Alcalde ordenó amarrarlo a una reja y azotarlo. Este hecho produjo la indignación de sus parientes. ${ }^{28}$

Los abusos de autoridad o la resistencia de los infractores de la ley a ser juzgados, eran el origen de estos conflictos. Sin haber alcanzado a ser una situación preocupante, se ve que los vecinos de la jurisdicción de la ciudad de Antioquia entre 1750 y 1779, se resistieron a las intromisiones de los jueces en sus vidas, las cuales eran cada vez más notorias.

La mayor parte de las víctimas de agresiones físicas eran mestizos y mulatos libres. La prevención que existía contra este sector de la población, considerado inquieto y propenso al desorden, hacía que las autoridades intervinieran rápidamente en las disputas protagonizadas por ellos. Es interesante anotar que a este grupo pertenecía un porcentaje alto, el 73,80\%, de las mujeres que fueron maltratadas. Si tenemos en cuenta que tres cuartas partes de la población de la jurisdicción de la ciudad de Antioquia era gente libre, es natural su participación en una gran cantidad de pleitos (ver cuadro $\mathrm{N}^{\circ}$ 66). A nuestro entender, es la composición demográfica, más que la propensión a los pleitos, lo que explica la presencia tan alta de mestizos y mulatos en los juicios por lesiones personales.

Dentro del grupo de víctimas sobresale la presencia de negros esclavos que se quejaban de maltrato por parte de sus amos. Desde mediados del siglo, los esclavos se presentaron ante los jueces para denunciar el haber sido

\footnotetext{
${ }^{28}$ A. H. A. Criminal. B. 92. Leg. 1740-1770. Doc. ํo 9. Fols. 1r-5v.
} 
castigados por sus dueños y pidieron que se les permitiese cambiar de amor. Como ejemplo de este proceso tenemos el caso del negro José, esclavo de don Félix Jaramillo, vecino de Medellín, quien en 1759 huyó para presentarse ante el Gobernador de la provincia a quejarse del "sumo castigo" que le daba su amo. Don Antonio Martínez, quien hizo el reconocimiento, encontró que el negro tenía en el muslo izquierdo unas llagas que estaban

muy peligrosas a causa de haberse vuelto una fístula profunda con mucho hedor malo en ella y coger los muslos y nervios de aquella parte y poder redundar la muerte sino se remedia la causa con las medicinas que requieren semejantes llagas. ${ }^{29}$

El esclavo puso de manifiesto las heridas y contusiones para solicitar al Gobernador que le "diese otro amo".

Estas quejas aumentaron considerablemente en la década del 90 como producto de la publicación de la Real Cédula de 31 de mayo de 1789, la cual fijaba nuevas normas para el tratamiento de los esclavos y creaba algunas obligaciones para los amos. ${ }^{30}$ En ella se establecía que los castigos infringidos a los esclavos no podían pasar de 25 azotes, dados con instrumento que no hiciera daño; prohibía terminantemente las mutilaciones y señalaba el procedimiento judicial que se debía seguir en las causas por malos tratamientos. Los esclavos rápidamente se apropiaron de su contenido e inundaron los juzgados con peticiones de compra de libertad y cambio de dueño, sustentadas en el incumplimiento de los deberes de alimentarlos y vestirlos "decentemente".

${ }^{29}$ A. H. A. Criminal. B. 56. Leg. 1740-1770. Doc. $\mathrm{N}^{\circ}$ 11. Fols. 1r, 4r-v.

${ }^{30}$ Jaramillo Uribe, Jaime. "Esclavos y Señores en la Sociedad Colombiana del siglo xvin". En: Ensayos sobre Historia Social Colombiana. Bogotá. Biblioteca Universitaria de Cultura Colombiana. 1968. Págs. 29 y 33.

La mayor parte de las causas por maltrato de esclavos no se encuentran en el fondo de juicios criminales, pues fueron tramitadas como juicios civiles por contener discusiones sobre la propiedad de éstos. En este trabajo solo se revisó el archivo de estos juicios hasta 1800. El escaso número de esclavos víctimas de agresiones físicas que figura para el periodo 1800-1819 en el cuadro $\mathrm{N}^{\circ} 15$, variaría considerablemente si se le pudieran adicionar los datos de los juicios tramitados en este periodo. 
Los propietarios de esclavos, por su parte, trataron de defender sus derechos como amos recurriendo a argucias legales y aún a castigos.

Esta situación nos la ilustra el juicio que sobre la compra de su libertad siguió en 1791 Andrés, esclavo de Josefa rodríguez. El esclavo, por intermedio del defensor general de menores, que quejó al Alcalde ordinario de que su propietaria le había pedido una "cantidad exorbitante" por su libertad, impidiéndole que pudiera obtenerla. La dueña argumentó que había recibido al esclavo a la muerte de su marido, a cuenta de la tutela de sus hijas, por lo que no le parecía "regular" que se rebajara su valor. El Alcalde, don Juan Pablo Pérez de Rublas, aprobó el avalúo hecho por peritos, quienes consideraron que el valor del esclavo era de 35 pesos, pues tenía una "quebradura bastante grande", dolencias de la cintura para abajo y un ojo nublado. Al entregar el esclavo al ama el valor de su libertad, ésta lo castigó con azotes y lo puso preso en unas herraduras. El Alcalde, entonces, le siguió juicio a María Josefa Rodríguez por haberse atrevido a castigar a un esclavo que estaba bajo el "amparo de la justicia" y porque después de castigarlo y ponerlo en prisión, no cumplió una orden del juzgado que le mandaba ponerlo en libertad. En su declaración, la procesada se defendía alegando ignorancia. ${ }^{31}$

En otras ocasiones fueron los amos los que se presentaron ante la autoridad a denunciar agresiones físicas hechas contra sus esclavos. Este es el caso de la demanda puesta en 1791 por doña Gervacia Sierra, vecina de Antioquia, contra el mulato Nicolás Herrón por haber hecho abortar a su esclava Tiburcia, al intentar forzarla. De acuerdo con el testimonio de la víctima, la criatura estaba viva cuando salió, y el agresor abrió un hoyo para sepultarla. Ella había ocultado este hecho por el temor de que le hicieran algún daño, confesándolo sólo al indagársele sobre el hijo que esperaba. En las dos confesiones que se le tomaron, el reo negó el hecho, afirmando que todo era falso. ${ }^{32}$

En las situaciones descritas, las dueñas actuaron en defensa de su derecho de propiedad. Una, para impedir que la libertad del esclavo fuera otorgada y la otra, para indagar por el hijo que su esclava estaba esperando.

\footnotetext{
${ }^{31}$ A. H. A. Esclavos. Tomo 32. Doc. $\mathrm{N}^{\circ} 1045$. Fols. 1r, 2r-3r, 19r-v, 22v-23v, 26r-v..

${ }^{32}$ A. H. A. Criminal. B. 9996 Leg. 1790-1800. Doc. No 8. Fols. 1r-v, 2v-3r, 4r-v, 7v-8r.
} 
El código de 1789 que supuestamente se promulgó para proteger a los esclavos, pudo servir para que los amos aumentaran el control sobre ellos. En algunas partes como Venezuela y el Caribe, los criollos se opusieron abiertamente a su aplicación. ${ }^{33}$ En la jurisdicción de la ciudad de Antioquia no se dio un rechazo abierto, pero los propietarios de esclavos en la práctica se negaban a cumplir sus disposiciones.

Con respecto a las edades de las víctimas encontramos que cuatro de ellas eran menores de nueve años y ocho estaban entre los 10 y los 19 años (ver cuadro $\mathrm{N}^{\circ} 17$ ). Algunos niños y adolescentes resultaron con lesiones en hechos que parecen haber sido accidentales, como ocurrió en 1757 con un sobrino de don Gregorio López, huérfano, quien fue herido por Manuel Antonio Hidalgo. Según la declaración del niño, estando en la puerta de su casa, el implicado entró a tomar agua, llevando la espada desnuda. Al salir, sin darse cuenta, le dio una estocada arriba del ombligo. ${ }^{34}$

Otros menores fueron agredidos como resultado de conflictos originados en el vecindario. Así, en 1785, Rosalía Gómez puso una queja contra su vecina Josefa García por haber aporreado a su hijo José María. En el reconocimiento del muchacho se encontró que tenía calentura y "pasmo", pero el perito consideró que la herida no era cosa de cuidado por ser muy corta. Con posterioridad, el muchacho fue llevado al hospital, donde fue revisado y se encontró que había sido azotado. Según el enfermo, fue castigado por su padre debido a la pendencia que tuvo con Josefa García, pero su recaída se debía a haberse lloviznado. Como el herido murió, la sindicada se vio a las puertas de ser procesada por homicidio. Al tomársele confesión, dos meses después de sucedidos los hechos, afirmó que ella sólo le dio a José María dos bofetadas, debido a que había maltratado a un hijo suyo. Aseguraba que no había fallecido como consecuencia de estos golpes, porque con posterioridad había estado cargando racimos de guineo y pajariando una roza en el sitio del Caimán. El asesor jurídico, el doctor José

33 Mömer, Magnus. La Reorganización Imperial en Hispanoamérica 1760-1810. Tunja. Ediciones Nuestra América. 1979. Pág. 31.

Lynch, John. Las Revoluciones Hispanoamericanas 1808-1826. Barcelona. Editorial Ariel. S.A. 1983. Pág. 32.

${ }^{34}$ A. H. A. Criminal. B. 34. Leg. 1700-1780. Doc. No 10. Fol. 1r-2r. 
Joaquín Gómez, consideró que la víctima no parecía haber muerto a consecuencia de los golpes propinados por Josefa y consecuentemente se la debía declarar libre del delito. Inexplicablemente el padre del muchacho no fue procesado, aunque parecía implicado en su muerte..$^{35}$

La agresividad en las relaciones familiares también explica algunos de los casos en que las víctimas fueron personas mayores de 50 años. En 1787 el Alcalde ordinario don José Joaquín de Otero Cossio inició un proceso contra Francisco Remigio Díaz por haber golpeado a su suegra Juana María López de 60 años. Según la declaración de la víctima, tenía dislocado el hueso del cuadril y un golpe en la punta del hombro, pues fue tirada al suelo por su yerno al interponerse para que dejara de golpear a la esposa de éste. Esta a su vez fue maltratada por tratar de impedir que se castigara a un hijo. ${ }^{36}$

Como puede verse, entre las personas que fueron "injuriadas de hecho" están presentes menores de edad y personas de edad avanzada. Sin embargo, la mayor parte de las víctimas tenían de 20 a 39 años (ver cuadro $\mathrm{N}^{\circ} 17$ ). Las personas adultas jóvenes son propensas a intervenir en pleitos y peleas, por eso es lógico que muchas de ellas reciban golpes y heridas. En múltiples estudios sobre crímenes contra la persona se ha encontrado que el grupo de personas entre 15 y 34 años, es el más propenso a intervenir en esta clase de hechos. ${ }^{37}$

De los dicho anteriormente, podemos concluir que el grupo de víctimas de los juicios por injuria de hecho, es un poco diferente al de los ofendidos en los procesos por injuria verbal. Comparándolos encontramos que las quejas por lesiones personales involucran un porcentaje alto de mujeres, además de esclavos y menores de edad, cuyas demandas no eran oídas en las causas por agravio.

\section{Los agresores}

Las características de las personas procesadas por el delito de lesiones personales en la ciudad de Antioquia entre 1750 y 1819 pueden ser esbozadas

${ }^{35}$ A. H. A. Criminal. B. 59. Leg. 1780-1790. Doc. $\mathrm{N}^{\circ} 2$ (II). Fols. 1r-2r, 4r-5v, 13r-14v, 15r-16v.

${ }^{36}$ A. H. A. Criminal. B. 81. Leg. 1780-1790. Doc. $\mathrm{N}^{\circ}$ 19. Fol. 1r-2v.

${ }^{37}$ Cohen, David y Eric A. Johnson. "French Criminality: Urban-Rural. Differences in the Nineteenth Century”. Journal of Interdisciplinary History. XII. \# Winter. 1982. Pág. 484. 
con alguna precisión, pues a un poco más de la mitad de los procesados se les tomó confesión o declaración (145 de 273). Al empezar estas indagatorias el acusado era interrogado sobre su nombre, vecindad, etnia, estado civil, edad, ocupación y, al concluirla, se dejaba constancia si la había firmado o no, lo que sirve de indicio sobre sus conocimientos de lectura y escritura. Con base en estos datos trataremos de ver quiénes y en qué circunstancias recurrieron a las vías de hecho en sus pleitos.

El primer rasgo para señalar es la poca presencia de las mujeres en el grupo de agresores (24 de 273), hecho que se puede explicar por su menor fuerza física y el que no acostumbraran a andar con machetes o bordones como los hombres. Es el sexo masculino el que solía emplear métodos violentos para defenderse de los ataques o para agredir a los oponentes.

Dentro del grupo de procesados sobresalen algunos por su tendencia a intervenir en pleitos o a provocarlos, constituyéndose en verdaderos perturbadores de "la paz pública". La atención de las autoridades civiles y eclesiásticas, sobre todo antes de 1790, se centró en estos sujetos, y se insistió en la conveniencia de desterrarlos para evitar pendencias. En 1762 el coadjutor del Valle de San Andrés de Cauca, el sacerdote don Javier de Villa y Castañeda solicitaba al capitán a guerra de ese lugar, don Andrés Salgado, que desterrar a Ignacio Oquendo por quimerista, revoltoso y vivir sin respeto a sus superiores. Hacía su solicitud teniendo en cuenta que en ese sitio vivían

en un continuo sobresalto de que a causa del dicho se ofrezcan muertes o lo maten por lo provocativo que es de los compañeros y su escandaloso e irregular modo de vivir. ${ }^{38}$

El hermano del acusado, Sebastián de Oquendo, declaró que éste maltrataba continuamente a su esposa, se apoderó de un camino que era de todos los vecinos no estando en tierras suyas y continuamente tenía pleitos con el vecindario.

\footnotetext{
${ }^{38}$ A. H. A. Criminal. B. 28. Leg. 1760-1770. Doc. № 2. Fol. 1r.
} 
Teniendo en cuenta los excesos que este sujeto había cometido en el pueblo de Sabanalarga y en el Valle de San Andrés del Cauca, consistentes en haber herido a Francisco de Castro, estar concubinado con una mujer casada, andar con armas ocultas aún en la iglesia y haber buscado a Marcelo de guzmán para matarlo, el capitán a guerra le ordenó salir desterrado.

Otro reo a quien se le acumularon varios cargos en contra fue a Migue Amasara, mestizo, guarda del estanco de aguardiente de la ciudad de Antioquia. En 1782 el gobernador Cayetano Buelta Lorenzana le siguió una causa por haber herido con un sable a José de Ayala, mulato, vecino de Popayán y a Manuel Zamarra, mulato vecino de Medellín, quienes se dedicaban a conducir las cargas de tabaco de la administración de Medellín a las subalternas. Según los heridos, amasara los atacó por haberle dicho "adiós zorrito". El mismo año fue puesta demanda verbal contra él y su hermano Antonio, por el hurto de dos reses. Cuatro años más tarde, el Alcalde de la Santa Hermandad reabrió la causa debido a los excesos cometidos por este sujeto. Se le acusaba de haber intentado herir a Francisco Muñoz, provocar a Antonio Ruiz haber injuriado a Francisco Miguel Cañola al decir que su hija era hija de un negro Mira y descomponerle el brazo a José Miguel de Flórez. El acusado en su confesión afirmó no haber tenido pendencias, sino "chanzas" por tener el espíritu jocoso. Señalaba que en cuatro ocasiones había estado preso, en dos casos por concubinato con indígenas de Sopetrán, en otro por contrabando de aguardiente y por los sablazos dados a los arrieros del estanco de tabaco. El Oidor visitador Juan Antonio Mon y Velarde, en consideración al genio inquieto y provocativo que se agravaba por su costumbre de tomar aguardiente, lo condenó a que sirviera un año en las obras públicas de esa ciudad y a destierro por seis años del pueblo de Sopetrán. ${ }^{39}$

En la década del 80 fueron comunes estos juicios contra individuos que constantemente intervenían en pleitos, pero posteriormente se hicieron raros estos casos. Ello pudo deberse a que el control ejercido por las autoridades sobre la población, impedía que alguien se dedicara a causar conflicto o a que los gobernantes dejaron de prestarle atención a muchas de estas pendencias.

${ }^{39}$ A. H. A. Criminal. B. 85. Leg. 1770-1790. Fol. 1r-2r, 5r-6v, 11r, 21r-22r, 23r,26r, 39r-40r. 
Otra característica de los agresores, que interesa señalar, es su origen étnico. De ellos, 61 (22,34\%) eran blancos; 178 (65,20\%) mestizos y mulatos libres; 26 (9,52\%) indios y ocho $(2,93 \%)$ negros esclavos. Si comparamos estas cifras con las referentes a las víctimas, encontramos que los blancos figuran más como ofensores que como ofendidos. Algunos de los pleitos en que intervinieron fueron entre blancos, casi siempre originados en rencores. Así, don Juan Antonio Díaz de Mazo, residente en el sitio de San Jerónimo, acusó en 1773 a don Antonio Piedrahíta, a don Salvador de Piedrahíta y a don Ignacio Delgado de salir a matarlo al camino real, armados de garrotes y espada. Según Díaz, el año anterior, siendo Alcalde pedáneo, había rondado a don Antonio de Piedrahíta, por estar "amancebado". Por su parte, el Alcalde de la Santa Hermandad, don Joaquín Restrepo, había prendido a don Salvador, por inobediente. En consecuencia, el ataque de que había sido objeto era una venganza por su actuación como juez. ${ }^{40}$

Sin embargo, la mayor parte de los agredidos por blancos eran gente de condición social baja, indios, esclavos y libertos. Los terratenientes y mineros solían castigar a sus agregados y vecinos, cuando creían que les habían faltado al respeto o que se estaban apropiando de sus bienes. Prevalidos del hecho de ser parientes de los jueces y de su condición social, trataban negarse a responder a los cargos cuando eran denunciados en el juzgado. En 1765, el Gobernador del pueblo de indio de El Peñol, acusó a don Cristóbal Echeverri de abrir la cabeza con un palo a un "niño de doctrina". El protector de naturales, Juan Andrés de Zabala, pedía que se castigara al culpable para que los indígenas dejaran de ser maltratados por lis libres que vivían contiguos a sus tierras. Echeverri al declarar, dijo que los hechos ocurrieron en las tierras de La Ceja de Guatapé, que eran de propiedad de él y de sus hermanos, donde la víctima y su madre habían hecho, sin licencia, una rocita. Argumentaba que los naturales, inquietos porque ellos poseían esas tierras, los vivían perturbando y provocando. A pesar de tener un globo de tierra grande, buscaban expulsarlos porque

\footnotetext{
${ }^{40}$ A. H. A. Criminal. B. 74. Leg. 1760-1780. Doc. No 7. Fol. 1r-v.
} 
anhelan vivir apartados de los blancos, porque éstos estorban sus excesos o son fiscales de su precipitud y libertinaje o porque tienen natural antipatía a los blancos. ${ }^{41}$

En otro caso de éstos, ocurridos en 1780, Juan Manuel Ochoa, quien había sido esclavo de don Lucas Ochoa, vecino de Yolombó, presentó ante el Gobernador demanda contra don Francisco Javier Jaramillo, vecino de Medellín, residente en la quebrada de Nus, por haberle dado palos y ordenado a sus esclavos que lo amarrasen y azotasen. El se presentó ante el juez pedáneo de Yolombó a quejarse de lo sucedido, pero éste no pudo hacer nada por haberse negado Jaramillo a responder, argumentando que no era su juez. Mientras tanto, Jaramillo presentó demanda contra Ochoa ante el Alcalde pedáneo de los minerales de Santo Domingo, quien formó una sumaria a su "gusto" y ordenó embargar la mina del oponente. Ochoa solicitó al Gobernador que ordenara el desembargo de sus bienes y remitiera el expediente al juez de Yolombó, porque quería ser juzgado por sus

propios jueces y no por extraños como lo es el de los minerales de Santo Domingo, quien cuando alguna jurisdicción tuviera en mi persona se la niego y lo recuso por parcial de don Javier Jaramillo. ${ }^{42}$

Una cantidad apreciable de los agresores eran mulatos y negros libres. A los 61 que declararon pertenecer a este grupo, hay que agregar un porcentaje apreciable de los libres que no especificaron su casta. Siendo así, podría llegar a ser la mitad o más de los reos vinculados a estos procesos. Los zambos y mulatos eran vistos como gente propensa a cometer "osadías". Los blancos constantemente solicitaban que se les castigara duramente porque de lo contrario, los vecinos principales quedaban sujetos a experimentar sus atrevimientos. ${ }^{43}$ Solían pedir penas extremas como azotes, y aún, que se les cortase la mano. ${ }^{44}$

\footnotetext{
${ }^{41}$ A. H. A. Criminal. B. 79. Leg. 1740-1780. Doc. $\mathrm{N}^{\circ}$ 10. Fols. 2r-v, 4r-v, 8r-v, 10r-12r.

${ }^{42}$ A. H. A. Criminal. B. 52. Leg. 1780-1790. Doc. $\mathrm{N}^{\circ}$ 2. Fols. 1r-v, 2r-4r.

${ }^{43}$ A. H. A. Criminal. B. 65. Leg. 1790-1800. Doc. No 15. Fol. $1 \mathrm{r}-\mathrm{v}$.

${ }^{44}$ A. H. A. Criminal. B. 83. Leg. 1790-1820. Doc. $\mathrm{N}^{\circ} 25$. Fols. 22r-24v.
} 
Esto explica por qué las autoridades vivían atentas a su comportamiento y los procesaban a la menor queja.

De los reos por "injurias de hecho" una décima parte eran indios tributarios pertenecientes a los diversos pueblos de indios de la provincia. Eran continuos los pleitos de los indios con los libres que vivían en sus resguardos, o con las autoridades. Algunas de estas peleas adquirían el carácter de motín, obligando al Gobernador a intervenir para calmar los ánimos. Como ejemplo de esta situación describiremos el tumulto que los indios del pueblo de Sopetrán formaron en 1797, contra don Francisco de Escobar, Alcalde de la Santa Hermandad, residente en ese pueblo. Según el relato del agredido, el día de la festividad de San Pedro, estando en una "escaramuza alegre y divertida", en compañía de gente "honrada”, fue atacado a piedra por el indio Jerónimo Barbarán. El Alcalde se defendió con el bastón que cargaba, dándole a quien le había tirado las piedras y a otro indio que le atacó, llamado Francisco Saranda. Al retirarse a su casa, se formó frente a ella un tumulto de indios que lo insultaron y desafiaron diciéndole que era

un cochino y alcalde de porquería, que se ensuciaban en él y los demás blancos de Sopetrán.. ${ }^{45}$

El acusador manifestó que los indios acostumbraban hacer estos tumultos por falta de corrección. El Corregidor era un anciano lleno de males y temeroso de los indios, pues éstos habían incendiado su casa y, con anterioridad, la del cura. Afirmaba que no reconocían superioridad.

a todo hombre de honor y blanco lo miran con total desprecio, lo tratan con ironía

Don Pedro Félix Pastor, protector de naturales, argumentó a favor de los indios, que éstos eran "leales al Rey", pues no habían querido participar en la sublevación de los cosecheros de tabaco de la otra banda del Cauca en

${ }^{45}$ A. H. A. Criminal. B. 76. Leg. 1797-1800. Doc. $\mathrm{N}^{\circ}$ 2. Fols. 1r-2r, 17v-18v. 
1781, la cual fue dirigida por gente libre que vivía en el resguardo de Sopetrán. El Gobernador Salcedo mandó liberar a los cuatro indios apresados, por considerar que todo se había originado en estar borracho el indio Barbarán. Ordenó al Corregidor celar la conducta de los naturales, no permitiéndoles que se embriagaran, ni vivieran ociosos.

La embriaguez solía ser común en las festividades indígenas que derivaban en peleas donde algunas personas salían heridas. Así, en 1804 el Corregidor de Sopetrán apresó al indio Julián Valderrama por haber dado puñaladas con una navaja de bolsillo al indio Vicencio Ortiz. De acuerdo con la confesión del reo, el hecho era resultado de una "bebezón" que tuvieron varios indios por haberlos invitado Pedro Nolasco a un "convite o junta" de los que se acostumbraba hacer en tiempo de "desyerba y rocerías". Al cargo de ser de mal genio y quimerista, respondió que

cuando se calienta con la bebida, pierde el conocimiento y no respeta a nadie... Que en su sano juicio, puede justificar que no se mete con nadie. ${ }^{46}$

El historiador William Taylor ha señalado para el caso de Nueva España que los indígenas ajustaron la embriagues ritual, común en sus sociedades antes de la conquista, a los numerosos días de fiesta del calendario católico. También muestra como la embriaguez de los naturales aumentó a lo largo de la época colonial, habiéndose modificado las pautas de comportamiento. Por último indica que la agresión de palabra o física era muchas veces resultado del consumo de bebidas, pues el alcohol aumenta la probabilidad de una conducta violenta. ${ }^{47}$ Los indígenas antioqueños del siglo xvIII, distintos a los mexicanos en tradición, cultura y densidad demográfica, parecen corroborar algunas de estas afirmaciones. Fueron el único grupo de la región en el cual el uso de la violencia física estuvo ligado al consumo de alcohol, fundamentalmente guarapo. Por los ejemplos narrados, estos hechos olían ocurrir en los días de fiesta religiosa o cuando la actividad agrícola requería de trabajos colectivos. Estos casos

\footnotetext{
${ }^{46}$ A. H. A. Criminal. B. 42. Leg. 1800-1810. Doc. $\mathrm{N}^{\circ}$ 7. Fol. 1r, 4v, 5r.

${ }_{47}$ Taylor, William. Embriaguez, Homicidio y Rebelión en las Poblaciones Coloniales Mexicanas. México. Fondo de Cultura Económica. 1987. Págs. 110-113.
} 
se hicieron más comunes al finalizar el periodo colonial, pero es muy difícil encontrar la causa del aumento de la embriaguez.

Otro aspecto que se puede estudiar sobre el grupo de los agresores es el relativo a las edades. De los 273 reos, siete $(2,56 \%)$ tenían menos de 20 años; 64 (23,44\%), entre 20 y 29 años; 39 (14,29\%), entre 30 y 39 años; 19 (6,96\%), entre 40 y 49 años; 13 (4,76\%), más de 50 años y se desconoce la edad de $131(47,995)$ (ver cuadro $\left.\mathrm{N}^{\circ} 18\right)$. Un gran porcentaje de los implicados, que debe ser más del 50\% si se consideran las personas que no declararon su edad, tenía entre 20 y 39 años. Esto corrobora la afirmación de que los adultos jóvenes son los más inclinados a intervenir en peleas. Teniendo en cuenta que la misma situación se presentó en el caso de las víctimas (ver cuadro $\mathrm{N}^{\circ} 17$ ), podemos concluir que la mayor parte de los pleitos que degeneraron en golpes y heridas, involucraron a personas que pertenecían a un mismo grupo generacional.

Como las edades más comunes entre los agresores coinciden con las de la población considerada económicamente activa, es importante analizar los oficios u ocupaciones que declararon tener.

Los datos recogidos sobre este aspecto muestran que cerca de la tercera parte de los reos eran labradores, rozadores o estancieros (ver cuadro $\mathrm{N}^{\circ} 19$ ). La vinculación a las actividades agropecuarias indica que se trata de personas con un oficio relativamente estable. Los embargos de bienes permiten deducir que la mayoría eran pequeños y medianos propietarios que con su trabajo sostenían el grupo familiar. Este hecho lo corroboran las peticiones de excarcelación, en las cuales señalaban a las autoridades que eran "el sostén" de su casa y su ausencia significaba que estuvieran padeciendo "necesidades".

Así, José María Tangarife, indio del pueblo de Sopetrán, que tuvo pleitos con Juan Nepomuceno Ramírez y otros indígenas en 1809, 1811 y 1812, en una solicitud hecha al gobernador para que lo dejara en libertad, decía que su familia estaba

pasando notables necesidades con mi ausencia y sin grano de maíz, sin más alimento que los cortos plátanos y pocas mazorcas de cacao, que produce 
mi posesión, la que se halla también padeciendo grande detrimento por esta inquietud que me han puesto, dicho Aguel y socios. ${ }^{48}$

Para tener una idea más precisa de la condición económica de los reos, veamos algunos ejemplos:

A don Facundo Arbeláez, blanco, que fue procesado en 1782 por intervenir en una pelea de su hijo natural, el negro Vicente Arbeláez, se le embargaron los siguientes bienes: Un pedazo de cañaduzal y un platanar en tierras de su propiedad; un trapiche de caballo y la casa del trapiche, así como la casa de su morada. Un número indeterminado de mulas y caballos que no se sabía donde paraban. En cuanto a unas reses encontradas, su esposa dijo que eran suyas por haberlas heredado de su padre. ${ }^{49}$

Un campesino pobre era el mestizo Marcos de Agudelo, vecino de Sopetrán, sumariado en 1792 por haber golpeado y herido a José Rodríguez y a la madre de éste, María Gervacia de Amaya. A él le secuestraron un almud de roza temprana, dos ranchos de vivienda, unas matas de plátano, una yegua y una potranca, una azada y un calabozo viejo. ${ }^{50}$

Menos pobre era el indígena Diego de Sisquiarco, Gobernador del pueblo de Sopetrán, quien en 1756 fue puesto preso por haber herido al indígena Martín Machado. Los bienes que le incautaron fueron su casa cubierta de iraca, con dos aposentos, una sala y una cocina maltratada. Un hacha y un machete calabozo. Medio almud de caña dulce y medio de platanar, una casa de trapiche con trapiche de caballo y un pozuelo, un rancho con su horno, una paila vaciada sacadora y tres ollas para cocinar el guarapo. Fuera de esto tenía un caballo, una yegua, una potranquita, dos vacas y una ternera. ${ }^{51}$

Entre los reos, uno de los que más propiedades tenía era el mulato Pedro Antonio Montes, acusado en 1815 de maltratar a su esposa. Entre sus propiedades figuran una estancia en las tierras de los ejidos de la ciudad de Antioquia

${ }^{48}$ A. H. A. Criminal. B. 100. Leg. 1800-1810. Doc. $N^{\circ} 28$. Fols. 1r-v., B. 78. Leg. 1800-1820. Doc. $N^{\circ}$ 6. B. 78. 1800-1820. Doc. $\mathrm{N}^{\circ} 12$.

${ }^{49}$ A. H. A. Criminal. B. 29. Leg. 1780-1790. Doc. $\mathrm{N}^{\circ}$ 3. Fols. $12 \mathrm{v}-13 \mathrm{r}$.

${ }^{50}$ A. H. A. Criminal. B. 64. Leg. 1790-1800. Doc. $N^{\circ}$. 4. Fols. 6r-v.

${ }^{51}$ A. H. A. Criminal. B. 67. Leg. 1750-1760. Doc. No 2. Fols. 13v-15r. 
en donde tenía una casa cubierta de paja, avaluada en 100 castellanos, 70 árboles de cacao, unas matas de plátano, medio almud de caña, 10 árboles de aguacate, dos de ciruelo, uno de tamarindo, uno de níspero, tres de mamey, una palma de coco y casa de trapiche con su molino. A herramienta consistía en tres calabozos, tres azadones, una barra, una azuela llana, una gurbia y tres mulas. En la ciudad de Antioquia poseía una casa cubierta de paja, con puertas y ventanas de madera, construida en solar propio, donde cultivaba cacao, plátano y palmas de coco. Allí tenía una ramada en paja donde trabajaba la carpintería, oficio para el cual tenía gran cantidad de herramienta consistente en sierras, formones, cepillos, limas, taladros, compás, buril, martillos, molduras, canalador, cinceles, clavos, así como listones de madera, tablas, trozos de madera. También era propietario de una esclava, que heredó de su madre y de dos pedazos de solar. ${ }^{52}$

Fuera de los pequeños y medianos propietarios, también se identificaban como labradores personas que no poseían tierras y trabajaban en propiedades ajenas. Es el caso del mestizo Juan Andrés Benítez quien, en 1814, declaró ser labrador en tierras de don Pablo de Vargas y de don Andrés López. ${ }^{53}$

La presencia de mineros, comerciantes y artesanos entre los procesados fue escasa y no llega a constituir un $5 \%$ (ver cuadro $\mathrm{N}^{\circ} 19$ ). Una gran parte de ellos eran pequeños y medianos propietarios, aunque hay algunas excepciones.

De los vinculados a la minería, unos eran mineros que poseían cuadrilla de esclavos, mientras que otros eran mazamorreros. Entre los primeros estaba don Plácido Misas, español, quien poseía minas y tierras en el sitio de San Luis de Góngora (hoy Yarumal). Misas fue uno de los grandes mineros de Antioquia en el siglo xviII, y fundió 11.819 pesos de oro entre 1785 y $1807 . .^{54}$

Los mazamorreros eran libres que explotaban las minas de aluvión utilizando menos de cinco trabajadores. Un gran porcentaje de ellos vivía en la

${ }^{52}$ A. H. A. Criminal. B. 78. Leg. 1800-1820. Doc. $\mathrm{N}^{\circ}$ 19. Fols. 23v-28r.

${ }^{53}$ A. H. A. Criminal. B. 33. 2do. Legajo. 1790-1817. Doc. $N^{\circ} 10$. Fols. 7r-8r.

${ }^{54}$ Twinam, Ann. Mineros, Comerciantes y Labradores. Las Raíces del Espíritu Empresarial en Antioquia. 1763-1810. Medellín. Fondo Rotatorio de Publicaciones. FAES. 1985. Pág. 86.

A. H. A. Criminal. B. 29. Leg. 1790-1800. Doc. $\mathrm{N}^{\circ}$ 3. Fol. 13r-v. 
zona del Valle de los Osos, el principal centro minero de esa época. La situación económica de estos individuos la podemos ilustrar citando el ejemplo de Miguel Jiménez, quien fue procesado en 1799 por haber azotado, junto con su esposa Nicolasa Pérez, a Josefa González, mujer de Juan Manuel Aguirre. Jiménez tenía su casa de morada en el real de minas de Nuestra Señora del Rosario. Entre los bienes que había en ella se inventariaron instrumentos de trabajo consistentes en dos almocafres viejos, una barra de hierro de mina, un machete, un azadón, un hacha y un peso chico de pesar oro. En la mina que estaba labrando había dos barras de hierro, un calabozo, dos zuelas, un recatón, dos almocafres, tres bateas, elementos que tenía guardados en una casita de paja. Fuera de esto poseía un macho, una mula, un caballo, dos vacas de vientre con sus terneras y una novillona.

Algunos mazamorreros podían adquirir cierta fortuna, lo que según ellos, despertaba la envidia de los vecinos. Era el caso de Jiménez, pues según sus palabras

como soy aplicado a trabajar en la mina que Dios me ha dado y que saco algún dinero con mi familia, se me mira con mejor modo de pasar que otros..$^{55}$

A fines de la época colonial los artesanos aumentaron considerablemente. En la ciudad de Antioquia en 1807 había 33 personas inscritas en el gremio de sastres, 29 en el de zapateros, 23 en el de plateros, 17 en el de herreros y 17 en el de carpinteros. ${ }^{56}$ Estas personas eran propensas a intervenir en conflictos, como lo demuestra el caso de Raimundo Ferraro, oficial de zapatería, quien participó en varias peleas. En 1796 se le embargaron las herramientas de su oficio consistentes en una tijera, dos tenazas, dos martillos, una cuchilla, tres leznas, varias hormas y cuatro mesas de madera. Además poseía una tenería con su casa de vivienda pajiza. ${ }^{57}$

\footnotetext{
${ }^{55}$ A. H. A. Criminal. B. 53. Leg. 1790-1800. Doc. $\mathrm{N}^{\circ} 24$. Fols. 10r-v, 16v-17v.

${ }^{56}$ Patiño Millán, Beatriz A. "La Provincia en el Siglo XVIII". En: Historia de Antioquia. Medellín. Suramericana de Seguros. 1988. Pág. 89.

${ }^{57}$ A. H. A. Criminal. B. 53. Leg. 1790-1800. Doc. $\mathrm{N}^{\circ}$ 16. Fols. $14 \mathrm{r}-\mathrm{v}$.
} 
En el grupo de oficios varios están incluidas parte de las mujeres que figuran como agresoras. Ellas acostumbraron declarar estar dedicadas a los "oficios caseros" u "oficios que correspondían a su sexo". Sin embargo, esto no significaba que carecieran de bienes y que no contribuyeran con su trabajo al sostenimiento de la familia. Así, a María Teresa Durango, alisas "Suplicio", quien fue procesada en 1778 por haber agredido a Petronila de Agudelo, se le embargaron entre otros bienes, una casa de paja, un pedazo de tierra de pan y una silla polaca de montar. En una representación del acusador, el padre de Petronila, se afirmaba que había ocultado una mina de oro corrido y que tenía en el sitio del Páramo, ocho bestias mulares y dos caballares. ${ }^{58}$ Esta mujer que estaba casada con Ignacio Salas, carguero del comerciante don Bernardo Martínez, parece haber disfrutado de cierta independencia económica.

Al igual que en los juicios por injuria, un alto porcentaje de los agresores de las causas de lesiones personales estaban vinculados a actividades productivas. Aunque el declarar un oficio no significaba que realmente se ejerciera, es bastante ilustrativo que sólo en unos pocos casos se refieran a algún reo como vago o "persona sin labranza ni oficio". Los embargos hechos permiten afirmar que básicamente se trataba de pequeños propietarios pobres. Fue excepcional que se vinculara a esta clase de procesos a medianos y grandes propietarios, lo que puede deberse a que no fueran denunciados por temor de su poder económico y político.

Otro aspecto que se puede estudiar es el estado civil de los reos procesados por "injurias de hecho". De 273 acusados, 41 (15,02\%) declararon ser solteros, 100 (36,63\%) viudos, y no se tiene información sobre 127 (46,52\%) (ver cuadro $\mathrm{N}^{\circ} 20$ ). Estos datos coinciden con los relativos a la edad y ocupación, pues la mayor parte de los procesados eran adultos jóvenes que estaban en edad de haber contraído matrimonio. En las sociedades rurales como la de Antioquia de entonces, era usual que la gente se casase muy joven y constituyera su familia como unidad económicamente independiente. El que pocos agresores fueran mayores de 50 años, explica que el porcentaje de viudos fuera tan pequeño.

\footnotetext{
${ }^{58}$ A. H. A. Criminal. B. 38. Leg. 1770-1780. Doc. $\mathrm{N}^{\circ}$ 7. Fols. 4r-v, 20r-21v.
} 
Es interesante anotar que de las 24 mujeres enjuiciadas, cuatro eran solteras, 12 casadas, cuatro viudas y se desconoce el estado civil de cuatro. Lo anterior muestra que el estado civil de las mujeres se precisó más que el de los hombres, pues por razones jurídicas se debía aclarar si estaban bajo tutela del padre, del marido o si eran viudas.

Pr último, nos referiremos al grado de alfabetismo de las personas implicadas en estos juicios. De acuerdo con la información que dieron los reos en las confesiones o declaraciones, 79 (28,94\%) firmaban, 107 (39,19\%) no firmaban y no se tiene información sobre 87 (31,87\%) (ver cuadro $\left.\mathrm{N}^{\circ} 21\right)$. Entre los 79 que firmaban, había 33 blancos, lo que implica que sabían firmar un poco más de la mitad de los agresores pertenecientes a ese grupo étnico. Las mujeres eran casi todas analfabetas, pues de las 24 sólo una firmaba, mientras que 15 declararon no saber hacerlo; si comparamos estos datos con los relativos a los juicios por injuria, encontramos que en estos últimos era más elevado el porcentaje de agresores que sabían firmar (37,5\%) (ver cuadro $\mathrm{N}^{\circ} 8$ ). Esto se explica porque el delito de injuria era más urbano y el sector social que intervenía en esos juicios tenía un nivel de vida más alto.

\section{Relaciones entre el agresor y la víctima}

Analizar el tipo de relaciones existentes entre el agresor y la víctima de un delito, permite conocer la cohesión o las divisiones existentes entre los grupos que componen una sociedad. Por eso es importante estudiar si las personas que intervienen en pleitos que degeneran en hechos de sangre se conocen entre sí o nunca se han visto. A partir de estos datos es posible conocer el significado que en una determinada época o lugar tienen la familia, el vecindario o la llegada de forasteros.

La primera característica que se debe anotar sobre los juicios por lesiones personales tramitados en la jurisdicción de la ciudad de Antioquia, es que un poco más de la cuarta parte fueron conflictos de tipo familiar (ver cuadro $\mathrm{N}^{\circ} 24$ ).

El mundo doméstico de finales del periodo colonial fue muy violento, siendo constantes las desavenencias entre cónyuges, padres e hijos o parientes. La creencia de que los padres podían reprender fuertemente a sus hijos y que el esposo podía castigar sin límite a su mujer, está presente en gran parte de las 
confesiones de los procesados. Rudesindo Jaramillo, quien fue procesado en 1791 por haber herido con un machete a su esposa Marcela López, afirmaba que el marido podía castigar a su mujer porque estaba dispuesto

en las sagradas letras y cánones que dan esta mayoría y dominio a los maridos con potestad de castigarla cuando la necesidad lo exigiere, por lo que no habiendo esta pendencia excedido los límites de casera, no habiendo yo usado del estricto derecho que conceden las leyes a los maridos en castigo del adulterio tan opuesto a la cristiandad y pública tranquilidad y habiendo sido mi mujer la causante, así de mi primer ímpetu como de que nos hubiésemos lastimado, pues ya por mi parte estaba acabada la pendencia, suplico a V.S. se sirva declararme por libre de toda pena y por un atentado o violencia la prisión que me hizo don Manuel Rada..$^{59}$

Susana Ramírez, india del pueblo de Sopetrán a quien el marido, Matías Romero, injuriaba y golpeaba, afirmó en 1808 que éste constantemente la amenazaba de muerte, asegurándole que podía hacerlo sin ser castigado, porque un vecino del lugar había matado a su esposa y "nada le hicieron". 60

En 1812 José Pino, mulato, vecino de Antioquia, acusado de maltratar a su esposa decía que la había castigado procurando sujetarla

para que viva en santo temor de Dios y conserve la fidelidad de su matrimonio, a que ambos son obligados. ${ }^{61}$

En su confesión afirmó que había golpeado a su esposa por haberse negado a "ejecutar actos lícitos a su estado". Al ser reconvenido por el juez para que dijera la verdad, dijo haberla castigado porque la comida que hizo no era del gusto de su paladar.

Las autoridades ilustradas trataron de cambiar este modo de pensar, subrayando que la esposa era una compañera y no una esclava. El Gobernador

\footnotetext{
${ }^{59}$ A. H. A. Criminal. B. 76. Leg. 1790-1790. Doc. $\mathrm{N}^{\circ}$ 4. Fols. 10r.-14r.

${ }^{60}$ A. H. A. Criminal. B. 46. Leg. 1800-1810. Doc. No 28. Fols. 1r-2v.

${ }^{61}$ A. H. A. Criminal. B. 33. 2do. Legajo. 1790-1817. Doc. N 6. Fols. 15v.-19r.
} 
Francisco Baraya y la Campa en el caso de Rudesindo Jaramillo conceptuó que éste debía salir del error de creer que por infidelidad podía matarla. ${ }^{62}$

En un juicio seguido en 1811 el doctor Ignacio Uribe, como asesor jurídico, afirmaba que se le debía explicar al reo

que el título de marido de ningún modo lo autoriza para castigar y afligir a su mujer en los términos que lo ha ejecutado. ${ }^{63}$

Por su parte, el síndico procurador general don Pablo Pardo, en calidad de fiscal de la causa contra José Pino sostenía que éste había castigado a su mujer

con notoria ofensa a la dignidad del sacramento, a la humanidad, al delicado sexo femenil y escándalo de los de primera magnitud para los demás hombres. ${ }^{64}$

Lo anterior permite suponer que el maltratar y castigar a la esposa fue tolerado por mucho tiempo en la sociedad antioqueña colonial. Sólo en la segunda mitad del siglo xviI, cuando las autoridades empiezan a perseguir los concubinatos, amancebamientos y otras conductas que atentaban contra la unidad familiar, se hizo común seguir causas por este motivo. Los gobernantes estaban empeñados en controlar las costumbres que fomentaban el desorden y, las disputas domésticas, indudablemente entraban en esta categoría. Se quería imponer un modelo de familia basado en el amor a la paz y los sentimientos cristianos. Para ello se hacía hincapié en que el esposo debía tratar a su mujer con cortesía y cumplir con las obligaciones de su estado.

Es probable que las mujeres, como hemos manifestado que ocurrió con los esclavos cuando se publicó el código de 1789, hayan aprovechado el cambio de actitud de los jueces para presentar demandas contra los procedimientos del marido. Los acusaban de maltratarlas, de no darles lo necesario para su mantenimiento y de ser ellas con su trabajo las que mantenían a la familia.

\footnotetext{
${ }^{62}$ A. H. A. Criminal. B. 9976 Leg. 1790-1796. Doc. N 4. Fols. 14v.-15r.

${ }^{63}$ A. H. A. Criminal. B. 78. Leg. 1800-1820. Doc. N 9. Fols. 15r.-v.

${ }^{64}$ A. H. A. Criminal. B. 33. 2do. Legajo. 1790-1817. Doc. $N^{\circ}$ 6. Fols. 22v.-23v.
} 
Así, María Antonia Lenis, quien en 1817 se quejó del maltrato que le daba su marido, le pidió al presbítero Francisco Javier García que atestiguara su

$$
\begin{aligned}
& \text { buen procedimiento, genio laborioso y arbitrios honestos de que se vale para } \\
& \text { comer y vestir, y aún de su propia diligencia sostiene y abriga a su ingrato } \\
& \text { esposo, hombre díscolo y reprensible y nada laborioso. }{ }^{65}
\end{aligned}
$$

No sólo las esposas eran maltratadas en el hogar; también se acostumbró castigar fuertemente a los hijos. Desafortunadamente fueron muy pocos los juicios que por esta causa se siguieron, aunque en varios procesos hay referencias a ello. Agustina Agudelo, al ser interrogada en 1811 acerca del castigo que le dio su esposo José Manuel Sánchez, afirmó que éste trataba con tanto rigor a un hijo que éste se vio obligado a huir de la casa. El maltrato se originaba en que Sánchez aseguraba que no era hijo suyo, por ser de color moreno. ${ }^{66}$

No sólo los padres castigaban a los hijos; algunas madres atentaron contra la vida de éstos. Es el caso de Matías, negra esclava de Manuel Pérez, quien intentó ahorcar a un hijo suyo en presencia de varias personas. De acuerdo con su confesión había hecho esto para amenazar a su ama y conseguir que dejara de regañarla. Aseguraba que con el mismo fin lo había hecho otras veces y que no la castigaron. ${ }^{67}$

Si consideramos como un indicativo la gran cantidad de causas seguidas por infanticidio, el maltratar a los niños debió ser frecuente (ver cuadro $\mathrm{N}^{\circ} 32$ ). No obstante múltiples circunstancias llevaban a que no se denunciara y para las autoridades era difícil proceder si no tenían evidencias que les permitieran abrir un juicio de oficio.

Las disputas entre cónyuges originaban pleitos entre parientes políticos, impregnando de violencia las relaciones familiares. Manual Serna, vecino de Antioquia, demandó en 1775 a Juan María Quiroz, su yerno, por haberlo querido matar. Los hechos tuvieron como causa el negarse la esposa de Quiroz a vivir fuera de la casa de sus padres. Ella lo acusó de vivir ocioso y declaró

\footnotetext{
${ }^{65}$ A. H. A. Criminal. B. 102. Leg. 1800-1820. Doc. $N^{\circ}$ 35. Fols. 6r.-7r.

${ }^{66}$ A. H. A. Criminal. B. 78. Leg. 1800-1820. Doc. $\mathrm{N}^{\circ}$ 9. Fols. 4r.-5v.

${ }^{67}$ A. H. A. Criminal. B. 96. Leg. 1790-1800. Doc. $N^{\circ} 13$. Fols. 8r.-9v.
} 
que los seis meses que llevaban de casados se habían mantenido a expensas de sus padres. ${ }^{68}$

En 1799 José Cano fue herido por Miguel Agudelo, al tratar de defender a la esposa de éste Cándida Bocanegra, su cuñada. Agudelo, que vivía en la casa de Cano, golpeó a su mujer por no haber ido a hacer una siembra tal como él se lo había ordenado. Al salir el dueño de casa en su ayuda fue apuñalado, siendo herido en la muñeca, el brazo y la "paleta". ${ }^{69}$

Como puede apreciarse, la intervención de los parientes en los pleitos entre esposos en lugar de ayudar a solucionar los problemas podía agravarlos. Frecuentemente el marido se resentía con la ayuda que la mujer obtuviera de su familia, pues consideraba que era una forma de disminuir su autoridad sobre ella.

Muchas de las disputas entre el esposo y los familiares de su mujer, se originaban en que ellos se habían opuesto a la realización del matrimonio. En 1787, don José Pichardo, español que ejercía el oficio de rescatante en el sitio de Petacas en el Valle de los Osos, fue acusado por su suegro don Gregorio de Villa de alevoso y ebrio. El acusado decía que era notorio el odio que le profesaba su suegro, razón por la cual presentaba los hechos de manera distinta a como habían sucedido. Los cierto era que él había sido provocado por su cuñado don Felipe de Villa quien había dicho que el sable que tenía era

para tasajear a un pícaro (perdone V.S. el mal estilo), cornudo, cabronazo, que intentaba dar que sentir a su casa. ${ }^{70}$

Su suegro no sólo toleraba que sus hijos lo insultaran, sino que había permitido a un esclavo suyo que lo retara y desafiara en el altozano de la iglesia de ese sitio.

En 1811 don Pedro Madrid, demandó a su suegro don José María Fernández por haberlo herido con un paño. En la pelea, que se originó por el

\footnotetext{
${ }^{68}$ A. H. A. Criminal. B. 93. Leg. 1770-1790. Doc. $\mathrm{N}^{\circ}$ 4. Fols. 1r.-2r., 5r.-v.

${ }^{69}$ A. H. A. Criminal. B. 86. Leg. 1780-1800. Doc. No 17. Fols. 5r.-v.

${ }^{70}$ A. H. A. Criminal. B. 60. Leg. 1780-1790. Doc. $N^{\circ} 22$. Fols. 6r.-9v.
} 
cobro de una deuda, Fernández afirmó que la había sido preciso aceptarlo como yerno porque la había "perdido" a su hija y le había deshonrado su casa. ${ }^{71}$

Estos conflictos dejan ver que las familias no perdonaban a aquellos que habían ofendido su honor. No era tanto la suerte de su hermana o una hija lo que preocupaba a los protagonistas de estos episodios, son limpiar su reputación. Para lograrlo estaban dispuestos a recurrir a la fuerza si era necesario.

Un gran porcentaje de las peleas familiares tenían origen en problemas de tipo económico. Los pleitos por tierras, por la introducción de ganado que dañaba las sementeras, etc. solían envolver a miembros de una misma familia. Así, por ejemplo, en 1785 Juan Ignacio de Serna y Blas Quiroz acusaron a Juan José Serna, hermano del primero y cuñado del segundo, de emboscarse junto con su mujer e hijos para atacarlos a ellos o a sus familias. La causa de la pelea era una demanda puesta contra Juan José por los daños que en las sementeras ocasionaban sus cerdos y bestias. ${ }^{72}$

La violencia existente en las relaciones familiares envolvía a todas las personas que integraban el mundo doméstico. Ya mencionamos que eran corrientes las denuncias por maltratos de los esclavos. Igualmente fueron víctimas de esta situación los agregados u otras personas que compartían la vivienda (ver cuadro $\mathrm{N}^{\circ} 24$ ). Estos conflictos fueron comunes en la población blanca, mestiza y mulata pobre, siendo más escasos entre los grandes propietarios.

Las relaciones extramatrimoniales también estaban impregnadas de violencia. Era frecuente que dos hombres se enfrentaran por una mujer o el golpear a la amante. Adicionalmente, hay que tener en cuenta que muchos de los problemas entre cónyuges se derivaban de la presunción o certeza de infidelidad. Ilustra esta situación el juicio seguido contra el esclavo Juan Antonio Varela, residente en el partido de Miranda por haber golpeado y azotado a María Josefa Herrera. Según su confesión él había estado en concubinato con ella por espacio de dos años y habían tenido un hijo que murió. El motivo que tuvo para castigarla era que ella andaba diciendo que la había dejado por tener otras mozas. ${ }^{73}$

\footnotetext{
${ }^{71}$ A. H. A. Criminal. B. 31. Leg. 1810-1840. Doc. $\mathrm{N}^{\circ}$ 10. Fols. 12v. -15 r.

${ }^{72}$ A. H. A. Criminal. B. 60. Leg. 1780-1790. Doc. $N^{\circ} 18$. Fols. 1r.-2v.

${ }^{73}$ A. H. A. Criminal. B. 84. Leg. 1810-1840. Doc. $N^{\circ}$ 7. Fol. 1r.-v.
} 
Otra característica que hay que anotar con respecto a los juicios por lesiones personales es que cerca del $40 \%$ fueron pleitos entre vecinos. Si comparamos este dato con el correspondiente a las causas por injuria verbal encontramos que en los vecindarios fueron más frecuentes las peleas de palabra que las que conllevaban derramamiento de sangre (ver cuadros $\mathrm{N}^{\circ} 11 \mathrm{y}$ 24). No obstante, en este ambiente de consejas y chismes era posible que muchos enfrentamientos terminaran en golpes y heridas. Los problemas que se derivaban de la convivencia diaria, daban lugar a numerosas disputas, y en muchas oportunidades se tomaba venganza por mano propia, antes de acudir a la justicia para que remediara la situación.

Lo anterior parece haber sucedido en una pelea que tuvieron en 185 Ignacio Serna y Santos Jaraba, vecinos de la ciudad de Antioquia. Serna declaró que había regañado a un hijo de Jaraba por haberle pegado a una hija suya llamada Atanasia. Después, frente a la casa de Serna, Jaraba le gritó: "salid hijo del demonio, galgo, atrevido” y al salir a averiguar lo que pasaba, le pegó con una vara o rejo. José Antonio Jaraba, hijo de Santos y Sixto de Villa, yerno de Jaraba le ayudaron a golpearlo. En la versión de Santos, ese día había reconvenido a Serna por estar cortando chamizas en las inmediaciones del solar de su casa, pues esto le ocasionaba perjuicio a sus gallinas. Por la noche un hijo de Jaraba, que se encontraba jugando en un callejón, fue golpeado por Serna y a los gritos, Jaraba concurrió. Al preguntarle a Serna por qué le había pegado a su hijo, le respondió golpeándole con una "lata de guadua". El defensor de los reos, Felipe Montes, decía que aunque estaba probado que habían herido a Serna, se los debía dejar libres por

haber sido propiamente un arrebato subitáneo, que no pudieron evitar, ni precaver sus resultados, por haberse como hombres poseído de aquella pasión; Santos en defensa de su hijo, acciones propias aun de las mismas fieras como lo acredita la experiencia; y Sixto y José Antonio en socorro de un padre natural y político. ${ }^{74}$

${ }^{74}$ A. H. A. Criminal. B. 88. Leg. 1810-1830. Doc. $\mathrm{N}^{\circ}$ 8. Fols. 1v.-2v., 7r.-8v., 12r.-v. 
La vida cotidiana de los barrios, con sus altercados y roces, originaba situaciones que terminaban en heridas y golpes. En 1780 Manuel Romero, natural de Santiago de Galicia (España), fue procesado por haber herido a José Sánchez. Los hechos ocurrieron en horas de la madrugada, al estar haciendo ruido Raimundo Ferraro y José Sánchez, frente a la puerta de la casa de Romero. Este se levantó y les reprochó que a esa hora estuvieran alborotando el vecindario. Como no hicieron caso a sus palabras, entró a su casa, sacó una lanza que tenía y con ella hirió a Sánchez. ${ }^{75}$

En el mundo rural también era corriente que se presentaran problemas entre quienes compartían un lindero o el uso de una quebrada, un camino, una puerta. El que los campesinos o mineros anduvieran permanentemente con machetes, hachas u otras herramientas de trabajo, propiciaba que las peleas terminaran con personas lesionadas. El menor reclamo de un vecino ocasionaba un pleito, como lo demuestra el proceso seguido en 1766 contra Juan José Ferraro por haber herido a Francisco Roque Benitez. La querella se suscitó porque Ferraro tapó dos puertas que usaban los transeúntes y dueños de tierras del lugar. ${ }^{76}$

Cerca del $8 \%$ de los juicios por lesiones personales tramitados en la jurisdicción de la ciudad de Antioquia fueron agresiones entre los vecinos y los funcionarios civiles o eclesiásticos. Al hablar de las víctimas nos referimos a aquellos casos en que las autoridades fueron objeto de atentados por parte de un vecino. Existen así mismo causas en que una persona demandó a un juez por maltratarla y apresarla injustamente. Esos juicios hacen pensar en abusos de poder por parte de los Alcaldes, sobre todo de los pedáneos. Esto es lo que parece haber ocurrido en 1817 en Cuerquia, cuando el Alcalde de ese partido, José Montaño, insultó, golpeó y puso presa a su hermana Dionisa Lara, sin que hubiese razón para hacerlo. En una representación el Alcalde decía que ésta lo había tratado como a cualquier persona sin tener en cuenta su autoridad de juez. Aseguraba que las declaraciones de los testigos eran falsedades y cavilaciones con las que buscaban deponerlos de su empleo.

${ }^{75}$ A. H. A. Criminal. B. 60. Leg. 1780-1790. Doc. N 5. Fols. 1r.-v., 11v.-16v.

${ }^{76}$ A. H. A. Criminal. B. 41. Leg. 1740-1770. Doc. $N^{\circ} 23$. Fol. 1r.-v. 
para quedar viviendo a libertad de conciencia, como hasta aquí siempre le han usado; pues no ha habido un juez de mis antecesores, que los haiga hecho cumplir con las obligaciones de cristiano, sino que antes por el contrario se han reído y burlado de ellos y como yo en cierto modo los quiero hacer cumplir con sus preceptos, que son dirigidos al mejor servicio de Dios y del Rey; a que oigan misa; frecuenten los sacramentos, concurran con sus personas a la apertura de caminos que repetidamente está mandado; nada de ellos les acomoda y por este motivo dicen soy tirano, que más bien se irán. ${ }^{77}$

En la época de la Independencia fueron frecuentes los problemas entre la autoridad y los vecinos, lo que puede ser un reflejo de los cambios políticos que estaban ocurriendo. No es extraño que los partidarios del Rey se quejaran de los jueces nombrados por los gobiernos republicanos y que al restaurarse la monarquía, los patriotas buscaran por este medio manifestar su insatisfacción.

Hay que anotar que ninguna de las agresiones contra la autoridad, ni de la autoridad contra los vecinos, tuvo consecuencias fatales. La relación entre los pobladores y los jueces era bastante conflictiva, pero por temor o respeto, no llegó al límite del homicidio. No debemos olvidar que el asesinato de un juez era considerado un crimen de lesa majestad humana y sus ejecutores se exponían a ser condenados a la pena de muerte sin que hubiera posibilidad de apelación. Los Alcaldes, por su parte, sabían que las autoridades provinciales y virreinales no veían con buenos ojos que maltrataran a sus gobernados. ${ }^{78}$

Los conflictos con forasteros representaron el $8 \%$ de los pleitos por "injuria de hecho". Un porcentaje grande de los vecinos de otros lugares que intervinieron en esta clase de disputas eran comerciantes. El cobro de deudas, el robo de mercancías y muchas otras situaciones que se derivaban del ejercicio

\footnotetext{
${ }^{77}$ A. H. A. Criminal. B. 33. 2do. 1790-1817. Doc. $\mathrm{N}^{\circ}$ 14. Fols. 1r.-v., 7r.-9v.

${ }^{78}$ El historiador William Taylor, en su estudio sobre la Nueva España durante el siglo xviII, encontró que las agresiones efectuadas por los funcionarios o en su contra representaban la cuarta parte de los ataques a mano armada. No obstante, sólo el 10\% de los homicidios cometidos en la Mixteca Alta y el 25\% de los cometidos en el Centro de México, involucran a autoridades. La mayor parte de estos casos están relacionados con abusos de poder por parte de los funcionarios.

Taylor William B. Ob. cit. Págs. 137-138.
} 
de su actividad propiciaban los enfrentamientos. El que algunos fueran solteros, recién llegados de España u otras provincias, indica que no estaban plenamente integrados a la sociedad local y que su situación era muy vulnerable.

El enfrentamiento con extraños, es decir con personas que no formaban parte de la comunidad, fue frecuente en los pueblos de indios. Solían tener problemas con los vecinos blancos que les disputaban las tierras y con los comerciantes que operaban en la zona. Así, en un pleito seguido en 1780 contra don Juan Piñero, comerciante, por haber herido con un palo al Gobernador del pueblo de Sabanalarga, se decía que había cometido otros excesos y atentados en ese resguardo. Por ese motivo el Gobernador de la provincia Cayetano Buelta Lorenzana, le dio plazo de un mes para que liquidara sus cuentas en ese lugar y se presentara en su juzgado. ${ }^{79}$

Las autoridades no solían tener un buen concepto de los forasteros, pues los veían como personas propensas a crear problemas. Para evitar que prófugos de la justicia y personas no deseables se establecieran en la provincia trataron de ejercer un control riguroso sobre los recién llegados. En 1786 el visitador Mon y Velarde dispuso que todo forastero debía presentarse a la justicia y dar razón de dónde venía, por qué motivo y si se pensaba establecer de forma permanente. ${ }^{80}$

De todo lo anterior podemos concluir que las relaciones entre vecinos tenía cierto grado de violencia, a pesar de los esfuerzos de las autoridades por lograr que se recurriera a ellas para solucionar los problemas. De acuerdo a las palabras del fiscal Andrés Avelino de Uruburu

el derecho no autoriza a nadie, para que repela con propia mano su injuria, el brazo de la justicia, es a quien le pertenece reprimir estos excesos lo contrario es proceder con absoluto desprecio de las leyes, quedando siempre la inocencia expuesta a perecer a manos del más poderoso. ${ }^{81}$

\footnotetext{
${ }^{79}$ A. H. A. Criminal. B. 32. Leg. 1780-1790. Doc. $\mathrm{N}^{\circ} 1$. Fols. 1r.-2v.

${ }^{80}$ A. H. A. Esclavos. Tomo 31. Doc. 1027. Fols. 1r.-4v.

${ }^{81}$ A. H. A. Criminal. B. 101. Leg. 1800-1810. Doc. No 10. Fol. 21 v.
} 
Los jueces aprovechaban los juicios para instruir la población al respecto. Una de las preguntas que invariablemente se hacía a las personas que intervenían en un pleito, era si sabían que a nadie le era facultativo tomar satisfacción por mano propia. Las sentencias también contenían esta clase de amonestaciones. Estas medidas parecen haber tenido éxito si se considera que el número de pleitos entre vecinos se mantuvo inalterado entre 1790 y 1819, a pesar de que en ese periodo se duplicó la población de la provincia.

Las disputas familiares, por el contrario, aumentaron al final del periodo colonial. Los numerosos casos de violencia familiar muestran que allí era donde los conflictos tomaban formas más violentas. Esto lo corroboraremos más adelante al referirnos al homicidio. En este campo las autoridades no parecen haber tenido suerte en su prédica sobre la necesidad de que la familia viviera en paz y armonía. Esto sugiere que el cambio en las ideas sobre el papel de la mujer, los hijos y la familia es un proceso más lento y menos fácil de controlar.

\section{El escenario de las "injurias de hecho"}

La pauta espacial y temporal de las "injurias de hecho" es más clara y fácil de precisar que la de las injurias de palabra. Las heridas y golpes solían denunciarse inmediatamente ocurrían ya fuera por algunos de los implicados, sus familiares o los vecinos. Además, en el interrogatorio a que era sometida la víctima y en la confesión del acusado solía preguntarse cuándo y donde habían ocurrido los hechos.

De acuerdo con estos datos, la época del año cuando eran más frecuentes los pleitos que degeneraban en hechos de sangre, eran los meses de diciembre y enero (ver cuadro $\mathrm{N}^{\circ} 23$ ). Como ya lo anotamos, en este periodo se celebraban cinco fiestas religiosas. Las festividades comenzaban el 8 de diciembre, día de la Concepción y terminaban el 6 de enero, día de la Epifanía. En la ciudad de Antioquia la última semana del año parece haber estado dedicada al regocijo. Gente de todos los sitios de la jurisdicción llegaba para participar de la celebración del 28 de diciembre día de los Inocentes. Esta fiesta local era una especie de carnaval popular, pues todo el día 
desde por la mañana hasta la noche, se invierte en algazara, juegos, chanzas de que no se ha hecho ni hace aprecio, porque la mayor parte salen a las calles y plazas con varios disfraces y máscaras todo propio de la gente común y parda. ${ }^{82}$

Como muchos estudiosos lo han señalado, los carnavales son fiestas de inversión del orden social. En esos días lo prohibido es permisible y los roles sociales y sexuales intercambiables; el pueblo puede imponer efímeramente sus reglas. ${ }^{83}$ En la ciudad Antioquia los mestizos y mulatos pobres se disfrazaban con máscaras y recorrían el lugar burlándose de personas ricas o autoridades y cometiendo desmanes aprovechándose de su anonimato. En estas condiciones eran frecuentes las riñas, los ajustes de cuentas y una serie de actos que desbordaban el orden social. Así, en 1784 Ignacio Bravo, mestizo, labrador, a quien se le siguió juicio por varias pendencias, decía en su confesión que había tenido una quimera con Narciso Marín

sin haberse conocido el uno al otro, porque ambos andaban de máscara un día de Inocentes, por cuenta de un tropezón tuvieron su quimera porque lo ajó mal de palabras el otro y que después que se quitó la máscara el declarante es cierto que lo fue a buscar con intención de preguntarle, que motivos había tenido para haberse desvergonzado con él y que habiéndolo topado en la puerta de una tienda del padre Quintero, lo llamó aparte y tuvieron algunas razones de desahogo y que intentó darle con una bayoneta el declarante a dicho Marín, pero que ésta no la llevaba cuando andaban

${ }^{82}$ A. H. A. Criminal. B. 83. Leg. 1790-1820. Doc. No 25. Fol. 17r.-v.

${ }^{83}$ En muchas ciudades hispanoamericanas durante la colonia como México y Santa fe de Bogotá, las fiestas de carnaval tenían lugar en los días de carnestolendas (carnes por retirar), empezando el domingo anterior a la Cuaresma y concluyendo el miércoles de ceniza.

Viqueira Albán, Juan P. ¿Relajados o Reprimidos? Diversiones Públicas y Vida Social en la Ciudad de México durante el Siglo de las Luces. México. Fondo de cultura Económica. 1987. Págs. 138-152.

Vargas Lesmes, Julián. La Sociedad de Santa fe Colonial. Bogotá. Centro de Investigación y Educación Popular. CINEP. 1990. Págs. 313-316. 
de máscara, porque después que se la quitó la fue a buscar a su casa donde la tenía dentro de una guambía. ${ }^{84}$

A fines de la época colonial las autoridades trataron de impedir la celebración de fiestas de este tipo. En 1809, un grupo de vecinos de la villa de Medellín, solicitó al Gobernador Ayala que les permitiera salir disfrazados el día de Inocentes tal como se acostumbraba en la ciudad de Antioquia. Los Alcaldes ordinarios de la villa no habían autorizado la celebración aduciendo que en varias Reales Cédulas se prohibían los carnavales bulliciosos, asonadas de gentes y los disfraces de máscaras. Argumentaban que el momento no era propicio, pues los organizadores intentaban representar la captura del Rey Fernando por parte de Napoleón, lo que era sonrojoso para "su alta majestad" y ofensivo al decoro de la nación. Además en estas ocasiones se preparaban máscaras figurando rostros y trajes de personas particulares para sonrojarlos. ${ }^{85}$

Otra época del año cuando solían presentarse esta clase de conflictos era el mes de marzo. Esto puede estar relacionado con la celebración de la Semana Santa, aunque ésta era una época de recogimiento y no de jolgorio, en la que se acostumbraba por parte de los curas hacer sermones, ejercicios espirituales y penitencia. ${ }^{86}$ De todas maneras había una interrupción del ritmo de trabajo cotidiano y la ciudad estaba muy concurrida, lo que podía ser utilizado para hacer los reclamos sobre deudas, ventilar los problemas familiares, etc. Fuera de la Semana Santa en este mes se celebraba la fiesta de San José y la Anunciación de Nuestra Señora.

Los meses cuando menos pleitos se presentaron fueron mayo y noviembre, mientras que en el resto del año el número fue muy estable. No debemos olvidar que en casi todos los meses había una fiesta de guarda. Por otra parte el pueblo constantemente organizaba bailes para celebrar la administración de los sacramentos (bautizo, matrimonio, etc.) y aún entierros. Las autoridades trataban de controlar estas "funciones", y era necesario pedir licencia para celebrarlas. En estos bailes solían presentarse problemas como nos lo corrobora la

\footnotetext{
${ }^{84}$ A. H. A. Criminal. B. 31. Leg. 1780-1790. Doc. $\mathrm{N}^{\circ}$ 4. Fols. 9v.-13v.

${ }^{85}$ A. H. A. Eclesiásticos. Tomo 84. Doc. 2355. Fols. 5r.-v.

${ }^{86}$ Vargas Lesmes, Julián. Ob. cit. Págs. 308-309.
} 
queja puesta en 1795 por Vicente Vahos, indio de Sopetrán, contra Rumaldo Rodríguez, por haberlo herido en un baile organizado en la casa de Angela Varea con motivo de un velorio. El Acalde del partido, don Juan José Mery decía que este baile se había hecho sin licencia, por esto después de la pelea entre Vahos y Rodríguez él puso presos a los concurrentes que pudo coger y a la dueña de casa.

Era corriente que la gente organizara bailes sin licencia o que éstos se prolongaran más allá de la hora señalada. En 1799 se presentaron problemas en el pueblo de San Antonio de Pereira, porque el Alcalde ordinario de Rionegro encarceló a los concurrentes al bautizo de un indiecito, debido a que siguieron el baile después de la hora autorizada. Según las autoridades del lugar estos bailes debían acabarse temprano para que los concurrentes pudieran cumplir al día siguiente con sus obligaciones. Consideraban estos festejos como ofensivos a Dios, por reducirse a juegos en que se perdía plata, embriaguez y peleas. ${ }^{87}$

Es necesario anotar que uno de los aspectos que los gobernantes ilustrados intentaron cambiar fue el de la celebración de las fiestas religiosas. La concepción que el pueblo tenía de estas fiestas como celebraciones que rompían con el ritmo cotidiano y que permitían salirse de las normas de comportamiento habitual, fue duramente combatida por tales gobernantes. ${ }^{88}$

En el caso de la provincia de Antioquia el visitador Mon y Velarde consideró excesivo el costo de la fiesta de Nuestra Señora de la Candelaria, que se celebraba en la villa de Medellín en la primera semana del mes de febrero. Durante esta celebración que abarcaba ocho días, los alférez nombrados por el Cabildo, debían costear tabaco y aguardiente para distribuir libremente entre los vecinos, así como fuegos artificiales. El visitador hizo una legislación para reducir los costos y darle a la celebración un tono más religioso. En el concepto de estos funcionarios las fiestas religiosas debían celebrarse, pero en ellas debía primar el recogimiento espiritual y no se debía convertir en una bacanal. Hay

\footnotetext{
${ }^{87}$ A. H. A. Criminal. B. 37. Leg. 1780-1800. Doc. $\mathrm{N}^{\circ}$ 17. Fols. 3r.-V., 11r.-12r.

${ }^{88}$ Viqueira Albán, Juan Pedro. Ob. cit. Págs. 152-153.
} 
necesidad de hacer un estudio de estas celebraciones para saber si su política tuvo éxito. ${ }^{89}$

Aunque las referencias anteriores muestras que las fiestas eran propicias para que se originaran conflictos, es necesario anotar que la mayor parte de los pleitos estudiados sucedieron en días comunes, cuando la gente estaba dedicada a actividades laborales. Los momentos de festividad parecen haber aumentado los enfrentamientos en un vecindario de por sí conflictivo. Desafortunadamente en muy pocos sumarios se dejó constancia del día de la semana en que ocurrieron los hechos, información que nos serviría para saber hasta que punto en los días no laborales se incrementaban los enfrentamientos.

Adicionalmente sólo en un poco más del 30\% de las causas se precisó la hora en que sucedió la pelea (ver cuadro $\mathrm{N}^{\circ} 23^{\mathrm{a}}$ ). Estos datos muestras que las horas de la noche eran más propicias para que se presentaran riñas. Sin embargo, el que un evento ocurriera de noche era un dato que rara vez se dejaba de anotar, mientras que se pasaba por alto precisar un momento específico del día. Además las circunstancias en que acaecieron muchas de las disputas hacen pensar que no se trataba de ataques nocturnos.

La pauta espacial de las agresiones físicas se puede definir con bastante precisión a partir de la información consignada en los juicios. Si comparamos los datos referentes a las injurias de palabras con los relativos a las "injurias de hecho", encontramos que en el segundo caso fue mayor el número de pleitos que ocurrió en lugares despoblados, donde había pocos testigos, como los caminos, las estancias rurales, las minas, las quebradas o los montes. Esto se debe a que el delito de injuria se constituía en la medida en que los insultos hubieran sido dichos en público, mientras que las evidencias físicas de las heridas y el maltrato bastaban para que las autoridades empezaran un sumario.

Un poco más del 10\% de las lesiones personales ocurrieron en caminos, circunstancias que era considerada como agravante del delito, porque usualmente significaba que se estaba vigilando a la víctima para atacarla cuando pasara (ver cuadro $\mathrm{N}^{\circ} 22$ ). Así, en 1750 José Miguel de Vergara puso demanda contra el zambo Juan José de Torres por haberlo esperado en

\footnotetext{
${ }^{89}$ Twinam, Ann. Ob. cit. Págs. 203-207.
} 
un bosque al pie del camino que él "traficaba", donde le salió de improviso, lo desarmó y le dio cuchilladas y estocadas, de las que se salvó por estar a caballo. Torres en su confesión aseguraba que no lo había atacado en camino real ni de improviso, solamente lo insultó estando a una distancia de cerca de 20 varas..$^{90}$

En todas estas demandas se hacía hincapié en que el agresor había procedido con alevosía y que la víctima estaba desprevenida y sin armas para defenderse. Después de haberlo agredido, el acusado había abandonado al herido dejándolo aturdido o medio muerto. También se enfatizaba que los hechos habían sucedido en un camino real, es decir aquellos que conducían a las principales ciudades o eran principios de otros, por ser una circunstancia agravante. ${ }^{91}$

Es preciso anotar que estos asaltos en caminos solían ser perpetrados por una sola persona, quien buscaba vengarse porque lo habían demandado o se había dicho algo de él. En la jurisdicción de la ciudad de Antioquia durante la época estudiada no se organizaron "gavillas de salteadores", que se dedicaran a atracar en los caminos a los traficantes y a robar en ranchos y haciendas. Estos síntomas de bandolerismo social fueron muy comunes en otras regiones de Hispanoamérica durante el siglo xvir y la Independencia. El que la sociedad antioqueña estuviera constituida por medianos y pequeños propietarios, sin una presencia fuerte de la hacienda, explicaría el que no se conformasen bandas de asaltantes. De acuerdo con algunas investigaciones los salteadores de caminos solían ser personas que carecían de ataduras a la tierra o la familia, hechos que no eran comunes entre los antioqueños. ${ }^{92}$

${ }^{90}$ A. H. A. Criminal. B. 73. Leg. 1700-1740. Doc. $\mathrm{N}^{\circ}$ 12. Fols. 1r.-2v., 8v.-10r.

${ }^{91}$ Escriche, Joaquín. Ob. cit. Págs. 397-398.

${ }_{92}$ Referencias al bandolerismo social en Hispanoamérica durante el siglo xviII se encuentran, entre otros, en:

Alberto Flores Galindo. "Los Rostros de la Plebe". Revista Andina. Cuzco. Perú. Tomo I. N 2. 1983. Págs. 315-352. Este artículo es parte de su tesis doctoral titulada Aristocratie et Plebe: Lima 1760-1830. Classes Sociales et Société Coloniale au Perou. Paris. 1983.

William B. Taylor. "Bandolerismo e Insurgencia en el Centro de Jalisco: 1790-1816". En: Revista Encuentro. Guadalajara. № 3. Abril-Junio. 1984. Págs. 5-54.

Francisco Zuluaga. "Clientelismo y Guerrillas en el Valle del Patía. 1536-1811". En: La Independencia. Ensayos de Historia Social. Bogotá. Instituto colombiano de Cultura. 1986. Págs. 111-130. 
El 11\% de las agresiones físicas ocurrieron en lugares de trabajo, bien fuera en rozas o minas. Los agresores solían ir en busca de la víctima al sitio donde ésta laboraba para hacerle reclamos relacionados con el uso del agua, la introducción de ganado que dañaba las sementeras u otro problema que existiera entre ellos. Un ejemplo de estas demandas es la presentada en 1810 por José Basilio Galván, vecino de Sopetrán, contra José Ignacio y Fulgencio García por haberlo agredido en sus labranzas. Según el demandante los atacantes, después de quitarle el cuchillo y el hacha con que estaba trabajando, le dieron varias puñaladas. José Ignacio García, que era cuñado de Basilio, en una representación afirmó que la disputa se había originado en que habiendo recogido unas guaduas sueltas en la propiedad de su suegro don José Galván, su cuñado quiso apropiarse de ellas argumentando que eran suyas. Aseguraba que el oponente lo había golpeado con un hacha en el brazo izquierdo descomponiéndoselo, después lo atacó con un cuchillo y tratando de evitar que huyera le arrojó dos piedras. ${ }^{93}$

Como se puede apreciar, los instrumentos de trabajo eran utilizados como armas para protegerse $u$ ofender al contrario. Aunque en algunos de estos pleitos se señala que la agresión fue premeditada, los relatos muestran que las heridas o golpes fueron el resultado más o menos casual del enfrentamiento.

Los ataques hechos en quebradas o montes solían ser contra mujeres que estaban buscando leña o lavando ropa. En estos casos el agresor esperaba que la víctima estuviera sola e indefensa para agredirla, lo que indica que su acción era deliberada. Esta situación la ilustra el juicio seguido contra Gabriel Montoya, vecino del partido de Miranda, a quien Eusebio Girón acusó de tener

el arrojo de encubriéndose en paraje yermo inmediato a la quebrada acechar o atisbar a mi mujer María Osorio, y valido de la fuerza cometió el atroz delito de adulterio consiguiendo su gusto con el carnal acto a que la forzó. ${ }^{94}$

\footnotetext{
${ }^{93}$ A. H. A. Criminal. B. 42. Leg. 1800-1810. Doc. $\mathrm{N}^{\circ}$ 14. Fols. 1r.-v., 5r.-v.

${ }^{94}$ A. H. A. Criminal. B. 77. Leg. 1800-1810. Doc. N 11. Fols. 1r.-v.
} 
El 30\% de las peleas estudiadas ocurrió en parajes rurales donde era factible que hubiera pocos o ningún testigo del hecho. Por otra parte, el 41\% de los pleitos tuvo lugar ante el vecindario, en las calles y casas de la ciudad de Antioquia o en los sitios pertenecientes a su jurisdicción.

Cerca del 10\% de los hechos denunciados fueron disputas callejeras, en las que el agresor o el agredido podía ser alguien que intervenía por casualidad, para separar a quienes estaban peleando. Esto fue lo que ocurrió la noche del 24 de diciembre de 1803, cuando los soldados Jerónimo Granel y Juan Gutiérrez, quienes acababan de salir de misa de gallo de la iglesia de Chiquinquirá, trataron de apartar a Agapito Sierra y Román Flórez que estaban peleando en la calle, Florencio Loa, que estaba entre los concurrentes, por descuido descargó un palo labrado con dos filos en la cabeza de Granel a quien le lastimó la oreja izquierda. Por el impacto el herido cayó al suelo, golpeándose un ojo y la nariz. ${ }^{95}$

El 43\% de las agresiones físicas ocurrió en la casa de uno de los implicados en el conflicto, en la de un familiar o en la de conocidos. Esto se explica porque buena parte de la violencia familiar tuvo como escenario el hogar que es el núcleo de la familia. Por otra parte las reuniones o bailes, en que proliferaban los enfrentamientos siempre se realizaban en una casa del vecindario. Para analizar este hecho no debemos perder de vista que en esta época la casa no era un recinto privado y que la diferencia entre calle y casa no era tan tajante como hoy.

El hogar era el sitio donde los jefes de familia trataban de imponer su autoridad sobre cónyuges, hijos, familiares y esclavos. La adopción del modelo patriarcal español llevaba implícita la idea de que el marido mandaba dentro de la casa y que los otros miembros de la familia debían obedecerlo. Sin embargo, las mujeres antioqueñas no parecen haber aceptado pasivamente estos preceptos, pues en algunos juicios el esposo justifica haberla golpeado porque no cumplía con sus obligaciones. Por ejemplo, Melchor Ciceros, quien puso una queja contra su esposa en 1798, decía que el motivo de las continuas disputas entre ellos era

${ }_{95}^{9}$ A. H. A. Criminal. B. 97. Leg. 1790-1810. Doc. $\mathrm{N}^{\circ}$ 15. Fol. 1 r. 
reprenderla para que sea mujer formal en su casa, que le ayude a trabajar en lo que pueda, y que no continúe en la casa de Luisa Pimienta, sino que se esté en su casa, atendiendo a sus obligaciones. ${ }^{96}$

Algunos problemas entre familiares parecen provenir de la intención de una parte de imponer su autoridad sobre la otra. En 1786 Blas de Vargas demandó a su yerno Juan de la rosa Sepúlveda por haberle salido en un camino a retarlo. Según los testimonios y la confesión del reo, el origen de la disputa estaba en que Sepúlveda llegó tarde a la casa y su suegro lo regañó. Al llamado de atención el sindicado había respondido.

que él iría a la hora que le diese gana, que era hombre libre y que fuera a gobernar sus calzones; que poco se le daba echar uno a los infiernos. ${ }^{97}$

Las situaciones anotadas permiten deducir que el modelo patriarcal de familia no era plenamente aceptado. Buena parte de la conflictividad familiar puede haber provenido del intento de las autoridades de imponerlo.

La proliferación de hechos ocurridos en las viviendas, es un indicativo de que los pleitos solían ocurrir en épocas de descanso. El carácter estacional de la economía minera y agrícola de la zona, llevaba a que una persona se ausentara por una o varias semanas de su casa para trabajar en el campo o la mina. Al retornar solía pedir cuentas sobre muchos asuntos, lo que daba origen a los conflictos.

Desde el punto de vista espacial y temporal los juicios seguidos en la jurisdicción de la ciudad de Antioquia entre 1750 y 1819 tenían pautas muy definidas. Las peleas entre vecinos solían llevarse a cabo en caminos, calles, lugares de trabajo o casas y tendían a incrementarse en épocas de festividades. Por otra parte, las disputas familiares ocurrían fundamentalmente dentro del hogar y sucedían en cualquier época del año.

\footnotetext{
${ }^{96}$ A. H. A. Criminal. B. 37. Leg. 1780-1800. Doc. $\mathrm{N}^{\circ} 14$. Fols. 1v.-4r.

${ }^{97}$ A. H. A. Criminal. B. 85. Leg. 1770-1790. Doc. $\mathrm{N}^{\circ}$ 15. Fols. 1v.-3r.
} 


\section{Las armas utilizadas}

Las armas utilizadas para agredir físicamente varían de una sociedad a otra y dentro de ésta a lo largo del tiempo. Por esta razón el criterio con el cual se define su peligrosidad es cambiante. La legislación española consideraba como arma, todo instrumento destinado a ofender a alguien o a la defensa propia..$^{98}$ Dentro de ellas distinguía las consideradas por ley, por estar permitido su uso y las catalogadas como prohibidas, por impedir la ley su utilización. Entre éstas últimas estaban las armas cortas de fuego como pistolas, trabucos, carabinas y las armas cortas blancas como puñales, navajas, dagas, cuchillos de punta, etc. Estas armas estaban prohibidas porque siendo puramente ofensivas y fáciles de ocultar, solían dar ocasión a muertes alevosas. Su uso era considerado un delito, no porque fuera en sí mismo un acto dañino, sino para prevenir otros que lo eran.

Las armas de fuego fueron muy poco usadas en la jurisdicción de la ciduad de Antioquia durante la época estudiada (ver cuadro $\mathrm{N}^{\circ} 26$ ). Esto parece deberse a lo costosas y escasas que eran, más que al hecho de estar prohibidas. El pueblo raso desconocía estas disposiciones como lo permite ver la declaración de Antonio de Restrepo, mulato, oficial de herrero, quien al preguntársele por qué cargaba una pistola respondió

que siempre ha cargado la pistola para resguardo de su persona y que ignoraba si estaba privado el uso de ella y que es cierto la tenía cargada con dos balas. ${ }^{99}$

En un escrito presentado en agosto de 1773 este sujeto trataba de justificar con su oficio la posesión de armas prohibidas. Decía que como oficial público siempre tenía algunas en su poder, ya fuera porque se las habían llevado para arreglarlas o porque él mantenía para la venta.

Por el contrario, las armas blancas fueron utilizadas con mucha frecuencia, sobre todo los cuchillos, navajas, espadas y sables. En estos casos también era frecuente que los reos afirmaran desconocer las normas que prohibían su

98 Escriche, Joaquín. Ob. cit. Pág. 218-219.

${ }^{99}$ A. H. A. Criminal. B. 38. Leg. 1770-1780. Doc. N 5. Fols. 14v.-17v., 36r.-37v. 
uso. Algunos argumentaron que acostumbraban cargas cuchillos y puñales para defenderse y porque eran muy útiles. Así, en 1794, Antonio Durango, quien estaba preso por haber hecho resistencia a las autoridades indígenas del pueblo de Sabanalarga, decía con respecto al puñal

esta es una arma muy menesterosa a todos los que habitamos, caminamos y laboramos por estos montes, de suerte que el que no tiene puñal carga cuchillo a causa de que cuando uno menos piensa se encuentra con un tigre, con un león o con un oso, y para poderse defender, o lograr de ellos engasta un hombre el puñal en un palo, que le sirve de lanza. ${ }^{100}$

Los Gobernadores de la provincia constantemente ordenaron la publicación de bandos en que se prohibía el uso de armas en los poblados. En 1785 el Gobernador Francisco Silvestre encargó al Alcalde pedáneo de San Pedro, en el Valle de los Osos, publicar uno en que se estipulaba

que nadie cargue armas, aunque sean de las permitidas, dentro de las poblaciones o rancherías de minas, permitiéndose sólo que éstas las puedan cargar para su resguardo y defensa, cuando vayan de camino; aunque no la gente de color, pues ésta sólo deberá cargar las propias de su labranza u ejercicio y cuando vayan a ellas y de que sin respeto alguno deberá proceder contra cualquiera que cargase armas cortas blancas o de chispa de las prohibidas con arreglo a la pragmática que de esto trata. ${ }^{101}$

A pesar de las prohibiciones reiteradas los antioqueños continuaron usando las armas blancas. Las autoridades tampoco fueron muy duras a la hora de aplicar las sanciones, pues siempre consideraban que el reo alegaba desconocer la norma. Las pocas penas que por este delito se impusieron consistían en la pérdida del arma, el pago de una multa o el pago de las costas del proceso.

${ }^{100}$ A. H. A. Criminal. B. 51. Leg. 1730-1800. Doc. No 4. Fols. 13r.-16v.

${ }^{101}$ A. H. A. Criminal. B. 94. Leg. 1780-1790. Doc. $N^{\circ}$ 5. Fols. 29r.-30r. 
Entre las herramientas de trabajo la que más se usó como arma fue el machete. Hay que considerar que los trabajadores rurales siempre tenían uno a mano, siendo fácil que lo emplearan para defenderse o agredir cuando una discusión llegaba a la agresión corporal. La utilización de este instrumento no era considerada como un indicativo de alevosía y premeditación por ser difícil de ocultar y no ser por sí misma un arma ofensiva. Otras herramientas como hachas, barras, etc. fueron usadas muy pocas veces.

El empleo de palos, bastante frecuente en las disputas, tampoco sugiere premeditación. Según los testimonios, los hombres de la región antioqueña acostumbraban usar uno, a modo de bordón, cuando salían de su casa. En 1775, don Ignacio Delgado, preso en la cárcel por haber intervenido en una disputa entre don Juan Antonio Díaz y don Antonio de Piedrahíta, decía que en el momento de la pelea tenía un palo en la mano, debido a que en el campo se usaba llevarlo en cualquier camino. Esto no significaba que lo hubiera usado para ofender o lastimar a alguien, pues había rehusado dárselo a los que reñían. ${ }^{102}$

Casi el 30\% de las agresiones físicas analizadas consistieron en golpes dados con las manos o los pies. En el caso de las mujeres las golpizas solían estar acompañadas de azotes dados con un lazo o látigo. En teoría, las lesiones causadas de esta forma serían menos graves que las hechas con un instrumento cortopunzante. Sin embargo, los golpes podían ocasionar fracturas o heridas serias y en algunos casos aún provocar la muerte.

De todos los elementos utilizados para causar daño físico a una persona, el que mayor grado de premeditación sugiere, es el uso de venenos. Aunque fueron escasos, existen algunos denuncios de intento de envenenamiento con solimán (sublimado corrosivo) o yerbas. Es posible que algunas muertes se hayan provocado de esta manera, sin que fuera posible detectarlo, dado el escaso desarrollo de la medicina. Los tres casos estudiados fueron denuncias presentadas por hombres contra mujeres cercanas a ellos por ser esposas, o esclavas de su casa, o ex-amantes.

${ }^{102}$ A. H. A. Criminal. B. 74. Leg. 1760-1780. Doc. $\mathrm{N}^{\circ}$ 7. Fols. 27r.-28v. y Doc N ${ }^{\circ} 1$. Fols. 38r.-v. 
En 1798 Melchor Ciceros acusó a su esposa María Teresa Guzmán de haberle dado solimán en la comida, pues al probar un caldo que le sirvió se le había puesto el paladar "muy traboso". Para constatar la presencia en la comida de esta sustancia fue llamado Miguel de Aldave, oficial de platero, quien revolvió el caldo con una cuchara de plata, y esta se puso negra. Con base en sus conocimientos el perito afirmó que ese era el efecto que causaba el solimán en la plata. A pesar de las evidencias, el asesor jurídico don Pantaleón Arango, dictaminó que se debía dejar libre a María Teresa porque no se podía probar que ella hubiera puesto el veneno en la comida. ${ }^{103}$

Como conclusión se puede establecer que en las peleas entre hombres, lo común fue el uso de las armas cortopunzantes o los golpes, mientras que en las disputas entre hombres y mujeres fueron más frecuentes los golpes, el látigo y aún el veneno.

\section{Los motivos}

El estudio de los motivos que dieron origen a las peleas que terminaron en hechos de sangre, nos ayuda a conocer la manera de pensar y de vivir de una sociedad. Por esta razón es interesante saber cuáles fueron los problemas por los que los antioqueños de finales del periodo colonial estaban dispuestos a agredir o ser agredidos físicamente. Para analizar este aspecto nos basaremos en lo declarado a los jueces por las víctimas, agresores y testigos.

Los problemas de tipo económico como el cobro de deudas, los daños que en las sementeras hacía el ganado de los vecinos, las discusiones sobre el derecho a una propiedad o al uso de unas aguas, fueron los causantes del $30 \%$ de las "injurias de hecho" estudiadas (ver cuadro $\mathrm{N}^{\circ} 25$ ). Aunque es un porcentaje significativo, hay que anotar que la incidencia de estos problemas fue menor en el caso de los pleitos por lesiones físicas que en los de injuria de palabra (ver cuadro $\mathrm{N}^{\circ} 12$ ).

Una porción alta de los enfrentamientos estudiados se originaron en el cobro de deudas o reclamos sobre la calidad y cantidad de lo vendido. Lo llamativo es que el valor de lo que se reclamaba casi nunca excedía de un peso.

${ }^{103}$ A. H. A. Criminal. B. 37. Leg. 1780-1800. Doc. $\mathrm{N}^{\circ} 14$. Fols. 1r.-v., 4v.-5r-.35v. 
Un ejemplo típico de esta situación es la pendencia que por el cobro de cuatro tomines de oro tuvieron en 1760 Ignacio Javier de Agudelo y Juan Bernardo Mejía, asistentes en el sitio de Sacaojal y cuñados. Como Agudelo no tenía con que pagar ofreció dar a cambio seis tomines de tabaco, siendo rechazado por Mejía que lo trató de tramposo y de querer mantenerse con lo ajeno. En el enfrentamiento que siguió resultaron heridos Agudelo y la mujer de su oponente. ${ }^{104}$

Ese mismo año a Salvador Machado, tratante, se le siguieron dos causas por las heridas que propinó a José Ignacio de Luna y Juan José Cañola al estar arreglando cuentas. En la primera oportunidad Machado parece haberse exasperado porque al reclamarle a Luna un faltante en un cacao que le vendió le dijo:

que estaba enseñado a tratar con mercaderes gruesos y no con mercachifle. ${ }^{105}$

En la segunda ocasión la disputa se presentó por una divergencia en la cantidad que Cañola le debía a Machado. Según éste último, el contrario lo había tratado de perro, maula (embustero, engañador) e hijo de puta y le había tirado con un palo que llevaba. Cañola, por su parte, sostenía que Machado era inclinado a riñas y diferencias

pareciendo, que con los pesos que se halla ya es dueño de avasallar a los hombres, principalmente a los pobres

Como lo anotamos en el caso de las injurias, el éxito económico de algunos pequeños mercaderes originaba resentimientos que salían a flore al hacer reclamos. Hay que tener en cuenta que la mercancía con que contaban estos tratantes era fiada, situación que los llevaba a apremiar a los clientes para que pagaran y a tratar de sacar una mayor ganancia elevando el monto de las deudas o rebajando las pesas y medidas.

${ }^{104}$ A. H. A. Criminal. B. 73. Leg. 1700-1740. Doc. $\mathrm{N}^{\circ} 24$. Fols. 2r.-v., 12r.-13r.

${ }^{105}$ A. H. A. Criminal. B. 74. Leg. 1760-1780. Doc. $\mathrm{N}^{\circ} 1$. Fols. 4v.-5v-. 24v.-25v., 38r.-38v. 
La forma como los jueces tramitaban los juicios ejecutivos por deudas también propiciaba los enfrentamientos. Según algunos testimonios, el mismo demandante era el encargado de entregar al demandado la notificación, situación esta que se prestaba para el intercambio de palabras y roces. En 1773 Antonio Restrepo, preso por haber intentado agredir a Ignacio Mira, decía que era

práctica ireconcusa (Sic) en los señores jueces el librar papel, en que manda pagar sin obligar al comparendo al demandado, ni extorsionarlo a que pague, lo que da ocasión a estas incidencias. ${ }^{106}$

En la década de 1780 fue cuando se originaron más pleitos por esta causa. La mayor parte de ellos eran entre vecinos que tenían divergencias sobre el monto y forma de pago de un crédito en dinero o especie. Así, en 1788 Juan Ignacio Holguín tuvo una pendencia con Manuel Sauceda y su cuñado Gabriel Montoya por el cobro de un almud de maíz. La pelea en que hubo empellones y Holguín fue arrastrado por el suelo, se caracterizó por un fuerte intercambio de agravios. El Alcalde ordinario, Antonio José de la fuente, en la sentencia consideró que era lamentable que por una "causa tan ratera" como el cobro de un almud de maíz los implicados se hubieran agraviado faltando a la caridad cristiana y se enfrascaran en un pelito que podía haber tenido consecuencias graves. Para evitar perjuicios a las partes, determinó cortar en pleito, previniéndoles que en caso de reincidir serían tratados con todo rigor. ${ }^{107}$

A partir de este momento los jueces trataron de abreviar estas demandas, buscando que las personas que intervenían en ellas no gastaran mucho tiempo y dinero. Se hizo hincapié en que el cobro de cantidades insignificantes no podía dar origen a pleitos que distraían a la gente de su trabajo. ${ }^{108}$ Estas medidas parecen haber tenido éxito pues a comienzos del siglo xix disminuyeron las agresiones físicas que se suscitaban por esta causa.

Cerca del $10 \%$ de los juicios por "injuria de hecho" tuvo origen en disputas por la propiedad de tierras o minas, el uso de aguas y caminos o los

\footnotetext{
${ }^{106}$ A. H. A. Criminal. B. 38. Leg. 1770-1780. Doc. $N^{\circ}$ 5. Fols. 36r.-37v.

${ }^{107}$ A. H. A. Criminal. B. 75. Leg. 1788-1790. Doc. N 2. Fols. 4r.5r., 11r.-v.

${ }^{108}$ A. H. A. Criminal. B. 83. Leg. 1790-1820. Doc. $\mathrm{N}^{\circ} 4$. Fols. 7v.-8r.
} 
daños que el ganado causaba en las sementeras. Un dato interesante es que la mayor parte de estas demandas se presentaron en dos momentos, uno que abarcó de 1750 a 1769 y otros a principios del siglo xix.

En los años finales del régimen colonial estos pleitos se volvieron especialmente violentos. Es difícil saber las causas de este fenómeno, pero pudo deberse a que el crecimiento de la población aumentó el número de personas que competían por las tierras, minas y aguas. En 1805, por ejemplo, Juan José de Flórez, mazamorrero residente en el partido de Yarumal, presentó demanda contra don Santos Cuartas por intentar despojarlo de una quebrada que estaba trabajando hacia tres años. Por esta razón tuvieron un altercado en que Cuartas resultó herido en la frente. Flórez argumentó que tenía derecho a explotar la mina, pues para hacer el registro sólo estaba esperando acabar de reconocerla y ponerla en funcionamiento. Se oponía a que el contrario trabajara en la misma quebrada porque significaba partir el agua de la que se servía para su laboreo. ${ }^{109}$

Por otra parte, las relaciones entre los dueños de tierras o minas y sus agregados eran muchas veces tensas y violentas. Esta situación la ilustra el juicio seguido en 1804 contra don Bautista Díaz, por haber herido a José Aniceto Barrantes, quien estaba agregado en tierras de don Juan Bautista Díaz. De acuerdo con los testimonios, el problema se originó por el ingreso de unos cerdos de don Juan Bautista en la labranza de Barrantes. Don Bautista, que era el mayordomo, se enojó porque los perros de José Aniceto mordieron los cerdos $\mathrm{y}$, armado con un machete y una escopeta, se dispuso a matar los perros. En la discusión que se suscitó resultó herido Barrantes. El agresor justificó su acción diciendo que el contrario, siendo un hombre de "baja esfera", había tomado un machete para defender a sus perros. Aseguraba que el herido estaba "picado" con él porque lo había encontrado robando leña y le quitó un hacha. ${ }^{110}$

El ejemplo anterior permite ver que existía una contradicción entre le deseo de los propietarios y administradores de tener sujetos a los trabajadores

${ }^{109}$ A. H. A. Criminal. B. 83. Leg. 1790-1820. Doc. $N^{\circ} 26$. Fols. 1r.-2r.

${ }^{110}$ A. H. A. Criminal. B. 30. Leg. 1800-1810. Doc. No 13. Fols. 1v.-3r., 12r.-15v. 
y la negativa de éstos a que se ejerciera un control absoluto sobre sus actos. Es importante anotar que de acuerdo con testimonios de la época, el grado de dependencia de los agregados no parece haber sido muy fuerte. En un documento de 1790 se dice que

... no tienen fijeza alguna pues unas veces están con unos, otras con otros propiamente debe llamárseles jornaleros... ${ }^{11}$

Es natural en una sociedad de pequeños propietarios que los trabajadores buscaran convertirse en dueños de su propio terreno. Por esto no debían estar dispuestos a que se los vinculara en forma definitiva a una propiedad.

El porcentaje de agresiones físicas que tuvo como causa el robo fue muy pequeño. Este hecho es llamativo porque las imputaciones de robo fueron el origen de un número apreciable de demandas por injuria (ver cuadro $\mathrm{N}^{\circ} 12$ ). La aparente contradicción entre estos dos datos, puede deberse a que muchos de los enfrentamientos ocasionados por hurtos están incluidos en los procesos seguidos por este delito. Un caso que ilustra esta situación es el juicio seguido contra Juan Andrés Benítez, mestizo, agregado en tierras ajenas, quien en 1814 fue procesado por haber herido a dos esclavos de Francisco Corea, que trataron de impedir que robara maíz de una roza en fruto. El procurador general, como fiscal de la causa, pedía que se lo castigara duramente porque de lo contrario

Que ciudadano tendrá seguras sus propiedades y su existencia sino se castiga con severidad a esta clase de gente, a estos perturbadores de la armonía de la sociedad?. ${ }^{112}$

El defensor, por su parte, argumentaba que se debía tener en consideración su pobreza e ignorancia y al ser la primera vez que estaba involucrado en esta clase de delito.

${ }^{111}$ Patiño Millán, Beatriz A. "La Provincia en el Siglo xviII". Pág. 78.

${ }^{112}$ A. H. A. Criminal. B. 33 2do. Legajo. 1790-1817. Doc. $\mathrm{N}^{\circ}$ 10. Fols. 1r.-v., 9v., 18v. 
En ninguno de los casos de violencia vinculada al robo, el agresor era un delincuente reconocido. Se trataba de ladrones ocasionales que, por defenderse, se vieron comprometidos en un hecho de sangre.

La mayor parte de los pleitos originados en problemas económicos se podían resolver a través de un juicio de carácter civil. Sin embargo, por múltiples causas los vecinos optaban por "hacerse justicia por sus propias manos". A lo largo del periodo estudiado, las autoridades buscaron que la justicia fuera aceptada como intermediaria, pero los juicios revelan que no fue fácil lograr este objetivo.

Los problemas cotidianos de la vida familiar y vecinal fueron la causa de la tercera parte de las agresiones físicas denunciadas en los juzgados de la jurisdicción de la ciudad de Antioquia. La motivación de muchas de estas peleas es difícil de precisar, pues se trataba de una violencia hasta cierto punto indiscriminada. Además, las razones expuestas en los juicios muchas veces no eran las reales, sino las admitidas por la ley o los jueces.

Un poco más del 10\% de los conflictos se originaron en problemas con los hijos o familiares. Los jefes de familia parecen haber sido muy susceptibles a que un hijo fuera maltratado o desacreditado por terceros. Estos hechos eran considerados como una afrenta a la familia y siempre estaban dispuestos a vengarlos. En 1752 la mujer de Benito Garro, acusado de haber herido a José de Lezcano, trató de defenderlo aduciendo como causa de la disputa que el oponente le había "abstraído" de la casa una hija casada. Además Garro habría actuado en defensa de su vida pues Lezcano

procuraba destruirle la vida después de haberle destruido la honra. ${ }^{113}$

Lezcano argumentaba que él no le había hecho ninguna ofensa debido a que

... no seré yo culpable de que su hija no atienda a las obligaciones que debe...

${ }^{113}$ A. H. A. Criminal. B. 27. Leg. 1750-1760. Doc. N². Fols. 11r.-12v, 14r.-v. 
La defensa del honor familiar podía desencadenar una serie de peleas y demandas. Así, en 1817, Ventura Rivera presentó una querella contra Joaquín Cañola, su pariente, por haberle pegado con un palo a su hijo Lino. El herido declaró que la causa de la agresión era que había "tratado mal de palabras" a dos hermanos de Cañola. Señaló que éstos eran unos mozos provocativos, desvergonzados, de mala crianza y que ordinariamente andaban en gavilla. Como se vé, en estos casos era difícil establecer quien había iniciado el enfrentamiento. ${ }^{114}$

Los chismes y habladurías eran los causantes de muchas de las quejas de "mala vecindad" y de problemas de familia. En algunas de estas causas, a veces sin especificar el motivo, se pedía que alguien fuera desterrado de un lugar o se lo prohibiera frecuentar un sitio. Los efectos que podían tener los comentarios y burlas se aprecian en la causa seguida en 1763 contra el mulato Miguel de Holguín por haber herido a Juana de Agudelo, india del pueblo de Buriticá. El sindicado declaró haber agredido a Juana porque ésta y sus hijos se burlaban de su mujer por no tener nariz, llamándola "cara de gata" o "la mocha". Juana, que era nuera de la esposa de Holguín, afirmó que la pelea también se había motivado en el hecho de no dejar que sus hijas fueran donde la abuela. El protector de naturales de la provincia presentó este caso como un ejemplo de las inquietudes, perjuicios y maltrato que los indígenas recibían de los libres que vivían en los resguardos. ${ }^{115}$

Los enfrentamientos causados por problemas de familia y de vecindad tenían un origen parecido al de algunos juicios por injuria de palabra. La diferencia estaba en que el agresor no recurría a la justicia para limpiar su honor, sino que trataba de hacerlo por sí mismo. La incidencia de este tipo de problema en la generación de violencia era muy grande, como se puede corroborar al constatar que cerca de la cuarta parte de los pleitos por "injuria de hecho" se originaron por esta causa. Este porcentaje se vuelve más significativo si tenemos en cuenta que sólo 10\% de los procesos por agravio verbal se debieron a esta clase de conflictos (ver cuadros $\mathrm{N}^{\circ} 12$ y 25 ).

${ }^{114}$ A. H. A. Criminal. B. 78 Leg. 1800-1820. Doc. $\mathrm{N}^{\circ}$ 24. Fols. 2r., 4r.-v.

${ }^{115}$ A. H. A. Criminal. B. 50. Leg. 1760-1780. Doc. $N^{\circ}$ 9. Fols. 1r.-v., 5r.-5r. 
Dentro de la violencia doméstica debemos incluir las quejar de maltrato denunciadas por los esclavos. Los dueños solían justificar su acción tildando al esclavo de ladrón, de haber huido o de tratar de obtener la liberta a muy bajo precio. Don José Rodríguez Paula, vecino de la ciudad de Antioquia, en 1781 sostuvo que había encerrado en un cuarto a su esclava María Antonia, por pretender cambiar de dueño o comprar su libertad. Argumentaba que esta era una falta de la esclava porque él la había mantenido con decencia y sin castigarla. En su concepto

un esclavo para dejar de servir debe justificar las causas, pues si no es así todos quedaremos expuestos a que siempre que diga el esclavo no querer servir a su señor por este motivo se le hubiera de dar gusto. ${ }^{116}$

En otro caso sucedido en 1806, Niceto, esclavo de don Graciliano de Lorza, acusó a su amo de amarrarlo y arrastrarlo de un caballo, por haberse quejado de maltrato al Alcalde del partido de Petacas. Al tratar su madre de defenderlo, Lorza la hirió con un sable en la muñeca y en la cara

La versión que el dueño presentaba de los hechos era diferente. Aseguraba que Niceto y su mujer habían huido y después de indagar los encontró en las montañas de Riogrande. Cuando regresaba con ellos fue asaltado por los parientes del esclavo, quienes en compañía de los libertos del difunto doctor Sancho Londoño trataron de liberar a los capturados. Decía no haber cometido delito alguno

por ser lícito defender los hombres, lo que es suyo y cautelar la pérdida de su vida, en cuyo acto, viéndome acometido y apedreado, usé de la defensa natural, más por amenaza, que con ánimo de ofenderlos, usando más prudencia, que la que suelen observarse en estos lances. ${ }^{117}$

${ }^{116}$ A. H. A. Esclavos. Tomo 31. Doc. 1013. Fols. 7r.-9v.

117 A. H. A. Criminal. B. 101. Leg. 1800-1810. Doc. No 14. Fols. 4v-5r., 8r.-v. 
Algunos de los esclavos que se quejaron a la justicia de maltrato por parte de los amos, afirmaron que no les daban de comer y vestir. Aunque los inculpados solían negar este cargo, existen varios documentos en que se afirma que muchos dueños de esclavos los tenían abandonados por no tener dinero para mantenerlos. En 1786 el visitador Mon y Velarde dispuso que se obligara a los amos a vender los esclavos que no pudieran sostener, pues esto tenía consecuencias funestas para la tranquilidad pública. ${ }^{118}$

Estos ejemplos muestran que los amos justificaban el castigo dado a los esclavos reivindicando su derecho de propiedad. Consideraban que la justicia no los podía obligar a vender o dejar en libertad a los esclavos, por constituir una parte apreciable de su patrimonio. ${ }^{119}$

Casi la cuarta parte de las agresiones físicas se derivaron de problemas en las relaciones sexuales. Las acusaciones de concubinato, los celos y el asedio sexual jugaron un papel muy importante en la violencia ejercida contra las mujeres.

Un porcentaje apreciable del maltrato a las esposas se originó en que uno de los cónyuges tenía relaciones extramatrimoniales. Así, en 1773, María de Restrepo declaró que su esposo Antonio Guzmán la había maltratado por haberlo ido a "acechar" a la casa de una mujer casada con quien tenía relaciones ilícitas. Meses antes de que presentara esta queja, el Alcalde ordinario había ordenado a Guzmán que no se comunicara por si o interpuesta persona con la referida mujer, pues de hacerlo se le impondrían dos meses de cárcel. ${ }^{120}$

En 1788 Petrona Gil se quejó ante el Alcalde del partido de río Arriba de Cauca, de la mala vida que le daba su esposo Remigio Gil cuando la lleva a la casa de la madre de Rengifo en el salado de Sopetrán, debido a que allí vivía una mujer

${ }_{118}$ A. H. A. Esclavos. Tomo 31. Doc. 1027. Fols. 1r.-4v.

119 José Félix Restrepo, ideólogo de la ley de Manumisión de esclavos promulgada en la provincia de Antioquia en 1814, opinaba que los esclavos estaban por fuera de la protección del gobierno, pues el amo dictaba las leyes que le sugería su antojo, las aplicaba a los casos particulares y ejercía una soberanía despótica. Consideraba necesario suprimir la esclavitud, porque era contradictoria con los principios del supremo poder nacional, a que debían estar sometidos todos los miembros de la nación.

Restrepo, José Félix de. Obras Completas. Medellín. Ediciones Académicas. 1961. Págs. 334-335.

${ }^{120}$ A. H. A. Criminal. B. 57. Leg. 1770-1780. Doc. No 7. Fols. 1r.-3r. 
con quien él había estado concubinado. Al ser interrogada por el juez declaró que su marido había estado amancebado con María Ceballos y había tenido dos hijos con ella. No podía afirmar si la relación continuaba, pero

se presume que lo estarán, así por la mala vida que le da a la declarante su marido como por las acciones que ha visto y observado ya viniendo tarde de la noche a acostarse, ya él atenderle más a su manceba la madre y hermana de su consabido marido. ${ }^{121}$

El marido declaró que esta acusación era falsa y que el verdadero motivo de la demanda presentada por su mujer era que él no quería vivir en el Río Arriba donde residía la madre de ella.

Por su parte Rudesindo Jaramillo, vecino de San Luis de Góngora, acusado de haber herido a su mujer Marcela López, decía que las pendencias entre ellos se debían a los repetidos adulterios de su esposa. Afirmaba que eran "públicos y notorios" sus concubinatos con Ramón Jaramillo, don Antonio Vélez y don Juan Ignacio Duque, pues él se había quejado a los Alcaldes y al cura. En una representación decía:

fui provocado a esta pendencia con precedencias muy dolorosas cuales son los repetidos y públicos adulterios incesantes desde trece años a esta parte con un desafecto tal, que por más esfuerzos que he hecho para conquistarla su amor todos han sido frustraneos (sic) y sólo han servido de acrecentar el menos precio y para dar una ligera pintura de su desarreglada vida. ${ }^{22}$

Los celos eran otra causa importante de desavenencias conyugales. Estos casos eran distintos a los anteriores debido a que se presumía la existencia del engaño, pero no era posible probarlo. Un ejemplo de esta situación es la causa seguida en 1773 a Salvador Ochoa por haber castigado "rigurosamente" a su esposa María Sebastiana Ruiz. En su confesión el reo decía que la había

${ }^{121}$ A. H. A. Criminal. B. 81. Leg. 1780-1790. Doc. $\mathrm{N}^{\circ} 19$. Fols. 12r.-v., 15v,17r.

${ }^{122}$ A. H. A. Criminal. B. 76. Leg. 1790-1790. Doc. $\mathrm{N}^{\circ} 4$. Fols. 6v-7v., 10r.-14r. 
golpeado por haber encontrado a Ignacio García en el solar de su casa a deshoras, en calzones blancos y sin sombrero. Afirmaba haber advertido a su mujer que no quería que este sujeto o sus hermanos fueran a su casa. ${ }^{123}$

Un motivo parecido fue aducido por Pedro Antonio Montes, procesado en 1816 por haber dado latigazos, golpes y quemar a su esposa Feliciana Palacio. En un escrito argumentaba que Feliciana no lo quería, le hacía desprecios y había tenido la aosadía de levantar la mano contra él y concluía señalando

\begin{abstract}
Un solo dicho, una sola malicia, una sola presunción tocante a la fidelidad del matrimonio es capaz de poner en movimiento a un hombre el más sencillo, cuanto más acciones tan significativas, conversaciones tan familiares, secretos y visitas tan continuas, como Feliciana tenía con Lora; y sobre todo pasajes tan palpables que no me dejaron, ni me dejan la menor duda de aquel ilícito comercio. ${ }^{124}$
\end{abstract}

Los ejemplos anteriores muestran que una buena parte de problemas conyugales se originaban en la infidelidad. Al analizar esta situación no debe olvidarse que a partir de la década de 1780 la justicia se dedicó a combatir los concubinatos y amancebamientos. Es posible que esta política, implementada para controlar socialmente a la población y mantener la unidad familiar, haya tenido efectos contrarios a los deseados. La intervención de la autoridad en lugar de integrar a la familia, parece haber dado lugar a que los cónyuges se resintieran y se sintieran vulnerados por una situación que antes toleraban.

Algunas de las agresiones físicas hechas a mujeres distintas a la esposa tuvieron como motivo la negativa de éstas a tener relaciones sexuales. En 1796 María Antonia Ferraro acusó a José Antonio Castañeda de haberla golpeado porque

había estado... solicitándola y siempre se le había denegado. ${ }^{125}$

${ }^{123}$ A. H. A. Criminal. B. 34. Leg. 1700-1780. Doc. $\mathrm{N}^{\circ}$ 18. Fols. 1v-2v., 27r.-29v.

${ }_{124}$ A. H. A. Criminal. B. 78. Leg. 1800-1820. Doc. $\mathrm{N}^{\circ} 19$. Fols. 104r.-106v.

${ }^{125}$ A. H. A. Criminal. B. 51. Leg. 1790-1800. Doc. No 14. Fols. 5r.-6v., 8r.-9v. 
El agresor negaba esta acusación señalando que la había golpeado para "refrenarle su desconcertada lengua". Exponía que lo quería sindicar de forzador, cuando el había procurado enamorarla sin violencia alguna. Para defenderse decía

Porque una cosa es enamorar y otra es forzar, lo cual jamás he llegado a imaginar con ésta ni otra persona alguna, ni mis acciones lo demuestran en estos autos, ni fuera de ellos.

En varios estudios sobre la criminalidad en Hispanoamérica en el periodo colonial, se ha encontrado que la violencia contra las mujeres estaba ligada a asaltos de tipo sexual. Los autores señalan que esta clase de delito era muy difícil de probar, pues las huellas físicas no eran una evidencia suficiente de la existencia del hecho. Además, los agresores siempre trataban de aminorar su responsabilidad disminuyendo la gravedad del hecho o presentándolo como algo fortuito. ${ }^{126}$

Los problemas con la autoridad fueron el origen de menos del 10\% de las lesiones personales. Ordinariamente estos pleitos eran producto de enfrentamientos que tenían por objeto evitar ser apresado o impedir el apresamiento de alguien.

Dos casos nos sirven para ilustrar la situación descrita. En el primero, ocurrido en 1764, se procesó al esclavo Juan del Pino por haber herido al soldado

${ }^{126}$ Susan Migden Socolow ha estudiado los tipos de crimen en que se vieron involucradas las mujeres de la región de Buenos Aires en la segunda mitad del siglo XVIII. En 70 casos analizados, encontró que la mayor parte de los delitos que involucraron mujeres eran de naturaleza sexual. Estos crímenes estaban incluidos en dos categorías básicas: las disputas domésticas y las ofensas sexuales. Las mujeres eran las víctimas o cómplices y en muy raras oportunidades aparecían como agresoras. Por su parte, François Giraud ha investigado las denuncias de violación en la región central de Nueva España, Puebla y el Bajío, durante el periodo 1720-1820. Al trabajar este delito sexual encontró que la mujer pasaba muy rápidamente de acusadora a acusada. Los esfuerzos de los defensores se dirigían a poner en duda el testimonio de las mujeres, tratando de poner en evidencia que no eran honorables.

Socolow, Susan Migden. "Women and Crime. Buenos Aires. 1757-1797". Journal of Latin American Studies. Cambridge University Press. 12, I. 1980. Págs. 41-44.

Giraud, François. Ob. cit. Pág. 339. 
Juan José de Medina cuando éste intentaba capturarlo. La orden de aprehensión contra del Pino había sido dictada por el Alcalde ordinario, don Ignacio Franco de Tovar, a petición del cura de Medellín y visitador de la provincia, doctor Juan Salvador de Villa y Castañeda, quien lo acusó de amancebamiento. Como puede apreciarse, al hacer resistencia a la justicia, el reo agravó considerablemente los cargos en su contra. ${ }^{127}$

En el segundo caso, doña Clara Díaz, esposa de don Felipe de Vargas, fue acusada en 1810 de tratar con palabras injuriosas y abofetear al Alcalde pedáneo de Sopetrán, quien había apresado a su cuñado don Juan José Vargas. La captura de Vargas se debió a que había engañado al juzgado con el fin de extraer un reo. ${ }^{128}$

Las acciones contra jueces o sus delegados se suscitaban porque el sindicado, sus familiares o amigos consideraban injusta la orden de aprehensión dictada contra él. En algunos juicios los implicados alegaban que el juez había actuado de manera improcedente abusando de su autoridad.

Por su parte, la legislación española consideraba que el delito de resistencia a la justicia debía castigarse con la mayor severidad, porque para la república era importante el respeto de los jueces. ${ }^{129}$

En el caso de la provincia de Antioquia, en donde el orden público dependía de la imagen y acción de la administración de la justicia, las autoridades estuvieron pendientes de controlar esta conducta. Ilustra esta situación un concepto emitido por el Gobernador Barón de Chaves, en el juicio seguido en 1760 por las heridas dadas al Alcalde ordinario don Francisco Salvador de Lara y Moncada:

siendo este delito, no sólo por su naturaleza execrable, por ser inmediatamente contra un juez real ordinario, sino que de quedarse impune quedaría abierta la puerta para muy graves y funestas consecuencias y mucho más

${ }^{127}$ A. H. A. Criminal. B. 41. Leg. 1740-1770. Doc. $\mathrm{N}^{\circ}$ 15. Fols. 1r., 3r.-v.

${ }_{128}$ A. H. A. Criminal. B. 84. Leg. 1810-1840. Doc. $\mathrm{N}^{\circ}$ 6. Fols. 1r-v, 8r.-v.

${ }^{129}$ Alvarez Posadilla, Juan. Ob. cit. Tomo III. Pág. 485. 
en estas partes donde los ministros reales, no tienen quien los sostenga, más que el respeto y autoridad. ${ }^{130}$

El análisis de los pleitos por "injuria real” seguidos en la jurisdicción de la ciudad de Antioquia muestra que la mayor parte de la violencia interpersonal no se originaba en problemas de tipo económico. Aunque en algunos momentos el cobro de deudas o los pleitos por la propiedad de tierras o minas produjeron enfrentamientos, los habitantes de la región parecen haber aceptado la intermediación del Estado en estos asuntos.

Los problemas derivados de la vida en familia y en vecindad, así como los conflictos que originaban las relaciones sexuales suscitaron cerca del $60 \%$ de las agresiones físicas. Para las autoridades esta violencia fue muy difícil de controlar debido a que estaba relacionada con patrones culturales muy arraigados. El que los gobernantes borbónicos se dedicaran a perseguir ciertas conductas sexuales, en lugar de eliminar los conflictos, parece haberlos agravado. Los juicios indican que no fue un proceso fácil la adopción del modelo de familia patriarcal hispánico, por parte de la población mestiza y mulata libre.

\section{Las sentencias}

Como las injurias reales eran de diversa clase y gravedad, la legislación española no tenía establecida una regla general para castigarlas. Las leyes dejaban al arbitrio del juez la imposición de la pena, que debía graduarse de acuerdo a la naturaleza de la ofensa, la calidad de las personas, los daños o perjuicios ocasionados y la alarma que el hecho hubiera producido en la comunidad. ${ }^{131}$

En el caso de las heridas no mortales, ni calificadas como alevosas, la Novísima Recopilación disponía que se debían imponer las penas de presidio, destierro o multa, según las circunstancias gravedad del delito. Si el juicio establecía que el agresor había sido culpable, se lo debía condenar, cuando menos, a los perjuicios causados, como los gastos de curación y la pérdida de trabajo.

\footnotetext{
${ }^{130}$ A. H. A. Criminal. B. 92. Leg. 1740-1770. Doc. No 19. Fols. 13v.-15r.

${ }^{131}$ Escriche, Joaquín. Ob. cit. Págs. 766, 876.

Alvarez Posadilla, Juan. Ob. cit. Tomo III. Págs. 469.
} 
En consecuencia, las penas impuestas en las causas de lesiones personales y heridas, seguidas en la jurisdicción de la ciudad de Antioquia, diferían mucho entre sí. En la mayor parte de los juicios la sentencia incluyó dos o tres penas distintas, combinando las de tipo pecuniario con las corporales. Cuando había varios reos, se determinaba una pena diferente para cada uno, teniendo en cuenta la participación y responsabilidad que hubiera tenido en el hecho. Un ejemplo de esta última situación es la sentencia proferida en 1805 en la causa contra María Alzate, Gertrudis Benalcázar, Anselmo Figueroa y Jerónima Figueroa por haber maltratado y herido a Pastora Layos. En ella el teniente de Gobernador Antonio Viana determinó absolver a los tres primeros y condenar a Jerónima a un año de cárcel. ${ }^{132}$

Un gran porcentaje de las sentencias incluyó penas pecuniarias como el pago de las costas del proceso, el pago de la curación, la pena de sangre, multas, etc. En 88 de las 137 sentencias emitidas, los reos fueron condenados al pago de las costas del proceso (ver cuadro $\mathrm{N}^{\circ} 27$ ). ${ }^{133}$ La cantidad cobrada por este concepto variaba, pues dependía de la duración del juicio y el número de diligencias efectuadas. En los juicios estudiados su valor osciló entre 147 y 2 pesos de oro, pero en la mayor parte de los casos no excedió los 20 pesos.

También difería mucho la cantidad pagada por gastos de curación. Fuera de lo cobrado en esta cuenta, por el práctico cirujano, se incluía los gastos en los medicamentos suministrados al herido. Así, en 1790 Francisco Javier Flórez, procesado por haber herido a Salvador Bravo fue condenado en el costo de la curación. De acuerdo con la cuenta presentada en el tratamiento del enfermo se habían gastado cinco puchas de aguardiente, dos arrobas y un tomín de carne, dos libras de cacao, cuatro almudes de maíz, dos y media libras de cera negra y un tomín y medio de dulce, lo que tenía un valor de cuatro pesos y tres tomines. Como el único bien del reo era una roza de maíz, el producto de ésta se adjudicó a Rafael Quintero, práctico cirujano encargado de la curación. ${ }^{134}$

132 A. H. A. Criminal. B. 101. Leg. 1800-1810. Doc. $\mathrm{N}^{\circ} 10$. Fol. 23 r.

${ }^{133}$ En el cuadro $\mathrm{N}^{\circ} 27$ los porcentajes se calculan sobre el número total de penas impuestas. Esta cantidad es superior al número de sentencias emitidas por las razones anteriormente anotadas.

${ }^{134}$ A. H. A. Criminal. B. 75. Leg. 1788-1790. Doc. N 1. Fols. 13r., 23v.-24r. 
El pago de los gastos de curación fue lo único que José Manuel Jiménez exigió para que se cortar la causa que, por heridas, seguía contra Montano González y Eduardo Correa. En 1804 presentó una cuenta que incluía un real de aguardiente, un tomín y medio de dulce, seis y medio tomines de carne, un real de cera negra, tres tomines de cacao, tres granos de jabón, un tomín de huevos, dos tomines de maíz, tres granos de sal, una vela, cuyo valor ascendía a dos pesos y un tomín. ${ }^{135}$

El monto de las multas también variaba, habiendo oscilado entre 2 y 40 pesos. Esta pena se usó en casos en que el reo había agravado el delito al huir o reincidir en una conducta que le había sido prohibida por un juez. En 1760 Salvador Machado se vio envuelto en dos causas por heridas. En la sentencia de la segunda el Gobernador lo condenó a pagar 24 pesos de multa por no haber cumplido con lo dispuesto en el fallo anterior. De la multa, ocho pesos eran para la manutención del herido y 16 pesos se atribuirían entre la Cámara Real y los gastos del Cabildo. ${ }^{136}$

La pena se sangre era una multa de 10 tomines pagadas al Rey por haber herido a una persona. Este castigo cayó en desuso en la década de 1780, tal vez porque su valor era tan bajo que no justificaba su aplicación. ${ }^{137}$

Los juristas ilustrados consideraban conveniente imponer penas pecuniarias a los reos de delitos no graves, dado el aprecio de los hombres por el dinero. Sin embargo, no creían prudente aplicarlas en el caso de delitos contra la seguridad personal de los ciudadanos o la sociedad, porque significaba dar licencia a los ricos y poderosos para delinquir. ${ }^{138}$

Los jueces de la ciudad de Antioquia no parecen haber tenido en cuenta estas precauciones, pues muchos sindicados de heridas graves sólo fueron condenados en las costas del proceso. Con este tipo de castigo el Estado cobraba el daño hecho a sus intereses, pero se dejaba de lado uno de los objetivos

\footnotetext{
${ }^{135}$ A. H. A. Criminal. B. 98. Leg. 1800-1810. Doc. $\mathrm{N}^{\circ} 19$. Fols. 12r., $13 \mathrm{r}$.

${ }^{136}$ A. H. A. Criminal. B. 74. Leg. 1760-1780. Doc. No 1. Fols. 61r.-63r.

${ }^{137}$ A. H. A. Criminal. B. 74. Leg. 1740-1760. Doc. $N^{\circ}$ 4. Fols. 14v-15r.

${ }^{138}$ Lardizábal y Uribe, Manuel. Discurso sobre las Penas. México. Editorial Porrúa S.A. 1982.
} Págs. 229-230. 
primordiales de las penas pecuniarias que era el resarcir al ofendido o a su familia de los daños y perjuicios causados.

Un número apreciable de las sentencias emitidas en las causas por "injuria real”, incluyó penas corporales como la cárcel, el destierro, el trabajo en obras públicas, el concierto o depósito de la persona.

En 46 de las 137 sentencias proferidas, al reo se le conmutó parte del castigo por la prisión sufrida. El tiempo de permanencia de los reos en la cárcel variaba de un caso a otro, pues dependía de la gravedad de las lesiones infringidas a la víctima, de la condición social y económica de las personas comprometidas en el juicio y del número de cargos acumulados en el proceso. Cuando había circunstancias agravantes, el agresor podía permanecer en la cárcel esperando la definición del juicio por varios meses.

Aunque la cárcel no estaba considerada como un castigo, la privación de la libertad y las molestias e incomodidades que se padecían en ella hacían que se pudiera contar entre las penas corporales aflictivas. ${ }^{139}$ En la ciudad de Antioquia los libres, esclavos e indígenas que estaban en la cárcel eran puestos a trabajar en obras públicas. Durante su estadía en prisión los reos eran puestos en cepos, vivían amarrados a una cadena, tenían que dormir en el suelo y, si la familia no velaba por ellos, aguantaban hambre. Las condiciones en que un reo permanecía en la cárcel fueron descritas en 1790 por don Nicolás de Lara, defensor del reo Francisco Javier Flórez, de la siguiente manera

en atención a que este miserable hace el tiempo de un año poco más o menos, que se haya sufriendo la dura y penosa prisión de una crecida cadena de hierro, puesta al pie y trabajando en las obras púbicas y como ésta le sirve de total embargo para poder trabajar con aquella libertad que el cuerpo necesita, suplica reverentemente a la piedad del Alcalde ordinario se sirva mandar el que se le quite, en el entretanto se concluye la causa. ${ }^{140}$

${ }^{139}$ Lardizábal y Uribe, Manuel. Ob. cit. Pág. 221.

${ }^{140}$ A. H. A. Criminal. B. 75. Leg. 1788-1790. Doc. No 1. Fol. 26 r. 
Por esta razón los asesores jurídicos y los jueces solían considerar que con el tiempo de permanencia en prisión el reo había recibido suficiente castigo. Así, en la causa seguida en 1786 contra Juan de la Rosa Sepúlveda por intentar herir a su suegro, el asesor jurídico doctor Ignacio Uribe, conceptuó

Y considerando suficientemente compurgado el expresado delito de irrespeto a que dio motivo la imprudente corrección de dicho su suegro, con la prisión y pena de trabajo personal de cuasi cinco meses que ha sufrido en la fábrica del Real Cabildo, le parece debe dársele por libre y quito de la acusación hecha por su suegro. ${ }^{141}$

Entre las penas corporales usadas estaban el destierro y la prohibición de ir a determinado lugar. Los juristas consideraban útil imponer esta clase de castigo a aquellas personas que cometían excesos, pero conservaban la probidad y la vergüenza. ${ }^{142}$ En la práctica estas prohibiciones no eran cumplidas y las autoridades se veían obligadas a apresar nuevamente al reo y a conminarlo para que cumpliera la sentencia. Esta situación la ilustran los siguientes ejemplos:

En octubre de 1787 el Oidor visitador Mon y Velarde determinó que don José Pichardo no fuera al sitio de Petacas, con el fin de evitar las continuas peleas que tenía con su suegro y sus cuñados residentes en ese lugar. Por no cumplir esta orden fue puesto preso en julio de 1788 y se reabrió la causa con la acusación de inobediencia a la justicia. Al tomársele confesión afirmó que el Teniente de Gobernador de los Osos le había dado permiso para residir en Petacas. Teniendo en cuenta eta circunstancia, el Oidor visitador mandó ponerlo en libertad, apercibiéndolo para que por ningún motivo pasara a ese real de minas, bajo la pena de 6 años de presidio si reincidía. ${ }^{143}$

Al reo Francisco Remigio Díaz, procesado por haber golpeado a su suegra y maltratado a su mujer, se le ordenó en noviembre de 1788 hacer vida con su esposa y residir en las tierras que su suegra tenía en Anzá. Por ningún motivo debía ir a la casa de su madre en Sopetrán, por presumirse que estaba

\footnotetext{
${ }^{141}$ A. H. A. Criminal. B. 85. Leg. 1770-1790. Doc. $N^{\circ}$ 5. Fols. 13r.-v.

${ }^{142}$ Lardizábal y Uribe, Manuel. Ob. cit. Pág. 218.

${ }^{143}$ A. H. A. Criminal. B. 60. Leg. 1780-1790. Doc. No 22. Fols. 17r.-v., 52r.-53v.
} 
concubinado con una mujer que allí habitaba. En julio de 1789 su mujer lo acusó de haberla llevado a vivir a Sopetrán y continuar golpeándola. Un mes después el Alcalde ordinario don Francisco José de Lora y Nuño le mandó cumplir la sentencia anterior, apercibiéndole que de reincidir, lo desterraría por dos años a una de las poblaciones que se estaban entablando. Dos años después, el Alcalde Juan Pablo Pérez de Rublas lo puso preso por no cumplir la orden anterior. En noviembre de 1791 se le mandó nuevamente pasar a vivir con su mujer al sitio de Anzá, sin dar lugar a más escándalos. ${ }^{144}$

La imposibilidad de hacer cumplir la pena de destierro debió influir para que su uso disminuyera notablemente después de 1789. Con posterioridad a esa fecha sólo se impuso en tres ocasiones, dos de ellas en el periodo de la Independencia.

La idea de que la continua y forzada ociosidad en que vivían los reclusos en las cárceles daba lugar a que se pervirtieran en lugar de corregirse, llevó a que se decidiera utilizarlos en la ejecución de trabajos públicos, fábricas de salitre y pólvora y en algunos lugares de América en obrajes o panaderías. ${ }^{145}$ El Oidor visitador Mon y Velarde parece haber sido quien introdujo esta práctica en la provincia de Antioquia, pues antes de 1785 no se impuso esta pena Este castigo se usó con cierta intensidad en las dos últimas décadas del siglo xviII, habiendo disminuido su empleo al comenzar el xix.

El tiempo por el que se obligaba a los reos a prestar este servicio varió desde una semana hasta cuatro años, dependiendo de múltiples factores. En las sentencias se especificaba que el reo debía trabajar en una determinada obra pública por un cierto tiempo "a ración y sin sueldo". En el caso de la ciudad de Antioquia las obras donde más se utilizó la mano de obra de los presos fueron la casa del Cabildo y posteriormente, el templo parroquial.

Con el mismo propósito de evitar la ociosidad, se acostumbró concertar a los reos o implicados en los juicios con alguien que se hiciera responsable de su conducta. En la Nueva Granada durante el siglo xviII el concierto era un contrato de trabajo por medio del cual un indio, libre o mestizo se comprometía a

${ }^{144}$ A. H. A. Criminal. B. 81. Leg. 1780-1790. Doc. No 19. Fols. 47v., 49v.-50r., 52v.-53r., 58r.

${ }^{145}$ Lardizábal y Uribe, Manuel. Ob. cit. Págs. 199, 215. 
trabajar por un salario durante un tiempo determinado. ${ }^{146}$ En los casos en que el concierto era ordenado por un juez, el concertado debía servir gratuitamente a la persona a quien era entregado. Este castigo fue muy utilizado con mujeres a las que se sindicó de concubinato, buscando a través de él que cambiaran su comportamiento. Así, en 1762 al depositario general don Gregorio Francisco Diez de la torre y Acevedo le fue entregada la mulata libre Francisca de la Serna, para que la sujetara y la apartara de la "mala amistad" que tenía con Mateo Lobato. En la sentencia se especificaba que debía mantenerla en las tierras de la Pancha, permitiéndole salir sólo para ir a misa y a cumplir el precepto en compañía de las señoras de la casa. ${ }^{147}$

Los concertados solían entregarse a uno de los vecinos que ocupaban cargos en el Cabildo, o a un pariente. Como puede verse, la persona estaba prácticamente en prisión, siéndole controlado hasta el más mínimo movimiento. Es difícil saber si estas disposiciones se cumplieron, pues dependía de la interpretación que les diera el encargado.

La imposición de penas corporales distintas a la prisión sufrida, dependió del arbitrio del juez. Al no existir una norma fija para establecer las penas, era posible que delitos de igual naturaleza, cometidos por personas de la misma condición social, fueran castigados de muy diverso modo. Esto llevaba a que en muchos casos no existiera proporción entre el castigo y el delito cometido.

En 26 de las 137 sentencias proferidas, a los reos se les absolvió de los cargos, por no existir evidencia contra ellos, o haber probado que cuando ejecutaron el hecho no eran responsables de sus actos. En 1768 Juan Urrego, vecino de Antioquia, fue absuelto del cargo de haber atacado con un chafarote y un puñal a don Francisco Rincón, por comprobarse que cuando ocurrió el suceso estaba "abstraído de su juicio natural". ${ }^{148}$

${ }^{146}$ Tovar Pinzón, Hermes. Grandes Empresas Agrícolas y Ganaderas. Su Desarrollo en el Siglo XVIII. Bogotá. Cooperativa de Profesores de la Universidad Nacional de Colombia. 1980. Pág. 82.

${ }^{147}$ A. H. A. Criminal. B. 57. Leg. 1760-1770. Doc. $N^{\circ}$ 7. Fols. 1v.-2r.

${ }^{148}$ A. H. A. Criminal. B. 56. Leg. 1740-1770. Doc. $N^{\circ}$ 23. Fols. 1r.-2r. 
Teresa Pérez, acusada en 1803 por Francisco José Sarrazola de intentar matarlo por medio de yerbas y maleficios, fue absuelta de los cargos por el asesor jurídico, doctor José Joaquín Uribe, quien conceptuó que las pruebas no merecían "aprecio en el concepto legal” y el expediente tenía muchos defectos. ${ }^{149}$

Años más tarde, en 1817, el doctor Faustino Martínez consideró que no había méritos para juzgar a Joaquín Cañola, a quien sindicaban de haber herido a Lino Rivera, porque en el sumario no constaba ser cierto el hecho y no se había hecho reconocimiento de la herida. ${ }^{150}$

Estos ejemplos nos muestran que antes de emitir una sentencia, los asesores jurídicos y jueces evaluaban las pruebas existentes y consideraban los descargos presentados. Comprobar la veracidad de algunos hechos era difícil, por eso optaban por absolver al sindicado. En esto se guiaban por la máxima del derecho que dice:

siendo mejor dejar impune al delincuente, que a castigar al inocente. ${ }^{151}$

Algunas de las causas por agresión personal terminaron con una transacción extrajudicial. A través de la intervención de personas de "autoridad", los jueces lograban que las partes se comprometieran a no ofenderse y se desdijeran de las acusaciones vertidas en contra del oponente. En los documentos que subscribían los litigantes se exponía que el convenio se hacía para evitar los perjuicios que ocasionaba un pleito dilatado y para vivir en paz y "buena amistad". Era corriente que la transacción se sustentara en

la ley de la cristiandad de perdonar la injuria recibida. ${ }^{152}$

149 A. H. A. Criminal. B. 45. Leg. 1800-1810. Doc. $\mathrm{N}^{\circ} 13$. Fols. 64v.-65r.

150 A. H. A. Criminal. B. 78. Leg. 1800-1820. Doc. No 24. Fol. 17r.

${ }^{151}$ A. H. A. Criminal. B. 33. 2do. Legajo. 1790-1817. Doc. $\mathrm{N}^{\circ} 72$ Fols. 19v.-20r.

${ }^{152}$ A. H. A. Criminal. B. 74. Legajo 1760-1780. Doc. N 1 . Fols. 14r.-v, B. 78. Legajo. 18001820. Doc. 12. Fols. 26r.-v 
En estos casos era usual que el agresor se comprometiera a pagar las costas procesales y a sufragar los gastos de la curación y jornales perdidos por la víctima.

Este mecanismo fue muy usado para terminar los pleitos entre parientes, sobre todo los que involucraban a cónyuges. En 1809 Matías Romero y Susana Ramírez subscribieron un convenio por el cual se comprometían a apartarse del pelito criminal y del divorcio que habían intentado y se perdonaban las faltas y agravios irrogados. En la caución de "non ofendendo" Romero se obligaba a

tratarla bien y fielmente con amor y cortesía, cumpliendo en cuanto le sea posible con las obligaciones de su estado, dando buen ejemplo a su familia, sujetándose al rigor de las leyes en caso de faltar. ${ }^{153}$

$\mathrm{Al}$ año siguiente, don Juan Ignacio Tamayo, acusado de maltratar a su esposa, y su suegro, don Sacramento Tamayo, hicieron un convenio por medio del cual el primero se comprometió a: Desdecirse y dar satisfacción a todos los que había agraviado, dejar a su esposa en casa de sus padres hasta que le fuera devuelta la casa que tenía enfrente de la de su suegro, no tratar a su mujer con palabras injuriosas, ni imputarle comunicación "infame" con algún individuo, ni ultrajarla o golpearla. Además se obligaba a no impedirle el cumplimiento de sus obligaciones cristianas como eran: confesarse, asistir a Misa e ir a la iglesia a los oficios divinos y devociones particulares; no privarla de visitar a todas aquellas personas de su clase y honestidad que la visitaran y a darle la ropa necesaria para su abrigo. En caso de incumplir este pacto insultándola, celándola, aporreándola, arrastrándola, el suegro no podía quitarle la esposa. ${ }^{154}$

Aunque los convenios de esta clase no eran comunes, en él se refleja con bastante claridad que las mujeres admitían truncar los juicios contra los esposos, siempre que éstos aceptaran cumplir algunas obligaciones. Para ellas era más conveniente llegar a este tipo de arreglo que les podía garantizar su

${ }^{153}$ A. H. A. Criminal. B. 46. Legajo 1800-1810. Doc. № 28. Fols. 68r.-69v.

${ }^{154}$ A. H. A. Criminal. B. 44. Legajo 1800-1810. Doc. $\mathrm{N}^{\circ}$ 19. Fols. 26r.-27v. 
estabilidad económica, que propiciar que el marido fuera condenado a presidio, obras públicas o destierro, lo que las dejaba a ellas y a sus hijos en la miseria.

Al desistir de seguir la causa, las esposas especificaban no haber sido forzadas o atemorizadas y estar actuando

con pleno conocimiento de la obligación en que nos hallamos constituidos de perdonar a nuestros prójimos y principalmente a una persona tan allegada como un esposo. ${ }^{155}$

El objetivo de las autoridades al propiciar los convenios o los desistimientos de las mujeres era mantener la unidad familiar. Así, en 1791, el Gobernador Francisco Baraya y la Campa decía que su deseo como juez era que los casados vivieran en armonía y que por ningún motivo vivieran separados. ${ }^{156}$

En los pleitos entre hermanos, cuñados o suegros y yernos, también se acostumbró recurrir a la transacción de los particulares, para evitar perjuicios a la familia. En 1811 don José Manuel Fernández y don Pedro Madrid, suegro y yerno, aceptaron truncar una causa que tramitaban, considerando

que lo que debe relucir en una familia es la paz y fraternidad y que cualquiera disensión doméstica por leve que sea es notada con escándalo en el público. ${ }^{157}$

Lo anterior muestra que no obstante ser dentro de la familia donde se suscitaban las agresiones físicas más violentas, los jueces que tramitaban estos juicios en lugar de castigar, buscaban conciliar. Al igual que en el caso de las injurias de palabras, lo que les interesaba era obtener el compromiso de no ofenderse, y de recurrir a la justicia en caso de que se presentara algún problema.

La cuarta parte de los juicios por lesiones personales tramitados (49 de 203) quedaron inconclusos porque: la víctima no se volvió a presentar, el

\footnotetext{
${ }^{155}$ A. H. A. Criminal. B. 78. Legajo 1800-1820. Doc. N 19. Fols. 116r.-117v.

${ }^{156}$ A. H. A. Criminal. B. 76. Legajo 1790-1796. Doc. No 4. Fols. 14v.-15r.

${ }^{157}$ A. H. A. Criminal. B. 31. Legajo 1810-1840. Doc. No 10. Fols. 20r.-v.
} 
reo huyó, o se presentó otra circunstancia. Es presumible que en un porcentaje apreciable de estos casos se llegara a un convenio extrajudicial.

El análisis de las penas impuestas en las causas por heridas y otras agresiones físicas, muestra que éstas variaron mucho en género, duración y monto. La aplicación de la ley por parte de los jueces estaba marcada por sesgos personales en los cuales desempeñaban papel importante factores como la consideración a un rango social, la necesidad de controlar determinada conducta, el respeto que la población debía tener al cargo que ocupaban. Lo cierto es que no existió correspondencia entre un tipo de delito y una pena, siendo posible que un reo fuera juzgado con moderación o con rigor. Sin embargo, el juez al tomar las decisiones debía tener en cuenta ciertas limitaciones impuestas por la costumbre, la imagen de la administración de justicia que se quería dar, los vínculos que tenía con la sociedad local, etc. De allí que nunca se condenaran los reos por heridas, a penas corporales como la mutilación de miembros o a la pena capital.

También es posible asegurar que los jueces trataban con mayor rigor al sindicado de herir o golpear a un vecino que al implicado en un pleito familiar, aunque las lesiones físicas producidas en el segundo caso fueran más graves. Esto se debía a que consideraban más importante mantener la unidad familiar que reparar o satisfacer el daño causado al orden social.

Los gobernantes borbónicos utilizaron los juicios por "injuria de hecho" para enseñar al vecindario que a nadie le era facultativo vengar un agravio por "mano propia”. Su intensión era lograr que la justicia fuera aceptada como intermediaria entre los particulares que tenían un conflicto. Esta idea presente en la legislación española, es reforzada en la segunda mitad del siglo xviI por algunos principios del pensamiento ilustrativo. El fin de las autoridades coloniales de este periodo al intensificar la aplicación de mecanismos de control social, fue lograr una mayor presencia del estado en las comunidades. Como lo ha señalado el historiador Germán Colmenares, la administración de justicia y el cobro de impuestos, eran las únicas manifestaciones del Estado, tangibles a los vecinos. ${ }^{158}$ De allí que los gobernantes hubieran hecho de la justicia

${ }^{158}$ Colmenares, Germán. "La Aplicación de la Ley Penal a fines de la colonia y comienzos de la República”. Cali. Versión mecanografiada sin publicar. Págs. 2-3. 
el instrumento para controlar las conductas que ponían en peligro el orden social. Al dictar sentencia, bien fuera imponiendo una pena o ratificando los convenios suscritos entre las partes, los jueces daban las pautas que debían regir las relaciones entre los vecinos y de éstos con el Estado. Con este mecanismo se intentó llevar a cabo un "proceso civilizador" que buscaba, entre otras cosas, eliminar la violencia en las relaciones interpersonales, fortalecer la unidad familiar y lograr que la población respetara las autoridades. ${ }^{159}$ En algunos campos, como el de los pleitos que se derivaban del cobro de deudas, parecen haber tenido éxito; en otros, como el de las disputas familiares, fracasaron. De todas maneras, muchos de los patrones culturales que con posterioridad se han dado como característicos de los antioqueños, fueron sin duda el resultado de este complejo proceso.

${ }^{159}$ El sociólogo Norbert Elías ha llamado proceso civilizador al cambio cultural ocurrido en Europa a partir del cual pautas de conducta propias de la clase alta se fueron difundiendo despaciosamente hasta penetrar los sectores de la sociedad.

Stone, Lawrence. "Interpersonal Violence in English Society 1300-1980". Past and Presente. Oxford. Corpus Christi College. $N^{\circ} 101$. Nov 1983. Pág. 29. [N. del E .] En la edición de 1994 el llamado de esta nota no está señalado dentro del texto, pero sí al final del capítulo. En la presente edición se determinó su ubicación actual. 



\section{El homicidio}

Las leyes castellanas definían el homicidio como

El acto de privar a uno de la vida o la muerte de un hombre hecha por otro. ${ }^{1}$

La palabra homicidio se formó por contracción de las palabras latinas hominis coedes.

De acuerdo con lo dispuesto en las Siete Partidas y en la Novísima Recopilación Castellana, el homicidio se dividía en voluntario e involuntario. El voluntario era el que se cometía con conocimiento de lo que se hacía y con ánimo de quitar la vida. Este podía ser simple o calificado. El simple era aquel que no estaba acompañado de circunstancias que lo agravasen y el calificado era el que por razón de la persona, lugar, fin, instrumento o modo, adquiría mayor gravedad.

Se considera que un homicidio era calificado en razón de la persona cuando se cometía por el padre, madre, hijo, hermano u otro pariente inmediato; en un recién nacido o por nacer, en el Rey, un eclesiástico o un juez. En cuanto al lugar, se tenía por agravado el que se había cometido en una iglesia o cementerio, en el palacio del Rey o la corte. Por razón del fin, se consideraban graves aquellos que se causaban para robar en un camino. Con relación al arma o instrumento, los cometidos con arma de fuego como escopeta, fusil o pistolete. Con respecto al modo, un homicidio era calificado si se había hecho con premeditación, a traición, con alevosía, acechando en un paraje al enemigo, disfrazándose, cogiéndole desprevenido o dándole veneno.

El homicidio voluntario era considerado necesario por la ley, cuando se cometía para defender la vida. Se llamaba necesario porque no se podía evitar sino a riesgo de perecer. En esta categoría se incluían los que se ejecutaban

${ }^{1}$ Escriche, Joaquín. Diccionario Razonado de Legislación y Jurisprudencia. París. México. Librería de la Viuda de Ch. Bouret. 1911. Pág. 822-824. 
para salvar la vida de personas a las que se estaba unido por lazos de sangre o de la naturaleza, como los parientes y los amos.

También se consideraba exento de toda pena el que mataba al hombre que encontraba "yaciendo" con su mujer donde quiera que fuera, o con su hija o hermana en su propia casa. En las mismas condiciones estaba el que mataba a quien estaba llevando una mujer forzada para "yacer" con ella, o con quien hubiera "yacido". Lo mismo ocurría con el que mataba a un ladrón que hallare de noche en su casa, hurtando o horadándola, o si le hallaba huyendo con el hurto y se resistía a ser apresado. ${ }^{2}$

El homicidio involuntario, por su parte, podía ser culpable o inculpable. Era culpable cuando se ejecutaba por imprudencia o impericia, pues no se perpetraba con el designio de matar, sino por falta de cuidado o de ciencia. Había homicidio por imprudencia en aquellos casos en que dos personas que estaban riñendo le quitaban la vida a una tercera que se había acercado, o cuando a consecuencia de las heridas y golpes dadas al castigar el padre al hijo, el amo al criado, el maestro al discípulo, moría el castigado. Se consideraba que un homicidio había sucedido por impericia cuando el médico daba al enfermo una medicina tan fuerte que lo mataba o el cirujano al cura a un herido o llagado le causaba la muerte.

Homicidio inculpable era el casual, o sea, el ejecutado por accidente o caso fortuito, sin culpa ni falta alguna por parte del que lo causaba.

El homicidio es el único acto social considerado casi universalmente como crimen. ${ }^{3}$ En el caso de la Nueva Granada algunas tribus prehispánicas lo consideraban delito e imponían fuertes penas al que lo cometía. Las leyes de los muiscas, por ejemplo, establecían que el que mataba a otro debía morir, aunque lo perdonasen los parientes del muerto, pues consideraban que la vida sólo la daba Dios y los hombres no la podían perdonar. ${ }^{4}$ La legislación española, puesta después de la Conquista, lo consideraba el mayor de los crímenes que

${ }^{2}$ Sala, Juan de. Ilustración del Derecho Español. Valencia. Librería de Mallen y sobrinos. 1844. Tomo II. Pág. 76.

${ }^{3}$ Taylor, William B. Embriaguez, Homicidio y Rebelión en las Poblaciones Coloniales Mexicanas. México. Fondo de Cultura Económica. 1987. Pág. 119.

${ }^{4}$ Simón, Fray Pedro. Noticias Historiales de las Conquistas de Tierra Firme en las Indias Occidentales. Bogotá. Biblioteca del Banco Popular. 1981. Tomo III. Pág. 395. 
se podía cometer contra un individuo de la sociedad, porque se le despojaba de la existencia, que era el primero y mayor beneficio recibido de la naturaleza. ${ }^{5}$

La aceptación generalizada del homicidio como delito hace que esta conducta criminal sea la que cuenta con las series documentales más completas. En el caso de la jurisdicción de la ciudad de Antioquia, entre 1750 y 1812, es posible afirmar que los jueces abrían la causa tan pronto tenían la primera noticia sobre un asesinato. Además, la familia o los vecinos denunciaban toda muerte que les parecía sospechosa para que fuera investigada por las autoridades. Por estas razones, el homicidio es el delito en cual el número de casos denunciados a las autoridades se aproxima más al número real de crímenes cometidos.

Los datos sobre el número de homicidios cometidos en una sociedad permiten medir el grado de violencia presente en las relaciones interpersonales. A través de las causas seguidas por la justicia, es posible saber la significación de esta conducta delictiva dentro de la vida de una comunidad, así como las razones por las cuales la gente está dispuesta a matar a otro. Debido a ello, existen investigaciones muy completas sobre el homicidio, relativas a diferentes regiones. Esto hace posible adelantar estudios comparativos, que muestren las semejanzas y las diferencias presentes en la evolución de este crimen.

De otra parte, en nuestros archivos sólo subsiste una parte del número total de juicios tramitados en la región de Antioquia, pues un porcentaje apreciable se perdió debido a la falta de interés de los funcionarios que tenían a cargo su cuidado, o por accidentes. Sin embargo, las causas que existen permiten saber cuáles fueron las tendencias y adelantar algunas conclusiones.

Teniendo presente estas anotaciones, veamos cuál fue la evolución numérica de este crimen en la jurisdicción de la ciudad de Antioquia durante el periodo colonial. Lo primero que hay que anotar es que en el fondo de juicios criminales del Archivo Histórico de Antioquia no existen causas por homicidio correspondientes al siglo xvi. Esta serie documental empieza en el año de 1635 y para el siglo xvi hay 11 juicios. Este número es apreciable, pues los juicios por injuria verbal o real que quedan son 32 , los de hurto seis, los de concubinato cuatro y los de fraude a las rentas cuatro.

\footnotetext{
${ }^{5}$ Escriche, Joaquín. Ob. cit. Pág. 822.
} 
Para el siglo xviII se presenta la siguiente situación: De la década de 1700 hay un proceso; en la siguiente, aumentan a tres; en los diez años siguientes se pasa a seis, y disminuyen a dos en el decenio posterior, para pasar en la década de 1740 a nueve. En conclusión, durante la primera parte del siglo, el número de causas va en aumento, constituyendo la mitad del siglo un periodo de mucha conflictividad. En los 50 años siguientes el proceso es un poco distinto pues, salvo la década de 1770 para la que sólo existen dos causas, en los cuatro decenios restantes el número juicios existentes es de siete (ver cuadro $\mathrm{N}^{\circ} 61$ ). Considerando que la población de la jurisdicción pasó de 15.369 habitantes en 1777 a 27.056 en 1797 , lo que se presentó fue una disminución proporcional en la incidencia del homicidio. ${ }^{6}$

En la primera década del siglo xix la cantidad de causas ascendió a 11, sobrepasando el máximo de nueve, impuesto 60 años antes No obstante, si tenemos en cuenta el crecimiento demográfico, no habría habido aumento relativo. Según los datos de los censos, de 1797 a 1808, el número de habitantes de la jurisdicción pasó de un poco más de 27.000 a 40.758 (ver cuadro $\mathrm{N}^{\circ}$ 65). Si se calcula el índice de homicidio por cada 10.000 habitantes, tenemos que se pasó de 0.26 homicidios al año, a 0.27 .

Desafortunadamente la serie documental de los homicidios se corta repetidamente en 1812, lo que impide ver su evolución posterior.

De los datos anteriores es posible concluir que el periodo en cual los conflictos entre los antioqueños adquirieron un mayor grado de violencia fue a mediados del siglo xvil. El elevado número de causas por homicidio existente para ese momento, es llamativo por varias razones: La primera, porque corresponden a una época anterior a la implementación de las reformas borbónicas, cuando el aumento del control social llevó a que creciera el número de personas procesadas por los diferentes crímenes. Los testimonios existentes señalan que antes de la década de 1780 muchas conductas delictivas no fueron perseguidas por las autoridades, razón por la cual la diferencia entre el número de

${ }^{6}$ Estas cifras sobre la población total de la jurisdicción de la ciudad de Antioquia han sido tomadas de:

Melo, Jorge Orlando. "La Minería Antioqueña en el Siglo XVIII: Interpretaciones y Perspectivas". Versión mecanográfica. Cuadro $\mathrm{N}^{\circ} 1$. 
juicios seguidos y el número de delitos cometidos era muy grande. ${ }^{7}$ La segunda, porque de acuerdo con los testimonios de los Gobernadores de la década del 80, una gran parte del archivo judicial había desaparecido. Esto hace suponer que el número real de homicidios correspondiente a este periodo fuera más elevado. Y por último, porque la población de la provincia en esta época era bastante pequeña, lo que eleva todavía más la incidencia del homicidio.

Comparativamente parece haber sido más violenta la sociedad de la primera mitad del siglo xviII, cuando la minería del oro y la economía general de la provincia estaban en crisis, que la de finales del periodo colonial cuando el desarrollo de la minería y el comercio habían permitido el surgimiento de un grupo numeroso de pequeños propietarios libres. Para medir el significado de esta afirmación hay que tener en cuenta que, a finales del siglo xvil y principios del xix, el denuncio de delitos por parte de los particulares se elevó, y los jueces estuvieron más interesados en perseguir a los criminales y conservar los procesos. En otras palabras, que para esta época se cuenta con un registro documental más completo.

Sobre esta base se pasará a ver quiénes y por qué se vieron comprometidos en un juicio por homicidio.

\section{Las víctimas}

El homicidio era un delito público, en que el juez debía actuar de oficio sin importar el sexo, etnia o edad de la víctima. ${ }^{8}$ En consecuencia, las causas por este delito se diferencian no por la calidad o condición de los implicados, sino por formas como se daba comienzo al proceso.

Algunos juicios fueron comenzados por el juez al tener noticias de que una persona había sido gravemente herida. En estos casos era posible tomar declaración a la víctima, quien señalaba el nombre del agresor y de los testigos del hecho. Sobre esta base el juez comenzaba una causa por heridas, que se

${ }^{7}$ Robledo, Emilio. Bosquejo Biográfico del Señor Oidor Juan Antonio Mon y Velarde. Visitador de Antioquia. 1785-1788. Bogotá. Publicaciones del Banco de la República. 1954. Tomo II. Págs. 316-317.

${ }^{8}$ Alvarez Posadilla, Juan. Práctica Criminal por Principios, o Modo y Forma de instruir los Procesos Criminales de las Causas de Oficio de Justicia. Valladolid. Imprenta de la Viuda e hijos de Santander. 1802. Tomo III. Pág. 101. 
transformaba en juicio por homicidio al fallecer la víctima. Un caso que ilustra esta situación es el proceso seguido, en 1771, contra el esclavo Marcos por la muerte de la esclava María de Jesús. Al hacer el primer reconocimiento de la víctima, se hizo constar que ésta tenía una herida que la atravesaba del pecho a la espalda y era de "próximo y grave peligro". Siete días después el escribano expidió una certificación sobre la muerte de la esclava anotando como prueba de su fallecimiento que al ver el cadáver la

Llamé por 3 veces por su nombre y no me respondió. ${ }^{9}$

Esta situación no era muy común pues implicaba la cercanía del juez y la presencia de testigos que rápidamente dieran cuenta del hecho. De allí que los casos que siguen este esquema hayan sucedió en el marco urbano de la ciudad de Antioquia.

En otro tipo de juicio la autoridad fue notificada del suceso cuando la víctima ya había fallecido, pero existían testigos del acontecimiento que podían señalar al autor. Esta situación puede ser ejemplificada con el juicio seguido en 1764 contra un esclavo bozal, llamado Francisco, por la muerte de su amo don José Granda. Los hechos ocurrieron cuando Granda estaba dirigiendo el trabajo de algunos esclavos suyos en una acequia de su mina, situada en los minerales de Riogrande en el Valle de los Osos. Los presentes pudieran testificar que el agresor había atacado por la espalda a la víctima con un hacha. ${ }^{10}$

En otras ocasiones el juez fue notificado de la presencia de un cadáver, sin que se contara con información sobre las circunstancias en que había sucedido el hecho, ni existiera certidumbre sobre quien había sido el homicida. Así, don Juan Piñero, capitán a guerra de San Andrés de Cauca, empezó en 1788 una causa por homicidio al denunciar Victorino Sepúlveda, residente en la quebrada de Ochali, el haber encontrado muerto a su yerno José Pío Quinto Chica. Según la declaración de Sepúlveda, su yerno había salido de su casa en la tarde y no volvió a dormir. A la mañana siguiente fue a buscarlo en compañía

\footnotetext{
${ }^{9}$ A. H. A. Criminal. B. 38. Leg. 1770-1780. Doc. $N^{\circ}$ 3. Fols. 1r, 49r.-v.

${ }^{10}$ A. H. A. Criminal. B. 50. Leg. 1760-1780. Doc. $\mathrm{N}^{\circ}$ 12. Fols. 2r., 5r.
} 
de su mujer y la de Chica, y lo encontró muerto entre la quebrada. Al sacar el cadáver apreció que tenía una herida en la cabeza e inmediatamente pasó a dar aviso al juez. ${ }^{11}$

Un caso parecido ocurrió en 1803 en el sitio de Miranda. El Alcalde pedáneo de ese sitio informó al Gobernador haber tenido noticias de que se había encontrado colgado de un palo, el cadáver de un hombre. Al hacer el reconocimiento del occiso el juez conceptuó que no se trataba de un suicidio, por que encontró que tenía

un golpe en las sienes, según enseñaba su cardenal y otro golpe en la parte noble de la garganta a modo de un chuzón en la ollita y por últimamente las espaldas de este cadáver muy acardenalao.... ${ }^{12}$

Esta situación era corriente en los homicidios que sucedían en el ambiente rural, sobre todo en quebradas y montes. En estos juicios el juez no contaba con testigos presenciales del hecho, ni tenía evidencias claras que señalaran a una persona como autora. La costumbre era encarcelar a todo aquel que hubiera tenido riñas o problemas con el muerto de acuerdo con el testimonio de los vecinos o familiares.

En algunos casos el juez procedía a investigar la muerte de una persona por haber notado en el cadáver huellas que evidenciaban que la muerte $\mathrm{n}$ había sido natural. Así, en 1765, el Alcalde pedáneo de San Pedro, don Manuel de Metauten, empezó un juicio por homicidio porque habiendo ido a oir misa a la iglesia parroquial de ese mineral, vio el cuero de una niña que iba a ser sepultado y notó que tenía "señales" sospechosas. Inmediatamente ordenó sacar el cadáver fuera de la iglesia para hacerle un reconocimiento hallando

Ciertas señales acardenaladas que manifestaban eran golpes, que le habían dado con lo que le quitaron la vida y que no fue acelerada su muerte

\footnotetext{
${ }^{11}$ A. H. A. Criminal. B. 75. Leg. 1788-1790. Doc. $\mathrm{N}^{\circ}$ 3. Fols. 1r.-3v.

${ }^{12}$ A. H. A. Criminal. B. 66. Leg. 1800-1810. Doc. No 8. Fol. 1 r.
} 
repentina como la dicha María Meneses, que la trajo para enterrar, vino diciéndolo. ${ }^{13}$

No sólo los jueces percibían señales sospechosas en un cuerpo que iba a ser enterrado o había sido sepultado. Los vecinos solían hacer comentarios cuando ocurría una muerte repentina y revisaban el cadáver en busca de indicios que les permitieran hacer conjeturas sobre las causas del deceso. Si había elementos que permitieran pensar que la muerte había tenido un origen distinto al señalado inicialmente, los familiares de las víctimas se presentaban ante el juez a pedir que se indagara el hecho. En 1757, Cristóbal Ramírez, vecino de Rionegro, se presentó en la casa del Alcalde de la Santa Hermandad don Antonio Franco a poner demanda contra Ignacio Arias, Bonifacio Arias y su cuñada Juana María Crespo a quienes sindicaba de la muerte de su hermano Pedro Ramírez. El acusador puso la demanda basado en testimonios que aseguraban que la muerte había sido intempestiva y que el difunto tenía el cuello rasguñado. ${ }^{14}$

En otro caso, sucedido en 1762, don Alejo de Otero Cossio sindicó a la negra María Dolores, de la muerte de un esclavo suyo, marido de la referida. Inicialmente se había dicho que un tigre lo había matado, pero al no encontrar huellas del animal, don Alejo hizo desenterrar el cadáver y halló que las heridas que tenía no eran mordeduras de tigre sino hechas con "hierro". Por esta razón pasó a poner el denuncio ante el Alcalde ordinario don Juan José de Lora Sandoval. ${ }^{15}$

Los rumores sobre una muerte sospechosa eran de tal magnitud que obligaban a los sindicados a pedir a los jueces que hicieran una indagatoria con el fin de esclarecer los hechos. En 1753, Juan Romero residente en el sitio de Obanja, pidió que se hiciera comparecer al juzgado a varios testigos para poder demostrar que él no había matado a su mujer. Los comentarios habían surgido porque ésta murió de repente una noche sin que ninguna de las personas que estaba en la casa oyera cosa alguna. Además, se consideró raro que el marido la enterrara al día siguiente a las siete y media de la mañana en la capilla que

\footnotetext{
${ }^{13}$ A. H. A. Criminal. B. 80. Leg. 1750-1780. Doc. No 10. Fols. 1r.-v.

${ }^{14}$ A. H. A. Criminal. B. 27. Leg. 1750-1760. Doc. No 7. Fols. 1r., 7v.-9r.

${ }^{15}$ A. H. A. Criminal. B. 41. Leg. 1740-1770. Doc. No 13. Fols. 1r.-v.
} 
los Jesuitas tenían en el sitio de Abejuco y no llevara el cadáver a la iglesia parroquial como era costumbre. ${ }^{16}$

En todas las formas de iniciación de causas por homicidio narradas anteriormente, se contaba con el cadáver que servía como evidencia de que se había cometido un crimen. Una situación distinta se presentaba en algunas acusaciones de infanticidio, pues no era usual que apareciera el cuerpo de la criatura que supuestamente se había asesinado. El hecho de que no naciera un niño dentro del término esperado o que desapareciera, daba lugar a comentarios, con base en los cuales los jueces daban comienzo a la causa. Un ejemplo de esto es el denuncio puesto en 1787 ante el visitador Mon y Velarde contra la negra Celedonia Serna. De acuerdo con la acusación hecha

La negra Celedonia de estado soltera ha estado dos veces embarazada y recientemente se halla parida guardando aun la casa, sin que en ninguna de las dos ocasiones se le haya visto el fruto de su parto, ni se sepa su paradero. ${ }^{17}$

Como se puede ver. El vecindario estaba pendiente de lo que sucedía en cada casa haciendo difícil ocultar un homicidio. La menor sospecha de que había sucedido algo raro daba origen a murmuraciones, con base en las cuales los jueces abrían una causa. Lo anterior sirve para corroborar que el asesinato era el delito más reportado a las autoridades, siendo posible que algunas personas fueran acusadas sin que existieran pruebas en contra de ellas.

Entre las víctimas de homicidio figura un alto porcentaje de mujeres. Este hecho puede tener relación con la propensión a denunciar toda muerte sospechosa. Así, de los 15 casos en que las víctimas pertenecían al sexo femenino, cuatro fueron comenzados por considerarse que la muerte no había sido natural y dos por presumirse que se había cometido un infanticidio.

Al comparar los datos sobre el sexo de las víctimas, en las tres clases de delitos contra la persona estudiados, se encuentra que a medida que aumentaba

\footnotetext{
${ }^{16}$ A. H. A. Criminal. B. 73. Leg. 1700-1740. Doc. $\mathrm{N}^{\circ} 14$. Fols. 1r.-v.

${ }^{17}$ A. H. A. Criminal. B. 39. Leg. 1780-1790. Doc. $\mathrm{N}^{\circ} 14$. Fols. 1r.-v.
} 
la gravedad del delito, crecía el porcentaje de víctimas que eran mujeres. Así, en los juicios por injuria las mujeres eran únicamente el 19,7\% de los ofendidos, en las causas por lesiones personales eran el 29,7\% de los agredidos físicamente $\mathrm{y}$ en los procesos por homicidio eran el 34,0\% de las víctimas (ver cuadros $\mathrm{N}^{\circ} 1$, 14 y 18). Estos datos permiten suponer que muchos de los casos de injuria que involucraban como agraviadas a mujeres no fueron reportados a las autoridades o que éstas no prestaban atención a las demandas, por considerarlas de poca importancia. La situación variaba en las denuncias por lesiones personales debido a la evidencia del maltrato, mientras que las acusaciones por homicidio siempre eran tramitadas.

El porcentaje de mujeres víctimas de homicidio en la jurisdicción de la ciudad de Antioquia es bastante elevado, si se compara con los datos existentes para otras zonas de Hispanoamérica en la misma época. Por ejemplo, William B. Taylor en su trabajo sobre el homicidio en las comunidades indígenas del Centro de México y la Mixteca Alta, entre 1780 y 1815, encontró que las mujeres eran sólo el $18 \%$ de las víctimas. ${ }^{18}$

Para explicar por qué el porcentaje de mujeres víctimas de homicidio es comparativamente tan elevado en la región de la ciudad de Antioquia, hay que tener en cuenta que siete de las 15 occisas eran recién nacidas, o niñas menores de 10 años. El infanticidio parece haber sido muy común en esta zona a finales del periodo colonial, tal como lo constatan las ordenanzas para el gobierno del Cabildo de Antioquia elaboradas por el Oidor visitador Mon y Velarde en 1787:

Nueve. Los muchos infanticidios y repetidos abortos que se experimentan por querer muchas por este punible medio ocultar su fragilidad a los ojos del mundo, reagravando su delito para los de Dios con perjuicio del Estado, hace indispensable que el Cabildo, por cuantos medios sean posibles propenda al establecimiento de una casa de misericordia a donde no sólo se recojan las niñas y niños, ya que no tienen otro amparo que la caridad cristiana,

${ }^{18}$ Taylor, William B. Ob. Cit., Pág. 132. Cuadro Nº 13. 
sino también los que desde su nacimiento experimentan esta desgracia, de modo que sirvan para niños expósitos. ${ }^{19}$

En la acepción extensa del término, infanticidio era la muerte dada a un niño desde el estado de embrión hasta la pubertad. Sin embargo, la jurisprudencia española siguiendo la medicina legal del siglo xvil y principios del xix consideraba que en sentido riguroso infanticidio era el homicidio de un niño en el momento de nacer o después de haber nacido y más propiamente el ejecutado por la madre o el padre o con su consentimiento. ${ }^{20}$

Para analizar al información obtenida se usará el término en su sentido amplio, debido a que en muchos de los casos estudiados no queda claro si se trató de un aborto o de un niño ya nacido. Además no todos los asesinatos relacionados con niños fueron cometidos por los padres. Teniendo en cuenta lo anterior, encontramos que de las víctimas la cuarta parte eran menores de 10 años (ver cuadro $\mathrm{N}^{\circ} 32$ ). Las denuncias de infanticidios fueron bastante comunes a partir de 1780, habiéndose reportado 11 de los 12 casos existentes entre esta fecha y 1810.

De estas víctimas, siete eran con seguridad mujeres, pero el número puede ser mayor porque de tres no se especificó su sexo, por tratarse de criaturas recién nacidas o que supuestamente nacieron (ver cuadro $\mathrm{N}^{\circ} 28$ ). Lo anterior implica que era más probable que se dejara botada o se arrojara en un monte 0 una quebrada una niña que un niño. El que esto ocurriera tiene que ver con la consideración que tenían los agresores del papel de la mujer en esa sociedad. Para una madre era tal vez más pesado alimentar y criar dentro de los cánones establecidos por la ley y la Iglesia, a una mujer que a un hombre. El que el sexo femenino tuviera las mismas posibilidades económicas que los varones pudo ser también una razón para que se decidiera eliminar o dejar botada una niña.

La ley establecía que un niño pertenecía a la casta o grupo racial de su madre. Teniendo en cuenta esto, podemos determinar que más de la mitad de las víctimas de infanticidio eran de origen negro. En cinco casos eran hijos de mulatas o negras libres, sumamente pobres. Es difícil establecer

\footnotetext{
${ }^{19}$ Robledo, Emilio. Ob. cit. Tomo II. Pág. 114.

${ }^{20}$ Escriche, Joaquín. Ob. cit. Pág. 856.
} 
las circunstancias en que sucedían estos hechos porque usualmente sólo se contaba con la declaración del padre o la madre agresor. En 1800, al Fiscal del Crimen de la Audiencia de Santa fe, Manuel Mariano de Blaya y Blaya, al hacer el dictamen en la causa seguida contra la mulata Juana María González, residente en San Jerónimo, decía que no se podía establecer la verdad debido a las contradicciones existentes en lo confesado por la rea:

Ella dijo al juez según se refiere en el auto cabeza de proceso que arrojó la criatura al río. En la confesión de foja 5 recibida por el Alcalde asegura la arrojó a un cañaveral que estaba al lado del río. En la de foja ocho expresamente dice que la enterró en el cañaveral. Todo lo que da a conocer que no ha dicho la verdad, y por consiguiente no se ha inquirido suficiente para imponerle el debido castigo. ${ }^{21}$

Para tratar de disminuir su responsabilidad esta rea aseguraba que la criatura que parió no era "de tiempo", pues el parto se había adelantado por haber cargado leña el día anterior.

En la misma época fue procesada por incesto con su padre e infanticidio la mulata María Francisca Sanana. En esta causa el cargo contra la sindicada era más claro, pues ésta confesó haber tomado bebidas de quiebrabarriga, perejil, mosquita y manzanilla procurando "mal parir" el hijo que esperaba de su padre. A pesar de haber recurrido a abortivos, a los nueve meses tuvo una niña que intentó ocultar enterrándola viva. ${ }^{22}$

Los infanticidios perpetrados por mulatas libres están relacionados con el ambiente de pobreza e ignorancia en que vivían. Aunque hoy parezca extraño, en ese medio parece que era posible disimular un embarazo diciendo estar enferma de la barriga y ocultando o botando el hijo que se había tenido.

En dos procesos las víctimas de infanticidio eran hijos de esclavas. Los amos eran quienes solían poner estas denuncias, por considerar que al botar o asesinar a estos niños se estaba actuando contra su derecho como dueño

${ }^{21}$ A. H. A. Criminal. B. 45. Leg. 1800-1810. Doc. $\mathrm{N}^{\circ} 1$. Fols. 3v.-4r., 9v.-10v.

${ }^{22}$ A. H. A. Criminal. B. 37. Leg. 1790-1800. Doc. $\mathrm{N}^{\circ} 18$. Fols. 2v.-3v. 
legítimo de la descendencia de sus esclavas. Esta situación es bastante clara en la causa seguida en 1877 contra Cayetana Espinosa, esclava de Matías de Espinosa, vecino de Antioquia. El amo al pasar el tiempo en que la esclava debía dar a luz y no ocurriendo el parto, decidió revisarla, encontrando que tenía una barriga postiza hecha de trapos. Al indagársele por el hijo dijo haberlo arrojado en la casa de doña Martina López, pero no fue encontrado allí. En la confesión la negra decía que las López le habían aconsejado.

Que no se casara, que se resistiera y que era una sinvergüenza, que eso era darle más hacienda a su amo. ${ }^{23}$

De allí se puede deducir que la esclava había dejado botado a su hija buscando que no fuera propiedad de su dueño.

Que éste era un mecanismo usado por las esclavas para libertar a sus hijos, lo muestra la causa seguida en 1765 por don José Ignacio Montoya para recuperar tres hijas que una esclava de su padre había botado en distintas casas. En su dictamen el asesor letrado, doctor Lorenzo Benitez, decía que era difícil establecer la propiedad sobre una de estas hijas porque

“...aunque la citada mulata Lorenza fuera hija de la Mónica, no por esto debe declararse por esclava, mediante a no probarse, que dicha Lorenza nació durante la esclavitud de la que se dice ser su madre...". ${ }^{24}$

A principios del siglo xix el asesinato de niños fue común entre los indígenas, pero en este caso el agresor no siempre fue uno de los padres. De tres juicios seguidos por esta causa entre 1800 y 1809, únicamente uno era un infanticidio en sentido estricto. En 1803, la india del pueblo de Sopetrán Gertrudis Guillén, confesó que era hija suya una recién nacida encontrada muerta en una acequia que pasaba por ese sitio. En su confesión fijo que no podía decir si la niña estaba viva cuando nació pues no la observó, pero aclaraba que no

${ }^{23}$ A. H. A. Criminal. B. 81. Leg. 1780-1790. Doc. $\mathrm{N}^{\circ}$ 18. Fols. 1r.-v., 10r.-11v.

${ }^{24}$ A. H. A. Esclavos. Tomo 30. Doc. $N^{\circ}$ 967. Fols. 1r.-v., 48r.-49v. 
la vio moverse ni la oyó llorar. Al preguntársele si sabía la ofensa que estaba cometiendo contra Dios y el escándalo que causaba al pueblo, respondió

Que sí pero que por su mala cabeza y su torpeza cometió lo referido, pero que de ello se arrepiente, y pide perdón a Dios y a la Real Justicia. ${ }^{25}$

De las víctimas de infanticidio sólo una era mestiza, otra era libre pero no se especificó su etnia y no fue reportado ningún caso en que el niño fuera blanco. De lo anterior se puede concluir que éste era un delito propio de los mulatos libres, esclavos e indios, es decir, de las denominadas "castas". Para las autoridades era especialmente atroz el asesinato de criaturas recién nacidas, pues significaba que se las había matado antes de recibir "el agua del bautismo". Los defensores, por su parte, trataban de justificar a las madres que habían cometido este crimen aduciendo su ignorancia, la fragilidad de su sexo y que casi todas eran menores de edad.

Al analizar globalmente la etnia de las víctimas de homicidio se encuentra que cinco eran blancas, 26 mestizas y mulatas libres, cinco indias y ocho negras esclavas (ver cuadro $\mathrm{N}^{\circ} 29$ ). Si se toman como base los datos de censo de 1788 , se encuentra que esta distribución se aproxima bastante a la que se obtiene al discriminar por razas la población de la jurisdicción de la ciudad de Antioquia (ver cuadro $\mathrm{N}^{\circ}$ 64). Así, el porcentaje de blancos, indios y esclavos víctimas es ligeramente mayor que el correspondiente a cada uno de estos grupos en relación con la población total, mientras que el de libres es un $6 \%$ menor.

Exceptuando el caso de los blancos, en cuyos asesinatos estuvieron comprometidos esclavos, la etnia y condición de los occisos tiende a ser igual a la de los agresores. En cuanto a los esclavos encontramos que la mitad de las víctimas fueron asesinadas o se sindicó de su muerte a otro esclavo. Por ejemplo, en 1761 fue procesado el esclavo Antonio, bozal, por haber asesinado a un esclavo de don Diego de la Sierra, también bozal. El sindicado había huido de la casa de su amo don Francisco Piedrahíta, vecino de Medellín, porque

${ }^{25}$ A. H. A. Criminal. B. 99101 Leg. 1800-1810. Doc. No 8. Fols. 1r.-v., 9r.-11r. 
éste lo había comprado en "contra de su voluntad". En la zona de Río Arriba de Cauca se encontró con el esclavo de Sierra, quien le propuso que le ayudara a trabajar en el salado que su amo tenía en Quirimará. La muerte se produjo como consecuencia de un altercado que tuvieron al no haberle querido pagar, el esclavo de Sierra, cuatro días que había trabajado. ${ }^{26}$

En 1803, un esclavo huido fue acusado de haber matado a Francisco, esclavo de don José Antonio Botero, en el sitio del Retiro, perteneciente a la jurisdicción de Rionegro. Los hechos se produjeron al haber salido la víctima como a las 8 de la noche a averiguar quién andaba en la huerta, pues había sentido ruido y los perros habían ladrado. Como el esclavo no regresó, otros dos fueron a buscarlo y lo hallaron muerto. Dadas las circunstancias, se sindicó de la muerte a Marcos, esclavo de la casa, quien "andaba fugitivo" y profesaba al muerto "mala voluntad". ${ }^{27}$

Los esclavos huidos se alimentaban de lo que les proporcionaba algún cómplice, como en el caso de Antonio, o de lo que hurtaban, como parece ocurrir en el caso de Marcos. Para defender la libertad adquirida se veían obligados a robar y en algunos casos a matar. Sus víctimas solían ser esclavos porque era con éstos con quienes entraban en contacto. Si no lograban llegar a un palenque o a un sitio bastante lejano de la residencia del amo, las huellas que dejaban los delitos cometidos permitían su captura tarde o temprano.

El que los esclavos se mataran entre sí, también fue frecuente en la primera mitad del siglo xviII. En la década de 1740 se produjeron cuatro de estos asesinatos, lo que indudablemente produjo temor entre los dueños de esclavos. En 1742, don José Luis de rojo, Alcalde mayor de minas de San Jacinto de los Osos, al reportar al gobernador la muerte propinada a su esclavo Ignacio por otro esclavo de su propiedad pedía:

Se sirva su merced de mandar y proveer lo que fuere servido en méritos de justicia para que sea castigado el agresor de semejante delito. Pues si se queda sin ejemplar no podremos los dueños de negros mantenerlos por ser

\footnotetext{
${ }^{26}$ A. H. A. Criminal. B. 41. Leg. 1740-1770. Doc. $N^{\circ} 11$. Fols. 1r.-2r., 3v.-7r.

${ }^{27}$ A. H. N. C. Negros y Esclavos de Antioquia. Tomo VI. Fols. 943r.-v., 948v.-949v.
} 
gente de poca razón y sin ejemplar viviendo juntos sin temor ninguno se matan los unos a los otros y viviremos los que los tenemos sin seguridad ninguna. Pues vivimos sólo con ellos y según su mal natural se arrojarán a matarnos dormidos. ${ }^{28}$

Las razones por las cuales los esclavos se mataban entre sí eran múltiples. La mayor parte, se derivaban de la situación de opresión en que vivían. Aunque parezca extraño, ésta era una forma de descargar el odio contra los amos y de buscar la libertad. En 1743 Hipólito, esclavo de don Javier Gómez, confesó haber matado a su compañero Gregorio por

El aborrecimiento que le tiene su señora y por no poder darle gusto en nada había pedido varias veces a sus amos lo vendiesen y nunca quisieron, por lo que el confesante eligió matar a uno de sus compañeros para de este modo salir de aquel maltrato vendiéndolo su amo o echándolo de la tierra. ${ }^{29}$

También fue frecuente que los esclavos fueran asesinados por negros o mulatos libres, como lo demuestra el hecho de que esto ocurriera en tres de los ocho casos de homicidios en esclavos estudiados.

Llama la atención que sólo uno de los esclavos haya muerto a consecuencia de un castigo propinado, si tenemos en cuenta la gran cantidad de quejas por maltrato puestas por los esclavos contra los amos. En 1784, se sindicó a Francisco Varela, encargado de conducirlo a la ciudad de Antioquia, de la muerte de Gaspar de Porras, esclavo de la testamentaria del padre francisco de Porras, que había huido a la ciudad de Honda. El albacea de la testamentaria acusó a Varela de haberle pegado con un palo y darle porrazos a Gaspar para que caminara más rápido, no obstante tener una lastimadura en un pie que le impedía hacerlo. A consecuencia del maltrato le dieron verdugones en todo el cuerpo y el esclavo llegó a Medellín más muero que vivo, siendo

${ }^{29}$ A. H. A. Criminal. B. 27. Leg. 1740-1750. Doc. $\mathrm{N}^{\circ} 2$. Fols. 3v.-4v. 
necesario dejarlo en la casa de don Félix de Zea, en donde falleció a pesar de las "pócimas" que le dieron. ${ }^{30}$

En este caso no fueron los amos los implicados en la muerte; por el contrario, son sus representantes los encargados de poner la demanda. Es posible que algunos amos hubieran provocado la muerte a sus esclavos, pero como era una circunstancia difícil de probar no se denunció. Para los dueños era fácil hacer pasar un deceso como producto de un accidente o de una enfermedad. También es cierto que los amos cuando castigaban a los esclavos buscaban reprenderlos pero no matarlos, pues esto representaba una pérdida de dinero bastante grande.

Una causa que ilustra lo arriba dicho es la seguida en 1724 por el Alcalde de la Hermandad, contra Bartolomé Rodríguez, por haber matado a azotes un esclavo de su madre Tomasa Agudelo. En el juicio, la dueña declaró que le había solicitado a su hijo que le diera al esclavo unos azotes por haber recibido quejas de que había cometido varios hurtos. Después del castigo el esclavo había estado sano durante dos meses y posteriormente, a consecuencia de un "achaque", murió. El Alcalde se vio en la necesidad de absolver a Rodríguez al no haberse podido comprobar los cargos en su contra. ${ }^{31}$

En cuanto a los indios, se encuentra que cuatro de las cinco víctimas fueron asesinadas por indígenas. Aunque esta proporción era bastante grande, las autoridades y el resto de la población no vió la situación con la misma alarma que la referida a los esclavos. Ello puede deberse a que los esclavos convivían con los dueños en la misma casa, mientras que los indígenas tenían sus habitaciones en los resguardos. El temor que se derivaba de la posibilidad de ser atacados, era por lo tanto mucho menor. Además, la ley veía al indígena como un menor de edad y tendía a aminorar su responsabilidad en los hechos. Consecuentemente, el indio era visto como alguien que debía ser instruido más que castigado rigurosamente.

Este hecho lo ilustra bastante bien la causa seguida en 1801 contra Fernanda Sagebidia, india del pueblo de Cañasgordas, por haber dado

\footnotetext{
${ }^{30}$ A. H. A. Criminal. B. 81. Leg. 1780-1790. Doc. $\mathrm{N}^{\circ} 12$. Fols. 3r.-v.

${ }^{31}$ A. H. A. Criminal. B. 73. Leg. 1700-1740. Doc. N 6. Fols. 1r., 23r., 27v.-28r.
} 
muerte a la menor Josefa Domicó. El teniente de Corregidor de ese resguardo, al interrogar a los testigos, les preguntó si la rea era "cristiana, católica, romana" y asistía a misa y a reza la doctrina. Su interés era establecer si la inculpada, una indígena "chocoa" que no hablaba español, estaba cristianizada y conocía la gravedad de la acción cometida. Los jueces de la ciudad de Antioquia, no pudieron tomarle confesión por no contar con un intérprete y se vieron obligados a encomendarla al Regidor don José Cruz Robledo para que le enseñara la doctrina cristiana y el idioma. ${ }^{32}$

Ninguna de las muertes de indígenas reportadas entre 1750 y 1812 ocurrió en las riñas que a consecuencia de la embriaguez se daban en los pueblos de indios o en las disputas que sostuvieron con los Corregidores, curas o pobladores libres que invadían los resguardos. Se conserva una sola causa de este tipo, seguida en 1723 contra Juan de Torres por haber herido y causado la muerte al indio Alcalde del pueblo de Sabanalarga, quien trató de apresarlo. El Gobernador de la provincia, Facundo Guerra Calderón, absolvió al homicida por considerar que propinó la herida involuntariamente y en estado de embriaguez. ${ }^{33}$

Los ejemplos seleccionados muestran que los jueces y la población no veían de igual manera todo tipo de asesinato. El sexo, la edad y la etnia de la víctima contaba bastante en esta apreciación. Así, el infanticidio y el que los esclavos se mataran entre sí, causaba horror y fueron conductas que se buscó erradicar. Por el contrario, los expedientes no contienen muchos comentarios sobre el asesinato entre indígenas y otros tipos de conductas.

Veamos ahora cómo vio la ley a los agresores y las ideas que en torno a ellos se formaron.

\section{Los agresores}

La primera característica que se debe anotar sobre los agresores, es que el número de personas juzgadas por asesinato fue mucho mayor que el de las víctimas (ver cuadro $\mathrm{N}^{\circ}$ 28). Esto se debe a que una gran cantidad de individuos fueron

\footnotetext{
${ }^{32}$ A. H. A. Criminal. B. 97. Leg. 1790-1810. Doc. N 12. Fols. 1r.-V., 13r.-v.

${ }^{33}$ A. H. A. Criminal. B. 49. Leg. 1678-1730. Doc. N 16. Fols. 2r.-V., 4r.-v., 17r.-18r.
} 
vinculados a los procesos por considerarse que eran cómplices o tenerse sospechas de que habían tenido alguna participación en los hechos. La situación se puede ejemplificar con la causa seguida en 1794 contra Agustín Sánchez, vecino de San Andrés de Cauca, por haber provocado la muerte de su esposa al abrirle e vientre para sacarle una criatura. De acuerdo con el dictamen del asesor jurídico, era cómplice del hecho Feliciano Rodríguez, suegro de Sánchez, por su

Inicua tácita condescendencia y ninguna repulsa del sacrificio que iba a sufrir su triste hija cuando aquel se lo comunicó, pues negado a las leyes de humanidad no hizo demostración alguna como podía en calidad de padre y autoridad de suegro siquiera dando parte a la justicia. ${ }^{34}$

Igualmente, por presenciar el hecho y no impedirlo, se consideró que estaban comprometidos en el crimen Silvestre Pérez, quien había sostenido la vela para alumbrar a Sánchez mientras realizaba la operación, así como a María Antonia Cardona y María Candelaria Monsalve.

A diferencia del caso anterior, muchas personas fueron juzgadas por simples rumores que los vinculaban a un asesinato, sin existir pruebas fehacientes en su contra. Otras eran procesadas por haber estado presentes aunque no existiera constancia de su participación en los hechos. Lo anterior llevaba a que un número apreciable de personas fueran apresadas por este delito, pero sólo una pequeña cantidad pudiera ser efectivamente enjuiciada y condenada.

La mejor idea sobre el tipo de personas procesadas por asesinato la tenemos al discriminar por sexo. Como lo muestra el cuadro $\mathrm{N}^{\circ} 28$, de 70 implicados, 48 (68,57\%) eran hombres y $22(31,43 \%)$ mujeres. Este último dato es bastante llamativo, pues en otras sociedades coloniales hispanoamericanas se ha encontrado que el número de mujeres implicadas en los homicidios como agresoras era muy bajo. Así, William Taylor, al estudiar el homicidio en algunas de las regiones de México, entre 1780 y 1820, encontró que la zona del Centro

${ }^{34}$ A. H. A. Criminal. B. 76. Leg. 1790-1796. Doc. $\mathrm{N}^{\circ}$ 8. Fols. 8r.-9v., 11r.-13v., 62r.-63v. 
de México, únicamente el 4\% de los implicados eran mujeres; en la Mixteca Alta, el 1\% y en el área de Jalisco Central, el 2,7\%.35

En cuanto a la jurisdicción de la ciudad de Antioquia, es necesario señalar que la participación de la mujer como agresora fue mayor en el homicidio que en los otros delitos contra la integridad personal. Al sexo femenino pertenecía el 16,6\% de las personas procesadas por injuria de palabra, el 8,79\% de los reos por lesiones personales y el $31,43 \%$ de los sindicados de asesinatos (ver cuadros $\mathrm{N}^{\circ} 1,14$ y 28 ).

De las 22 mujeres procesadas, seis fueron sindicadas de cómplices y siete enjuiciadas por sospechosas. El gran número de mujeres inculpadas por indicios indirectos, parece deberse a que las autoridades y la comunidad creían que ellas estaban involucradas en los homicidios más allá de los que las pruebas permitían establecer. Buena parte de las procesadas por cómplices fueron vinculadas a la causa por haber dado motivos para el asesinato y no porque hubieran participado en él.

En 1766, María Quintero, esclava de doña Apolonia Castaño, fue enjuiciada por la muerte que Javier de Vargas dio a su marido. Aunque en su confesión declaró que cuando Vargas y al víctima empezaron a pelear, ella salió a buscar gente para que los apartara, el juez consideró que eran sus continuas infidelidades las que habían dado lugar al suceso y que por lo tanto era responsable. ${ }^{36}$

La misma razón llevó a que María de Villa fuera vinculada al proceso que en 1776 se siguió contra su esposo Apolinar Holguín, por haber dado muerte a Ignacio Barrera. En el expediente constaba que Holguín había matado a Barrera por haberlo encontrado a media noche en su casa y que su mujer se había salvado de ser asesinada por haberse refugiado en la casa de su suegra. Sin embargo, el juez pedáneo la puso presa porque los testimonios acusaban a María de lo sucedido, debido a su "mala fe en el matrimonio". ${ }^{37}$

${ }^{35}$ Taylor, William B. Ob. cit., Pág. 132. Del mismo Autor: "Amigos de Sombrero: The Patterns of Homicide in Rural Central Jalisco, 1784-1820”. Versión Mecanografiada. s.f. Pág. 15.

${ }^{36}$ A. H. A. Criminal. B. 56. Leg. 1740-1770. Doc. N 19. Fols. 2r.-2v., 39r.-40v.

${ }^{37}$ A. H. A. Criminal. B. 57. Leg. 1770-1780. Doc. N 8. Fols. 5v.-6v-, 12v.-13v. 
Los chismes del vecindario y los prejuicios podían llevar a que las mujeres fueron acusadas de algunas muertes sospechosas. En 1803, Bárbara Tavera Morales y su hija Bernardina fueron puestas presas al haber aparecido ahorcado su esposo y padre. Según los testigos, el difunto había tenido disgustos con Pedro Agudelo, debido a que éste tenía relaciones con su hija. Pero en sus confesiones las sindicadas negaron este hecho y expusieron que el occiso había expresado querer suicidarse debido a que estaba enfermo y no podía trabajar para sostener a su familia. En su defensa Bárbara Tavera exponía:

Y cuando así fuese no resulta culpa alguna en nosotras, para que el señor fiscal nos acuse de agresoras de la citada muerte, ni menos prestan mérito los autos para que se nos tenga por reas, máxime cuando es público y notorio que en el largo tiempo del achaque de dicho mi esposo lo mantuve con mi trabajo y pordioseando de puerta en puerta cumpliendo con mi obligación y con el amor conyugal que es verídico le miraba. Cómo es posible imaginar quitase la vida a mi esposo, cuando es constante pedía limosna para conservársela? Si tal pensamiento hubiera tenido, no había sido tiempo oportuno o mejor modo dejarle entregar su espíritu a la fuerza de el hambre? Claro está. ${ }^{38}$

Pero la vinculación de las mujeres a los homicidios no fue siempre producto de suposiciones. En la última década del siglo xviI varias mujeres asesinaron a hombres, lo cual ocasionó temor entre las autoridades. Es así como en noviembre de 1799 el fiscal de la causa contra la mulata María Dolores Chavarría, quien por robar había matado a un esclavo de 19 años, señaló preocupado que, en el curso del año, tres mujeres habían cometido asesinatos. En su concepto la causa de esta situación era la tolerancia con "el género femenino", lo que las llevaba a pensar que en su fuero no intervenía la justicia, ni se les iba a imponer penas por delitos. El defensor de la rea, por su parte, trataba de disculparla alegando

${ }^{38}$ A. H. A. Criminal. B. 66. Leg. 1800-1810. Doc. $N^{\circ}$ 8. Fols. 3r.-v., 6v.-8r., 8v.-10r., 14r.-15r. 
La falta de reflexión e imbecilidad o poco acuerdo que por lo común padecen las mujeres, principalmente las de ínfima clase y criadas en los montes, como esta miserable inocente. ${ }^{39}$

Ese mismo año, el síndico procurador general don Nicolás de Lara, como fiscal de la causa seguida contra Marcela Metauten por haber matado a su esposo Ramón Morales, señaló que las mujeres eran

Enemigos encubiertos que tienen los hombres dentro de su casa. ${ }^{40}$

Debido a que el delito cometido por esta mujer tenía "horrorizada" a la gente, pedía que se la condenara a la pena de muerte, pues ello serviría de escarmiento al sexo femenino.

Los testimonios anteriores permiten concluir que existía un marcado prejuicio contra las mujeres, especialmente las pertenecientes a las castas y pobres. Este prejuicio llevaba a que se las considerara como homicidas potenciales. La debilidad del sexo femenino, la ignorancia propia de las clases bajas y la falta de castigos severos eran aducidas como causas de los asesinatos cometidos por mujeres. De estos juicios se desprende que entre las autoridades antioqueñas existía una imagen totalmente negativa de la mujer del común. Esto puede deberse a que la conducta de las mulatas, mestizas, indígenas y esclavas no encajaba dentro del modelo femenino propugnado por la sociedad blanca. En las clases bajas fue corriente que la esposa no estuviera sujeta a la autoridad del marido y la pasividad y la resignación no parecen haber sido rasgos de su comportamiento.

Un poco más de la tercera parte de los agresores eran personas que tenían entre 20 y 29 años; de ellos, un buen porcentaje no había alcanzado la mayoría de edad que estaba fijada en 25 años (ver cuadro $\mathrm{N}^{\circ} 31$ ). Este patrón coincide plenamente con el encontrado en otros lugares, pues la mayoría de los asesinos suelen ser personas jóvenes. ${ }^{41}$

\footnotetext{
${ }^{39}$ A. H. A. Criminal. B. 37. Leg. 1780-1800. Doc. No 19. Fols. 31r.-33r., 34v.-35v.

${ }^{40}$ A. H. A. Criminal. B. 101. Leg. 1800-1810. Doc. $\mathrm{N}^{\circ} 2$. Fols. 6v.

${ }^{41}$ Taylor, William B. Ob. cit., Pág. 130.
} 
A medida que aumenta el rango de edad, el número de agresores disminuye sensiblemente. No obstante, cerca del 95 de los implicados en los juicios por asesinato tenía más de 50 años. El agresor de más edad fue María Meneses, de 70 años, quien en 1765 fue procesada por la muerte de su nieta de 4 años. El defensor de esta rea obtuvo su excarcelación argumentando que la sindicada padecía una enfermedad que la "privaba de juicio". Al solicitar que se la dejara en libertad señalaba:

Atendiendo a que la referida María Meneses, es una pobre vieja y enferma en tal conformidad que puede acontecer halle muerte en la cárcel según el accidente que padece, que como llevo dicho ya tres veces le ha retentado en ella. ${ }^{42}$

El 7\% de los agresores tenía menos de 20 años, siendo el más joven de ellos Torcuato Tuberquia, indio de 13 años. Este natural fue sindicado en 1809 de que, para robarle unos panes de chócolo, dio muerte al indio Pedro Higuita, quien tenía 809 años. El protector de naturales Nicolás de Lara, en defensa de Torcuato, señalaba que no se le podía imponer una pena, pues por su edad no tenía los conocimientos que se requerían para cometer un asesinato. Además, el crimen había ocurrido en una época de escasez de víveres y el muchacho se había dejado llevar por la "violencia del hambre". ${ }^{43}$

Los jueces de la ciudad de Antioquia eran benevolentes con los sindicados de edades extremas. De acuerdo con la legislación española, "la debilidad de la edad" era una circunstancia que se podía alegar a favor de un reo. Se juzgaba que en la vida del hombre había dos extremos que se tocaban: la infancia y la decrepitud. Las leyes consideraban a los niños incapaces de delinquir y establecían que a los menores de 17 años se les debía aplicar penas moderadas. Con respecto a los viejos, existían normas que estipulaban que no se les debían imponer penas tan severas como a los jóvenes. ${ }^{44}$

\footnotetext{
${ }^{42}$ A. H. A. Criminal. B. 80. Leg. 1750-1780. Doc. $\mathrm{N}^{\circ}$ 10. Fols. 1r.-v., 12r.-13v.

${ }^{43}$ A. H. A. Criminal. B. 99. Leg. 1800-1810. Doc. $\mathrm{N}^{\circ}$ 30. Fols. 15r.-v.

${ }^{44}$ Escriche, Joaquín. Ob. cit. Pág. 660.
} 
Otro aspecto que es importante analizar es el estado civil de las personas implicadas en los juicios por asesinato. De 70 agresores 14 eran solteros, 16 casados, 13 viudos y se ignora el estado civil de 27 (ver cuadro $\mathrm{N}^{\circ} 34$ ). Si tenemos en cuenta que la mayoría eran personas jóvenes, indudablemente el rasgo más llamativo es que cerca de la quinta parte de los sindicados fueran viudos. Este hecho se debe a que siete mujeres y cinco hombres fueron acusados del homicidio de sus respectivos cónyuges. En el momento del crimen ellos eran casados, pero al serles tomada la confesión o declaración dijeron que eran viudos. Como veremos más adelante, el uxoricidio fue bastante común en la jurisdicción de la ciudad de Antioquia durante la época estudiada.

Al distribuir a los agresores de acuerdo con las categorías étnicas existentes en ese momento, encontramos que seis eran blancos, 42 libres de diversos colores, cinco indios y 17 negros esclavos (ver cuadro $\mathrm{N}^{\circ} 30$ ). De acuerdo con estos datos, la cuarta parte de los implicados eran esclavos, lo que constituye una cita alta pues éstos no representaban más del 17\% de la población total (ver cuadro $\mathrm{N}^{\circ}$ 64). El análisis de los datos muestra que nueve esclavos fueron acusados de ser los homicidas directos dado que existían testimonios que permitían asegurarlo; a una se la acusó de infanticidio, por existir indicios contra ella y siete fueron juzgados como cómplices.

A mediados del siglo xvil, parece haber en la jurisdicción de la ciudad de Antioquia una crisis de las relaciones esclavistas, como lo demuestra el hecho de que se registraran varios casos de esclavos que mataron a sus compañeros o asesinaron a sus amos. Como ya se anotó, de la década de 1740 se conservan cuatro juicios seguidos contra esclavos sindicados de la muerte de otro esclavo. En este periodo también fue frecuente que los esclavos mataran a sus dueños. En 1742 se siguió proceso contra Félix e Ignacio, esclavos de Salvador Hidalgo, propietario de la mina La Blanquita en el Valle de Murri, por haber intentado asesinarlo mientras dormía. Cuando estaban siendo juzgados estos esclavos se fugaron de la cárcel y se refugiaron en una de las iglesias de Antioquia, de donde salían a cometer hurtos en las estancias y casas de ese distrito. ${ }^{45}$

\footnotetext{
${ }^{45}$ A. H. A. Criminal. B. 27. Leg. 1740-1750. Doc. $\mathrm{N}^{\circ}$ 1. Fols. 1r., 45r-v.
} 
Seis años después, en 1748, Rafael y Rosa, esclavos de Javier Gómez de Múnera, fueron sindicados de haberlo matado mientras dormía. Al condenarlos a muerte el Alcalde de la Santa Hermandad de Medellín, Manuel José Uribe, decía que era necesario dar ejemplo a los demás esclavos.

Pues a corto tiempo se ha experimentado en esta provincia el que los esclavos hayan muerto a tres amos. ${ }^{46}$

En la década siguiente continuaron presentándose estos hechos. Así, en 1753, el negro Bartolo asesinó a su amo Valentín Ruiz, al tener con este una disputa sobre el precio de su libertad. Como el esclavo se refugió en la ermita de Jesús Nazareno, el Alcalde ordinario de Antioquia solicitó al cura que permitiera sacar al reo para juzgarlo. Argumentaba que esta clase de delito no podía quedar sin castigo pues

A su imitación no queda duda alguna de que en lo adelante se podrán cometer otros semejantes excesos, cediendo esto en grave perjuicio y daño de la república y de no verificarse el castigo a tan execrable delito, quedarán tímidos y obligados todos los vecinos de esta provincia a no servirse de sus esclavos por aquel recelo, que prudentemente tendrán de ellos y en éstos como de tan mala índole crecerá a este paso su malignidad y atrevimiento, para cometer semejantes y aun mayores delitos. ${ }^{47}$

$\mathrm{Al}$ año siguiente, don Juan de Areiza fue asesinado por sus esclavos José Miguel y Francisco, quienes le dieron varios machetazos en la cabeza. Como cómplices del hecho fueron juzgados los esclavos Juan José y José Toribio, quienes se hallaron presentes en el hecho y animaron a los homicidas a matar al amo. El apoderado de la esposa y del hijo de la víctima, don Francisco Javier Ruiz de Alarcón, solicitaba que se tramitara rápidamente la causa porque

\footnotetext{
${ }^{46}$ A. H. A. Criminal. B. 34. Leg. 1700-1780. Doc. $N^{\circ}$ 5. Fols. 2v.-4r.

${ }^{47}$ A. H. A. Criminal. B. 27. Leg. 1750-1760. Doc. $\mathrm{N}^{\circ}$ 4. Fols. 1r., 8r.-v.
} 
De omitirse o dilatarse el castigo que merece tan execrable delito como el de que se trata, es correlativo que con la falta de ejemplar no cesaran semejantes maldades como se están experimentando y han experimentado en esta provincia y ciudad. ${ }^{48}$

Como puede verse, en todas las causas se reiteraba la necesidad de imponer un castigo riguroso y rápido, como la única forma de detener estos crímenes. El elevado número de homicidios cometido por los esclavos creó temores entre los dueños y las autoridades, pues eran vistos como enemigos potenciales de los que había que cuidarse permanentemente, dado que se convivía con ellos. Los ejemplos muestran que los esclavos tenían oportunidades para atacar a sus víctimas cuando éstas estaban totalmente indefensas. Podían matar al amo mientras dormía o escoger un momento cuando estuviera solo y sin arma.

Se debe anotar que después de 1770 los asesinatos de amos dejaron de presentarse en la jurisdicción de la ciudad de Antioquia. Para explicar este proceso debemos tener en cuenta algunos cambios que se dieron en esa región en las relaciones amo-esclavo. El primer fenómeno que merece señalarse es que los dueños de grandes cuadrillas de esclavos empezaron a venderlos. Entre 1775 y 1799 en la ciudad de Antioquia se vendieron 414 esclavos en 325 transacciones. Una buena parte de estos esclavos fueron adquiridos por comerciantes que los llevaban a expender a otras ciudades de la provincia y del virreinato. Otra cantidad apreciable fue adquirida por medianos propietarios mestizos y mulatos. El resultado fue una disminución en el número de esclavos por persona, pero simultáneamente un aumento del número de dueños. ${ }^{49}$

Otro proceso importante fue el incremento del número de manumisiones. De 1775 a 1799 en la ciudad de Antioquia 212 esclavos obtuvieron carta de libertad y 87 fueron manumitidos a través de una cláusula testamentaria.

${ }^{48}$ A. H. A. Criminal. B. 27. Leg. 1750-1760. Doc. $N^{\circ}$ 5. Fols. 1r.-v., 2r.-4v., 141r.-144v.

${ }^{49}$ Patiño Millán, Beatriz A. Riqueza, Pobreza y Diferenciación Social en la Antioquia del Siglo xviII. Versión Mecanográfica. Medellín. Centro de Investigaciones de Ciencias Humanas. Universidad de Antioquia. 1985. Pág. 71-74. Cuadro Nº 7. 
La mayoría de estas libertades se dio voluntariamente por los amos y comprometían al esclavo a una serie de obligaciones con el amo o sus descendientes. Este mecanismo indudablemente contribuyó a disminuir las tensiones en las relaciones amo-esclavo. Observando una buena conducta era posible obtener la libertad tan anhelada, sin exponerse a ser condenado a muerte por atentar contra el dueño. ${ }^{50}$

La aplicación de la Real Cédula de 31 de Mayo de 1789, también contribuyó a disminuir las fricciones entre amos y esclavos. A partir de su expedición los esclavos pudieron solicitar cambio de dueño aduciendo malos tratos y obtener otros beneficios como la compra de la libertad por un precio bajo. En lugar de asesinar al propietario, los esclavos parecen haber optado por recurrir a los jueces para que éstos aliviaran su situación. ${ }^{51}$

Después de 1790, las causas estudiadas fueron remitidas al juzgado de gobernación o a la Audiencia desde Cáceres, Remedios o El Retiro. Es necesario señalar que en dos de los tres casos presentados entre 1790 y 1809 los esclavos fueron enjuiciados por sospechas, y los jueces no encontraron méritos para condenarlos.

Teniendo como base la anterior experiencia, los intelectuales antioqueños que en la época de la independencia propugnaron por la abolición de la esclavitud, argumentaron que esta relación era contraria a las buenas costumbres y origen de toda clase de delitos. José Félix de Restrepo, en el discurso sobre la manumisión de esclavos pronunciado en 1821 en el congreso de Cúcuta decía:

Se puede asegurar que la servidumbre es el taller de todos los crímenes; pero hay algunos que son como una inmediata y necesaria consecuencia suya, tales como el hurto, el suicidio, el asesinato, el aborto, la prostitución, el lenocinio y el perjurio. Los esclavos carecen de ordinario de lo preciso; pero aun en el supuesto de que tengan lo absolutamente necesario, ven en sus manos el goce de algunas comodidades y placeres que sus facultades

\footnotetext{
${ }^{50}$ Ibídem. Pág. 74-77. Cuadro $\mathrm{N}^{\circ} 8$.

${ }^{51}$ Jaramillo Uribe, Jaime. "Esclavos y Señores en la Sociedad Colombiana del Siglo XVIII". En: Ensayos sobre Historia Social Colombiana. Biblioteca Universitaria de Cultura Colombiana. 1968. Pág. 33.
} 
no les permite. Esta es una violenta tentación para el hurto. Si tienen amos feroces que los castigan con brutalidad (esto es frecuente), no se presenta otro remedio a sus males que quitarse la vida. Otros, más prudentes, pero no menos crueles, prefieren quitarla a sus amos y conservar la suya, que de ordinario pierden luego en el cadalso... Las esclavas que han caído en alguna fragilidad, intimadas del castigo o movidas del pudor, procuran el aborto o descuidan la prole. Los esclavos son muchas veces el instrumento de la venganza de sus amos y los falsos testigos de sus injusticias. ${ }^{52}$

Como puede verse, los antioqueños proindependentistas consideraban la esclavitud como destructora no sólo de la libertad del hombre, sino también de su moral. De allí que el 20 de abril de 1814 el poder legislativo del Estado de Antioquia aprobara la "ley sobre la manumisión de la posteridad de los esclavos africanos y medios para redimir sucesivamente a sus padres". ${ }^{53}$ Con esta ley lo que se pretendía era acelerar el proceso de manumisión que se venía dando en la provincia. La experiencia les indicaba que éste era el medio más eficaz y menos traumático para acabar con la esclavitud y conformar un nuevo tipo de relaciones laborales basadas en el trabajo de hombres libres.

Los negros y mulatos libres también eran propensos a cometer asesinatos. Un poco más de la quinta parte de los agresores procesados entre 1750 y 1812 eran libres de origen racial negro, pero es posible que el número fuera mayor, si se tiene en cuenta la gran cantidad de sindicados de quienes se ignora la etnia precisa (ver cuadro $\mathrm{N}^{\circ} 30$ ).

Algunos de los inculpados eran libertos y de otros se ignoraba su calidad por no haber nacido en la región. Así, el Gobernador Cayetano Buelta Lorenzana ordenó en 1782 que se capturara a un negro llamado Juan José Medina, quien había asesinado a José Escudero, en el sitio de Santa Bárbara, perteneciente a la jurisdicción de Arma. Según los informes, Medina se había ocultado en la zona de la desembocadura de la "quebrada" de San Juan al

\footnotetext{
${ }^{52}$ Restrepo, José Félix. Obras Completas. Ediciones Académicas Rafael Montoya y Montoya. Medellín. Editorial Bedout. 1961. Pág. 319-320.

${ }^{53}$ Tisnés Jiménez, Roberto M. Don Juan Del Corral. Libertador de los Esclavos. Cali. Biblioteca del Banco Popular. 1980. Págs. 271-274.
} 
río Cauca, donde daba abrigo a otros delincuentes. En su confesión Medina afirmó haber nacido cerca de la ciudad de Popayán, de donde salió siendo muchacho con un padre dominico que lo llevó a Chiquinquirá. Luego estuvo viviendo en la región de Ambalema y de allí pasó a la provincia de Antioquia donde vivía hacía 20 años. Aunque afirmaba que sus padres eran negros libres, en realidad las autoridades desconocían su condición. Al igual que en el caso de los esclavos, el fiscal pedía que se lo castigara durante par aque los de su "clase" no se atrevieran a ejecutar iguales excesos. ${ }^{54}$

En otros casos, sí constaba que el procesado por asesinato había sido esclavo. En 1807, Venancio Londoño, quien fue esclavo fue presbítero Juan José de Saldarriaga vecino de Medellín, ahogó en la quebrada de Miranda una hija de diez meses. El defensor de la causa alegaba a favor del reo que éste había vivido dedicado a la labor de minas, separado del trato de la sociedad y por esto carecía de conocimientos sobre la gravedad del hecho ejecutado. En su entender

La ignorancia es causante del poco temor, y por consiguiente motivo de las acciones indeliberadas, y ajenas de una regular reflexión. Los hombres constituidos en estado grosero, su misma ceguedad los precipita a abrazar el partido más seguro a su entender. Y he aquí una operación errónea, y una ejecución criminosa. ${ }^{55}$

Así mismo, señalaba que en la provincia se estaba pasando por una época de hambrunas y que el reo había cometido el delito que se le imputaba al ver que no era capaz de alimentar a su familia. Como puede verse, la situación económica y social de los negros y mulatos libres también los empujaba a cometer asesinatos. Además, la idea de que eran insolentes y atrevidos llevaba a que se sospechara de ellos y a que las autoridades estuvieran prontas a castigarlos ejemplarmente.

\footnotetext{
${ }^{54}$ A. H. A. Criminal. B. 86. Leg. 1780-1800. Doc. $\mathrm{N}^{\circ}$ 1. Fols. 1r.-3r., 30r.-34v.

${ }^{55}$ A. H. A. Criminal. B. 88. Leg. 1810-1830. Doc. $N^{\circ}$ 3. Fols. 1r.-v., 25v.-26v., 15r.-15r.
} 
De los procesados por homicidio, cinco hombres y una mujer, eran blancos. La mayor parte de ellos eran blancos pobres sin participación relevante en la vida social y política de la región. Solamente un miembro de la élite fue sindicado de homicidio en el periodo estudiado. Se trataba de don José Cruz Robledo, a quien se sindicó en 1797 de haber ordenado a los esclavos de mina de Candeva, situada en la jurisdicción de Cáceres, que ahogaran en la quebrada de Puquí al español don Félix Lemos. Según la esclava de Lemos, el crimen había sido cometido para robarle a la víctima tres y media arrobas de oro que llevaba.

De acuerdo con el censo de Cáceres de 1796, Robledo era el mayordomo de esa mina que contaba con 31 esclavos y era propiedad de la testamentaria de su abuela materna doña Juana María Herrera. ${ }^{56}$ Inmediata a las minas tenía una hacienda llamada Carichibe. En 1798 heredó los bienes de su padre adoptivo, el Alcalde mayor provincial de la ciudad de Antioquia don Manuel de la Riba Ladrón de Guevara, esposo de su tía. Tales bienes consistían en una casa de teja en esta ciudad, un pedazo de la hacienda Llanogrande, ganado vacuno y caballar y 16 esclavos. ${ }^{57}$ Don José Cruz fue Alcalde ordinario de segundo voto en 1785 y reemplazó a su padre adoptivo en el puesto de Alcalde mayor provincial.

Las autoridades de la ciudad de Antioquia desecharon el cargo presentado contra Robledo, pues el único testigo presencial existente era la esclava de Lemos. Así, en agosto de 1799, el Gobernador Salcedo dictaminó que no existían méritos para ponerlo en prisión y tomarle confesión. El móvil del robo tampoco tenía mucho peso, debido a que los bienes que le encontraron al muerto fueron avaluados en sólo 178 pesos 3 tomines. Por lo tanto, en abril de 1800, el Gobernador y el teniente asesor Antonio Viana al dictar sentencia absolvieron a Robledo el delito que se le imputaba:

Atendiendo la prueba que éste produjo en tiempo y a su notoria buena conducta con que siempre se ha manejado en aquellos territorios, la misma que no

${ }^{56}$ A. H. A. Censos. Tomo 336. Doc. 6462. Fols. 1r.-24v.

${ }^{57}$ A. H. A. Mortuorias. Tomo 242. Doc. 5407. 
ofreció a los vecinos de Cáceres razón de dudar en dicho naufragio para formar sospechas contra Robledo. ${ }^{58}$

La mayor parte de los sindicados de homicidio eran personas pobres que contaban con muy pocos recursos. Según los datos dados en las confesiones y lo consignado en los embargos, diez eran personas vinculadas a labores agropecuarias (ver cuadro $\mathrm{N}^{\circ} 33$ ). Los bienes de Agustín Sánchez, procesado en 1794 por la muerte de su esposa, eran: tres reses paridas y un torete, tres marranos y seis marranitos, una mula, un hacha, un machete y la casa de vivienda. Esta última, localizada en el sitio de Cuerquia, estaba construida en tierras de los "Chavarrías", de lo que se infiere que Sánchez trabajaba en tierras ajenas. ${ }^{59}$

Cuatro de las mujeres sindicadas declararon dedicarse a la labranza o a hacer sementeras. Marcela Metauten, enjuiciada en 1799 por el asesinato de su esposo, tenía los siguientes bienes: Un rancho de vivienda, un almud de caña dulce en tierras de los indios de Sopetrán, un azadón, dos machetes calabozos, una yegua y una mula. ${ }^{60}$

Los datos muestran que un gran porcentaje de los que dijeron ser labradores trabajaban en tierras ajenas. Este término, más que denotar la condición de propietario, se usaba para expresar que la persona se dedicaba a labores agrícolas o ganaderas. Además, cinco de los esclavos procesados trabajaban en haciendas, lo que eleva a 15 el número de implicados dedicados a actividades en el campo.

De los procesados, diez dijeron dedicarse a la minería. Con excepción de don José Cruz Robledo, a quien nos referimos arriba, los otros eran mazamorreros o pequeños mineros independientes. Entre éstos estaba Francisco Telmo de Piedrahíta, negro libre acusado en 1756 de la muerte de Juan Andrés García, a quien se le embargó una mina llamada San José, localizada en el valle de San Jacinto de Osos, una caja de madera con cerradura y llave, dos vacas con sus crías y una daga poblana con puño de plata. Su cómplice Rita García, la

\footnotetext{
${ }^{58}$ A. H. A. Criminal. B. 37 Leg. 1790-1800. Doc. No 12. Fols. 1r.-2v., 90r., 101r., 189v.-190r.

${ }^{59}$ A. H. A. Criminal. B. 76 Leg. 1790-1796. Doc. No 8. Fols. 2r., 11r.-13v.23r.

${ }^{60}$ A. H. A. Criminal. B. 101. Leg. 1800-1810. Doc. $\mathrm{N}^{\circ}$ 2. Fols. 1r.-v., 5r.-6v.
} 
esposa del muerto, declaró también dedicarse a lavar oro en las minas. Estos reos huyeron de la justicia, y sólo fueron capturados en 1760. Al tomarles confesión dijeron que durante el tiempo que estuvieron prófugos se escondieron en las sabanas de Cancán pertenecientes al sitio de Yolombó y se dedicaron a trabajar un amagamiento en la quebrada de la Amoladora. Una vez apresados se les confiscaron 52 pesos de oro y un tomín, una gargantilla de oro avaluada en cinco pesos, 22 cuentas de oro de un rosario y una gargantilla pertenecientes a Rita; una pailita de martillo, una ollita chocolatera, un recatón, un machete viejo y una lanza. ${ }^{61}$

A Apolinar Holguín, acusado en 1776 de haber matado a José Ignacio Barrera, le secuestraron un peso de pesar oro, un fuste de montar a caballo, una ternerita, una lanza, un cajoncito de madera, una mina de oro corrido, una casita en el sitio de San Andrés de Cauca y otra en Chiri. Segú una memoria, había vendido pedazos de la mina a varios sujetos por valor de 57 pesos. ${ }^{62}$

De las mujeres acusadas de homicidio, cinco declararon dedicarse a trabajar en minas. Ninguna de ellas especificó si era propietaria de una mina o si trabajaba en yacimientos pertenecientes a otras personas. Por otra parte, siete de los esclavos enjuiciados estaban dedicados a la explotación de minerales. Lo anterior implica que las zonas mineras eran especialmente violentas y que, tanto entre los esclavos de las cuadrillas, como entre los mineros libres, había muchos individuos propensos a cometer asesinatos. El Gobernador Barón de Chaves decía en 1756, refiriéndose al asesinato cometido por Francisco Telmo de Piedrahíta en los minerales de los Osos, que esto se debía a:

La ninguna sujeción con que viven los más vecinos de aquellos parajes, tan remotos de los poblados por falta de jueces, ni persona que haga cabeza entre ellos, quedándose los delitos impunes y abierto los ejemplares para que otros los prosigan. ${ }^{63}$

\footnotetext{
${ }^{61}$ A. H. A. Criminal. B. 74. Leg. 1740-1760. Doc. $\mathrm{N}^{\circ}$ 3. Fols. 14r.-v., 22r.-26r.

${ }^{62}$ A. H. A. Criminal. B. 57. Leg. 1770-1780. Doc. $N^{\circ}$ 8. Fols. 10v.-11r.

${ }^{63}$ A. H. A. Criminal. B. 74. Leg. 1740-1760. Doc. $\mathrm{N}^{\circ}$ 3. Fols. 2r.-v.
} 
Únicamente uno de los procesados se dedicaba a actividades comerciales. Se trataba de Gabriel de Layos, mulato de 25 años, acusado en 1787 de haber aconsejado a Celedonia Serna que botase la criatura que esperaba de él. En su confesión el reo dijo ser ventero de Alcalde ordinario Juan Esteban Martínez, uno de los grandes comerciantes de la zona. ${ }^{64}$

Un grupo de ocho implicados declaró dedicarse a actividades diversas que iban desde ser guarda del estanco de aguardiente, "raspar caña brava", "hacer ollas de la tierra”, hasta ser peluquero. Este último, era Ignacio Arévalo, blanco originario de la ciudad de Santa fe, quien en 1781 fue procesado por haber matado en una riña a don Agustín de Tapia. Los bienes que se le embargaron, además de la ropa de su uso, consistían en una bolsa de echar navajas, una bolsa de peinar pelucas, tres instrumentos de hacer pelucas, unas tijeras, una piedra de amolar navajas de afeitar y una silla de montar. ${ }^{65}$

Los datos anteriores muestran que los comprometidos en asesinatos eran personas pobres, pertenecientes a las capas bajas de la población. La mayoría se dedicaban a labores agrarias o mineras y solamente en un caso se dijo que se trataba de un vago. Así, las "clases peligrosas" parecen coincidir con las clases trabajadoras compuestas de blancos pobres, libres, esclavos e indios.

Los procesados en los juicios por homicidio tenían un bajo nivel educativo, como se corrobora al analizar su grado de alfabetismo, únicamente 13 de los 70 (18,57\%) sabía firmar, lo que es un índice de que tenían conocimientos de lectura y escritura. Entre éstos figuran una mujer libre y un esclavo (ver cuadro $\left.\mathrm{N}^{\circ} 35\right)$. De los implicados 45 (64.29\%) eran totalmente analfabetas. Sobra decir que en este grupo estaba la mayor parte de los esclavos y negros o mulatos libres. No obstante, esta situación pareciera responder a una condición generalizada de la sociedad. Hasta bien entrado el siglo xx, el analfabetismo en los sectores rurales de Antioquia era del 83,4\%.66

Para concluir esta parte, se debe señalar que la mayoría de las personas sindicadas de haber cometido un asesinato eran adultos jóvenes, pobres y analfabetas. Además, hay que anotar que en la jurisdicción de la ciudad de

\footnotetext{
${ }^{64}$ A. H. A. Criminal. B. 39. Leg. 1780-1790. Doc. $\mathrm{N}^{\circ} 14$. Fols. 17r.-18r.

${ }^{65}$ A. H. A. Criminal. B. 31. Leg. 1780-1790. Doc. No 1. Fols. 10r.-14r.

${ }^{66}$ Contraloría General de la República. Censo de 1938. Antioquia. Pág. 121.
} 
Antioquia existió cierto prejuicio contra las mujeres libres, esclavas o indias, que llevó a que fueran consideradas como asesinas potenciales. Un buen número de los enjuiciados eran mujeres, pero un alto porcentaje fue puesto en prisión por simples sospechas y no porque existieran pruebas contra ellas. Por otra parte, los hechos llevaron a que la población esclava fuera vista con prevención y temor. Esta imagen se hizo extensiva a la población libre de origen negro, como lo demuestra el hecho de que una parte apreciable de los libres procesados por homicidio fueran de este grupo. El racismo que se deriva de las relaciones esclavistas jugó un papel muy importante en la formación de un estereotipo del negro y mulato libre, quien fue considerado como rebelde, atrevido y poco observador de las normas. De allí que las autoridades estuvieran dispuestas a procesarlos por homicidio.

\section{Relaciones entre el agresor y la víctima}

Para analizar adecuadamente la significación del delito de homicidio en la jurisdicción de la ciudad de Antioquia, es necesario estudiar el tipo de relación interpersonal existente entre las víctimas y los agresores. De acuerdo con la pauta universal establecida por los sociólogos no es corriente el asesinato de personas totalmente extrañas. ${ }^{67}$ De los 43 casos estudiados sólo en dos (4,65\%) el sindicado y el muerto no eran de la misma comunidad y se había conocido unos días antes (ver cuadro $\mathrm{N}^{\circ} 40$ ). Así, por ejemplo, don José Cruz Robledo fue acusado de haber mandado a ahogar en la quebrada de Puqui a don Félix Antonio de Castro y Lemus, español nacido en Galicia, médico de profesión, quien uno o dos días antes de paso para Cáceres, había llegado a la mina que administraba Robledo. Lemus no había tenido una residencia fija en el Nuevo Reino, pues, según su esclava había ejercido su oficio en la villa de Tenerife, Lorica, Corozal, Magangué, Mompox y en la provincia de Antioquia había estado en Zaragoza, Boca de San Bartolomé, Rionegro, Marinilla, Medellín, Sopetrán, San Andrés y el Puerto de Espíritu Santo. ${ }^{68}$ Como se ve entre el supuesto agresor y la víctima no podía existir enemistad alguna debido a que

${ }^{67}$ Taylor, William B. Ob. cit., Pág. 132.

${ }^{68}$ A. H. A. Criminal. B. 37. Leg. 1790-1800. Doc. $\mathrm{N}^{\circ}$ 12. Fols. 40v.-42v., 44v.-46v. 
apenas se conocían y por ello quien presentó la demanda adujo como motivo del crimen el robo.

Un rasgo sobresaliente es que un porcentaje muy elevado de los homicidios (41,9\%) ocurrió dentro del núcleo familiar. Comparando los datos relativos a los juicios por injuria verbal y "de hecho" con los juicios por homicidio, se encuentra que a medida que aumentaba el grado de violencia del delito su incidencia dentro de la familia fue mayor. El $17 \%$ de las causas por injuria fueron seguidas entre miembros de una misma familia, fundamentalmente entre hermanos, primos y parientes políticos como cuñados o suegros y yernos (ver cuadro $\mathrm{N}^{\circ} 11$ ). En cuanto a los procesos por lesiones personales se debe señalar que un poco más de la cuarta parte fue entre parientes. El 15,5\% fueron demandas por agresión física sucedidas dentro del núcleo familiar restringido, sobresaliendo las quejas presentadas por maltrato a la esposa. Por otra parte, el 13,4\% fueron juicios tramitados entre personas que estaban vinculadas por diferentes grados de parentesco de consanguinidad o afinidad (ver cuadro $\mathrm{N}^{\circ}$ 24). La pauta en los procesos por homicidio fue un poco distinta. En este caso la mayor parte de los homicidios en que el agresor y la víctima eran familiares, involucraron cónyuges o padres e hijos. Es decir, que a medida que se incrementó la violencia del delito fue más grande su incidencia dentro del núcleo familiar restringido.

Este patrón en los asesinatos se ha presentado en otras sociedades en diferentes periodos de su historia. Para la sociedad inglesa, el historiador Lawrence Stone sostiene que los homicidios entre miembros de la familia biológica han ido en aumento desde el siglo xiv al siglo xx. Según los datos con que cuenta este historiador, en el siglo xiv, el $8 \%$ de los asesinatos era entre familiares, a fines del siglo xvi el porcentaje era de cerca del $15 \%$, en el siglo xvi era casi el 20\% y hoy en día es aproximadamente el 50\%. Adicionalmente señala que en el siglo xvil la mayoría de las víctimas de la violencia familiar eran niños, mientras que en la actualidad las víctimas más comunes son las esposas o amantes. En su concepto esto se debe a que el homicidio debido a la casualidad ha declinado, pero se ha incrementado el que tiene como motivo la pasión sexual. Esta situación estaría enmarcada dentro de una tendencia general a la 
disminución del homicidio, debido a que las vecindades rurales que eran muy violentas en el siglo xvi paulatinamente se volvieron pacíficas. ${ }^{69}$

William B. Taylor, en su investigación sobre diferentes regiones mexicanas a fines del periodo colonial, encontró que en la zona del Centro de México se presentaba una distribución muy equilibrada entre los homicidios cometidos entre parientes con aquellos en que intervenían vecinos y forasteros. En el área central de Jalisco la pauta era distinta pues la mayor parte de los asesinatos sucedieron entre vecinos o forasteros. Este último caso era muy común entre los agresores no indios, debido a que una parte apreciable de los homicidios cometidos por ellos era producto de asaltos armados para robar. En la Mixteca Alta, por su parte, se presentaba una concentración muy elevada de homicidios entre parientes. El 51\% de los homicidios cometidos por los indígenas de esta zona fueron contra la esposa o un compañero o rival sexual. De esta situación Taylor deduce que en la sociedad campesina indígena era en el hogar donde los conflictos tendían a asumir formas más violentas. ${ }^{70}$

Es muy difícil sacar conclusiones sobre la naturaleza de las relaciones familiares a partir de la elevada incidencia del homicidio entre sus miembros. Sin embargo, al analizar los juicios es posible detectar algunos puntos de tensión que pueden ser el origen de este proceso.

En el caso de la jurisdicción de la ciudad de Antioquia, se debe señalar que el homicidio más frecuente dentro de la familia fue el cometido por un cónyuge contra otro. Esta situación se presentó desde comienzos del siglo xviII hasta los años finales del régimen colonial. Así, cerca de la cuarta parte de los procesos que se conservan para el periodo 1700-1750 son de esta clase. En tres de estas causas el marido fue sindicado de matar a la mujer, crimen que usualmente tenía como origen el adulterio de uno de los cónyuges. Un ejemplo es el proceso seguido en 1719 contra el negro Simón "El Horro" por haber ahogado a su mujer en la Quebrada de Juan García. El crimen lo cometió con la complicidad de su amante, una india llamada Ana. Según el expediente, la víctima estaba "gafa de los pies", razón por la cual estaba postrada en una cama.

${ }^{69}$ Stone, Lawrence. "Interpersonal Violence in English Society. 1300-1980". En: Past and Present. Oxford. $\mathrm{N}^{\circ} 10$. Noviembre de 1983. Págs. 27-90.

70 Taylor, William B. Ob. cit., Pág. 1987. Págs. 132-136. Ob. cit. s.f. Pag. 18. Cuadro 7. 
Es indudable que la esposa era considerada una carga y ante la imposibilidad de anular el vínculo conyugal se optó por asesinato. Esto lo corrobora el que los homicidas después de ejecutar el hecho hubieran solicitado al cura de Sabanalarga que los casara..$^{71}$

Para la primera mitad del siglo xviII existen dos causas en las cuales la esposa fue procesada por haber sido cómplice en el homicidio del marido. Lo llamativo es que en ambos casos la mujer utilizó a los esclavos de la casa para ejecutar el asesinato. En 1738 doña María Teresa Zapata fue acusada de ser cómplice en la muerte de su esposo, don Manuel Rivas, llevada a cabo por los esclavos Salvador y Nicolás. El padre de la sindicada, el maestre de campo don Francisco Javier Zapata y Múnera, presentó pruebas de que su hija estaba demente. De acuerdo con estas pruebas doña María Teresa había actuado bajo el influjo del negro Nicolás debido a que éste

Era el más propincuo a cuidarla y sujetarla en sus descarríos y le obedecía en todo aquello que le mandaba de donde no es error o mi decir que el dicho negro con su mala inclinación le propondría era conveniente matar a su marido y que de no hacerlo le iría mal..$^{72}$

En vista de lo anterior, el Alcalde ordinario exoneró de la pena de muerte a la procesada por considerar que había actuado careciendo de libre albedrío y no había participado voluntariamente en el hecho.

Para el periodo 1750-812 los asesinatos entre cónyuges continuaron siendo cerca de la cuarta parte del total de homicidios (ver cuadro $\mathrm{N}^{\circ} 40$ ). Pero en esta época, las acusaciones contra las esposas aventajaron las hechas contra los esposos. Hay que anotar, sin embargo, que la mayor parte de las mujeres fueron procesadas por simples indicios o suposiciones, pues de las seis esposas involucradas en esta clase de procesos, sólo a una se le probó la participación directa en el crimen. Se trató de Marcela Metauten, mestiza de 39 o 40 años, residentes en Sopetrán, quien en 1799, mató con un garrote a

\footnotetext{
${ }^{71}$ A. H. A. Criminal. B. 72. Leg. 1700-1740. Doc. $\mathrm{N}^{\circ}$ 5. Fols. 1r.-v., 2v.-4r.

${ }^{72}$ A. H. A. Criminal. B. 72. Leg. 1700-1740. Doc. No 8. Fols. 3r.-v., 45r.-v., 95v.-96v.
} 
su marido Ramón Morales mientras éste dormía. En su confesión decía que había ejecutado el hecho cansada del maltrato que él le había dado a lo largo del matrimonio.

Pues al poco tiempo de haberse casado empezó a experimentar los rigores de su marido, unas veces con palabras ofensivas, otras con palos, garrotadas, puñetes, latigazos y hasta llegar a darle con piedras... que de tres años a esta parte estaba amancebado el dicho su marido, y en ellos ha experimentado más rigor que aun en los anteriores pues llegó a amenazarla con quitarle la vida a fuerza de azotes hasta que los perros bebieran la sangre. ${ }^{73}$

Como puede verse, la costumbre de maltratar a la esposa, de la cual hablamos al referirnos a las causas por lesiones personales, podía dar origen a una respuesta violenta. Los hombres, apoyados en la creencia tradicional de que el marido podía castigar a la esposa, tenían comportamientos y conductas que podían crear en la esposa resentimientos y odios. Al vivir bajo el mismo techo, la mujer tenía muchas oportunidades para tomar venganza. Es posible que algunas muertes provocadas con venenos a otros medios no visibles hayan pasado inadvertidas.

De asesinar a la esposa fueron acusados cuatro hombres, pero al igual que en el caso de las mujeres, gran parte de estas sindicaciones eran fruto de rumores y habladurías. Únicamente en el juicio seguido en 1804 contra don Manuel Díaz del Castillo, por la muerte de su esposa Cornelia Velásquez, se pudo probar que el crimen había sido ejecutado en forma alevosa y premeditada. En el expediente consta que estos cónyuges peleaban continuamente, habiéndose quejado Josefa a las autoridades en varias oportunidades. El reo sostenía que las frecuentes disputas se debían a que Cornelia no lo quería, ni le guardaba la "fe conyugal", y que la había asesinado por sus continuas provocaciones. De acuerdo con su confesión,

\footnotetext{
${ }^{73}$ A. H. A. Criminal. B. 101. Leg. 1800-1810. Doc. $\mathrm{N}^{\circ}$ 2. Fols. 5r.-6v.
} 
Su mujer Cornelia Velásquez le tenía amenazado lo había de matar con solimán, y que en una ocasión le quitó un calabozo de las manos con que lo iba a matar, estando dormitando en la cama. Que en otra ocasión le rompió también la cabeza con una piedra, que hizo caer al confesante, al suelo, bajo abajo y se bañó todo en sangre. ${ }^{74}$

Como puede verse, el argumento presentado era casi igual al del caso anterior. En los dos procesos el reo sostenía que la infidelidad del cónyuge había dado origen a continuas disensiones domésticas que hacían la vida marital imposible. Trataba de explicar lo sucedido señalando que la vida durante el matrimonio había sido pesada y penosa, pues permanentemente era objeto de agresiones verbales y físicas.

La conclusión que se puede sacar de estos dos expedientes es que cuando uno de los cónyuges no se acogía al patrón monogámico, las relaciones familiares estaban llenas de perturbación y problemas. Fuera víctima o agresora, la conducta de la mujer era presentada por defensores y fiscales como censurable y causante de lo sucedido. Usualmente se le reprochaba haber sido infiel y propiciar con su acción un desenlace fatal. Lo cierto es que la información contenida en los procesos no muestra a las mujeres como sumisas y resignadas y, por el contrario, muchas de las implicadas son descritas como de genio indómito y altanero.

Otro número apreciable de los homicidios ocurridos dentro de la familia fueron cometidos por los padres contra los hijos. A partir de 1780 se volvió frecuente el infanticidio y el aborto, lo que demuestra la existencia de graves tensiones en el medio familiar. Antes de esa fecha los infanticidios no parecen haber sido comunes, como lo evidencia el hecho de que no exista ningún juicio de esta clase para la primera mitad del siglo xviII. Además, las pocas denuncias que se conservan de lesiones personales causadas por padres e hijos, son posteriores a la fecha anotada (ver cuadro $\mathrm{N}^{\circ} 24$ ).

De los siete expedientes de esta clase que existen, en seis, las madres son sindicadas del crimen, mientras que sólo un hombre fue procesado por esta

\footnotetext{
${ }^{74}$ A. H. A. Criminal. B. 101. Leg. 1800-1810. Doc. $\mathrm{N}^{\circ}$ 1. Fols. 9r.-13r., 21r.-22v.
} 
causa. Para explicar esta situación hay que tener en cuenta algunos procesos ocurridos a fines de la época colonial. El primero es que en la década de 1780 las autoridades empezaron a perseguir duramente el concubinato y todo tipo de relaciones ilícitas. Las mujeres solteras parecen haber recurrido al aborto o a dejar botada la criatura, para ocultar que habían tenido relaciones extramatrimoniales. En segundo lugar, el acelerado crecimiento de la población, que se da a finales del siglo xviII, dio origen a un aumento de la población sin tierra y agravó la situación económica de las clases bajas. Las condiciones de las madres soleras debieron volverse muy precarias y esto las llevaba a deshacerse de sus hijos. ${ }^{75}$

Para ilustrar lo anterior podemos utilizar el juicio seguido en 1800 contra María Magdalena Peña, vecina del valle de San Andrés de Cauca, quien se dedicaba a trabajar en minas y rozas. De acuerdo con su confesión, parió un hijo en el monte, cuando había ido a buscar un almud de maíz, y lo dejó abandonado, pues le pareció que estaba muerto porque no se movía. En su favor alegaba que no tenía motivos para tratar de ocultar el hijo, debido a

No ser casada, y no ser el primero que había parido, pues ya estaba experimentado el que era partos, y más habiéndose visto en el primer hijo muy arriesgada a morirse, por lo trabajosa que se vio. ${ }^{76}$

Como se aprecia, el juez al tomar la confesión trató de esclarecer si la sindicada había tratado de ocultar al hijo para esconder las relaciones ilícitas que sostenía. Las autoridades se centraban en perseguir toda relación por fuera del matrimonio, considerando que esta era la razón para que se presentaran estos hechos. Esta idea estaba basada en la evidencia que aportaban las causas tramitadas por ellas. Es innegable que la mayor parte de los homicidios cometidos dentro de la familia tenían que ver con conflictos generados por relaciones ilícitas. A esto hay que agregarle los homicidios cometidos contra un compañero o rival sexual que constituyen un número apreciable.

${ }^{75}$ Patiño Millán, Beatriz. "La Provincia en el Siglo XVIII". En: Historia de Antioquia. Medellín. Suramericana de Seguros. 1988. Págs. 78-79.

${ }^{76}$ A. H. A. Criminal. B. 43. Leg. 1800-1810. Doc. N 1. Fols. 5r.-6r. 
Al igual que en el caso de la familia, los conflictos entre amantes y rivales fueron proporcionalmente más importantes a medida que aumentaba la violencia del delito. En las causas por injuria sólo en el 2,1\% de los casos la víctima y el agresor estaban relacionados de esta manera. En los pleitos por agresión física, el 7,9\% de los implicados tenían esta clase de vínculo, mientras que en los juicios por homicidio eran el 13,9\% (ver cuadros $\mathrm{N}^{\circ} 11,24$ y 40).

La violencia que podía haber en las relaciones de concubinato quedan manifiestas en el juicio seguido en 1771 contra el esclavo Marcos Méndez por haber asesinado a la esclava María de Jesús, con quien había tenido "mala amistad". En la confesión que alcanzó a hacer la víctima antes de morir, afirmó que en varias oportunidades trató de separarse de Marcos, pero no le había sido posible porque éste la amenazaba y castigaba. Afirmó que una ocasión al resistirse a tener relaciones con él, la había herido con un cuchillo en el muslo. Poco después, habiéndoselo encontrado en la barranca del Tonusco, la amarró y castigó inhumanamente. Concluía su descripción de estos maltratos diciendo

Que la amistad era de puro miedo y que nunca le dio interés alguno y que en una ocasión llevó un paño de holán largo como mantel de altar con unos encajitos finos y no lo quiso recibir y en su presencia corto un pañuelo y se llevó lo demás y en otra ocasión llevó una y media vara de tafetán y después supo que era hurtado, lo que sigiló por miedo del Marcos. ${ }^{77}$

Por asesinar a un rival sexual solamente fueron procesados hombres, a quienes se acusó de matar al esposo de su amante o al amante de su esposa. Así, el defensor de Santiago Rocha, quien fue procesado por dos homicidios en 1804, argumentaba que éste había asesinado a Manuel Holguín, vecino de Yolombó, por haberlo encontrado cometiendo adulterio con su esposa. A favor del reo sostenía que Bobadilla y otros autores afirmaban que

\footnotetext{
${ }^{77}$ A. H. A. Criminal. B. 38. Leg. 1770-1780. Doc. $\mathrm{N}^{\circ}$ 3. Fols. 18v.-22r.
} 
Por defensa de la honra, es lícito matar a otro, como por defensa de la vida, pues la fama se prefiere a ésta. ${ }^{78}$

Las doctrinas jurídicas como la anterior, son producto de la sociedad patriarcal que las autoridades españolas quisieron imponer en sus colonias hispanoamericanas. De acuerdo con estas doctrinas, los hombres podían matar al que ofendiera el honor de su casa, pero este derecho no cobijaba a las mujeres. Para acogerse a esta legislación los defensores de hombres trataban de presentar los hechos de manera que parecieran ser el resultado de los celos y la pasión. Con la utilización de este argumento se buscaba disminuir la responsabilidad del sindicado y obtener que no fuera condenado a muerte. Aunque los hombres eran los ejecutores del homicidio, la infidelidad de la mujer era presentada como la causa, lo que llevaba a que fueran vinculadas a los procesos y se las encarcelara.

Una cuarta parte de los homicidios fueron cometidos contra vecinos, siendo casi siempre producto de riñas y disputas. Si se compara este dato con el obtenido en los juicios por injuria verbal y "de hecho", encontramos que a medida que el delito era más grave, disminuía su incidencia en las vecindades. Así, en el 53,5\% de las demandas presentadas por injuria, la víctima y el agresor eran moradores de un mismo sitio o vivían en la ciudad de Antioquia. Este porcentaje era de $39,7 \%$ en el caso de los juicios por lesiones personales y bajaba a $23,2 \%$ en los procesos seguidos por homicidio (ver cuadros $\mathrm{N}^{\circ} 11$, $24,40)$. Como puede verse, entre los vecinos había muchas disputas verbales, una cantidad considerable de peleas con golpes y heridas pero no era fácil que se llegara al asesinato. Es más, la lectura de los procesos muestra como éstos solían ser producto de la casualidad y no realizados de forma premeditada y consiente.

Un ejemplo que ilustra lo anterior es el juicio seguido en 1751 contra Ignacio Oquendo por haber matado a Francisco Torres en el sitio del Cacique, pueblo de Sabanalarga. De acuerdo con lo declarado por un testigo, la víctima y el agresor empezaron la disputa en un baile que se celebraba en la casa del padre de torres, debido a que Oquendo se burló de un ciego que estaba allí.

${ }^{78}$ A. H. A. Criminal. B. 99. Leg. 1800-1810. Doc. $\mathrm{N}^{\circ} 18$. Fols. 8r.-11v. 
Al salir de la fiesta volvieron a pelear y habiéndole tirado el occiso con una lanza a su oponente lo hirió en la nuca. En la refriega que siguió, Oquendo logró quitarle la lanza a Torres y con ella le dio muerte. Con base en estos hechos, el defensor alegó a favor del sindicado que éste no había procedido a traición y con alevosía, sino provocado por la víctima. Argumentaba que el derecho beneficiaba a la parte provocada

Pues sino lo fuera nunca ejecutara, ni sucediera lance, ni desgracia alguna, como hubiera sucedido en este caso que se litiga por que si dicho difunto no hubiera salido a atajarle el paso a dicho mi parte, éste se hubiera ido a su casa como se iba y no se hubiera ofrecido cosa alguna. ${ }^{79}$

Un segundo ejemplo de esta violencia casual e indiscriminada es el proceso tramitado en 1781 contra Ignacio Arévalo por haber matado a don Agustín Tapia. Según la declaración que alcanzó a hacer Tapia, él había ido al aposento ocupado por Arévalo, en el Colegio que había sido de los Jesuitas, para intervenir en una disputa entre Arévalo y don Lucas Sevillano. Al entrar en el cuarto, Arévalo arremetió contra Tapia diciéndole "pícaro, tu eres uno de ellos" y lo hirió con unas tijeras que tenía en la mano. En su confesión Arévalo dijo que había tenido varias disputas con la víctima, con Sevillano y con Nicolás Hurtado, quienes continuamente lo ultrajaban la palabra y hecho. Señalaba que había actuado "llevado de la impaciencia", debido a que creyó que Tapia llegaba para ayudar a golpearlo. ${ }^{80}$

Los dos casos narrados muestran que el homicidio en las vecindades era producto de riñas, las cuales se suscitaban de manera fortuita, y en ellas la víctima podía haber sido cualquiera de los que intervenía. Aunque los que tomaban parte en la disputa podían haber tenido peleas anteriormente, la muerte de alguno de ellos no era premeditada sino accidental. Se trataba de heridas graves, que debido a los escasos recursos de la medicina de ese tiempo casi siempre eran mortales.

\footnotetext{
${ }^{79}$ A. H. A. Criminal. B. 27. Leg. 1750-1760. Doc. $\mathrm{N}^{\circ}$ 1. Fols. 4r.-6v., 28r.-29r.

${ }^{80}$ A. H. A. Criminal. B. 31. Leg. 1780-1790. Doc. N 1. Fols. 1r.-v., 5r.-v., 12r.-14r.
} 
Para concluir, debemos señalar que el estudio de las relaciones interpersonales existentes entre el agresor y la víctima en los homicidios cometidos en la jurisdicción de la ciudad de Antioquia, muestra que en el mundo familiar y doméstico era donde los conflictos podían llegar a ser más violentos. Para esclarecer esta situación es indispensable estudiar más el papel de la mujer dentro de la familia. La mayor parte de los expedientes señalan sus acciones y conducta como la causa principal de los asesinatos, pero en el estado actual de las investigaciones es difícil evaluar estas afirmaciones. El análisis de los juicios criminales permite señalar algunas características, que deben ser complementadas y contrastadas con lo obtenido en otras fuentes. Esta es una tarea por hacer.

\section{El escenario de los homicidios}

El estudio de distribución temporal de los homicidios ocurridos en la jurisdicción de la ciudad de Antioquia entre 1750 y 1782, permite establecer algunas pautas. Los juicios seguidos por este delito eran los que tenían datos más completos sobre este aspecto, debido a que se iniciaban inmediatamente se reportaba un asesinato y en los interrogatorios hechos a los testigos y reos se preguntaba por la hora, día y mes en que había sucedido.

Un poco menos de la tercera parte de los asesinatos se cometieron de noche (ver cuadro $\mathrm{N}^{\circ} 39$ ). Para explicar este hecho debemos tener en cuenta que gran parte de las muertes consideradas sospechosas ocurrieron en este momento del día. Precisamente el que sucedieran a esas horas y sin que hubiera testigos era lo que suscitaba los rumores. Así, la muerte de la esposa de Juan romero ocurrida en 1753 fue tildada de dudosa por el vecindario debido a que sucedió cuando estaba durmiendo. Romero se vio obligado a demostrar que su cónyuge había fallecido de muerte natural, después que él se había acostado a dormir y sin que se diera cuenta. ${ }^{81}$

De otro lado, cerca de la cuarta parte de los homicidios reportados ocurrieron en la mañana. Las horas del amanecer y las de medianoche eran las que se escogían para cometer los asesinatos dentro del núcleo familiar. El homicida

${ }^{81}$ A. H. A. Criminal. B. 73. Leg. 1770-1740. Doc. $\mathrm{N}^{\circ} 14$. Fols. 1r.-v. 
podía contar con que la víctima estaba totalmente indefensa, muchas veces dormida, lo que facilitaba darle muerte. Marcela Metauten, quien mató a su marido en 1799 mientras éste dormía, declaró haberlo hecho "al último canto de los gallos". ${ }^{82}$

También éstas eran las horas en que sucedieron algunos de los infanticidios o abortos denunciados, ya que era el momento propicio para deshacerse del cadáver. Gertrudis Guillén, procesada por infanticidio en 1803, respondió al habérsele preguntado cuándo había tenido el parto:

Que fue el día treinta del pasado octubre, que fue domingo al amanecer cuando llovía muchísimo, y que la acequia llevaba considerada copia de agua, en la cual al lado de arriba de la puente echó la criatura, la misma que había parido. ${ }^{83}$

Como se ve, la hora en que botó la criatura y las condiciones climáticas garantizaban que no hubiera testigos del hecho.

Por último hay que registrar que en las horas de la tarde sucedieron muy pocos asesinatos. Los homicidios cometidos en este momento del día fueron realizados delante de personas que podían declarar acerca de las circunstancias que habían rodeado el acontecimiento. Esta situación se puede constatar al leer el expediente del juicio seguido en 1781-82 contra el negro Juan José Medina por haber dado muerte a José Escudero, vecino del sitio de Santa Bárbara. En su confesión el sindicado reconoció haberlo asesinado, debido a que le era imposible negar un hecho que había sucedido a la una de la tarde en la casa de una tía de la víctima, delante de varios testigos. ${ }^{84}$

La distribución de los homicidios a lo largo del día muestra que la mayor parte se verificaban fuera de los momentos normales de trabajo. Las horas del amanecer y de la noche, cuando la gente estaba descansando, eran las que solían aprovecharse para cometer estas acciones.

\footnotetext{
${ }^{82}$ A. H. A. Criminal. B. 101. Leg. 1800-1810. Doc. $\mathrm{N}^{\circ}$ 2. Fols. 5r.-6v.

${ }^{83}$ A. H. A. Criminal. B. 101. Leg. 1800-1810. Doc. $\mathrm{N}^{\circ}$ 8. Fols. 9r.-11r.

${ }^{84}$ A. H. A. Criminal. B. 86. Leg. 1780-1800. Doc. $\mathrm{N}^{\circ}$. 1. Fols. 30r.-34r.
} 
La relación entre los homicidios y los momentos de descanso, también se ve al determinar los días en que fue frecuente este tipo de delito. El pequeño porcentaje de expedientes en los que se consigna el dato, permite establecer que la posibilidad de que se perpetrara un asesinato era mayor en el fin de semana (ver cuadro $\mathrm{N}^{\circ} 38$ ). De acuerdo con lo establecido por la Iglesia Católica, el domingo se debía dedicar al descanso y la oración. En la jurisdicción de la ciudad de Antioquia era el día que se les daba a los esclavos y trabajadores para que laboraran por su cuenta. Esto significaba una variación en la rutina de trabajo, lo que parece haber propiciado que se presentaran peleas y disputas, que podían terminar con la muerte de uno de los contrincantes. Además, los sábados y domingos solían hacerse los bailes y se tomaba licor, lo que conllevaba un aumento de las riñas que podían terminar trágicamente. Así, en 1751, Ignacio Oquendo y Francisco Torres riñeron en un baile que se celebraba un día domingo. Antes de que se presentara el altercado, Torres había ido a empeñar una lanza por un trago de aguardiente. Como la ventera no aceptó el trato, Torres se irritó, lo que dio lugar a que iniciara la disputa en la que se produjo su muerte. ${ }^{85}$

Al analizar la distribución por meses, se encuentra que en diciembre se presentó un mayor número de homicidios (ver cuadro $\mathrm{N}^{\circ} 37$ ). Como ya se anotó esta era la época del año en que había una mayor concentración de fiestas, lo que llevaba a la suspensión de las actividades agrícolas o mineras. Esta combinación de descanso y festejo solía dar lugar a que se presentara una gran cantidad de disputa, como lo demuestra el que en este periodo se presentaran muchas demandas por agresión personal (ver cuadro $\mathrm{N}^{\circ} 23$ ).

Es difícil explicar el elevado número de asesinatos que ocurrían en los meses de agosto y octubre, pues no eran épocas que tuvieran una especial significación desde el punto de vista de las fiestas religiosas. En agosto, se celebraba únicamente la fiesta de la Asunción de la Virgen, el día 15 y octubre era el único mes en que no había fiesta de guardar. Además, la información sobre los juicios por lesiones personales muestra que el mes de octubre era una época en que se presentaban pocas disputas (ver cuadro $\mathrm{N}^{\circ} 23$ ).

\footnotetext{
${ }^{85}$ A. H. A. Criminal. B. 27. Leg. 1750-1760. Doc. $N^{\circ}$ 1. Fols. 3r.-4r., 28r.-29r.
} 
Lo que los datos permiten establecer es que en la segunda mitad del año era cuando ocurría un mayor número de homicidios. De 42 juicios en que se consigna esta información, 30 sucedieron en los meses de julio y diciembre. Para analizar este hecho hay que tener en cuenta que una gran parte de la zona estudiada es "tierra caliente", lo que hace factible que se den hasta tres cosechas al año de algunos productos; por este motivo es difícil establecer con nitidez un ciclo de trabajo agrícola que empiece y concluya en un momento determinado del año. Por otra parte, los yacimientos auríferos de las tierras altas del Valle de los Osos, pertenecientes a la jurisdicción de la ciudad de Antioquia, se explotaban en las épocas de invierno. Los meses de julio y agosto han sido tradicionalmente secos, mientras que de septiembre, hasta principios de diciembre es época de lluvias. A partir de estos datos es difícil establecer una relación entre periodos de trabajo o descanso y la incidencia del delito de homicidio. Un volumen grande no presentaba en periodos de fiesta como diciembre, pero otra cantidad apreciable ocurría en momentos en que como octubre era muy intenso el trabajo agrícola y minero.

La información sobre los lugares donde se cometieron los homicidios es bastante precisa en los expedientes. La tercera parte de los asesinatos se perpetraron dentro de la casa de alguno de los implicados, lo que se explica por el elevado porcentaje de muertes que se dieron en el mundo familiar y doméstico (ver cuadro $\mathrm{N}^{\circ}$ 36). En Antioquia a fines de la época colonial el hogar era un lugar de mucha violencia, como lo indica el que allí se hubiera producido un poco menos de la quinta parte de las injurias verbales y algo más de una cuarta parte de las agresiones físicas (ver cuadros $\mathrm{N}^{\circ} 9$ y 22).

Una de las razones de este hecho puede ser la existencia de cierta promiscuidad. Entre los ricos, en una misma casa convivía la familia con los esclavos y un sinnúmero de agregados, mientras que, en los sitios o barrios de gente pobre, en una pequeña vivienda habitaban varias familias. El Oidor visitador Mon y Velarde describía esta situación así:

Por cuanto en algunas casas de muy corto recinto ocurre el que vivan el día, dos o tres familias y algunas numerosas, sin que haya las piezas y divisiones correspondientes, viviendo todos confundidos y desnudos, lo que 
es causa de la mayor disolución y torpeza, despertando la malicia en la más tierna edad, se previene que en lo sucesivo se evite semejante desorden tan perjudicial a la causa de dios y a la honestidad y recato con que debe educarse la gente cristiana. ${ }^{86}$

La convivencia con personas no pertenecientes a la familia y la promiscuidad que ella conllevaba, podía dar origen a disputas que terminaban trágicamente. En 1803 Santiago Rocha, negro libre, dio muerte a María Herrera, de 12 años de edad, en Soeptrán. Este sujeto vivía con la víctima en una casa de una hermana de ella, lo que dio lugar a que se rumorara que tenían relaciones. Por este motivo riñeron las hermanas de María con Rocha, lo que llevó a que éste la asesinara dentro de la casa. Según la confesión del reo le había

Quito la vida, por mirar los trabajos que estaba pasando, a causa del estropeo que le daban Angela y Juana Herrera, hermanas de aquella. ${ }^{87}$

Era usual que los matrimonios convivieran con los padres de alguno de los cónyuges, lo que posibilitaba la interferencia de éstos en sus disputas, y daba lugar a problemas. En 1804 Manuel Díaz del Castillo, natural de Santa Bárbara de Iscuandé, asesinó a su esposa en la sala de la casa de la madre de aquella donde vivían. El sindicado acusaba a su suegra de propiciar problemas entre ellos, pues había ordenando a su hija que le "negase el débito" y al pedirle Díaz que le aconsejase para que viviesen en paz le respondió

Que eso sería porque no le hiciera más hijos. ${ }^{88}$

Estos testimonios explican por qué la convivencia en una misma casa podía convertirse en fuente de conflictos, dando lugar a que éstos se tornaran violentos. En el hogar se tenía la posibilidad de asesinar a alguien sin que opusiera resistencia y de forma tal que no despertara sospechas. Era el sitio

\footnotetext{
${ }^{86}$ Robledo, Emilio. Ob. cit. Tomo II. Págs. 107-108.

${ }^{87}$ A. H. A. Criminal. B. 99. Leg. 1800-1810. Doc. $\mathrm{N}^{\circ} 18$. Fols. 2r.-v., 5v.-7v.

${ }^{88}$ A. H. A. Criminal. B. 101. Leg. 1800-1810. Doc. No 1. Fols. 21r.-22v.
} 
donde se daban los asesinatos entre cónyuges y rivales o compañeros sexuales, pues allí se contaba con los medios y se daban los motivos para efectuarlo.

Un gran porcentaje de los asesinatos se cometió en lugares apartados del núcleo urbano y de los sitios, donde era fácil asesinar a alguien sin contar con testigos y deshacerse de cuerpo. Es así como la cuarta parte de los homicidios se llevó a cabo en quebradas o ríos que pasaban a cierta distancia de los pobladores. El echar el cuerpo al río para ocultarlo, es una práctica vigente en las áreas rurales del país y en aquel tiempo fue bastante usada. En algunos casos el agresor golpeaba a la víctima hasta dejarla inconsciente y luego la arrastraba hasta el río donde la sumergía para ahogarla. De allí que al hacer el reconocimiento de los cadáveres encontrados en quebradas, se especifique que el cuerpo presentaba golpes y heridas. En 1782 el Alcalde pedáneo de Sacaojal al hacer el reconocimiento del cadáver de Anselma Torres, quien apareció muerta en una quebrada del sitio de Juan García, hizo constar que la occisa tenía una herida en la sien y dos en la cabeza, hechas con piedra. ${ }^{89}$

El ahogar en ríos o quebradas fue un método muy utilizado para cometer infanticidio. En estos casos no era necesario golpear a la víctima antes, pues ésta no tenía fuerzas para oponer resistencia. La india Fernando Chaquerivia, quien en 1801 mató a la niña Josefa Domicó en el sitio de Cañasgordas, declaró haberlo efectuado de la siguiente manera:

Que la había llevado mucho más arriba de donde la encontraron en el río de Cañas gordas y la tuvo sujeta dentro del agua hasta que se ahogó, que después la arrastró hasta donde la hallaron y allí con una horqueta de palo la apretó contra la arena y con una guasca le amarró el pelo para que no se sobreaguara para no ser descubierta..$^{90}$

$\mathrm{Al}$ analizar esta información se debe tener en cuenta que las quebradas y los ríos jugaban un papel muy importante en la vida de la región. Su aprovechamiento era necesario para el desarrollo de las actividades agrícolas y

\footnotetext{
${ }^{89}$ A. H. A. Criminal. B. 52. Leg. 1780-1790. Doc. N 8. Fols. 1r.-v.

${ }^{90}$ A. H. A. Criminal. B. 97. Leg. 1790-1810. Doc. $\mathrm{N}^{\circ}$ 12. Fols. 6r.-8r.
} 
mineras. Además, eran lugares de actividad social debido a que los habitantes continuamente iban a buscar agua, lavar la ropa, dar de beber a los animales, etc.

Dejar botado un cuerpo en el monte o enterrarlo, también fue una práctica muy usada. En el caso de los infanticidios se utilizó enterrar la criatura para ocultar el cuerpo, muchas veces estando viva. Los lugares escogidos usualmente no quedaban muy lejos de la casa del agresor, como se indica en el juicio seguido en 1799 a la mulata libre María Francisca Santana. De acuerdo con su confesión, como resultado de relaciones incestuosas con su padre parió

Una hija mujer en el mes de septiembre pasado la que enterró viva y sin bautizar junto a una talanquera que sirve de cerca a la isla en donde vive la confesante con sus padres. ${ }^{91}$

Los homicidios cometidos en los caminos fueron muy pocos, lo que significa que se podía transitar por ellos con cierta seguridad. Los casos estudiados corresponden a pendencias por celos o abortos provocados por violación que se llevaron a cabo a un lado del camino y no hay en ellos ninguna característica que permita hablar del asalto. Por ejemplo, en 1760, Francisco Telmo de Piedrahíta, mató al negro Juan Andrés García en el camino que conducía de Santa Rosa de Osos a su casa. El incidente se originó al intervenir Piedrahíta en una pelea que la víctima tenía con su mujer. García no aceptó la injerencia e intentó agredir a Piedrahíta con un cuchillo, viéndose éste precisado a sacar una daga que lleva en la cinta y matarlo. ${ }^{92}$

Tampoco fue frecuente que se cometieran asesinatos en los lugares de trabajo. Esto coincide con que las muertes solían ocurrir en las horas y días cuando las personas no estaban laborando en la agricultura o a la minería. Por esta razón, es raro encontrar un caso como el del negro Francisco, quien en 1764, asesinó a su amo don José Granda, cuando estaban trabajando en una acequia de la mina de éste. ${ }^{93}$

\footnotetext{
${ }^{91}$ A. H. A. Criminal. B. 37. Leg. 1790-1800. Doc. $\mathrm{N}^{\circ} 18$. Fols. 2v.-3v.

${ }^{92}$ A. H. A. Criminal. B. 74. Leg. 1740-1760. Doc. $N^{\circ}$ 3. Fols. 22r.-23v.

${ }^{93}$ A. H. A. Criminal. B. 50. Leg. 1760-1780. Doc. $\mathrm{N}^{\circ} 12$. Fols. 5r., 16r-v.
} 
La información sobre los lugares donde ocurrieron los homicidios muestra que ocho casos sucedieron en zonas mineras. Algunos documentos permiten asegurar que los minerales de los Osos y San Andrés de Cauca eran zonas bastante violentas, en las cuales era imposible para las autoridades controlar una población que vivía dispersa explotando yacimientos auríferos. En 1785, el visitador de las cinco pedanías del Valle de los Osos, Pedro Rodríguez de Zea, opinaba que el desorden existente en esta zona provenía de la falta de cárcel, pues ello permitía que los delincuentes se fugaran quedando impunes los delitos. Por esta razón recomendaba al Gobernador Francisco Silvestre dar las providencias necesarias para que en cada pedanía se construyera una cárcel. ${ }^{94}$

Igualmente se debe señalar que la mayor parte de los homicidios correspondientes a la jurisdicción de la ciudad de Antioquia se cometieron en sitios pequeños y en el ámbito rural. De las muertes estudiadas, únicamente dos ocurrieron en el casco urbano de la ciudad. En contraste se tiene que en el sitio de Miranda, zona agrícola situada en el pueblo de Sopetrán, se denunciaron cuatro asesinatos en la primera década del siglo xix. De acuerdo con una representación hecha en 1803 por el Alcalde pedáneo de ese sitio, los miranderos continuamente eran procesados por amancebamientos, irrespetos, contrabando de aguardiente y muertes. Al poner de presente esta situación al Gobernador decía:

\begin{abstract}
Porque si Vuestra Señoría examina con desprecio dónde mataron a Ramón Morales? Se dirá que en la Miranda. Que dónde mataron a Cayetano Amasara? Se dirá que en la Miranda. Qué por qué se mandó Nicolás Castañeda de mi partido al presidio? Se dirá que porque mató a una muchacha de la Miranda, siendo este mismo patricio de alli. ${ }^{95}$
\end{abstract}

Es dificil explicar la elevada incidencia del homicidio en el área de Sopetrán, pero se debe tener en cuenta que esta era una región en donde eran corrientes los concubinatos y adulterios. Allí era frecuente que mujeres solteras fueran la cabeza de familia, lo que indica la presencia de relaciones extramatrimoniales y

\footnotetext{
${ }^{94}$ A. H. A. Visitas. B. 76. Leg. 1800-1810. Doc. ํ 2104. Fols. 20v.-30v.

${ }^{95}$ A. H. A. Criminal. B. 99. Leg. 1800-1810. Doc. $\mathrm{N}^{\circ}$ 13. Fols. 5r.-8v.
} 
de hijos ilegítimos. Esta situación se puede constatar en el censo de Sopetrán de 1779 , pues de las 346 cabezas de familia, blancas, mestizas y mulatas que allí figura, 58 eran mujeres solteras o viudas. En el resguardo indígena localizado en la zona, ocurría el mismo fenómeno. La matrícula de naturales efectuada en 1787 muestra que de 128 cabezas de familia inscritas, 72 eran mujeres, viudas solteras, o casadas con libres. ${ }^{96}$

Como puede apreciarse, en la región convivían y se mezclaban personas de distinto origen étnico, lo que sin duda propiciaba que se presentaran conflictos por celos o resentimientos amorosos.

Los que se puede asegurar es que a finales de régimen colonial en la región de Antioquia el homicidio era más rural que urbano. En la ciudad de Antioquia no se reportaron asesinatos después de la década de 1780 , lo que puede deberse a las medidas de control social implementadas por los gobernantes ilustrados. El que la justicia fuera más eficaz y pronta también incidió en este resultado. En las áreas rurales la situación fue distinta debido a que los jueces pedáneos no estaban en capacidad de supervisar todo el territorio puesto bajo de jurisdicción.

\section{Las armas utilizadas}

En los interrogatorios a que eran sometidas las personas implicadas en un homicidio se indagaba por el tipo de arma utilizada para perpetrarlo. La importancia de esta información radica en que la elección del arma está relacionada con el grado de premeditación del hecho. De todos los medios que es posible usar para asesinar a alguien, los venenos son los que implican un mayor grado de intencionalidad y detectar su empleo es bastante difícil. En la época estudiada era prácticamente imposible para las autoridades probar la utilización de venenos. Así, en 1757, Juana María Crespo fue procesada por haber envenenado a su esposo Pedro Ramírez con solimán (sublimado corrosivo). La acusación se basaba en la declaración de su cuñada, Bárbara Ramírez, quien afirmaba haber visto en una carterita de Juana unos "polvos muy blancos". El defensor desacreditó este testimonio sobre la base de que la declarante no conocía el

${ }^{96}$ A. H. A. Censos. Tomo 345. Doc. $N^{\circ}$ 6550. Fols. 25r.-46v. Indios. Tomo 26. Doc. № 794. Fols. 7r.-14r. 
solimán y le era imposible distinguirlo de cualquier otro polvo blanco. Anotaba además que Bárbara no decía

Que los mencionados polvos, lo vido echar, ni dar en la bebida, que dice le dieron al difunto, y era muy natural, que si le cupo semejante recelo hubiera solicitado o inquirido si estaban en ser dichos. ${ }^{97}$

Ante la imposibilidad de probar que Ramírez no había fallecido de muerte natural, el juez absolvió a Juana María y otros implicados en el caso.

En la misma categoría de los venenos podemos ubicar los abortivos, cuyo uso aparece testificado en varios de los documentos estudiados. Las yerbas que se utilizaban para producir este efecto eran el perejil (Carum petroselinum I.), la quiebrabarriga, la mosquita y la manzanilla (Hippomane mancenilla). ${ }^{98}$

El empleo indiscriminado de sustancias peligrosas, que podían causar la muerte a quien las ingería, y de abortivos, trató de ser reglamentado por las autoridades. Durante la Independencia, en 1812, el tribunal de justicia del Estado de Antioquia determinó que sólo podían administrar medicamentos peligrosos como purgas, vomitivos y sangrías aquellos individuos conocidos por su experiencia y que contaran con el consentimiento de los respectivos Cabildos. También establecía que serían procesadas aquellas personas que auxiliaran o proporcionaran los abortos. ${ }^{99}$

El uso de armas de fuego también implica premeditación, pues con excepción de la caza, la única razón para portar una pistola o fusil es para atacar a alguien o defenderse. ${ }^{100}$ En el siglo xviI las armas de fuego eran costosas y escasas, de allí que en los expedientes rara vez se mencionara su utilización. En los juicios por homicidio solamente en un caso, sucedido en la villa de Medellín, se menciona que el homicida utilizó un arma de fuego. ${ }^{101}$ Desafortunadamente

\footnotetext{
${ }^{97}$ A. H. A. Criminal. B. 27. Leg. 1750-1760. Doc. $\mathrm{N}^{\circ}$ 7. Fols. 21v.-23r., 37r.-38r.

98 A. H. A. Criminal. B. 37. Leg. 1790-1800. Doc. No 18. Fols. 2v.-3v. B. 45. Leg. 18001810. Doc. $\mathrm{N}^{\circ}$ 1. Fols. 6r.-v.

${ }^{99}$ A. H. A. Capitulares. Tomo 650. Doc. $\mathrm{N}^{\circ}$ 10349. Fols. 55-56.

100 Taylor, William B. Ob. Cit., Pág. 126.

${ }^{101}$ A. H. A. Criminal. B. 35. Leg. 1750-1770. Doc. No 1. Fol. 1r.
} 
de esta causa sólo existe un informe y no se puede constatar si fue cierto que se usó este tipo de arma.

Las armas cortas blancas como cuchillos, dagas, navajas eran consideradas como armas prohibidas y las leyes mandaban que no se portaran en público. Algunos de estos instrumentos eran empleados en las casas como herramienta para algunos oficios. Su prohibición se basaba en el hecho de que eran puramente ofensivas y fáciles de ocultar, lo que daba lugar a que con ellas se cometieran muertes alevosas. ${ }^{102}$ En 1753 el Alcalde ordinario de la ciudad de Antioquia, don Agustín de Villa y Castañeda, se basó en esta disposición para pedir que se le permitiera extraer del asilo eclesiástico al negro Bartolo, a quien se sindicaba de haber matado a su amo con un cuchillo. Argumentaba que el hecho había sido perpetrado con alevosía y traición, puesto que había propinado las heridas estando

Indefenso el amo y sin poder ni deber precaverlo, porque el esclavo es doméstico y no debe presumirse el amo tenga tal atrevimiento como porque el arma era corta y la llevaba encubierta. ${ }^{103}$

A pesar de estar prohibidas, en la jurisdicción de la ciudad de Antioquia las armas cortas blancas fueron las más utilizadas para cometer asesinatos. La quinta parte de los asesinatos fueron perpetrados con cuchillo, daga o navaja, que parecen haber sido elementos con los que contaba cualquier persona (ver cuadro $\mathrm{N}^{\circ} 42$ ).

Los instrumentos de trabajo como machetes, hachas o tijeras también fueron empleados como armas homicidas. Los inventarios de bienes muestran que en la mayor parte de las casas de la región se contaba con herramientas para la agricultura o la minería. Se trataba de elementos que siempre se tenían a mano, siendo fácil usarlos en caso de presentarse una disputa. El empleo de herramientas de trabajo como armas, fue corriente entre los esclavos, debido a que les era fácil tener acceso a ellas. Así, en 1754, los esclavos sindicados de

${ }^{102}$ Escriche, Joaquín. Ob. cit. Págs. 218-219.

${ }^{103}$ A. H. A. Criminal. B. 27. Leg. 1750-1760. Doc. N 4. Fols. 5r.-5v., 10r.-11v. 
asesinar a don Juan de Areiza, declararon haber usado el machete perteneciente a uno de ellos para llevar a cabo el hecho. Por su parte, el negro Antonio José procesado en 1761 por el homicidio de otro esclavo, confesó haber utilizado para matarlo el hacha con que estaba rajando leña. ${ }^{104}$ Los testimonios anteriores muestran como estos instrumentos se empleaban para ofender o defenderse por estarse usando o llevarlos consigo. Manejarlos como arma parece ser producto de la casualidad y no algo premeditado.

Algunas de las víctimas murieron a consecuencia de los golpes propinados con piedras, palos, manos o pies. Como se anotó anteriormente a estos medios se recurría para hacer perder el sentido y posteriormente ahogar a una persona. En otros casos la muerte era producto del maltrato recibido al haber sido castigado duramente. En el expediente seguido en 1784 contra Francisco Varela por la muerte de un esclavo, se indica que éste lo golpeó y le dio con un palo para obligarlo a caminar. Según el acusador el negro había fallecido por tener

La sangre corrompida de los palos y porrazos. ${ }^{105}$

El empleo de instrumentos contundentes es el que sugiere menos premeditación. De allí que en el caso analizado, la argumentación del acusador haga poco énfasis en el carácter alevoso y peligroso del arma utilizada y se centre en las consecuencias mortales que pudieron tener los golpes.

Con base en los datos anteriores, se puede concluir que en la jurisdicción de la ciudad de Antioquia a fines de la época colonial fue común el uso de armas blancas cortas y herramientas de trabajo cortantes para cometer homicidios. Para analizar este dato hay que tener en cuenta que en las sociedades rurales de ese entonces los hombres solían cargar cuchillos, machetes o cualquier otra arma cortopunzante. Sin embargo, la característica que más llama la atención es que muchos asesinatos se perpetraran sin recurrir a un arma específica, a través del procedimiento de ahogar o enterrar vivo a alguien. Este rasgo indudablemente se debe a que un elevado porcentaje de las víctimas eran niños

${ }^{104}$ A. H. A. Criminal. B. 27. Leg. 1750-1760. Doc. N 5. Fols. 2r.-4v., 13r.-15r. B. 41. Leg. 1740-1770. Doc. No 11. Fols. 3v.-7r.

${ }^{105}$ A. H. A. Criminal. B. 81. Leg. 1780-1790. Doc. No 12. Fols. 3r.-v. 
y una parte apreciable de los agresores eran mujeres. Además, las mujeres no acostumbraban andar armadas, por los que recurrían a medios como las piedras, palos o venenos cuando pensaban ofender a alguien. En general, se puede afirmar que los factores de mayor incidencia parecen tener en la elección de las armas, fueron el sexo y la edad del agresor y la víctima. Como en estos aspectos la sociedad antioqueña era "sui generis", la gama de los instrumentos utilizados para matar fue distinta a la de otras sociedades de aquella época, pues en ellas el uso de armas cortopunzantes fue más generalizado. ${ }^{106}$

\section{Los motivos}

Como algunos criminólogos lo han anotado, es difícil establecer los motivos reales por los que se comete un homicidio. Las declaraciones que las autoridades reciben de los agresores; de las víctimas, en aquellos casos en que se alcanza a recibir su testimonio y de los testigos, más que indicar unas razones verdaderas hablan de las explicaciones y normas de una sociedad y la forma cómo interpreta una determinada situación. Sin embargo, los historiadores coinciden en que ésta es una información muy importante, que indica cuáles eran los valores imperantes en una comunidad en un determinado momento y muestra cuáles eran los motivos por los que la gente creía que se podía matar a alguien. ${ }^{107}$

Al analizar los motivos de los homicidios se debe tener en cuenta que existen diferencias entre los motivos que se aducen en las confesiones y testimonios y los que esgrimen los defensores en sus escritos. Los primeros se refieren más a las circunstancias que habían rodeado el hecho y tratan de explicar por qué sucedió, mientras que los segundos enfatizan en las causales que de acuerdo con la jurisprudencia aminoraban la culpabilidad del acusado. Como se anotó anteriormente, los defensores siempre trataban de mostrar que el hecho no había sido premeditado, porque esto disminuía la pena. De allí que buscaran presentarlo como un acto hecho en defensa propia o producto de una influencia externa maléfica. Estos argumentos, pertenecientes a la tradición

106 Taylor, William B. Ob. Cit., 1987. Pág. 128. Cuadro $\mathrm{N}^{\circ} 12$.

${ }^{107}$ Ibídem. Págs. 139-140. 
jurídica y a los valores de la sociedad española, eran retomados por los agresores al hacer sus confesiones. Así al serle preguntado en 1760 a francisco Telmo de Piedrahíta los motivos por los que había matado a Juan Andrés García respondió:

Que lo primero lo mató porque el enemigo malo lo tentó, lo segundo porque la defensa es permitida y lo tercero por tantos oprobios y desafíos que le hizo. ${ }^{108}$

Por su parte, Venancio Londoño en 1808 declaró haber ahogado a su hija

Sin haber tenido motivo, ni causa para ello, sino porque el demonio lo provocó a cometer aquel atentado. ${ }^{109}$

Como se ve, los acusados presentaban los hechos como si fueran resultado de factores en los que su voluntad no intervenía y trataban de mostrar que los responsables no eran ellos sino el demonio o el destino.

Otro recurso utilizado por los defensores y aprovechado por los sindicados en los interrogatorios, era afirmar que se había actuado "fuera de juicio". La persona manifestaba sufrir de demencia, ser tonto o padecer de una enfermedad que altera sus facultades. Llama la atención que en algunas de estas declaraciones los acusados hablarán en tercera persona para referirse a sí mismos. En 1765, María Meneses al ser interrogada sobre la muerte de su nieta decía

Que más bien le parecía hubiese sido la dicha María Meneses le hubiese quitado la vida a su nieta mediante a tenerla en los brazos y al mismo tiempo haberle dado un accidente que siempre padece repentino y que cuando del accidente volvió en conocimiento hallo muerte a la angelita, su nieta. ${ }^{110}$

Al declarar en estos términos la persona pretendía mostrar que no era responsable de lo sucedido y, por lo tanto, no debía ser juzgada por ello.

\footnotetext{
${ }^{108}$ A. H. A. Criminal. B. 74. Leg. 1740-1760. Doc. $\mathrm{N}^{\circ}$ 3. Fols. 22r.-23v.

${ }^{109}$ A. H. A. Criminal. B. 88. Leg. 1810-1830. Doc. $N^{\circ} 3$. Fols. 35v.-36v-

${ }^{110}$ A. H. A. Criminal. B. 80. Leg. 1750-1780. Doc. $\mathrm{N}^{\circ} 10$. Fols. 3v.-4r.
} 
Los argumentos anteriores se utilizaban debido a que la persona sabía que serían tenidos en cuenta al evaluar el caso. Se tiene a veces la impresión de que la persona decía aquello que las autoridades esperaban que respondiera. Sería interesante poder conocer los medios a través de los cuales los acusados, que eran en su mayoría gente pobre y analfabeta, se apropiaban de estas ideas. Lo más probable es que el sistema utilizado por los jueces, consistente en preguntas y respuestas, les permitiera dirigir los testimonios. Por otra parte, es posible que al rendir confesión, los sindicados siguieran los consejos de su defensor o de algún tinterillo. También se podía tratar de ideas comunes entre los sectores populares, como es el caso de la creencia de que el demonio es quien está detrás de las malas acciones.

Este tipo de razonamiento fue empleado en un poco más de la cuarta parte de los juicios por homicidio (ver cuadro $\mathrm{N}^{\circ} 41$ ). ${ }^{111}$ Se trataba de casos en que la persona no negaba que había cometido el asesinato, pero trataba de demostrar que lo había hecho sin premeditación y alevosía. Esta categoría de motivos es propia del homicidio, pues no se utilizó en las causas de injuria y lesiones personales estudiadas (ver cuadros $N^{\circ} 12$ y 25). Ello se debe a que por estos delitos una persona podía ser condenada a prisión, obras públicas, destierro, pero no a la horca. La posibilidad de ser condenado a muerte llevaba a que la persona sindicada de asesinato tratara por todos los medios de disminuir su responsabilidad.

En diez de los 43 juicios por asesinato analizados se señaló un problema de tipo económico como causa del asesinato. Al comparar este dato con los relativos a injurias de palabra y de "hecho", se encuentra que a medida que aumentó la gravedad del delito, fue menor la incidencia de esta clase de motivos. Paralelamente también disminuyó la gama de problemas sobre la propiedad, por los que la gente se enfrentaba. Así, cerca de la mitad de los motivos aducidos en los procesos por injuria se referían a problemas económicos, un poco menos de la tercera parte de las causas señaladas en los juicios por heridas y golpes eran de esta índole, mientras que sólo el 15\% de los móviles mencionados en los

${ }^{111}$ El número de motivos contabilizados es mayor que la cantidad de causas de homicidio estudiadas, debido a que los sindicados o los declarantes rara vez reducían las causas a una sola. 
expedientes por homicidio pertenecen a esta categoría (ver cuadros $\mathrm{N}^{\circ} 12,25 \mathrm{y}$ 41). Este hecho muestra que la gente se insultaba y aún intercambiaba golpes cuando tenía un pleito sobre la propiedad de un bien, cobraba una deuda u otro asunto económico, pero rara vez llegaba a matar por esta causa. Es indudable que esto tenía origen en los valores y creencias vigentes, pues de acuerdo con ellos, únicamente era lícito matar en defensa de la vida y de la honra.

En menos de la décima parte de los juicios por asesinato se señaló el robo como motivo del hecho. Asesinar a alguien para hurtar algo era considerado uno de los crímenes más graves y las autoridades eran muy severas en estos casos. Por esta razón el agresor y su defensor trataban de mostrar que el crimen había sido cometido con las facultades mentales perturbadas o para poder sobrevivir. En 1799, María de los Dolores Chavarría confesó haber matado al esclavo José María Chavarría, para robarle siete castellanos que llevaba debido a que los necesitaba para algunas "urgencias”. Al preguntársele por qué había ejecutado el crimen respondió

Que se persuade sería tentación del demonio que le instó a ejecutar semejante muerte y que antes y después de ella sabía y sabe que por el delito cometido le ha de castigar dios y la Real Justica. ${ }^{112}$

Como el delito se había cometido en forma premeditada, el defensor trató de salvarla de la horca haciendo hincapié en que estaba "destituida enteramente del juicio".

En 1810, Torcuato Tuberquia declaró haber matado a un muchacho por robarle unos panes de maíz que llevaba. Trató de justificar su acción aduciendo:

Haberlo hecho sin la menor reflexión y llevado de la necesidad, pues había dos o tres días que no comía nada por la pobreza de sus padres y que en aquel tiempo no tenían que darle. ${ }^{113}$

112 A. H. A. Criminal. B. 37. Leg. 1780-1800. Doc. $\mathrm{N}^{\circ}$ 19. Fols. 24v.-27v., 55v.-59r.

${ }^{113}$ A. H. A. Criminal. B. 99. Leg. 1800-1810. Doc. $\mathrm{N}^{\circ} 30$. Fols. 16v-18r. 
Como puede verse, siempre se buscaba disminuir la importancia del robo como móvil y se señalaban otras causas para disminuir la responsabilidad del agresor.

En cuatro de los expedientes analizados, los agresores afirmaron haber perpetrado el homicidio debido a problemas de trabajo. Los sindicados alegaban que la víctima les había impuesto trabajos muy duros, les impedía que realizaran oficios para ellos mismos o se había negado a pagarles el jornal. Esta situación fue común entre los esclavos, quienes señalaban los continuos maltratos y difíciles condiciones laborales como motivo del asesinato de sus amos o compañeros. La esclavitud era fuente de roces e injusticias que podían llevar al esclavo a huir, rebelarse o matar a alguien.

A modo de ilustración podemos citar el motivo por el que el negro Bartolo declaró haber matado a su amor en 1753. En enfrentamiento entre los dos se suscitó porque el amo quería obligar al esclavo a trabajar en la siembra, a pesar de que hacía un año que estaba tullido. Ante la negativa de Bartolo, le pidió que pagara su valor y le exigió 200 pesos para darle al carta de libertad. La muerte se produjo en la disputa que tuvieron sobre el precio de la manumisión. ${ }^{114}$

Los esclavos de don Juan de Areiza confesaron en 1754 haberlo asesinado, porque estaban aburridos debido a que era un hombre "muy riguroso". El esclavo José Miguel al describir las condiciones en que trabajaban declaró:

que no solamente no les daba en el tiempo de las cosechas para rozar aun siguiera un guineo para mantenerse en las rocerías, ni menos una chamarra o calzón de lienzo,... que el confesante dice lo tenía por ningún mantenimiento la comida del guineo para el trabajo tan recio, como el de rozar y que también no teniendo los esclavos más que tan sólo por suyo el día de fiesta y en éste querer moler alguno su cañita en el trapiche del dicho amo no lo consentía, y se hallaban obligados a ir a otros trapiches de la vecindad a moler su caña con súplicas y ruegos que hacían a los dueños. ${ }^{115}$

${ }^{114}$ A. H. A. Criminal. B. 27. Leg. 1750-1760. Doc. N 4. Fols. 5r.-v.

${ }^{115}$ A. H. A. Criminal. B. 27. Leg. 1750-1760. Doc. N 5. Fols. 16r.-18v. 
Como se ve, la relación de esclavitud generaba suficientes motivos para que los esclavos buscaran un medio para liberarse de esa situación. Matar al amo era una salida de tipo inmediato pero su consecuencia era morir ahorcados. Tal vez por eso los esclavos la fueron abandonando para adoptar unos medios de resistencia menos radicales, pero con los que no se exponían a perder la vida. Entre éstos estaban el robo, los engaños y la huida.

En los juicios por asesinato los motivos económicos no se utilizaban para justificar el hecho. Al señalarlos, los agresores y defensores trataban de relacionarlos con la necesidad de garantizar la sobrevivencia y unas condiciones mínimas de vida. Esto se debía a que las leyes y las autoridades no aceptaban que se matara por robar o quitarle una propiedad a alguien. Lo anterior significa que muchos agresores han podido ocultar razones de este tipo, buscando que los tribunales los trataran con mayor benignidad.

En 13 de las 43 causas por homicidio, los agresores afirmaron que su acción había tenido origen en problemas familiares o de la vida en vecindad. Como anotamos al referirnos a los juicios por heridas, en el mundo doméstico antioqueño fue común el maltrato físico. Esta situación podía llevar a que la persona que recibía la agresión decidiera vengarse y optara por matar al agresor. Los esclavos y cónyuges recurrieron a este medio, tal vez porque consideraban que era el único modo de liberarse del castigo continuo. En estos casos el homicida se presentaba como una víctima que no había tenido otra salida. En 1799, Marcela Metauten confesó haber matado a su marido y afirmaba que el motivo

Que tuvo para matar a su marido fue el maltrato que le dio en los veinte años de matrimonio. ${ }^{116}$

En estos casos se cumplía el adagio de que la violencia engendra violencia.

Algunas veces el juicio por asesinato se inició por sospecharse que una persona había fallecido como consecuencia del maltrato recibido. En estos

${ }^{116}$ A. H. A. Criminal. B. 101. Leg. 1800-1810. Doc. $\mathrm{N}^{\circ}$ 2. Fols. 5r.-6v. 
casos era difícil demostrar la culpabilidad del agresor, porque rara vez las autoridades contaban con pruebas suficientes. Un ejemplo de esto es el juicio seguido en 1813 contra José Pino, a quien algunas personas sindicaron de la muerte de su esposa. Sin embargo José Ignacio Ibarra, quien la había asistido en su enfermedad, sostuvo

Que ningunos antecedentes antes de la enfermedad, ni después de la muerte ha sabido de que su marido se la hubiera causado, con golpes o de otro modo,... y en concepto del declarante la muerte de aquella mujer provino de tabardillo. ${ }^{117}$

En estos casos la muerte era producto del maltrato, pero los motivos por los que éste se había propinado eran muy diversos. Entre ellos estaban los celos, el haber desobedecido una orden, la creencia de que los esclavos y las esposas podían ser duramente reprendidos. Lo cierto es que muchas muertes originadas en golpes y heridas dadas como castigo, pudieron pasar inadvertidas.

Algunos agresores declararon haber matado a la víctima por estar cansados de que los ultrajara. Los insultos acerca de la procedencia racial $u$ hombría podían llevar a que se asesinara a quien los profería. En 1781, don Agustín Tapias, antes de fallecer, declaró que Ignacio Arévalo lo había herido en una riña que se ocasionó porque a Arévalo lo trataron de indio. Por su parte, en su confesión, Arévalo afirmó que él había amenazado a Tapias con golpearlo con un arma y llevado de la impaciencia lo trató también de "indio y cholo". ${ }^{118}$

En los casos anteriores los agresores trataron de justificar su acción argumentando que las agresiones constantes los habían llevado a perder el control de sus actos. La muerte era presentada como el resultado de un ataque de ira producido por el maltrato o los ultrajes, y no como un hecho premeditado. Sin embargo, los jueces no prestaban mucha atención a esta clase de explicación, porque consideraban que la persona debía haberse quejado ante la justicia y no tomar venganza por sí mismo. Además, existía la idea de que los esclavos

${ }_{117}$ A. H. A. Criminal. B. 44. Leg. 1800-1810. Doc. N 22. Fols. 10r.-v.

${ }^{118}$ A. H. A. Criminal. B. 31. Leg. 1780-1790. Doc. N 1. Fols. 12r.-14r. 
debían vivir subordinados al amo, la esposa al marido, el agregado al dueño, aunque de estas personas se recibieran agravios.

Llama la atención, que en sólo tres de los expedientes por homicidio, seguidos en la jurisdicción de la ciudad de Antioquia se haya argumentado que el agresor estuviera embriagado en el momento de cometer el homicidio. De acuerdo con las ideas vigentes en España, el alcohol podía destruir el juicio natural de las personas y en esta medida reducir la responsabilidad sobre las acciones. Esta creencia se difundió en las colonias americanas y fue un argumento utilizado para tratar de disminuir las penas. Es así como William Taylor encontró que el 27\% de los agresores del Centro de México declararon que el alcohol había sido la causa de la violencia, mientras que este elemento estaba asociado con el $60 \%$ de los homicidios y el $40 \%$ de los asaltos que se presentaron en esta región. ${ }^{119}$ En los expedientes por él analizados, halló que se acostumbraba beber antes de cometer un asalto premeditado, para darse valor y aprovecharse de la ventaja de una menor responsabilidad, de acuerdo con la ley.

En Antioquia, por el contrario, muy pocas veces se hizo referencia a la embriaguez y no fue presentada por los agresores o víctimas como las causas directas del hecho. El esclavo Marcos Méndez, alias "Vísperas", confesó en 1771 haber matado a la esclava María de Jesús, porque ésta lo trato mal, e incidentalmente anotó que la había mandado llamar con su mujer para darle un trago. En su ratificación apuntó que antes del hecho había comprado media pucha de aguardiente para quitarse un dolor de muelas y que había estado bebiendo con el mulato Juan Antonio, habiendo llamado a la víctima para que los acompañara. ${ }^{120}$ Esta aclaración la hizo, luego de que el defensor trató de disminuir su responsabilidad, argumentando que había perpetrado el hecho "enajenado del uso de la razón”, por estar ebrio.

De los expedientes, se infiere que en Antioquia a fines de la época colonial las autoridades no daban ninguna acogida a la tesis de que el alcohol, al alterar el juicio natural, disminuía la culpa. Tampoco parece una idea aceptada

${ }^{119}$ Taylor, William B. Ob. cit., 1987. Pág. 147-149.

${ }^{120}$ A. H. A. Criminal. B. 38. Leg. 1770-1780. Doc. $\mathrm{N}^{\circ}$ 3. Fols. 59r.-62r., 76r.-78v., 108r.-110v. 
por el pueblo, porque rara vez las personas directamente comprometidas en los hechos, la utilización en sus declaraciones. Esto también puede ser un indicio de que a pesar de lo que se sostenía en algunos informes oficiales, el consumo de licores no era una práctica cotidiana entre la población.

Cerca de la tercera aparte de los motivos argüidos por los agresores, se refieren a problemas en las relaciones sexuales y conyugales. La infidelidad del marido o la mujer y los celos que se despertaban por sospechas, fueron causa de un apreciable número de muertes. Algunas mujeres fueron acusadas de asesinar o ser cómplices de la muerte del marido, por presumirse que estaban en concubinato. Entre el pueblo existía la idea de que 1 homicidio era un medio de tapar evidencias y poder ser libres.

En 1757 Juana María Crespo e Ignacio Arias fueron acusados de haber matado al marido de aquella, por ser concubinos. Sin embargo este cargo no se pudo probar, porque aunque algunos testigos afirmaban que los sindicados tenían "mala amistad", los reos lo negaron en sus confesiones y las autoridades no contaron con pruebas fehacientes. ${ }^{121}$

Lo mismo ocurrió en el proceso seguido en 1762 contra María Ignacia Zapata, Solano García y Blas de Torres, por la muerte del marido de María Ignacia, Juan María Delgado. Los testigos afirmaron que la muerte no había sido accidental y que

Se presume serían ellos, por la frecuencia de dicho Solano en la casa de Juan María y amistad con su mujer, y el vulgo le discurre así. ${ }^{122}$

No obstante, García en su confesión negó el cargo aduciendo

Que desde muy tierna edad ha frecuentado la casa de Micaela Taborda, y por ser esta frecuencia, fuera de toda maldad, entraba en ella como en su casa y con la misma familiaridad, trataba a todas sus hijas, siendo una de ellas la mujer de Juan María.

${ }^{121}$ A. H. A. Criminal. B. 27. Leg. 1750-1760. Doc. No 7. Fols. 7v.-9r., 25v.-27v., 27v.-29v.

${ }^{122}$ A. H. A. Criminal. B. 57. Leg. 1760-1770. Doc. $\mathrm{N}^{\circ}$ 5. Fols. 7r.-8r., 16v. 
Como puede apreciarse, entre el pueblo existía la idea de que al infidelidad de la mujer era la causa de muchas acciones violentas. Se suponía que cualquier hecho que llevara a que la mujer no guardaba la subordinación debida al esposo, producía un resquebrajamiento de la unidad familiar y podía llevar a que ésta se disolviera.

Un gran porcentaje de los hombres sindicados de la muerte de su esposa o el amante de ella, afirmaron que lo habían hecho llevado de los celos. La evidencia o sospecha de que la mujer era infiel, se consideraba como una causa suficiente para cometer el crimen. En 1776 Andrea Holguín, trató de demostrar que su hijo Apolinar Holguín no debía ser condenado por la muerte de José Ignacio Barrera, debido a que éste había ejecutado el hecho

Encontrándole en su casa a deshoras de la noche acostado con María de Villa, su legítima mujer, en el actual y fragante acto y crimen de adulterio. ${ }^{123}$

Sindicaba a su nuera como responsable de la muerte y de que su hijo se encontrara prófugo de la justicia. Ella con sus repetidos adulterios había expuesto al marido a matar a otros o a que lo mataran a él.

Al evaluar estas declaraciones no hay que olvidar que la legislación española consideraba exento de culpa quien mataba al que encontraba "yaciendo" con su mujer, sin importar el sitio. ${ }^{124}$

En otros casos las acusaciones de infidelidad contra la mujer eran menos precisas. El marido afirmaba haber matado a su mujer porque tenía relaciones con otros, pero no la había cogido "in fraganti" ni aportaba evidencias definitivas. Así, Manuel Díaz del Castillo confesó en 1804 haber matado a su mujer, Cornelia Velásquez, y entre otros motivos anotó

Que para descargo de su conciencia le es preciso hacer presente varios pasajes y hechos que le hicieron sospechar que su mujer no lo quería, ni le guardaba la fe conyugal. ${ }^{125}$

\footnotetext{
${ }^{123}$ A. H. A. Criminal. B. 57. Leg. 1770-1780. Doc. $\mathrm{N}^{\circ}$ 8. Fols. 15r.-16r.

${ }^{124}$ Escriche, Joaquín. Ob. cit. Pág. 822.

${ }^{125}$ A. H. A. Criminal. B. 101. Leg. 1800-1810. Doc. No 1. Fols. 9r.-13r.
} 
El reo narraba una serie de anécdotas que le hicieron presumir que su mujer tenía relaciones con el escribano don Pantaleón González, pero ninguna era una prueba definitiva.

Estos procesos muestran que el énfasis era puesto en la infidelidad y traición de la esposa. De acuerdo con las pautas de la sociedad española, las relaciones extramatrimoniales eran menos censurables en el caso de los hombres que en el de las mujeres. Era una idea común que el marido tenía derecho de castigar y aun matar a la esposa por esta causa. En el modelo de sociedad patriarcal que los españoles quisieron imponer en América, ésta era una de las peores afrentas contra el honor, y se podía tomar venganza de ella. Los antioqueños parecen haberse apropiado de esta tradición, ya que en los expedientes se hace énfasis en el papel de los celos como desencadenadores de pasiones incontrolables. Po resta razón, en algunos casos hay que preguntarse si la infidelidad era real, o se trataba de un argumento utilizado para obtener ventajas de las autoridades.

La necesidad de ocultar las relaciones sexuales extramatrimoniales llevaba a las mujeres a abortar, dejar botados los hijos o ejecutar un infanticidio. Algunas jóvenes sindicadas afirmaron haber cometido estos delitos por temor a la reacción de la familia, especialmente del padre. Juana María González, mulata de 25 años, confesó en 1800 haber

Malparido una criatura de que estaba en cinta y enterrándola en el monte dentro de un cañaveral, para que su padrastro y madre no lo supieran. ${ }^{126}$

Por otra parte, en 1803 Gertrudis Guillén india de 20 años, afirmó haber botado a una acequia una criatura por temor a su padre. ${ }^{127}$

Un aspecto que llama la atención, es que este motivo fue esgrimido únicamente en juicios correspondientes a la última década del siglo xviI y la primera del xix. Es probable que esto sea resultado de la campaña que a partir de 1780 llevaron a cabo las autoridades contra los concubinatos y

${ }^{126}$ A. H. A. Criminal. B. 45. Leg. 1800-1810. Doc. $N^{\circ} 1$. Fols. 4v.-5r.

${ }^{127}$ A. H. A. Criminal. B. 101. Leg. 1800-1810. Doc. No 8. Fols. 9r.-11r. 
amancebamientos. El temor de ser procesadas, encarceladas y desterradas por estos delitos, pudo llevar a que las mujeres trataran de ocultar las evidencias de su falta. Como no existe prueba más fehaciente de una mala amistad que un embarazo y el nacimiento de un hijo, es entendible que las mujeres trataran por todos los medios de ocultarlos.

Se debe anotar que en la mayor parte de las declaraciones sobre las causas por las cuales se cometía un homicidio, se hace referencia a problemas derivados de la existencia de relaciones sexuales ilícitas. La incidencia de este tipo de motivos crecía a medida que aumentaba la gravedad del delito. Unicamente el $18 \%$ de las causas argüidas en los juicios por injuria fueron en esta clase, mientras que en los juicios por lesiones personales eran cerca de la cuarta parte, y en los juicios por homicidio, casi la tercera (ver cuadros $\mathrm{N}^{\circ} 12,25$ y 41).

De acuerdo con estos datos los celos y otros problemas derivados de las relaciones ilícitas, eran los factores que más fácilmente desencadenaban un asesinato. La unidad familiar era fácilmente resquebrajada por este tipo de relaciones, lo que convertía al hogar en el lugar más violento de esa sociedad. Para analizar esta situación no debemos perder de vista que las autoridades al combatir los amancebamientos y concubinatos convirtieron conductas privadas en hechos sociales. ${ }^{128}$

El control de la conducta individual, sobre todo de las mujeres, se convirtió en una tarea colectiva, en la que tenía un gran papel el chisme y la conseja. Es comprensible que los cónyuges prestaron oídos a las murmuraciones, propiciándose de esta forma disputas domésticas, agresiones físicas y aun la muerte. Por otra parte, a muchas personas se las involucró en un asesinato con base en chismes y presunciones. Esto muestra que éste era un mecanismo que podía usarse para poner en problemas a un enemigo o tratar de deshacerse de una persona. De allí que sea posible afirmar que el uso de las murmuraciones como forma de control social era un arma de doble filo, debido a que podían propiciar conductas más peligrosas para la sociedad que las que supuestamente combatían.

${ }^{128}$ Colmenares, Germán. "La Aplicación de la Ley Penal a fines de la Colonia y comienzos de la República”. Sin publicar. Versión Mecanográfica. Págs. 4-6. 
Para evaluar la significación de los diferentes tipos de motivos enumerados por los sindicados de homicidio en sus confesiones, debemos tener en cuenta que en la mayor parte de los juicios se hacía referencia a dos o más causas. Unas estaban dirigidas a permitir su defensa legal, de allí que alegaran que habían cometido el asesinato en defensa propia o con las facultades mentales enajenadas. Otras eran explicaciones de los motivos por los cuales ejecutaron la acción, como ocurría en los casos en que afirmaban haber sido continuamente maltratados, haber actuado bajo la influencia de los celos, etc. La evaluación de estos motivos ha cambiado con el tiempo y en función de los intereses de quien estudia el expediente. Las autoridades coloniales al dictar sentencia analizaban más detalladamente el primer tipo de causa. En cambio para los historiadores de hoy son más importantes los que pertenecen al segundo grupo porque permite conocer aspectos del modo de pensar y de las creencias de esa sociedad.

\section{Las sentencias}

De acuerdo con la legislación castellana la pena ordinaria del delito de homicidio era la pena de muerte. La ley 4, título 23, libro 8 de la Recopilación Castellana establecía que el que mataba a otro debía morir por ello, sin importar que el muerto fuera libre o esclavo y el homicida caballero, noble o plebeyo. ${ }^{129}$ Sin embargo, esto no significaba que la pena capital se impusiera en todos los casos de homicidio, pues su aplicación dependía del grado de alevosía y premeditación del hecho, así como de consideraciones de tipo social y político.

Antes de hablar de la forma y frecuencia con que se ejecutaba la pena de muerte en Antioquia, se debe anotar que en la segunda mitad del siglo xviI algunos autores ilustrados criticaron durante su aplicación y pidieron su abolición. Tal vez el autor que mejor expresó estas ideas fue Cesare Beccaria en su obra De los Delitos y de las Penas, publicada en Liorna en 1764. En este libro, Beccaria sostenía que el imponer la pena de muerte no era un derecho que resultara de la soberanía y las leyes, pues

${ }^{129}$ Alvarez Posadilla, Juan. Ob. cit. Tomo III. Pág. 106. 
Estas no son más que la suma de mínimas porciones de la libertad particular de cada uno; representan la voluntad general, que es el agregado de las voluntades particulares. Quién ha querido dejar nunca a otros hombres el arbitrio de matarlo? Cómo puede estar, en el mínimo sacrificio de la libertad de cada uno, el del mayor de todos los bienes, la vida? ${ }^{130}$

Consideraba que además de no ser la pena de muerte un derecho, la experiencia había demostrado que no apartaba a determinados hombres de ofender la sociedad. En su concepto no era la intensidad de la pena lo que producía efecto sobre el ánimo del hombre, sino la duración de ésta. Lo que servía de freno a los delitos, no era el pasajero espectáculo de la muerte de un criminal, sino el largo y continuado ejemplo de un hombre privado de la libertad. Por esta razón, sugería cambiar la pena capital por la de esclavitud perpetua, dado que la continuidad de ésta servía para disuadir el ánimo a los criminales.

En contra de esta opinión, algunos juristas españoles del siglo xviI consideraban que la pena de muerte no debía ser suprimida, pues era útil y necesaria al bien de la sociedad. Criticaban el argumento de Beccaria de que el derecho y potestad de castigar de la república dependía del contrato social y las condiciones puestas en él. En contraposición señalaban

Pero supuesta la voluntad o elección de los hombres, la potestad y el derecho de gobernar y al facultad de escoger los medios conducentes para ello viene de Dios, ... Tienen pues las supremas Potestades una superioridad legítima sobre todos los ciudadanos que componen la república, dimanada ya del conocimiento de los hombres, ya de la dispocion (sic) divina; pero que los hombres no pueden revocar. ${ }^{131}$

${ }^{130}$ Beccaria, Cesare. De los Delitos y de las Penas. Bogotá. Editorial Temis S.A. 1987. Págs. $35-42$.

${ }^{131}$ Lardizábal y Uribe, Manuel de. Discurso sobre las Penas. México. Editorial Porrúa. S. A. 1982. Págs. 164-188.

Alvarez Posadilla, Juan. Ob. cit. Tomo III. Págs. 29-33. 
Como la potestad de castigar venía de dios y no del contrato social, las "supremas potestades" tenían derecho de privar de la vida al súbdito, siempre que ello fuera necesario para el bien de la república.

También criticaban estos juristas la idea de Beccaria de que la esclavitud perpetua era el medio más eficaz para contener los delitos. Señalaban que el hacer cumplir esta pena era difícil, pues los esclavos perpetuos procurarían obtener su libertad, más si sabían que siempre conservarían la vida. Consideraban que la muerte era un espectáculo momentáneo, pero servía de freno, debido a que cada persona tenía la certeza de perder la vida si cometía algunos delitos. Esta impresión no era momentánea, sino permanente y duradera.

En lo que la mayor parte de los juristas del siglo xviI estaba de acuerdo era en que muchas veces se había abusado de la pena de muerte, imponiéndola con profusión y ejecutándola con crueldad. Por esta razón autores como Manuel de Lardizábal y Uribe pedía a los jueces usarla

Con la mayor sobriedad y con toda la circunspección posible.

Los abogados y jueces de la provincia de Antioquia a fines del siglo XviI y principios del siglo xIx, parecen haber compartido la opinión de los juristas españoles partidarios de la pena de muerte. En las dos Constituciones redactadas durante el periodo de la Independencia no se prohibió su aplicación. Sin embargo, los redactores de la Constitución de 1812 eran partidarios de aplicarla con cautela, como se infiere del artículo 11 de la sección referente a los derechos del hombre en sociedad:

La ley no ha de establecer penas crueles, sino proporcionadas a la naturaleza de los delitos: ellas deben ser estricta y evidentemente necesarias y útiles a la sociedad. ${ }^{132}$

${ }_{132}$ Pombo, Manuel Antonio y José Joaquín Guerra. Constituciones de Colombia. Bogotá. Biblioteca del Banco Popular. 1986. Tomo I. Pág. 476. 
En la constitución de 1815 se limitaba la facultad de imponer esta pena, pues en el artículo 20 del título vi relativo al poder judicial, se estableció que ningún juez o magistrado de la provincia podía ejecutar una sentencia a pena de muerte, sin consultar al Supremo Tribunal de justicia. ${ }^{133}$

Pasando de la teoría a la práctica, es importante anotar que en la Nueva Granada durante el siglo xvir la imposición de la pena capital estuvo reservada a casos especiales como las rebeliones masivas o los asesinatos atroces. ${ }^{134} \mathrm{En}$ la provincia de Antioquia sólo consta su aplicación en los casos de homicidio, habiéndose usado selectivamente como método de control de ciertos sectores de la población.

En seis de los 21 juicios de homicidio que se conservan para el periodo 1700-1749 se condenó a alguno de los reos a la pena de muerte. Estas sentencias involucraban a siete personas, de las cuales cinco eran hombres y dos mujeres. Tal vez el rasgo más interesante sea que cuatro de los condenados eran esclavos involucrados en la muerte de su amo o algunos de sus compañeros. De estas sentencias tres se profirieron en la década de 1740 a 1749 , momento en que las relaciones esclavistas entraron en crisis y se produjo un aumento sustancial del número de homicidios.

En marzo de 1743, el Alcalde de Medellín condenó a la horca al negro Hipólito por haber dado muerte voluntaria y alevosa al negro Gregorio, su compañero. Para que su castigo sirviera de ejemplo dispuso que se le diera muerte en la horca, en donde sería puesto pendiente hasta que muriera naturalmente. ${ }^{135}$ La misma pena se impuso en 1746 al esclavo Ignacio, acusado de haber matado a un compañero. ${ }^{136}$

Dos años más tarde el Alcalde de Medellín condenó a la horca a los esclavos Rafael y Rosa por haber ayudado a dar muerte a su amo Javier de Múnera. De acuerdo con la sentencia se impuso esta pena porque los implicados habían procedido a ejecutar el crimen con alevosía, violencia y de "hecho y caso pensado". Como en la provincia no había quien ejecutara la "muerte

\footnotetext{
${ }^{133}$ Pombo, Manuel Antonio y José Joaquín Guerra. Ob. cit. Tomo ir. Pág. 363.

${ }^{134}$ Colmenares, Germán. Ob. cit. Págs. 14-16.

${ }^{135}$ A. H. A. Criminal. B. 27. Leg. 1740-1750. Doc. $\mathrm{N}^{\circ} 2$. Fol. $5 \mathrm{v}$.

${ }^{136}$ A. H. A. Criminal. B. 27. Leg. 1740-1750. Doc. $\mathrm{N}^{\circ}$ 5. Fols. 15v.-16r.
} 
corporal ordinaria de horca", se les conmutó este suplicio por el de garrote en rollo vil plantado en el suelo. Para que esta muerte sirviera de ejemplo a los demás esclavos de la provincia, se dispuso que a Rafael después de muerto se le cortara la cabeza y las manos. La primera se pondría fija en un palo en el lugar en que ejecutaron la muerte, y las segundas se clavarían en los árboles del camino real. En la región no hubo quien ejecutara la pena de muerte, pues el verdugo de la ciudad de Antioquia se fugó. Por esta razón, el Alcalde solicitó al Gobernador que le conmutara la pena al negro Rafael, por la de ser verdugo perpetuo de la villa, ya que de este modo se podía ejecutar la sentencia en la mulata Rosa. ${ }^{137}$

Durante la primera mitad del siglo xviII, la falta de verdugo que ejecutara la pena de muerte determinó que una sentencia no se pudiera cumplir y obligó a conmutar la pena de muerte de dos esclavos en la de ejercer perpetuamente este oficio. ${ }^{138}$ En este periodo la pena capital fue utilizada para contener a los esclavos. Se disponía la exhibición de la cabeza y las manos de los condenados en lugares públicos.

Para que sirva de ejemplo y freno a los esclavos, de que se componen los caudales de este lugar y se contenga en semejantes delitos, observando la obediencia, obsequio y fidelidad que como tales y sirvientes deben a sus señores. ${ }^{139}$

En la segunda mitad del siglo xvill el uso de la pena capital disminuyó, como lo muestra el hecho de que sólo fuera impuesta en siete de los 43 juicios estudiados (ver cuadro $\mathrm{N}^{\circ} 43$ ). ${ }^{140}$ De los ocho reos a los que se les impuso esta

${ }^{137}$ A. H. A. Criminal. B. 34. Leg. 1780-1750. Doc. $N^{\circ}$ 5. Fols. 2v.-4r.

${ }_{138}$ A. H. A. Criminal. B. 91. Leg. 1700-1740. Doc. N 8. B. 72. Leg. 1700-1740. Doc. $\mathrm{N}^{\circ}$ 8. Fols. 37v.-38r.

B. 34. Leg. 1700-1780. Doc. $\mathrm{N}^{\circ}$ 5. Fols. 2v.-4r.

${ }^{139}$ A. H. A. Criminal. B. 72. Leg. 1700-1740. Doc. $N^{\circ}$ 8. Fols. 37v-38r.

${ }^{140}$ En el cuadro $\mathrm{N}^{\circ} 43$ el número de sentencias es menor que el de causas estudiadas, debido a que hay un juicio en que el reo es procesado por dos asesinatos distintos pero sólo se le impone una pena. El otro caso que falta corresponde a una causa que no se sentencia porque al reo se le otorgó inmunidad eclesiástica. 
condena, siete eran hombres y una era mujer. Este último caso corresponde al de la negra liberta Dolores Chavarría, procesada en 1801 por haber asesinado al esclavo José María Chavarría. El fiscal de la causa pidió que se condenara a la rea a pena de muerte.

Sin usar de más caridad, que la que se hace, en ejecutar la justicia según derecho pues, la tolerancia, en este género femenino es la causa para que algunas mujeres se desmanden como lo experimentamos en tres muertes acaecidas en esta provincia en corto tiempo. ${ }^{141}$

El asesor jurídico que estudio la causa, el doctor Ignacio Uribe, estuvo de acuerdo en que se la debía condenar a la pena del "último suplicio" para que sirviera de desagravio a la vindicta pública y de ejemplo al pueblo. Este concepto fue aceptado por la Real Audiencia, la cual determinó que la sentencia a muerte se debía ejecutar en el sitio de Santa Rosa de Osos en donde había cometido el asesinato.

Como lo anotaba el fiscal, a finales del siglo xviII, las mujeres no solían ser condenadas a castigos muy drásticos. Los jueces tenían en cuenta la ignorancia de las implicadas, la "debilidad" del sexo femenino y otras circunstancias atenuantes en el momento de imponer las penas. En el caso de María Dolores Chavarría la pena de muerte fue aplicada selectivamente, pues las autoridades buscaban dar un ejemplo que sirviera de contención a las mujeres.

Que la aplicación de la pena de muerte era selectiva lo corrobora el que los ocho condenados, cuatro fueran esclavos y dos negros libres. Para que sirviera de ejemplo a los pobladores, en 1757 fue condenado a muerte el esclavo Francisco, sindicado de haber dado muerte en compañía de otros tres esclavos a su amo, don Juan de Areiza. En la sentencia el Alcalde de la hermandad decía que el crimen había sido cometido de "caso y hecho pensado", razón por la cual el negro debía ser condenado a la horca. El castigo se debía ejecutar en el mismo sitio donde se había cometido el delito para temor y ejemplo de los demás. Después de ejecutada la sentencia el cuerpo se debía despedazar y repartir en

${ }^{141}$ A. H. A. Criminal. B. 37. Leg. 1780-1800. Doc. $\mathrm{N}^{\circ}$ 19. Fols. 34v., 78r., 82v.-84r. 
las partes públicas que se considerara conveniente. ${ }^{142}$ En noviembre de 1758 fue condenado a la horca José Miguel, otros de los esclavos que perpetraron este crimen. En ese caso el Alcalde de la hermandad dispuso

Que se ejecutara en parte pública de este territorio, dejándole colgado para el común ejemplar y vindicación de la ofensa cometida contra el señor. ${ }^{143}$

Como puede verse, las autoridades utilizaron la pena de muerte para aterrorizar a la población y mostrar lo que le podía pasar a todo el que se atreviera a matar a otro. La ejecución pública era una prueba de la fuerza de la ley con todo aquel que había violado las reglas de la comunidad. La mutilación del cuerpo del asesino, después de la muerte, se hacía para aumentar el terror, ya que esto se oponía a las creencias sobre la integridad del cuerpo. Como lo ha señalado el historiador E. P. Thompson, la ejecución era la más dramática expresión de las formas de control social o "teatro del poder". ${ }^{144}$ En el caso específico de Antioquia se empleó para amedrentar a los esclavos y a los negros libres considerados peligrosos y perturbadores del orden social.

Dos de los reos condenados a la pena capital dijeron ser blancos: Ignacio de Arévalo, sentenciado por haber dado "muerte alevosa" a don Agustín Tapia y Manuel Díaz del Castillo, procesado por la "muerte violenta y alevosa" de su mujer Cornelia Velásquez. Aunque las sentencias se profirieron, no fueron ejecutadas debido a que los reos hicieron fuga. En 1783, Arévalo huyó de la cárcel para acogerse al asilo eclesiástico en la parroquia de Jesús Nazareno de la ciudad de Antioquia. De acuerdo con el dictamen dado por el obispado de Popayán, Arévalo debía gozar del asilo eclesiástico por que en el momento en que dio la herida a Tapia estaba

${ }_{142}$ A. H. A. Criminal. B. 27. Leg. 1750-1760. Doc. $\mathrm{N}^{\circ}$ 5. Fols. 152r.-153v.

${ }^{143}$ A. H. A. Criminal. B. 34. Leg. 1700-1780. Doc. No 12. Fols. 8r.-v.

144 Thompson, E. P. "Folklore, Anthropology, and Social History". Brighton Sussex. John L. Noyce, Publisher. 1979. Págs. 10-11. 
En un estado, en que privado enteramente del uso de la razón, no se hallaba dueño de sus acciones y por consiguiente incapaz de reflexionar lo que hacía. ${ }^{145}$

Díaz del Castillo, por su parte, fue condenado a la horca, en octubre de 1805, por la Real Audiencia. El reo interpuso un recurso de súplica y en enero de 1807 huyó de la cárcel, luego de haber hecho varios intentos de fuga. ${ }^{146}$ Que este reo hubiera burlado a la justicia se convirtió en un precedente negativo para la autoridad. Los reos de algunas causas por maltrato a la esposa, seguidas en los años siguientes amenazaron a su cónyuge con matarla pues

Nada le harán porque Castillo mató a su mujer y nada le hicieron. ${ }^{147}$

Llama la atención que para ejecutar la sentencia a muerte de un blanco las autoridades haya esperado más de un año, dando a éste oportunidades de evadirse, mientras que en el caso de los esclavos la sentencia se llevaba a cabo en pocos días.

Ningún indio fue condenado a muerte a finales de la época colonial. Esto pudo deberse a los indígenas eran considerados jurídicamente como menores de edad, y por lo tanto, no totalmente responsables de sus hechos. El trabajo de William Taylor sobre las comunidades indígenas del Centro de México corrobora lo anterior, pues de 152 causas sentenciadas, únicamente en cuatro casos los reos fueron condenados al "último suplicio". A un gran número de los implicados no se les impuso pena, ya que en 56 casos los reos fueron perdonados y en 22 fueron declarados libres de culpa. El autor anota que en México la pena de muerte solía imponerse a los asaltantes de caminos que mataban y robaban a sus víctimas, así como en los casos de homicidio con violación. ${ }^{148}$

Los datos anteriores permiten afirmar que en el siglo xviI las ejecuciones fueron menos frecuentes en Hispanoamérica que en Inglaterra o Francia.

\footnotetext{
145 A. H. A. Criminal. B. 31. Leg. 1780-1790. Doc. N 1. Fols. 99v.-101r., 117r.-120v.

${ }^{146}$ A. H. A. Criminal. B. 101. Leg. 1800-1810. Doc. N 1. Fols. 59r.-V., 102r.-v.

${ }_{147}$ A. H. A. Criminal. B. 46. Leg. 1800-1810. Doc. N 28. Fols. 1r.-2v.

148 Taylor, William B. Ob. cit. 1987. Pág. 150. Cuadro Nº 17.
} 
Los habitantes de la jurisdicción de la ciudad de Antioquia fueron testigos de estas escenas dos o tres veces en una década. Además, la mayor parte de estas sentencias no se llevó a cabo en la plaza u otro lugar público de la ciudad, sino en las áreas rurales donde se habían cometido los asesinatos. El que la gente no estuviera acostumbrada a presenciar este tipo de castigo podía hacerlo más eficaz para las autoridades. Como algunos autores lo han anotado, al hacerse frecuente la pena de muerte, la gente perdía el temor que le servía de contención, y el castigo no cumplía su función. ${ }^{149}$

El historiador francés Michel Bée ha mostrado que en las sociedades preindustriales la escena de la ejecución se inscribía en un fondo de valores religiosos cristianos. Tanto en la pena de muerte, como en el sistema penitencial de la Iglesia, se buscaba provocar el arrepentimiento del culpable, el terror de los asistentes y asegurar la expiación del agravio cometido contra Dios y la sociedad. Este hecho se corrobora con la asistencia que la Iglesia hace al condenado con sus sacramentos y oraciones. ${ }^{150}$

Desafortunadamente en los expedientes estudiados existen pocas referencias a la parte ritual de la ejecución, lo que lleva a pensar que aquí no tuvieron el dramatismo europeo. En algunos de los juicios de mediados del siglo xvil se anota que se debía comunicar la sentencia de muerte al cura de la ciudad y al padre rector de la Compañía de Jesús, para que asistiesen al condenado y le proporcionasen "los más eficaces medios para su salvación". ${ }^{151}$ La asistencia de la iglesia también tenía que ver con el entierro del cadáver una vez cumplida la ejecución. Así, en 1772 la Venerable Orden Tercera de la ciudad de Antioquia, solicitó al Alcalde que le entregara el cuerpo del esclavo Marcos Méndez. En su concepto

${ }^{149}$ Hay, Douglas. "Property, Authority and the Criminal Law". En: Albion's Fatal Tree. Crime and Scoiety in Eighteenth-Century England. New York. Pantheon Books. 1975. Págs. 56-57.

Colmenares, Germán. Ob. cit. Págs. 14-16.

${ }^{150}$ Bée, Michel. “Le Spectacle de L'exécution dans la France D’ancien Régime”. En: Annales. Economies. Sociétés. Civilisations. 38 Année. N 4. Juillet-Aout. 1983. Págs. 843-862.

${ }^{151}$ A. H. A. Criminal. B. 34. Leg. 1700-1780. Doc. No 12. Fols. 8r.-v. 
La justicia ha dado bastante ejemplo y escarmiento par que tenga lugar la misericordia de enterarlo en lugar sagrado. ${ }^{152}$

En la segunda mitad del siglo xvir también se permutó la pena de muerte por la de ejercer el oficio de verdugo. En el proceso que se seguía en 1788 contra el negro libre Juan José Medina, el Oidor visitador Mon y Velarde propuso que se le conmutara la pena por la de ser verdugo, teniendo en cuenta:

Su calidad, estado y robustez personal, como también a los escasos fondos que tiene esta ciudad para costear verdugo y pregonero, careciendo de uno y otro que se hacen indispensables. ${ }^{153}$

La Audiencia aprobó esta sugerencia debido a los defectos que se había cometido en la formación de sumario, el haber sido atacado el reo por la víctima con un palo y que el homicidio se había cometido fuera de la ciudad de Antioquia.

Como ya se anotó, en la legislación española la prisión tenía un carácter preventivo. La cárcel era el lugar que se tenía para custodia y seguridad de los reos mientras se seguía la causa. ${ }^{154}$ No obstante, la privación de la libertad, así como las incomodidades y molestias que se sufrían durante el tiempo que se estaba en la cárcel, hacían que pudiera ser considerada como una pena corporal. En la jurisdicción de la ciudad de Antioquia, se impuso como pena en algunos procesos por homicidio, sobre todo en los que involucran mujeres como sindicadas.

En aquellos casos en que era difícil probar que las reas habían cometido el crimen, pero se tenían fuertes indicios, los jueces acostumbraron imponer como castigo la prisión sufrida. Esto sucedió en el juicio seguido entre 1787 y 1788 contra Celedonia y Juana Antonia de la Serna con el infanticidio de dos hijos de la primera. El asesor jurídico, el doctor Ignacio Uribe, consideró como suficiente castigo la prisión sufrida debido a que no existía prueba de que

\footnotetext{
152 A. H. A. Criminal. B. 38. Leg. 1770-1780. Doc. $\mathrm{N}^{\circ}$ 3. Fols. 149r.-v.

${ }_{153}$ A. H. A. Criminal. B. 86. Leg. 1780-1800. Doc. $N^{\circ}$ 1. Fols. 52r.-, 113r.-114v.

${ }^{154}$ Lardizábal y Uribe, Manuel de. Ob. cit. Pág. 211.
} 
Celedonia hubiera asesinado el primer hijo, y en cuanto al segundo, constaba que lo había botado debido a su pobreza y los malos consejos. El Alcalde ordinario acogió este dictamen, teniendo en cuenta que las reas habían estado trabajando en la obra del Cabildo en oficios propios de su sexo. En la sentencia se amonestaba a las implicadas para que en lo sucesivo vivieran según las leyes de la religión, sin dar lugar a más escándalos. ${ }^{155}$

A finales de la época colonial el uso de la prisión cambió, pues se empezó a imponer como una pena que se debía cumplir después de dictada la sentencia. La mayor parte de las mujeres implicadas en asesinatos e infanticidios fueron condenadas a permanecer encarceladas por un tiempo determinado. Así, en mayo de 1800, Marcela Metauten, quien había sido procesada por matar a su marido, fue sentenciada a estar diez años en la cárcel y hacer la comida para los reos que debían trabajar en la fábrica de la iglesia. ${ }^{156}$

El mismo año, Francisca Santana, sindicada de infanticidio e incesto, fue condenada por el Alcalde ordinario de Antioquia a 200 azotes en la calle pública y seis años de reclusión en la cárcel. En enero de 1801 la Audiencia cambió la sentencia por diez años en la cárcel de mujeres y diez años de destierro de la provincia. ${ }^{157}$

Algunos de los juristas españoles del siglo xvil no eran partidarios de condenar los reos a estar recluidos en la cárcel, porque consideraban que éstas eran "escuelas de iniquidad", donde los malos ejemplos hacían perverso al que no lo era. Esto se facilitaba por estar mezclados delincuentes de diferentes clases y vivir continuamente ociosos. ${ }^{158} \mathrm{~A}$ pesar de estos problemas, los jueces antioqueños utilizaron esta pena para castigar a las mujeres sindicadas de homicidio. Ello pudo deberse a que no se acostumbró condenarlas a la pena de muerte, obras públicas o presidio de Cartagena y a que el destierro era una pena difícil de hacer cumplir. Al condenarlas a realizar determinados oficios procuraban que no permanecieran ociosas y fuera útil su estadía en la cárcel.

\footnotetext{
${ }^{155}$ A. H. A. Criminal. B. 39. Leg. 1780-1790. Doc. N 14. Fols. 36r.-37r.

${ }_{156}$ A. H. A. Criminal. B. 101. Leg. 1800-1810. Doc. N² 2. Fols. 18r.-v.

${ }^{157}$ A. H. A. Criminal. B. 37. Leg. 1790-1800. Doc. $\mathrm{N}^{\circ}$ 18. Fols. 26r.-v., 28r.

${ }^{158}$ Lardizábal y Uribe, Manuel. Ob. cit. Págs. 211-218.

Escriche, Joaquín. Ob. cit. Pág. 1382.
} 
En algunos casos en que constaba que un reo había cometido el homicidio, pero existían circunstancias que atenuaban su culpabilidad, se usó condenarlo a obras públicas. Esto fue lo que sucedió con Agustín Sánchez quien en 1794 ejecutó una operación cesárea a su mujer y ésta falleció a consecuencia de ella. El doctor José Joaquín Londoño, asesor jurídico consultado, dictaminó que en los autos no constaba que Sánchez hubiera tenido mala intención con su mujer. Lo que se podía ver era que éste había tenido un proceder.

Indiscreto hijo de la rusticidad de este montuno que oprimido del dolor y lance en que miraba a su mujer abortó un discurso opuesto de los fines que se proponía. ${ }^{159}$

Por esta razón consideró que se le debía declarar libre de la pena capital y de los cinco años de destierro con que por ley se condenaba al médico imperito, asignándole por castigo servir durante cuatro meses en las obras públicas.

Lo llamativo del caso es que tanto el acusado como el asesor hayan hablado de la posibilidad de hacer una operación cesárea, desde 1794, cuando la Real Cédula que permitió efectuarla es de 1798. E acuerdo con ella, esta operación se debía ejecutar después de muerta la madre para salvar la criatura. ${ }^{160}$

Sólo uno de los procesados por homicidio fue condenado a pagar su pena en el Presidio de Cartagena. En 1809, Venancio Londoño, acusado de infanticidio, fue condenado por el Gobernador Francisco de Ayala a ocho años en uno de los presidios de esa ciudad. Antes de la Independencia, el reo no pudo ser enviado a cumplir la pena, debido a que una invasión de los indios Cunas impidió llegar por la vía del Chocó. En enero de 1811 el Cabildo de Antioquia decía le que era difícil librar 30 castellanos que valía remitir al acusado y proponía que se dedicara a una obra pública. Finalmente en septiembre de ese año, el reo fue conducido al sitio de San Pedro a donde había sido destinado. ${ }^{161}$

${ }^{159}$ A. H. A. Criminal. B. 76. Leg. 1790-1796. Doc. No 8. Fols. 62r.-63v., 64r.-65r.

${ }^{160}$ Martínez Zulaica, Antonio. La Medicina del Siglo xviII en el Nuevo Reino de Granada. Tunja. Ediciones La Rana y el Águila. 1972-1973. Pág. 164.

${ }^{161}$ A. H. A. Criminal. B. 88. Leg. 1810-1830. Doc. N 3. Fols. 47r., 56r., 62r.-63r., 65r.-v., 71r. 
Los presidios, arsenales y obras públicas reemplazaron las penas de galeras y minas de azogue que existían en la legislación castellana. Como se ha dicho, los juristas ilustrados consideraban inadecuado remitir los reos a presidios, porque allí se volvían peores y en algunos casos incorregibles. ${ }^{162}$ Esta idea pudo estar presente en las autoridades de la gobernación de Antioquia, pues rara vez imponían esta pena (ver cuadros $\mathrm{N}^{\circ} 13,27$ y 43). Otros factores que incidía era que el envío de los reos era difícil y algunos debían esperar varios años antes de empezar a cumplir su condena.

Las autoridades de la ciudad de Antioquia no acostumbraron condenar los reos de homicidio a la pena de destierro. Uno de los pocos casos en que esto se hizo, fue en la causa seguida en 1751 contra Ignacio Oquendo por la muerte de Francisco Torres. El Alcalde de la santa hermandad, José Rodríguez Lujano, consideró que Oquendo no debía ser condenado a la pena de muerte debido a que había matado a Torres para defender su vida. Para que sirviera de escarmiento y ejemplo, condenó al sindicado a un año de destierro fuera de la jurisdicción de la ciudad de Antioquia y otro fuera de los términos del pueblo de Sabanalarga. También debía pagar 20 pesos por concepto de alimentos a la viuda, la pena de sangre y las costas procesales. ${ }^{163}$

El uso poco frecuente de esta pena pudo deberse a que no era un castigo adecuado para personas sindicadas de homicidio. En los casos de reos peligrosos se consideraba inconveniente que por liberar un lugar de un daño, se fuera a causar en otro. ${ }^{164}$ Además, como se vio en lo relativo a lesiones personales, para las autoridades era imposible hacer cumplir esta pena, lo que daba lugar a que se cometiera todo tipo de excesos.

En cuatro juicios por homicidio los reos se salvaron de ser condenados a la pena de muerte o a prisión, debido a que se acogieron a indultos promulgados por el Rey. Con esta gracia se vieron favorecidos Los esclavos Antonio y Marcos, quienes en 1761 y 1804 respectivamente, fueron procesados por haber matado a otro esclavo. En el primero de los casos, el Alcalde ordinario de Antioquia considero que el reo estaba comprendido en el indulto debido a que

${ }^{162}$ Lardizábal y Uribe, Manuel de. Ob. cit. Págs. 197-199.

${ }^{163}$ A. H. A. Criminal. B. 27. Leg. 1750-1760. Doc. No 1. Fols. 30r.-31r.

${ }^{164}$ Lardizábal y Uribe, Manuel. Ob. cit. Págs. 218-219. 
la muerte había sido involuntaria. En el segundo, la Real Audiencia declaró que Marcos debía gozar de esta gracia porque en los autos no había "méritos" para sindicarlo del crimen. ${ }^{165}$

Como puede verse, estos esclavos se beneficiaron del indulto debido a la imposibilidad de probar que hubieran cometido el crimen o que hubieran actuado con alevosía y premeditación.

Los otros beneficiarios de indultos fueron dos mujeres, la mulata Juana María de Mora y la indígena Gertrudis Guillén. En 1784 el asesor jurídico, doctor Ignacio Uribe, consideró que Juana María podía acogerse al Real indulto promulgado en 1784 , pues en el juicio seguido contra ella no resultaba convicta, ni confesa. ${ }^{166}$

El caso de Gertrudis fue distinto, pues en abril de 1804 el Gobernador Víctor de Salcedo, la condenó a seis años de cárcel por el delito de infanticidio. El 2 de mayo el protector de naturales de provincia solicitó que se le permitiera acogerse al indulto que el día anterior se había publicado. El Gobernador estimó que la rea no estaba comprendida en él y decidió enviar el caso a la Audiencia. En Junio ese tribunal declaró que se le debía conceder esa gracia y dispuso que se entregara a su padre quien debía cuidar de su educación y conducta y encargó al cura de Sopetrán que la instruyera en la doctrina cristiana. ${ }^{167}$

Este último caso fue el único en que se concedió indulto a un reo declarado culpable y cuyo delito estaba plenamente probado. Por esta razón las autoridades provinciales no eran partidarias de otorgarlo, pero la Audiencia no encontró ningún impedimento en hacerlo. Este tribunal, situado a bastante distancia, consideró que el delito cometido por la rea no era de los exceptuados y dejó de lado las consideraciones sobre su conveniencia.

El hecho de que el Rey acostumbrara otorgar indultos servía para crear la imagen de una justicia benevolente, que castigaba duramente a los culpables pero tenía piedad en aquellos casos en que se presentaban dudas. La impresión que recibía el pueblo al ver ejecutar la pena de muerte era contrarrestada por

${ }^{165}$ A. H. A. Criminal. B. 41. Leg. 1740-1770. Doc. No 11. Fols. 33r.-34r.

A. H. N. C. Negros y Esclavos de Antioquia. Tomo rv. Fols. 987v.-988r.

166 A. H. A. Criminal. B. 52. Leg. 1780-1790. Doc. $N^{\circ}$ 8. Fols. 20r.-21r.

${ }^{167}$ A. H. A. Criminal. B. 101. Leg. 1800-1810. Doc. $\mathrm{N}^{\circ} 8$. Fols. 24v., 25r.-v., 28r.-v. 
la que producían los indultos. Estos eran presentados como gracias otorgadas por el Rey y con ellos se pretendía mostrar que el monarca y los jueces que actuaban en su nombre, eran justos. Es decir, se desechaba la imposición de un castigo para mantener la fe en el sistema judicial.

Un porcentaje relativamente alto de los reos por homicidio fue absuelto de los cargos existentes contra ellos (ver cuadro $\mathrm{N}^{\circ} 43$ ). Esto se debía a que los jueces, antes de dictar sentencia, evaluaban cuidadosamente las pruebas con que contaban. Como muchos homicidios se cometían en lugares y horas donde no había testigos y no existían evidencias claras contra alguien, se tenía que dejar libres a los acusados. No hay que olvidar que en muchos casos la causa se inició porque había dudas acerca de la muerte de la víctima, pero era sumamente difícil probar que la muerte no había sido natural o accidental.

En 1763 el Alcalde ordinario, don Gregorio Francisco Diez de la Torre, encontró que en el curso de la causa seguida contra la negra María Dolores y Gaspar Muriel, por la muerte del esposo de la primera, no existían evidencias que permitieran sindicarlos del delito. Por esto los declaró libres del cargo y los absolvió de pagar las costas. ${ }^{168}$

Lo mismo ocurrió en el juicio seguido entre 1803 y 1804 a Bárbara Tavera, Bernardina Miranda y el indio Pedro Agudelo por la muerte del esposo de la primera y padre de la segunda, José Ignacio Miranda. El Gobernador, Víctor de Salcedo, tuvo que absolverlos de delito por no haber podido probar nada en su contra. ${ }^{169}$

En algunas ocasiones la falta de pruebas llevó a que los sindicados ni siguiera fueran puestos presos. Esto ocurrió en el juicio seguido contra don José Cruz Robledo y sus esclavos por la muerte de don Félix Lemus. De acuerdo con el dictamen del Gobernador Salcedo y el asesor jurídico Viana, no había en el expediente el más leve indicio de que ellos hubieran causado el naufragio en que falleció la víctima y quedaba claro que por su diligencia se había evitado la pérdida total de sus bienes. Después de conocida la sentencia, Robledo demandó

${ }^{168}$ A. H. A. Criminal. B. 41. Leg. 1740-1770. Doc. $\mathrm{N}^{\circ} 13$. Fols. 40v-41r.

${ }^{169}$ A. H. A. Criminal. B. 66. Leg. 1800-1810. Doc. N 8. Fol. 41r. 
a don Manuel y don José de Lara, por haber sido quienes apoyaron el cargo contra él y pedía que los condenaran a pagar las costas del proceso. ${ }^{170}$

La absolución del cargo de homicidio no parece haber dependido de la condición social del sindicado pues benefició a esclavos, indios, libres y blancos. Los jueces se mostraban poco propensos a condenar si no existían pruebas ciertas, plenas y claras. En esto seguían la máxima del derecho español que decía que

Los Jueces en los delitos que no son claramente probados, o que fueren dudoso, más inclinados han de ser a absolver al reo, que a condenarle, porque más justa, y santa cosa es quitar la pena al que la merece, que darla al que no la merece, por ser el daño reparable. ${ }^{171}$

Cerca de la quinta parte de los juicios por homicidio quedó inconclusa (ver cuadro $\mathrm{N}^{\circ} 43$ ). Este hecho se debe a que algunos de los expedientes estudiados eran diligencias enviadas al Gobernador para que emitiera un concepto y su tramitación se continuó en el lugar de origen. De otros expedientes se conservan sólo los trámites realizados por los Alcaldes pedáneos, pero no figura la parte del juicio que se debió llevar ante el Alcalde ordinario o el Gobernador.

El estudio de las sentencias proferidas por los jueces de la jurisdicción de la ciudad de Antioquia entre 1750 y 1819 muestra que en ellas se combinó el castigo, la corrección y la clemencia. Sin embargo, estas tres modalidades de administrar justicia no se aplicaron de igual manera entre la población. En el caso de los mestizos, blancos e indios se acostumbró hacer un análisis minucioso de las circunstancias atenuantes. Un porcentaje elevado de ellos fue absuelto del cargo y cuando se les comprobó la ejecución del crimen se les impuso penas corporales como la cárcel o las obras públicas. Esto significa que con ellos se usó la misericordia o se buscó que corrigieran su conducta. Los negros libres y los esclavos, por su parte, fueron tratados con mayor dureza. Las sentencias de pena de muerte que fueron ejecutadas se aplicaron a este sector de la población.

170 A. H. A. Criminal. B. 37. Leg. 1790-1800. Doc. N 12. Fols. 189v.-190r., 191r.-192v.

${ }^{171}$ Hevia Bolaños, Juan de. Curia Filipica. Madrid. Imprenta de Pedro Marín. 1776. Pág. 232. 
No obstante, algunos de ellos se beneficiaron de la expedición de indultos, lo que muestra que con ellos se utilizó el castigo o la misericordia.

En síntesis, la escogencia de un determinado tipo de pena dependió de las consideraciones de los jueces. Al emitir sentencia éstos tenían en cuenta la incidencia que el delito había tenido en la sociedad y el momento en que había sido ejecutado. Entre 1740 y 1770 , cuando la crisis de las relaciones esclavistas llevó a que varios esclavos mataran a sus amos o a compañeros, las autoridades fueron muy rigurosas con ellos. Con las mujeres, el procedimiento fue parecido. Desde 1750 a 1975 los tribunales las trataron con benignidad, imponiéndoles como pena la prisión sufrida. A fines del siglo xvil y principios del xix, cuando un número elevado de ellas se vio inmiscuido en procesos por homicidio, las autoridades recurrieron a la pena de muerte o les impusieron largas condenas en la cárcel. En ambas coyunturas la estabilidad del orden social parece haberse visto comprometida y por esto los jueces se apresuraron a controlar estas conductas.

Al analizar las penas impuestas no se debe olvidar que uno de los principales objetivos de los gobernantes ilustrados fue el control social de la población. Para lograrlo recurrieron tanto al "teatro del poder" que encierra la ejecución de la pena capital, como a demostrar que se debía tener fe en la justicia. Al llevar a cabo un proceso, los jueces instruían a la población sobre lo que era legalmente aceptable. A través de la evaluación completa y rigurosa de las pruebas se trataba de mostrar que la justicia sólo castigaba cuando tenía bases sólidas para hacerlo. Aunque la aplicación de estos principios fuera discrecional, se hacía de tal manera que la población quedara convencida de la imparcialidad del aparato de justicia.

El estudio del homicidio permite conocer cuáles son las tensiones que producen violencia entre las personas en una determinada sociedad. ${ }^{172}$ De acuerdo con este postulado, es posible afirmar que en la sociedad antioqueña de fines del periodo colonial el conflicto principal giraba alrededor del papel de la mujer dentro de la familia. El adulterio femenino o los indicios sobre su existencia, llevaban al marido a maltratar físicamente o asesinar a la esposa. Esta también podía ser

${ }^{172}$ Taylor, William B. Ob. cit., Pág. 162. 
la causa por la cual las mujeres decidían matar a sus esposos. Si bien el modelo patriarcal de familia fue el que las autoridades coloniales trataron de imponer, en la práctica, la conducta de la mujer no correspondía del todo a estas pautas.

En la jurisdicción de la ciudad de Antioquia durante la época colonial las actividades de las mujeres pertenecientes a las "castas" no se restringieron a preparar la comida, arreglar la casa y cuidar a los hijos. Muchas de ellas realizaban faenas agrícolas o trabajaban en los minerales extrayendo oro. Estas y otras actividades, les permitían moverse libremente por los poblados y aun en las zonas rurales, teniendo una vida social muy activa. En más de una oportunidad los expedientes se refieren a mujeres que transitaban por los caminos en compañía de hombres que no eran sus maridos o que asistían a fiestas sin ellos. Esta situación ponía en entredicho la posición del marido, impulsándola a agredirla y aun a eliminarla.

La existencia entre los mestizos, mulatos e indios de un núcleo representativo de mujeres que figuraban como cabeza de familia también muestra la relativa independencia de la mujer en esta sociedad. Estos datos se refieren a mujeres solteras con hijos, o viudas, quienes tenían a su cargo sostener la familia. De otra parte, la precariedad de la institución familiar que nacía de relaciones extramatrimoniales daba lugar a que se presentaran abortos, infanticidios o se botara a muchas criaturas recién nacidas.

A diferencia de otros lugares de Hispanoamérica, en Antioquia no era la existencia de relaciones patriarcales lo que producía la violencia en la familia. Por el contrario, era el desajuste entre este modelo que pretendía imponer la sociedad blanca y la realidad, lo que volvía conflictiva la situación. Esto lo evidencia el hecho de que cuando las autoridades coloniales se dedicaron a perseguir el concubinato y el amancebamiento, para consolidar la institución familiar, fue cuando la situación se volvió más violenta.

Los autores que han realizado la violencia en las relaciones familiares han elaborado una serie de hipótesis explicativas. Para ciertos lugares y épocas la existencia de estos conflictos evidenciaría que la continuidad del pueblo y el mantenimiento de unas relaciones internas pacíficas se colocan por encima de la armonía del hogar, los derechos individuales y la lealtad interna en las familias numerosas. En otros contextos han sido estudiados como un indicativo de la 
desorganización de la sociedad. ${ }^{173}$ La pauta existente en la región antioqueña parece acercarse más a la segunda opción que a la primera. Aunque el índice de homicidios entre vecinos no es muy alto, los datos sobre pleitos por injuria y lesiones personales muestran que la vida en los pueblos de esta región no estaba exenta de conflictos. Las continuas peleas entre personas de igual condición económica y social indican que no existía solidaridad y lealtad entre los miembros de la comunidad. Por el contrario, entre los distintos grupos étnicos que componían la población había oposición de intereses y recelos. En la sociedad antioqueña de fines de la época colonial había oposición de intereses entre los amos y los esclavos, entre los indígenas y los libres que habían invadido sus resguardos, entre las personas que habían logrado cierto éxito económico y movilidad social y el resto de la población.

Durante el periodo estudiado, las autoridades provinciales se dedicaron a controlar la violencia entre grupos sociales y lograron ciertos cambios. Así, los conflictos que se derivaban de las relaciones esclavistas disminuyeron en agresividad y rebajó el número de homicidios perpetrados por esclavos. En cuanto a las relaciones familiares sus logros no fueron los mismos, pues las agresiones entre sus miembros aumentaron en frecuencia y gravedad. Los datos con que se cuenta no permiten establecer de manera concluyente el por qué se dieron estos procesos. Es necesario avanzar más en su investigación, pues eso nos permitirá tener una mejor comprensión de la sociedad antioqueña de ese entonces y tal vez de la de hoy.

${ }^{173}$ Ibídem. Pág. 163-164, 227-228. 
Conclusiones 



\section{Las leyes}

En la administración de justicia la ley es lo permanente. La larga duración de las disposiciones legales se hace visible cuando constatamos que los códigos suelen tener vigencia por varias décadas, incluso varios siglos. El derecho es uno de los componentes de la cultura que más lentamente cambia, como lo dijo el historiador francés Jules Michelet, a veces parece estar por fuera del tiempo, fuera del porvenir y fuera del pasado. ${ }^{1}$

La legislación criminal vigente en las colonias españolas de América era la misma que se aplicaba en España. Estaba conformada por una serie de colecciones de leyes que se encontraban agrupadas en la Recopilación Castellana, elaborada en el siglo xvi durante el reinado de Felipe II. En lo que no estaba contenido en esta colección se debía seguir lo dispuesto en el Fuero Real o las Siete Partidas, códigos elaborados desde el siglo xiII.

Las autoridades españolas y algunos de los funcionarios que actuaron en América durante el siglo xviII, eran conscientes de que estas leyes no eran adecuadas al espíritu de su tiempo. En múltiples ocasiones anotaron que era necesario expedir un código que no diera lugar a "interpretaciones y comentos". La demora en la tramitación de los juicios y las diferencias tan grandes que había en las decisiones tomadas por los jueces, se atribuía a la falta de una colección de leyes que se tuvieran que aplicar de manera general. Durante el gobierno de Carlos III (1759-1788) se intentó reformar la legislación, pero no se logró elaborar un nuevo código. En consecuencia, se dejaron de aplicar algunas de las disposiciones más drásticas y se remplazaron por lo establecido por la costumbre.

Durante la Independencia, los redactores de las Constituciones dejaron consignada la necesidad de expedir un código de leyes penales. Sin embargo, los múltiples problemas que enfrentó la organización del nuevo Estado, llevaron

${ }^{1}$ Lefebre, Georges. El nacimiento de la Historiografía Moderna. Barcelona. Ediciones Martínez Roca, S. A. 1974. Pág. 207. 
a que se postergara esta tarea. En lo criminal, las leyes españolas estuvieran vigentes hasta 1837 cuando se expidió el primer código penal neogranadino.

Las leyes criminales españolas eran de origen medieval, no correspondían al espíritu y pensamiento "ilustrado" del siglo xviI, lo que hacía muy difícil aplicarlas de manera escrita. A pesar de estos problemas, las autoridades antioqueñas de fines del periodo colonial las utilizaron como reguladoras de la vida social. Desafortunadamente, los datos con que se cuenta no permiten analizar muchos de los componentes ideológicos que conllevó el empleo de la justicia en la preservación del orden social. Algunos investigadores, siguiendo al historiador de la revolución de la Independencia, el antioqueño José Manuel Restrepo, han sostenido que las leyes coloniales fueron más respetadas por la población que las elaboradas en la época republicana:

Acaso este vicio de no cumplirse las leyes, que aún subsiste en la Nueva Granada, nace de la forma de gobierno republicano, en el que un gran número de ciudades concurre a su formación, y por lo mismo no se veneran por ellos. Era muy diferente el respeto que profesábamos a la obediencia que se prestaba a las leyes cuando emanaban del Gabinete de Madrid, sancionándose a dos mil leguas de distancia de nosotros, las que se ejecutaban con vigor y exactitud por los agentes del Gobierno español. ${ }^{2}$

Sin embargo, los juicios analizados para la región de Antioquia muestra que a mediados del siglo xvil la mayor parte de la población, y aun autoridades locales, desconocían las disposiciones legales y las incumplían. Esta situación parece haber variado un poco a finales del periodo colonial, pero dado el escaso desarrollo de los estudios sobre el tema es difícil sacar conclusiones. Para hacerlo es necesario investigar el papel que la religión y la Iglesia, así como el aumento del control fiscal, tuvieron en la modelación de la conducta con respecto a la ley. Además, sería deseable comparar lo sucedido en la provincia de

${ }^{2}$ Colmenares, Germán. "La Ley y el Orden Social: Fundamento Profano y Fundamento Divino". Boletín Cultural y Bibliográfico. Vol. 27. º 22. 1990. Pág. 5. 
Antioquia con lo que pasó a otras regiones del virreinato de la Nueva Granada y aún de Hispanoamérica.

\section{El juicio criminal}

La legislación estipulaba que un juicio criminal se dividía en dos partes: Una encaminada a la justificación del delito y sus autores, llamada sumario y otra denominada plenario, en que se discutía la culpabilidad o inocencia de los procesados y culminaba con la sentencia proferida por el juez. En la práctica, muchos de los expedientes tramitados en la jurisdicción de la ciudad de Antioquia no cumplieron con la totalidad de los pasos estipulados. Esto se debía a que el juez seguía un procedimiento abreviado para la sustanciación de la causa o a que por algún factor el juicio quedaba incompleto.

Al analizar los juicios seguidos por injuria, lesiones personales y homicidio entre 1750-1820, se puede ver que la administración de justicia se fue haciendo más rigurosa desde el punto de vista procedimental. Esto es visible en aspectos como forma en que se tomaban y evaluaban los testimonios y las confesiones, partes fundamentadas para establecer el delito e identificar a los culpables.

El aumento del formalismo legal pudo ser consecuencia de que empezaran a actuar abogados graduados en la administración de justicia. A partir de la década de 1770 , estos abogados intervienen en la tramitación de los juicios como asesores jurídicos, fiscales, defensores o jueces. Su presencia fue muy importante, debido a que señalaban los vicios de procedimiento que podían afectar el seguimiento de una causa.

Paralelamente, los personajes ilustrados que estuvieron al mando del gobierno de la provincia tuvieron el propósito de agilizar y hacer más eficaz la administración de justicia. Así, en los informes presentados por los Gobernadores Francisco Silvestre (1775-1776, 1782-1785) y Juan Antonio Mon y Velarde (1785-1788) se enumeran los principales problemas que se presentaban para aplicar justicia y se proponen algunas reformas. ${ }^{3}$

${ }^{3}$ Silvestre, Francisco. Relación de la Provincia de Antioquia. Medellín. Ediciones Especiales. Secretaría de Educación y Cultura de Antioquia. 1988. Págs. 187-200, 505-513. 
Ellos buscan hacer de la justicia un mecanismo de control más eficiente, que sirviera para perseguir conductas consideradas desviadas como el robo, el incesto y el amancebamiento. Para cumplir con este papel, era necesario que las personas relacionadas con el seguimiento de los juicios actuaran conforme a lo dispuesto por la ley. Veían que era indispensable combatir la venalidad e ignorancia de jueces y escribanos, así como construir cárceles seguras y evitar la pérdida constante de documentos judiciales.

Los juicios estudiados muestran que a finales del periodo colonial las autoridades utilizaron la tramitación de las causas para instruir a la población acerca de las conductas consideradas incorrectas, los procedimientos que se debían seguir para presentar una queja o los castigos impuestos a determinados delitos. El hincapié puesto en el cumplimiento del procedimiento era muy importante, pues se buscaba hacer visible que la justicia funcionaba y que nadie podía estar exento de ella. El reforzar estos aspectos tenía un papel fundamental en el empleo de la ley como medio de imponer unos determinados supuestos ideológicos.

Para poder avanzar en la comprensión de este proceso, es necesario investigar más la incidencia de las reformas propuestas por los gobernantes borbónicos en la administración de justicia. Existen pocos estudios concretos que permitan conocer si realmente se hicieron cambios y cuáles fueron los factores que incidieron en el resultado.

\section{Los jueces}

La documentación consultada muestra que la acción de la justicia en el ámbito rural era bastante precaria y problemática. El control de la población que vivía en los numerosos sitios pertenecientes a la jurisdicción de la ciudad de Antioquia, estaba a cargo de un Alcalde pedáneo nombrado anualmente. La labor de estos funcionarios era continuamente criticada por la población y las autoridades. Así, el fiscal de la Audiencia Francisco Moreno y Escandón, decía en 1772 que los Alcaldes pedáneos cometían múltiples abusos, particularmente contra los indios 
y gente miserable. ${ }^{4}$ Por su parte, el Gobernador de Antioquia Francisco Silvestre, señalaba que el problema más grande de la administración de justicia eran los Alcaldes pedáneos. Los describía como "gente de campo", de poca inteligencia, que apenas sabía firmar y actuaba bajo la dirección de "tinterillos y cavilosos". 5

Debido a estas circunstancias la justicia sólo podía operar plenamente en las ciudades y villas, así como en los sitios muy próximos a ellas. En la ciudad de Antioquia, capital provincial, actuaban como jueces de primera instancia los Alcaldes ordinarios, elegidos por el Cabildo y los Gobernadores, nombrados por el Rey. Tampoco estos funcionarios se escapaban de ser criticados, pues a los jueces ordinarios se les acusaba de dirigir sus actos por

El respeto, el sentimiento privado o el parentesco y no la recta imparcialidad. ${ }^{6}$

Las quejas contra los Alcaldes pedáneos y ordinarios, unidas a la preocupación sobre la forma de garantizar el control de la población, llevaron a que los gobernantes borbónicos intentaran limitar el poder de los criollos en la administración de justicia. Como producto de esta política la actividad de los Alcaldes pedáneos, escogidos entre los habitantes del lugar, siempre estuvo restringida a la tramitación de causas civiles de poca monta y a aprehender a los reos y tomar declaraciones de testigos en los procesos criminales. A los jueces ordinarios, que se elegían entre los vecinos principales y más acomodados, se les obligó a consultar las decisiones que tomaban en las causas de alguna gravedad a los asesores jurídicos. Paralelamente se fortaleció el papel que en este campo tenían los Gobernadores, representantes directos de la Corona.

Como en la Nueva Granada se formaron las intendencias, los Gobernadores fueron los funcionarios encargados de implementar en las provincias las reformas borbónicas. La mayor parte de estos funcionarios eran militares españoles, que habían hecho su carrera en diferentes regimientos de España o América. Su

\footnotetext{
${ }^{4}$ Colmenares, Germán. Relaciones e Informes de los Gobernantes de la Nueva Granada. Bogotá. Biblioteca Banco Popular. 1989. Tomo I. Pág. 158.

${ }^{5}$ Silvestre, Francisco. Ob. cit. Pág. 196.

${ }^{6}$ Silvestre, Francisco. Descripción del Reino de Santa fe de Bogotá. Bogotá. Biblioteca Popular de Cultura Colombiana. 1950. Pág. 211.
} 
disciplina y obediencia a las disposiciones centrales, fue utilizada para tratar de dar homogeneidad a algunos aspectos de la administración provincial.

A partir de 1796 se nombró para la provincia de Antioquia un Teniente de Gobernador asesor, puesto ocupado por abogados criollos, quienes estaban encargados de dar conceptos y dictámenes jurídicos en las causas seguidas por los Alcaldes ordinarios o el Gobernador. Como burócratas de carrera estos funcionarios estaban sujetos a un sistema estricto de designación, control y promoción que garantizaba su eficacia. Al otorgarles un papel importante en la administración de justicia, se buscaba que la supervisión de la conducta de la población estuviera en manos de personas leales a la Corona y que compartían sus políticas. Lo irónico fue, que muchos de los criollos ilustrados incorporados a esta carrera terminaron siendo líderes del proceso de Independencia.

En el caso de la provincia de Antioquia hay una vinculación clara entre los abogados incorporados a la administración de justicia como jueces, asesores, defensores o fiscales y el movimiento de la Independencia. Muchos figuran como redactores de las Constituciones del Estado de 1812 y 1815 y ejercieron una influencia muy grande en el proceso. Sería bueno investigar si en otros lugares de la Nueva Granada se presenta algo parecido en este campo.

\section{Las conductas delictivas}

Los delitos son eventos de tiempo corto. Por un breve momento ellos interrumpen la vida cotidiana de las localidades escandalizando a sus habitantes o causando temor y estupor. Esta permanencia es bastante efímera, pues dura hasta que se produzca un nuevo crimen o acontecimiento que haga olvidar al anterior.

A pesar de su carácter episódico y anecdótico, los datos sobre conductas delictivas permiten establecer pautas de comportamiento que tienen una mediana o larga duración. Así, el estudio de las características de las personas que se ven comprometidas en un juicio criminal, posibilita conocer aspectos de la estructura de una sociedad y del tipo de relaciones que existen entre sus miembros. Las conclusiones a que se llega con esta clase de análisis pueden servir de indicios explicativos, pero para estar seguros de su validez es necesario confrontarlas con las obtenidas en investigaciones hechas con otro tipo de fuentes. Estas preocupaciones se derivan de los límites que tiene la 
información contenida en los juicios criminales, pues no se debe olvidar que es obtenida para corroborar la existencia de un delito y encontrar a un culpable. Desde el punto de vista estadístico los datos que se elaboran a partir de estos documentos tienen cierto grado de incertidumbre, debido a que es imposible saber el número total de infracciones cometidas contra la ley.

Sin perder de vista estas anotaciones, a continuación se esbozaran algunas características de la sociedad antioqueña que se reflejan en los juicios por delitos contra la persona seguidos en la jurisdicción de la ciudad de Antioquia entre 1750 y 1820 .

\section{El Mestizaje}

Los expedientes estudiados registran la complejidad del proceso de mestizaje que se dio en la región y permiten conocer las creencias y valores que generó. Así, los datos sobre el origen étnico de los agresores muestran que los mestizos y mulatos libres eran objeto de un control especial por parte de las autoridades. Como no estaban sujetos a restricciones de movilización y laboralmente no tenían una clara relación de subordinación, se los consideraba "peligrosos". La suspicacia y el temor llevaban a que a la más leve queja o indicio fueran procesados. ${ }^{7}$ De allí que fueran el $64.9 \%$ de los acusados de injuria verbal, el $65.2 \%$ de los comprometidos en lesiones personales y el $60.0 \%$ de los sindicados de homicidio (ver cuadros $\mathrm{N}^{\circ} 3,16$ y 30 ).

Pero, más allá de la prevención que indudablemente existía contra ellos, estas cifras reflejan la composición étnica de la población. Según el censo de 1788 los libres de "varios colores" eran el 64.9\% de los habitantes de la jurisdicción de la ciudad de Antioquia (ver cuadro $\mathrm{N}^{\circ}$ 65). Por otra parte, los padrones efectuados entre 1805 y 1806 en la ciudad de Antioquia y los pueblos de Sopetrán y San Jerónimo, muestran que al empezar el siglo xix a ese sector de la población pertenecía cerca del $75 \%$ del vecindario (ver cuadro $\mathrm{N}^{\circ} 66$ ).

La superioridad numérica de los individuos "libres" también se corrobora con los datos sobre el origen racial de las víctimas. De las personas que

${ }^{7}$ Colmenares, Germán. "La Aplicación de la Ley Penal a fines de la Colonia y comienzos de la República”. Cali. Versión mecanografiada sin publicar. s. f. Pág. 9. 
presentaron quejas por injuria el 49,1\% eran libres, mientras que el 68,2\% de los agredidos físicamente y el $59.1 \%$ de las víctimas de homicidio pertenecían a este grupo (ver cuadros $\mathrm{N}^{\circ} 2,15$ y 29) Lo más llamativo de estos datos es que casi la mitad de las personas que pusieron demandas por injuria, conducta relacionada con el deseo de preservar una posición y estima social, eran mestizos y negros libres. Ello indica que fuera del mestizaje racial en la región de Antioquia, durante el siglo xviII, se dio un proceso de transculturación, que llevó a que la población de "colores" adoptara patrones culturales propios del grupo blanco. Este fenómeno parece ser el resultado de la política de control social de la población mestiza, puesta en práctica por los gobernantes "ilustrados" de fines de siglo.

El mestizaje alteró el esquema de jerarquías sociales basado en la etnia que pretendió imponer la corona española. La sociedad dual del siglo XVI, indios y españoles, vencedores y vencidos, se fue transformando en una estructura más compleja con la introducción del elemento esclavo y a medida que aumentaban los individuos de raza mixturada. El surgimiento de una gran cantidad de gente mestiza y mulata libre era problemático para las autoridades, debido a que, ante la carencia de instituciones apropiadas para hacerlo, no hacerlo, no era fácil su sujeción desde el punto de vista fiscal, judicial y eclesiástico.

En la jurisdicción de la ciudad de Antioquia la población libre vivía dispersa trabajando en pequeñas propiedades agrarias o dedicada a extraer oro de los ríos o depósitos aluviales. A finales del siglo XVIII las autoridades trataron de reducir esta gente a poblados, buscando controlarla mejor. Los beneficios que se tendrían con el nuevo esquema de población son descritos en la visita hecha en 1785, por orden del Gobernador Francisco Silvestre, a la zona minera del Valle de Osos. El visitador Pedro Rodríguez de Zea decía que ese valle estaba habitado por:

Personas nobles, dueños de cuadrillas, mestizos, mulatos y negros libres componiéndose mucha parte de gente ociosa, vaga y mal entretenida. ${ }^{8}$

${ }^{8}$ A. H. A. Visitas. Tomo 76. Documento 2104. Fols. 20v.-31v. 
Para solucionar estos problemas propuso que los vecinos de San Pedro construyeran sus casas inmediatas a la iglesia del sitio, lo que permitiría que se administrara mejor la justicia y pudieran asistir a la iglesia. Así mismo, veía la necesidad de crear viceparroquias y fundar poblaciones en esas montañas. Los nuevos pobladores se aplicarían al laboreo de las tierras y las minas, lográndose así el exterminio de los ladrones y ociosos. Además, si a la gente "parda" de la provincia se le daba gratuitamente tierra en ese valle, cada nuevo poblador se convertía en un mazamorreo y de ese modo contribuía a la Real hacienda.

Los funcionarios "ilustrados" eran consientes del papel que la administración de justicia tenía en la constitución de una sociedad más "ordenada". Por ello, Rodríguez de Zea hacia énfasis en la necesidad de que los Alcaldes pedáneos cumplieran las órdenes superiores y se construyera una cárcel en cada sitio. A la falta de carácter atribuía el desorden existente, pues al no haber seguridad, los delincuentes se fugaban y quedaban impunes los delitos.

Como se puede ver, la política se reordenamiento poblacional implementada en la provincia de Antioquia en la década de 1780, estaba dirigida a buscar el control de la población libre. Ese empeño se concretó en las fundaciones de las colonias de San Carlos del Priego, San Antonio del Infante (Don Matías), San Luis de Góngora (Yarumal), Carolina del Príncipe y San Fernando de Borbón (Amagá), ordenadas y auspiciadas entre 1787 y 1788 por el visitador Mon y Velarde. ${ }^{9}$

Este esfuerzo estuvo acompañado por la intensificación de la persecución de ciertas conductas que ponían en peligro el orden social, como la existencia de gran cantidad de relaciones extramatrimoniales, o la propensión a desconocer la calidad de las personas. Las autoridades antioqueñas compartían la idea generalizada en la Nueva Granada, de que los mestizos eran inestables, "buscarruidos", gente de vida irregular y malas costumbres, por ellos se propusieron vigilar su conducta. ${ }^{10}$ Como resultado de esta política los juicios por concubinatos e injuria aumentaron a fines del régimen colonial. De 19 juicios

\footnotetext{
${ }^{9}$ Robledo, Emilio. Ob. cit. Tomo II. Págs. 327-329.

${ }^{10}$ Jaramillo Uribe, Jaime. "Mestizaje y Diferenciación Social en el Nuevo Reino de Granada en la Segunda Mitad del Siglo XVIII". En: Ensayos sobre Historia Social Colombiana. Bogotá. Biblioteca Universitaria de Cultura Económica. 1968. Pág. 174.
} 
por concubinato seguidos en la década de 1770 se pasó a 74 en la de 1780 , 99 en la de 1790 y 100 en los diez primeros años del siglo xix. Las denuncias por agravios pasaron de 16 en la década de 1780 a 43 en la de 1790 y 25 en la de 1800 (ver cuadro $\mathrm{N}^{\circ} 55$ )

Lo llamativo de este proceso en la región antioqueña es que la población mestiza empezó a acudir a los tribunales a presentar denuncias por haber sido injuriado de palabra o "hecho". En los vecindarios el chisme y los rumores eran la base para acusar a alguien ante la justicia, de tener una "amistad ilícita", de haber cometido un robo, y aún, de ser un asesino. El ambiente se llenó de disputas entre personas que casi siempre tenían una posición económica y social semejante. Las controversias estaban acompañadas del uso de palabras denigrativas o insultantes como ladrón, pícaro, hijo de puta. Algunas designaciones sobre el origen racial se volvieron peyorativas pues hacían alusión a un nacimiento ilegítimo o sembraban la duda sobre la posición que se tenía por linaje. Zambo, mulato, "revuelto", "clase vil", "mala raza" son expresiones con las que se pone en duda la calidad de las personas.

Los mestizos y mulatos empezaron a defenderse de acusaciones contra su honor y honradez lo que indica que se apropiaron de conceptos utilizados antes sólo por la élite blanca. En este proceso jugaron un papel determinante algunos libres que habían obtenido cierta fortuna con actividades comerciales o mineras. Estos sujetos empiezan a "blanquearse" utilizando algunos mecanismos que puso a su disposición la Corona como las milicias de pardos o las "Cédulas de gracias al sacar".

Como lo ha señalado Jaramillo Uribe, la situación debió alarmar a los blancos, sobre todo a los pobres, pues vieron borrarse las líneas que los separaban de la gente libre. ${ }^{11}$ Los procesos reflejaban cierto grado de altanería de los miembros de las "castas" con las autoridades civiles y eclesiásticas, así como la propensión a desconocer pretendidas preeminencias sociales. Los mestizos y mulatos buscaban mejorar su posición social sembrando dudas sobre la honorabilidad y conducta de sus vecinos.

${ }^{11}$ Ibídem. Pág. 182. 
Los continuos pleitos entre los miembros de los vecindarios tuvieron como consecuencia su fraccionamiento. Los expedientes de los juicios por injuria y lesiones personales dejan ver la presencia de una tensión étnica y oposición de interés entre los diferentes grupos raciales y sociales. La violencia existente en la relación entre los pobladores, dificultaba la realización de acciones colectivas contra el régimen. Esto se hizo visible en el movimiento que, en 1781, adelantaron los cosecheros de tabaco de la región del río Cauca contra la organización del estanco, por cuenta de la Real Hacienda.

La división entre las castas y la población blanca era notoria a fines de la colonia. Pedro Fermín de Vargas, pensador preindependientista, consideraba que esta situación era el resultado de la política de la corona. Afirmaba que el desdén con que los criollos miraban a los indios, mulatos y negros, daba lugar a la diversidad de opiniones y de intereses que hacía que la corona pudiera gobernar tranquila. ${ }^{12}$ Para poder llevar a cabo la independencia de España proponía que los diferentes grupos se unieran y olvidaran los resentimientos. En el mismo orden de ideas el doctor José Manuel Retrepo, quien había ejercido la abogacía en la provincia de Antioquia, señalaba como factores contrarios al movimiento de independencia

La despoblación de estos países y su extensión, la división de los colores en castas y su mutua oposición. ${ }^{13}$

En el caso particular de Antioquia la población libre se declaró partidaria de la Independencia, pero su participación en las decisiones tomadas, entre 1810 y 1815 parece haber sido escasa. Las discusiones sobre la forma como se iba a organizar el nuevo Estado no parecen haberla afectado mucho, pues en los juicios no se reflejan un movimiento al respecto. Lo cierto es que las dos Constituciones elaboradas en el periodo, negaron el uso de derechos políticos a gran parte de esta población que no cumplía con los requisitos necesarios para ser ciudadano.

12 Vargas, Pedro Fermín. Pensamientos Políticos. Bogotá. Nueva Biblioteca Colombiana de Cultura. 1986. Págs. 161, 178.

${ }^{13}$ Restrepo, José Manuel. Historia de la Revolución de Colombia. Medellín. Editorial Bedout. 1969. Tomo I. Pág. 45. 
Es importante estudiar la política seguida por los gobiernos republicanos con los diferentes grupos étnicos, para saber cuáles fueron los aspectos que continuaron y cuáles cambiaron. Sin embargo, se puede asegurar que el desdén con que muchos autores del siglo XIX miran al pueblo y su pretensión de "ser soberano", es indudablemente un legado del desprecio o temor que había existido contra las castas.

\section{La esclavitud}

La tradición historiográfica antioqueña ha sostenido que el trato dado en esta región a los esclavos fue relativamente benévolo. Esto se explicaría porque la esclavitud en la región se caracterizaba por la inexistencia de grandes cuadrillas, la dedicación de la mayor parte de los esclavos al servicio doméstico, la ausencia de castigos crueles y el reconocimiento del derecho a tener "peculio propio", que éstos destinaban a comprar su manumisión o la de algún miembro de su familia. ${ }^{14}$

Esta imagen idílica de las relaciones esclavistas en Antioquia, se resquebraja al analizar la información contenida en los juicios por lesiones personales y homicidio seguidos en la jurisdicción de la ciudad de Antioquia. De acuerdo con estos datos el $11.6 \%$ de las personas agredidas físicamente y el $18.1 \%$ de las víctimas de homicidio eran esclavos. En el caso de los agresores, pertenecían a este grupo el $2.9 \%$ de los involucrados en heridas o golpes y el $24.2 \%$ de los homicidas (ver cuadros $\mathrm{N}^{\circ} 15,16,29$ y 30 ).

El análisis de los datos sobre homicidio evidencia la existencia de una crisis en las relaciones amo-esclavos en el periodo 1740-1760. En ese momento en la jurisdicción de la ciudad de Antioquia se dio una oleada de asesinatos que involucraron a esclavos, lo que dio origen a temores entre los propietarios y las autoridades. Los motivos que los esclavos dijeron haber tenido para matar a sus amos o a compañeros fueron el rigor del régimen de trabajo, el que el amo no les daba de comer o vestir y los castigos crueles.

\footnotetext{
${ }^{14}$ Ospina Rodríguez, Mariano. "El Doctor José Félix de Restrepo y su Epoca”. En: Escritos sobre Economía y Política. Bogotá. Biblioteca Universitaria de Cultura Colombiana. 1969. Págs. 1031-45.
} 
Algunos datos sobre la evolución de población esclava en la zona durante la primera mitad del siglo xviII, permiten ver el contexto en que se dio este proceso. A fines del siglo xvi y principios del siglo xviI la crisis de la minería en las tierras bajas, obligó a los mineros vecinos de la ciudad de Antioquia a trasladar parte de sus cuadrillas de esclavos a propiedades agrarias. En ese momento existían cuadrillas grandes como la de don Felipe de Herrera, quien tenía 83 esclavos en 1704 o la de don Juan García hijo, que era propietario de 60 esclavos en $1724 .{ }^{15}$ Ellos, o sus herederos, empezaron a tener dificultades para sufragar los altos costos que tenía el mantenimiento de esta mano de obra, debido a que estaban fuertemente endeudados. Para solucionar la situación procedieron a pagar deudas con esclavos, a venderlos o a manumitirlos. Así, entre 1706 y 1730 en la ciudad de Antioquia se pagaron acreencias con 137 esclavos, se vendieron 103 y se manumitieron 93. ${ }^{16}$

De acuerdo con los datos de los libros de fundición la crisis minera empezó a superarse a partir de 1750. Sin embargo, en el montaje de las minas que se van a empezar a explotar en las tierras altas del valle de los Osos van a participar pocos vecinos de la ciudad de Antioquia. En un informe de 1755 sobre los minerales de Riochico y Riogrande, localizados en esa zona, se decía que allí trabajaban 405 esclavos pertenecientes en gran parte a vecinos de la jurisdicción de Medellín. ${ }^{17}$

La información contenida en testamentos y causas mortuorias, revela que la mayor parte de los esclavos existentes, a mediados del siglo, en la región de la ciudad de Antioquia, estaban dedicados a la agricultura. Ninguna de las cuadrillas tenía más de 50 esclavos y un gran porcentaje de sus miembros eran menores de edad. La existencia de tasas de natalidad

${ }^{15}$ Suárez, Ivonne. Oro y Sociedad Colonial en Antioquia 1575-1700. Monografía de Grado. Medellín. Departamento de Historia. Universidad de Antioquia. 1983. Cuadro $\mathrm{N}^{\circ} 7$.

${ }^{16}$ La mayor parte de los esclavos vendidos eran criollos. Durante este periodo, que coincide con la vigencia del asiento francés (1707-1713) y el asiento inglés (1713-1736), sólo se vendieron 21 esclavos bozales en la ciudad de Antioquia.

Patiño Millán Beatriz. Riqueza, Pobreza y Diferenciación Social en la Antioquia del Siglo XVIII. Medellín. Centro de Investigaciones de la Facultad de ciencias Humanas. Universidad de Antioquia. 1985. Cuadros $\mathrm{N}^{\circ} 1,2$ y 6.

${ }^{17}$ Patiño Millán, Beatriz. Ob. cit. Pág. 419. 
positivas reflejaría que las condiciones de trabajo en las estancias y hatos eran relativamente benignas. ${ }^{18}$

Esta tesis queda cuestionada al ver la información contenida en los expedientes criminales. En ellos se evidencia que buena parte de la manutención de los esclavos corría por cuenta de ellos mismos. La situación debía ser menos favorable en el caso de los niños y ancianos, en la medida en que no eran económicamente productivos.

En estas condiciones, algunos esclavos utilizaron el homicidio para protestar por las condiciones de trabajo a que estaban sometidos. Como respuesta a una exigencia que consideran desmedida o un llamado de atención, deciden matar al amo o a un compañero. Los esclavos al asesinar a su dueño creían estar acabando con la explotación o el maltrato. Era una acción individual o de grupo, que no conllevaba un cuestionamiento de fondo de las relaciones esclavistas. La mayor parte de los comprometidos en estos crímenes fueron sentenciados a muerte, pagando con su vida el haber intentado transformar el sistema.

Las formas como los esclavos intentaron oponerse a la esclavitud en las postrimerías del periodo colonial fueron distintas. A finales de 1781 los esclavos de la jurisdicción de la ciudad de Antioquia estaban organizando un levantamiento para pedir al Cabildo.

La Cédula de Su Majestad en que manda que los esclavos sean libres, pagando tributo, como los indios. ${ }^{19}$

En este movimiento, que debía llevarse a cabo el $1^{\circ}$. De enero de 1782 cuando los miembros del Cabildo estuvieran haciendo las elecciones de oficios concejiles, estaban comprometidos los esclavos de algunos grandes propietarios de tierra como los presbíteros de don Antonio de Lora, don Juan Salvador de Lastra y don Francisco Manuel Díez del Mazo. Según Pelayo, esclavo del padre Lora, los esclavos intentaban proclamar su libertad para salir

\footnotetext{
${ }^{18}$ Ibídem. Págs. 68-69.

${ }^{19}$ A. H. A. Comuneros. Tomo 332. Doc. N 6323. Fols. 24r.-31r.
} 
del dominio de sus amos. Los participantes en la insurrección debían llevar armas, pues si los señores del Cabildo se negaban a entregarle la Cédula

\begin{abstract}
Defenderse con dichas armas y matar a los que se opusieran a ella y quisieran prenderlos, para cuyo efecto tenían dispuesto fortificarse en un paraje oportuno o bien, en el río de Cauca o de la Otra Banda, hacia la Miranda o Tablazo, y allí pagar el tributo a su Majestad, según tenían entendido decía la Cédula referida, y en caso de no conseguirlo así, trabajarían para sus amos en calidad de libres, pagándoles dos tomines por día
\end{abstract}

La posibilidad de realización de este movimiento alarmó a los propietarios y a las autoridades debido a que en la jurisdicción de la ciudad de Antioquia los esclavos eran el 16,3\% de la población (ver cuadro $\mathrm{N}^{\circ} 65$ ). En 1788 había en esta zona 3.164 esclavos, lo que significaba que allí estaba concentrada la tercera parte de los esclavos existentes en la provincia. De acuerdo con una lisa presentada por el escribano, 21 propietarios de la ciudad de Antioquia, Rionegro, Marinilla y Medellín contribuyeron con 198 pesos al pago de los gastos que se ofrecieron en la contención de la conspiración. ${ }^{20}$

Después de esta fecha, tal vez previendo la posibilidad de una insurrección, algunos de los propietarios de cuadrillas procedieron a vender esclavos. Así, entre 1785 y 1799 se comercializaron 326 esclavos. ${ }^{21}$ Una parte de ellos fue adquirida por comerciantes para llevarlos a vender a otros lugares de la provincia o en el Chocó, Mompox y Santa Marta. Otra parte pasó a manos de medianos propietarios mestizos y mulatos, lo que dio lugar a que se ampliara el número de dueños de esclavos en la región.

Las manumisiones también fueron frecuentes en esta ápoca, como lo demuestra el que de 1785 a 1799 se hubiera otorgado carta de libertad a 172 esclavos. ${ }^{22}$ De estas manumisiones 74 fueron pagadas por los esclavos, 33 otorgadas gratuitamente por los amos sin contraprestación alguna y 65 fueron dadas gratuitamente, pero el esclavo debía cumplir con ciertas obligaciones.

\footnotetext{
${ }^{20}$ A. H. A. Comuneros. Tomo 332. Doc. $\mathrm{N}^{\circ}$ 6323. Fols. 116v.-117r.

${ }^{21}$ Patiño Millán, Beatriz. Ob. cit. Cuadro $\mathrm{N}^{\circ} .7$.

${ }_{22}$ Ibídem. Cuadro $\mathrm{N}^{\circ} 8$.
} 
Como consecuencia de este doble proceso, a comienzos del siglo xIx, habían desaparecido las cuadrillas grandes de esclavos. Según el censo de la ciudad de Antioquia de 1806, 74 propietarios blancos y 148 propietarios mestizos y mulatos tenían esclavos. De todos ellos, sólo un propietario poseía más de 25 esclavos. ${ }^{23}$

Al intensificarse las ventas y las manumisiones los esclavos comenzaron a presentarse en los juzgados a pedir que no se vendiera algún miembro de su familia, que se les permitiera cambiar de sueño o a solicitar un avalúo para comprar su libertad. Estas peticiones solían estar acompañadas de quejas por maltratos o acusaciones de que no se les daba alimentación o vestuario. Algunas denuncias parecen haber sido hechas para obtener que sus demandas fueran satisfechas. Los testimonios presentados reflejan que este tipo de queja podía ser puesta por sugerencia de algún vecino enemigo del amo o que quería obtener los servicios del esclavo.

El Oidor visitador Mon y Velarde, al señalar, en 1786, que había recibido continuas reclamaciones por parte de esclavos, decía que éstas se originaban

Ya por el inhumano y bárbaro tratamiento que reciben de sus amos, quienes considerándose despóticos en su vida y persona, parecen olvidarse de la caridad con que deben tratar sus prójimos, y ya por la escasez de la ración con que les contribuye, tolerándose por esta causa el trabajo en días festivo, con punible abandono del pasto espiritual, de que absolutamente descuidan. ${ }^{24}$

Para solucionar esta situación Mon y Velarde procedió a obtener información en diferentes lugares de la provincia sobre los horarios en que debían trabajar los esclavos en minas y estancias, la ración que era necesario darles, la cantidad y calidad de ropa que debía suministrárseles y los castigos que podía imponer el dueño a los esclavos. Con base en ella, intentó reglamentar el trato que se les debía dar.

\footnotetext{
${ }^{23}$ A. H. A. Censos. Tomo 333. Doc. $\mathrm{N}^{\circ}$ 6360. Fols. 503-513.

${ }^{24}$ Robledo, Emilio. Ob. cit. Tomo I. Pág. 71.
} 
En las tres últimas décadas del siglo xviI las acciones colectivas e individuales de los esclavos se dirigieron a la obtención de su libertad. Muchos compraron la suya, la de su mujer o la de sus hijos, buscando que su descendencia fuera libre. Inundaron los tribunales con peticiones en que expresaban su deseo de tener libertad para moverse, contratar, tener propiedades y poder constituir una familia. Este proceso coincide con la expedición de la Real Cédula de mayo de 1789 en la que se promulgaron nuevas normas para el trato a los esclavos. Este reglamento parece haberles dado las herramientas legales para sustentar sus solicitudes contra el maltrato y otros abusos de los amos. En la práctica, esto llevó a que se cuestionaran elementos de la relación esclavista.

Al empezar el siglo xix las manumisiones aumentaron, dando lugar a la disminución gradual del número de esclavos. Esto se hace evidente al mirar los datos de los censos, pues en 1808 había 4.160 esclavos en la jurisdicción de la ciudad de Antioquia, mientras que en 1820, sin contar la zona del Valle de los Osos, se contaron 1.192 (ver cuadros $\mathrm{N}^{\circ} 67$ y 68).

En este contexto algunos miembros de la élite intelectual antioqueña empiezan a cuestionar las relaciones esclavistas. Argumentaban que la esclavitud daba lugar a que los negros fueron homicidas, ladrones, embusteros, perezosos. Además, consideraban que utilizar trabajadores libres era ventajoso desde el punto de vista económico. A este respecto, don José Félix de Restrepo, abogado antioqueño que sustentó la ley de manumisión de esclavos en el congreso de Cúcuta (182), afirmaba:

La libertad de los esclavos es el medio infalible, el único medio por donde pueden florecer la agricultura y las minas. Nada es más propio del hombre que emplear mayores esfuerzos en aquel ejercicio en donde encuentra mayor utilidad. El esclavo no tiene interés en afanarse por un trabajo cuyas ventajas no le tocan: Sólo hace aquellos a que la necesidad le obliga; que la cosecha sea abundante, o escasa, le es indiferente; su triste ración no se ha de aumentar, y él es, con toda propiedad, el burro de la fábula. Por el contrario, el hombre libre que trabaja para sí y su descendencia, que puede 
disponer del fruto de sus tareas, duplica los esfuerzos, y sus cosechas son más abundantes. ${ }^{25}$

En la Independencia, la legislatura de la provincia de Antioquia fue la primera de la Nueva Granada en aprobar una ley de libertad de partos para los esclavos. El dictador Juan de Corral, al solicitar en 1814 que se sancionara, argumentaba que era necesaria para mantener la tranquilidad interior de la provincia. Consideraba que la existencia del Estado podía verse en peligro si no se hacían extensivas a los esclavos las leyes de justicia:

\begin{abstract}
Nada es más temerario ni más inconsecuente que la proclamación de nuestros derechos, si los principios de libertad, de seguridad, de igualdad y de propiedad no han de comprender a unos hombres como nosotros, marcados de los mismos privilegios por el Soberano legislador del Universo, y cien veces más oprimidos que lo que estábamos nosotros por la dominación de los españoles. Que hombre por bárbaro que sea, podría condenar en el silencio de sus pasiones los amagos que hicieron nuestros infelices esclavos para lanzar el yugo de la servidumbre. ${ }^{26}$
\end{abstract}

La intención del gobierno patriota de Antioquia era crear los medios para una paulatina extinción de la esclavitud. Se comenzaba por liberar a los que nacían, buscando que los propietarios no recibieran perjuicios muy grandes. Los esclavos nacidos después de la medida permanecerían sujetos a los amos hasta los 16 años, tiempo suficiente para que estos quedaran recompensados de los gastos que habían hecho en su crianza. ${ }^{27}$

Desde el punto de vista político, buscaban evitar los desastres que acarrearía una sublevación de esclavos. Al tomar estas medidas tenían presentes las consecuencias que había tenido la insurrección de esclavos en Haití.

\footnotetext{
${ }^{25}$ Restrepo, José Félix de. Obras Completas. Medellín. Ediciones Académicas. Rafael Montoya y Montoya. 1961. Págs. 315, 324-325.

${ }^{26}$ Tisnés Jiménez, Roberto M. Don Juan del Corral. Libertador de los Esclavos. Bogotá. Biblioteca Banco Popular. 1980. Págs. 269.

${ }^{27}$ Restrepo, José Félix de. Ob. cit. Págs. 338-339.
} 
El que la élite antioqueña estuviera dispuesta a manumitir los esclavos fue fruto del temor que éstos le inspiraban y de la experiencia sobre las bondades del trabajo libre. No era la benevolencia la que los llevaba a apoyar estas medidas, sino el deseo de evitar conflictos que podían amenazar su seguridad. Además, la medida no ponía en peligro la economía de la región, debido a que la minería y la agricultura se basaban en la utilización de la mano de obra de pequeños y medianos propietarios libres.

A lo largo del siglo xvin las relaciones esclavistas parecen haber estado en crisis en la provincia de Antioquia. A mediados del siglo los esclavos protestaron contra sus condiciones de vida a través de los homicidios, mientras que a finales del periodo colonial se presentaron en los juzgados a denunciar agresiones físicas. Es importante investigar si estas conductas se dieron en otros lugares de la Nueva Granada. Ello nos permitirá conocer si las relaciones esclavistas crean las condiciones para que se cometan ciertos delitos. También es importante estudiar la conducta seguida por los propietarios y las autoridades, para saber si sus respuestas fueron distintas a las de los antioqueños.

\section{La mujer}

La historiografía colombiana ha investigado muy poco el papel que la mujer ha tenido en los procesos económicos, sociales y políticos del país. Para la región antioqueña en el periodo colonial existen algunos estudios que se refieren a mujeres de la élite como doña Ana de Castrillón o doña Javiera Londoño, pero no hay trabajos sobre la vida de las mueres de las clases populares.

Esta carencia fue una limitante para nuestro estudio, debido a que el análisis de los juicios por delitos contra la persona muestra que las mujeres estuvieron involucradas en una gran cantidad de juicios por agresión física y asesinato. A finales del siglo xviII y principios del siglo xix, parece haber un desajuste en el papel de la mujer dentro de la estructura familiar, que lleva a que ésta sea la víctima en el 19,7\% de las causas diligenciadas por injuria, el $29,6 \%$ de las tramitadas por heridas o golpes y el 34,1\% de las seguidas por homicidio (ver cuadros $\mathrm{N}^{\circ} 1,14$ y 28). Pero al comparar con los datos existentes para otros sitios de Hispanoamérica, lo más llamativo es la gran cantidad de mujeres a quienes se proceso como agresoras. En el caso de las injurias de 
palabras, el 16,6\% de los implicados eran mujeres, en el de la "injuria de hecho" el porcentaje era del 8,7\% y en el homicidio era del 31,4\%.

Algunos observadores de la Antioquia colonial señalaron la relación existente entre el comportamiento de las mujeres y ciertas conductas delictivas. El visitador Mon y Velarde, en documentos fechados en 1787 y 1788, decía que en la región eran frecuentes los amancebamientos, el maltrato de los maridos a las mujeres, el infanticidio y los abortos. ${ }^{28}$ En su concepto, esto se debía a la propensión que hacia el libertinaje tenía la gente libre que se veía a sí misma.

Como exentas de toda servidumbre y con facultad de vivir a su antojo sin ser útiles a la república, y muy perjudiciales al servicio de ambas majestades. ${ }^{29}$

Para cambiar estos patrones de conducta propuso al Cabildo de la ciudad de Antioquia, que se concertara en casas de "recogimiento y buena opinión", tanto a las muchachas huérfanas, como a aquellas que, teniendo padres, no estuvieran recibiendo la educación correspondiente y se comportaran licenciosamente. Las personas que se hicieran cargo de ellas debían instruirlas en la doctrina cristiana, enseñarles todos los ministerios propios de su sexo y mantenerlas con honestidad y recato.

Igualmente sugería que se estableciera una escuela de primeras letras para niñas, pues por carecer de educación se criaban sin vergüenza, ignorando la doctrina cristiana, y cuando llegaban a adultas, no podían instruir a sus hijos ni conocían las obligaciones que tenían. Además, se debía crear una escuela en la cual se les enseñara los "oficios mujeriles" de hilar, coser, hacer medias, para que supieran alguna industria y tuvieran ocupación. Las dos escuelas debían estar dirigidas por maestras de honradas costumbres, buena crianza y notoria buena conducta.

Para impedir los infanticidios y abortos proponía la creación de una casa de misericordia en la cual se recogerían los niños expósitos y aquellos que vivieran de la caridad cristiana.

\footnotetext{
${ }^{28}$ Robledo, Emilio. Ob. cit. Tomo II. Pág. 184.

${ }^{29}$ Ibídem. Págs. 112-114.
} 
Como puede verse, sus propuestas iban encaminadas a transformar la conducta de las mujeres de las clases populares. A través de los conciertos y las escuelas, aquellas recibirían una educación cristiana que debía servirles de guía de conducta. La instrucción religiosa y la enseñanza de oficios prácticos permitirían a las mujeres cambiar las costumbres familiares y, por ende, se modificarían los patrones de comportamiento de la gente perteneciente a las castas.

Buena parte de los investigadores que han hecho trabajos sobre Antioquia afirman que las medidas adoptadas por este funcionario cambiaron las conductas de los habitantes de la región. Doña Virginia Gutiérrez de Pineda, en su estudio clásico sobre la familia en Colombia, sostiene que el estímulo de Mon y Velarde habría llevado a que la sociedad antioqueña pasara de tener una escasa cultura religiosa, desajuste familiar, dominio de las relaciones de hecho en la estructura familiar y frecuente y fácil prostitución del ego femenino, a ser una sociedad agrícola de costumbres puritanas, con una religión al servicio de su actividad económica y reguladora de su moral. ${ }^{30}$

Sin embargo, el análisis de los juicios criminales evidencia que el cambio en los patrones de conducta familiar no fue inmediato y fácil. Contra lo que se ha supuesto, después de la visita de este funcionario aumentaron los juicios seguidos por infanticidio y por agresión física entre cónyuges. Los procesos correspondientes a la última década del siglo xviı y las dos primeras décadas del siglo xix, evidencian la existencia de una crisis en las relaciones familiares. Esta parece tener relación con la persecución por parte de las autoridades de las relaciones extramatrimoniales. Se creó un ambiente de resquemor y suspicacia en el cual eran frecuentes los celos y rencores. Como resultado de ello se presentaban peleas entre cónyuges las cuales daban lugar a maltratos y, aún, a asesinatos. La situación también originaban los infanticidios, pues buena parte de ellos se cometían para ocultar relaciones "ilícitas". Los chismes y comentarios sobre la conducta sexual fueron la causa por la cual muchas mujeres acudieron a los juzgados a presentar denuncias por injuria.

${ }^{30}$ Gutiérrez de Pineda, Virginia. Familia y Cultura en Colombia. Bogotá. Biblioteca Básica Colombiana. 1975. Págs. 374-375. 
Para el vecindario y las personas involucradas, estos hechos tenían origen en el comportamiento de las mujeres. Se las veía como culpables de los problemas, pues éstos eran propiciados por su infidelidad y mal cumplimiento de sus obligaciones. La opinión que de las mujeres de las castas se tenía, era negativa, aún en el caso de ser víctima. Se las consideraba como mentirosas, ignorantes, débiles de carácter y "enemigas de los hombres". Los defensores trataban de salvarlas del castigo mostrando que actuaban sin juicio y sin razón, es decir, que eran incapaces mentales.

Las autoridades ilustradas trataron de cambiar algunas de estas conductas, especialmente la creencia de que era lícito que el esposo propinara castigos fuertes a su mujer. Los Alcaldes, asesores jurídicos y fiscales señalaron en forma reiterada que la esposa era una compañera y no una esclava. Consideraban que los golpes y maltratos eran una ofensa a la dignidad del sacramento y un escándalo para la sociedad. Trataron de modificar la creencia generalizada entre los hombres de que en caso de infidelidad era lícito matar a la esposa.

Los gobernadores borbónicos no parecen hacer tenido éxito en su empeño de imponer un modelo de familia cristiana patriarcal en donde imperara la paz y la armonía. A finales de la época colonial las disputas familiares aumentaron en lugar de disminuir. Los juicios seguidos por lesiones personales y homicidio indican que el hogar era el sitio donde los conflictos se podían tornar más violentos y dramáticos. La dificultad para controlar estos conflictos muestra que era muy arduo transformar patrones culturales tan arraigados.

Es necesario estudiar los juicios criminales existentes para la segunda mitad del siglo xix. Esta es la única forma de saber si realmente los patrones de conducta familiar cambiaron y si hubo transformaciones en la opinión que se tenía sobre el comportamiento de las mujeres de las clases populares. Muchas creencias sobre el papel de la familia en la región antioqueña, pueden cambiar al analizar los conflictos que dentro de ella se han presentado. Investigarlo permitirá conocer mejor la cultura de la región y quizás, ayudará a explicar algunos de los factores de la violencia que hoy en día se presenta. 


\section{Bibliografía}

Archivo Histórico de Antioquia. (A.H.A.). Fondos Capitulares. Censos, Comuneros, Criminal, Eclesiásticos, Esclavos, Indios, Montuorias, Visitas.

Archivo Histórico Nacional. (A.H.N.). Fondos Caciques e Indios, Juicios Criminales, Negros y Esclavos de Antioquia, Visitas de Antioquia.

Archivo Notarial de Antioquia. (A.N.A.). Fondo Protocolos Notariales.

Aguado Bleye, Pedro. Manual de Historia de España. Madrid. Espasa-Calpe.

S.A. 1971. Tomo I, II y III.

Aguilera, Miguel La Legislación y el Derecho en Colombia. Historia Extensa de Colombia. Vol. XXIV. Bogotá. 1965.

Alvarez Posadilla, Juan. Práctica Criminal por Principios o Modo y Forma de Instruir los Procesos Criminales de las Causas de Oficio de Justicia. Valladolid. Imprenta de la Viuda e Hijos de Santander. 1802.

Arango Mejía, Gabriel. Genealogías de Antioquia y Caldas. Medellín. Imprenta Departamental. 1942.

Aufdertheide, Patricia. "Upright Citizens in Criminal Records: Investigations in Cachoeira and Geremoabo, Brazil, 1780-1836." The Americas. Vol. XXXVIII. Number 2. October 1981.

Barrow, R. H. Los romanos. México. Fondo de Cultura Económica. 1970.

Beccaria, Cesare. De los Delitos y de las Penas. Bogotá. Editorial Temis. S.A. 1987.

Bée, Michel. "Le Spectacle de L'exécution dans la France D’ancien Régime”. Annales, Economies, Sociétés. Civililisations. 38. Année. $\mathrm{N}^{\circ} 4$. Juillet-Aout. 1983.

Benitez, José Antonio. Carnero de Medellín. Ediciones Autores Antioqueños. 1988.

Bowser, Frederick P. El Esclavo Africano en el Perú Colonial (1524-1650). México. Siglo XXI Editores S.A. 1977.

Burkholder Mark A. y D. S. Chandler. De la Impotencia a la Autoridad. La corona Española y las Audiencias en América. 1687-1808. México. Fondo de Cultura Económica. 1984. 
Cárdenas Acosta, Pablo E. El Movimiento Comunal de 1781 en el Nuevo Reino de Granada. Reivindicaciones Históricas. Bogotá. Ed. Kelley. 1960. Cataño, Gonzalo. La Sociología en Colombia. Bogotá. Plaza y Janés. 1986. Cohen, David y Eric A. Johnson. "French Criminality: Urban-Rural Differences in the Nineteenth Century". Journal of Interdisciplinary History. XII. \# 3. Winter. 1982.

Colmenares, Germán. Historia Económica y Social de Colombia. 1537-1819. Cali. Universidad del Valle. 1972.

Colmenares, Germán. Cali: Terratenientes, Mineros y Comerciantes. Siglo XVIII. Cali. Universidad del Valle. 1976.

Colmenares, Germán. "La Aplicación de la Ley Penal a fines de la Colonia y comienzos de la República". Cali. Versión Mecanografiada sin publicar. s.f. Colmenares, Germán. Relaciones e Informes de los Gobernantes de la Nueva Granada. Bogotá. Biblioteca Banco Popular. 1989.

Colmenares, Germán. "La Ley y el Orden Social: Fundamento Profano y Fundamento Divino". Boletín Cultural y Bibliográfico. Vol. 27. N 22. 1990.

Cortés Santos, Rodulfo. El Régimen de "Las Gracias al Sacar" en Venezuela durante el Período Hispano. Tomo II. Fuentes para la historia colonial de Venezuela. Caracas. Biblioteca de la Academia Nacional de la Historia. 1978.

Delval, Juan. "Beccaria en España”. En: Beccaria, Cesare. De los Delitos y de las Penas. Madrid. Alianza Editorial. 1982.

Diccionario Enciclopédico Hispanoamericano de Literatura, Ciencias, Artes, etc. Barcelona. Montaner y Simón. Nueva York. W.M. Jackson Inc.

Diéz Echarri, Emiliano y Roca Franquesa, José María. Historia de la Literatura Española e Iberoamericana. Madrid. Aguilar. 1960.

Enciclopedia Universal Ilustrada Europeo-Americana. Espasa-Calpe. S.A. Madrid. 1958.

Escriche, Joaquín. Diccionario Razonado de Legislación y Jurisprudencia. Paris. México. Librería de la Viuda de Ch. Bouret. 1911.

Flores Galindo, Alberto. "Los Rostros de la Plebe". Revista Andina. Cuzco Andina. Cuzco. Perú. Tomo I. N 2. 1983. 
Gabriel de Domínguez, Zoila. "Delito y Sociedad en el Nuevo Reino de Granada. Período Virreinal (1740-1810)". Universitas Humanística. No 8 y 9. Años 1974 y 1975.

García, Antonio José D. D. Kalendario Manual y Guía de Forasteros en Santa fe de Bogotá Capital del Nuevo Reino de Granada para el año de 1806. Edición Facsimilar. Bogotá. Banco de la República. Departamento Editorial. 1988.

Ginzburg, Carlo. El Queso y los Gusanos. El Cosmos según un Molinero del siglo XVI. Barcelona. Muchnek Editores. 1986.

Giraud, François. "La Reacción Social ante la violación: del Discurso a la Práctica.

Nueva España. Siglo XVIII". En: El Placer de Pecar y el Afán de Normar. México. Joaquín Mortiz. Instituto Nacional de Antropología e Historia. 1987.

Gutiérrez de Pineda, Virginia. Familia y Cultura en Colombia. Bogotá. Biblioteca Básica Colombiana. 1975.

Hay, Douglas. "Property, Authority and The criminal Law". En: Albion's Fatal Tree. Crime and Society in Eighteenth-Century England. New York. Pantheon Books. 1975.

Hevia Bolaños, Juan de. Curia Filipica. Madrid. Imprenta de Pedro Marín. 1776.

Jaramillo Uribe, Jaime. "Esclavos y Señores en la Sociedad Colombiana del siglo XVIII". En: Ensayos sobre Historia Social Colombiana. Bogotá. Biblioteca Universitaria de Cultura Colombiana. 1968.

Jaramillo Uribe, Jaime. "Mestizaje y Diferenciación Social en el Nuevo Reino de Granada en la Segunda Mitad del Siglo XVIII". En: Ensayos sobre Historia Social Colombiana. Bogotá. Biblioteca Universitaria de Cultura Económica. 1968.

Jaramillo Uribe, Jaime. "La Administración Colonial". En: Manual de Historia de Colombia. Bogotá. Procultura S.A. Instituto Colombiano de Cultura. 1982.

Johnson, Lyman L. Editor. The Problem of Order in Changing Societies. Essays on Crime and Policing in Argentina and Uruguay, 1750-1940. Albuquerque. University of New Mexico Press. 1990. 
Lardizábal y Uribe, Manuel de. Discurso sobre las Penas. México. Editorial Porrúa S. A. 1982.

Lefebre, Georges. El nacimiento de la Historiografía Moderna. Barcelona. Ediciones Martínez Roca, S. A. 1974.

Levy, René y Philippe Robert. "Le Sociologue et L'Histoire Pénale”. Annales.

Economies. Sociétés. Civilisations. 39². Année. $\mathrm{N}^{\circ} 2$. Mars-Avril 1984.

Lewin, Linda. "The Oligarchical Limitation of Social Banditry in Brazil: The Case of the "Good" Thief Antonio Silvino". Past and Present. № 82. February 1979.

Luna Rivillas, Gloria. Documentos para el Estudio de la Criminalidad Sexual en la Provincia y Gobernación de Antioquia. (Siglos XVII-XVIII). Crímenes, Escándalos y Pecados Públicos o del poco temor y respeto a las dos Majestades. Tesis de grado. Facultad de Ciencias Humanas. Universidad Nacional-Sede Medellín. 1988.

Lynch, John. Las Revoluciones Hispanoamericanas 1808-1826. Barcelona. Editorial Ariel S. A. 1983.

Martínez Zulaica, Antonio. La Medicina del Siglo XVIII en el Nuevo Reino de

Granada. Tunja. Ediciones La Rana y el Águila. 1972-1973.

Martínez, Miguel. La Criminalidad en Antioquia. Tesis para doctorado. Medellín. 1985.

Marzhal, Peter. Town in the Empire Gobernment Politics and Society in Seventeenth Century Popayán. Texas. University of Texas. 1978. Melo, Jorge Orlando. "La Minería Antioqueña en el Siglo XVIII: Interpretaciones y Perspectivas”. Versión mecanográfica. Medellín. FAES. 1984.

Menéndez Pidal, Ramón. (Director). Historia de España. Madrid. Espasa-Calpe. S.A. 1940. Tomo III. España Visigoda. (414-711 d. J.C.).

Mömer, Magnus. "Estratificación Social Hispanoamericana durante el Período Colonial”. Versión preliminar mecanográfica. Estocolmo. 1980.

Mömer, Magnus. La Reorganización Imperial en Hispanoamérica 1760-1810. Tunja. Ediciones Nuestra América. 1979.

Ortega, Sergio. Editor. De la Santidad a la Perversión. O de porqué no se cumplía la ley de Dios en la sociedad novohispana. México. Grijalbo. 1985. 
Ortega Noriega, Sergio. "El discurso teológico de Santo Tomás de Aquino sobre el Matrimonio, La Familia y los Comportamientos Sexuales". En: El Placer de Pecar y el Afán de Normar. México. Joaquín Mortiz. Instituto Nacional de Antropología e Historia. 1987.

Ospina Rodríguez, Mariano. "El Doctor José Félix de Restrepo y su Época”. En:

Escritos sobre Economía y Política. Bogotá. Biblioteca Universitaria de Cultura Colombiana. 1969.

Patiño Millán, Beatriz A. "La Provincia en el Siglo XVIII". En: Historia de Antioquia. Medellín. Suramericana de Seguros. 1988.

Patiño Millán Beatriz. Riqueza, Pobreza y Diferenciación Social en la Antioquia del Siglo XVIII. Versión Mecanográfica. Medellín. Centro de Investigaciones de la Facultad de ciencias Humanas. Universidad de Antioquia. 1985.

Phelan, John Leddy. El Pueblo y el Rey. La Revolución Comunera en Colombia. 1781. Bogotá. Carlos Valencia Editores. 1980.

Pombo, Manuel Antonio y Guerra, José Joaquín. Constituciones de Colombia. Bogotá. Biblioteca Banco Popular. 1986.

Reinhardt, Steven G. "Crime and Royal Justice in Ancien Régime France : Modes of Analysis". Journal of Interdisciplinary History. XIII 3. Winter 1983. Restrepo Sáenz, José María. Gobernadores de Antioquia. Tomo ı. 1547-1819.

Bogotá. Imprenta Nacional. 1931. Tomo II. 1819-1873. Bogotá. Editorial Lumen Christi. 1970.

Restrepo, José Félix de. Obras Completas. Medellín. Ediciones Académicas. Rafael Montoya y Montoya. Medellín. Editorial Bedout. 1961.

Restrepo, José Manuel. Historia de la Revolución de la República de Colombia. Medellín. Bedout. 1969.

Robinson, David J. "Estudio Preliminar". En: Silvestre, Francisco. Relación de la Provincia de Antioquia.

Robledo, Emilio. Bosquejo Biográfico del Oidor Juan Antonio Mon y Velarde. Visitador de Antioquia 1785-1788. Bogotá. Publicaciones del Banco de la República. 1954.

Rodríguez, Pablo. "Promesas, Seducción y Matrimonio en Antioquia Colonial", “El Amancebamiento en Medellín Colonial”. 1990-1991. s. p. 19901991. 
Sala, Juan de. Ilustración del Derecho Español. Valencia, Librería de Mallen y Sobrinos. 1844.

Sánchez G., Gonzalo. "Los Estudios sobre la Violencia: Balance y Perspectivas".

En: Pasado y Presente de la Violencia en Colombia. Bogotá. Fondo Editorial Cerec. 1986.

Silva Olarte, Renán. Escolares y Catedráticos en la Sociedad Colonial. Bogotá. Universidad Pedagógica Nacional. Centro de Investigaciones. CIUP. 1985.

Silva Olarte, Renán. Prensa y Revolución a finales del Siglo xviII. Contribución a un Análisis de la Formación de la Ideología de Independencia Nacional. Bogotá. Colección Bibliográfica Banco de la República. 1988.

Silvestre, Francisco. Descripción del Reino de Santa fe de Bogotá. Bogotá. Biblioteca Popular de Cultura Colombiana. 1950.

Silvestre, Francisco. Relación de la Provincia de Antioquia. Medellín. Ediciones Especiales. Vol. 4. Secretaría de Educación y Cultura de Antioquia. 1988.

Simón, Fray Pedro. Noticias Historiales de las Conquistas de Tierra Firme en las Indias Occidentales. Bogotá. Biblioteca del Banco Popular. 1981. Socolow, Susan Migden. "Women and Crime. Buenos Aires. 1757-1797". Journal of Latin American Studies. Cambridge University Press. 12, I. 1980.

Stone, Lawrence. "Interpersonal Violence in English Society. 1300-1980”. En: Past and Present. Oxford. $\mathrm{N}^{\circ}$ 10. Nov de 1983.

Suárez, Ivonne. Oro y Sociedad Colonial en Antioquia 1575-1700. Monografía de Grado. Medellín. Departamento de Historia. Universidad de Antioquia. 1983.

Szuchman, Mark D. "Disorder and Social Control in Buenos Aires, 1810-1860". Journal of Interdisciplinary History. XV. I. Summer 1984.

Taylor, William B. "Amigos de Sombrero: The Patterns of Homicide in Rural Central Jalisco, 1784-1820". Versión Mecanografiada. s.f.

Taylor, William B. "Bandolerismo e Insurgencia en el Centro de Jalisco: 17901816”. En: Revista Encuentro. Guadalajara. N 3. Abril-Junio. 1984. 
Taylor, William B. Embriaguez, Homicidio y Rebelión en las Poblaciones Coloniales Mexicanas. México. Fondo de Cultura Económica, 1987. Thompson, E. P. "Folklore, Anthropology, and Social History". Brighton Sussex. John L. Noyce Publisher. 1979.

Tisnés Jiménez, Roberto M. Don Juan Del Corral. Libertador de los Esclavos. Cali. Biblioteca del Banco Popular. 1980.

Tovar Pinzón, Hermes. Grandes Empresas Agrícolas y Ganaderas. Su Desarrollo en el Siglo XVIII. Bogotá. Cooperativa de Profesores de la Universidad Nacional de Colombia. 1980.

Twinam, Ann. Mineros, Comerciantes y Labradores. 1763-1810. Medellín. Fondo Rotatorio de Publicaciones. FAES. 1985.

Uribe de Hincapié, María Teresa y Jesús María Alvarez. Las Raíces del Poder Regional. El Caso Antioqueño. Documento Preliminar. $\mathrm{N}^{\circ} 5$. Medellín. Centro de Investigaciones de las Ciencias sociales. "CENICS". 1986. Valencia Llano, Alonso. "El Chisme y el escándalo en la sociedad colonial". En Estudios Sociales. Medellín. FAES. № 3. Septiembre de 1988. Vargas Lesmes, Julián. La Sociedad de Santa fe Colonial. Bogotá. Centro de Investigación y Educación Popular. CINEP. 1990.

Vargas, Pedro Fermín. Pensamientos Políticos. Bogotá. Nueva Biblioteca Colombiana de Cultura. 1986.

Vélez, Fernando. Datos para la Historia del Derecho Nacional. Medellín. Imprenta del Departamento. 1891.

Viqueira Albán, Juan P. Relajados o Reprimidos? Diversiones Públicas y Vida Social en la Ciudad de México durante el Siglo de las Luces. México. Fondo de cultura Económica. 1987.

Zuluagam Francisco. "Clientelismo y Guerrillas en el Valle del Patía. 1536-1811" En: La Independencia. Ensayos de Historia Social. Bogotá. Instituto Colombiano de Cultura. 1986. 

Anexos 



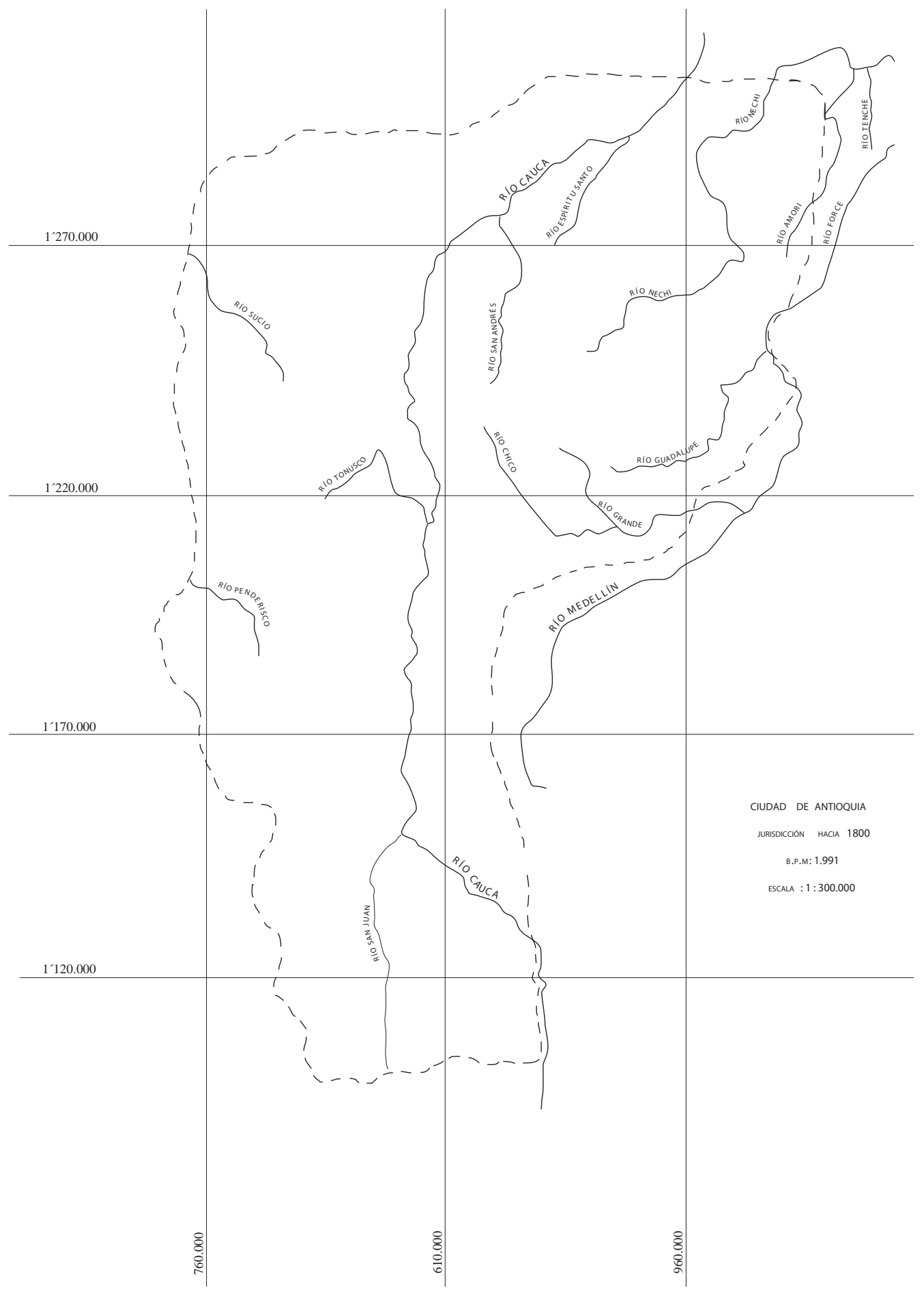


Beatriz Patiño Millán

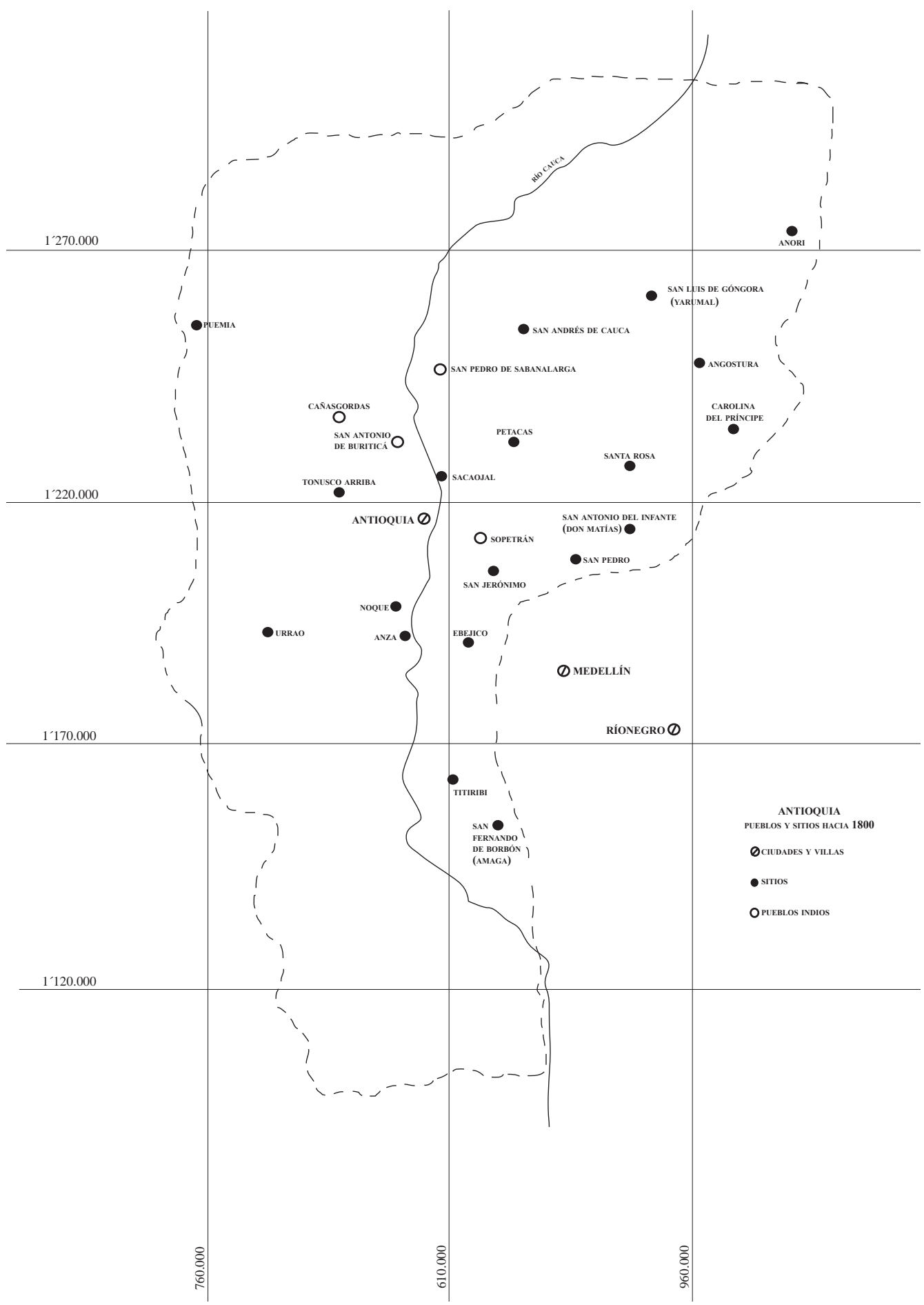




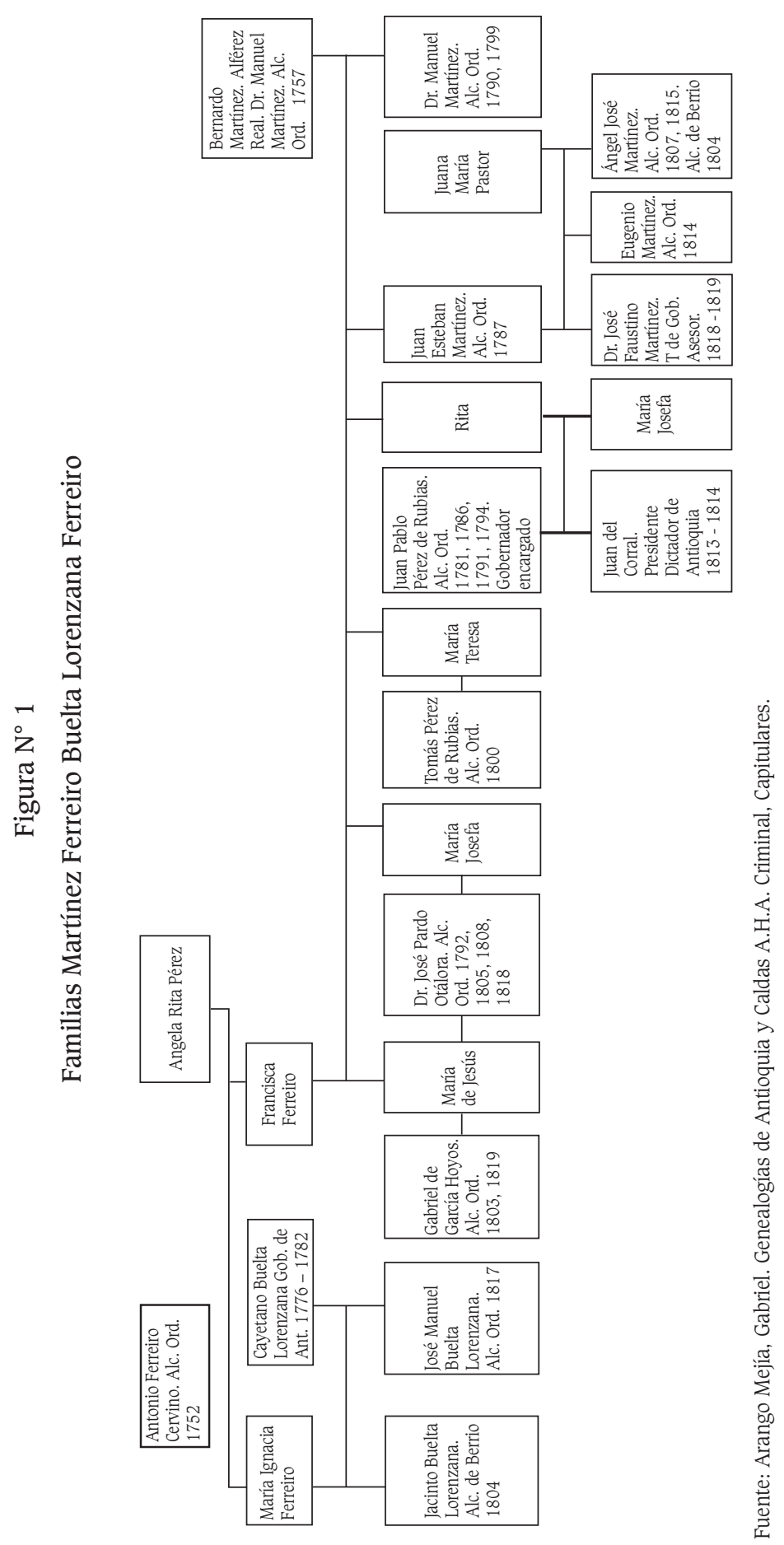


Beatriz Patiño Millán

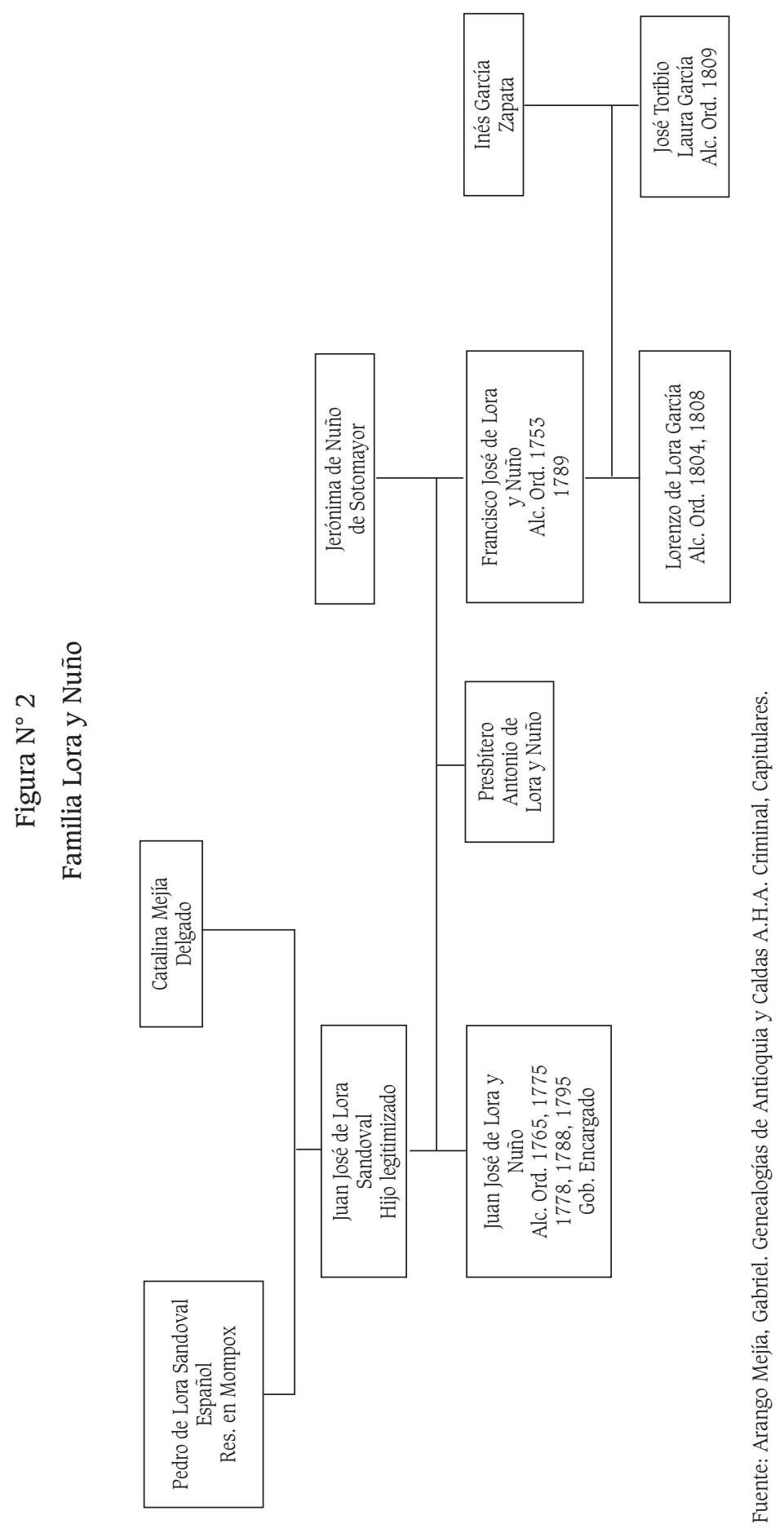




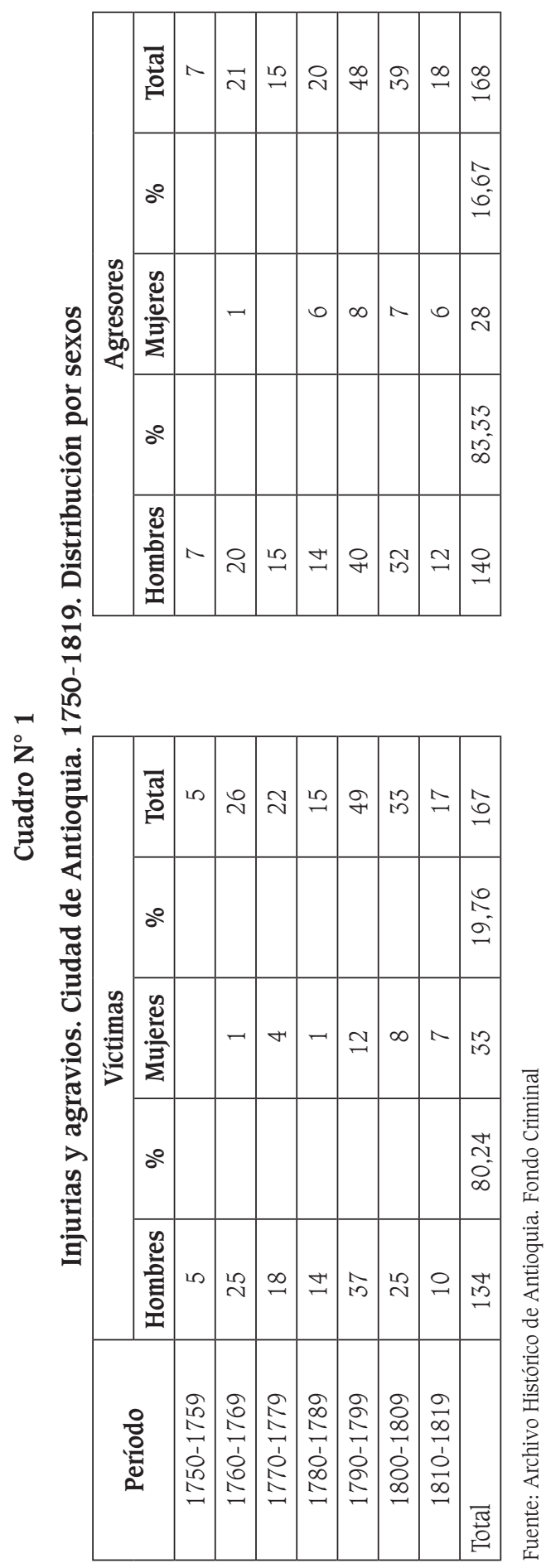


Beatriz Patiño Millán

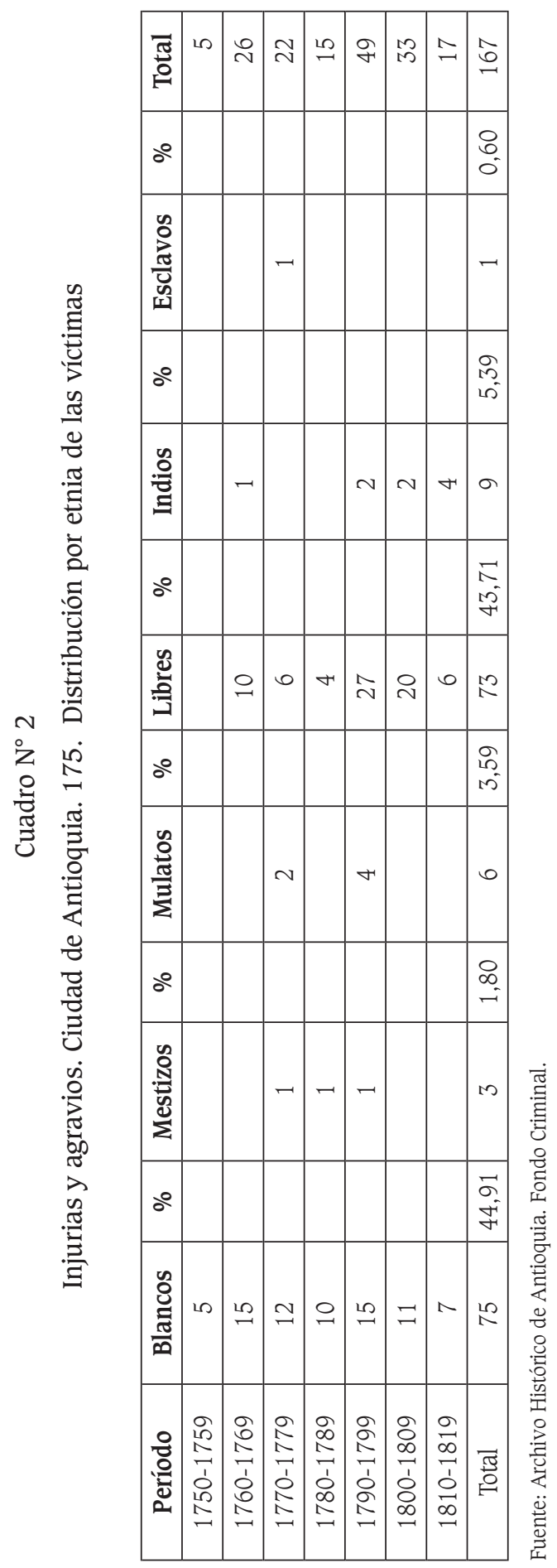




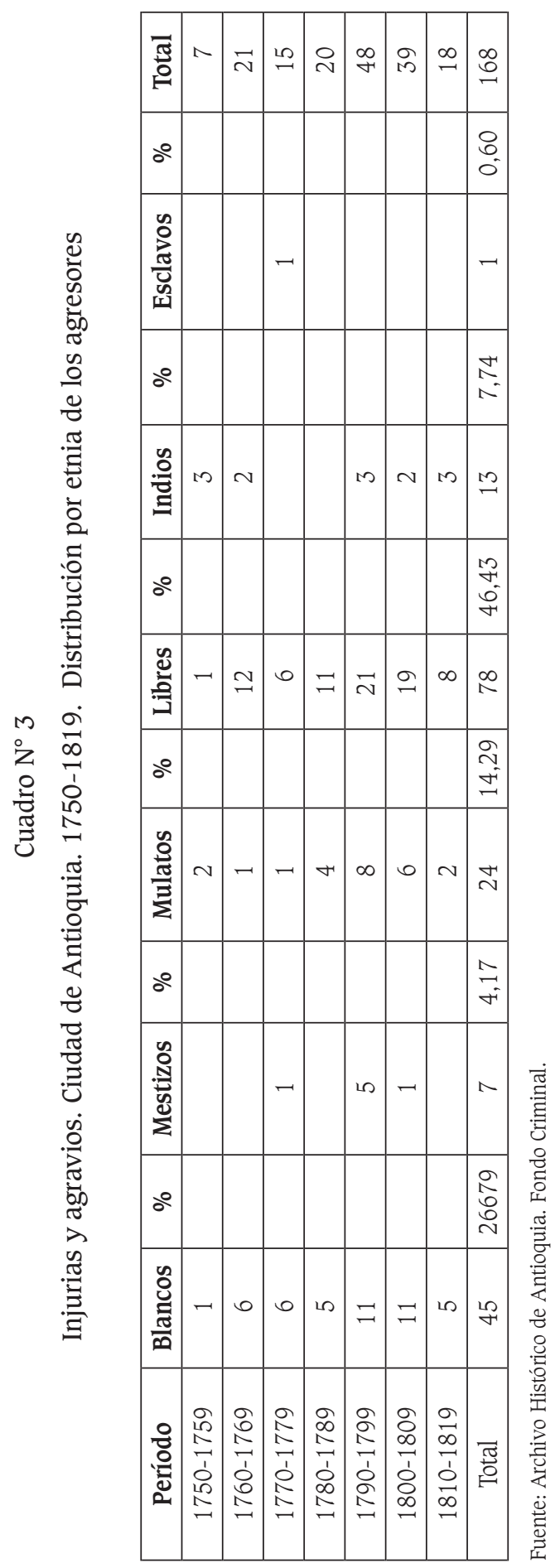


Beatriz Patiño Millán

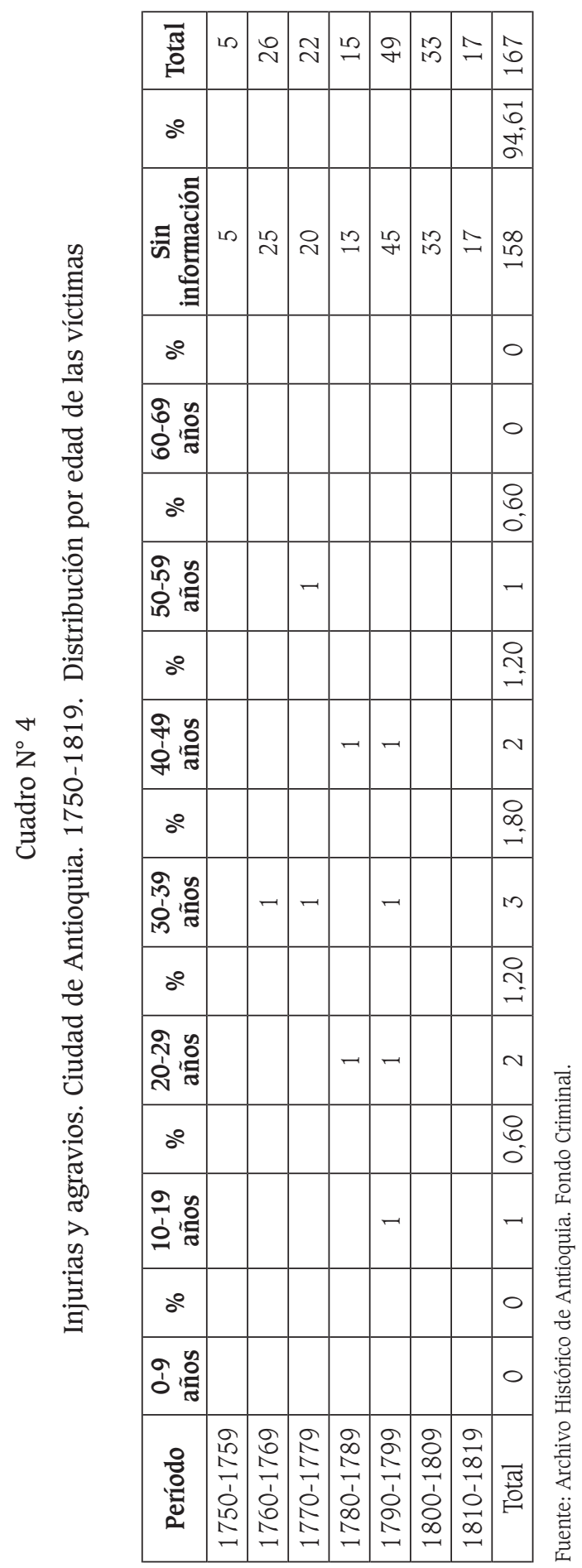




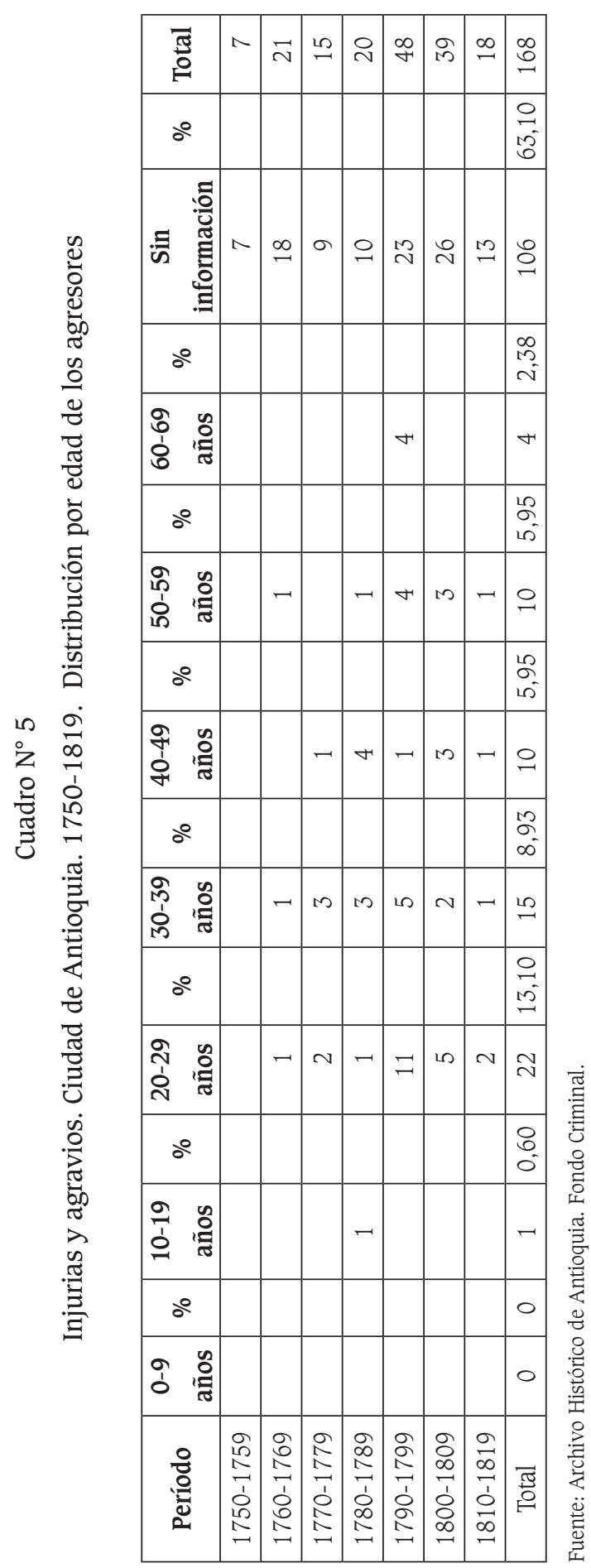


Beatriz Patiño Millán

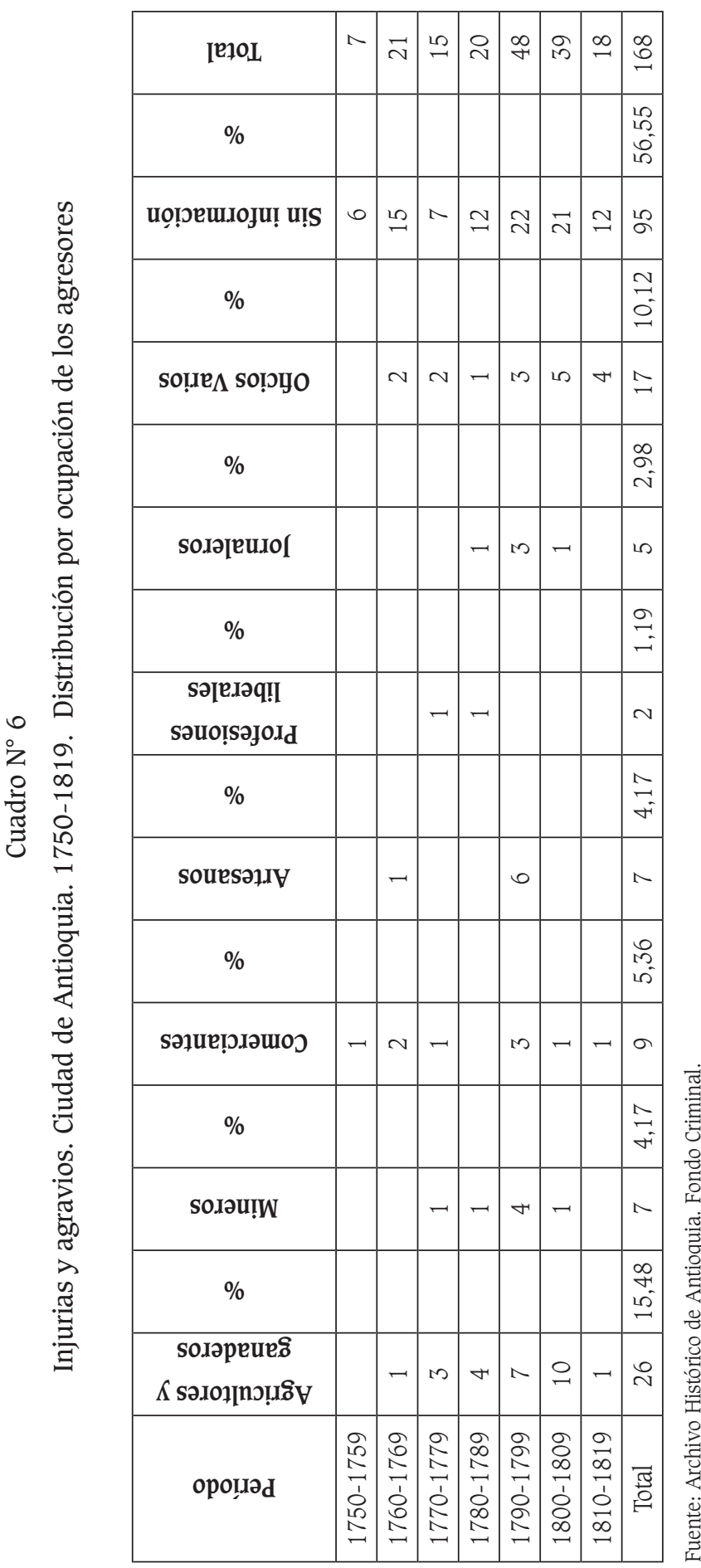




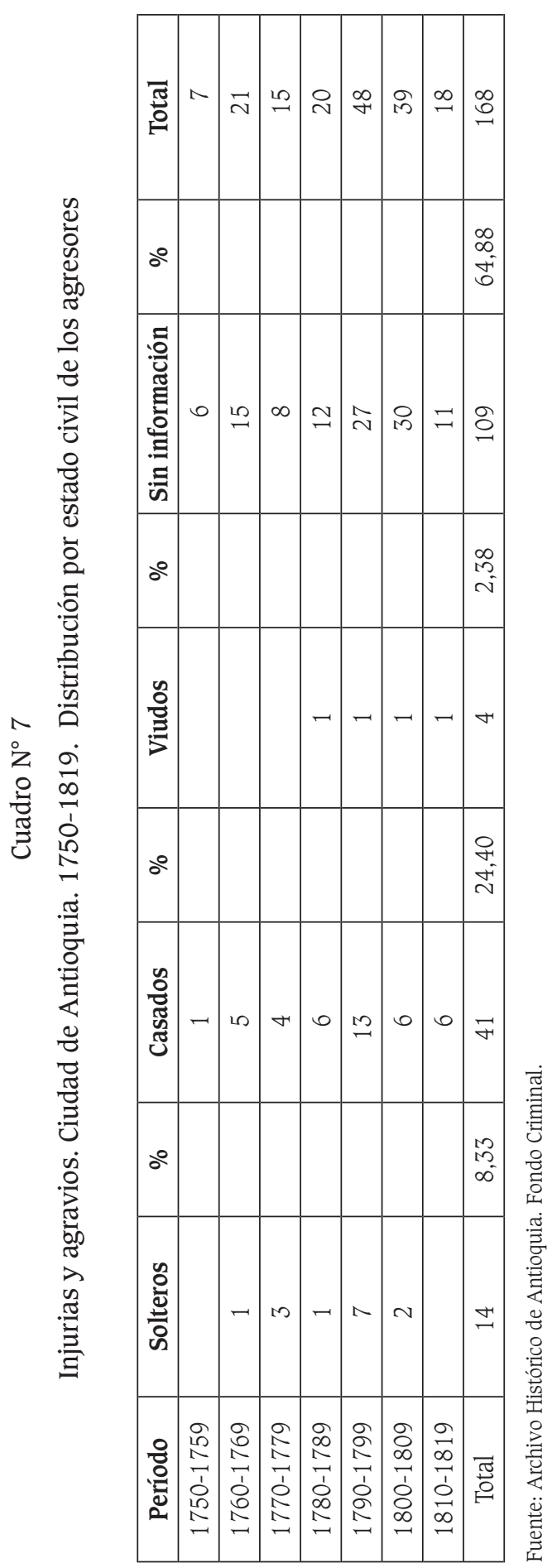


Beatriz Patiño Millán

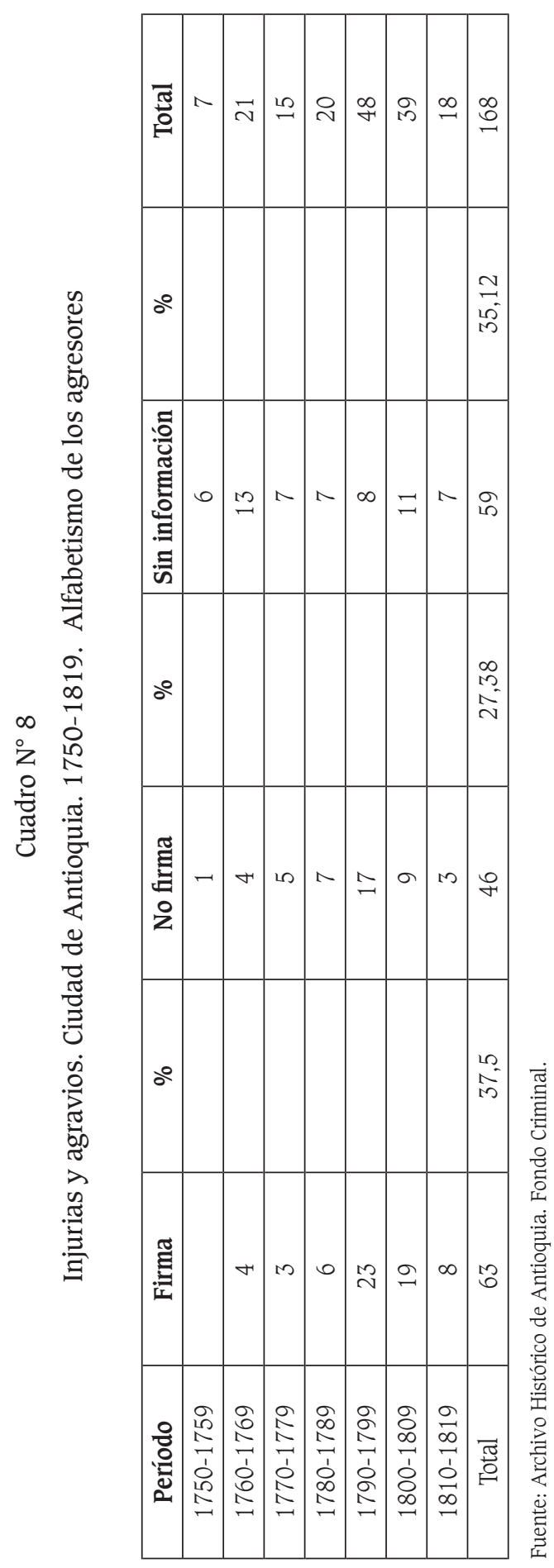




\begin{tabular}{|c|c|c|c|c|c|c|c|c|c|}
\hline & [R]OL & $\wedge$ & $\approx$ & ㄱ & $\stackrel{0}{=}$ & $\stackrel{\leftrightarrow}{+}$ & $\stackrel{\bullet}{\sim}$ & $\rightleftarrows$ & $\stackrel{\infty}{+}$ \\
\hline & $\%$ & & & & & & & & $\begin{array}{l}\tilde{\sigma} \\
0 \\
0\end{array}$ \\
\hline & $\begin{array}{l}\text { uọ̣peu.joju! } \\
\text { U!̣S }\end{array}$ & $\sim$ & $\circ$ & 0 & a) & $\stackrel{\sim}{\sim}$ & $\stackrel{2}{\rightarrow}$ & o & $\overparen{b}$ \\
\hline & $\%$ & & & & & & & & $\begin{array}{l}\text { M } \\
0 \\
\text { in }\end{array}$ \\
\hline 氖 & оџ о ерехqәпо & & & $\sim$ & & & - & & $M$ \\
\hline$\frac{0}{0}$ & $\%$ & & & & & & & & $\begin{array}{l}\forall \\
0 \\
0\end{array}$ \\
\hline :? & solpo esej & $\sim$ & $\sigma$ & $\sim$ & m & $\sigma$ & 0 & $\sim$ & $\stackrel{N}{N}$ \\
\hline a & $\%$ & & & & & & & & $\begin{array}{l}\text { ô } \\
\infty\end{array}$ \\
\hline ’’ & 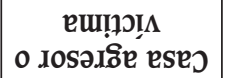 & - & 10 & 10 & - & $\sigma$ & $m$ & $m$ & $\stackrel{\infty}{\sim}$ \\
\hline .త్ర & $\%$ & & & & & & & & $\begin{array}{l}\infty \\
0 \\
0 \\
0\end{array}$ \\
\hline 总 & eu!̣ & & & - & & & & & - \\
\hline 胥 & $\%$ & & & & & & & & $\begin{array}{l}\infty \\
\infty \\
10\end{array}$ \\
\hline $\begin{array}{l}\dot{U} \\
\dot{\otimes}\end{array}$ & 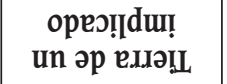 & & & $\sim$ & - & $\sim$ & & & 10 \\
\hline ప్రాల & $\%$ & & & & & & & & $\stackrel{\circ}{\mathscr{t}^{\prime}}$ \\
\hline$\cdot \stackrel{\Xi}{Z}$ & ગાણอ & - & $\sim$ & $\sim$ & - & 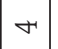 & $\sim$ & $\sim$ & 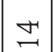 \\
\hline & $\%$ & & & & & & & & $\begin{array}{l}\infty \\
1 \\
n \\
n\end{array}$ \\
\hline & ou!̣ueว & & - & & - & - & - & - & 20 \\
\hline & opoüd & 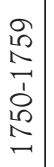 & 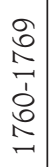 & 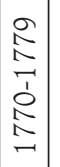 & 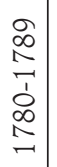 & 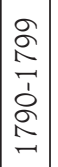 & $\mid \begin{array}{c}2 \\
0 \\
0 \\
1 \\
1 \\
0 \\
0 \\
0 \\
-0\end{array}$ & $\begin{array}{c}\sigma \\
\overrightarrow{1} \\
\infty \\
\overrightarrow{1} \\
0 \\
\infty \\
\infty\end{array}$ & 중 \\
\hline
\end{tabular}


Beatriz Patiño Millán

\begin{tabular}{|c|c|c|c|c|c|c|c|c|c|}
\hline & [ש]OL & 0 & ㄱ & $\stackrel{0}{\sim}$ & $\stackrel{0}{\sim}$ & $\rightleftarrows$ & $\stackrel{\llcorner}{\sim}$ & $\stackrel{10}{\longrightarrow}$ & م્ \\
\hline & $\%$ & & & & & & & & 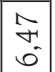 \\
\hline & ग!凹 & - & - & & $\sim$ & & DD & $v$ & の \\
\hline & $\%$ & & & & & & & & $\begin{array}{l}\Omega \\
0 \\
0\end{array}$ \\
\hline & $\Lambda O N$ & & $M$ & - & $\sim$ & $\Lambda$ & $\sim$ & & $\stackrel{20}{=}$ \\
\hline & $\%$ & & & & & & & & $\begin{array}{l}0 \\
2 \\
10\end{array}$ \\
\hline$\Xi$ & 100 & - & & $m$ & - & $\sim$ & & - & $\infty$ \\
\hline $\begin{array}{l}8 \\
\vdots \\
\vdots\end{array}$ & $\%$ & & & & & & & & \begin{tabular}{l}
$\stackrel{2}{1}$ \\
\multirow{1}{*}{}
\end{tabular} \\
\hline مُ & dəS & & - & - & 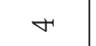 & 0 & 10 & 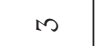 & ㄱ \\
\hline$\frac{\vec{n}}{0.0}$ & $\%$ & & & & & & & & $\stackrel{2}{2}$ \\
\hline ๑ి & oळ̂ & - & - & $\sim$ & - & B & $\sim$ & & 으 \\
\hline ํ. & $\%$ & & & & & & & & $\begin{array}{l}\hat{\sigma} \\
10\end{array}$ \\
\hline هं & Inl & $\neg$ & $\sim$ & 10 & - & 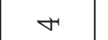 & 0 & & 음 \\
\hline$\stackrel{2}{\circ}$ & $\%$ & & & & & & & & $\begin{array}{l}5 \\
0 \\
0\end{array}$ \\
\hline 完 & unl & & $\sim$ & - & - & - & & $\sim$ & $\Lambda$ \\
\hline "ర్తు & $\%$ & & & & & & & & $\begin{array}{l}1 \\
0 \\
0 \\
-\end{array}$ \\
\hline ت己 & KeW & & $B$ & $\sim$ & & B & $r$ & $\sim$ & $\stackrel{\sqcup}{\sqcup}$ \\
\hline$\stackrel{0}{2}$ & $\%$ & & & & & & & & 范 \\
\hline ప్ర & IqH & - & - & & - & $\sigma$ & - & - & $a$ \\
\hline $\overrightarrow{0}$ & $\%$ & & & & & & & & $\begin{array}{l}1 \\
0 \\
0 \\
0\end{array}$ \\
\hline $\bar{\Xi}$ & IEW & & - & - & $D$ & 0 & $\sim$ & - & $\rightleftarrows$ \\
\hline & $\%$ & & & & & & & & $\begin{array}{l}\tilde{N} \\
\sigma^{2}\end{array}$ \\
\hline & qDA & & $\sim$ & & & $\sim$ & & $\sim$ & 0 \\
\hline & $\%$ & & & & & & & & $\begin{array}{l}2 \\
\text { in }\end{array}$ \\
\hline & วü & - & D & & & B & & - & $\infty$ \\
\hline & ороџు. & 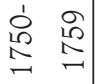 & 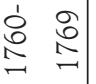 & 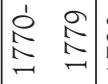 & 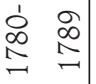 & $\begin{array}{ll}1 & \text { হ } \\
& - \\
-1\end{array}$ & $\begin{array}{ll}1 & 0 \\
8 & 8 \\
\infty & \infty \\
- & -1\end{array}$ & 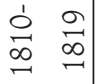 & 퓽 \\
\hline
\end{tabular}




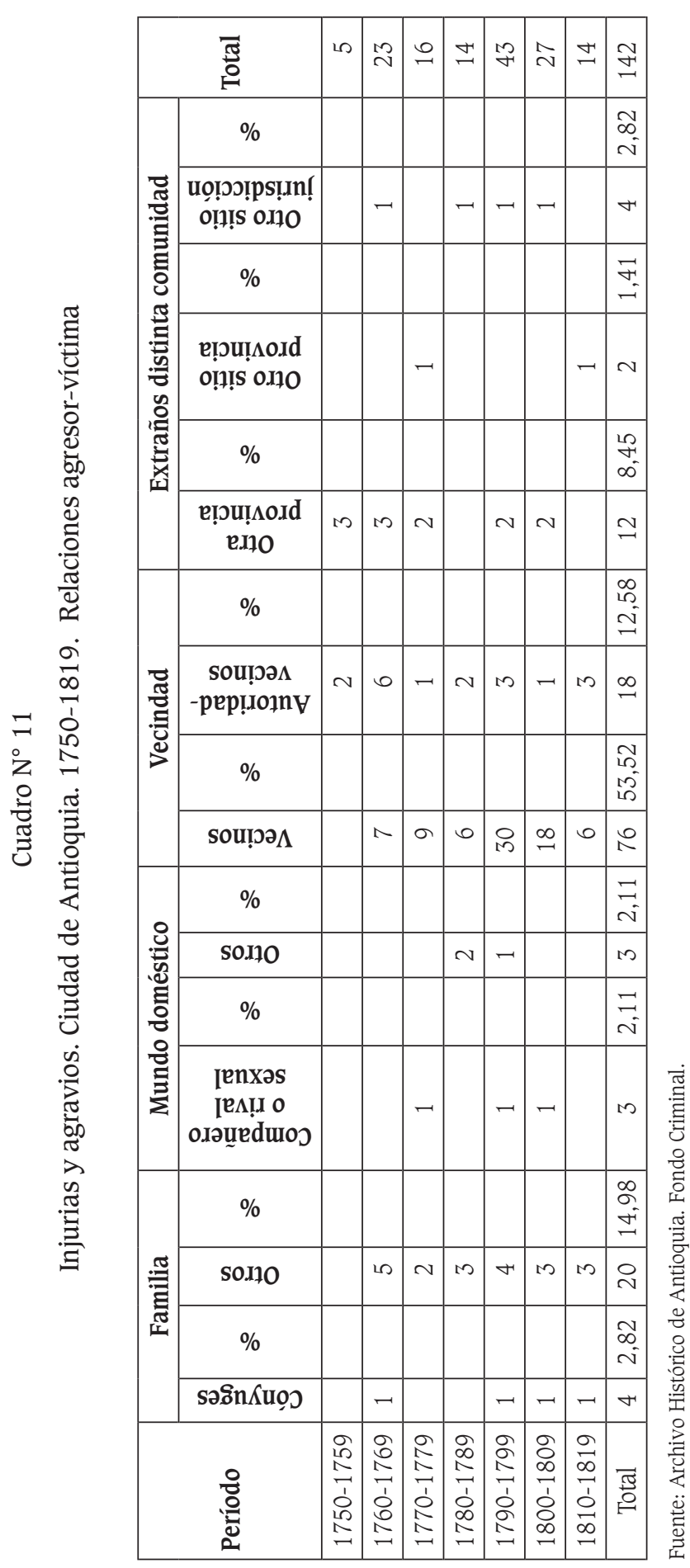




\section{Cuadro $\mathrm{N}^{\circ} 12$}

Injurias y agravios. Ciudad de Antioquia. 1750-1819.

Motivos argüidos por las víctimas y los agresores

\begin{tabular}{|c|c|c|}
\hline Categoría & Número de casos & $\%$ \\
\hline \multicolumn{3}{|l|}{ Problemas económicos } \\
\hline Pago. Cobro deudas & 21 & 13,64 \\
\hline Imputación robo & 24 & 15,58 \\
\hline Limpiar crédito con mercaderes & 1 & 0,65 \\
\hline Problemas cantidad - calidad compras & 4 & 2,60 \\
\hline Daño propiedad & 3 & 1,95 \\
\hline Problemas cantidad - calidad trabajo & 4 & 2,60 \\
\hline Problemas tierras & 14 & 9,09 \\
\hline Problemas ganados & 2 & 1,30 \\
\hline Problemas minas & 1 & 0,65 \\
\hline Disputas por capellanía & 2 & 1,30 \\
\hline Total & 76 & 49,35 \\
\hline \multicolumn{3}{|l|}{ Problemas vida en familia y vecindad } \\
\hline Problemas hijos-familia & 5 & 3,25 \\
\hline Problemas vida-vecindad & 10 & 6,49 \\
\hline Total & 15 & 9,74 \\
\hline \multicolumn{3}{|l|}{ Problemas relaciones sexuales } \\
\hline Imputación de concubinato & 16 & 10,39 \\
\hline Cumplimiento palabra de matrimonio & 3 & 1,95 \\
\hline Persecución sexual & 5 & 3,25 \\
\hline Celos & 3 & 1,95 \\
\hline Imputación falsa hombría & 1 & 0,65 \\
\hline Total & 28 & 18,18 \\
\hline \multicolumn{3}{|l|}{ Problemas con la autoridad } \\
\hline Desacato - resistencia justicia & 13 & 8,44 \\
\hline Problemas rentas reales & 5 & 3,25 \\
\hline Total & 18 & 11,69 \\
\hline \multicolumn{3}{|l|}{ Problemas honor personal } \\
\hline Acusación soborno & 1 & 0,65 \\
\hline Afirmaciones hechas en juicio & 5 & 3,25 \\
\hline Imputación procedencia racial dudosa & 2 & 1,30 \\
\hline Total & 8 & 5,19 \\
\hline Sin especificar & 9 & 5,84 \\
\hline Total & 154 & \\
\hline
\end{tabular}

Fuente: Archivo Histórico de Antioquia. Fondo Criminal. 


\section{Cuadro $\mathrm{N}^{\circ} 13$}

Injurias y agravios. Ciudad de Antioquia. 1750-1819.

Sentencias

\begin{tabular}{|l|c|c|}
\hline \multicolumn{1}{|c|}{ Pena } & Número de casos & \% \\
\hline Prisión sufrida & 16 & 7,27 \\
\hline Presidio de Cartagena & 4 & 1,82 \\
\hline Destierro & 9 & 4,09 \\
\hline Prohibición ir o ver lugar, casa o persona & 7 & 3,18 \\
\hline Obras públicas & 4 & 1,82 \\
\hline Concierto o depósito de la persona & 4 & 1,82 \\
\hline No ejercer empleo & 2 & 0,91 \\
\hline No nominarse con un título & 1 & 0,45 \\
\hline Pago costas y papel sellado & 62 & 28,18 \\
\hline Pérdida de armas & 2 & 0,91 \\
\hline Arreglo de los daños & 1 & 0,45 \\
\hline Multa & 6 & 2,73 \\
\hline Dar satisfacción & 13 & 5,91 \\
\hline Convenio entre las partes & 15 & 6,82 \\
\hline Una parte desiste de la querella & 16 & 7,27 \\
\hline No probó la imputación & 11 & 5,00 \\
\hline Se da por concluía sin pena & 5 & 2,27 \\
\hline Se remite a otro tribunal & 4 & 1,82 \\
\hline Inconclusa & 38 & 17,27 \\
\hline Total & 220 & 100 \\
\hline
\end{tabular}

Fuente: Archivo Histórico de Antioquia. Fondo Criminal. 
Beatriz Patiño Millán

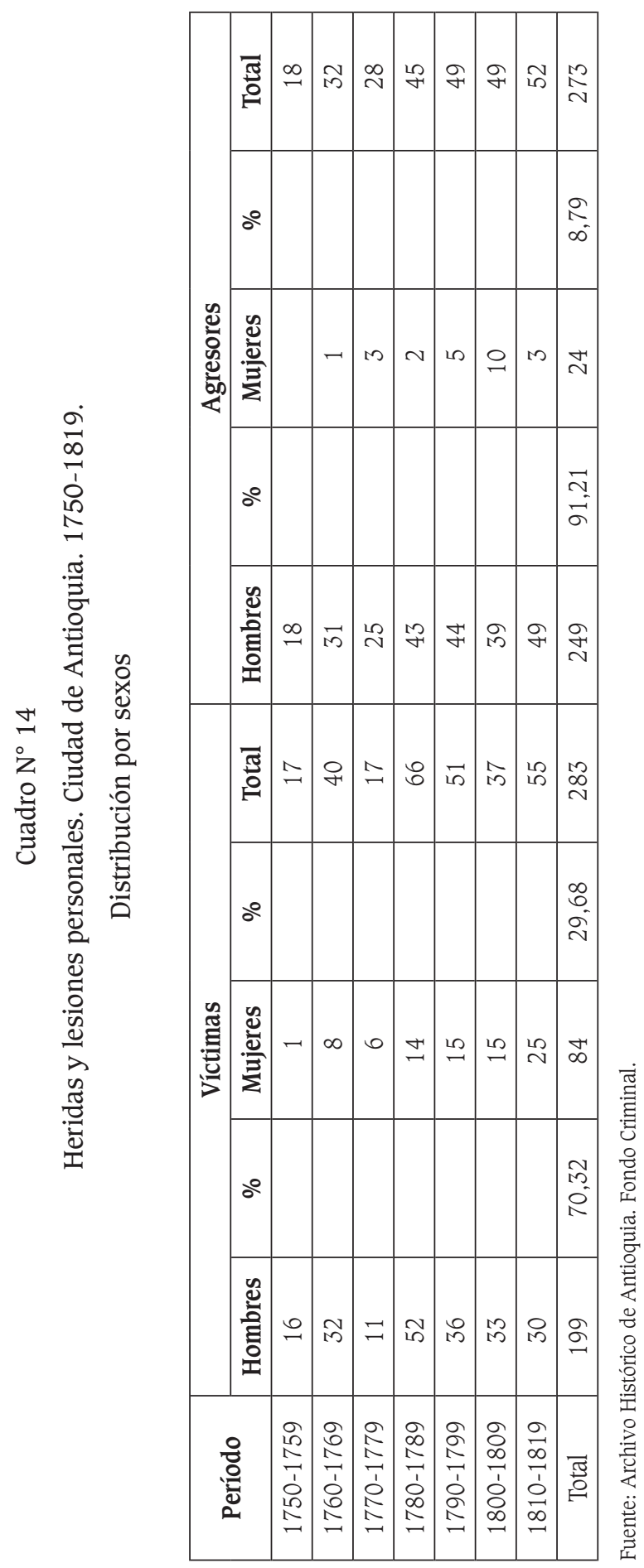




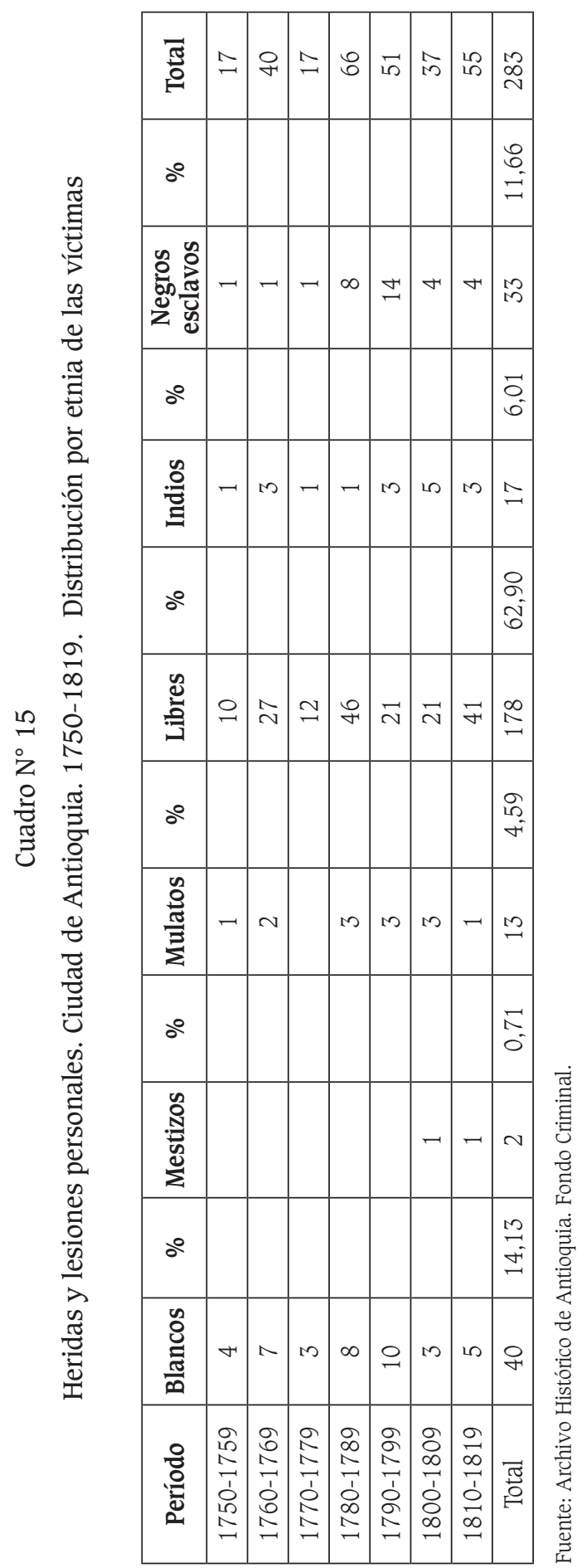


Beatriz Patiño Millán

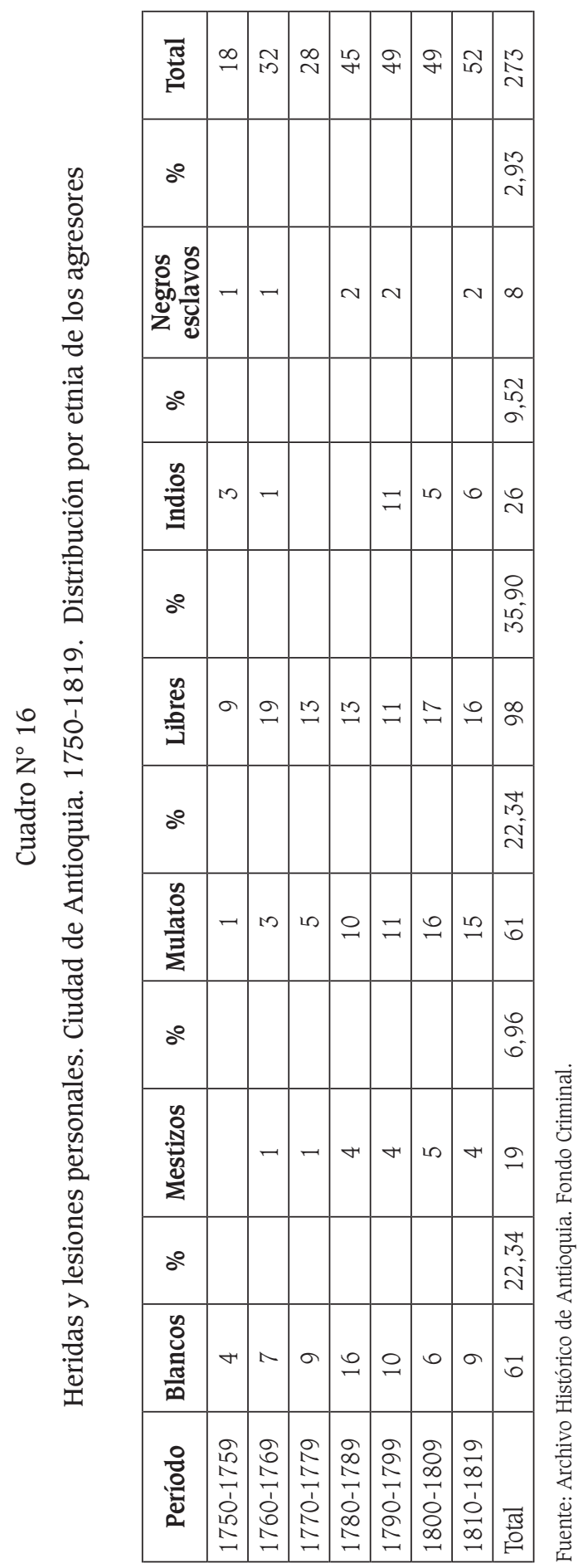


Criminalidad, Ley Penal y Estructura Social en la Provincia de Antioquia 1750-1820

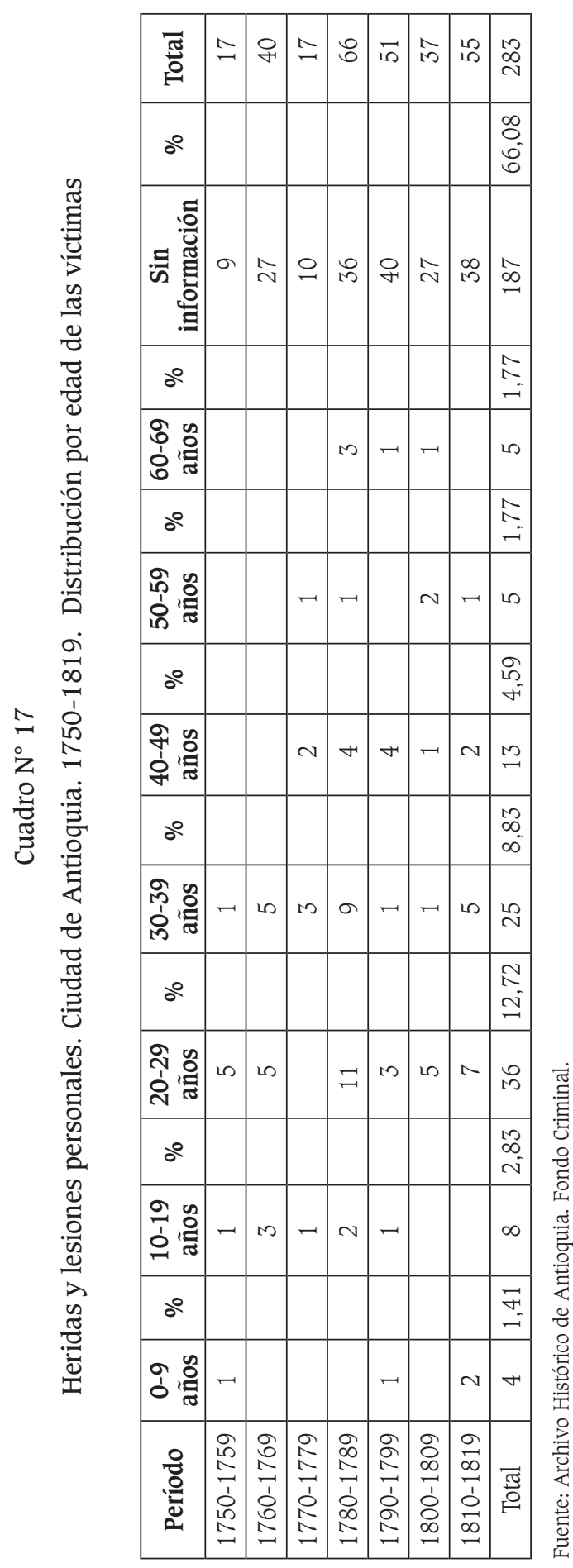


Beatriz Patiño Millán

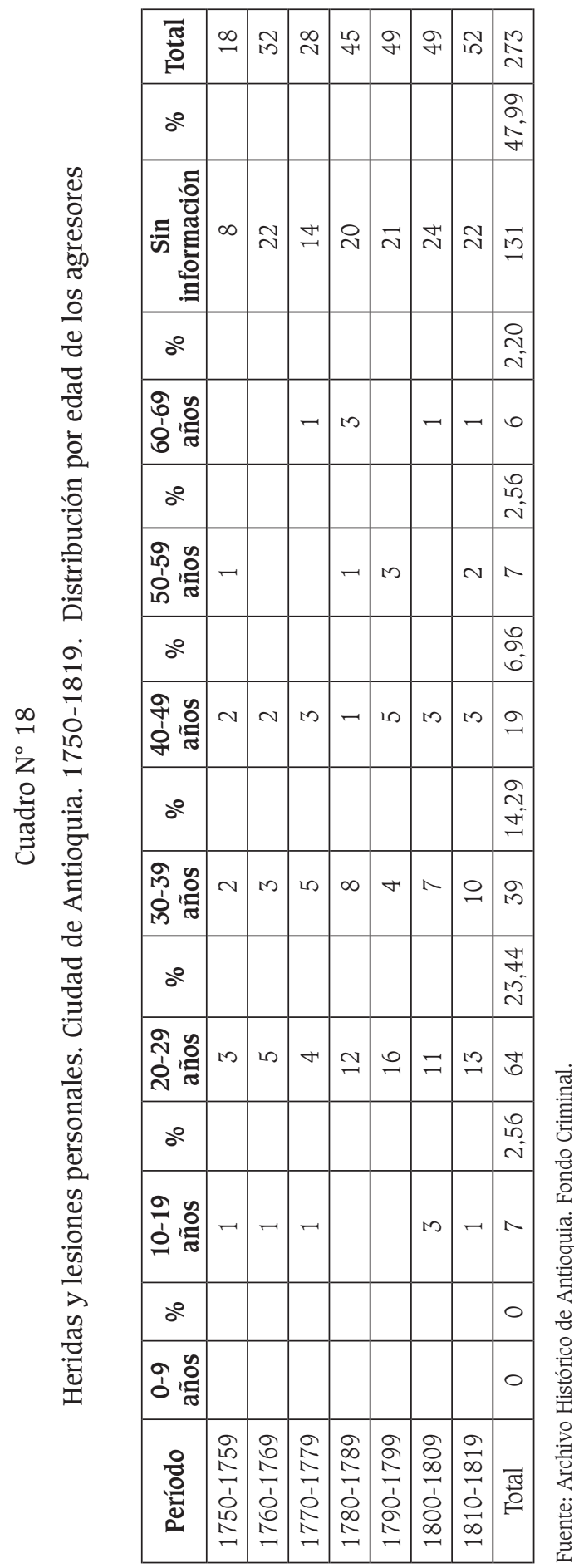




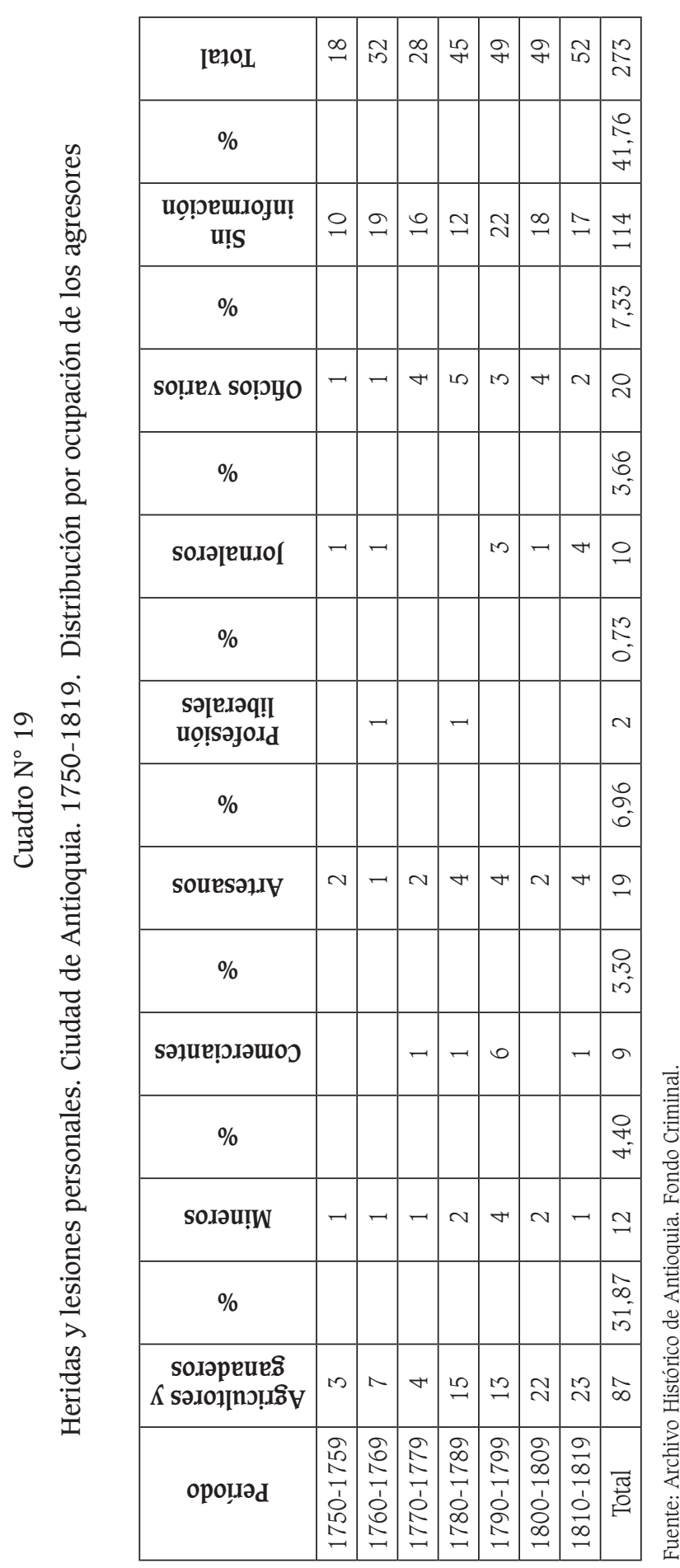


Beatriz Patiño Millán

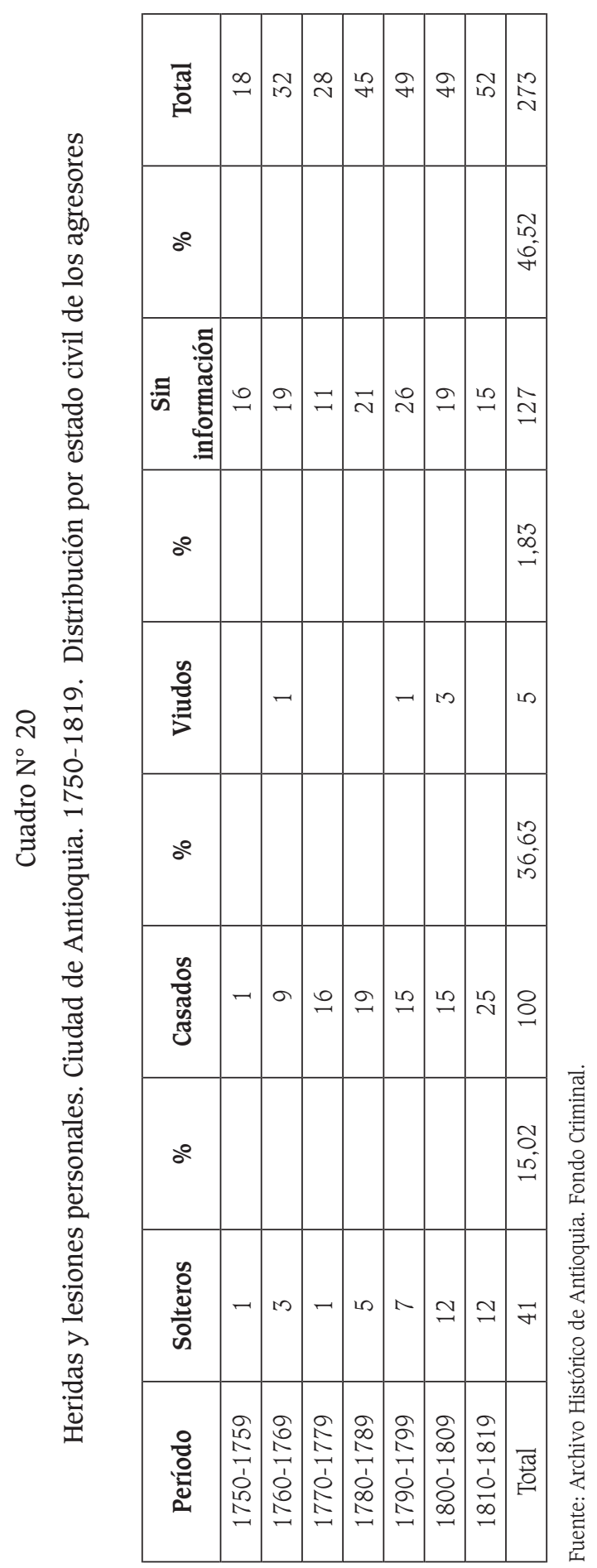




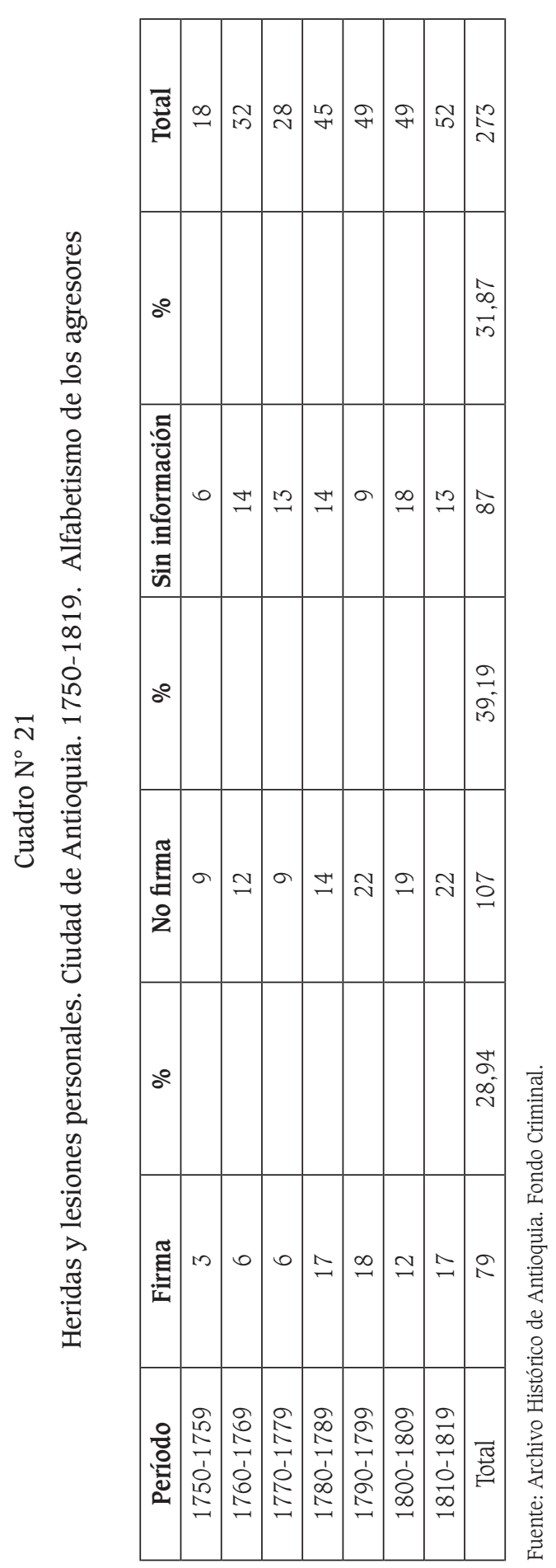


Beatriz Patiño Millán

\begin{tabular}{|c|c|c|c|c|c|c|c|c|c|}
\hline & [ש]O」 & $\approx$ & $\stackrel{\circ}{\sim}$ & $\cong$ & $\stackrel{\mathscr{P}}{\not}$ & 只 & 욤 & $\rightleftarrows$ & 을 \\
\hline & & & & & & & & & $\begin{array}{l}10 \\
0 \\
0 \\
0\end{array}$ \\
\hline & $\begin{array}{c}\text { uọ़२นuоJu! } \\
\text { u!S }\end{array}$ & - & 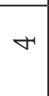 & $M$ & a & 10 & a & a & 움 \\
\hline 号 & $\%$ & & & & & & & & a \\
\hline n & Solfo esej & - & 10 & m & 으 & 0 & $\sim$ & $n$ & 㭊 \\
\hline $\begin{array}{l}\mathbb{0} \\
\Xi\end{array}$ & $\%$ & & & & & & & & $\begin{array}{l}\hat{0} \\
0^{\circ} \\
\text { N }\end{array}$ \\
\hline 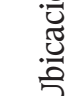 & 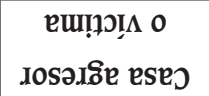 & 0 & $\infty$ & $\sigma$ & $\infty$ & $\stackrel{10}{2}$ & 0 & $\Xi$ & i \\
\hline$\stackrel{\sim}{ }$ & $\%$ & & & & & & & & $\begin{array}{l}0 \\
\infty \\
1\end{array}$ \\
\hline ำ & $\begin{array}{c}\text { old } \\
\text { o epexqәñ }\end{array}$ & $\rightarrow$ & & $v$ & & & - & $v$ & 0 \\
\hline v. & $\%$ & & & & & & & & $\begin{array}{l}0 \\
\infty \\
0\end{array}$ \\
\hline 苂 & eu!̣ & - & - & & $\sim$ & - & - & & 0 \\
\hline ర్ల & $\%$ & & & & & & & & 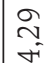 \\
\hline ت己 & әұుош-оdшеว & & $\sigma$ & & - & - & N & - & a \\
\hline 胥 & $\%$ & & & & & & & & in \\
\hline$\frac{w}{\tilde{\Xi}}$ & $\begin{array}{l}\text { opeว!̣du! } \\
\text { un әр ешәџ! }\end{array}$ & - & $v$ & - & $v$ & B & ما & 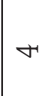 & $\infty$ \\
\hline$\stackrel{\circ}{\mathscr{E}}$ & $\%$ & & & & & & & & $\begin{array}{l}\hat{1} \\
10 \\
\infty\end{array}$ \\
\hline $\overrightarrow{0}$ & ગાણว & & $\rightarrow$ & $v$ & 0 & $v$ & $\sim$ & 10 & $\infty$ \\
\hline 离 & $\%$ & & & & & & & & $\begin{array}{l}10 \\
0 \\
0 \\
0\end{array}$ \\
\hline & ou!̣ues & 0 & - & $\sim$ & 20 & 10 & $\sim$ & $\sim$ & 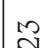 \\
\hline & opolı. & 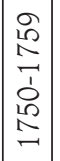 & $\begin{array}{l}0 \\
0 \\
2 \\
\\
0 \\
0 \\
1 \\
\end{array}$ & 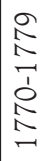 & 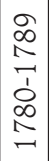 & 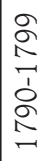 & 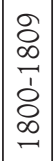 & $\begin{array}{l}0 \\
0 \\
\infty \\
1 \\
0 \\
0 \\
\infty \\
0\end{array}$ & 종 \\
\hline
\end{tabular}


Criminalidad, Ley Penal y Estructura Social en la Provincia de Antioquia 1750-1820

\begin{tabular}{|c|c|c|c|c|c|c|c|c|c|}
\hline & [Q]OI & 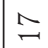 & $\stackrel{\sim 20}{N}$ & $\approx$ & 合 & 茨 & N & 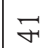 & 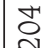 \\
\hline & $\%$ & & & & & & & & $\begin{array}{l}0 \\
= \\
=\end{array}$ \\
\hline & बִִ & r & 10 & & $\sim$ & 10 & \% & $r$ & $\stackrel{\hbar}{\sim}$ \\
\hline & $\%$ & & & & & & & & $\begin{array}{l}\hat{\text { s. }} \\
\text { is }\end{array}$ \\
\hline & $\Lambda \mathrm{ON}^{\mathrm{N}}$ & - & & $\sim$ & $\sim$ & D & - & $\sim$ & $\Xi$ \\
\hline छ્ય & $\%$ & & & & & & & & $\begin{array}{l}0 \\
\infty \\
0\end{array}$ \\
\hline 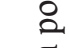 & $\mathfrak{p O}$ & & - & - & - & in & $\sim$ & 0 & む \\
\hline :0్ㅡㅁ & $\%$ & & & & & & & & $\infty$ \\
\hline 葛 & dəS & - & -1 & - & H & $\sim$ & 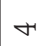 & m & 0 \\
\hline a & $\%$ & & & & & & & & $\begin{array}{l}\infty \\
\infty \\
\infty\end{array}$ \\
\hline & oß̂ & $\sim$ & in & $\sim$ & $\infty$ & $\sim$ & $\sigma$ & $\sim$ & $\stackrel{\infty}{\sim}$ \\
\hline 옷 & $\%$ & & & & & & & & $\begin{array}{l}10 \\
10 \\
12\end{array}$ \\
\hline 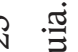 & [n] & $\sigma$ & -1 & $\sim$ & $\sigma$ & $\sim$ & - & - & 20 \\
\hline : & $\%$ & & & & & & & & $\begin{array}{l}0 \\
\infty \\
0 \\
0\end{array}$ \\
\hline 0 & und & - & - & - & 10 & 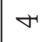 & & $\sim$ & $\Xi$ \\
\hline ] & $\%$ & & & & & & & & $\begin{array}{l}\curvearrowright \\
10 \\
10 \\
\end{array}$ \\
\hline تี & SeW & & -1 & $\sim$ & - & in & in & - & $\exists$ \\
\hline$\frac{\tilde{Q}}{\text { త్ర }}$ & $\%$ & & & & & & & & $\begin{array}{l}+ \\
\infty \\
N\end{array}$ \\
\hline क्ष & IqV & 一 & $\sim$ & $\sim$ & - & $v$ & H & H & 0 \\
\hline $\mathscr{E}$ & $\%$ & & & & & & & & $\begin{array}{l}\infty \\
0 \\
0\end{array}$ \\
\hline$\vec{Q}$ & IeW & & $n$ & $\sim$ & 0 & $\sim$ & $B$ & 0 & $\widetilde{N}$ \\
\hline$\vec{\theta}$ & $\%$ & & & & & & & & $\begin{array}{l}N \\
\infty \\
\infty\end{array}$ \\
\hline 童 & qәJ & - & $\sim$ & - & in & $B$ & BD & 10 & $\stackrel{\infty}{\sim}$ \\
\hline & $\%$ & & & & & & & & $\stackrel{10}{N}$ \\
\hline & วug & $\sim$ & م & - & 10 & 10 & T & 10 & $\stackrel{20}{N}$ \\
\hline & ороц्रd & 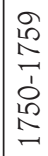 & 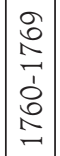 & 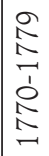 & $\begin{array}{l}\infty \\
\infty \\
1 \\
\\
0 \\
\infty \\
\infty \\
1 \\
\end{array}$ & 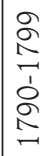 & 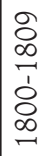 & $\begin{array}{l}\sigma \\
\sigma \\
\infty \\
1 \\
0 \\
0 \\
\infty \\
-1\end{array}$ & 즁 \\
\hline
\end{tabular}


Beatriz Patiño Millán

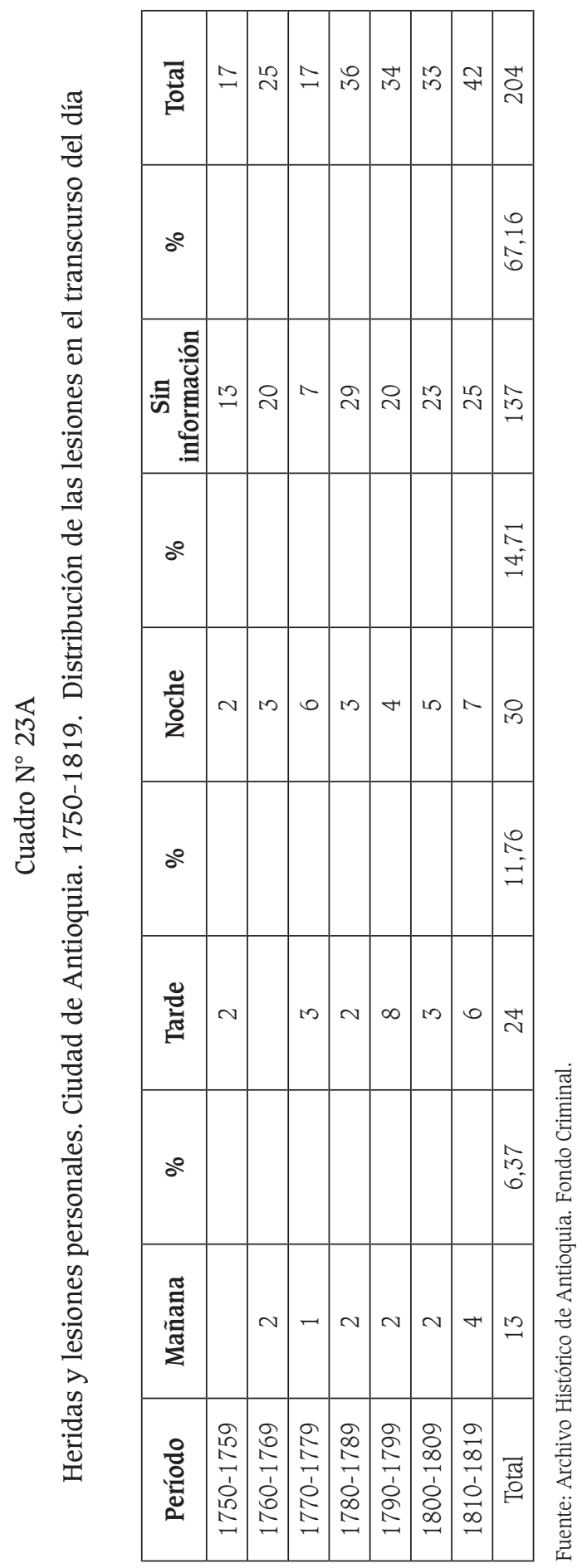




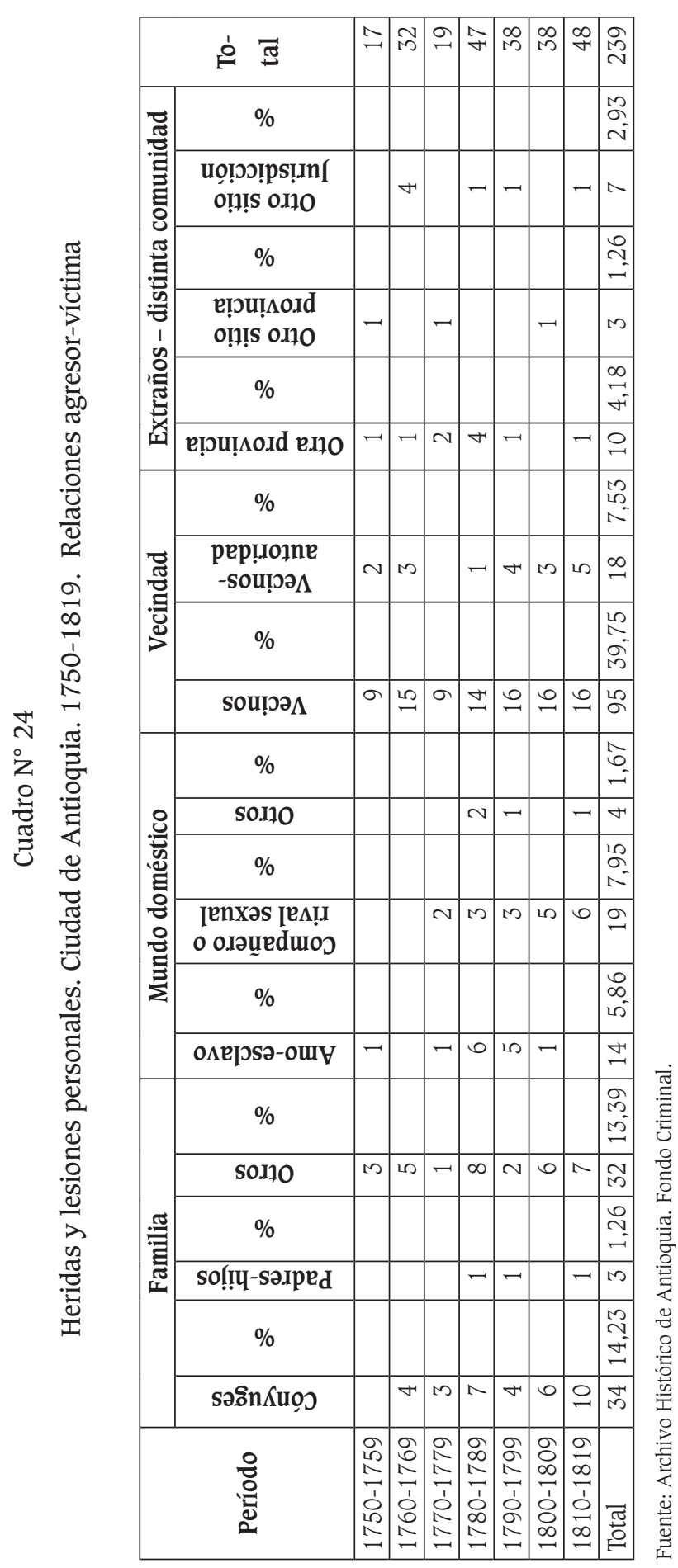


Cuadro $\mathrm{N}^{\circ} 25$

Heridas y lesiones personales. Ciudad de Antioquia. 1750-1819.

Motivos argüidos por las víctimas y los agresores

\begin{tabular}{|c|c|c|}
\hline Categoría & Número de casos & $\%$ \\
\hline \multicolumn{3}{|l|}{ Problemas económicos } \\
\hline Pago. Cobro de deudas & 30 & 13,45 \\
\hline Robo & 5 & 2,24 \\
\hline Problemas cantidad- calidad de compras & 5 & 2,24 \\
\hline Problemas cantidad - calidad trabajo & 5 & 2,24 \\
\hline Problemas propiedad tierra o mina & 6 & 2,69 \\
\hline Problemas ganado & 9 & 4,04 \\
\hline Problemas agua & 3 & 1,35 \\
\hline Problemas caminos & 4 & 1,79 \\
\hline Total & 67 & 30,04 \\
\hline \multicolumn{3}{|l|}{ Problemas vida en familia y vecindad } \\
\hline Problemas hijos-familia & 26 & 11,66 \\
\hline Problemas vida vecindad & 26 & 11,66 \\
\hline Pretensión esclavo: libertad o cambio de amo & 8 & 3,59 \\
\hline Quejas maltrato & 8 & 3,59 \\
\hline Embriaguez & 6 & 2,69 \\
\hline Trato indebido & 2 & 0,90 \\
\hline Total & 76 & 34,08 \\
\hline \multicolumn{3}{|l|}{ Problemas relaciones sexuales } \\
\hline Concubinato & 23 & 10,31 \\
\hline Persecución sexual & 8 & 3,59 \\
\hline Celos & 22 & 9,87 \\
\hline Total & 53 & 23,77 \\
\hline \multicolumn{3}{|l|}{ Problemas con la autoridad } \\
\hline Resistencia a la justicia & 20 & 8,97 \\
\hline Total & 20 & 8,97 \\
\hline Casualidad & 4 & 1,79 \\
\hline Sin especificar & 3 & 1,35 \\
\hline Total & 223 & \\
\hline
\end{tabular}

Fuente: Archivo Histórico de Antioquia. Fondo Criminal. 


\section{Cuadro $\mathrm{N}^{\circ} 26$}

Heridas y lesiones personales. Ciudad de Antioquia. 1750-1819.

Armas utilizadas por los agresores

\begin{tabular}{|l|c|c|}
\hline \multicolumn{1}{|c|}{ Armas } & Número de casos & $\%$ \\
\hline Cuchillo & 19 & 8,26 \\
\hline Machete & 22 & 9,57 \\
\hline Espada & 10 & 4,35 \\
\hline Navaja & 8 & 3,48 \\
\hline Puñal & 5 & 2,17 \\
\hline Bayoneta & 3 & 1,30 \\
\hline Sable & 15 & 6,52 \\
\hline Lanza & 3 & 1,30 \\
\hline Asta & 1 & 0,43 \\
\hline Tijeras & 1 & 0,43 \\
\hline Armas de fuego & 4 & 1,74 \\
\hline Hacha & 1 & 0,43 \\
\hline Barra de hierro & 1 & 0,43 \\
\hline Mazo de carpintería & 1 & 0,43 \\
\hline Trapiche & 1 & 0,43 \\
\hline Grillete & 2 & 0,87 \\
\hline Piedras & 6 & 2,61 \\
\hline Palos & 39 & 16,96 \\
\hline Hueso & 12 & 0,43 \\
\hline Golpes, mordeduras o arañazos & 230 & 29,57 \\
\hline Lazo & & 1,74 \\
\hline Látigo & 3,22 \\
\hline Yerbas (veneno) & 1,30 \\
\hline Total & 3 & \\
\hline
\end{tabular}

Fuente: Archivo Histórico de Antioquia. Fondo Criminal. 
Cuadro $\mathrm{N}^{\circ} 27$

Heridas y lesiones personales. Ciudad de Antioquia. 1750-1819.

Sentencias

\begin{tabular}{|c|c|c|}
\hline Pena & Número de casos & $\%$ \\
\hline Prisión sufrida & 46 & 12,71 \\
\hline Presidio de Cartagena & 1 & 0,28 \\
\hline Destierro & 17 & 4,70 \\
\hline Prohibición ir o ver a lugar, casa o persona & 5 & 1,38 \\
\hline Obras públicas & 18 & 4,97 \\
\hline Concierto depósito de la persona & 10 & 2,76 \\
\hline No ejercer empleo & 1 & 0,28 \\
\hline Pago costas y papel sellado & 88 & 24,31 \\
\hline Multa & 8 & 2,21 \\
\hline Pérdida de arma & 3 & 0,83 \\
\hline Pérdida de deuda & 2 & 0,55 \\
\hline Pago de curación & 17 & 4,70 \\
\hline Pago de jornales & 3 & 0,83 \\
\hline Pago de dote & 1 & 0,28 \\
\hline Pena de sangre & 8 & 2,21 \\
\hline Dar libertad perdida o vender esclavo & 6 & 1,66 \\
\hline Dar satisfacción & 2 & 0,55 \\
\hline Convenio entre las partes & 17 & 4,70 \\
\hline Obligación no ofender esposa & 2 & 0,55 \\
\hline Una parte desiste de la querella & 28 & 7,73 \\
\hline Absolución & 26 & 7,18 \\
\hline Indulto & 4 & 1,10 \\
\hline Inconclusas & 49 & 13,54 \\
\hline Total & 362 & \\
\hline
\end{tabular}

Fuente: Archivo Histórico de Antioquia. Fondo Criminal. 
Criminalidad, Ley Penal y Estructura Social en la Provincia de Antioquia 1750-1820

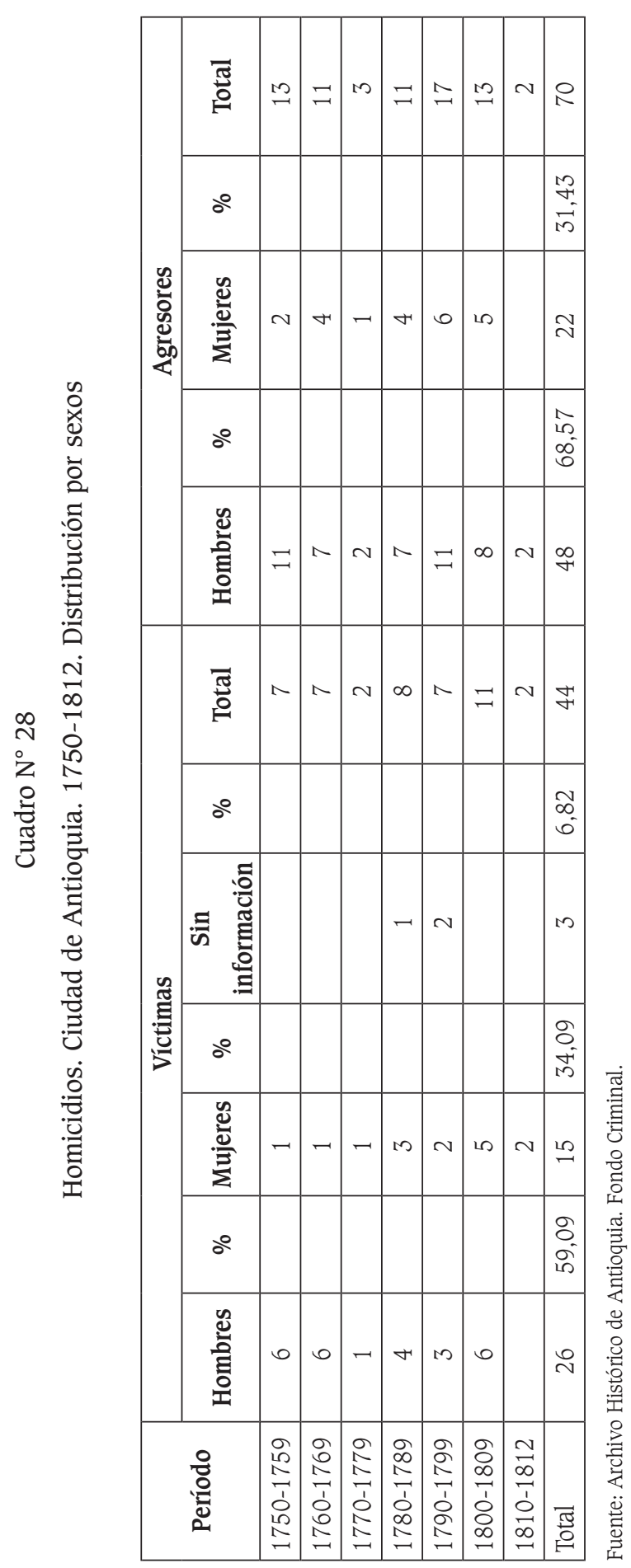


Beatriz Patiño Millán

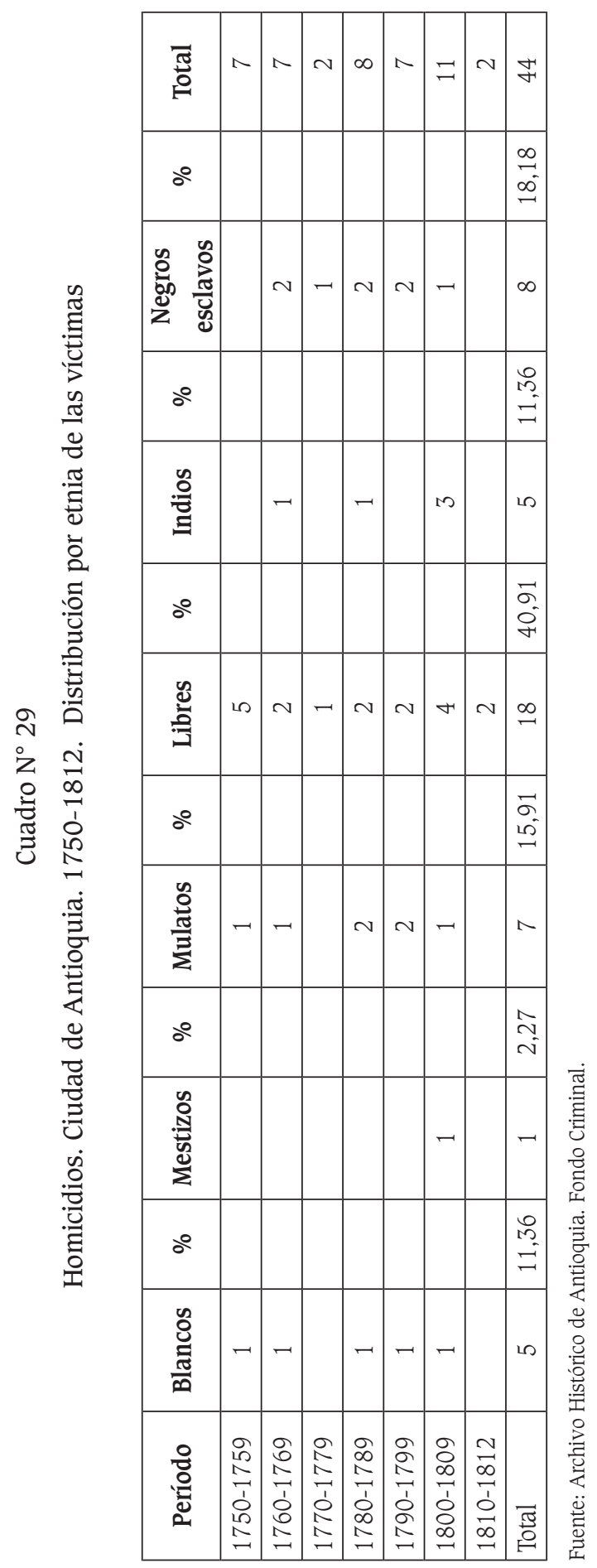




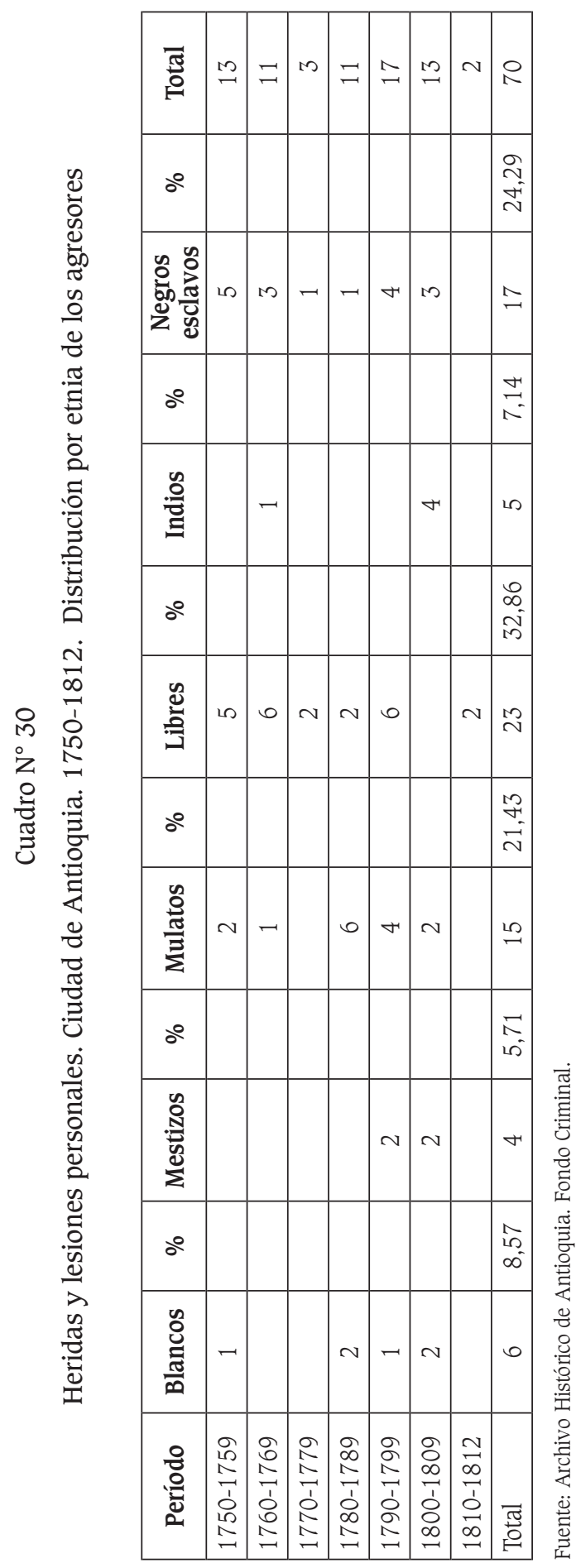


Beatriz Patiño Millán

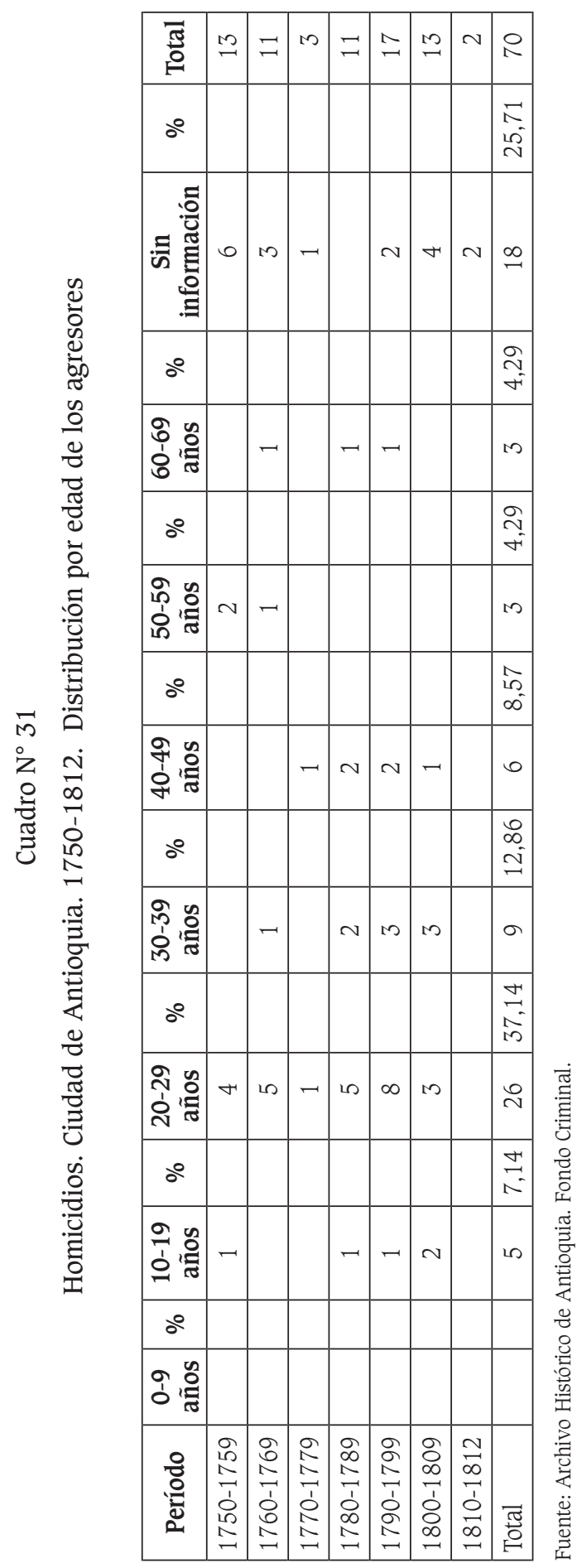


Criminalidad, Ley Penal y Estructura Social en la Provincia de Antioquia 1750-1820

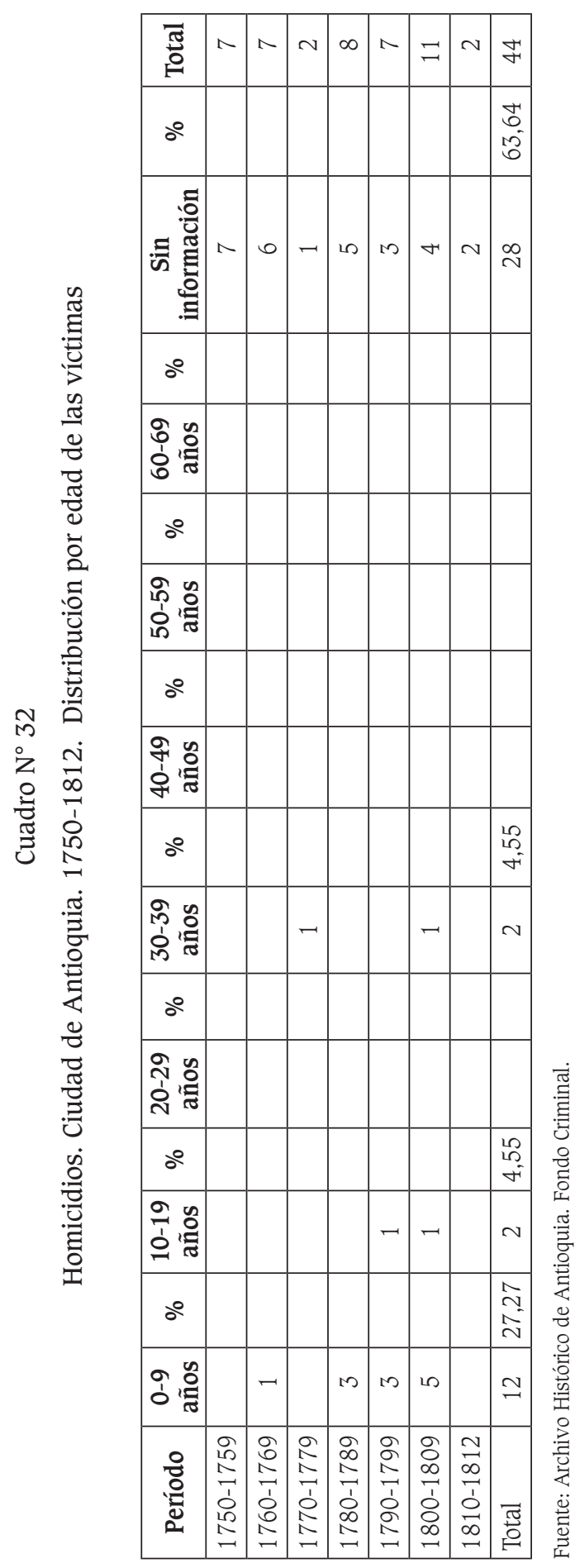


Beatriz Patiño Millán

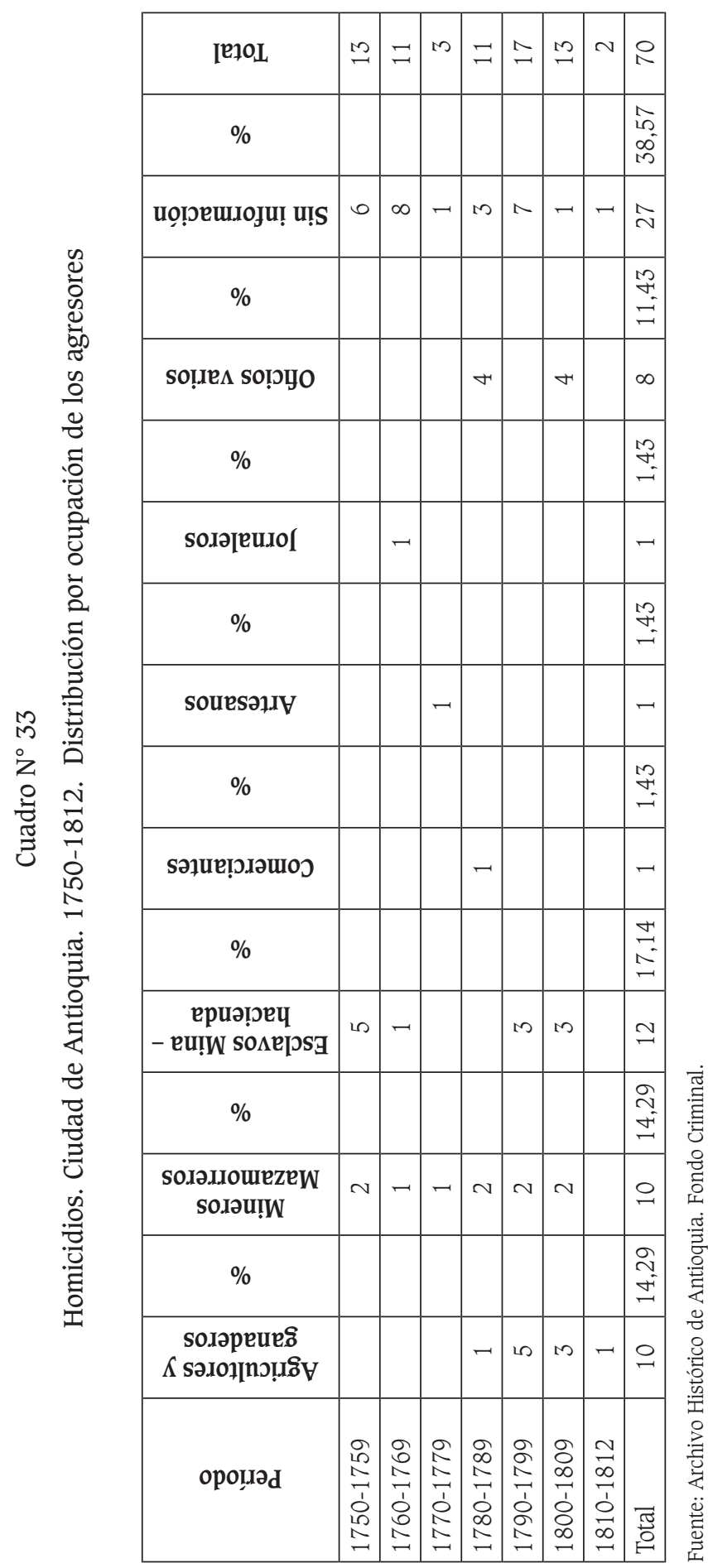


Criminalidad, Ley Penal y Estructura Social en la Provincia de Antioquia 1750-1820

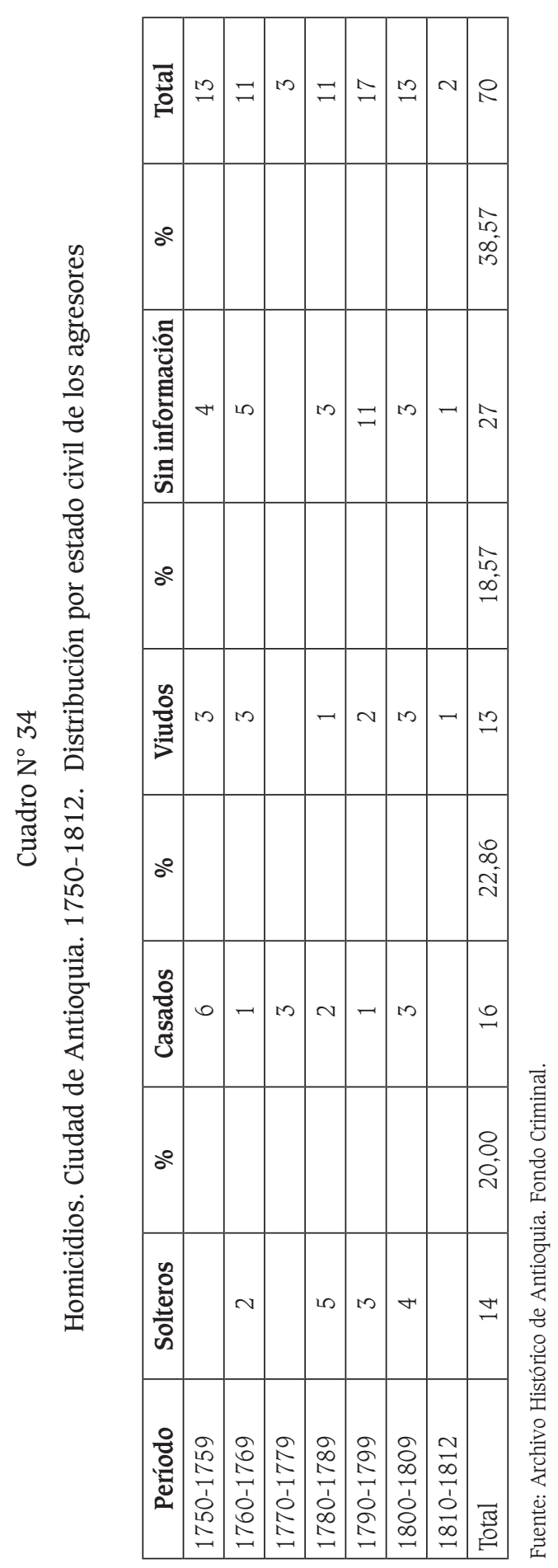


Beatriz Patiño Millán

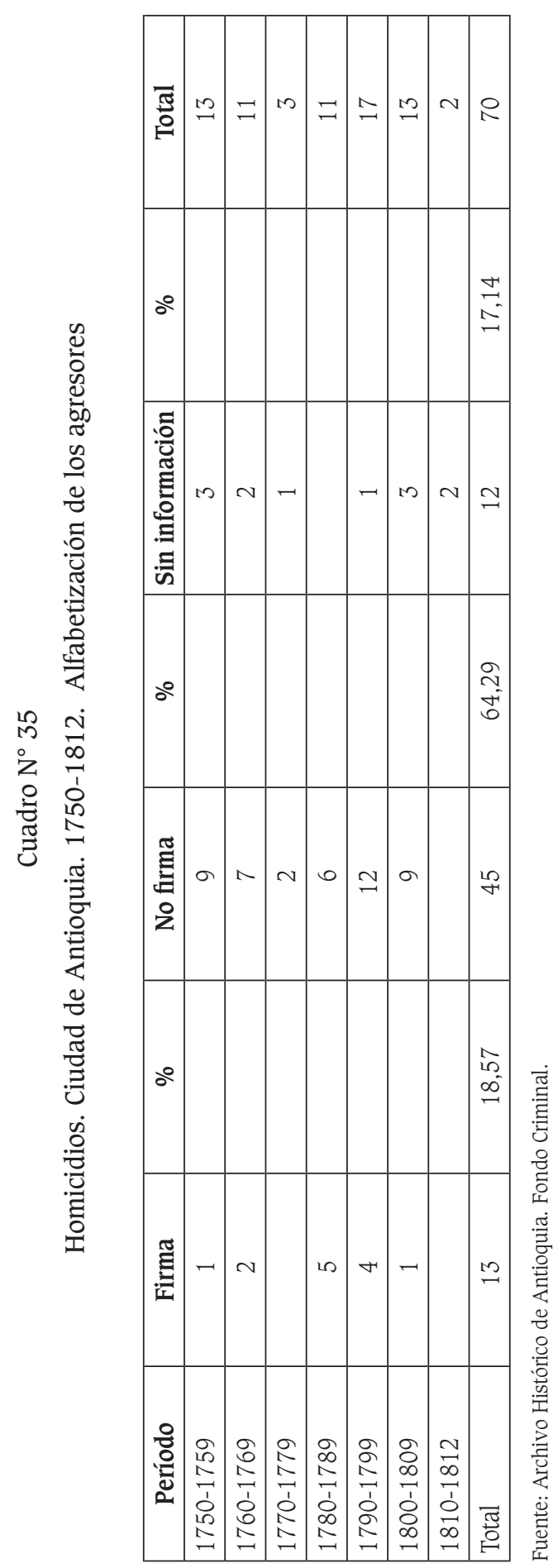




\begin{tabular}{|c|c|c|c|c|c|c|c|c|c|}
\hline \multirow{20}{*}{ 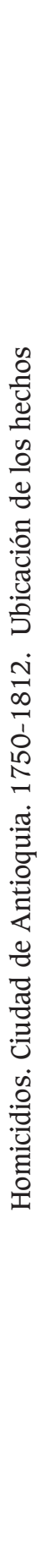 } & [E]OL & $\sim$ & $\wedge$ & $\sim$ & $\infty$ & $\wedge$ & $\exists$ & $\sim$ & 字 \\
\hline & & & & & & & & & $\begin{array}{l}10 \\
20 \\
\forall\end{array}$ \\
\hline & $\begin{array}{c}\text { Uo!̣ } \\
\text {-ew.ıјu! U!S }\end{array}$ & - & - & & & & & & $\sim$ \\
\hline & $\%$ & & & & & & & & $\stackrel{\sim}{\sim}$ \\
\hline & Solno esej & & & & - & & & & - \\
\hline & $\%$ & & & & & & & & $\begin{array}{l}\text { gे } \\
\text { mi }\end{array}$ \\
\hline & 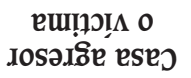 & $m$ & D & $\sim$ & $\sim$ & $\sim$ & $\sim$ & - & 10 \\
\hline & $\%$ & & & & & & & & $\begin{array}{l}8 \\
0 \\
\text { in }\end{array}$ \\
\hline & $\begin{array}{c}\text { où o } \\
\text { eppexqәñ }\end{array}$ & & & & $\nabla$ & $m$ & $\sigma$ & & $\Xi$ \\
\hline & $\%$ & & & & & & & & $\begin{array}{l}10 \\
20 \\
8\end{array}$ \\
\hline & eu!W & & - & & & & - & & $v$ \\
\hline & $\%$ & & & & & & & & $\begin{array}{l}\sigma \\
\sigma \\
10\end{array}$ \\
\hline & $\begin{array}{l}\text { วұนош } \\
\text {-odurग }\end{array}$ & & $\sim$ & & & - & $\sigma$ & & $\Lambda$ \\
\hline & $\%$ & & & & & & & & $\begin{array}{l}10 \\
10 \\
\forall\end{array}$ \\
\hline & 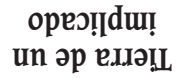 & - & & & & & & - & $\sim$ \\
\hline & $\%$ & & & & & & & & $\begin{array}{l}\hat{v} \\
\tilde{N}\end{array}$ \\
\hline & ગાएગ & - & & & & & & & - \\
\hline & $\%$ & & & & & & & & $\begin{array}{l}\mathcal{N}^{-} \\
0^{-}\end{array}$ \\
\hline & ou!̣ues & - & & & -1 & - & & & $m$ \\
\hline & 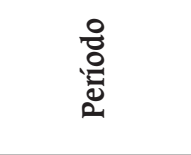 & 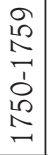 & $\begin{array}{l}8 \\
0 \\
7 \\
1 \\
8 \\
2 \\
\end{array}$ & 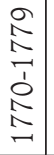 & 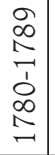 & 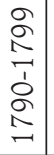 & 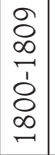 & 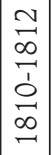 & 可 \\
\hline
\end{tabular}


Beatriz Patiño Millán

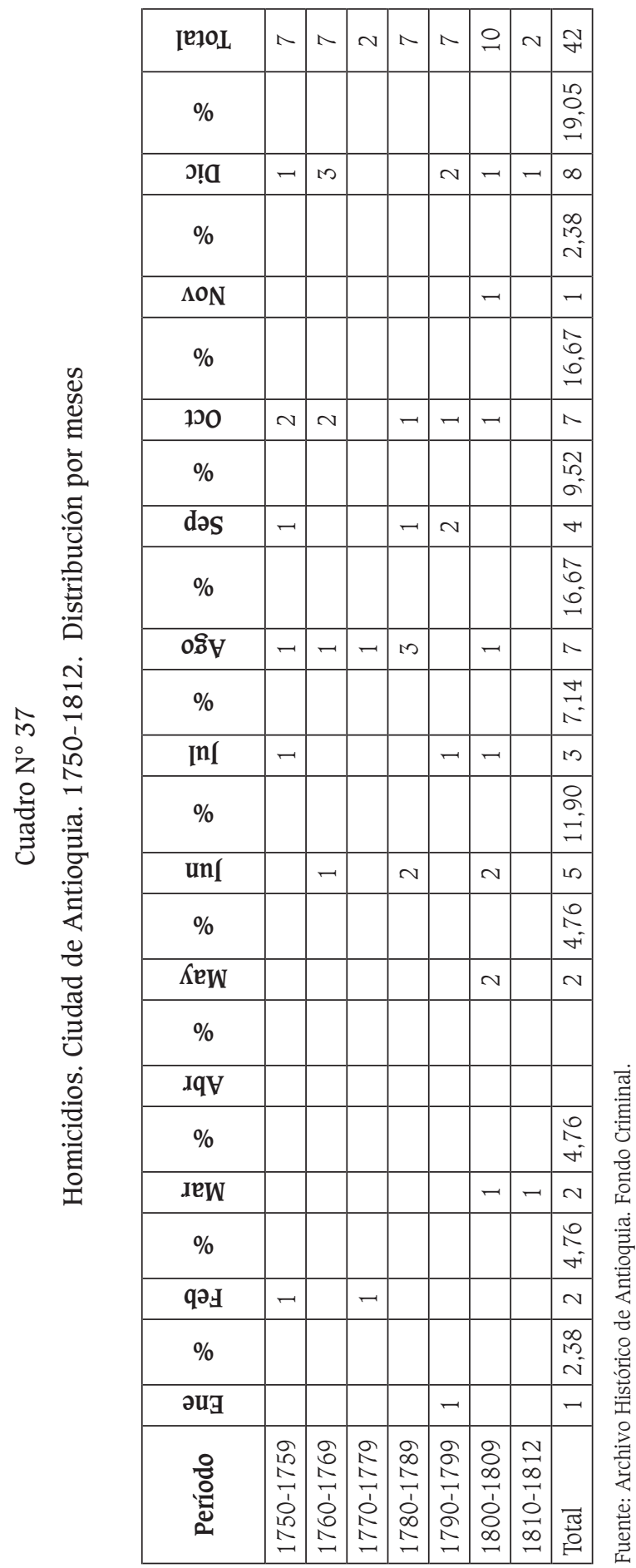


Criminalidad, Ley Penal y Estructura Social en la Provincia de Antioquia 1750-1820

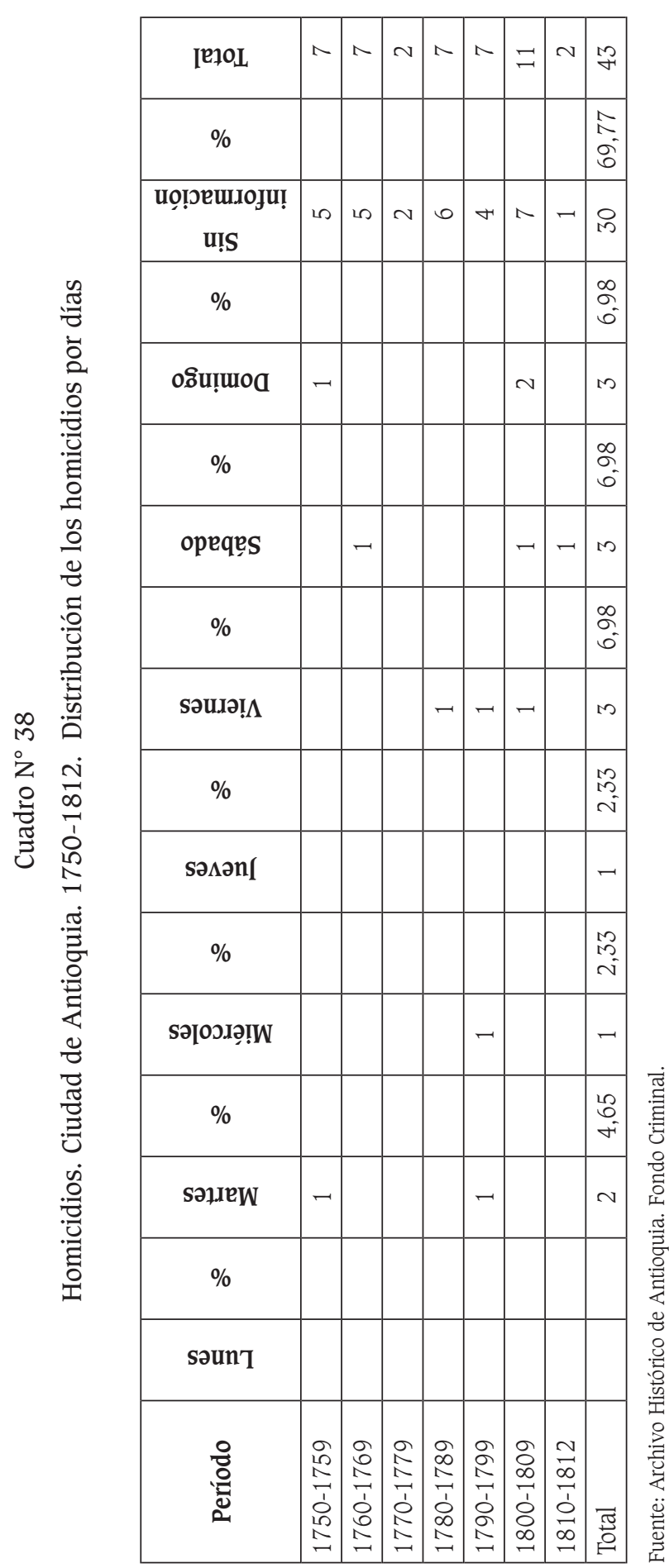


Beatriz Patiño Millán

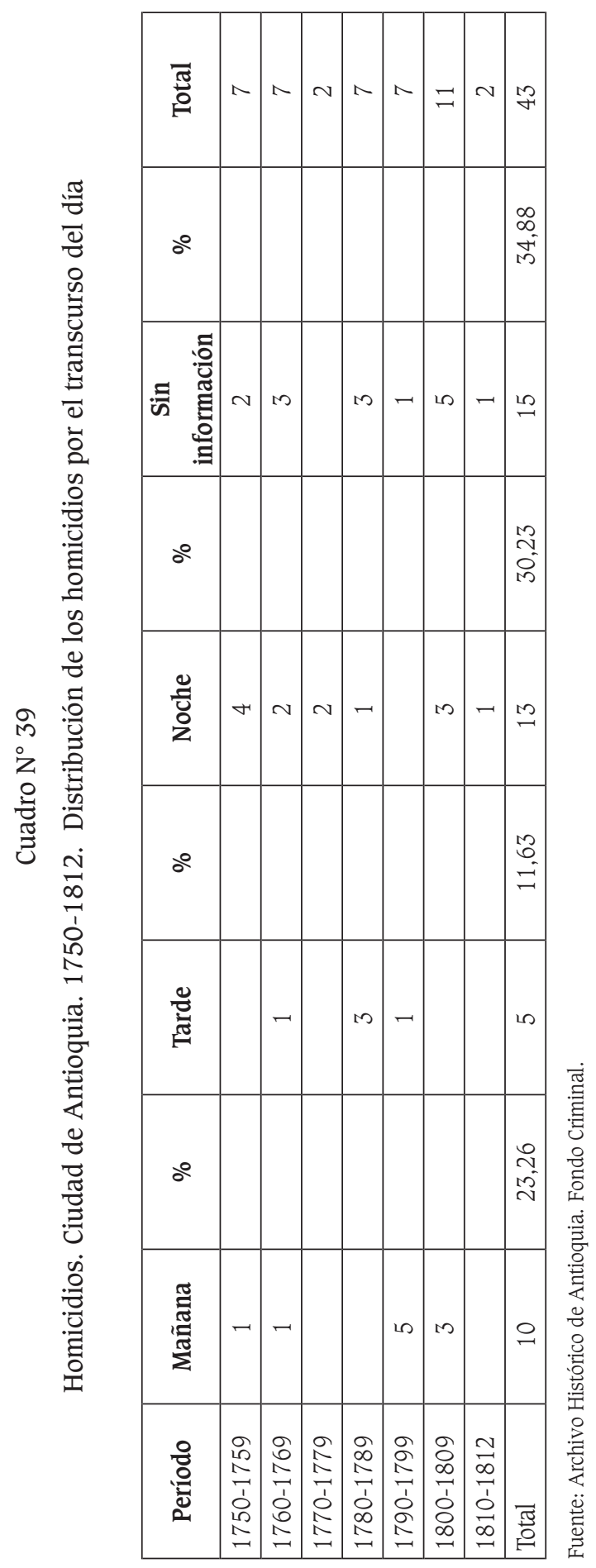




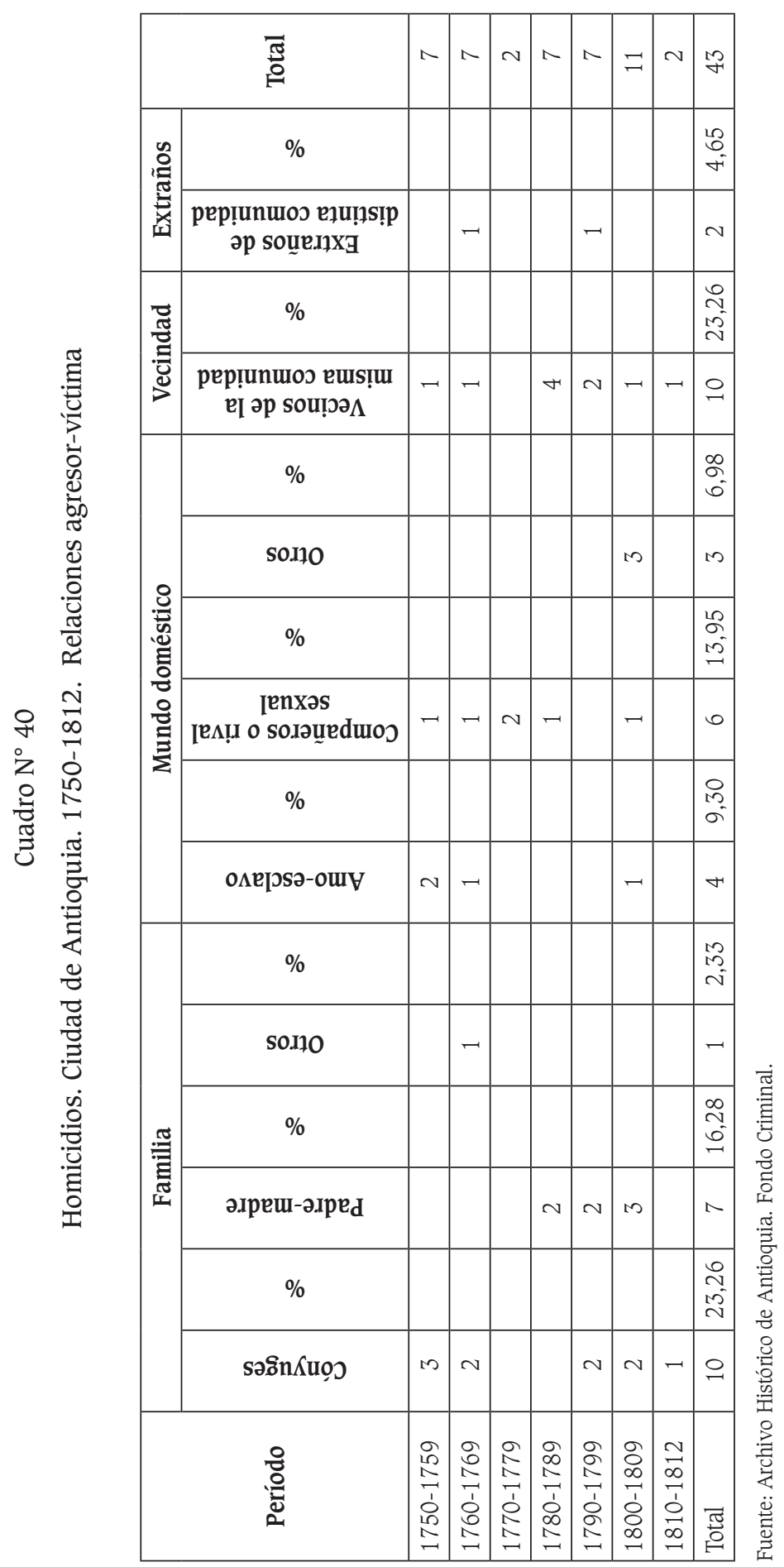




\section{Cuadro $\mathrm{N}^{\circ} 41$}

Homicidios. Ciudad de Antioquia. 1750-1812.

Motivos argüidos por las víctimas y los agresores

\begin{tabular}{|l|r|r|}
\hline \multicolumn{1}{|c|}{ Categoría } & Número de casos & $\%$ \\
\hline Problemas económicos & & \\
Robo & 4 & 6,06 \\
Miseria & 1 & 1,52 \\
Problemas por compras & 1 & 1,52 \\
Problemas por trabajo & 4 & 6,06 \\
Total & 10 & 15,15 \\
\hline Problemas vida en familia y vecindad & & \\
No querer que el hijo fuera esclavo & 1 & 1,52 \\
Quejas maltrato & 5 & 7,58 \\
Ultrajes & 3 & 4,55 \\
Embriaguez & 3 & 4,55 \\
Mal parto & 1 & 1,52 \\
Total & 13 & 19,70 \\
\hline Problemas relaciones sexuales & & \\
Concubinato o infidelidad & 5 & 7,58 \\
Persecución sexual & 10 & 3,03 \\
Celos & 4 & 15,15 \\
Ocultar embarazo & 21 & 6,06 \\
Total & 17 & 31,82 \\
\hline Varios & 5 & \\
Defensa & 4 & 6,06 \\
Perturbación mental locura & 7,58 \\
Tentación del diablo & 5 & 7,58 \\
Accidente & 1 & 25,76 \\
Total & & \\
\hline Sin especificar & & \\
Total & & \\
\hline
\end{tabular}

Fuente: Archivo Histórico de Antioquia. Fondo Criminal. 


\section{Cuadro $\mathrm{N}^{\circ} 42$}

Homicidios. Ciudad de Antioquia. 1750-1812.

\section{Armas utilizadas por los agresores}

\begin{tabular}{|l|c|c|}
\hline \multicolumn{1}{|c|}{ Armas } & Número de casos & $\%$ \\
\hline Cuchillo & 6 & 13,95 \\
\hline Machete & 2 & 4,65 \\
\hline Daga & 1 & 2,33 \\
\hline Navaja & 2 & 4,65 \\
\hline Lanza & 2 & 4,65 \\
\hline Tijeras & 1 & 2,33 \\
\hline Arma de fuego & 1 & 2,33 \\
\hline Hacha & 3 & 4,65 \\
\hline Trapiche & 1 & 2,33 \\
\hline Piedras & 2 & 4,65 \\
\hline Palos & 2 & 4,65 \\
\hline Golpes & 2 & 4,65 \\
\hline Lazo & 1 & 2,33 \\
\hline Veneno (abortivo) & 2 & 4,65 \\
\hline Agua (ahogar) & 7 & 16,28 \\
\hline Tierra (enterrar vivo) & 2 & 4,65 \\
\hline Tigre & 1 & 2,33 \\
\hline Sin información & 6 & 13,95 \\
\hline Total & 43 & \\
\hline
\end{tabular}

Fuente: Archivo Histórico de Antioquia. Fondo Criminal. 
Cuadro $\mathrm{N}^{\circ} 43$

Homicidios. Ciudad de Antioquia. 1750-1812.

Sentencias

\begin{tabular}{|l|c|c|}
\hline \multicolumn{1}{|c|}{ Pena } & Número de casos & $\%$ \\
\hline Pena de muerte & 7 & 17,07 \\
\hline Azotes & 1 & 2,44 \\
\hline Prisión & 7 & 17,07 \\
\hline Presidio de Cartagena & 1 & 2,44 \\
\hline Destierro & 1 & 2,44 \\
\hline Obras públicas & 3 & 7,32 \\
\hline Ejercer oficio de verdugo & 1 & 2,44 \\
\hline Absolución & 8 & 19,51 \\
\hline Indulto & 4 & 9,76 \\
\hline Inconclusa & 8 & 19,51 \\
\hline Total & 41 & \\
\hline
\end{tabular}

Fuente: Archivo Histórico de Antioquia. Fondo Criminal.

Cuadro $\mathrm{N}^{\circ} 44$

Homicidios. Ciudad de Antioquia. 1750-1812.

Distribución por sexo de los testigos

\begin{tabular}{|r|c|c|c|c|c|}
\hline Período & Hombres & \% & Mujeres & \% & Total \\
\hline $1750-1759$ & 58 & & 13 & & 71 \\
\hline $1760-1769$ & 25 & & 4 & & 29 \\
\hline $1770-1779$ & 16 & & 6 & & 22 \\
\hline $1780-1789$ & 61 & & 17 & & 78 \\
\hline $1790-1799$ & 83 & & 12 & & 95 \\
\hline $1800-1809$ & 72 & & 24 & & 96 \\
\hline $1810-1812$ & 4 & & 2 & & 6 \\
\hline Total & 319 & 80,35 & 78 & 19,65 & 397 \\
\hline
\end{tabular}

Fuente: Archivo Histórico de Antioquia. Fondo Criminal. 
Criminalidad, Ley Penal y Estructura Social en la Provincia de Antioquia 1750-1820

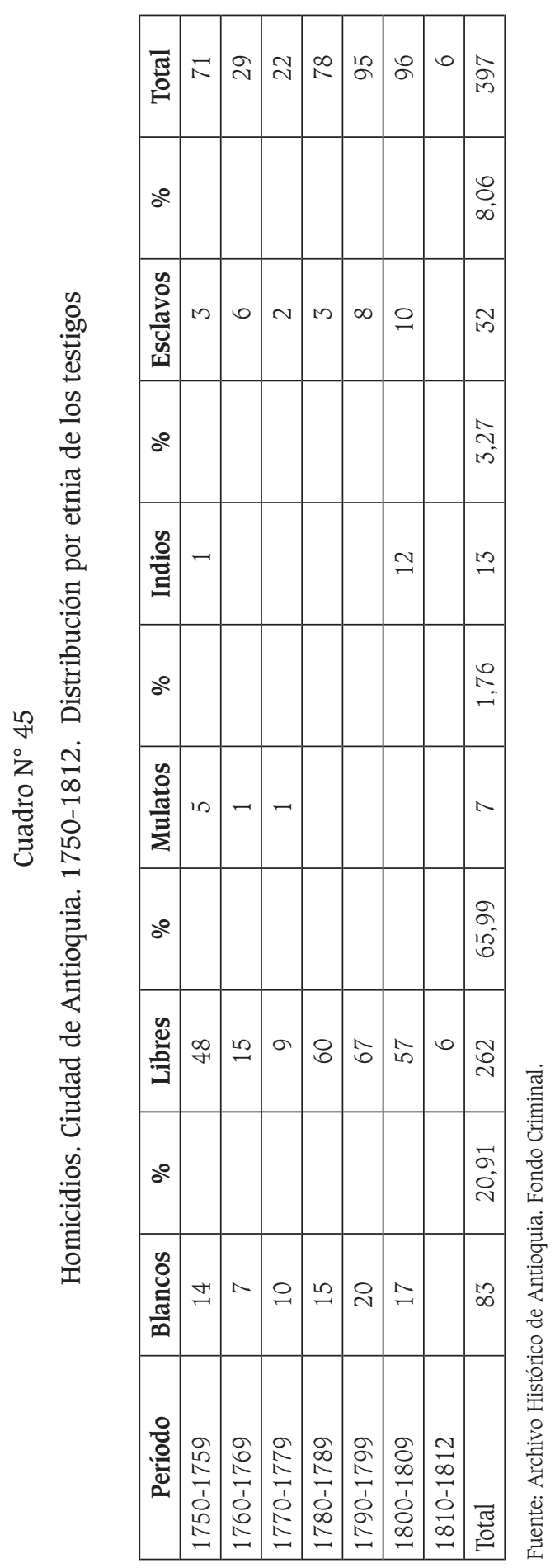


Beatriz Patiño Millán

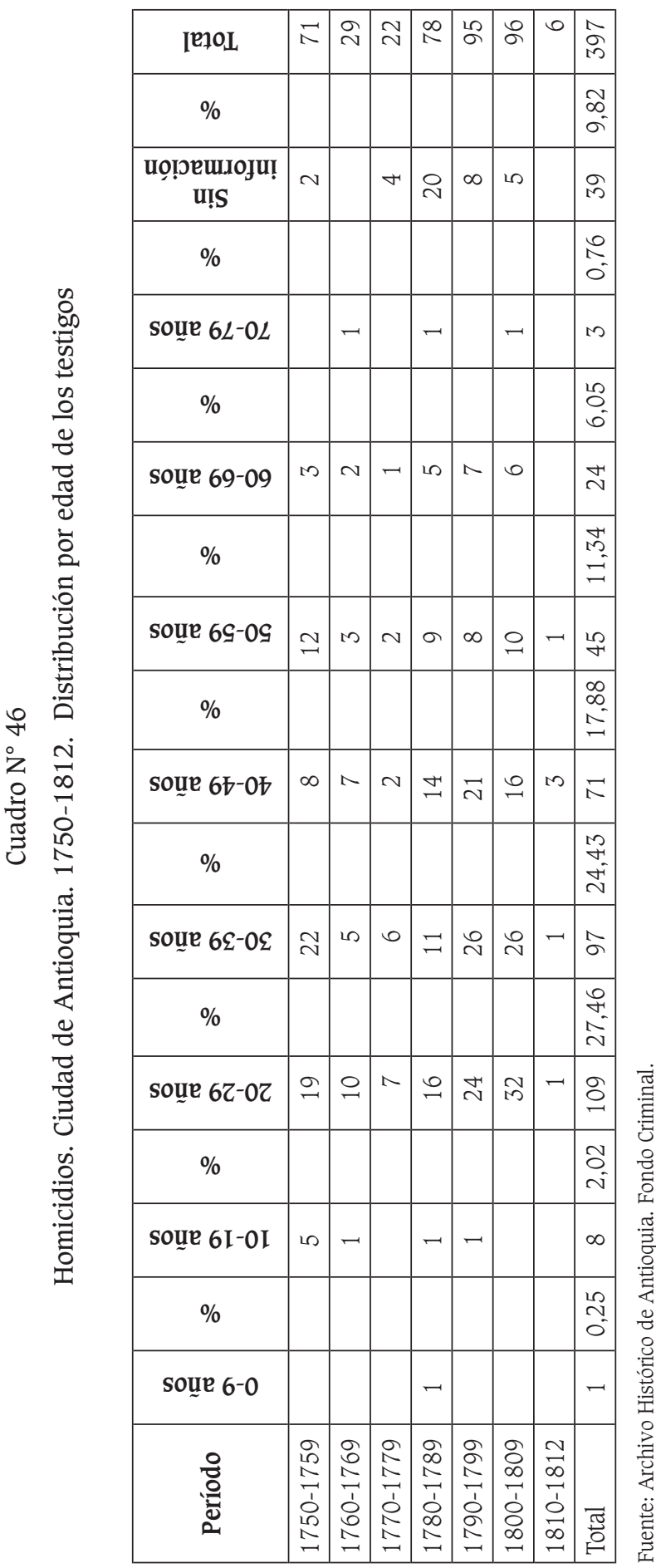




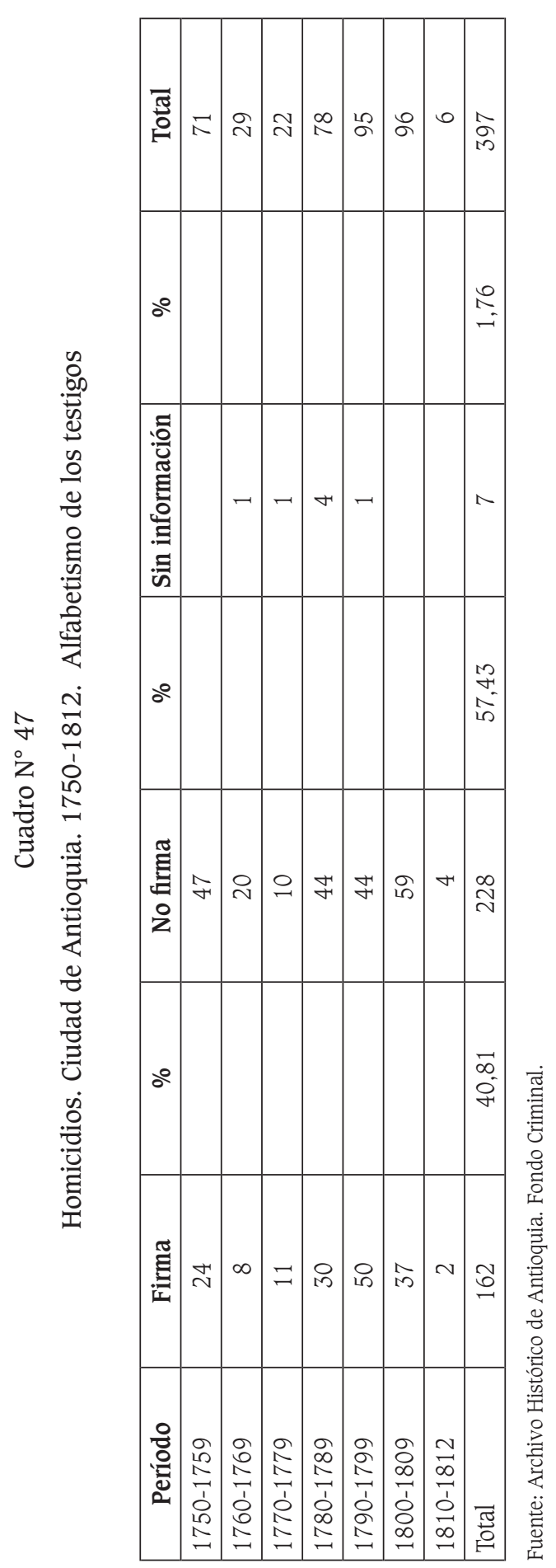


Beatriz Patiño Millán

\begin{tabular}{|c|c|c|c|c|c|c|c|c|c|}
\hline \multirow{20}{*}{ 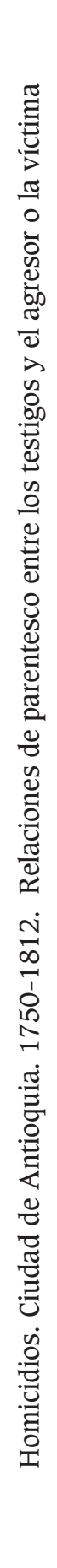 } & [ए]OL & 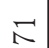 & ণ & $\approx$ & $\infty$ & 2 & 유 & 0 & ล̄ \\
\hline & $\%$ & & & & & & & & $\begin{array}{l}8 \\
0 \\
8\end{array}$ \\
\hline & ounsิu!̣ & $\underset{+}{\infty}$ & $\stackrel{\sim}{\sim}$ & $\stackrel{\infty}{-}$ & $\mathfrak{N}$ & $\infty$ & ชิ & 20 & $\frac{0}{m}$ \\
\hline & $\%$ & & & & & & & & $\begin{array}{c}\hat{\sim} \\
\tilde{v}\end{array}$ \\
\hline & 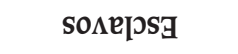 & & & & & - & $\infty$ & & a \\
\hline & $\%$ & & & & & & & & $\begin{array}{l}0 \\
10 \\
0\end{array}$ \\
\hline & səspeduos & & & & & $\sim$ & & & $\sim$ \\
\hline & $\%$ & & & & & & & & $\begin{array}{l}\Omega \\
\frac{R}{\sigma}\end{array}$ \\
\hline & әрนวฺ̣е & $\infty$ & - & & & & 으 & & 인 \\
\hline & $\%$ & & & & & & & & $\stackrel{\sim}{i}$ \\
\hline & 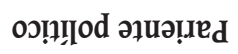 & 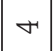 & $\sim$ & & 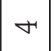 & - & $\sim$ & & 음 \\
\hline & $\%$ & & & & & & & & $\begin{array}{l}\hat{N} \\
\mathrm{~N}\end{array}$ \\
\hline & sou!̣d-soIJL & $\infty$ & - & & & $\sim$ & 10 & & $\Xi$ \\
\hline & $\%$ & & & & & & & & $\begin{array}{c}\hat{N} \\
\text { in }\end{array}$ \\
\hline & sочеш.رН & $m$ & & - & & - & $\sim$ & - & $\because$ \\
\hline & $\%$ & & & & & & & & $\begin{array}{l}0 \\
=\end{array}$ \\
\hline & səริnরuọ & $m$ & & $\sim$ & $\sim$ & & & & $\Lambda$ \\
\hline & $\%$ & & & & & & & & $\stackrel{0}{N}$ \\
\hline & səupe $_{\mathbf{d}}$ & $\sim$ & & - & & $\sim$ & $\sim$ & & $\wedge$ \\
\hline & $\begin{array}{l}\text { 응 } \\
\text { 임 } \\
0\end{array}$ & 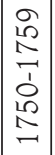 & $\begin{array}{l}0 \\
0 \\
2 \\
1 \\
\delta \\
0 \\
\end{array}$ & 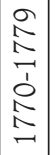 & 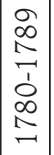 & 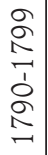 & \begin{tabular}{l}
8 \\
8 \\
$\infty$ \\
\hdashline 1 \\
8 \\
$\infty$ \\
$\infty$
\end{tabular} & 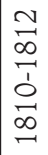 & 중 \\
\hline
\end{tabular}




\section{Cuadro $\mathrm{N}^{\circ} 49$}

Injurias y lesiones personales. Ciudad de Antioquia. 1810-1819.

Distribución por sexo de los testigos

\begin{tabular}{|l|c|c|}
\hline \multicolumn{1}{|c|}{ Sexo } & Número & \% \\
\hline Hombres & 227 & 89,02 \\
\hline Mujeres & 28 & 10,98 \\
\hline Total & 255 & \\
\hline
\end{tabular}

Fuente: Archivo Histórico de Antioquia. Fondo Criminal.

\section{Cuadro $\mathrm{N}^{\circ} 50$}

Injurias y lesiones personales. Ciudad de Antioquia. 1810-1819.

Distribución por etnia de los testigos

\begin{tabular}{|l|c|c|}
\hline \multicolumn{1}{|c|}{ Etnia } & Número & $\%$ \\
\hline Blancos & 38 & 14,90 \\
\hline Libres & 207 & 81,18 \\
\hline Mulatos & 1 & 0,39 \\
\hline Indios & 5 & 1,96 \\
\hline Esclavos & 4 & 1,57 \\
\hline Total & 255 & \\
\hline
\end{tabular}

Fuente: Archivo Histórico de Antioquia. Fondo Criminal.

\section{Cuadro $\mathrm{N}^{\circ} 51$}

Injurias y lesiones personales. Ciudad de Antioquia. 1810-1819.

Distribución por edad de los testigos

\begin{tabular}{|l|c|c|}
\hline \multicolumn{1}{|c|}{ Edad (Años) } & Número & $\%$ \\
\hline $10-19$ & 4 & 1,57 \\
\hline $20-29$ & 96 & 37,65 \\
\hline $30-39$ & 60 & 23,53 \\
\hline $40-49$ & 45 & 17,65 \\
\hline $50-59$ & 27 & 10,59 \\
\hline $60-69$ & 5 & 1,96 \\
\hline $70-79$ & 1 & 0,39 \\
\hline Sin información & 17 & 6,67 \\
\hline Total & 255 & \\
\hline
\end{tabular}

Fuente: Archivo Histórico de Antioquia. Fondo Criminal. 


\section{Cuadro $\mathrm{N}^{\circ} 52$}

Injurias y lesiones personales. Ciudad de Antioquia. 1810-1819.

Alfabetismo de los testigos

\begin{tabular}{|l|c|c|}
\hline \multicolumn{1}{|c|}{ Alfabetismo } & Número & \% \\
\hline Firma & 134 & 52,55 \\
\hline No Firma & 121 & 47,45 \\
\hline Total & 255 & \\
\hline
\end{tabular}

Fuente: Archivo Histórico de Antioquia. Fondo Criminal.

\section{Cuadro $\mathrm{N}^{\circ} 53$}

Injurias y lesiones personales. Ciudad de Antioquia. 1810-1819.

Relaciones de parentesco entre los testigos y el agresor o la víctima

\begin{tabular}{|l|c|c|}
\hline \multicolumn{1}{|c|}{ Parentesco } & Número & \% \\
\hline Cónyuges & 1 & 0,39 \\
\hline Hermanos & 1 & 0,39 \\
\hline Tíos-primos & 2 & 0,78 \\
\hline Pariente político & 2 & 0,78 \\
\hline Pariente & 18 & 7,06 \\
\hline Compadre & 2 & 0,78 \\
\hline Esclavo sirviente & 2 & 0,78 \\
\hline Sin información & 227 & 89,02 \\
\hline Total & 255 & \\
\hline
\end{tabular}

Fuente: Archivo Histórico de Antioquia. Fondo Criminal.

\section{Cuadro $\mathrm{N}^{\circ} 54$}

Injurias y agravios. Ciudad de Antioquia. 1810-1819.

Formas de iniciación de la causa

\begin{tabular}{|l|c|c|}
\hline \multicolumn{1}{|c|}{ Acusación } & Número de casos & \% \\
\hline A petición del injurado & 100 & 73,53 \\
\hline A petición de un representante de injurado & 18 & 13,24 \\
\hline A petición del agresor & 4 & 2,94 \\
\hline De oficio por un juez & 12 & 8,82 \\
\hline Sin información & 2 & 1,47 \\
\hline Total & 136 & \\
\hline
\end{tabular}

Fuente: Archivo Histórico de Antioquia. Fondo Criminal. 
Criminalidad, Ley Penal y Estructura Social en la Provincia de Antioquia 1750-1820

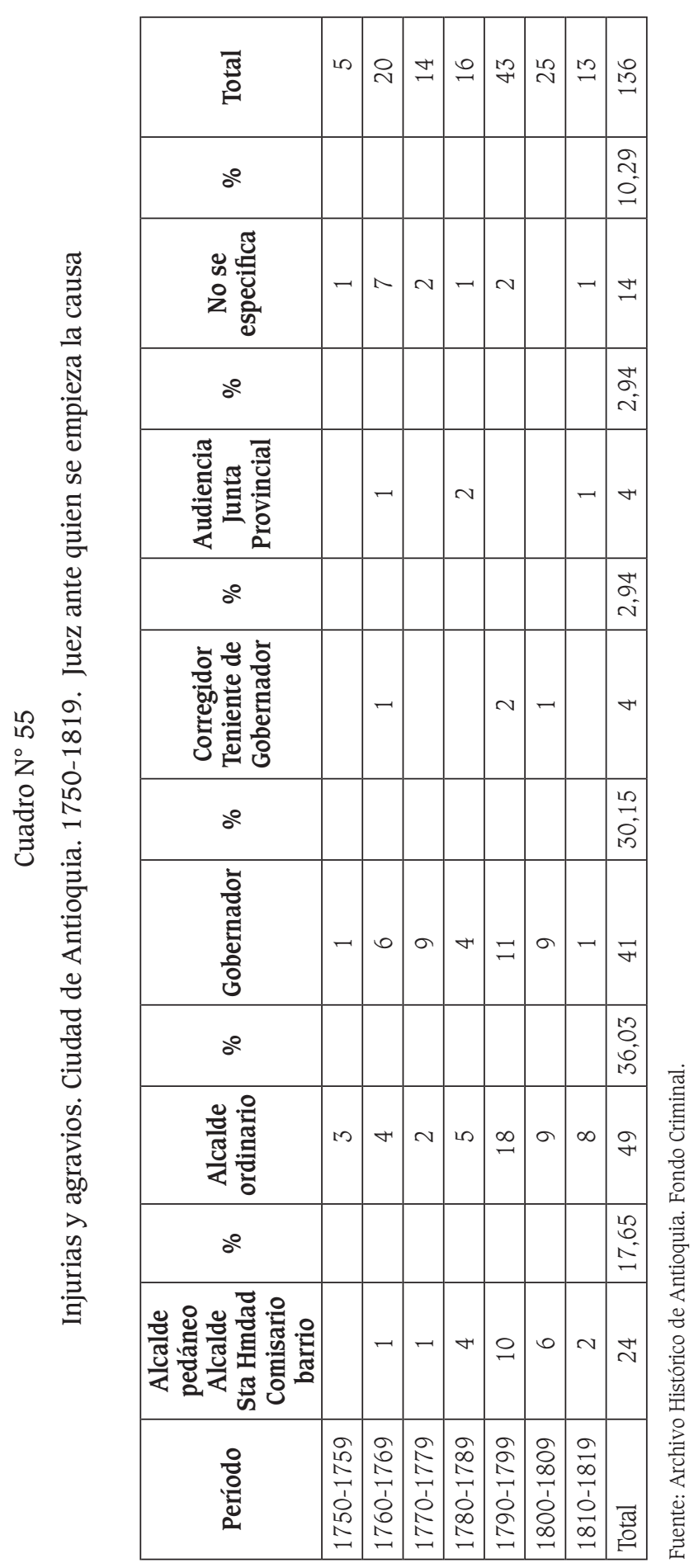


Beatriz Patiño Millán

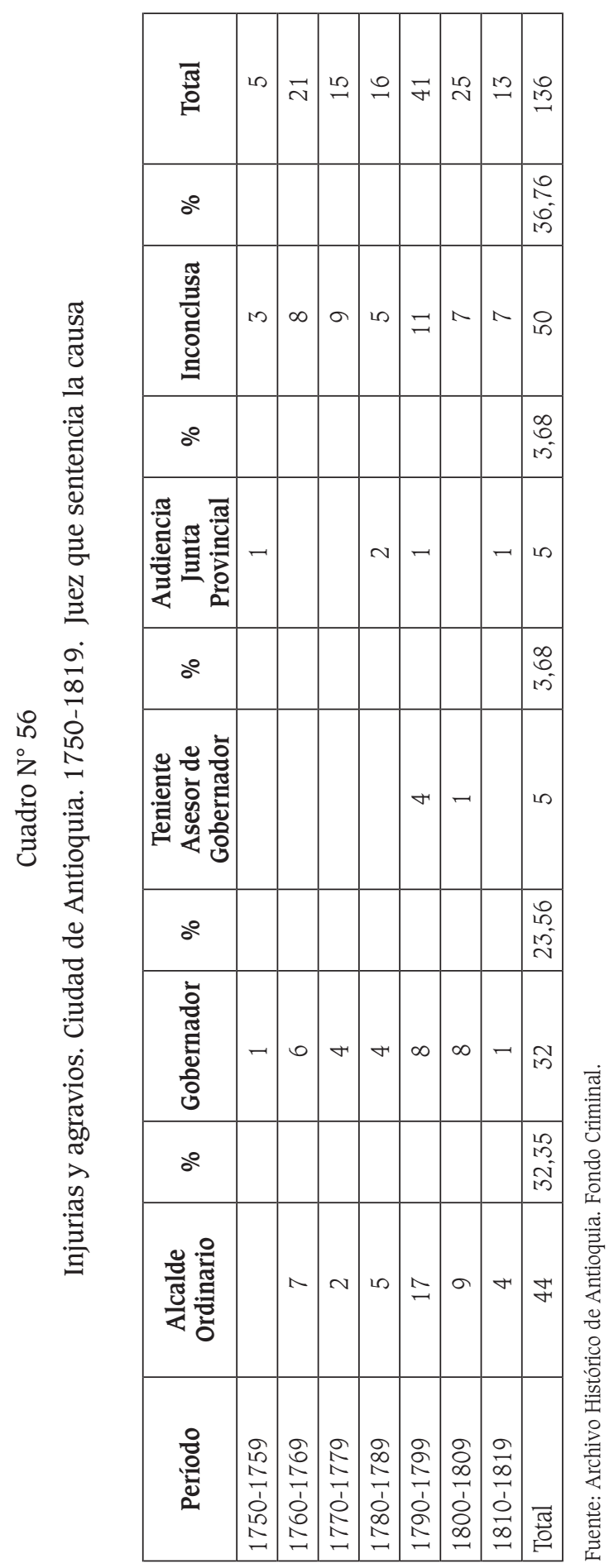




\section{Cuadro $\mathrm{N}^{\circ} 57$}

Heridas y lesiones personales.

Ciudad de Antioquia. 1750-1819.

Formas de iniciación de la causa

\begin{tabular}{|l|c|c|}
\hline \multicolumn{1}{|c|}{ Acusación } & Número de casos & \% \\
\hline A petición de la víctima & 88 & 43,35 \\
\hline A petición de un representante de la víctima & 39 & 19,21 \\
\hline A petición del agresor & 11 & 5,42 \\
\hline A petición de un tercero & 9 & 4,43 \\
\hline De oficio por un juez & 56 & 27,59 \\
\hline Total & 203 & \\
\hline
\end{tabular}

Fuente: Archivo Histórico de Antioquia. Fondo Criminal. 
Beatriz Patiño Millán

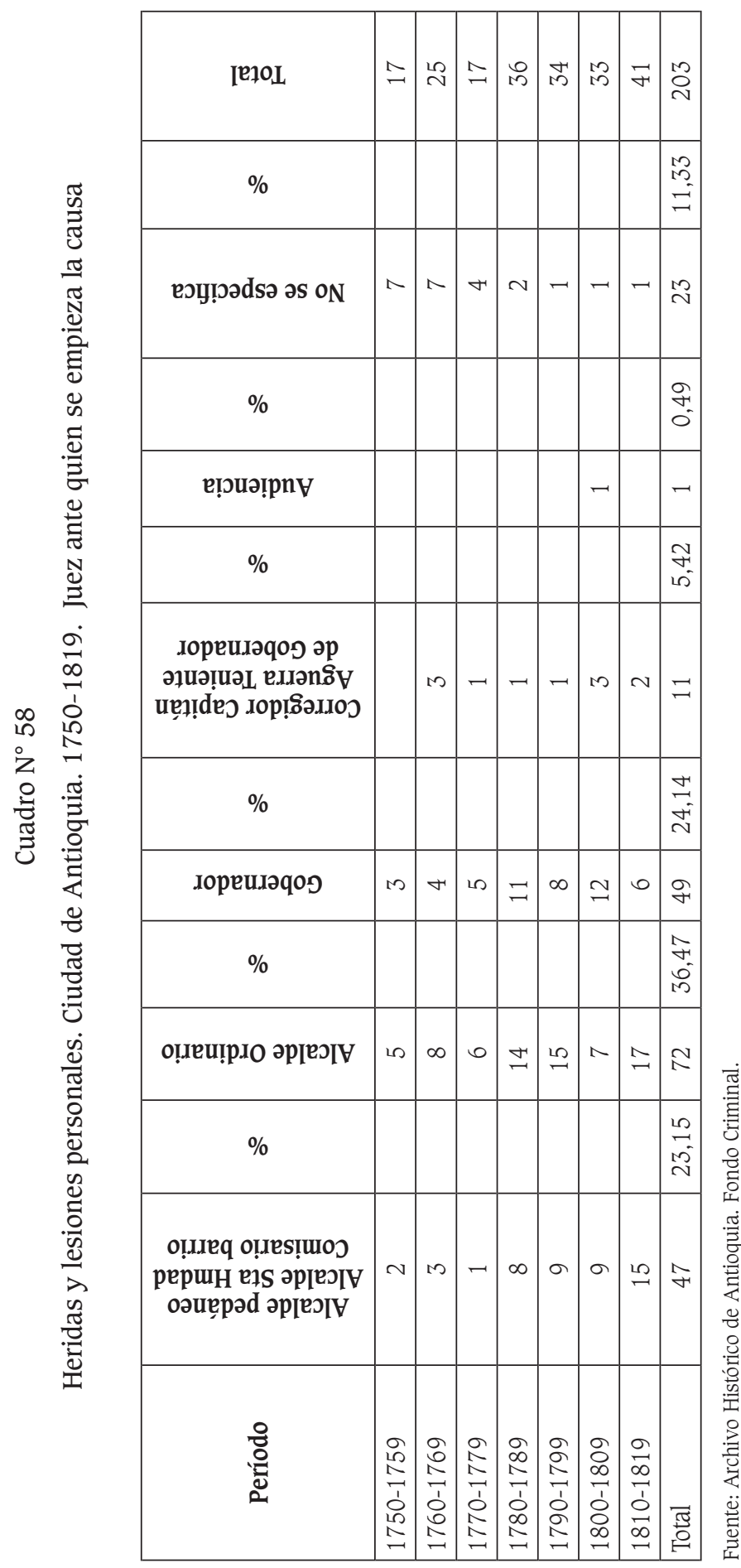


Criminalidad, Ley Penal y Estructura Social en la Provincia de Antioquia 1750-1820

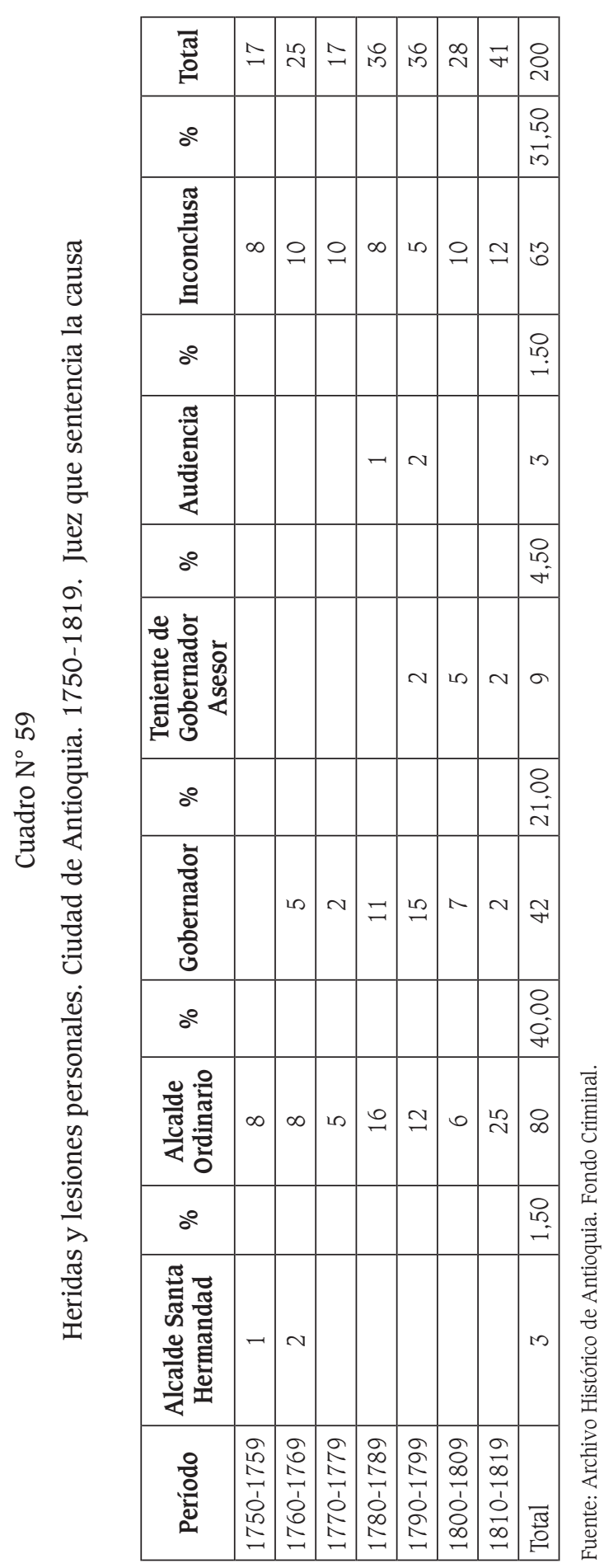


Cuadro $\mathrm{N}^{\circ} 60$

Homicidios. Ciudad de Antioquia. 1750-1812.

Formas de iniciación de la causa

\begin{tabular}{|l|c|c|}
\hline \multicolumn{1}{|c|}{ Acusación } & Número de casos & \% \\
\hline A petición de la familia de la víctima & 5 & 11,63 \\
\hline A petición de un tercero & 7 & 16,28 \\
\hline De oficio por el alcalde & 30 & 69,77 \\
\hline A petición del agresor & 1 & 2,33 \\
\hline Total & 43 & \\
\hline
\end{tabular}

Fuente: Archivo Histórico de Antioquia. Fondo Criminal. 
Criminalidad, Ley Penal y Estructura Social en la Provincia de Antioquia 1750-1820

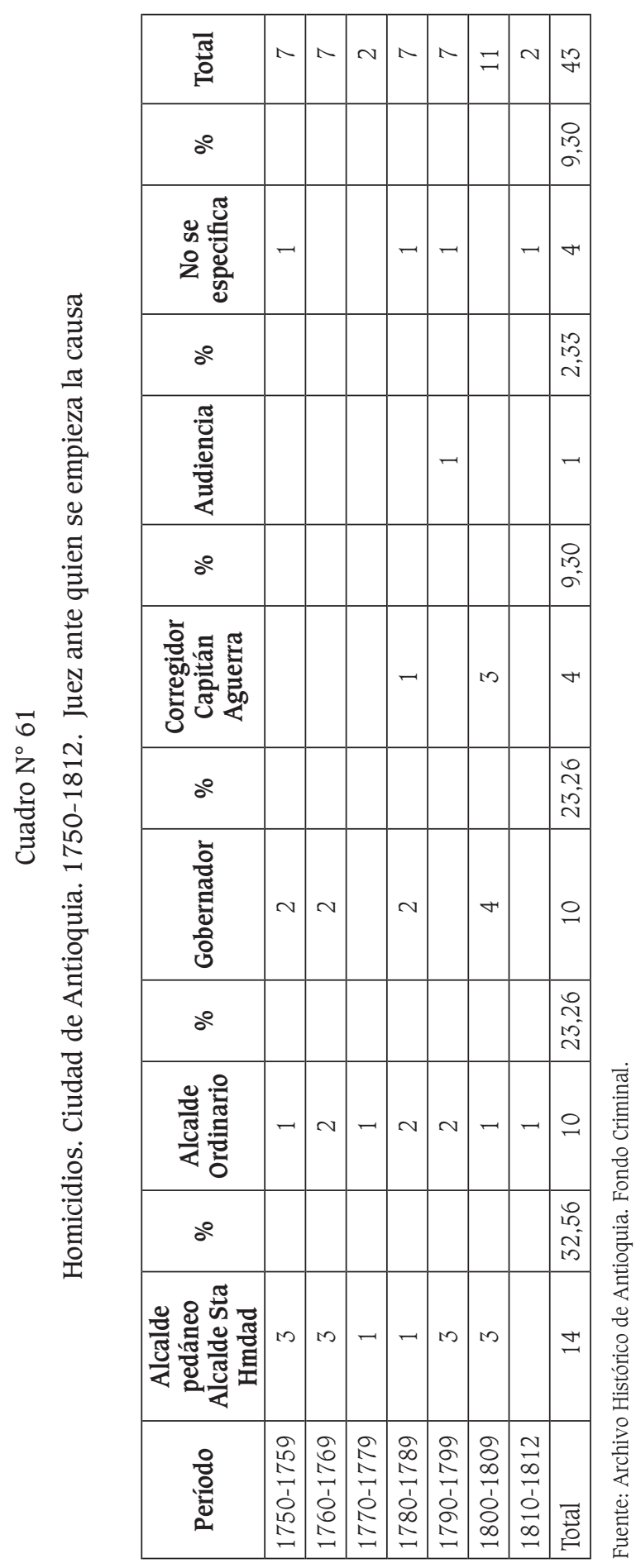


Beatriz Patiño Millán

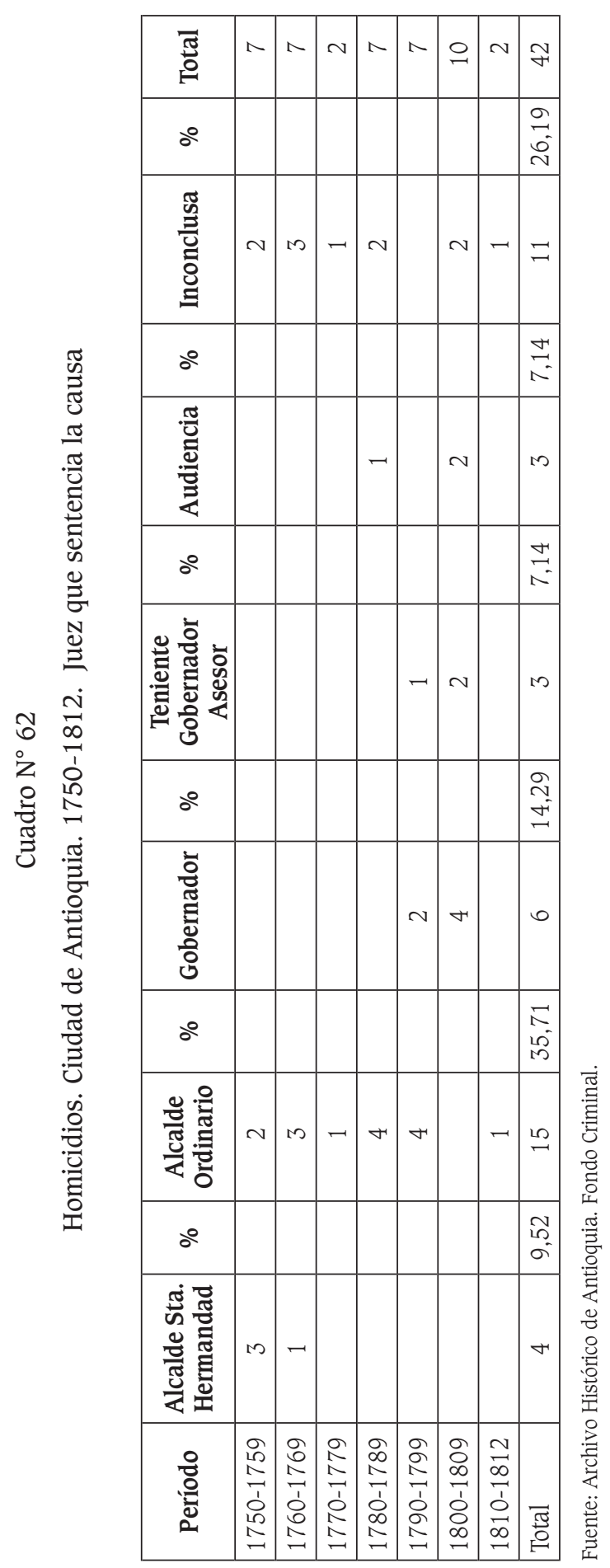




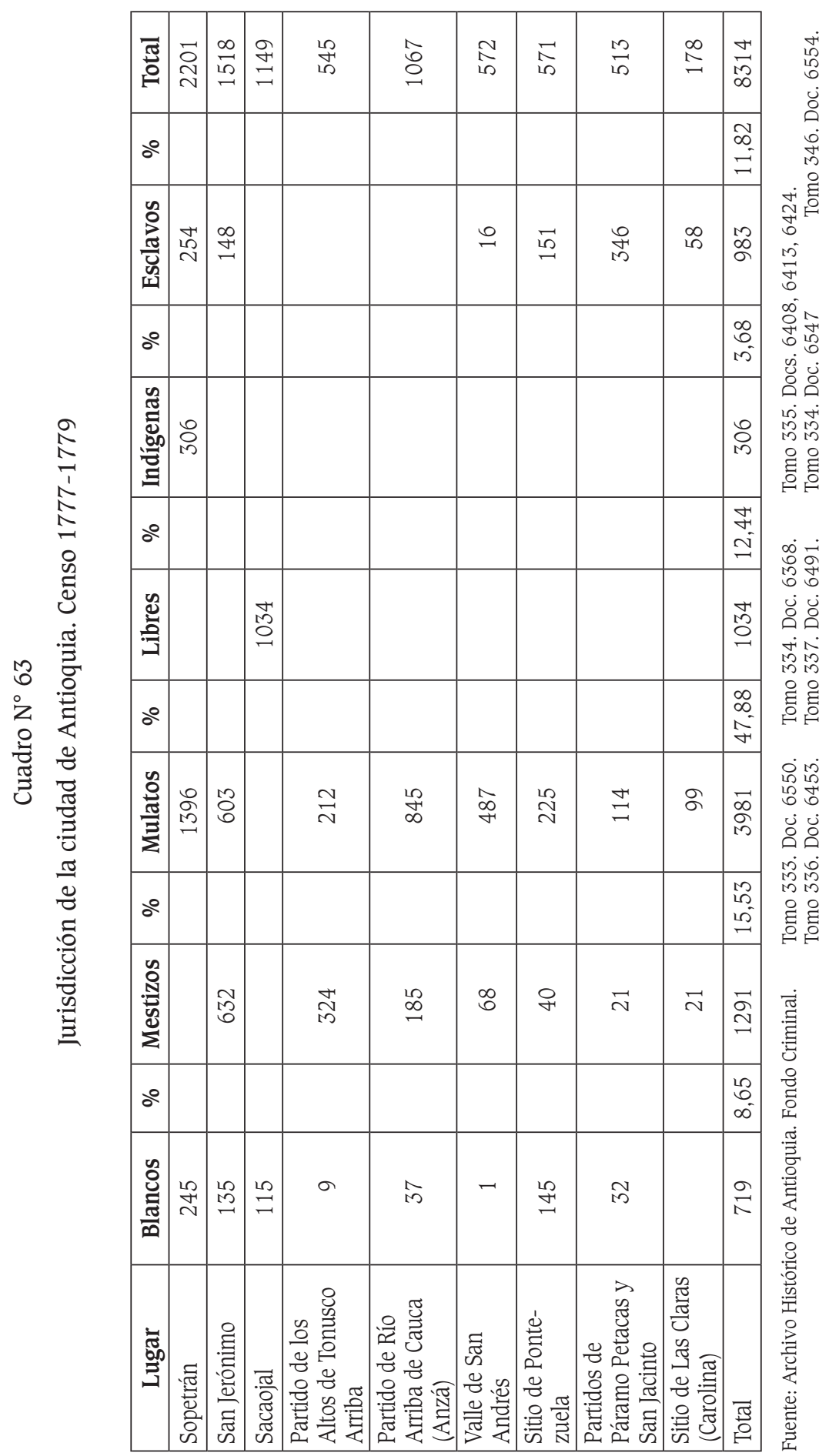




\section{Cuadro $\mathrm{N}^{\circ} 64$}

Población del Distrito de la Audiencia de Santa fe. 1778-1780

\begin{tabular}{|l|c|c|c|c|}
\hline & Hombres & Mujeres & Total & \% \\
\hline Estado Eclesiástico & 1962 & 470 & 2432 & 0,33 \\
\hline Blancos & 92748 & 95477 & 188225 & 25,34 \\
\hline Indios & 66731 & 73592 & 140323 & 18,89 \\
\hline Libres & 18496 & 181018 & 365614 & 49,22 \\
\hline Esclavos & 23236 & 22929 & 46165 & 6,22 \\
\hline Total & 369273 & 373486 & 742759 & \\
\hline
\end{tabular}

Población de la Provincia de Antioquia. 1778

\begin{tabular}{|l|c|r|r|r|}
\hline & Hombres & Mujeres & \multicolumn{1}{c|}{ Total } & \multicolumn{1}{c|}{$\%$} \\
\hline Estado Eclesiástico & 111 & & 111 & 0,24 \\
\hline Blancos & 3850 & 3905 & 7755 & 16,73 \\
\hline Indios & 1092 & 942 & 2034 & 4,39 \\
\hline Libres & 16524 & 11011 & 27535 & 59,39 \\
\hline Esclavos & 4896 & 4035 & 8931 & 19,26 \\
\hline Total & 26473 & 19893 & 46366 & \\
\hline
\end{tabular}

Fuente: Relación de Mando del Arzobispo Virrey. 1789. En: Colmenares, Germán. Relaciones e Informes de los Gobernantes de la Nueva Granada. Bogotá. Biblioteca Banco Popular. 1989. Tomo I. Cuadro A. 


\section{Cuadro $\mathrm{N}^{\circ} 65$}

Jurisdicción de la ciudad de Antioquia. Censo 1788

\begin{tabular}{|l|c|c|c|c|c|c|}
\hline & $\begin{array}{c}\text { Hombres } \\
\text { casados }\end{array}$ & $\begin{array}{c}\text { Hombres sol- } \\
\text { teros incluso } \\
\text { párvulos }\end{array}$ & $\begin{array}{c}\text { Mujeres } \\
\text { casadas }\end{array}$ & $\begin{array}{c}\text { Mujeres sol- } \\
\text { teras incluso } \\
\text { párvulas }\end{array}$ & Total & $\%$ \\
\hline Eclesiásticos & & 21 & & & 21 & 0,11 \\
\hline Blancos & 320 & 703 & 360 & 611 & 1994 & 10,32 \\
\hline Indios & 205 & 632 & 230 & 530 & 1597 & 8,27 \\
\hline $\begin{array}{l}\text { Libres de varios } \\
\text { colores }\end{array}$ & 1350 & 4520 & 2136 & 4536 & 12542 & 64,92 \\
\hline Esclavos & 611 & 1010 & 525 & 1018 & 3164 & 16,38 \\
\hline Total & 2486 & 6886 & 3251 & 6695 & 19318 & \\
\hline
\end{tabular}

Población total de la Provincia. Censo 1788

\begin{tabular}{|l|c|c|c|c|}
\hline & Hombres & Mujeres & Total & $\%$ \\
\hline Eclesiásticos & 83 & & 83 & 0,15 \\
\hline Blancos & 3857 & 4234 & 8091 & 14,43 \\
\hline Indios & 1836 & 1662 & 3498 & 6,24 \\
\hline Libres & 15402 & 19512 & 34914 & 62,29 \\
\hline Esclavos & 4296 & 5170 & 9466 & 16,89 \\
\hline Total & 25474 & 30578 & 56052 & \\
\hline
\end{tabular}

Fuente: Relación de Mando del Arzobispo Virrey. 1789. En: Colmenares, Germán. Relaciones e Informes de los Gobernantes de la Nueva Granada. Bogotá. Biblioteca Banco Popular. 1989. Tomo I. Cuadro B. 


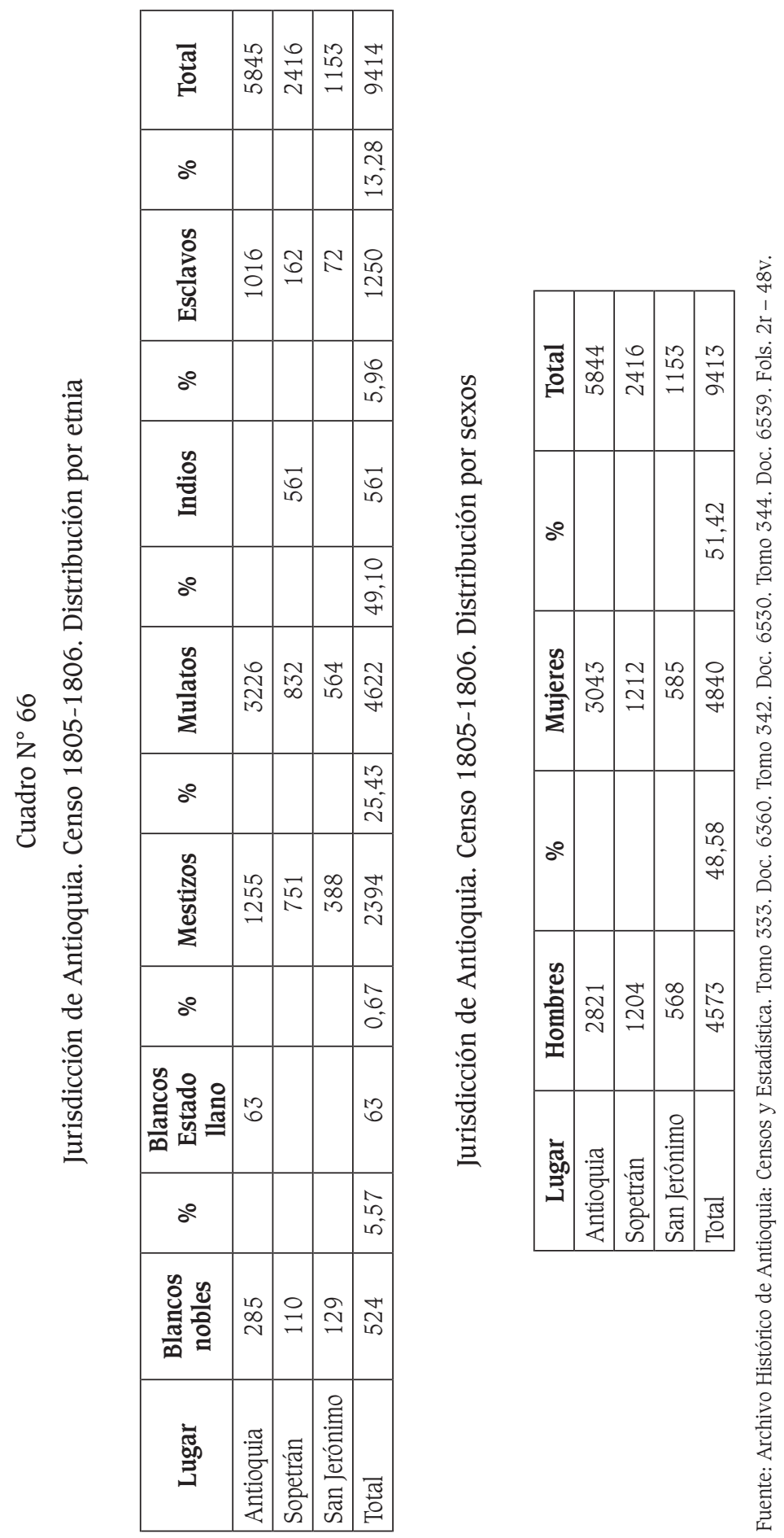


Criminalidad, Ley Penal y Estructura Social en la Provincia de Antioquia 1750-1820

\begin{tabular}{|c|c|c|c|c|c|c|c|c|c|c|}
\hline & 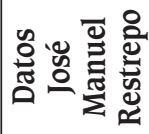 & \begin{tabular}{l}
$\infty$ \\
$\infty$ \\
$\infty$ \\
\hdashline
\end{tabular} & 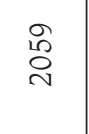 & $\mid \begin{array}{c}\mathbb{N} \\
\stackrel{\sim}{二}\end{array}$ & 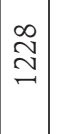 & 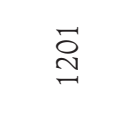 & $\stackrel{\varpi}{\rightleftharpoons}$ & ڤે & 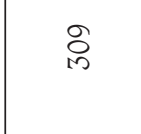 & 잉 \\
\hline & 苞 & 兽 & $\stackrel{\stackrel{\circ}{\oplus}}{\sim}$ & $\begin{array}{l}\hat{o} \\
\stackrel{0}{7}\end{array}$ & 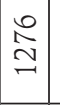 & $\underset{\sim}{\stackrel{D}{\sim}}$ & $\stackrel{\varpi}{\leftrightarrows}$ & & 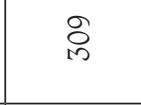 & 8 \\
\hline & $\therefore$ & & & & & & & & & \\
\hline & 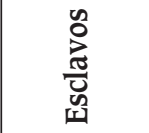 & 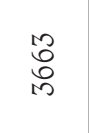 & 요 & $\hat{\sigma}$ & & & $\stackrel{\llcorner}{\mathrm{N}}$ & & $\vec{\sim}$ & $\stackrel{\infty}{\rightarrow}$ \\
\hline & $\therefore$ & & & & & & & & & \\
\hline $\begin{array}{l}8 \\
8 \\
0 \\
0 \\
0\end{array}$ & 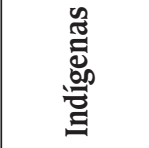 & & 웅 & & & $\underset{\infty}{\stackrel{D}{ }}$ & ং & & $\stackrel{\infty}{\stackrel{\infty}{n}}$ & . \\
\hline 莺 & $\therefore$ & & & & & & & & & \\
\hline 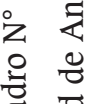 & 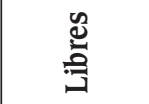 & & & & & $\overrightarrow{\substack{\infty \\
m}}$ & 品 & & 옴 & \\
\hline $\begin{array}{l}3 \\
\end{array}$ & $\therefore$ & & & & & & & & & \\
\hline : & $\frac{\stackrel{0}{0}}{\overbrace{\pi}^{\pi}}$ & 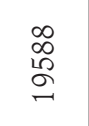 & 啰 & $\overrightarrow{0}$ & & & & & & i্ন \\
\hline 氙 & $\therefore$ & & & & & & & & & \\
\hline & 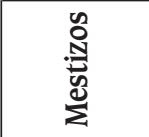 & & 하 & ָ̊ & & & & & & $\begin{array}{l}10 \\
0 \\
100\end{array}$ \\
\hline & ○ & & & & & & & & & \\
\hline & 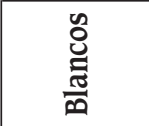 & 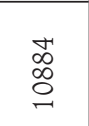 & $\stackrel{\text { ㅇ }}{N}$ & $\stackrel{\Omega}{\Omega}$ & & & & & & 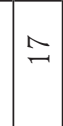 \\
\hline & 䔍 & 惫 & 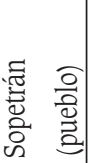 & 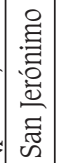 & 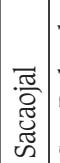 & 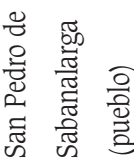 & 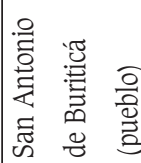 & 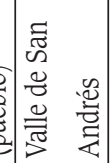 & 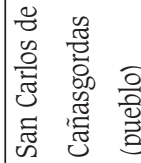 & $\frac{8}{5}$ \\
\hline
\end{tabular}


Beatriz Patiño Millán

\begin{tabular}{|c|c|c|c|c|c|c|c|c|c|c|}
\hline 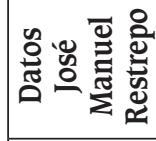 & ร & $\stackrel{\Xi}{\Xi}$ & 离 & $\begin{array}{c}0 \\
\stackrel{2}{0} \\
m\end{array}$ & $\begin{array}{l}\stackrel{n}{2} \\
\stackrel{\sim}{\sim}\end{array}$ & 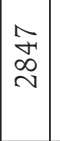 & 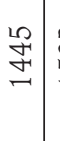 & 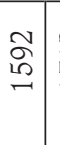 & $\underset{\mathbb{Z}}{\mathbb{Z}}$ & \begin{tabular}{l}
$\infty$ \\
0 \\
$\vdots$ \\
\multirow{1}{*}{}
\end{tabular} \\
\hline స్తే & & & & & & $\begin{array}{l}7 \\
7 \\
0 \\
0\end{array}$ & & & & 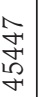 \\
\hline$\therefore$ & & & & & & & & & & $\begin{array}{l}\stackrel{0}{2} \\
\sigma^{\circ}\end{array}$ \\
\hline 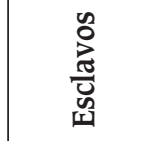 & & & & & & $\stackrel{0}{2}$ & & & & $\begin{array}{l}\stackrel{8}{b} \\
\vec{\sigma}\end{array}$ \\
\hline$\therefore$ & & & & & & & & & & $\begin{array}{l}\infty \\
\infty \\
\infty \\
\boldsymbol{F}^{-}\end{array}$ \\
\hline 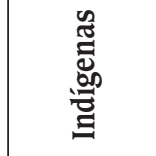 & & & & & & & & & & $\stackrel{\vec{\sim}}{\overrightarrow{\mathrm{N}}}$ \\
\hline$\therefore$ & & & & & & & & & & $\hat{o}_{i}$ \\
\hline 通 & & & & & & & & & & Æ్f \\
\hline$\therefore$ & & & & & & & & & & $\begin{array}{l}\infty \\
\infty \\
\vdots \\
\vdots \\
+1\end{array}$ \\
\hline $\begin{array}{l}\frac{n}{0} \\
\frac{\pi}{\pi} \\
\sum_{\Sigma}^{2}\end{array}$ & & & & & & & & & & 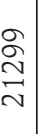 \\
\hline$\therefore$ & & & & & & & & & & $\begin{array}{l}\text { ? } \\
\infty^{-}\end{array}$ \\
\hline 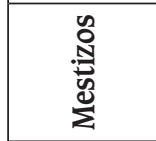 & & & & & & $\begin{array}{l}\stackrel{L}{1} \\
\infty \\
\sim \\
\sim\end{array} \mid$ & & & & 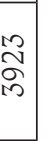 \\
\hline$\circ^{\circ}$ & & & & & & & & & & 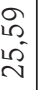 \\
\hline 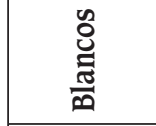 & & & & & & 定 & & & & 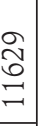 \\
\hline 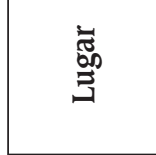 & : & 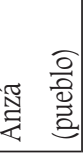 & 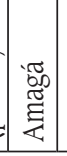 & 蒻 & 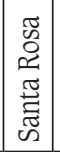 & 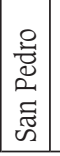 & 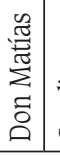 & 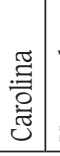 & 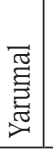 & 要 \\
\hline
\end{tabular}




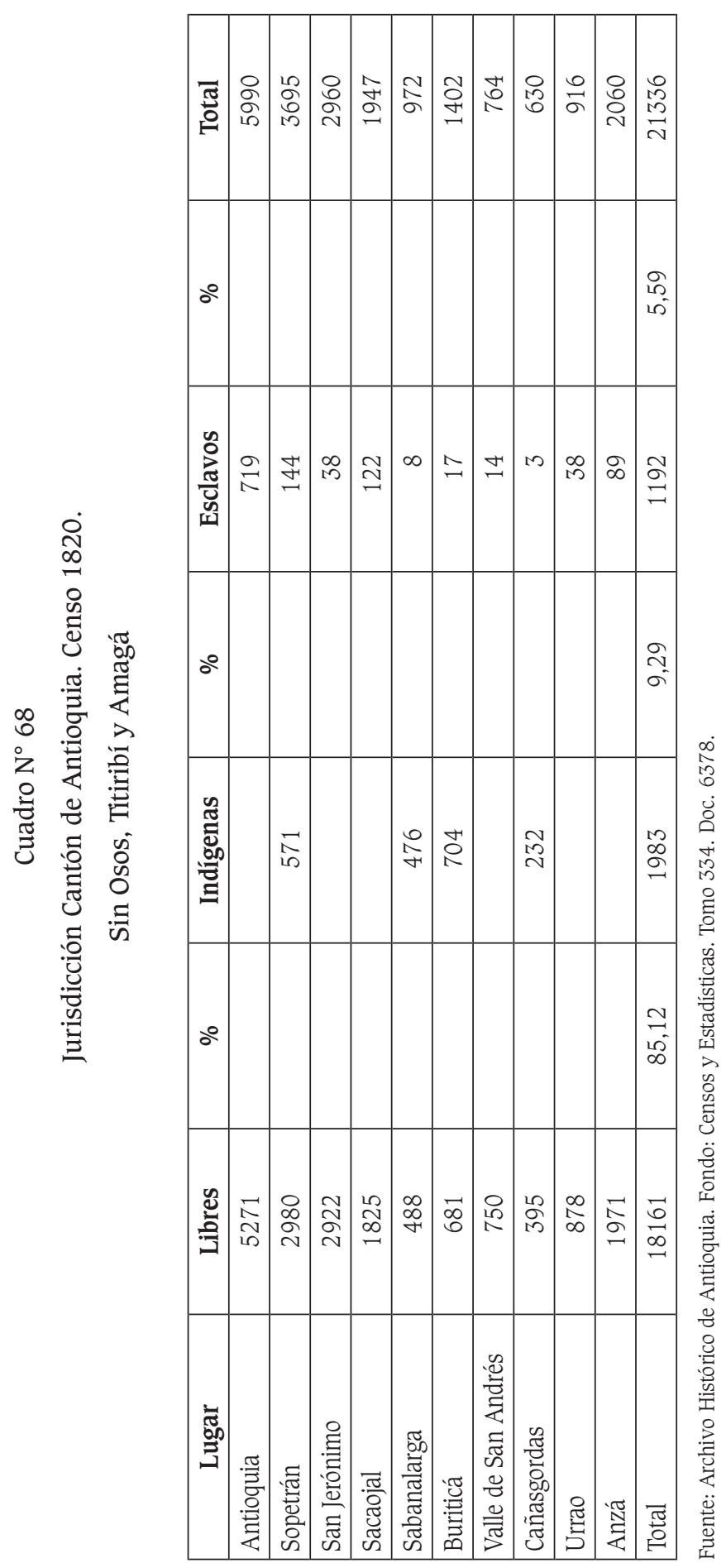



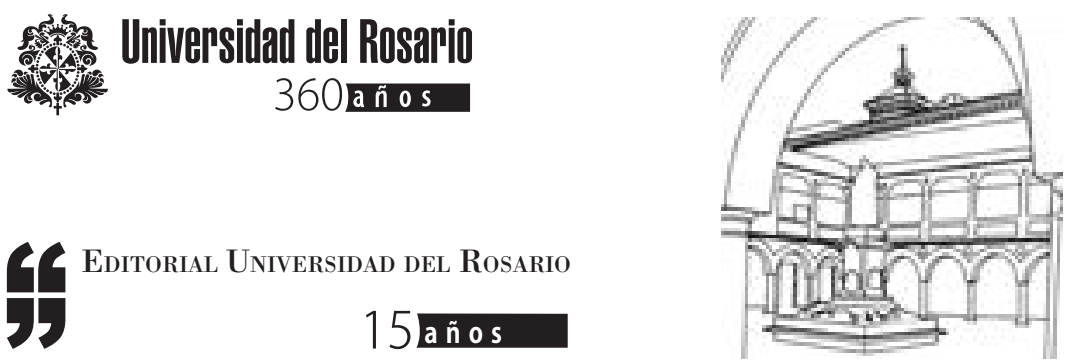

Este libro fue compuesto en caracteres Caxton 10 puntos, impreso sobre papel propal de 70 gramos y encuadernado con método Hot Melt, en el mes de agosto de 2013, en Bogotá D. C., Colombia

XPRESS Estudio Gráfico y Digital 